\author{
UNIVERSIDADE DE SÃO PAULO \\ FACULDADE DE FILOSOFIA, LETRAS E CIÊNCIAS HUMANAS \\ DEPARTAMENTO DE LETRAS MODERNAS \\ PROGRAMA DE PÓS-GRADUAÇÃO EM ESTUDOS LINGUÍSTICOS, LITERÁRIOS E \\ TRADUTOLÓGICOS EM FRANCÊS
}

MARIA LUCIA CLARO CRISTOVÃO

\title{
A imagem nos livros didáticos de Francês Língua Estrangeira: funções, preconizações, possibilidades.
}

Tese apresentada ao Programa de PósGraduação em Estudos Linguísticos, Literários e Tradutológicos em Francês do Departamento de Letras Modernas da Faculdade de Filosofia, Letras e Ciências Humanas para a obtenção do Título de Doutor em Letras

Orientadora: Prof ${ }^{\mathrm{a}} \mathrm{Dr}^{\mathrm{a}}$ Cristina Moerbeck Casadei Pietraróia

Versão corrigida

São Paulo

2015 
A minha mãe, Helena A Fátima A João Henrique Em memória de meu pai, João 


\section{AGRADECIMENTOS}

À minha orientadora Cristina Casadei Pietraróia, por sua orientação generosa e confiante, por suas leituras precisas e atenciosas, pelo entusiasmo e dedicação com que realiza seu trabalho docente.

À professora Eliane Gouvêa Lousada pelas sugestões e conselhos que tanto contribuíram para a realização deste trabalho, pela ajuda e apoio constantes durante todo o meu percurso acadêmico.

À professora Neide Maia González pela leitura atenta, pelas sugestões e comentários preciosos durante o exame de qualificação.

A Marc Boisson, Diretor de Ensino e Cultura da Aliança Francesa de São Paulo, por apoiar este trabalho e por ter me ajudado, com sua generosidade, profissionalismo e amizade, a realizá-lo e a concluí-lo.

A cada um dos professores que responderam gentilmente ao questionário de coleta de dados desta tese, com informações preciosas, precisas, detalhadas, completas.

A todos os amigos, imprescindíveis, pelo apoio, atenção e ajuda constantes.

À minha família, pelo amor incondicional e permanente. 


\section{RESUMO}

Esta tese tem por objetivo investigar o uso pedagógico da imagem nos livros didáticos de Francês Língua Estrangeira (FLE) e sua possível transformação nas últimas décadas. É fato que o suporte visual ocupa uma posição de destaque na sociedade contemporânea e que vivemos em uma civilização da imagem. Pesquisadores como Kress \& van Leeuwen (2001, 2006), Dondis (2007) e Joly (2007) nos mostram que a imagem possui uma linguagem que deve ser estudada, lida e analisada com ferramentas que lhe sejam próprias, tanto quanto a linguagem verbal. No entanto, seja na sociedade em geral ou, mais particularmente, na esfera educacional, não somos preparados para essa tarefa.

$\mathrm{Na}$ área do ensino-aprendizagem de uma língua materna ou estrangeira, a leitura da imagem se faz, sobretudo, por meio do livro didático, um suporte que mantém sua legitimidade como meio principal na transmissão de conteúdos oficiais por uma instituição (CORACINI, 1999). Ora, nas últimas décadas a presença da imagem nos livros didáticos de FLE parece ter aumentado e se desenvolvido em uma progressão bem mais intensa do que as propostas para sua exploração pedagógica.

Nesta pesquisa, buscamos verificar essa hipótese por meio de uma análise da presença da imagem em livros didáticos de FLE publicados nas últimas décadas e também das preconizações que essas mesmas publicações fornecem ao professor para o uso do suporte visual. Utilizamos como base teórica a noção de multimodalidade e a Gramática do Design Visual desenvolvidas por Kress \& van Leeuwen (2001, 2006). Em uma segunda etapa da análise, definimos funções previstas e funções possíveis para o uso da imagem e do texto multimodal em uma aula de FLE. Dedicamo-nos também ouvir a voz do professor por meio da aplicação de um questionário, com o intuito de compreender suas facilidades e dificuldades ao seguir as orientações fornecidas pelo livro didático e também as adaptações realizadas em sua prática docente no processo de transformação de um artefato em um instrumento (RABARDEL, 2003). Concluímos esta tese indicando possibilidades para a exploração da imagem e do texto multimodal capazes de contribuir para um ensinoaprendizagem do FLE mais reflexivo e produtivo.

\section{Palavras-chave:}

Ensino de língua estrangeira, imagem, livro didático, multimodalidade. 


\section{RÉSUMÉ}

La présente thèse a pour but d'analyser l'utilisation pédagogique de l'image dans les manuels de Français Langue Étrangère (FLE) et son éventuelle transformation au cours des dernières décennies. C'est un fait que le support visuel occupe une position de premier plan dans la société contemporaine et que nous vivons dans une civilisation de l'image. Des chercheurs comme Kress \& van Leeuwen (2001, 2006), Dondis (2007) e Joly (2007) nous montrent que l'image possède un langage propre qui doit être lu, étudié et analysé avec des outils dédiés, tout comme le langage verbal. Néanmoins, que ce soit dans la société en général ou plus particulièrement dans le domaine éducationnel, nous ne sommes pas préparés pour réaliser cette tâche.

Dans le domaine de l'enseignement-apprentissage d'une langue maternelle ou étrangère, la lecture de l'image se fait notamment à travers le livre didactique, un support qui garde sa légitimité comme principal moyen de transmission de contenus officiels d'une institution (CORACINI, 1999). Or, tout au long des dernières décennies, la présence de l'image dans les manuels de FLE semble avoir augmenté et s'être développée bien davantage que les propositions pour son exploitation pédagogique.

Dans cette recherche, nous vérifions cette hypothèse à travers une analyse de la présence de l'image dans des manuels de FLE publiés dans les dernières décennies ainsi que par l'étude des préconisations que les mêmes publications fournissent au professeur pour l'usage du support visuel. Pour ce faire, nous utilisons comme base théorique la notion de multimodalité et la Grammaire du Design Visuel développées par Kress \& van Leeuwen (2001, 2006). Dans une deuxième étape de cette analyse, nous définissons des fonctions prescrites et des fonctions possibles pour l'utilisation de l'image et du texte multimodal dans un cours de FLE. Nous écoutons également la voix du professeur par l'application d'un questionnaire, l'objectif étant de comprendre les facilités et les difficultés éprouvées au moment de suivre les orientations fournies par le guide pédagogique et de connaître les adaptations que l'enseignant met en place dans ses pratiques dans le processus de transformation d'un artéfact en un instrument (RABARDEL, 2003). Nous concluons cette thèse en indiquant des démarches possibles pour l'exploitation de l'image et du texte multimodal qui pourraient contribuer à un enseignement-apprentissage du FLE à la fois plus réfléchi et plus productif.

\section{Mots-clés :}

Enseignement de langues étrangères, image, manuel didactique, multimodalité. 


\begin{abstract}
The objective of this thesis is to explore the pedagogical use of image in French as a Foreign Language (FFL) textbooks and how this use may have been transformed during the last decades. It is a fact that visual aids have a meaningful position in contemporary society and that we live in a civilization of images. Researchers such as Kress \& van Leeuwen (2001, 2006), Dondis (2007) and Joly (2007) show us that the image has a distinct language that must be studied, read and analyzed by means of appropriate tools, in the same manner as the verbal language. Nevertheless, considering society in general or, more specifically, the educational sphere, we are not prepared for this task.

In the field of teaching-learning of a mother or foreign tongue, the reading of the image is achieved mainly through textbooks, the medium which holds its legitimacy as main carrier of official content by an institution (CORACINI, 1999). In recent decades, however, the presence of images in FFL textbooks seems to have increased and developed in a progression much more intense than that of the proposals for their pedagogical consideration.

In this survey, we seek to confirm this hypothesis though an analysis of the occurrence of images in FFL textbooks published in the last decades along with the recommendations for the use of visual aids the same publishers provide for the teachers. Our theory is based on the notion of multimodality and the Grammar of Visual Design developed by Kress \& van Leeuwen $(2001,2006)$. In a second stage of the analysis, we define the predictable functions and possible functions for the use of images and the multimodal texts in a FFL classroom.

We also commit ourselves to listen to the voice of the teacher by administering a questionnaire that aims to help us understand the benefits and difficulties of following the instructions provided by the textbook and what the teacher has adapted during the process of transforming an artifact into an instrument (RABARDEL, 2003). We conclude this thesis by presenting possibilities for exploring images and multimodal texts that will contribute to a more reflective and productive FFL teaching-learning.
\end{abstract}

\title{
Keywords:
}

Foreign languages teaching, image, textbook, multimodality. 


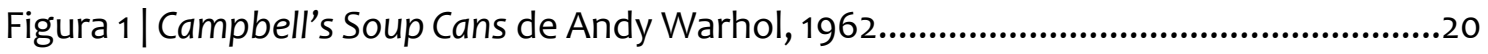

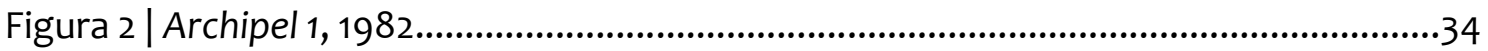

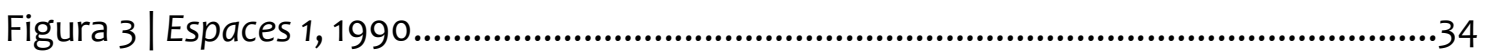

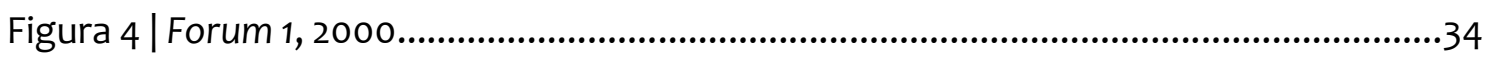

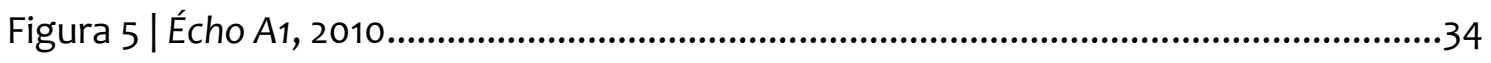

Figura 6 | Orbis Sensualium Pictus, 1658. Capítulo 91: Objetos da escrita..............................44

Figura 7 | Orbis Sensualium Pictus, 1658. Capítulo 123: Partes internas de uma cidade.......45

Figura $8 \mid$ Cours de langue et de civilisation française........................................................47

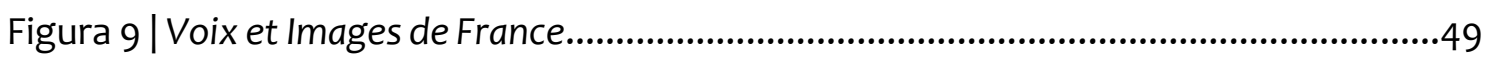

Figura 10 | Écho A1 versão digital. CLE Internacional, 2010 .................................................52

Figura 11 | Le labo de langues que acompanha o livro didático Saison...................................53

Figura 12 | Parcours digital que acompanha o livro didático Alter Ego+ 1............................54

Figura 13 | Parcours digital que acompanha o livro didático Alter Ego+ 1 .............................54

Figura 14 | O Estado de São Paulo, 08.12.1962 .......................................................................58

Figura 15 | O Estado de São Paulo, 02.12.1972.....................................................................59

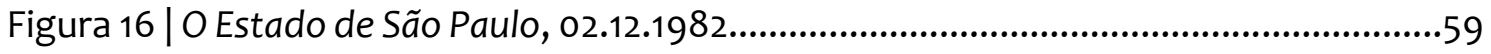

Figura 17 | O Estado de São Paulo, 05.12.1992.......................................................................60

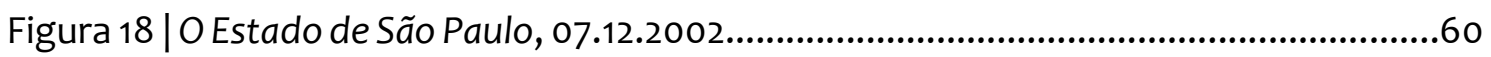

Figura 19 | O Estado de São Paulo, 02.12.2012 .......................................................................60

Figura 20 | O Estado de São Paulo, 02.12.2012 - Caderno Aliás.....................................................61

Figura 21 | Imagens citadas por Kleiman (2005: 49) …...................................................68

Figura 22 | Kress e van Leeuwen (2006: 42) .....................................................................76

Figura 23 | Kress e van Leeuwen (2006: 42) .......................................................................76

Figura 24 | Kress e van Leeuwen (2006: 48) ......................................................................77

Figura 25 | Exemplo de estrutura representacional narrativa............................................79

Figura 26 | Exemplo de estrutura representacional conceitual..........................................80

Figura 27| Trípticos horizontais e verticais (KRESS \& VAN LEEUWEN, 2006: 201) .............82

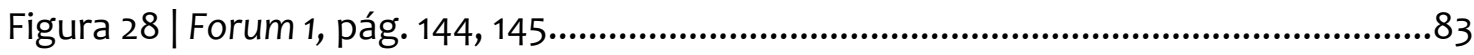

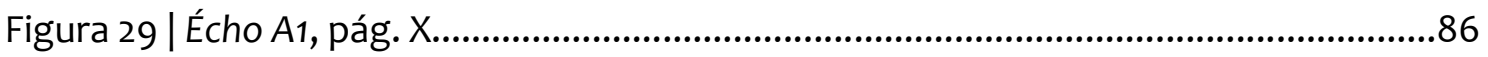

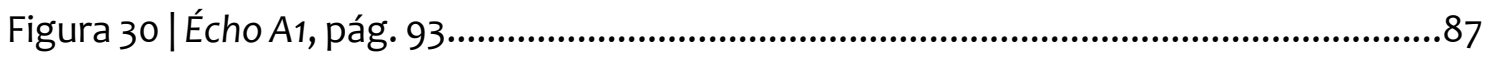

Figura 31 | Archipel 1 - Capa do livro do aluno...............................................................99 


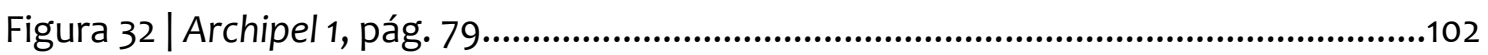

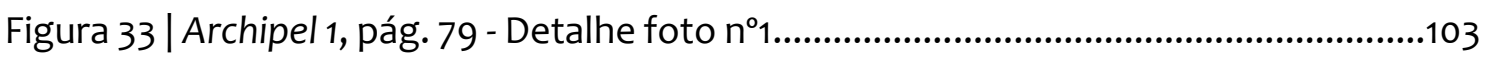

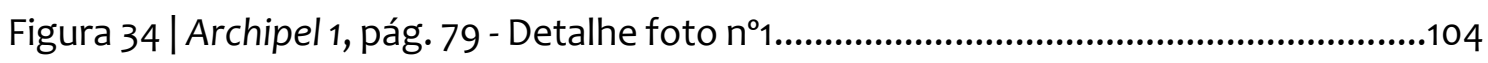

Figura 35 | Archipel 1, pág. 79 - Detalhe foto n¹...............................................................105

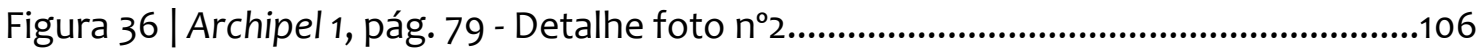

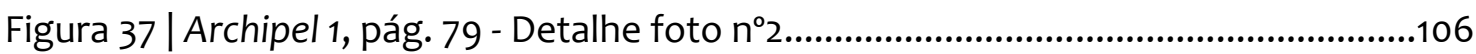

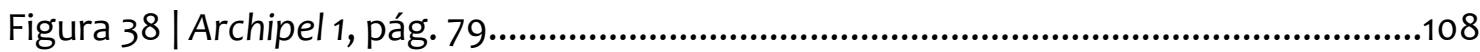

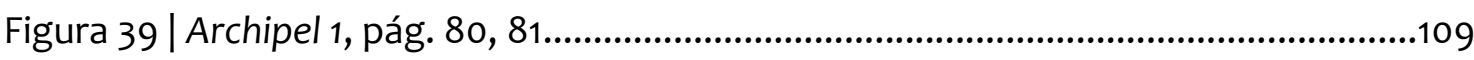

Figura 40 | Archipel 1, pág. 56, 57 ..........................................................................................110

Figura 41 | Archipel 1, pág. 56 - Detalhe...................................................................................111

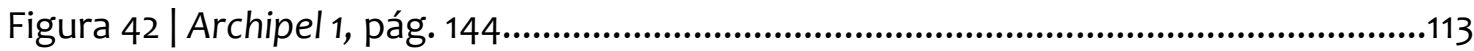

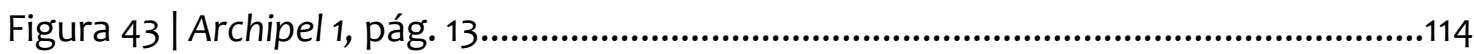

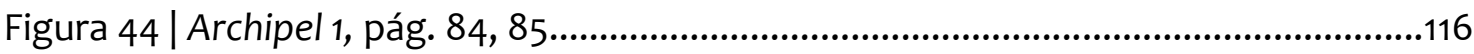

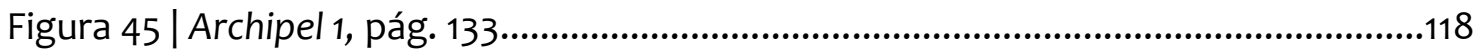

Figura 46 | Archipel 1, pág. 109..........................................................................................120

Figura 47 | Gráfico - Presença quantitativa da imagem em Archipel 1..............................121

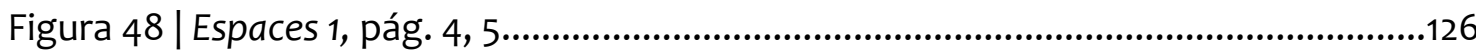

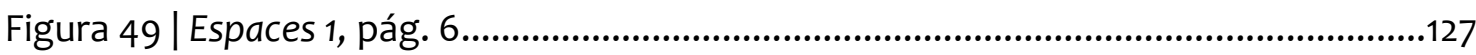

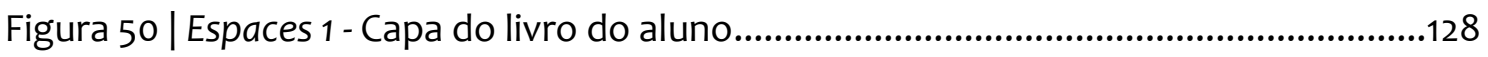

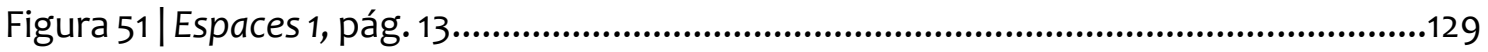

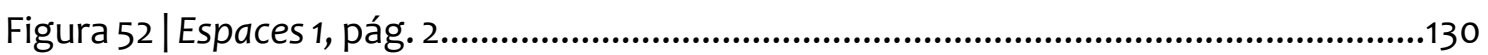

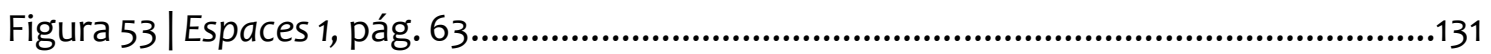

Figura 54 | Espaces 1, pág.13...........................................................................................132

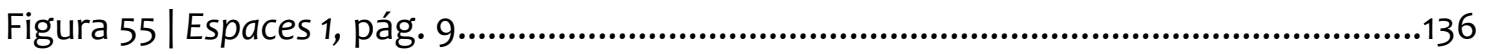

Figura 56 | Espaces 1, pág. 10, 11.........................................................................................138

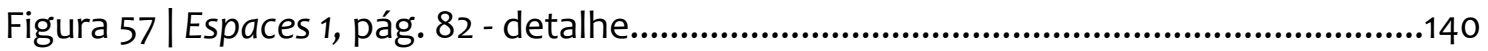

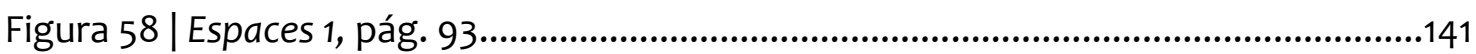

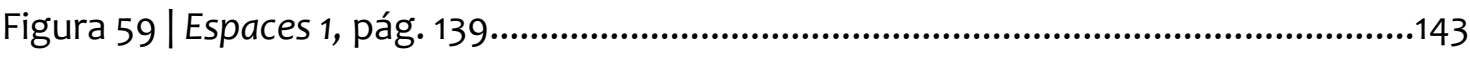

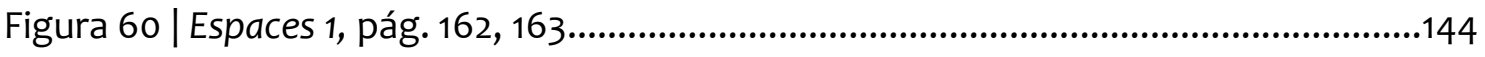

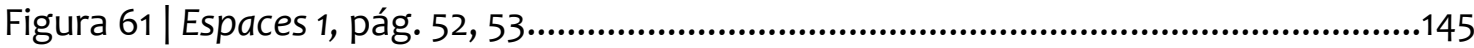

Figura 62 | Gráfico - Balanço comparativo Archipel 1 / Espaces 1.......................................147

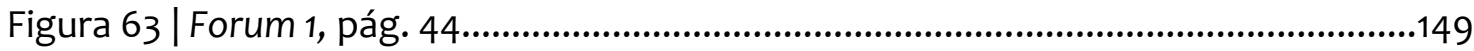

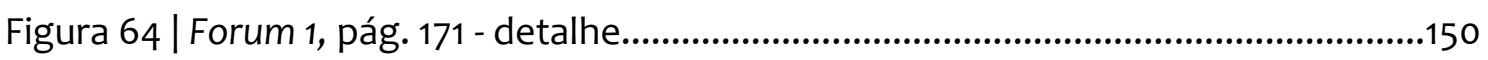




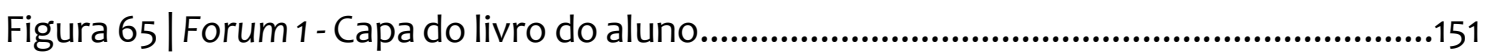

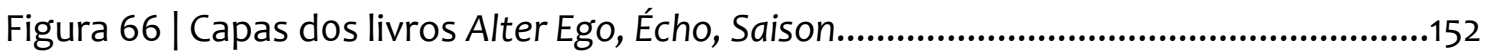

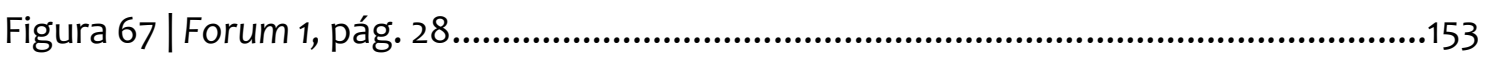

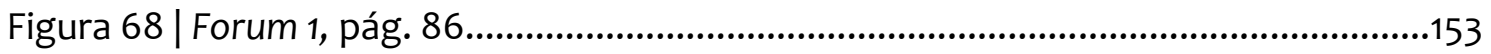

Figura 69 | Forum 1, pág. 140.............................................................................................154

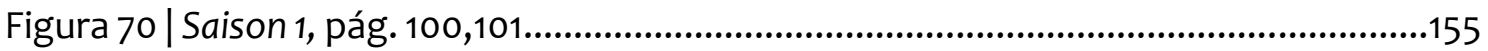

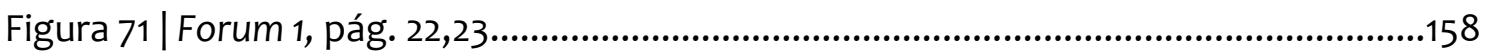

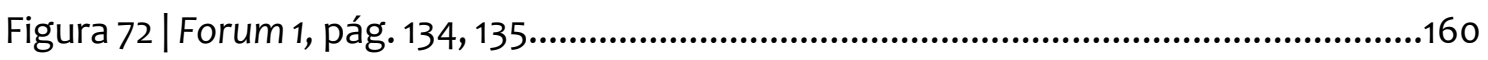

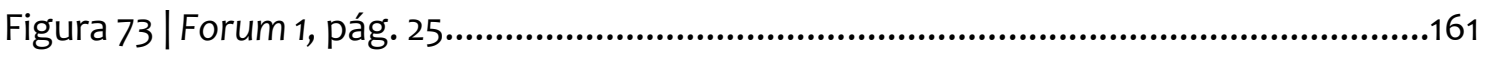

Figura 74 | Forum 1, pág. 137................................................................................................161

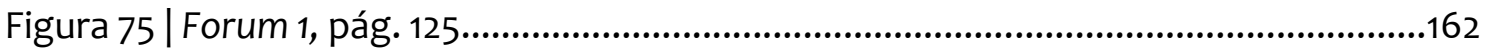

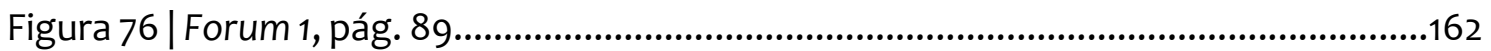

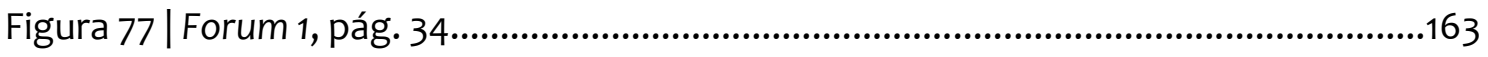

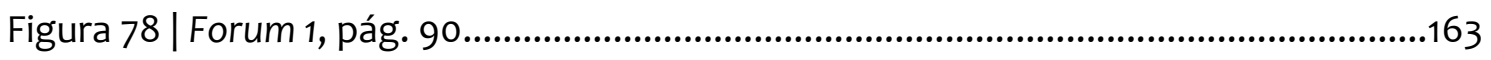

Figura 79 | Forum 1, pág. 88..................................................................................................164

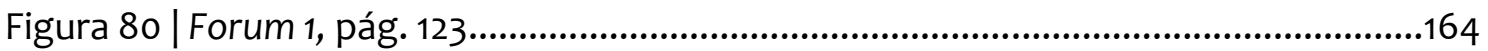

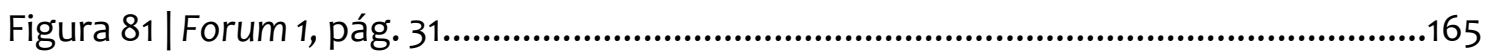

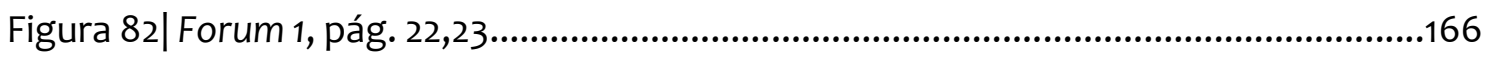

Figura 83 | Gráfico - Balanço comparativo Archipel 1 / Espaces 1 / Forum 1 1..........................169

Figura 84 | Écho A1 - Capa do livro do aluno.........................................................................171

Figura 85 | Capa dos livros didáticos da coleção Écho......................................................172

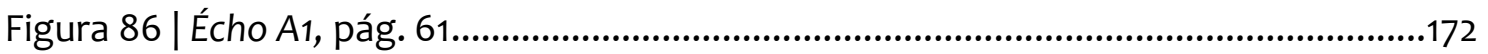

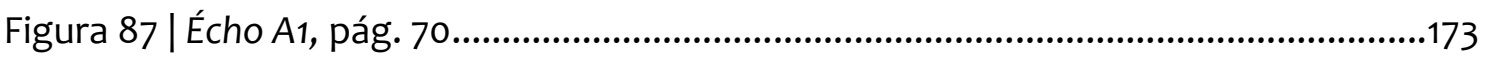

Figura 88 | Écho A1, pág. 50.............................................................................................173

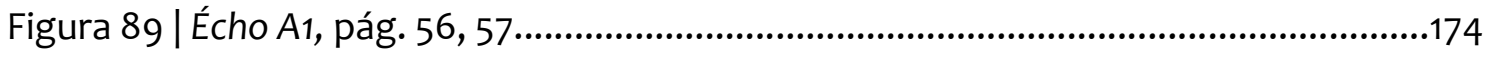

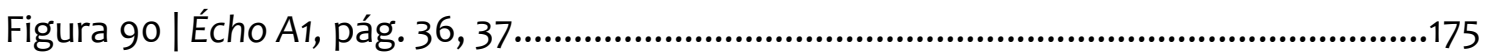

Figura 91 | Écho A1 - Guia pedagógico, pág. IV e V....................................................... 176

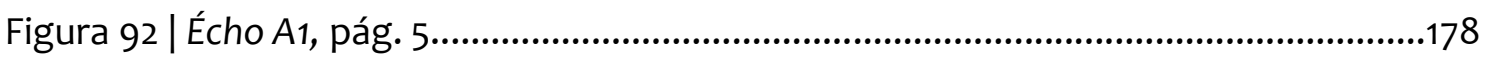

Figura 93 | Écho A1, pág. 46,47 .......................................................................................178

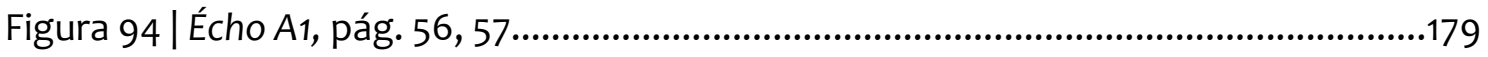

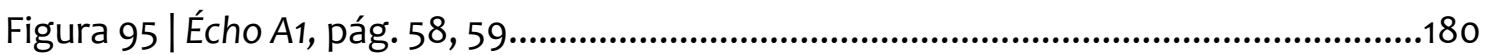

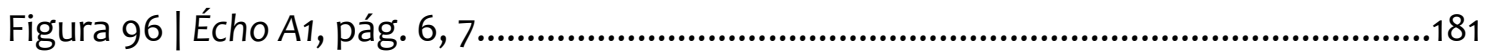

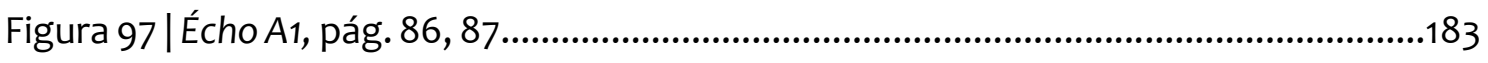




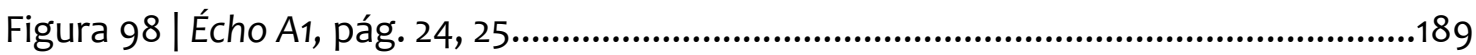

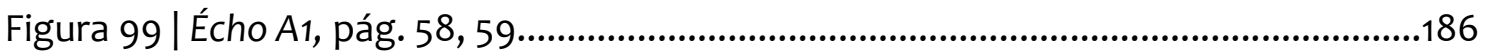

Figura 100 | Écho A1, pág. 76.......................................................................................187

Figura 101 | Gráfico - Balanço comparativo Archipel 1 / Espaces 1 / Forum 1/Écho A1 ............189

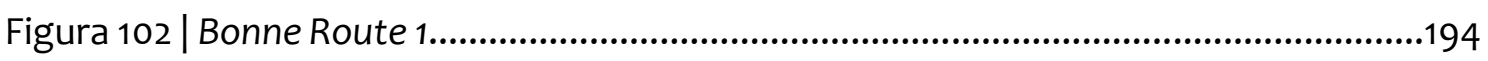

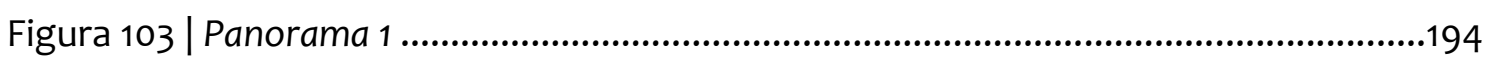

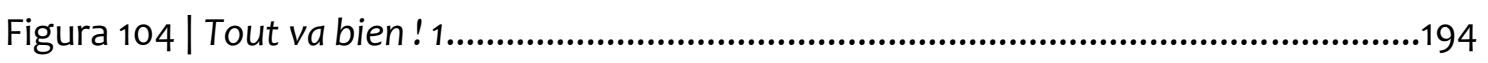

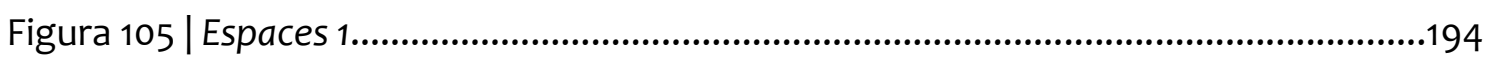

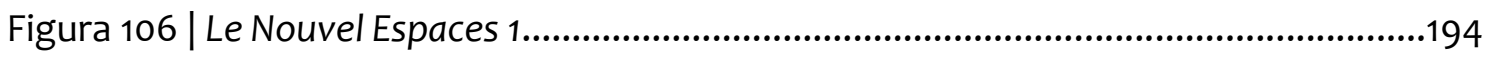

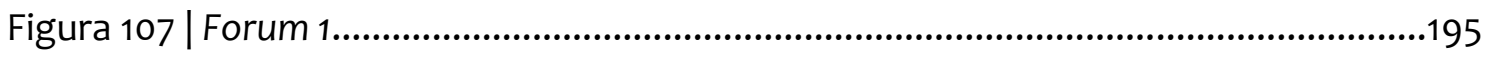

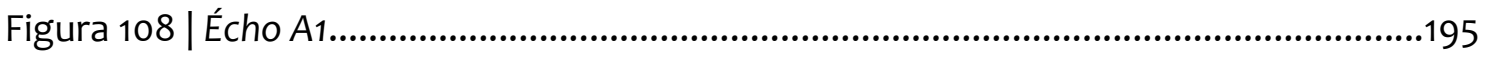

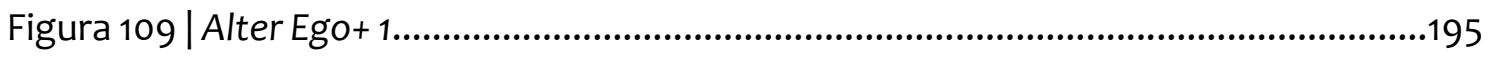

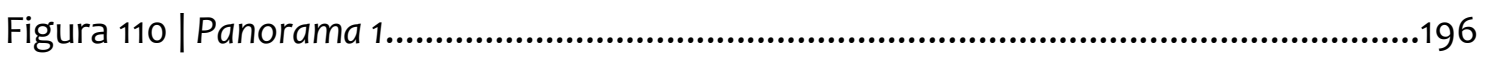

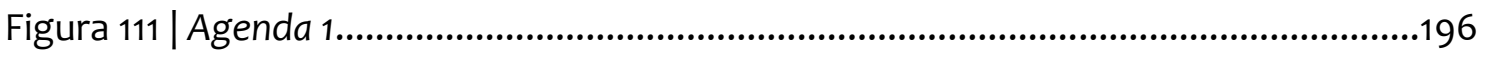

Figura 112 | Archipel 1, pág. 101...........................................................................................197

Figura 113 | Archipel 1, pág. 55..............................................................................................197

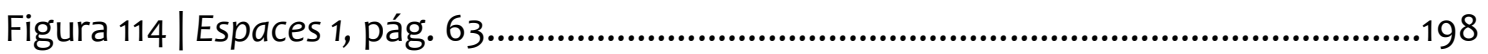

Figura 115 | Forum 1, pág. 19...............................................................................................198

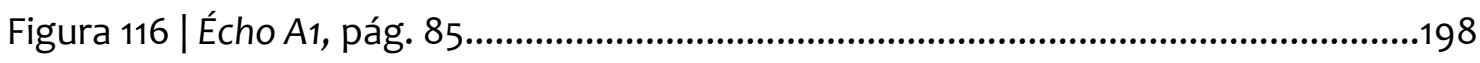

Figura 117| Alter Ego+1, pág. 85 ........................................................................................198

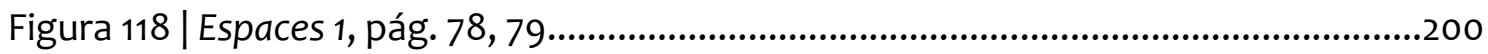

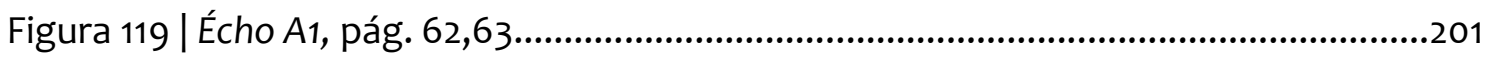

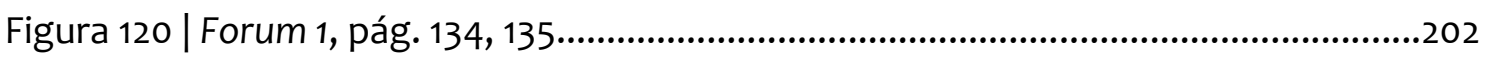

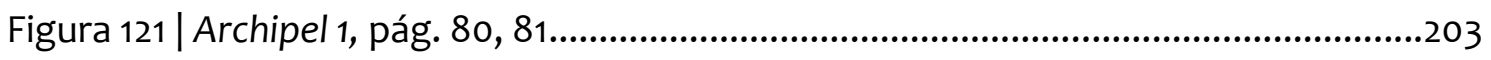

Figura 122 | Espaces 1, pág. 82, 83...................................................................................204

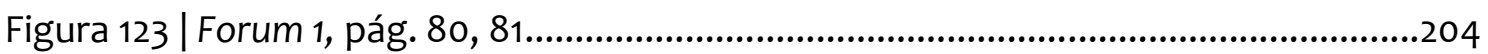

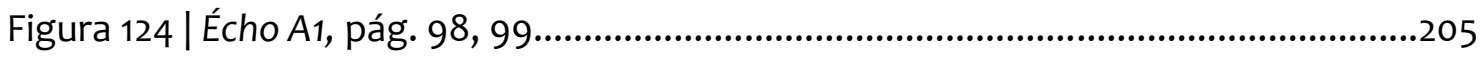

Figura 125 | Forum 1, pág. 61...............................................................................................207

Figura 126 | Écho A1, pág. 58, 59 .................................................................................208

Figura 127 | Forum 1, pág. 154….........................................................................................209

Figura 128 | Forum 1, pág. 103 (detalhe) …...........................................................................211

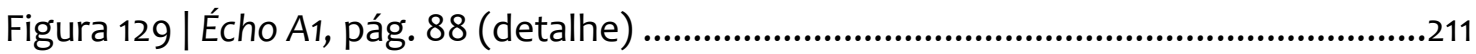

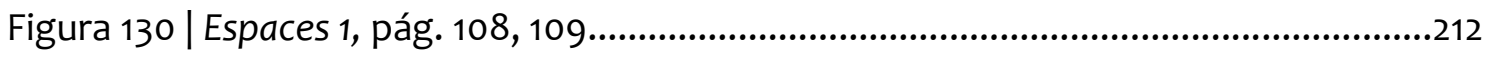




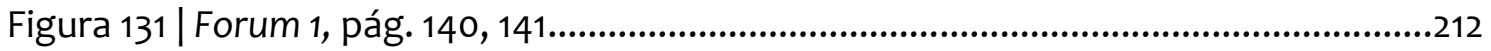

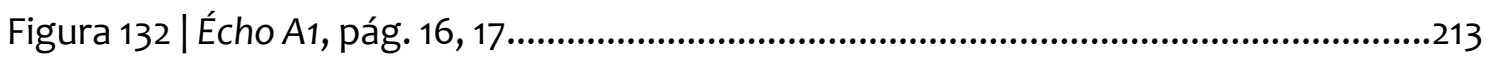

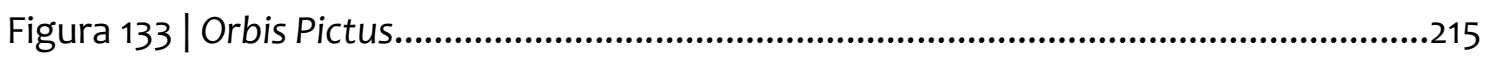

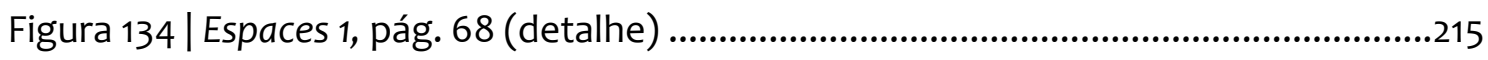

Figura 135 | Espaces 1, pág. 93 (detalhe) ..............................................................................215

Figura 136 | Forum 1, pág. 88 (detalhe) …............................................................................216

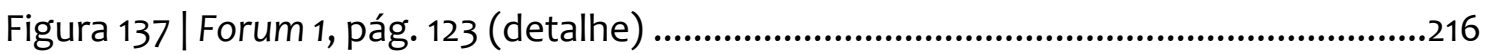

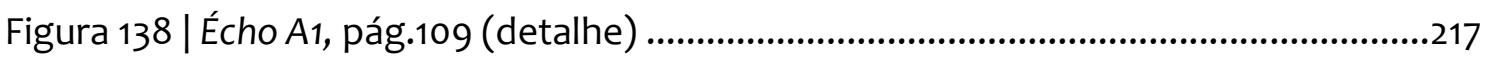

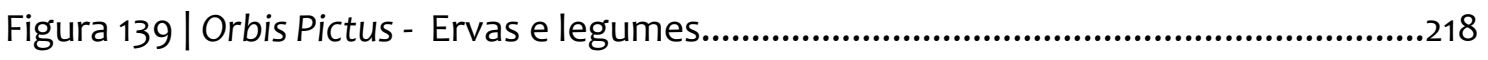

Figura 140 | Espaces 1, pág. 93 (detalhe) - Frutas e legumes................................................218

Figura 141 | Orbis Pictus - Árvore genealógica (1658) .......................................................219

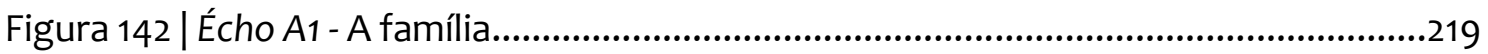

Figura 143 | Forum 1, pág. 88 (detalhe) ..........................................................................220

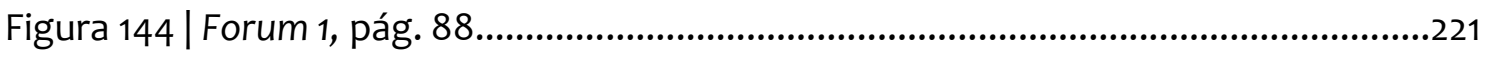

Figura 145 | Espaces 1, pág. 169 (detalhe) ..........................................................................222

Figura 146 | Forum 1, pág. 144 (detalhe) …............................................................................223

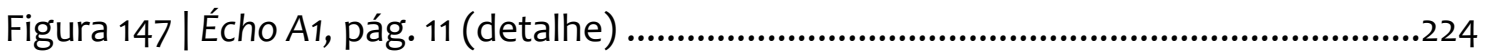

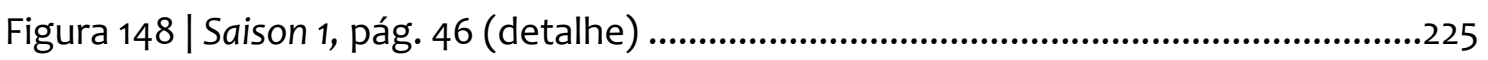

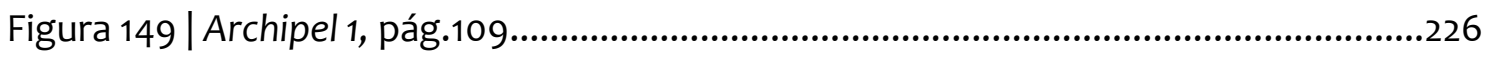

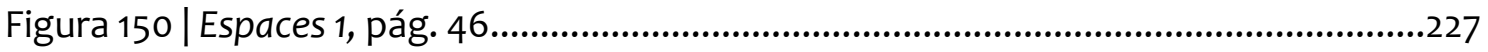

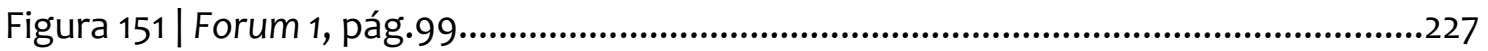

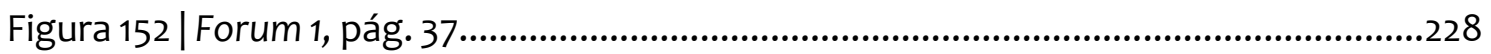

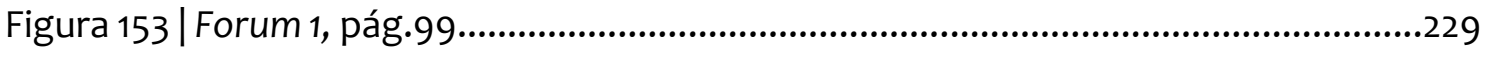

Figura 154 | Tipos de imagem mais utilizados em cada componente do LD....................230

Figura 155 | Forum 1, pág. 22, 23 ......................................................................................234

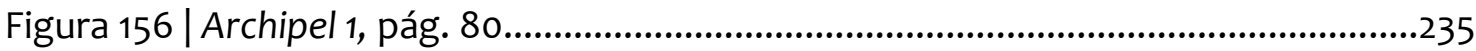

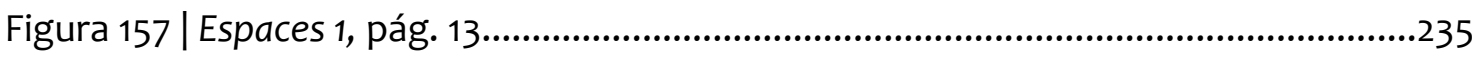

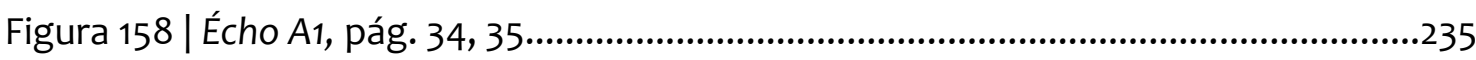

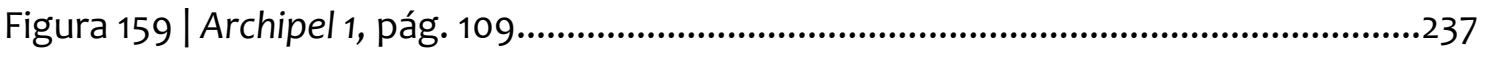

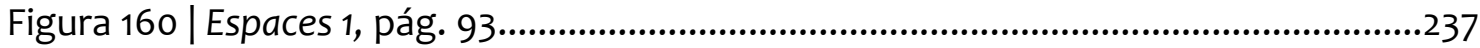

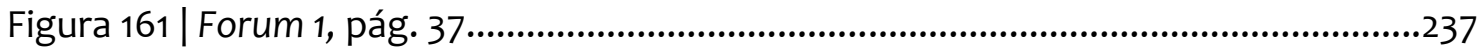

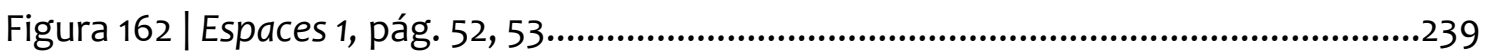

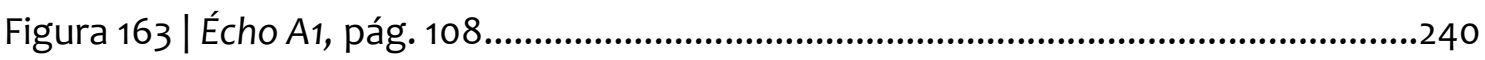




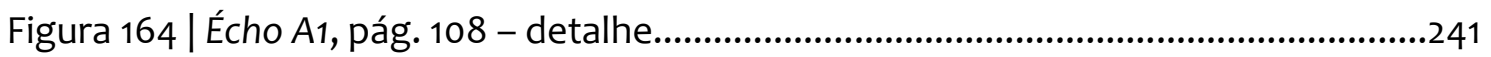

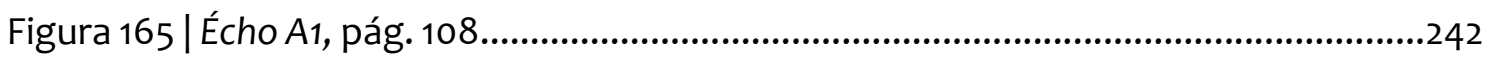

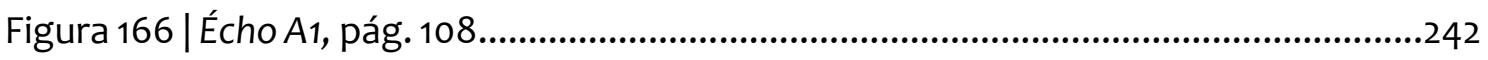

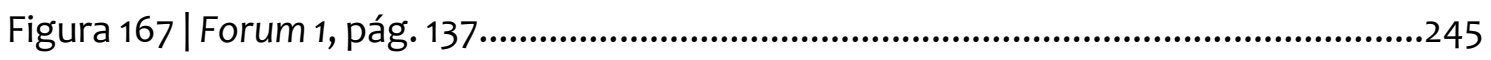

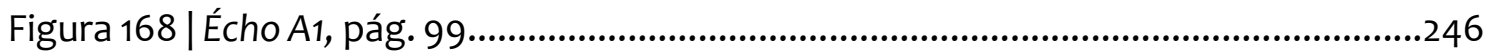

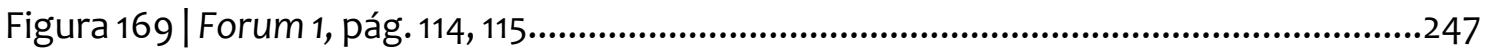

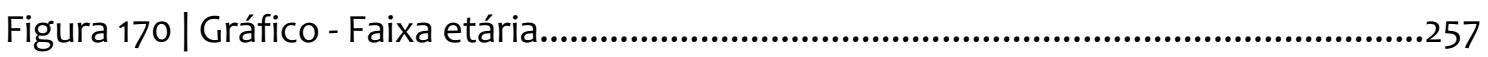

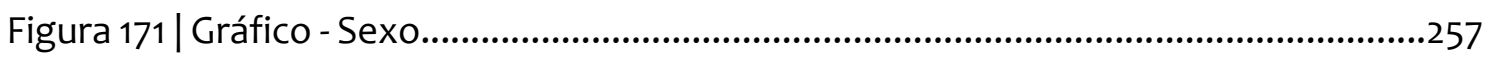

Figura 172 | Gráfico - Anos de experiência no ensino.......................................................258

Figura 173 | Gráfico - Instituição de Ensino........................................................................258

Figura 174 | Gráfico - Busca de (in)formação sobre a imagem no dia-a-dia.......................259

Figura 175 | Gráfico - Forma como a imagem está mais presente em sua vida..................262

Figura 176 | Gráfico - Apreciação de texto acompanhado por imagem..............................262

Figura 177 | Gráfico - Preferências de gêneros textuais com imagem (em \%) ...................263

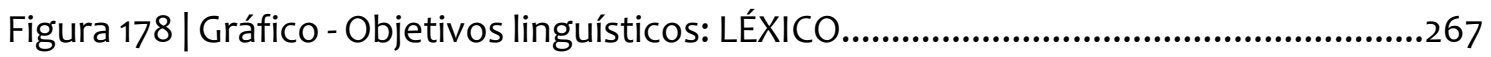

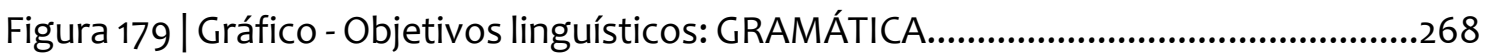

Figura 180 | Gráfico - Objetivos linguísticos: FONÉTICA....................................................268

Figura 181 | Gráfico - Objetivos CULTURAIS E INTERCULTURAIS.....................................268

Figura 182 | Gráfico - Objetivos comunicativos: COMPREENSÃO......................................269

Figura 183 | Gráfico - Objetivos comunicativos: PRODUÇÃO...............................................269

Figura 184 | Gráfico - Objetivos comunicativos: INTERAÇÃO..........................................269

Figura 185 | Gráfico - Ajudar a desenvolver ESTRATÉGIAS DE APRENDIZAGEM...............270

Figura 186 | Gráfico - Para a realização de JOGOS E DE ATIVIDADES LÚDICAS..................270

Figura 187 | Gráfico - Livro didático mais utilizado............................................................271

Figura 188 | Gráfico - Objetivos para o uso da imagem........................................................272

Figura 189 | Gráfico - Quantidade de orientações................................................................272

Figura 190 | Gráfico - Qualidade das orientações...............................................................273

Figura 191 | Gráfico - Clareza e pertinência..................................................................273

Figura 192 | Gráfico - Contribuição para os objetivos didáticos..........................................273

Figura 193 | Gráfico - Objetivos para o uso da imagem.......................................................274

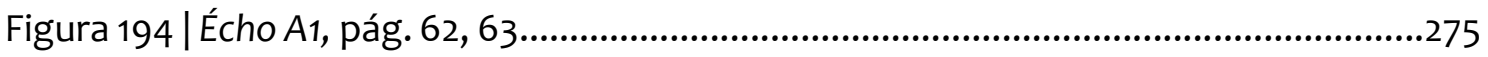

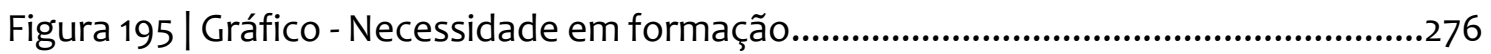

Figura 196 | Gráfico - Frequência da utilização da imagem em aula de FLE......................281 


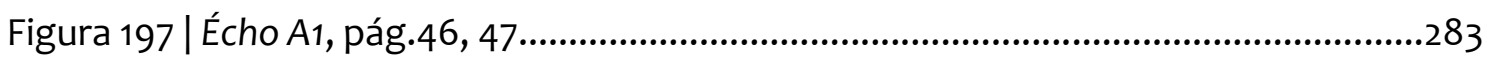

Figura 198 | Écho A1 - Guia pedagógico, página 38.........................................................284

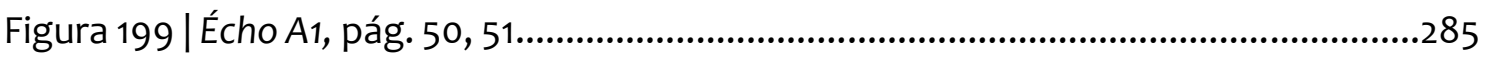

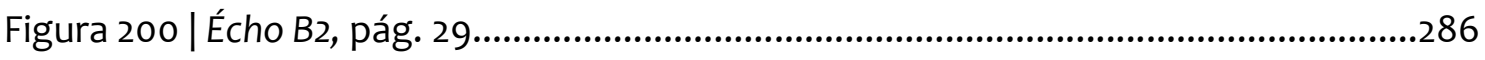

Figura 201 | Écho A1, pág. 53 ….........................................................................................287

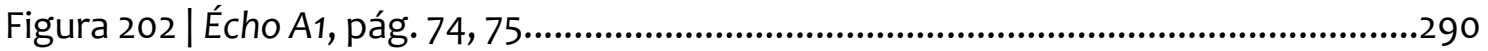




\section{SUMÁRIO}

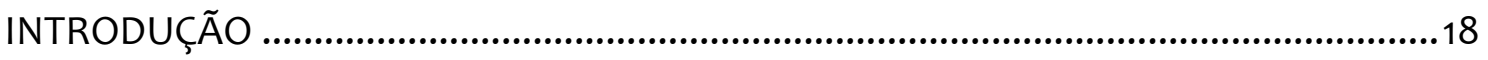

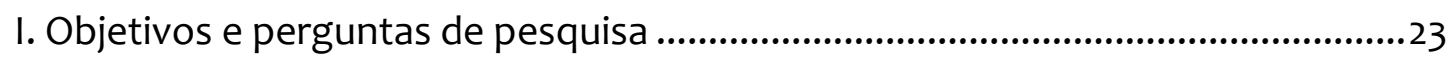

II. Histórico e Contexto de pesquisa ........................................................................ 29

III. Metodologia da pesquisa ................................................................................... 32

CAPÍTULO 1 | A IMAGEM NO ENSINO-APRENDIZAGEM DE LÍNGUAS ESTRANGEIRAS 38

1.1. Imagem, uma introdução .................................................................................. 39

1.2. O uso da imagem no ensino-aprendizagem de línguas estrangeiras.................42

1.2.1. Comenius e o primeiro livro didático ilustrado ................................ 43

1.2.2. O texto e a imagem na história das metodologias de FLE.............. 46

1.2.3. Evolução tecnológica e novos canais para a imagem no material didático de FLE........................................................................................ 51

CAPÍTULO 2 | BASES TEÓRICAS PARA UMA ANÁLISE DA IMAGEM .......................... 56

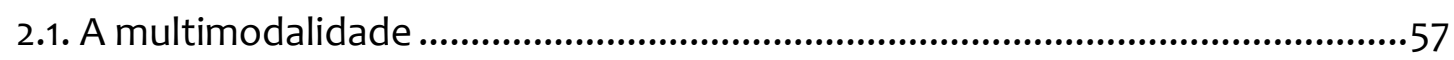

2.2. A imagem como texto e discurso visual que exige uma leitura própria........... 64

2.3. Ler, interpretar e compreender a imagem....................................................... 66

2.3.1. Alfabetização e letramento na linguagem escrita........................... 66

2.3.2. Letramento visual ........................................................................... 70

2.4. A Gramática do Design Visual de Kress e van Leeuwen ....................................72

2.4.1. Uma teoria social de representação semiótica ............................... 74

2.4.2. As metafunções da imagem no modo semiótico visual ..................75

2.4.2.1. A metafunção representacional ..................................................... 78

2.4.2.2. A metafunção interacional ......................................................... 80

2.4.2.3. A metafunção composicional....................................................... 82

CAPÍTULO 3 | ANÁLISE DO USO DA IMAGEM EM LIVROS DIDÁTICOS DE FLE ...........90

3.1. Livro didático: definição, edição, utilizações previstas e efetivas...................... 91

3.1.1. Definição e autoria: a questão do mercado editorial ....................... 91

3.1.2. Utilizações previstas, utilizações efetivas........................................ 94

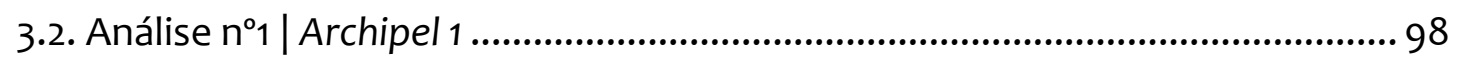

3.2.1. Análise da capa do livro do aluno Archipel 1 .................................. 99

3.2.2. Análise quantitativa das imagens no livro do aluno ...................... 99 
3.2.3. Análise qualitativa e funcional das imagens no livro do aluno.... 101

3.2.4. Preconizações do guia pedagógico para o uso da imagem .......... 116

3.2.5. Balanço quantitativo e qualitativo ................................................... 124

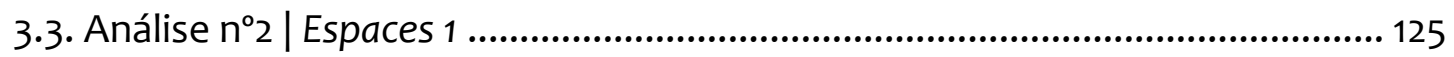

3.3.1. Análise da capa do livro didático Espaces 1 .................................. 127

3.3.2. Análise quantitativa das imagens no livro do aluno .....................128

3.3.3. Análise qualitativa e funcional das imagens.................................131

3.3.4. Preconizações do guia pedagógico para o uso da imagem ......... 142

3.3.5. Balanço qualitativo e quantitativo ................................................146

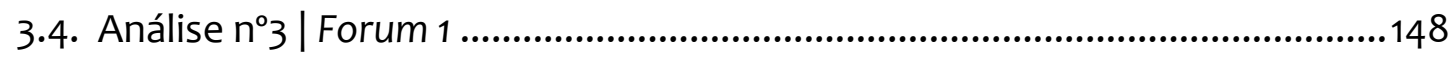

3.4.1. Análise da capa do livro didático Forum 1 ...................................150

3.4.2. Análise quantitativa das imagens no livro do aluno Forum 1....... 152

3.4.3. Análise qualitativa e funcional das imagens ............................... 155

3.4.4. Preconizações do guia pedagógico para o uso da imagem .........166

3.4.5. Balanço qualitativo e quantitativo ................................................168

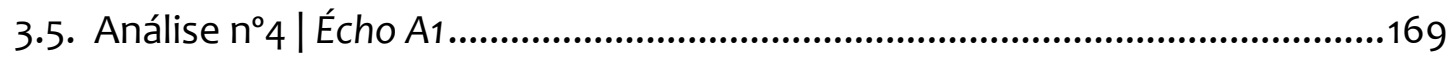

3.5.1. Análise da capa do livro didático Écho A1 ....................................171

3.5.2. Análise quantitativa das imagens no livro do aluno ..................... 172

3.5.3. Análise qualitativa e funcional das imagens................................. 175

3.5.4. Preconizações do guia pedagógico para o uso da imagem .........180

3.5.5. Balanço qualitativo e quantitativo .................................................188

3.6. Considerações ao final desta etapa.................................................................190

CAPÍTULO 4 | A IMAGEM NO ENSINO-APRENDIZAGEM DO FLE: UTILIZAÇÕES PRECONIZADAS, UTILIZAÇÕES POSSÍVEIS ..............................................................192

4.1. A imagem na capa dos livros didáticos .............................................................193

4.2. A imagem na página de abertura de uma lição ou de um conjunto de lições196

4.3. A imagem e as situações comunicativas ...........................................................199

4.3.1. Situações mais amplas para uma abertura temática da lição...... 200

4.3.2. Diálogos situacionais para compreensão oral .............................. 203

4.3.3. Atividades de produção oral ......................................................... 209

4.4. A imagem e o conteúdo linguístico .................................................................. 210

4.4.1. A imagem e a gramática ...............................................................210

4.4.2. A imagem e o léxico ........................................................................ 214

4.4.3. A imagem e a fonética....................................................................222

4.5. A imagem e a compreensão e produção escritas..............................................225 
4.6. A imagem e o conteúdo sociocultural .228

4.7. Conclusões sobre os tipos de imagem mais utilizados

4.8. Funções possíveis para a imagem no ensino-aprendizagem do FLE

4.8.1. Função situacional

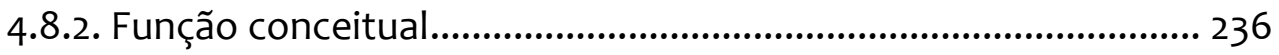

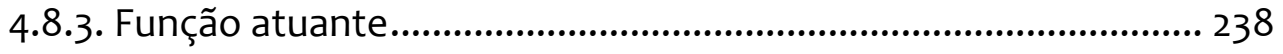

4.8.4. Função expressiva......................................................................243

4.8.5. Multifunções e multileituras ......................................................... 244

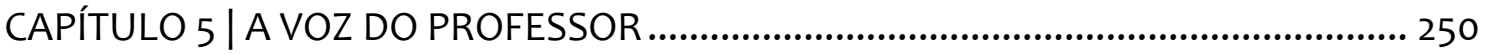

5.1. Metodologia para a coleta de dados: o questionário ...................................... 251

5.1.1. Forma e conteúdo do questionário ...............................................252

5.1.2. Público-alvo, contexto e etapas de aplicação do questionário .. 254 5.2. Dados quantitativos e qualitativos obtidos nos questionários....................... 256

5.3. Análise dos dados coletados.........................................................................276

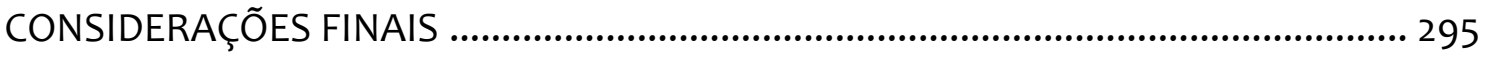

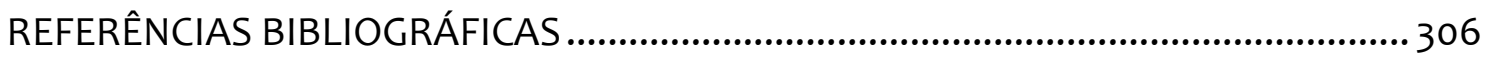

APÊNDICE 


\section{INTRODUÇÃO}

Graças à arte, o homem sente-se finalmente vencedor, detentor de um poder de imobilizar e de conservar não só o que vive à sua volta como aquilo que vive interiormente.

René Huyghe 


\section{INTRODUÇÃO}

Elas são onipresentes nos dias de hoje. Seja por meio da fotografia, da televisão, da Internet, seja sob a forma de vídeo, impressa ou digital, seja com um objetivo publicitário, informativo ou ilustrativo, as imagens fazem parte de nosso cotidiano a ponto de termos a impressão de viver em uma “civilização de imagens" (JOLY, 2007). O desenvolvimento de diferentes mídias e de novas tecnologias durante o século XX acompanhou-se de imagens e de sua progressão em quantidade e em qualidade em nossa sociedade.

Se as imagens apareceram desde o início desse século como o elemento central de certas invenções como a televisão, outras inovações tecnológicas que tentaram inicialmente lhes negar uma posição de destaque, como o computador e o telefone celular, já não podem mais ser concebidas sem elas.

As imagens estão em toda a parte e, no entanto, apesar de termos a impressão de se tratar de um fenômeno recente, Philippe Hamon (2001) nos lembra que essa grande invasão começou durante o século XIX, quando a profusão de imagens transformou a cultura visual dos habitantes das grandes cidades. Espaços públicos, como as ruas, e privados, como os apartamentos da sociedade burguesa, tornaram-se então um espaço saturado de imagens diversas e justapostas: cartazes afixados nas paredes dos imóveis, fotografias nos álbuns e nos apartamentos, jornais e revistas ilustrados, caricaturas e cartões postais. Segundo Hamon (2001), o que se considerava "grande pintura" dessa época passa a ser ameaçado por um mundo de imagens que o autor define como “imageries". Tal ameaça parece explicar essa modificação da cultura visual dos habitantes das cidades nesse século XIX, evocada pelo autor citado. Passamos da "pintura" à "imagem", um termo bem mais abrangente e numeroso. Podemos associar esse último adjetivo à questão da multiplicidade das imagens. Até então, cada pintura ou escultura era uma obra única de um artista e enquadrava-se em um ambiente restrito, uma vez que era necessário deslocar-se até um Salão de exposições para poder observála, analisá-la e integrá-la à nossa cultura visual.

Já as novas imagens do século XIX, como a fotografia, o cinema, os cartazes, as ilustrações, os bibelôs e estatuetas produzidos de forma industrial caracterizam-se pela possibilidade quase infinita de multiplicação. Ao contrário da "grande pintura" citada por Hamon (2001), essas imagens não estão restritas a um espaço delimitado e disponível 
para poucas pessoas. Elas invadem as grandes cidades transformando então o que se pode considerar como a cultura visual dos cidadãos dessa época.

Seria interessante lembrar aqui a reflexão de Alberto Manguel (2009: 27-28) em torno da expressão "museu imaginário" de Malraux:

André Malraux (...) argumentou com lucidez que, ao situarmos uma obra de arte entre as obras de arte criadas antes e depois dela, nós, os espectadores modernos, tornávamo-nos os primeiros a ouvir aquilo que ele chamou de "canto da metamorfose" - quer dizer, o diálogo que uma pintura ou escultura trava com outras pinturas e esculturas, de outras culturas e de outros tempos. No passado, diz Malraux, quem contemplava o portal esculpido de uma igreja gótica só poderia fazer comparações com outros portais esculpidos dentro da mesma área cultural; nós, ao contrário, temos à nossa disposição incontáveis imagens de esculturas do mundo inteiro (desde as estátuas da Suméria àquelas de Elefanta, desde os frisos da Acrópole até os tesouros de mármore de Florença) que falam para nós em uma língua comum, de feitios e formas, o que permite que nossa reação ao portal gótico seja retomada em mil outras obras esculpidas. A esse precioso patrimônio de imagens reproduzidas, que está à nossa disposição na página e na tela, Malraux chamou de "museu imaginário".

(MANGUEL, 2009: 27-28)

Manguel acrescenta ainda que, ao lermos uma imagem, nos servimos não apenas desse museu imaginário constituído pela iconografia mundial, mas também de um amplo espectro de circunstâncias, sociais ou privadas, fortuitas ou obrigatórias. Ou seja, ao construirmos o sentido de uma imagem, utilizamos vários vocabulários que darão abertura para diferentes interpretações da mesma.

Ao analisarmos as considerações de Hamon e de Manguel, notamos que a industrialização da imagem no século XIX trouxe não somente uma democratização da "grande pintura" ou escultura, através de reproduções que constituíram nosso "museu imaginário", mas também uma transformação da nossa cultura visual, com a invasão das "imageries" citadas por Hamon. Esse museu imaginário passa a ser composto, além de grandes obras de arte de diferentes culturas e civilizações, também pelo que poderíamos definir como uma grande loja de souvenirs do mesmo museu, com objetos diversos, justapostos, desconexos.

Durante o século XX, a relação entre esses dois tipos de imagem de nosso museu imaginário (grande arte e imageries) intensifica-se, eliminando algumas barreiras que as mantinham separadas até então. A obra Campbell's Soup Cans de Andy Warhol (1962), composta por 32 serigrafias ilustrando as latas de sopa Campbell, marca uma nova 
relação entre os termos "grande pintura" e imagem. A noção de consumo desenfreado associada aos tempos modernos parece incluir também um grande consumo da imagem que ocorre de forma voluntária ou involuntária, consciente ou não.

Figura 1 | Campbell's Soup Cans de Andy Warhol, $1962^{1}$

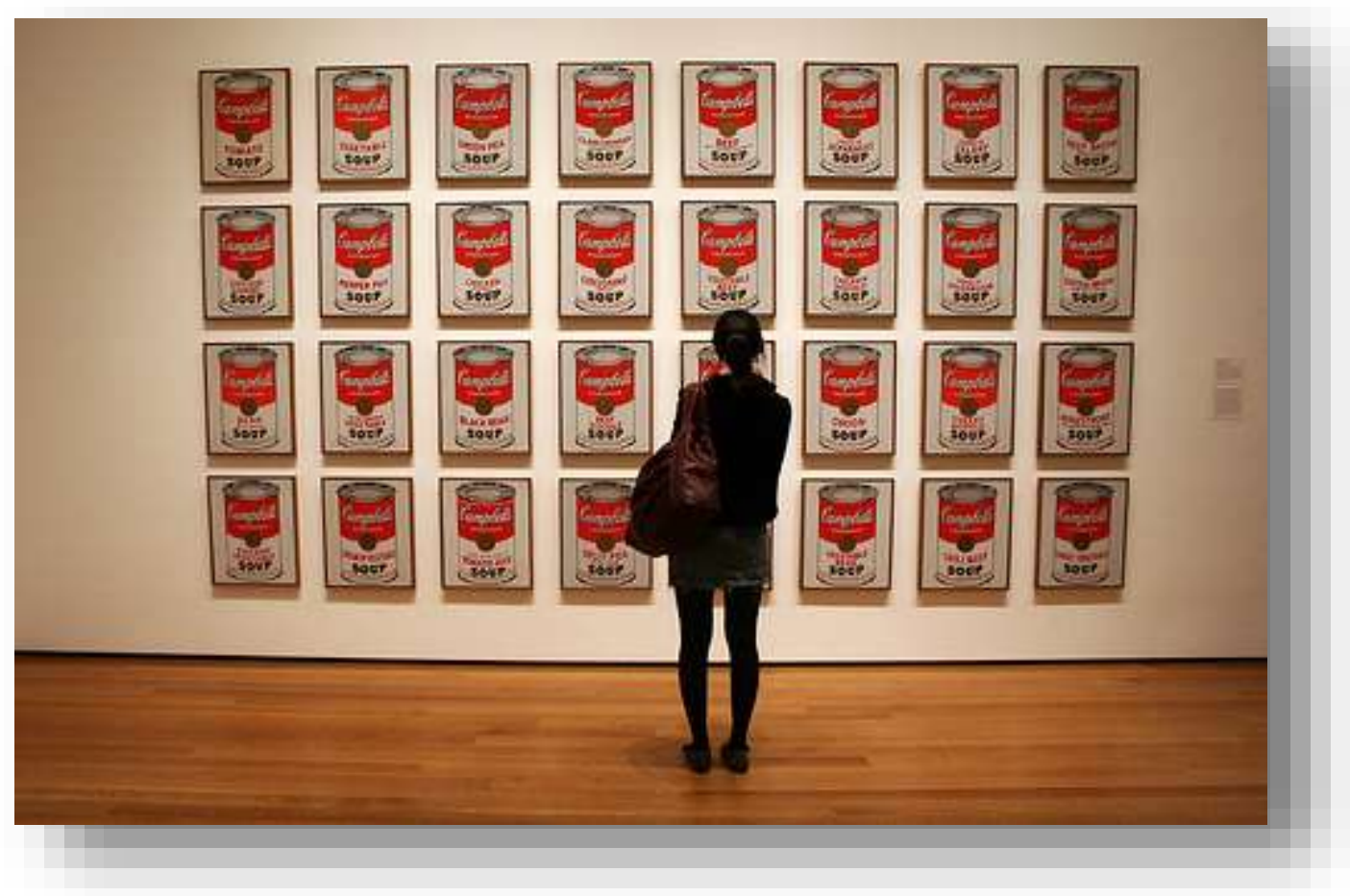

Esse consumo desenfreado de imagens ganhou fôlego nos últimos anos, com o advento das imagens virtuais. Constantemente expostos às imagens, somos levados a decifrá-las, analisá-las e interpretá-las sem termos sido iniciados a essa interpretação. Temos a impressão de saber ler essas imagens de forma natural, sem necessidade de um aprendizado ou de um pré-requisito específico. De acordo com a autora e pesquisadora Martine Joly (2007), as imagens nos parecem ameaçadoras devido ao seguinte paradoxo: não fomos iniciados à sua leitura e sabemos que muitas delas foram construídas por especialistas que podem manipular nossa ingenuidade. No entanto, segundo a autora, uma iniciação básica à análise da imagem nos mostraria que, na verdade, não somos totalmente ingênuos ou passivos nessa leitura, pois ela ativa em nós convenções, histórias e culturas interiorizadas. "É precisamente por sermos feitos da mesma massa 
da imagem que ela nos é tão familiar e que não somos as cobaias que por vezes julgamos ser." (JOLY, 2007: 10).

O termo "massa de imagens" é interessante, pois remete à definição do "museu imaginário" de Malraux, dentro de uma terminologia menos nobre e mais consumista que parece incluir o grande banco de imagens e as imageries comuns a vários cidadãos do planeta, em um mundo cada vez mais globalizado.

Apesar dessa bagagem cultural comum, segundo Joly (2007), é necessário um esforço mínimo de análise para compreender melhor as imagens, sua especificidade e as mensagens que elas veiculam. Mas não poderemos analisar essas imagens se não soubermos do que estamos falando exatamente ou a razão pela qual queremos fazê-lo. Por isso, uma introdução ou uma educação à análise da imagem se faz necessária (JOLY, 2007). Ou seja, precisamos de uma abordagem teórica da imagem para poder compreender sua especificidade.

Ainda segundo a mesma autora, a imagem é uma mensagem visual compreendida entre expressão e comunicação. Por essa razão, toda análise da imagem deverá levar em consideração a função dessa mensagem, seu horizonte de expectativa e seus diferentes tipos de contexto.

A pesquisadora Donis A. Dondis (2007), por sua vez, define essa educação à imagem como um "alfabetismo visual" verbalmente alfabetizados, devemos aprender os elementos que compõem a linguagem escrita, ou seja, as letras, as palavras, a ortografia, a gramática e a sintaxe. Uma vez que essa técnica é dominada, qualquer pessoa poderá produzir infinitas possibilidades de criação e também um estilo pessoal. Paralelamente, o modo visual é composto por um conjunto de dados "que, como a linguagem, podem ser usados para compor e compreender mensagens em diversos níveis de utilidade, desde o mais puramente funcional até os mais elevados domínios da expressão artística". Ainda segundo a autora, os objetivos do alfabetismo visual são os mesmos que motivaram o desenvolvimento da linguagem escrita: “construir um sistema básico para a aprendizagem, a identificação, a compreensão de mensagens visuais que sejam acessíveis a todas as pessoas" (2007: 23).

Essa mesma necessidade de um letramento visual é defendida pelos teóricos Gunther Kress e Theo van Leeuwen (2001, 2006). Eles afirmam que, apesar da grande

\footnotetext{
2 "Visual literacy", no texto original.
} 
quantidade de trabalhos realizados sobre o tema da imagem, pouca atenção foi dada à estrutura como os elementos visuais se organizam no texto visual ou seja, à sua "gramática":

Apesar da grande quantidade de trabalhos feitos sobre as imagens, o resultado mostra que não foi dada muita atenção para os significados das regularidades com as quais os elementos que compõem a imagem são utilizados - em suma, à sua gramática - pelo menos não de forma explícita ou sistematizada. É justamente esse foco no significado que procuramos, acima de tudo, em nosso livro. Temos a intenção de fornecer descrições utilizáveis de macro estruturas de composição que se tornaram estáveis na história da semiótica visual ocidental, e analisar como elas são usadas por criadores de imagens contemporâneas para produzir sentido. ${ }^{3}$

(KRESS \& VAN LEEUWEN, $2006: 1$ )

Diante da multiplicação de signos visuais nos textos produzidos pela sociedade contemporânea, Kress e van Leeuwen (2006) apontam para a importância e a necessidade de se desenvolver uma metodologia para a análise da imagem e para se compreender como recursos semióticos verbais e visuais interagem entre si na construção de estruturas de significados sociais. Para isso, os autores desenvolveram a “Gramática do Design Visual” (GDV), voltada para o estudo da comunicação visual nas culturas ocidentais e que constituirá um dos fundamentos teóricos desta pesquisa.

Kress e van Leeuwen (2006) insistem também no aspecto social das estruturas das representações visuais, já que elas estão sempre ligadas às instituições sociais que as produziram. Por essa razão, essas estruturas visuais possuem uma importante dimensão semântica e nunca são meramente formais.

Ao retomarmos as considerações de Manguel (2006), Joly (2007), Dondis (2007) e Kress e van Leeuwen (2006) podemos reagrupar os elementos de base para uma análise visual em duas vertentes. De um lado, encontramos elementos unificadores e compartilhados por diferentes sociedades na leitura da imagem: vários termos utilizados por esses autores remetem a algo em comum de que nos servimos ao analisar uma imagem. Termos como, por exemplo, patrimônio de imagens reproduzidas; museu

\footnotetext{
3 Tradução nossa. No original: " Yet the result has been that, despite the very large amount of work done on images, not much attention has been paid to the meanings of regularities in the way image elements are used - in short, to their grammar - at least not in explicit or systematic ways. It is this focus on meaning that we seek, above all, to describe and capture in our book. We intend to provide usable descriptions of major compositional structures which have become established as conventions in the course of the history of Western visual semiotics, and to analyse how they are used to produce meaning by contemporary image-makers. "
} 
imaginário; vocabulário que herdamos; iconografia mundial; sistema básico para a aprendizagem, a identificação, a compreensão de mensagens visuais que sejam acessíveis a todas as pessoas.

Por outro lado, os mesmos autores citam elementos particulares a um indivíduo, a uma cultura ou sociedade na leitura da imagem. Esses elementos aparecem na utilização de termos como: circunstâncias sociais ou privadas; vocabulário pessoal de possíveis interpretações; contexto de produção e de recepção da imagem.

Essas duas vertentes constituídas, por um lado, por uma bagagem universal comum na produção e na recepção de imagens e, por outro, pelos diferentes contextos socioculturais de produção e de leitura das mesmas confirmam a complexidade do tema, assim como a transparência na construção de sentido em alguns casos e as diferenças de interpretação que podem surgir em outros.

$\mathrm{Na}$ área da linguística, as abordagens teóricas de Vygotsky (1998) e de Mikhail Bakhtin (2004) conferiram à linguagem uma natureza social, na qual os aspectos puramente formais da alfabetização deram espaço aos aspectos enunciativo-discursivos. Para Bakhtin (2004) o valor de um enunciado não é determinado pela língua como sistema puramente formal e linguístico mas sim pelas diferentes interações que a mesma língua estabelece com a realidade, com os sujeitos falantes da mesma língua ou com outros enunciados. Desta forma, Bakhtin vê a linguagem como um fenômeno social, não sendo possível separar a língua do fluxo da comunicação verbal.

Fazendo-se um paralelo entre a linguagem verbal e a linguagem visual, podemos afirmar que, mesmo se Kress e van Leeuwen (2006) descrevem uma metodologia para a análise formal da imagem e de suas estruturas recorrentes nas culturas ocidentais, essas imagens estabelecem uma série de relações de interação entre as pessoas, os lugares e os objetos que nelas estão retratados. A mesma também está sempre inserida em um contexto sociocultural e não pode ser separada dos outros suportes semióticos com os quais interage na construção de significados. Significados esses cujas construções dependerão também do contexto sociocultural do observador.

\section{Objetivos e perguntas de pesquisa}

No campo da educação, a leitura de imagens acontece, sobretudo, por meio de livros didáticos. É bem verdade que é cada vez mais comum o uso de documentos autênticos em sala de aula, como revistas, jornais, sites da Internet. No entanto, seja no 
ensino de uma língua materna ou estrangeira, seja na esfera pública ou privada, o livro didático mantém sua imagem de legitimidade como meio fundamental de transmissão de conteúdos oficiais por uma instituição (CORACINI, 1999; SOUZA, 1999; ARAÚJO, 2011). Por essa razão, nesta pesquisa, buscamos nos livros didáticos elementos que nos permitam entender a função e o uso que se tem feito da imagem nas últimas décadas dentro do ensino-aprendizagem do Francês língua estrangeira (doravante FLE).

Vários trabalhos têm discutido a questão da leitura da imagem na esfera educacional e dentro desta, no ensino-aprendizagem de uma língua estrangeira. No Brasil, a pesquisadora Rosilma Araújo Bühler (2009) interessou-se pela leitura de imagens em livros didáticos de língua alemã e de língua inglesa. Baseando-se na teoria da Gramática Visual de Kress e van Leeuwen (2006), a autora propôs uma leitura contrastiva de imagens pertencentes a dois livros didáticos, um de alemão e outro de inglês. As estruturas representacionais encontradas pela análise comparativa desses livros trouxeram à tona elementos socioculturais próprios das culturas reproduzidas nos livros didáticos por seus autores.

Baseadas nos mesmos pressupostos teóricos, outras pesquisas foram desenvolvidas recentemente sobre o uso da imagem nos livros didáticos de línguas estrangeiras. Adriana Batista de Souza (2011), em uma dissertação de mestrado sobre a leitura de imagens e de textos verbais no livro didático de inglês, interessou-se por verificar como a interação entre o verbal e o visual é feita nesses livros didáticos e também como essa interação pode contribuir para atingir os objetivos pedagógicos que o próprio livro didático propõe. Já Márcia Novellino (2011), em sua tese de doutorado, pesquisou as imagens em movimento que acompanham uma série de livros didáticos de inglês, visando contribuir para as pesquisas sobre a relação entre os modos visuais e verbais. A pesquisadora Danielle Alves (2011) analisou algumas imagens presentes em livros didáticos de língua italiana com o objetivo de verificar se as mesmas foram usadas de forma coerente com a unidade didática. Em uma pesquisa mais recente, Michely Salles (2014) interessou-se por estudar as atividades propostas em livros didáticos de língua portuguesa para as linguagens verbal e visual.

Apesar de essas pesquisas serem cada vez mais numerosas tanto no campo do livro didático de língua materna quanto no do livro didático de língua estrangeira, poucas publicações têm sido feitas na área do ensino-aprendizagem do FLE. Acreditamos, portanto, poder contribuir, por meio de uma análise do papel da imagem em livros 
didáticos de FLE, a essa crescente reflexão sobre a necessidade de desenvolvimento de letramentos múltiplos tanto na sociedade em geral como na área da educação.

No caso do ensino-aprendizagem do FLE, nossa área de estudo nesta tese, o aumento da quantidade e da qualidade das imagens nos livros didáticos intensificou-se bastante a partir da década de 1980. É bem verdade que as imagens constituíram um ponto essencial para a metodologia $\mathrm{SGAV}^{4}$ que foi desenvolvida na Europa na década de 50, mas a busca por outras respostas no ensino-aprendizagem de línguas estrangeiras conheceu uma renovação importante a partir dos anos 70, com a abordagem comunicativa da língua.

O livro didático Archipel 1 (COURTILLON, RAILLARD, 1982) marca um momento de transição entre essas duas metodologias e introduz uma nova relação com a imagem ao adotar a abordagem comunicativa. As imagens e os documentos autênticos ${ }^{5}$ - ou seja, documentos que não foram concebidos expressamente para um curso de línguas ganham as páginas dos livros didáticos de FLE. Trata-se de uma opção que também foi adotada pela metodologia que se seguiu historicamente, a perspectiva acional ${ }^{6}$, desenvolvida pelo Conselho da Europa com a publicação do Quadro Europeu Comum de Referência para Línguas (CONSELHO DA EUROPA, 2001). Longe de se oporem, essas duas metodologias se complementam. Ao comparamos seus princípios, podemos dizer que a primeira tem seu foco na comunicação como objetivo de aprendizagem, enquanto que para a segunda, a comunicação é sobretudo um meio dentro de um objetivo mais vasto: a ação e a interação entre os alunos e os cidadãos usuários da língua-alvo.

Nesta tese de doutoramento, interessa-nos conhecer qual papel os livros didáticos de FLE publicados nas últimas décadas reservam à utilização do suporte visual para fins pedagógicos. Os livros concebidos nas últimas quatro décadas nos interessam particularmente por duas razões principais: por representarem certa unidade metodológica, e também por corresponderem historicamente a uma época de grande evolução tecnológica da imagem nos meios de comunicação, dentre os quais, a área de edição de livros didáticos. Nosso objeto de estudo nesta tese, portanto, são livros didáticos concebidos dentro dessas duas metodologias específicas: a abordagem comunicativa e a perspectiva acional. Esse recorte no campo de pesquisa nos permite,

\footnotetext{
${ }^{4}$ Méthodologie SGAV : méthodologie "Structuro-globale audiovisuelle".

5 Utilizaremos essa expressão segundo o sentido que lhe foi atribuído por Daniel Coste (1970).

6 De agora em diante, adotaremos a expressão "perspectiva acional" como tradução para o termo "perspective actionnelle" em francês.
} 
portanto, realizar um estudo mais homogêneo dentro de uma mesma linha metodológica que se desenvolveu paralelamente a uma grande evolução tecnológica no campo da edição.

E quando falamos na evolução tecnológica das últimas décadas, é importante lembrar que a imagem nos livros didáticos de FLE passou a ser apresentada também por meio de outros suportes como: DVDs, CR-ROMs e CDs de áudio que passaram a acompanhar o livro do aluno e o caderno de exercícios. De fato, houve uma expansão da imagem móvel nos livros didáticos com os vídeos que compõem esse material, sem falar na imagem numérica e nas atividades interativas presentes nos livros didáticos digitais e nos aplicativos correspondentes para tablets e smartphones. É também cada vez mais comum a criação de sites na Internet e até de páginas em redes sociais especialmente concebidas para os usuários de um determinado livro didático, assim como atividades Web 2.0 e plataformas on-line criadas especificamente em complemento a uma publicação. Segundo as palavras do pesquisador francês Alain Choppin (2004: 553), "O livro didático, em tais situações, não tem mais existência independente, mas torna-se um elemento constitutivo de um conjunto multimídia."

A utilização da imagem nesses diferentes meios e suportes, suas possibilidades de uso na pedagogia e problemáticas decorrentes constituem um tema extremamente vasto e complexo. Por essa razão, para melhor delimitar nosso corpus, optamos pela análise exclusiva da imagem fixa nos livros didáticos de FLE publicados nas últimas quatro décadas. Essa opção parece-nos coerente também para que tenhamos os mesmos suportes de análise disponíveis em todo o material estudado. De fato, os primeiros métodos da abordagem comunicativa não vinham acompanhados de CD-ROMs nem de DVDs. O conteúdo didático era apresentado em forma de vídeo para a classe. O DVD encartado no livro do aluno surgiu um pouco mais tarde quando a imagem móvel passou a integrar o material didático disponibilizado ao professor (uma transformação em relação às imagens ainda fixas da metodologia SGAV) e, em seguida, também aos alunos.

Nesta tese, buscamos, portanto, analisar qual o espaço dedicado às imagens nos livros didáticos de FLE publicados nas últimas quatro décadas. Interessa-nos saber não somente qual o espaço físico ocupado pelas imagens nas páginas do livro do aluno, mas também - e sobretudo - qual o espaço pedagógico reservado para sua utilização em sala de aula e se houve, desde então, uma transformação em seu uso pedagógico. 
Antes de passarmos às perguntas de pesquisa que guiam este estudo, parece-nos importante definir desde já a concepção que utilizamos do termo "texto". De acordo com as autoras Leonor Lopes Fávero e Ingedore Villaça Koch (1983), esse termo pode ser tomado em duas acepções:

Texto em sentido amplo, designando toda e qualquer manifestação da capacidade textual do ser humano (uma música, um filme, uma escultura, um poema etc.), e, em se tratando de linguagem verbal, temos o discurso, atividade comunicativa de um sujeito, numa situação de comunicação dada, englobando o conjunto de enunciados produzidos pelo locutor (ou pelo locutor e interlocutor, no caso dos diálogos) e o evento de sua enunciação.

(FÁVERO \& KOCH, 1983: 25)

Nesta tese, adotamos a primeira acepção citada pelas autoras ao utilizarmos o termo "texto". Esse sentido mais amplo é usado nesta tese para nos referirmos a diferentes modos semióticos: texto verbal, texto oral, texto visual. Por essa razão, utilizamos neste trabalho expressões como "texto visual" e "texto verbal". Vale ressaltar, no entanto, que quando falamos em relação "texto-imagem" em um livro didático, o termo "texto" aparece em oposição a "imagem" e, portanto, refere-se ao texto linguístico (texto escrito e verbal).

Passemos agora às perguntas de pesquisa que guiam este estudo:

- Qual espaço físico os livros didáticos de FLE reservam para a imagem do ponto de vista estrutural, ou seja, na composição de suas páginas? A evolução tecnológica na qualidade da imagem acompanhou-se também do aumento de sua presença nos livros didáticos? Em outras palavras, buscamos estudar qual o espaço físico dedicado à imagem em alguns exemplos de manuais das duas metodologias citadas. Elas estão presentes em todas as páginas? Na maioria ou na minoria delas? Qual a proporção entre as páginas do livro do aluno compostas exclusivamente por textos e as páginas compostas por texto e imagem?

- Que espaço pedagógico é previsto para as imagens nesses livros didáticos e em seus respectivos guias para o professor? Analisamos, para isso, os enunciados das 
atividades propostas no livro do aluno e também as preconizações para o uso da imagem no respectivo guia pedagógico. Que orientações o guia pedagógico reserva para a exploração das imagens do livro do aluno? Há atividades previstas para se trabalhar as imagens? Em caso afirmativo, de que forma? Qual a relação entre texto e imagem? A imagem aparece sempre subordinada ao texto, como uma simples ilustração do mesmo? Que relações de poder e/ou de interação entre texto e imagem encontramos nas páginas desses livros didáticos?

- Em caso de aumento da presença da imagem nos livros didáticos, houve mudanças no tratamento pedagógico reservado ao suporte visual? Pretendemos obter essa resposta a partir da análise dos elementos levantados na pergunta anterior. As preconizações dos guias pedagógicos para o uso da imagem e as atividades previstas para a mesma nos livros didáticos sofreram mudanças ao longo das últimas décadas? Que relação podemos estabelecer entre evolução técnica e evolução pedagógica no que diz respeito ao uso da imagem no ensino-aprendizagem do FLE?

- Que funções estão previstas para a imagem nos livros didáticos de FLE? Que funções a imagem pode exercer no ensino-aprendizagem do FLE? Como favorecer o desenvolvimento de letramentos múltiplos nos alunos de FLE capacitando-os a interagir em diferentes situações sócio discursivas? Que tipo de atividades podem favorecer o desenvolvimento desses letramentos e promover, consequentemente, um melhor aprendizado e uma melhor aquisição da língua francesa?

- Qual a opinião dos professores sobre as imagens dos livros didáticos e as respectivas preconizações para o seu uso? Quais utilizações os professores de FLE preveem para a imagem e realizam efetivamente em sala de aula? As preconizações do guia pedagógico e as atividades propostas no livro do aluno lhes parecem claras, pertinentes e realizáveis em seu contexto de trabalho? Há necessidade de adaptações? Em caso de adaptações, que outros elementos são levados em conta pelo professor (perfil dos alunos, nível de aprendizado, etc.)? Que formações poderiam ajudar os professores na tarefa de trabalhar a imagem em sala de aula? 


\section{Histórico e Contexto de pesquisa}

Esta pesquisa surgiu a partir das experiências na área do ensino do FLE que desenvolvo7 há dez anos em uma escola privada de FLE instalada na capital de São Paulo, a Aliança Francesa de São Paulo. Trabalhei primeiramente nessa escola de forma exclusiva como professora e assumi, em seguida, outras funções no departamento pedagógico onde trabalho atualmente como Adjunta ao Diretor de Ensino. Dessa experiência - tanto dentro da sala de aula como fora dela, principalmente no trabalho de formação dos professores - surgiu o interesse de refletir de forma mais aprofundada sobre o papel que as imagens podem exercer, em um mundo tão imagético, no ensinoaprendizagem de uma língua estrangeira.

A Aliança Francesa está instalada há 130 anos no Brasil e há 81 anos na cidade de São Paulo e dedica-se, de forma exclusiva, à difusão da língua francesa e da cultura de países francófonos. Trata-se de uma instituição sem fins lucrativos que dispõe de sete unidades na cidade de São Paulo, nas quais são ministrados cursos de francês para os seis níveis de competências descritos pelo Quadro Europeu Comum de Referência para Línguas, doravante QECR (CONSELHO DA EUROPA, 2001): A1 (descoberta), A2 (intermediário), B1 (acesso), B2 (avançado), C1 (autonomia), C2 (domínio). Cada nível é dividido em módulos de 45h a 6oh. Quanto mais avançado o nível, maior a duração em número de horas do curso, em uma progressão que se baseia nas competências descritas pelo QECR para cada um desses níveis e também no número de horas estimativo estabelecido pelo $\mathrm{CIEP}^{8}$ para falantes de uma língua materna latina.

A Aliança Francesa de São Paulo adota livros didáticos em todos os níveis de seus cursos regulares $^{9}$, a única exceção são os módulos temáticos do curso C2 que dispensam a utilização de livros didáticos pois seu conteúdo foi elaborado pelo departamento pedagógico juntamente com um grupo de professores da instituição. Sendo assim, os cerca de 70 professores de FLE da escola trabalham diariamente com um livro didático.

\footnotetext{
7 Estabelecemos uma diferença na utilização de dois pronomes pessoais distintos. Utilizaremos a $1^{\text {a }}$ pessoa do plural, "nós”, quando nos referirmos à pesquisadora que está escrevendo e apresentando este trabalho. Utilizaremos a $1^{\text {a }}$ pessoa do singular quando tomarmos a palavra, não como pesquisadora, mas como colaboradora da Aliança Francesa de São Paulo.

${ }^{8}$ CIEP: Centre International d’Études Pédagogiques.

9 "Cursos regulares" são os cursos de FLE da instituição. Em outros tipos de cursos que oferecemos, como cursos livres culturais ou cursos especiais preparatórios para exames, não há adoção de um livro didático.
} 
Paralelamente, a instituição investiu em uma atualização de seus equipamentos tecnológicos ao longo dos últimos anos. Desde 2010, todas as salas das sete unidades da escola estão equipadas com computadores, vídeo-projetores, conexão Internet e quadro digital interativo (Tableau Numérique Interactif) ${ }^{10}$. Como coordenadora pedagógica da escola, participei da concepção de 44 sequências didáticas de nível A1 a B1 concebidas exclusivamente para o TNI, já que os livros digitais em FLE ainda não estavam disponíveis nessa época. Boa parte dessas sequências eram compostas por imagens, o que me levava a uma preocupação quanto à escolha e à exploração pedagógica das mesmas.

Em 2011, em uma decisão tomada em nível nacional da rede das Alianças Francesas no Brasil, adotou-se um novo livro didático que vem acompanhado por uma versão digital para uso no TNI. Apesar da qualidade da imagem e do suporte visual, a proposta estrutural do livro não se adequava a nosso contexto de trabalho e foi preciso, portanto, intensificar o diálogo com os professores e a quantidade de reuniões e de formações pedagógicas para encontrarmos soluções em conjunto. Algumas atividades propostas pelo livro didático não nos pareciam pertinentes. Em uma visita à Aliança Francesa de São Paulo e durante uma conversa com nossos professores, um dos autores do livro, ao comentar uma dessas atividades - no caso, um exercício em que alunos iniciantes devem transcrever um diálogo - afirmou que a mesma também não lhe parecia pertinente e que ela foi proposta não pelos autores do livro didático, mas sim, por outra equipe antes da publicação do material.

Em discussões informais com dois outros autores de livros didáticos de FLE que trabalharam em duas outras editoras, percebi que o autor do livro didático tem um controle limitado na escolha das imagens já que as mesmas estão submetidas a direitos autorais, por vezes bastante caros. Buscando mais informações sobre o processo de criação de um livro didático, aprendi com esses autores que vários elementos estruturais da obra como, por exemplo, o número de páginas ou o espaço físico reservado às imagens, muitas vezes são pré-determinados pelo editor.

Dentro desse contexto, a necessidade de formação dos professores à utilização do material didático adotado na escola pareceu-me cada vez mais evidente. Notei que alguns professores, principalmente os mais novos que haviam integrado a instituição há pouco tempo, acreditavam que as preconizações do livro didático e do respectivo guia

\footnotetext{
${ }^{10}$ De agora em diante, TNI.
} 
pedagógico deveriam ser seguidas estritamente sem grandes reflexões, pois se tratava de uma "norma" estipulada pela instituição. Essa atitude me parecia bastante preocupante pois ela ignorava ou relegava a um aspecto secundário o que me parece essencial em uma aula de língua estrangeira na qual um livro didático é adotado: o jogo entre o distanciamento e ao mesmo tempo a apropriação que o professor deve ter em relação a esse material.

Por distanciamento, entendo não tanto um olhar crítico e/ou negativo em relação às propostas das editoras - que, de qualquer forma, nunca poderão agradar a todos os profissionais nem a todo tipo de público, principalmente por serem feitas para países e contextos tão diferentes - mas sim, um olhar que leve em conta o contexto de aplicação desse livro didático, o perfil, as dificuldades, facilidades e necessidades desse público específico. Informações estas que apenas o professor em questão detém e das quais deverá se servir para utilizar, adaptar e se apropriar desse material didático escolhido pela instituição para criar - a partir dele e de seus alunos - seu próprio curso.

As reuniões e formações pedagógicas tornaram-se, portanto, mais frequentes em meu contexto de trabalho dentro de um processo que tinha como objetivo valorizar o trabalho do professor e conscientizar o mesmo de que nem sempre as indicações do guia pedagógico eram as mais pertinentes para os seus alunos, para os seus objetivos, para o seu contexto de trabalho. Nessa época, propusemos aos professores adaptações em algumas sequências pedagógicas do livro didático para que as mesmas se adaptassem melhor a nosso contexto. Essas sequências previam: descoberta dos aspectos linguísticos de forma indutiva e contextualizada, produções orais e escritas próximas das da vida real, valorização dos documentos autênticos e também da autenticidade no trabalho com os mesmos em recepção e em produção. Os professores passaram também a compartilhar suas próprias adaptações e atividades complementares com o departamento pedagógico e com os colegas.

Paralelamente a esse trabalho de formação dos professores, ministrei aulas como professora de FLE nos últimos vinte anos utilizando diferentes livros didáticos. Durante essa experiência, tive a impressão de notar um aumento na quantidade e na qualidade das imagens nessas publicações, sem sentir, no entanto, uma diferença na utilização pedagógica preconizada para as mesmas. Interessei-me em investigar mais profundamente essa questão. 
A partir dessas diversas experiências, optei por utilizar a própria instituição em que trabalho para realizar este estudo e buscar, por meio dele, respostas às perguntas de pesquisa apresentadas na seção anterior. Como vimos, esta tese busca conhecer não somente as preconizações dos livros didáticos de FLE para o uso da imagem, mas também a opinião dos professores sobre essas orientações e os usos que eles reservam efetivamente para o suporte visual de que dispõem. Por essa razão, escolhemos para esta pesquisa quatro livros didáticos que foram adotados pela Aliança Francesa de São Paulo nas últimas quatro décadas e fizemos a coleta de dados a partir de questionários realizados junto a seus professores.

\section{Metodologia da pesquisa}

Conforme vimos anteriormente e a fim de restringir nosso campo da pesquisa e de nos concentrarmos em uma época que se caracterizou por uma intensa evolução tecnológica no uso da imagem, este estudo levará em conta apenas livros didáticos de FLE pertencentes às duas metodologias mais recentes no ensino-aprendizagem de línguas estrangeiras: a abordagem comunicativa, desenvolvida a partir da década de 1970, e a perspectiva acional, que surgiu com a publicação do QECR (CONSELHO DA EUROPA, 2001) e que é a referência metodológica atual da Aliança Francesa de São Paulo.

\section{Critérios para a escolha dos métodos a serem analisados:}

Além das razões evocadas acima, também foram levados em conta os seguintes critérios na escolha dos livros didáticos a serem estudados:

- Buscar livros didáticos de editoras diferentes já que, muitas vezes, uma editora pode privilegiar mais do que outra a utilização de imagens;

- Buscar livros didáticos das editoras mais representativas no mercado editorial do FLE, como CLE International, Didier, Hachette FLE;

- Buscar livros didáticos pertencentes ao mesmo nível de aprendizagem. Neste caso, escolhemos quatro livros didáticos concebidos para alunos iniciantes em FLE, ou seja, todos os livros analisados são do nível A1 do QECR. Isso garantiu uma homogeneidade nos critérios de análise, evitando-se que uma eventual mudança no 
tratamento da imagem de um livro para outro pudesse se justificar pela diferença do nível de alunos aos quais as publicações se destinam.

- Escolher apenas livros didáticos que tivessem sido adotados nas últimas décadas pela Aliança Francesa de São Paulo. Como esta pesquisa prevê também a aplicação de um questionário junto aos professores da instituição, sua experiência com os livros didáticos analisados criou um elo importante para este estudo.

Por todas as razões citadas acima, selecionamos os seguintes livros didáticos para análise:

- Archipel 1 - das autoras Janine COURTILLON e Sabine RAILLARD. Livro publicado pela editora Didier em 1982;

- Espaces 1 - dos autores Guy CAPELLE e Noëlle GIDON. Livro publicado pela editora Hachette FLE em 1990;

- Forum 1 - dos autores Christine BAYLON, Angels CAMPÀ, Claude MESTREIT, Julio MURILLO, Manuel TOST. Livro publicado pela editora Hachette FLE em 2000;

- Écho A1 - dos autores Jacky GIRARDET e Jacques PÉCHEUR. Livro publicado pela editora CLE International em 2010. 
Figura 2 | Archipel 1, 1982.

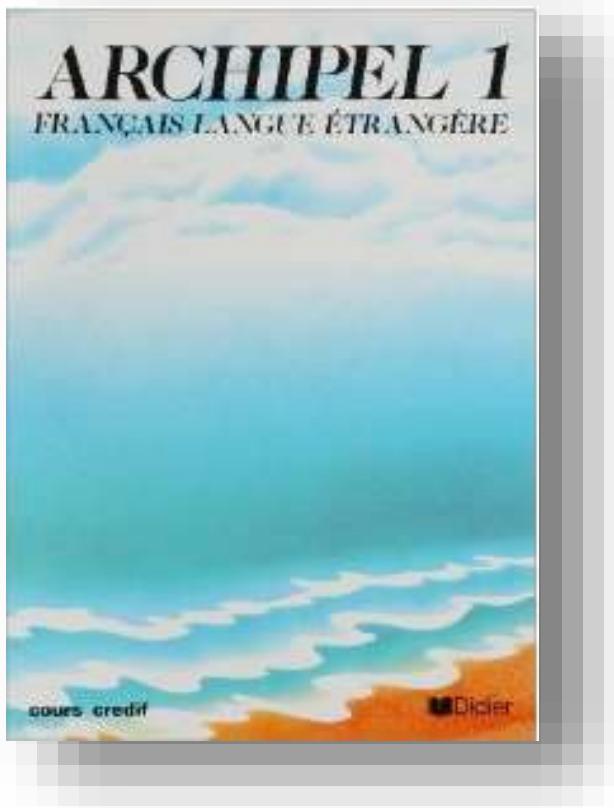

Figura 4 | Forum 1, 2000.

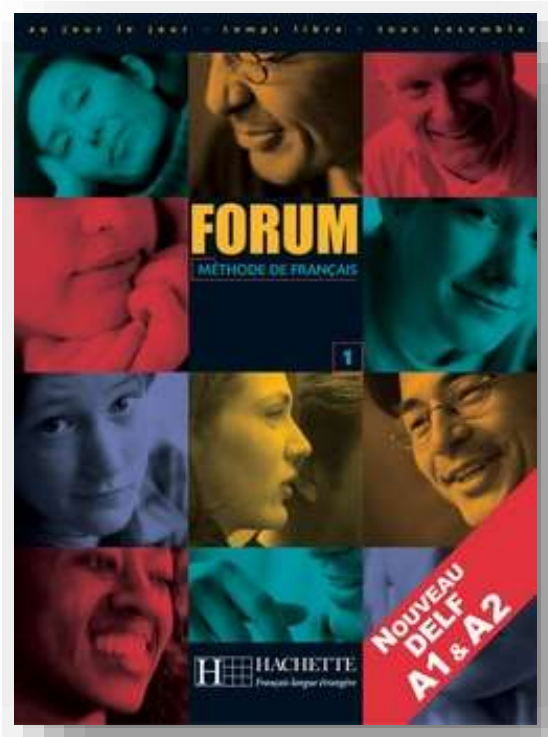

Figura 3 | Espaces 1, 1990.

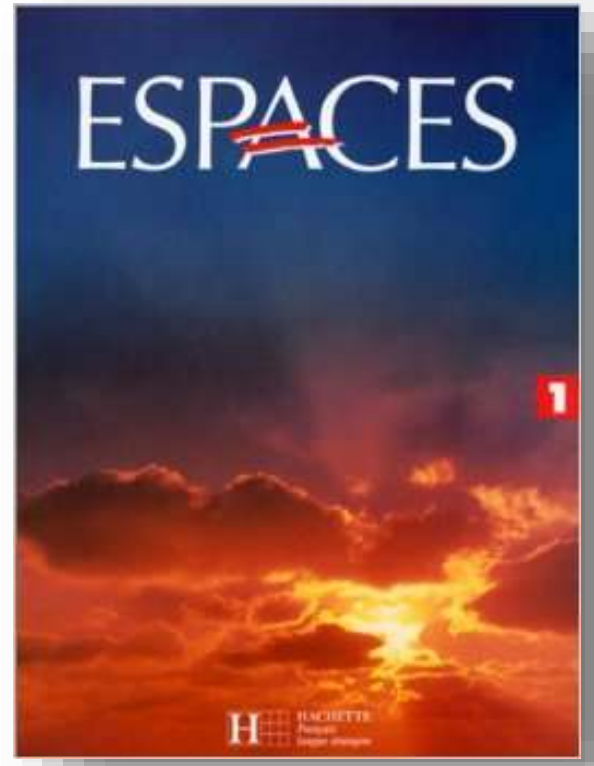

Figura 5 | Écho A1, 2010.

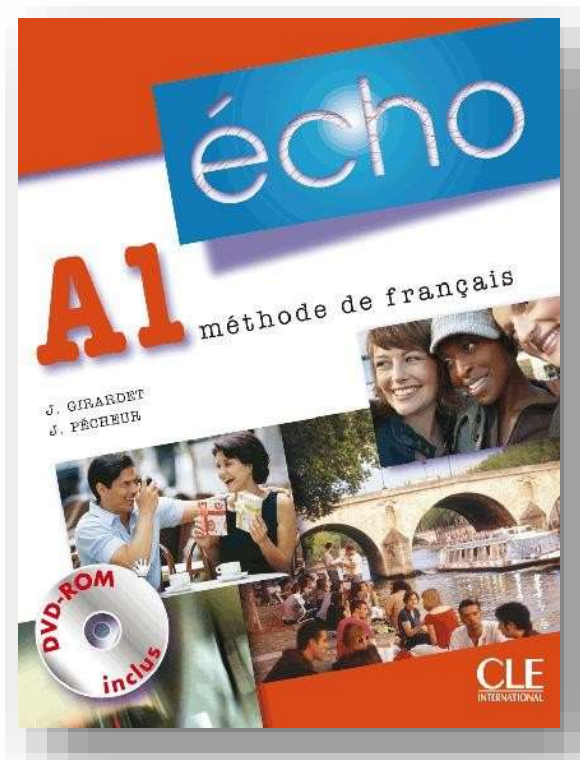

Esses quatro livros didáticos escolhidos são também bastante representativos de cada década em questão. Para cada um deles, analisamos dois suportes da coleção: livro do aluno e guia pedagógico. 
A análise do corpus foi feita em quatro etapas:

ETAPA 1:

Análise individual de cada livro do aluno e de seu respectivo guia pedagógico.

Objetivos:

- Identificar as características da capa do livro do aluno;

- Fazer uma análise quantitativa da presença das imagens: identificar a quantidade de páginas ilustradas em cada livro do aluno, assim como a proporção entre páginas compostas unicamente por textos e páginas compostas por textos e imagens;

- Fazer uma análise quantitativa da menção às imagens do livro do aluno no guia pedagógico;

- Fazer uma análise qualitativa do uso pedagógico preconizado para essas imagens: atividades propostas para a imagem nos enunciados do livro do aluno e nas respectivas orientações do guia pedagógico. Buscamos nos enunciados das atividades e no guia pedagógico pistas para compreender e para definir a função pedagógica da imagem prevista nas sequências didáticas e, de forma mais ampla, no ensino-aprendizagem de uma língua estrangeira;

- Identificar os tipos de imagens presentes no livro do aluno: fotos, desenhos, documentos autênticos, etc.

ETAPA 2:

Análise transversal dos quatro livros didáticos estudados.

\section{Objetivos:}

- Comprovar se houve realmente um aumento na quantidade de imagens utilizadas nos livros didáticos analisados;

- Verificar se esse eventual aumento foi acompanhado na mesma progressão por um aumento de citações à imagem no guia pedagógico;

- Identificar os tipos de imagem (fotos, desenhos, gráficos) mais utilizados nas últimas décadas para cada um dos componentes construtivos de uma lição/unidade em um livro didático de FLE: introdução temática, diálogos situacionais para compreensão oral, 
gramática, léxico, fonética, compreensão e produção escritas, aspectos culturais. Em outras palavras: que tipos de imagens são usadas para que funções?

\section{ETAPA 3:}

\section{Buscar novas vias para o uso pedagógico da imagem em textos compostos por mais} de um meio semiótico.

Objetivos:

- Identificar e definir as funções e os usos que a imagem pode ter no ensinoaprendizagem do FLE, a partir do cruzamento dessas análises e das utilizações possíveis para a imagem, mesmo quando as mesmas não estão descritas no livro;

- Identificar outras possibilidades de utilização da imagem e de atividades que favoreçam o desenvolvimento de letramentos múltiplos em FLE, capacitando o aluno a interagir em diferentes situações sócio discursivas.

\section{ETAPA 4:}

\section{A voz do professor: coleta e análise de dados}

Objetivos:

- Identificar a opinião do professor de FLE - grande responsável pela mediação entre o livro didático, a aprendizagem da língua e o aluno - sobre os seguintes aspectos:

- Quantidade e qualidade das imagens presentes nos livros didáticos;

- Quantidade e qualidade das preconizações do guia pedagógico para a utilização dessas imagens;

- Eventual necessidade de adaptação das imagens dos livros didáticos ou das atividades propostas para a mesma;

- A importância da imagem em sua vida cultural e cotidiana;

- Suas representações sobre a imagem;

- Suas práticas de ensino ligadas ao uso da imagem.

- Identificar eventuais necessidades de formações específicas nessa área para os professores de FLE. 
Acreditamos que esses eixos da pesquisa nos trarão elementos para propor um uso pedagógico mais reflexivo e eficaz não só da imagem, mas também de textos compostos por vários meios semióticos no ensino-aprendizagem do FLE. 


\section{CAPÍTULO 1| A IMAGEM NO}

\section{ENSINO-APRENDIZAGEM DE LÍNGUAS ESTRANGEIRAS}

La première écriture est une image peinte. 


\subsection{Imagem, uma introdução}

Imagem: uma única palavra é utilizada para definir uma infinidade de evocações. Com esse termo, podemos nos referir tanto às representações mentais que sempre acompanharam o ser humano quanto às inúmeras formas que essas representações mentais, visuais ou imaginárias podem tomar materialmente.

De acordo com o autor Michel Melot (2007), essa distinção entre a noção de imagem como ideia e de imagem como suporte material aparece em duas grandes famílias lexicais de origem indo-europeia. A primeira família é formada pelo radical weid - 'eidos' em grego, de onde vem o termo ideia - tendo dado origem aos termos ídolo e vídeo ('ver' em latim). Essa noção parece mais estreitamente ligada ao processo da visão, ou seja, ao aspecto mental da imagem. A segunda família é formada pelo radical weik que, através do grego eikon, deu origem a 'ícone’ e designa uma imagem material.

Ora, como definir a origem da imagem se o termo em si abrange noções tão distintas? Melot (2007) nos fornece uma pista de resposta para essa questão quando une as duas noções, na citação a seguir:

A origem da imagem não deve ser buscada através dos séculos. Ela sempre esteve dentro de nós. Uma forma torna-se imagem assim que ela é observada, fazendo com que surjam imediatamente associações da memória. Mas essas associações são inúmeras, frágeis, efêmeras. A língua vem frequentemente lhes fornecer um nome, estabilizando, assim, a relação. Podemos então falar de figura. ${ }^{11}$

(MELOT, 2007: 24)

Partindo dessa citação, consideramos neste trabalho a noção de imagem, não como ideia mental - cuja origem seria, portanto, a mesma da humanidade, já que ela sempre esteve "dentro de nós", mas sim, a noção de imagem como figura, ou seja, de uma imagem concretizada em um suporte material.

Dentro dessa perspectiva, encontramos a mais antiga imagem do mundo na forma de cinco blocos de ocre vermelho gravados pela mão do homem com formas de quadriláteros, há 77.000 anos, em uma gruta perto da cidade do Cabo, na África do Sul.

\footnotetext{
${ }^{11}$ Tradução nossa. Citação original : “L'origine de l'image n'est pas à chercher dans les siècles. Elle est toujours en nous. Une forme devient image dès qu'elle est observée, faisant aussitôt surgir des associations de la mémoire. Mais ces associations sont innombrables, fragiles et éphémères. La langue vient souvent leur donner un nom, stabilisant ainsi la relation. On peut alors parler de figure. ”
} 
As primeiras representações e desenhos pré-históricos parecem estar ligados ao desenvolvimento da linguagem que permite a figuração. A pedagogia confirma, segundo Melot (2007: 25), que a aprendizagem da representação das figuras está ligada à aprendizagem das palavras que permitem nomeá-las: “a imagem mental precede a língua, mas a língua precede sua materialização, que consiste então em uma espécie de ideograma". Ao analisar essa citação, notamos uma transição entre as duas noções de imagem que mencionamos anteriormente: imagem mental (image) e imagem material (picture). Curiosamente, a linguagem verbal aparece como mediadora desse processo de materialização da imagem, como vemos abaixo (esquema nosso):

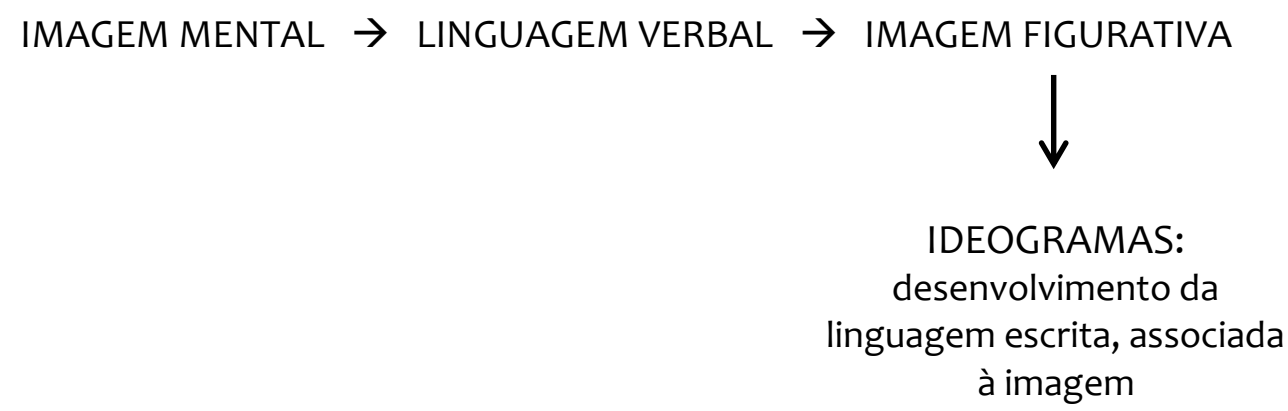

Esses desenhos pré-históricos destinavam-se a comunicar mensagens e, segundo Joly (2007), muitos deles constituíram aquilo que chamamos "os pré-anunciadores da escrita" e que são considerados também os primeiros meios de comunicação humana.

É interessante notar como a imagem e a linguagem estavam, desde o princípio, tão estreitamente associadas. A naturalidade dessa associação é confirmada por Joly (2007: 11):

A oposição imagem/linguagem é uma falsa oposição, uma vez que a linguagem não só participa na construção da mensagem visual, mas transmite-a, completando-a mesmo, numa circularidade simultaneamente reflexiva e criadora.

(JOLY, 2007: 11)

Retomando nosso percurso histórico, é importante lembrar como as imagens constituíram uma questão essencial nas religiões judaico-cristãs. De fato, a noção da imagem e seu estatuto constituíram temas de grande discussão. A questão da proibição, em algumas religiões, de se fabricar e adorar imagens é um exemplo de como a imagem pode ser confundida ou substituída pelo modelo que ela representa, por meio da semelhança. Essa discussão sobre o real estatuto da imagem perdurou na sociedade 
ocidental do século IV ao século VII da nossa era, opondo iconófilos e iconoclastas, e constitui um exemplo do questionamento sobre a natureza divina ou não da imagem (JOLY, 2007).

A função educadora da imagem, preconizada na Antiguidade por Aristóteles, parece afirmar-se na Idade Média com pinturas murais e vitrais que representavam, por meio de signos visuais, passagens das escrituras sagradas.

Já na época Renascimento, assistimos a uma laicização da imagem, com o surgimento de gêneros pictóricos não religiosos. A noção de "artista", substituindo a de "artesão", e a noção de autoria também surgiram nessa época e forneceram as bases para o conceito de arte e de imagem artística que temos nos dias de hoje.

A invenção da fotografia constitui uma etapa importantíssima nesse percurso da imagem. De acordo com Dondis (2007), o advento da câmera é um acontecimento comparável ao advento do livro no que se refere ao desenvolvimento da linguagem visual. Com o surgimento da imprensa, houve um deslocamento dos meios auditivos da linguagem verbal para seus meios visuais. No campo da linguagem visual, a fotografia mudou a forma de vermos o mundo e multiplicou suas representações. Nossa preparação para a leitura dessa linguagem, no entanto, não se desenvolveu com a mesma rapidez.

O professor e pesquisador francês Francis Yaiche (2002) afirma que ninguém fica indiferente a uma fotografia pois nos sentimos todos envolvidos por ela seja como fotógrafos amadores ou como "consumidores" de imagens. Segundo o autor, a fotografia faz reagir, relembra memórias, convida ao debate, solicita impressões, faz falar e suscita a vontade de escrever. Um suporte, portanto, perfeito para a sala de aula. Yaiche afirma que a ideia de recorrer à fotografia em sala de aula deveria ser uma técnica utilizada com mais frequência. Apesar de vivermos em uma civilização da imagem, a mesma ainda está pouco presente como suporte ou objeto de aprendizagem.

Em seu livro Photos-expressions, Yaiche (2002) propõe várias atividades de exploração da fotografia dentro do ensino-aprendizagem do FLE. Acreditamos que esse tipo trabalho é essencial para que os professores façam um uso mais consciente e aprofundado tanto das fotografias que já estão presentes nos livros didáticos quanto daquelas que o próprio professor e/ou os próprios alunos trouxerem para a sala de aula. 
Um aspecto interessante do uso da fotografia como meio de expressão individual do aluno em sala de aula é evocado pelo autor da seguinte forma:

Sabemos que frequentemente um aluno tem reticências em falar de si mesmo na medida em que deve falar em seu próprio nome, sob sua própria identidade; no entanto, assim que lhe propomos de construir uma história (sozinho ou em grupo) a partir de um suporte projetado como uma simulação global ou uma foto, damos ao aluno a possiblidade de expressar certas preocupações de forma desdramatizada e, sobretudo, sem que os outros saibam que, desta forma, ele fala de si mesmo, expressando uma preocupação pessoal mais ou menos consciente. [...] Não poder falar de si na escola significa, às vezes, não poder falar e isso constitui, então, um obstáculo à aprendizagem. ${ }^{12}$

(YAICHE, 2002: 11)

Retomamos, mais adiante nesta pesquisa, essa questão da imagem como meio de expressão para o aluno, um ponto que nos parece fundamental no ensinoaprendizagem do FLE.

\subsection{O uso da imagem no ensino-aprendizagem de línguas estrangeiras}

A imagem já foi vista como uma inimiga da pedagogia, ou seja, como um obstáculo ao que é realmente importante, isto é, o acesso ao conceito. Essa ideia ainda encontra eco nos dias de hoje e muitos teóricos consideram que, numa sociedade como a nossa, invadida e dominada pela imagem, um retorno à abstração e ao conceito seria extremamente bem-vindo.

Tal discussão põe em evidência a constante busca por um equilíbrio entre imagem e texto. Segundo o pensador Neil Postman (1981), durante o século XIX e início do século $X X$, o texto dominava completamente a esfera intelectual, o que levou a escola a introduzir a imagem para compensar esse domínio. De acordo com o mesmo autor, o papel da escola nos dias de hoje, num mundo que é - antes de tudo - um mundo de imagens, seria o de privilegiar o texto de maneira intensa e até mesmo exclusiva.

${ }^{12}$ Tradução nossa. No original : "On le sait, bien souvent un élève a des réticences à parler de lui dans la mesure où il doit parler sous son propre nom, sous sa propre identité ; mais dès lors qu'on lui propose de construire une histoire (seul ou en groupe) à partir d'un support projectif comme une simulation globale ou une photo, on lui donne la possibilité d'exprimer certaines préoccupations d'une façon dédramatisée, et surtout sans que les autres sachent que de la sorte il parle de lui, exprime une préoccupation personnelle plus ou moins consciente. [...] Ne pas pouvoir parler de soi à l'école est parfois ne pas pouvoir parler du tout, et cela constitue alors un obstacle à apprendre. » 
Mas como dissociar escola e sociedade? A imagem ocupa atualmente um papel essencial na vida dos alunos e as publicações didáticas tentam acompanhar a evolução tecnológica das últimas décadas. Evolução essa que permitiu uma diminuição dos custos de impressão a cores e abriu o caminho para a revolução digital, ou seja, aumentou consideravelmente a difusão e o domínio da imagem.

\subsubsection{Comenius e o primeiro livro didático ilustrado}

No campo do ensino-aprendizagem de línguas estrangeiras, a relação estabelecida entre o ensino e a imagem tem sido privilegiada, mas também tem se revelado inconstante. O escritor, teólogo e humanista Jan Amos Komensky, mais conhecido pelo nome latim de Comenius (1592-1670), publicou em 1658 Orbis Sensualium Pictus, considerado hoje o primeiro livro didático ilustrado. A intenção de Comenius, ao criar este material didático destinado às crianças, era a de fazer do aprendizado de uma língua estrangeira - no caso, o latim - uma verdadeira atividade lúdica (GERMAIN, 2004).

Para isso, ele concebeu um livro que associa a língua materna e o latim - por meio de listas de vocabulário - a aspectos e objetos que compõem o mundo, apresentados de forma ilustrada, por meio de xilogravuras. Esses aspectos são definidos pelo próprio educador como "imagens e nomes de todas as coisas fundamentais no mundo e nas atividades da vida”. Eles são apresentados em unidades didáticas, ou capítulos, que têm como títulos: "O Homem”, “A escrita”, “A agricultura”, “As árvores”, “A horta”, “A escola", etc. O texto e sua imagem correspondente estão ligados por números que permitem identificar rapidamente a ilustração de cada novo elemento lexical (Fig. 6, 7).

Comenius uniu linguagem visual e linguagem escrita em um livro que nomeia, mostra e escreve sobre diversos assuntos. O pesquisador Carlos Miranda (2011) apresenta da seguinte forma a relação entre texto e imagem nesse livro:

Assunto e aquisição da linguagem não estão separados. As imagens não são meras ilustrações do texto escrito: são apresentações figurativas do assunto comentado. [...]

Orbis Pictus possui 150 unidades didáticas que vão da natureza à religião, passando pelo homem, por seu corpo e por suas atividades produtivas e societárias. A aprendizagem da linguagem imagem e escrita - e a aprendizagem do conhecimento, os assuntos de cada unidade didática, articulam-se na construção de uma visão de mundo. 
De acordo com o mesmo pesquisador, a iconografia na educação havia sido utilizada, até então, apenas em afrescos pintados em igrejas para os fiéis católicos e em livros de intelectuais que tinham como mecenas nobres e reis. Por essa razão, Comenius pode ser considerado o primeiro educador a utilizar a imagem em um livro didático para a educação em contexto escolar. O livro conheceu um grande sucesso e foi utilizado na Europa durante os dois séculos seguintes à sua publicação.

A publicação desse livro no século XVII desmistifica a ideia de que o uso da imagem em contexto escolar para a educação tenha sido introduzido pela sociedade industrial moderna.

Figura 6 | Orbis Sensualium Pictus¹3, 1658. Capítulo 91: Objetos da escrita

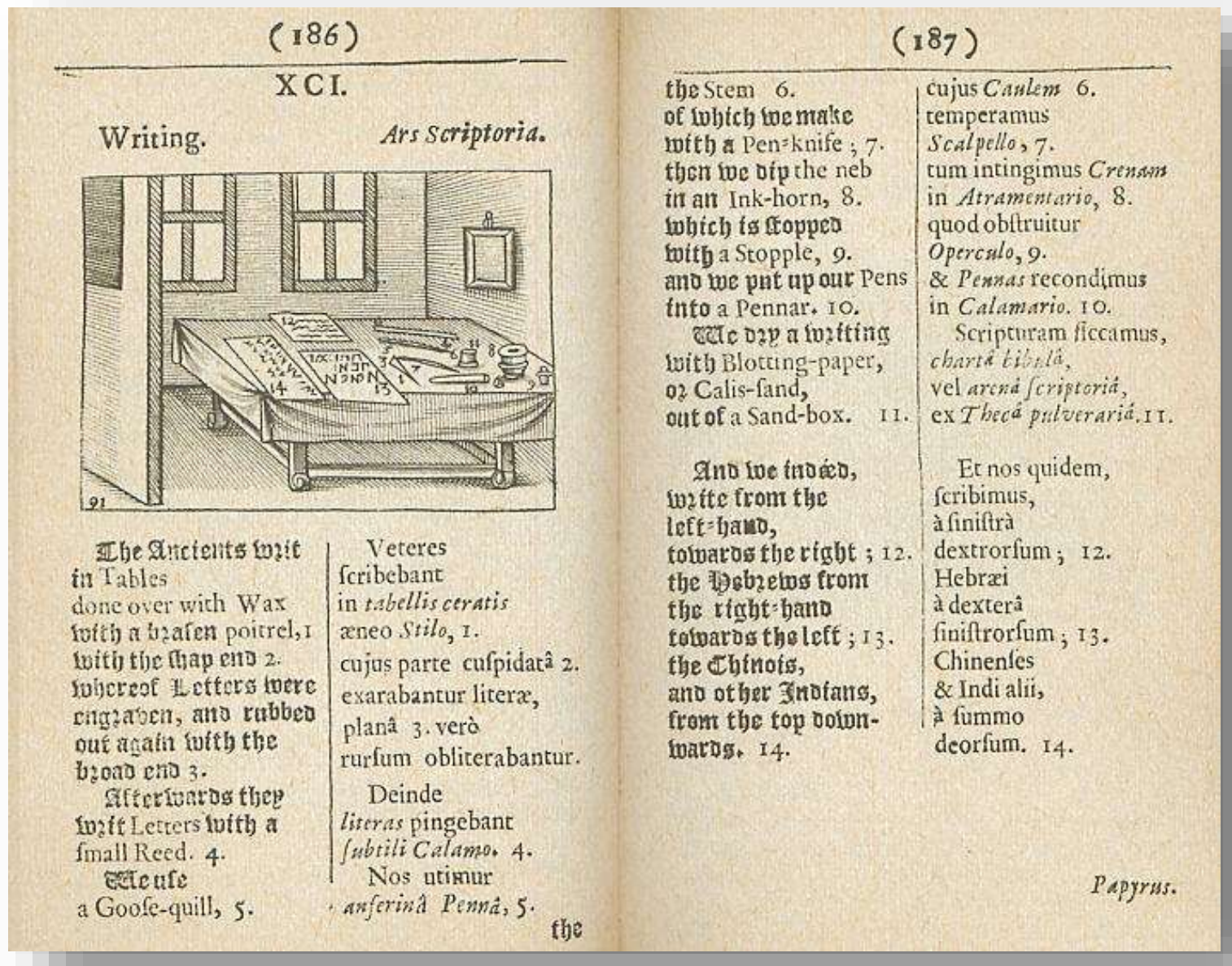

13 Imagem retirada do site:

http://www.uned.es/manesvirtual/Historia/Comenius/OPictus/OPictusAA.htm em 19.03.2011. 
Figura 7 | Orbis Sensualium Pictus, $1658^{14}$.

Capítulo 123: Partes internas de uma cidade

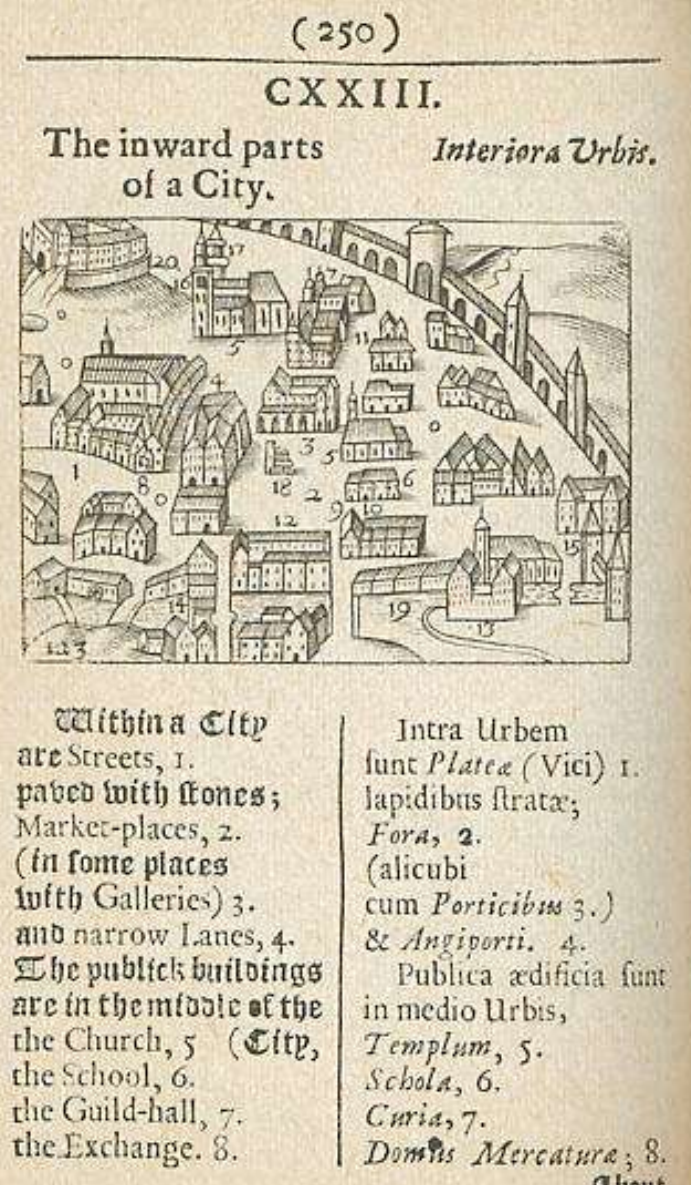

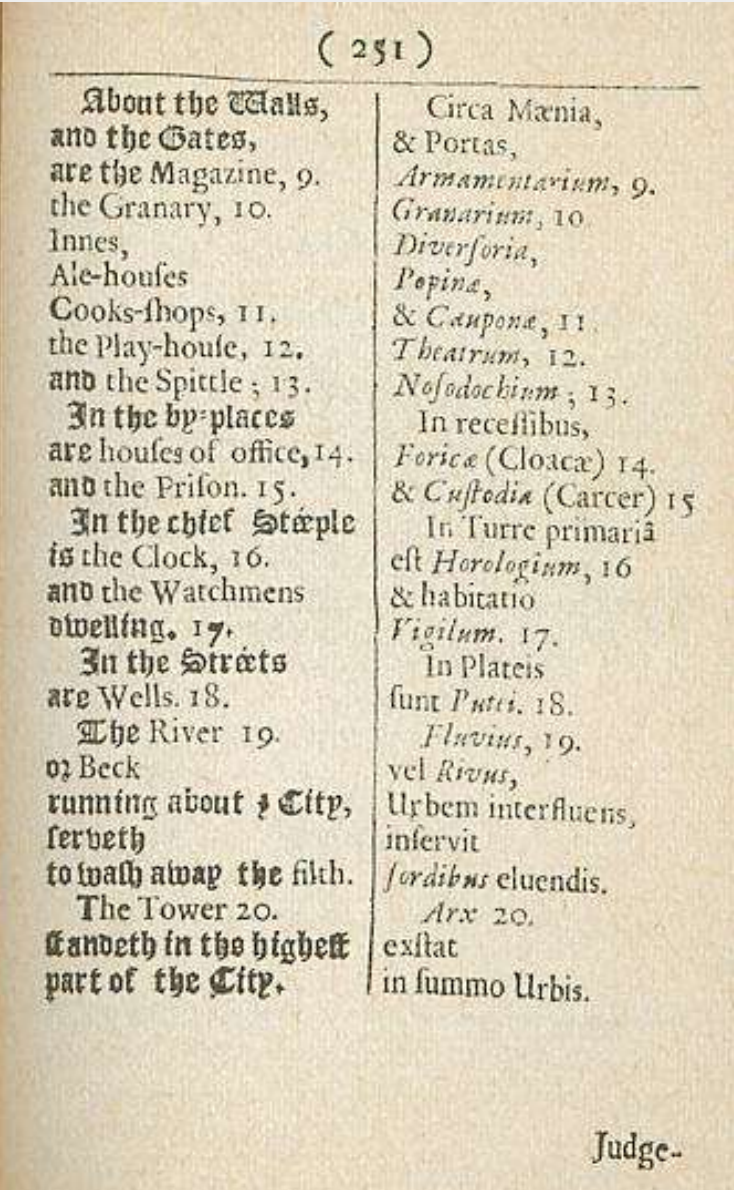

glbout

No que diz respeito à função lúdica da ilustração, vale lembrar um dos estatutos da imagem estabelecidos por Philippe Meirieu (2003). De acordo com o autor, a imagem "iluminura" tem a função de diminuir a austeridade do texto, servindo de ilustração e acompanhamento ao que é realmente "sério", ou seja, a leitura. Essa visão ainda é amplamente utilizada pelos livros didáticos, mas, segundo Meirieu, traz um grande paradoxo, uma vez que, muitas vezes, os alunos dedicam mais tempo à imagem do que ao texto que a acompanha.

${ }^{14}$ Imagem retirada do site:

http://www.uned.es/manesvirtual/Historia/Comenius/OPictus/OPictusAA.htm em 19.03.2011. 


\subsubsection{O texto e a imagem na história das metodologias de FLE}

Antes de nos concentrarmos na análise de livros didáticos pertencentes às metodologias da abordagem comunicativa e da perspectiva acional, parece-nos pertinente propor um breve panorama histórico das metodologias que foram mais frequentemente utilizadas no ensino-aprendizagem do FLE, buscando relembrar, em cada uma delas, o papel reservado à imagem na aprendizagem e a relação hierárquica entre texto e imagem.

Dentro da evolução do ensino das línguas estrangeiras, observamos momentos em que o texto escrito e a leitura se sobrepuseram ao aspecto oral e comunicativo da língua. O método gramática-tradução - também chamado de tradicional ou “clássico", pois se prestava inicialmente sobretudo ao ensino das línguas clássicas como o grego e o latim - é considerado a primeira sistematização metodológica no ensino de línguas. $O$ grande objetivo dessa metodologia era não somente compreender e utilizar uma língua, mas também ter acesso a uma cultura literária de alto nível, buscando-se no ensino das línguas vivas os mesmos objetivos do ensino das línguas clássicas, isto é, a aquisição de uma disciplina mental (GERMAIN, 2004) e o desenvolvimento intelectual do aluno. Autores como Gide, Hugo e Flaubert serviram de base para o ensino de francês, no qual se privilegiava o estudo do vocabulário, da gramática e da tradução (PIETRARÓIA, 1997). O texto literário constituía então o elemento fundamental de estudo dessa metodologia, passando-se da língua-alvo à língua materna sem recorrer à utilização da imagem.

Já a metodologia direta - que surgiu por volta do início do século XIX e sucedeu à gramática-tradução - renuncia à mediação da língua materna e propõe uma aprendizagem que se faz diretamente dentro da língua-alvo. Ora, uma vez que o sentido deixa de ser traduzido, ele deve ser alcançado de forma direta através de uma apreensão instantânea, como podemos constatar nesta passagem de Godard proferida numa conferência pedagógica de 1902. Nela o autor explica como a leitura direta, proposta por essa metodologia, dispensa o aluno da operação de tradução através da revelação imediata do sentido do texto:

De um só olhar, ele abraça a frase lida, ou melhor, deixa de vêla para compreendê-la. Mesmo ignorando algumas palavras, ele tem, desde o primeiro instante, a percepção mais ou menos clara do sentido geral e da organização do conjunto. (...) Ao trabalho analítico e lento da leitura gramatical, a leitura direta substitui assim uma impressão sintética e instantânea.

(GODARD, 1902: 221, apud PIETRARÓIA, 1997: 31) 
Talvez essa proposta de se alcançar o sentido através de uma "impressão instantânea" possa explicar porque a metodologia direta recorreu à utilização da imagem no ensino da língua estrangeira. Dentro dessa metodologia, a imagem tem uma função ilustrativa da linguagem, buscando facilitar esse acesso direto ao sentido. É graças aos objetos reais e às imagens do livro que o professor pode mostrar o sentido dos elementos linguísticos estudados. (Figura 8).

Figura 8 | Cours de langue et de civilisation française (MAUGER, 1953).

2 LEÇON 1

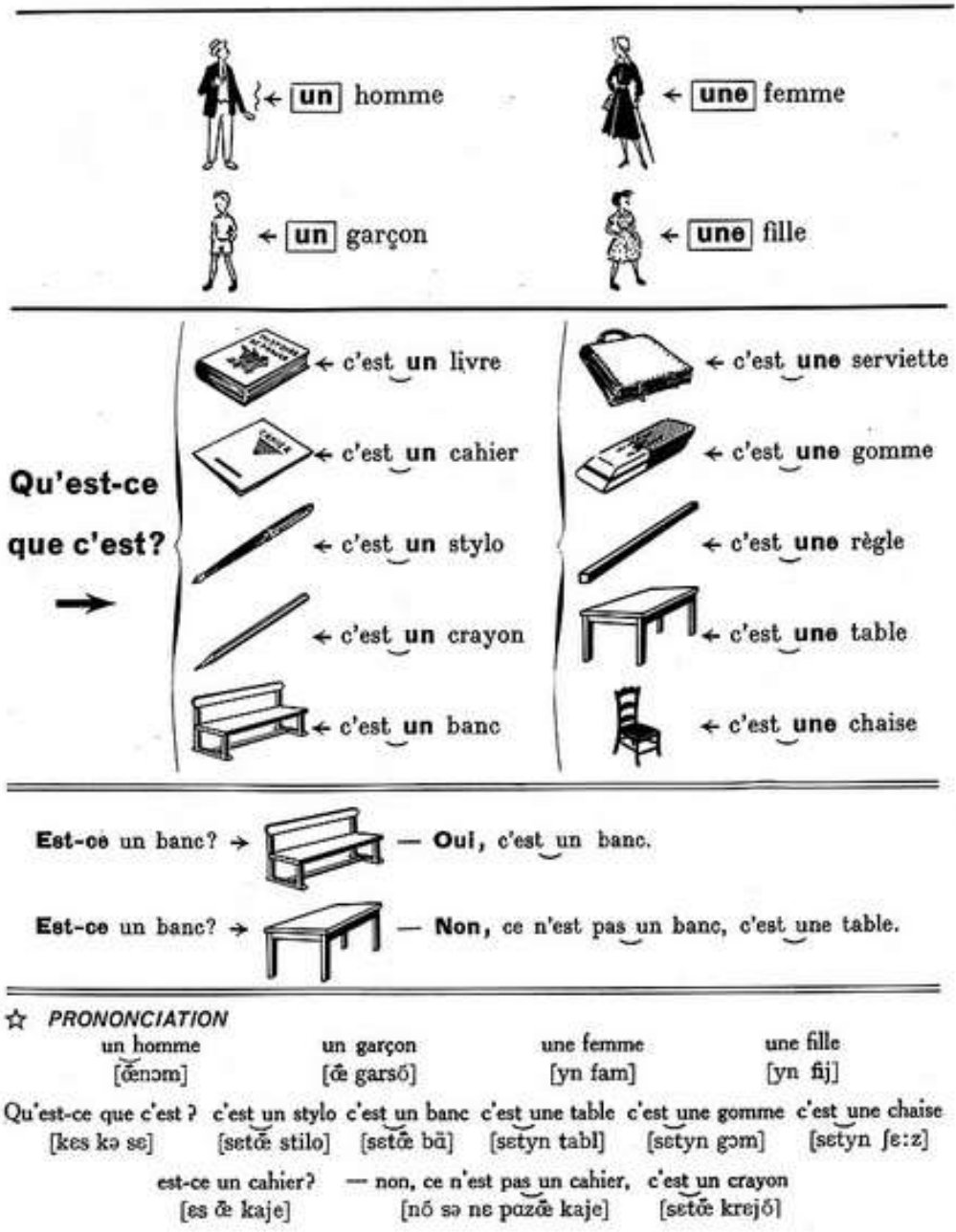

Ao compararmos as imagens dos métodos Orbis Sensualium Pictus, (COMENIUS, 1658) (Fig. 6,7) e Cours de langue et de civilisation française (MAUGER, 1953) (Fig. 8), 
notamos que, apesar dos três séculos que separam essas duas publicações, a função da imagem no ensino da língua estrangeira é basicamente a mesma: dar ao aluno um "acesso" ao sentido pela ilustração lexical. Se Comenius utilizava listas de palavras e imagens colocadas em destaque para ilustrar o sentido de um termo, o mesmo é feito por Mauger, porém de forma mais integrada entre os dois suportes, por meio de setas ou com o texto como legenda da imagem correspondente.

Revolucionária em sua época, a metodologia direta é também considerada de certa forma precursora da metodologia audiovisual. Dentro desse contexto, é interessante notar como a imagem parece se destacar justamente dentro das metodologias que relegam a escrita e o texto a um segundo plano, como se fosse a própria imagem - e não a linguagem oral - um contraponto à linguagem escrita. $O$ primeiro manual publicado dentro da metodologia SGAV intitulava-se, não por acaso, Voix et Images de France (BOUDOT, 1968), numa associação curiosa entre o discurso e a imagem. O trabalho com o texto escrito iniciava-se apenas após cerca de 60 horas de ensino a fim de não "atrapalhar" a compreensão global do sentido nessa primeira fase de aprendizagem. As imagens dos manuais SGAV são situacionais, no sentido em que ilustram situações de comunicação. (Figura 9).

Claude Germain nos lembra que, de acordo com Petar Guberina - um dos teóricos dessa metodologia - a aprendizagem de uma língua estrangeira passa pelos sentidos auditivo e visual.

O ouvido é o aspecto « auditivo » da metodologia SAGV e a vista, seu aspeto « visual ». O ouvido e a vista funcionam como filtros entre os stimuli exteriores e o cérebro. ${ }^{15}$

(GERMAIN, 1993: 155).

\footnotetext{
15 Tradução nossa. No original: "L'oreille, c'est l'aspect "audio" de la méthode SGAV et la vue, c'est
} son aspect 'visuel". L'oreille et l'œil servent de filtres entre les stimuli extérieurs et le cerveau. » 
Figura 9 | Voix et Images de France (BOUDOT, 1968).
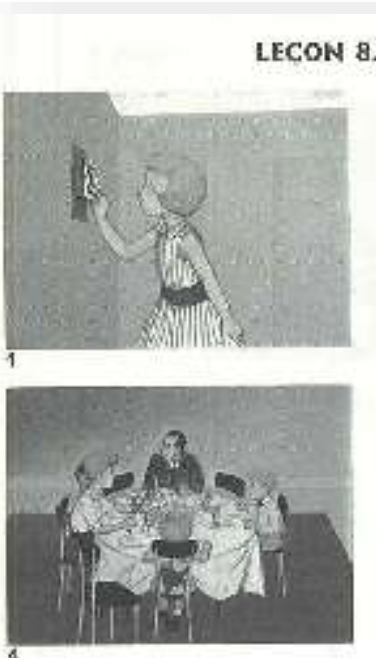

2
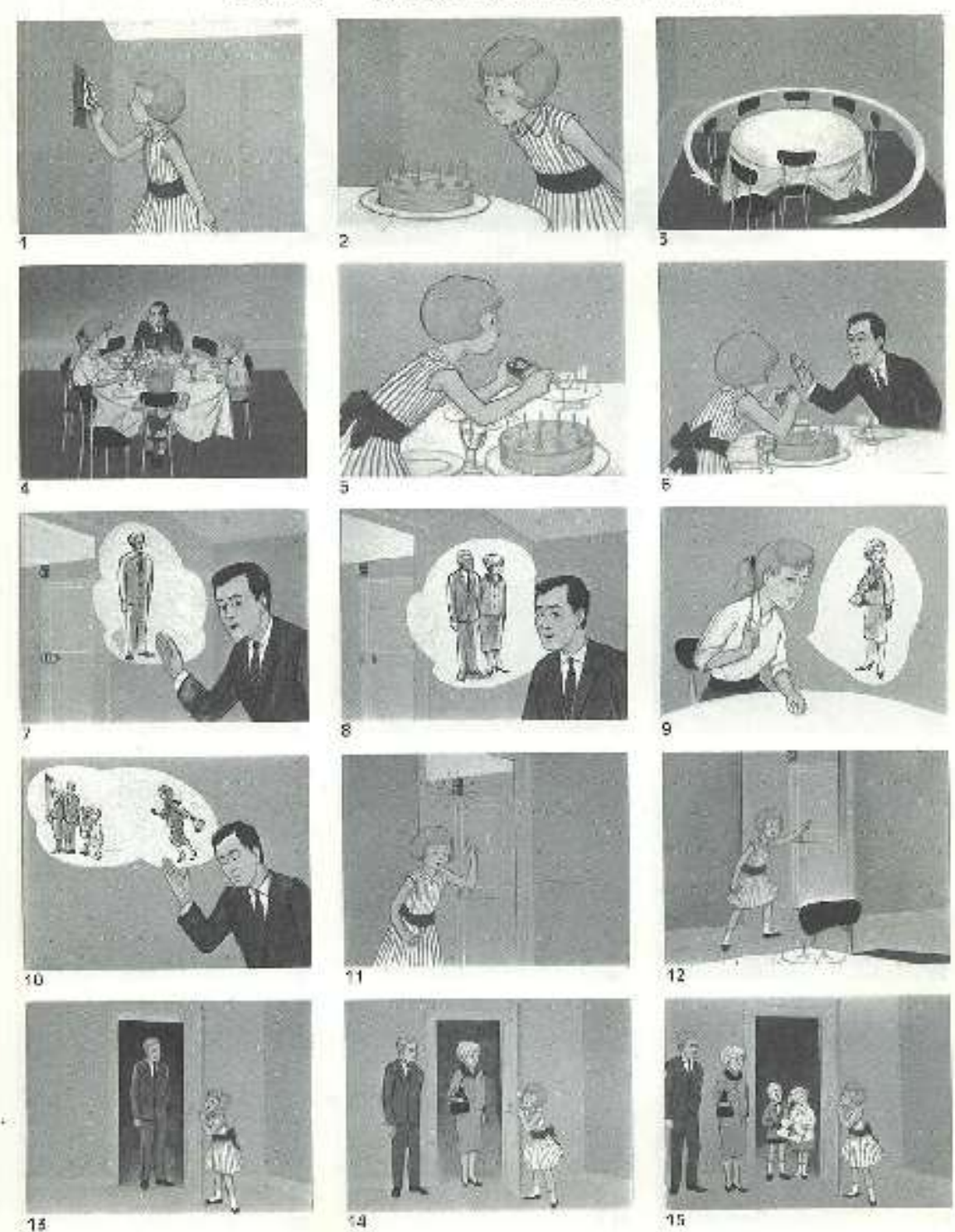

A abordagem comunicativa, metodologia desenvolvida como uma convergência de várias correntes durante os anos 1970 (GERMAIN, 1993), traz uma dimensão dupla da língua: a forma linguística deve estar adaptada não somente à situação de comunicação (estatuto do interlocutor, idade, posição social, etc.), mas também à intenção de comunicação (pedir uma informação, pedir permissão, dar uma ordem, etc.), num processo bem mais de criação do que de imitação ou de repetição. O professor recorre, 
bem mais frequentemente, aos documentos ditos "autênticos", que devem corresponder aos interesses e necessidades linguísticas do aluno. Ora, muitas vezes esses documentos eram também compostos por imagens que passaram a ocupar um espaço mais importante nos livros didáticos. As atividades propostas pela abordagem comunicativa implicam sempre uma intenção de comunicação.

Em nosso trabalho, pretendemos estudar como a imagem é utilizada nessa metodologia para conduzir o aluno à comunicação, ou seja, como a imagem foi utilizada com o objetivo de « fazer comunicar » em língua estrangeira.

O Quadro Europeu Comum de Referência (CONSELHO DA EUROPA, 2011) não exclui os componentes da competência comunicativa, mas os integra em uma perspectiva bem mais ampla e complexa. Sem renegar os "actes de parole", o QECR insere os mesmos em um contexto social e insiste na importância dos objetivos para se alcançar um determinado resultado, num ambiente definido. Essa perspectiva "da ação" ocupa um lugar fundamental nessa obra e é descrita da seguinte maneira:

A perspectiva privilegiada aqui é, de um modo geral, de tipo acional no sentido em que ela considera antes de tudo o usuário e o aprendiz de uma língua como atores sociais que têm tarefas a realizar (tarefas que não se referem somente à linguagem) em circunstâncias e em um ambiente determinado, no interior de uma área de ação particular. Se os atos de fala realizam-se dentro de atividades da linguagem, estas inscrevem-se por sua vez no interior de ações em contexto social que lhes dão seu sentido pleno. Há "tarefa" na medida em que a ação é realizada por um ou mais sujeitos que mobilizam estrategicamente as competências de que dispõem para alcançar um determinado resultado. A perspectiva acional leva, portanto, também em conta os recursos cognitivos, afetivos, intencionais e o conjunto de capacidades que o ator social possui e põe em prática. ${ }^{16}$

(CONSELHO DA EUROPA, 2001: 15)

\footnotetext{
${ }^{16}$ Tradução nossa. No original: « La perspective privilégiée ici est, très généralement aussi, de type actionnel en ce qu'elle considère avant tout l'usager et l'apprenant d'une langue comme des acteurs sociaux ayant à accomplir des tâches (qui ne sont pas seulement langagières) dans des circonstances et un environnement donné, à l'intérieur d'un domaine d'action particulier. Si les actes de parole se réalisent dans des activités langagières, celles-ci s'inscrivent elles-mêmes à l'intérieur d'actions en contexte social qui seules leur donnent leur pleine signification. Il y a "tâche " dans la mesure où l'action est le fait d'un (ou de plusieurs) sujet(s) qui y mobilise(nt) stratégiquement les compétences dont il(s) dispose(nt) en vue de parvenir à un résultat déterminé. La perspective actionnelle prend donc aussi en compte les ressources cognitives, affectives, volitives et l'ensemble des capacités que possède et met en œuvre l'acteur social. »
} 
Os livros didáticos que se baseiam no QECR, além de colocar em evidência em suas capas os níveis do Quadro Europeu, costumam recorrer no interior do livro didático a palavras-chave dessa perspectiva dita acional, como por exemplo, “projetos" e "tarefas".

Ao analisar os percursos da leitura em língua estrangeira, a pesquisadora Cristina Casadei Pietraróia (1997) define com a expressão “da onipotência à ausência” o papel do texto e da leitura dentro dos períodos que vão da metodologia gramática-tradução até as metodologias comunicativas. Curiosamente, a imagem parece ocupar um papel de importância inversa ao da leitura a partir da mesma época e até os dias de hoje: de uma total ausência do uso da imagem na metodologia tradicional, passamos a uma fase da imagem como ilustração no método direto, da imagem com uma função situacional de suporte ao documento oral na metodologia audiovisual para chegarmos, atualmente, a uma situação que parece marcada pela onipotência da imagem no ensino-aprendizagem de línguas estrangeiras, bem como na própria sociedade.

\subsubsection{Evolução tecnológica e novos canais para a imagem no material didático de FLE}

Paralelamente a essa transformação metodológica que acabamos de retomar resumidamente, é preciso também levar em conta o progresso tecnológico que tornou a impressão em cores bem menos dispendiosa. A imagem difunde-se em todas as áreas e também no ensino de línguas que utiliza livros cada vez mais ilustrados e atrativos para o aluno.

Há alguns anos, as grandes editoras da área do FLE lançaram os primeiros livros didáticos digitais para o ensino da língua. As versões digitais de Écho (2010, CLE International), Latitudes (2009, Dider) e Alter Ego (2004, Hachette) foram lançadas ao longo do ano de 2010. No entanto, é importante ressaltar que esses livros foram primeiramente concebidos para uma versão impressa antes de terem seu conteúdo transposto para uma versão digital.

De fato, o que as editoras propõem na versão digital dos livros didáticos aproxima-se mais de uma versão escaneada do manual impresso do que de um suporte pedagógico revolucionário. É verdade, no entanto, que esses livros didáticos digitais da área do FLE trazem funcionalidades importantes, como a possibilidade para o professor 
de reorganizar os conteúdos do livro em um espaço chamado comumente de "minhas páginas" (Figura 10).

Figura 10 | Écho A1 versão digital. CLE Internacional, 2010.

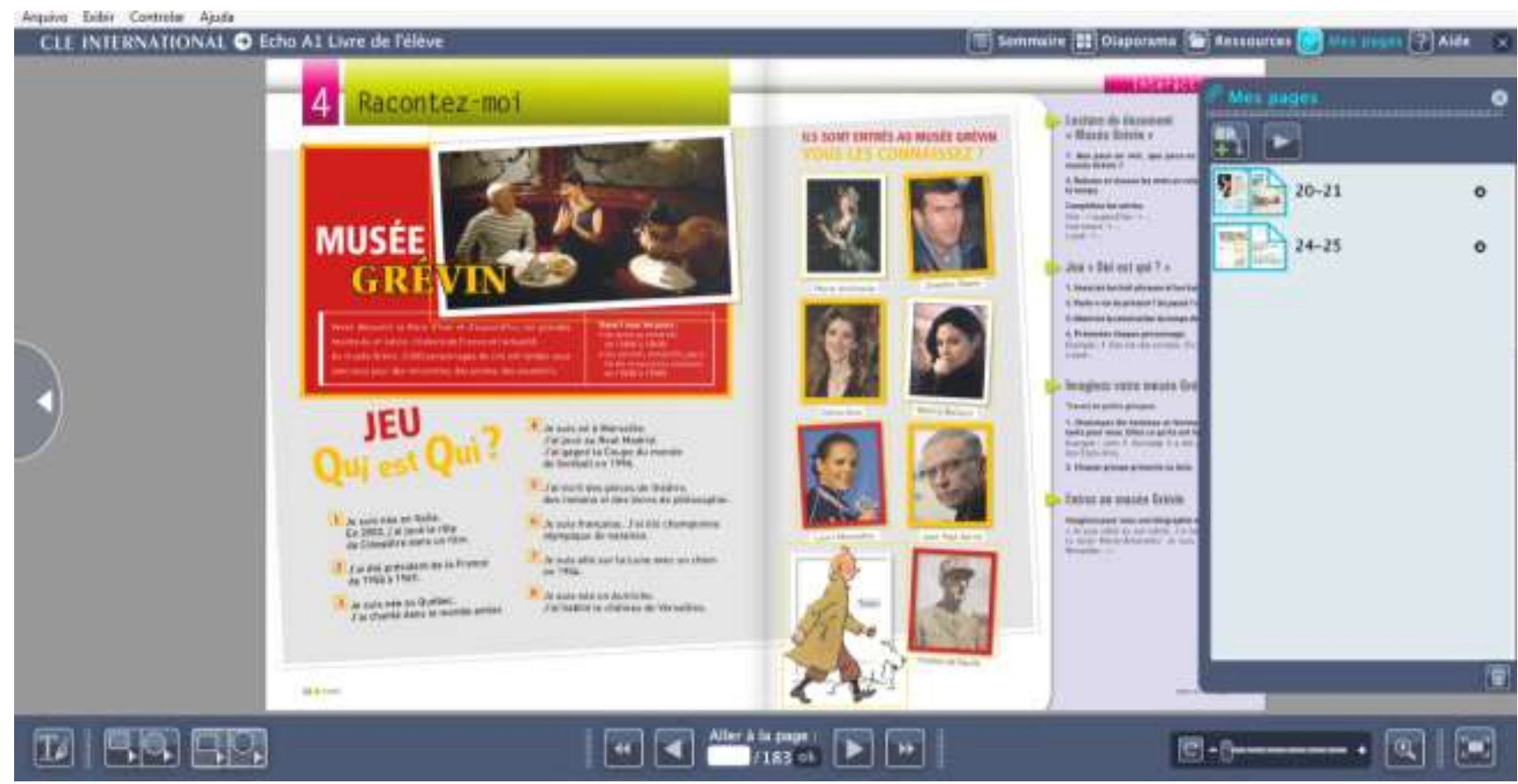

O professor pode, assim, modificar a ordem das páginas do livro de forma a adaptá-la à sua própria sequência didática, acrescentar documentos próprios, inserir links para a Internet nas próprias páginas do livro digital, etc. Ele tem também acesso a ferramentas de busca dentro do livro o que lhe traz autonomia em seu uso. Livros digitais publicados mais recentemente, como Alter Ego+ (2012) e Saison (2014), além de manter as funcionalidades acima, têm insistido mais na criação de atividade interativas, suplementares às que já existem no livro impresso.

Dentro desse contexto, o uso da imagem na versão digital dos manuais parece não se afastar muito daquele dos manuais impressos, com ganhos, porém, na qualidade de apresentação e na possibilidade de manipulação da imagem. No entanto, parecemos estar ainda longe da criação de um suporte verdadeiramente diferente do impresso, no que diz respeito à sua concepção pedagógica.

Uma das provas dessa distância, é o fato de que os livros digitais de FLE lançados nos últimos anos não estejam acompanhados de um guia pedagógico especial: o livro do 
professor para a versão digital é o mesmo da versão impressa, o que denota uma mesma preconização do uso pedagógico da imagem, qualquer que seja o suporte em questão.

Além dos livros em versão digital, as editoras têm também multiplicado os suportes chamados "periféricos", ou seja, que acompanham o lançamento de um livro didático de FLE. Alguns exemplos de suportes suplementares onde a imagem fixa - que nos interessa particularmente nesse trabalho - também está presente:

- Complementos on-line como os sites compagnons. Eles destinam-se a um trabalho individual em autonomia ou em grupo e propõem, principalmente, exercícios autocorretivos de morfossintaxe e de vocabulário. Segundo os pesquisadores Guichon e Soubrié (2013) essas atividades parecem retomar as baterias de exercícios que marcaram o início dos recursos multimídia nos anos 1980;

- Aplicativos para smartphones, como os que foram criados no final de 2014 pela editora Didier, como um complemento de vocabulário e de fonética para o método Saison (2014);

- Plataformas on-line como o Labo de Langues, desenvolvido pela editora Didier e que permite que haja uma interação entre o professor e o grupo fora da sala de aula. Um estoque de imagens também está disponível nessa plataforma (Figura 11), permitindo que o professor as utilize na criação de suas próprias sequências didáticas;

- Exercícios interativos autocorretivos com possibilidade de troca de mensagens entre os professores e alunos, como o Parcours digital, criado pela editora Hachette FLE para o livro didático Alter Ego+ (Figuras 12, 13).

Figura 11 | Le labo de langues que acompanha o livro didático Saison - Editora Didier, 2014.

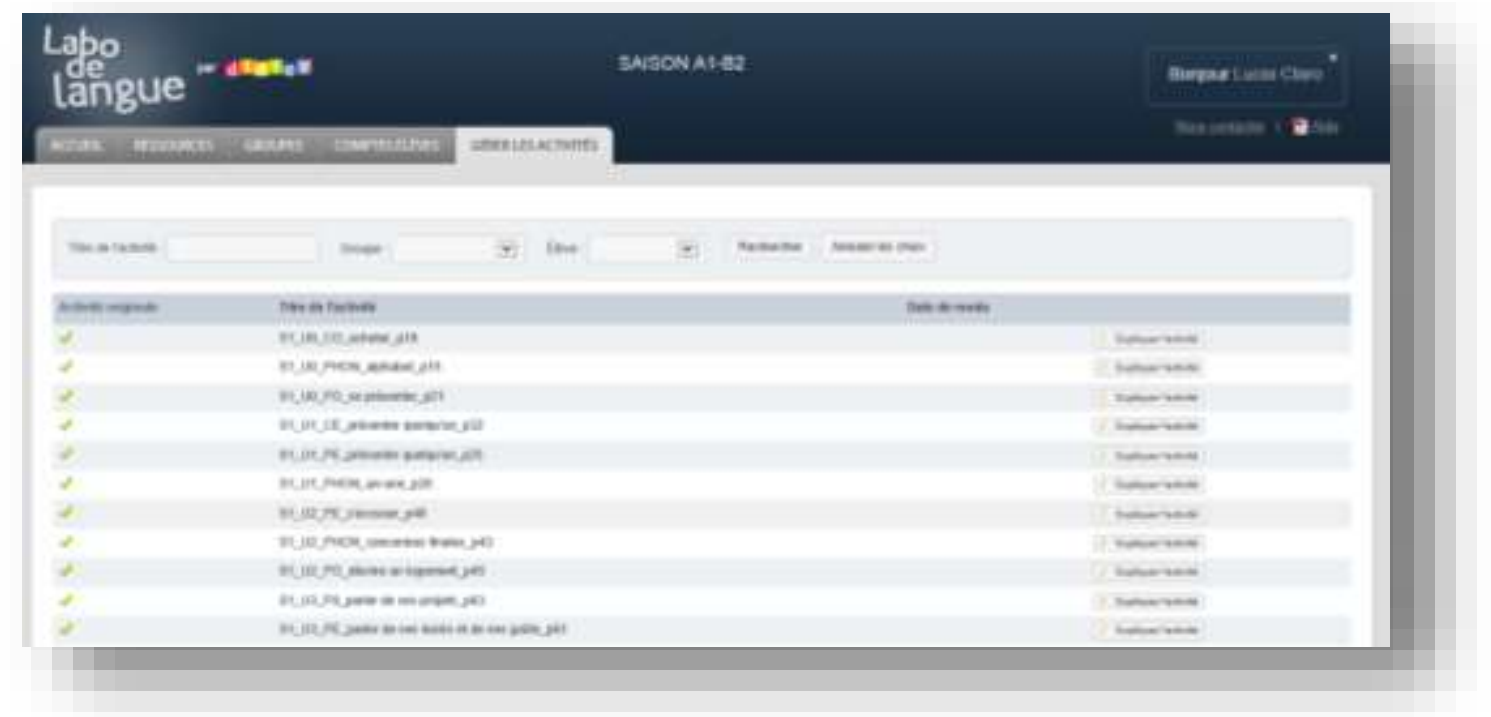


Figura 12 | Parcours digital que acompanha o livro didático Alter Ego+ 1- Hachette FLE, 2012.

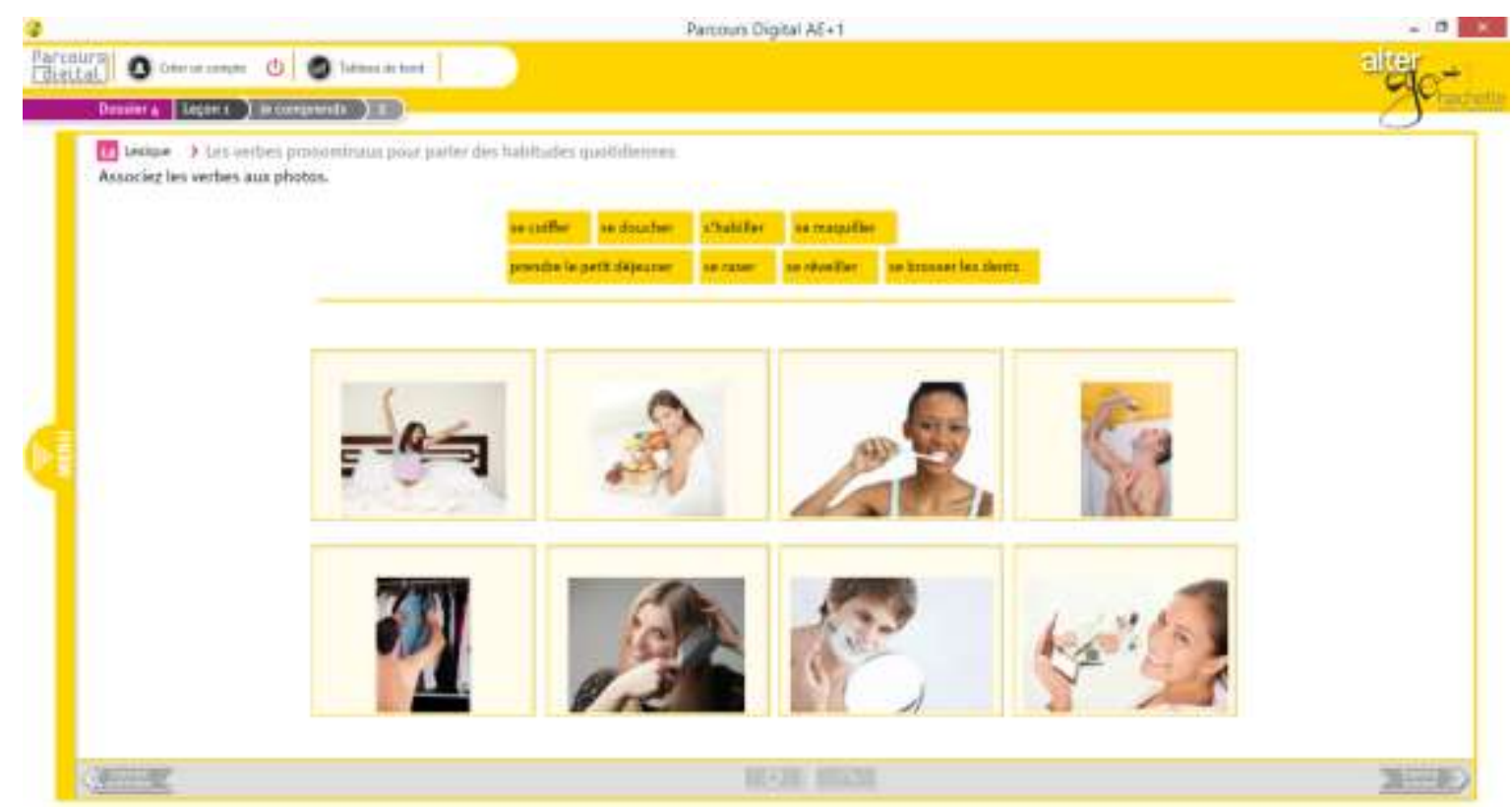

Figura 13 | Parcours digital que acompanha o livro didático Alter Ego+ 1- Hachette FLE, 2012.

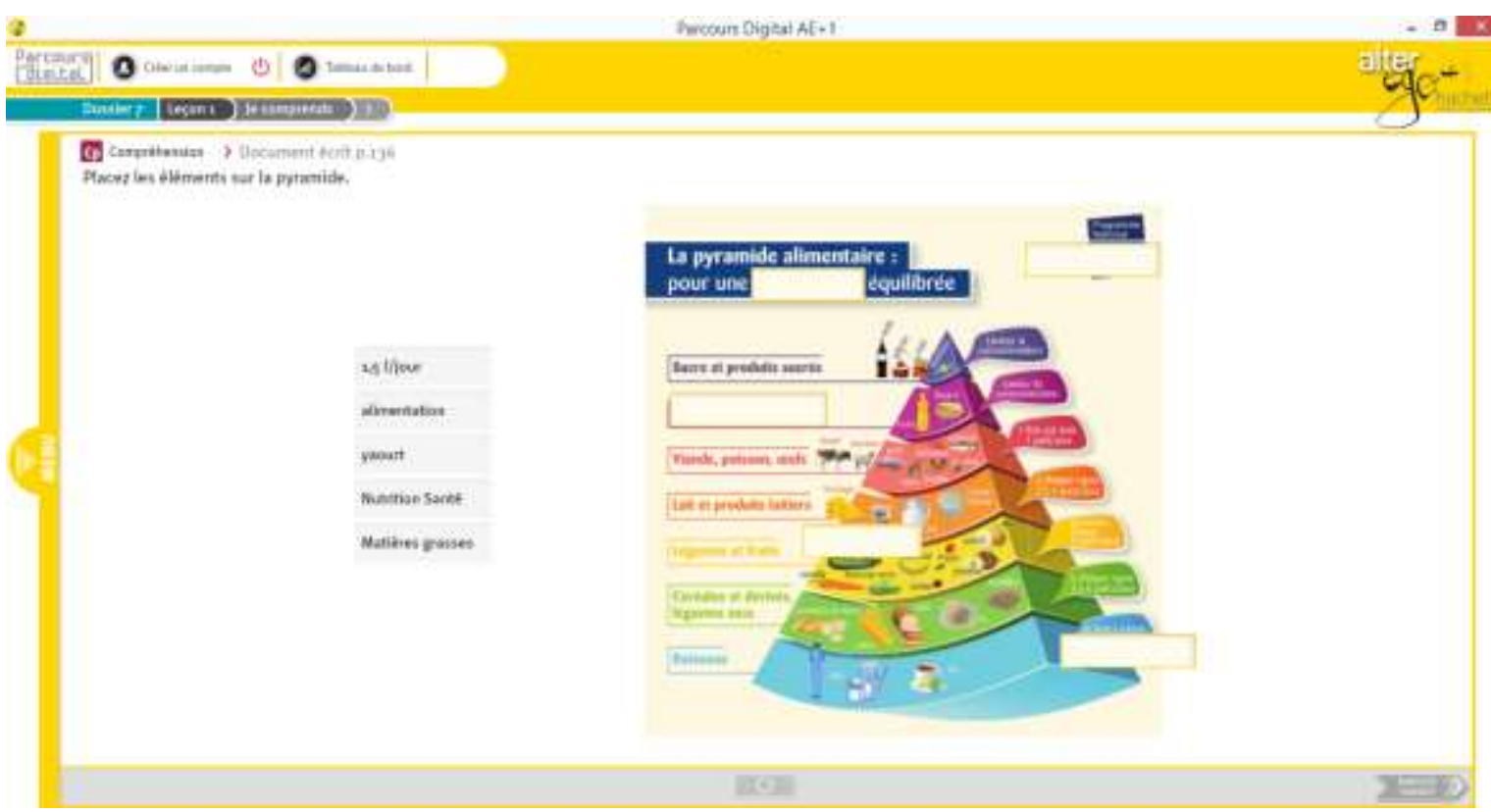


Alguns livros didáticos mais recentes que seguem a perspectiva acional do QECR têm proposto espaços on-line de prolongamento do livro didático para a publicação das atividades web 2.0 realizadas pelos alunos. É o caso, por exemplo do livro didático Version originale publicado pela editora Maison des Langues que possui um site específico para essa função: http://20.versionoriginale.emdl.fr/

Como vimos, a imagem fixa estende-se cada vez mais para além do livro impresso nas atuais coleções didáticas voltadas ao ensino-aprendizagem do FLE. Estudar esses suportes digitais que acompanham o livro didático de FLE, bem como sua utilização e sua integração à sala de aula ultrapassaria largamente os objetivos do presente estudo. Por essa razão, reiteramos nossa escolha em analisar apenas as imagens fixas presentes no livro do aluno e no guia pedagógico. 


\section{CAPÍTULO 2 | BASES TEÓRICAS PARA UMA ANÁLISE DA IMAGEM}

Toda boa história é, está claro, uma imagem e uma ideia, e quanto mais elas estiverem entremeadas melhor terá sido a solução do problema. 


\section{CAPÍTULO 2 | BASES TEÓRICAS PARA UMA ANÁLISE DA IMAGEM}

Apresentamos, neste capítulo, os fundamentos teóricos essenciais que guiam nossa pesquisa e partimos das noções de "multimodalidade" e de "texto multimodal", desenvolvidas pelos teóricos Gunther Kress e Theo van Leeuwen (2001, 2006). Segundo os autores, um texto multimodal é composto por diversos códigos semióticos que interagem na construção de significados. Trata-se não somente de códigos linguísticos e verbais, mas também de outros meios semióticos como a imagem e o som. Essa combinação entre diferentes códigos presentes em um texto multimodal e a respectiva interação entre eles na criação de sentidos constitui a noção de multimodalidade.

Para a leitura e compreensão de textos multimodais, cada vez mais comuns em nossas sociedades, os teóricos preconizam a necessidade de um letramento visual e criaram, para isso, uma gramática própria para a leitura da imagem, a "Gramatica do Design Visual", que abordaremos em seguida. A necessidade de uma alfabetização ou de um letramento visual também foi ressaltada por outros teóricos de cujas análises nos serviremos neste capítulo.

\subsection{A multimodalidade}

O desenvolvimento de diferentes mídias e de novas tecnologias, sobretudo nas últimas décadas, acompanhou-se de imagens e de sua progressão em quantidade e em qualidade. Seja com um objetivo publicitário, informativo ou ilustrativo, a imagem está ao alcance de todos e é utilizada na produção dos mais diversos documentos. Não somente nos meios de comunicação, mas também os textos produzidos por empresas, escolas e até na esfera familiar passaram a ter ilustrações em cores e layouts cada vez mais sofisticados.

Nesse contexto, outros recursos semióticos passaram a se relacionar com a linguagem verbal e os tradicionais textos escritos deram lugar a textos que apresentam duas ou mais modalidades semióticas em interação para a realização de significados, no que se define como multimodalidade (KRESS \& VAN LEEUWEN, 2006). Notícias, periódicos científicos e campanhas publicitárias constroem, ou melhor, dão a construir significados por meio da utilização de mais de um código semiótico. Os enunciados que encontramos nesses gêneros textuais projetam seus sentidos por meio de uma 
multimodalidade discursiva que estabelece um novo "design textual”. Já não são apenas os signos alfabéticos que criam o discurso, mas também as imagens e as relações intrínsecas das mesmas com as palavras em um texto multimodal. Para os autores, esse conceito de multimodalidade pode ser tratado a partir do sistema de composição de uma tela de computador, de um livro ou de uma página de jornal.

De fato, uma ilustração possível da cultura da imagem em que vivemos atualmente e também da intensificação do texto multimodal em nossa sociedade são as primeiras páginas de jornais nas últimas décadas. As primeiras páginas do jornal "O Estado de São Paulo" publicadas entre 1962 e 2012 parecem comprovar essa demanda social crescente por um letramento multimodal, conforme podemos observar a seguir (Figuras 14 a 20).

Figura 14 | O Estado de São Paulo, 08.12.1962

Fonte: http://acervo.estadao.com.br/ - Site consultado em 09.12.2012.

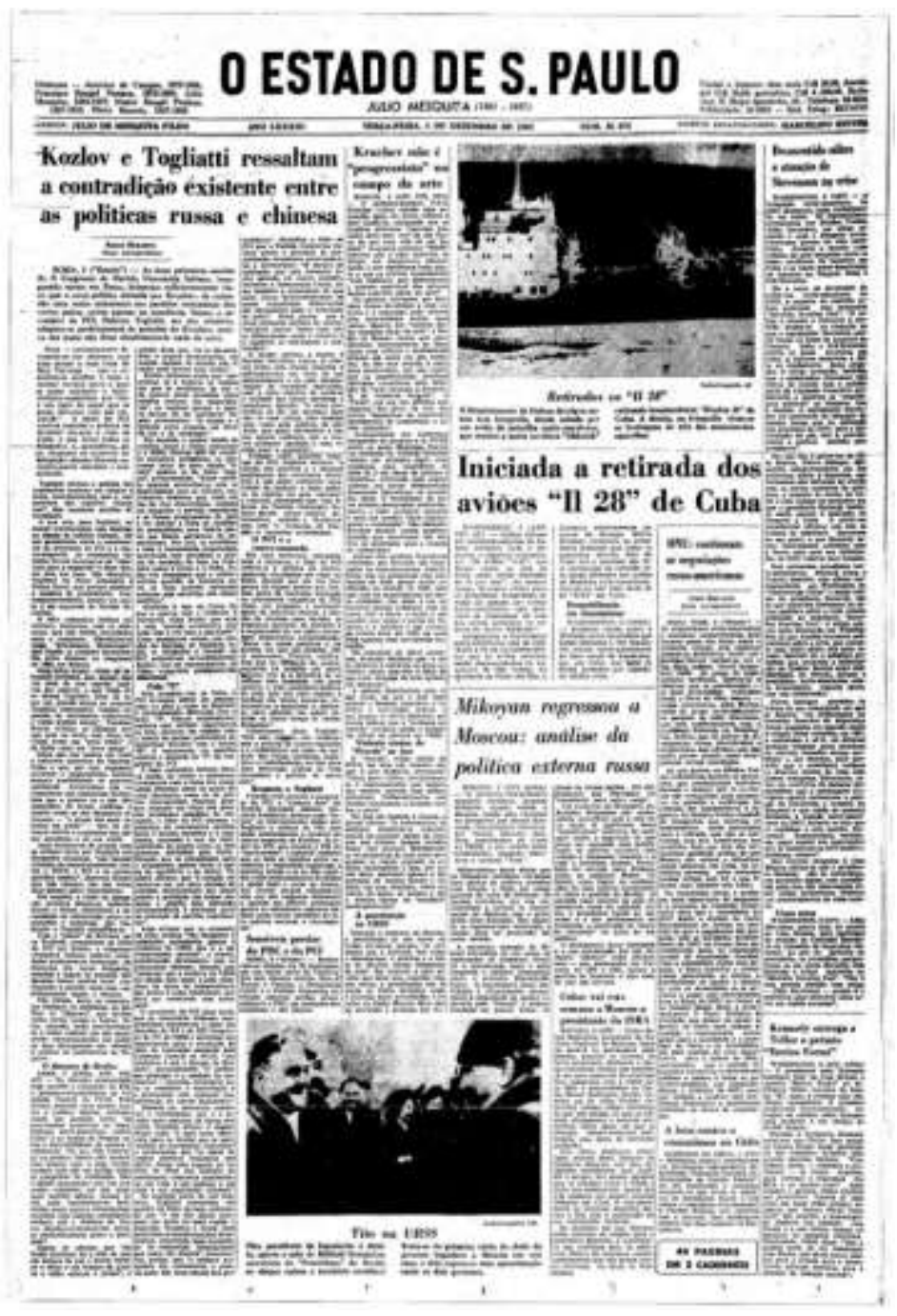


Figura 15 | O Estado de São Paulo, 02.12.1972 Fonte: http://acervo.estadao.com.br/ Site consultado em 09.12.2012.
O ESTADO DE S. PAULO

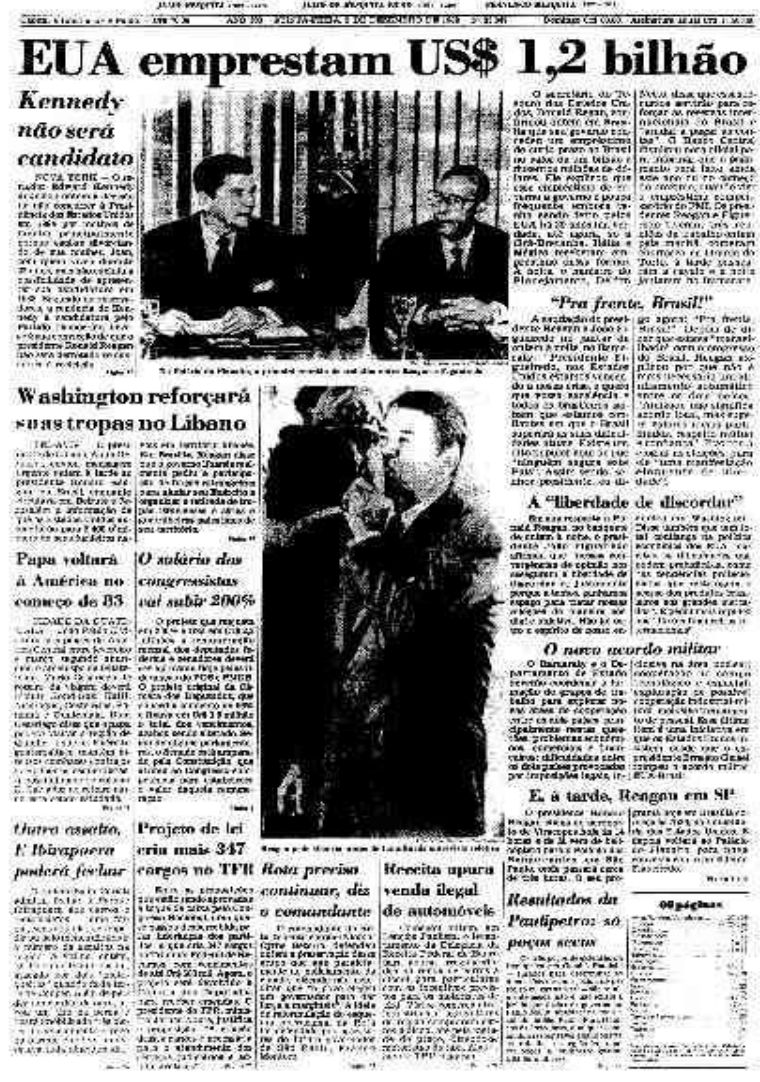

OESTADO DE S.PAULO

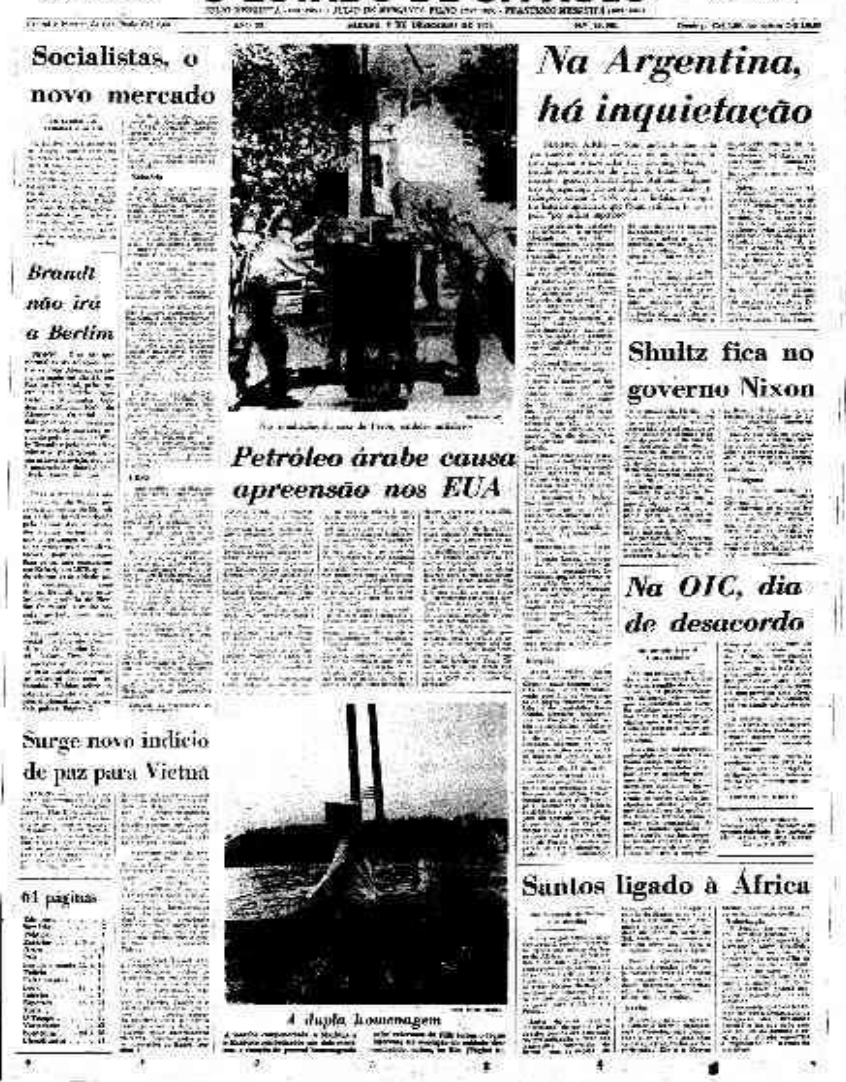

Figura 16 | O Estado de São Paulo, 02.12.1982. Fonte:

http://acervo.estadao.com.br/

Site consultado em 09.12.2012. 
Figura 17 | O Estado de São Paulo, 05.12.1992.

Fonte: http://acervo.estadao.com.br/ Site consultado em 09.12.2012.

\section{$=$ OESTADO DE S. PAULO}

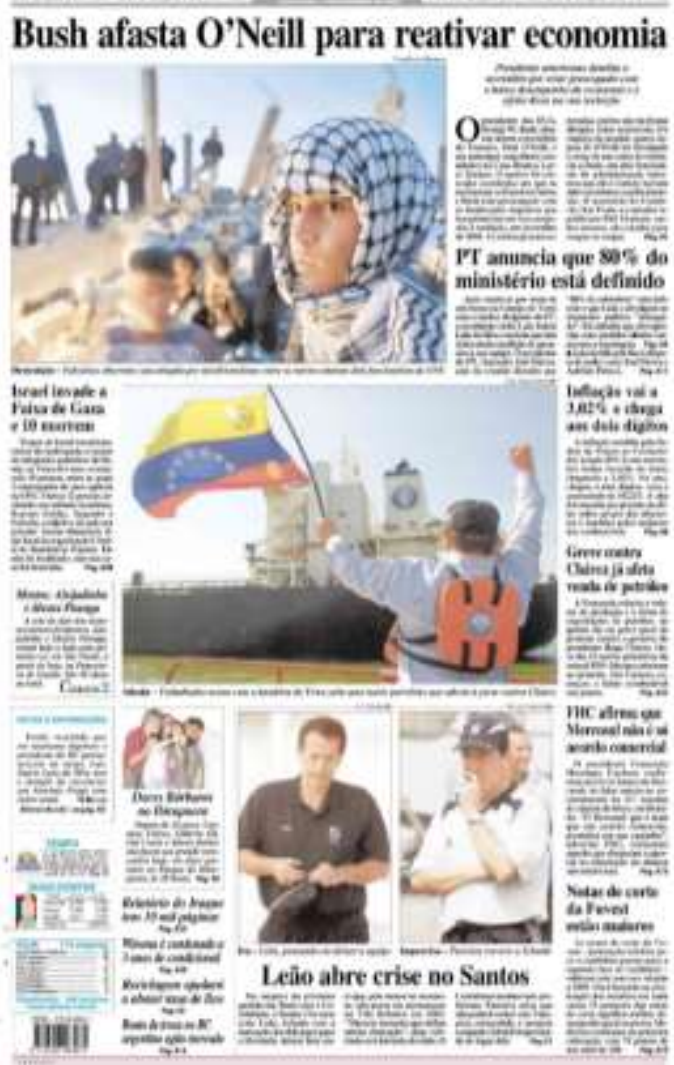

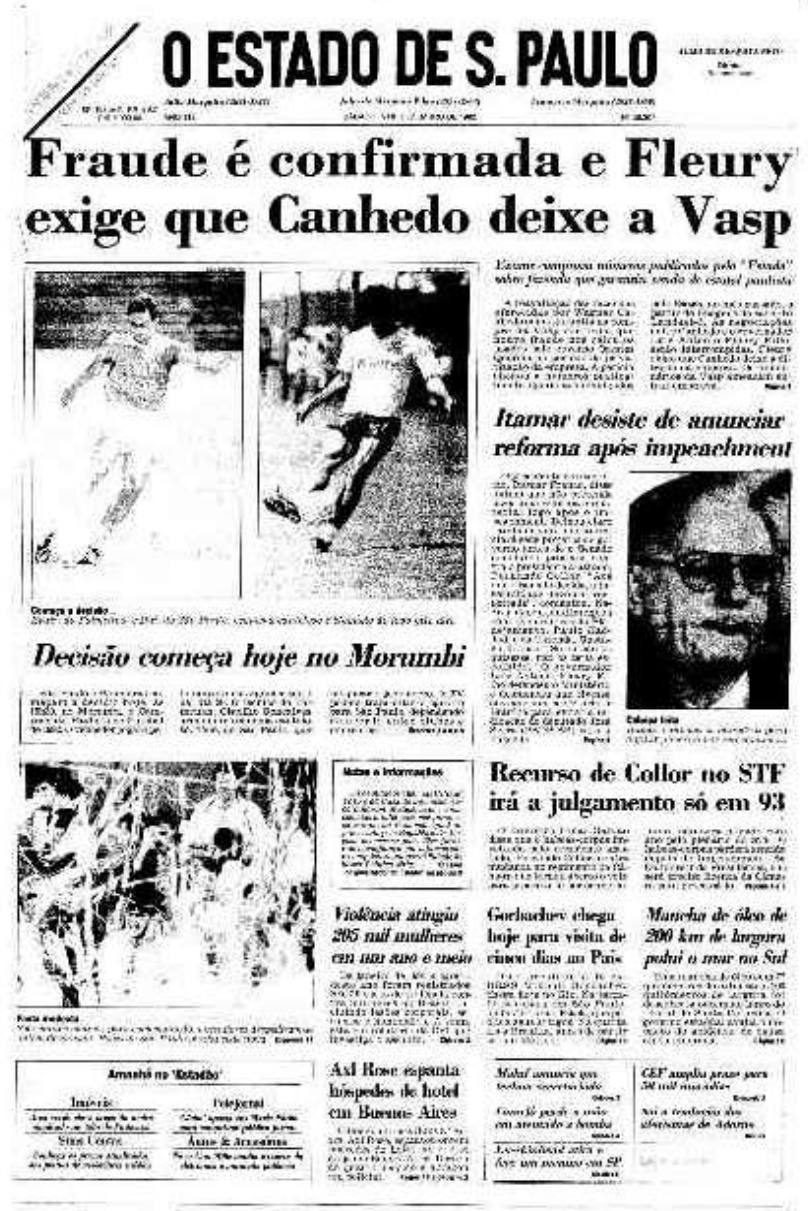

Figura 18 | O Estado de São Paulo, 07.12.2002.

Fonte: http://acervo.estadao.com.br/ Site consultado em 09.12.2012. 
Figura 19 | O Estado de São Paulo, 02.12.2012.

Fonte: http://acervo.estadao.com.br/

Site consultado em 09.12.2012.

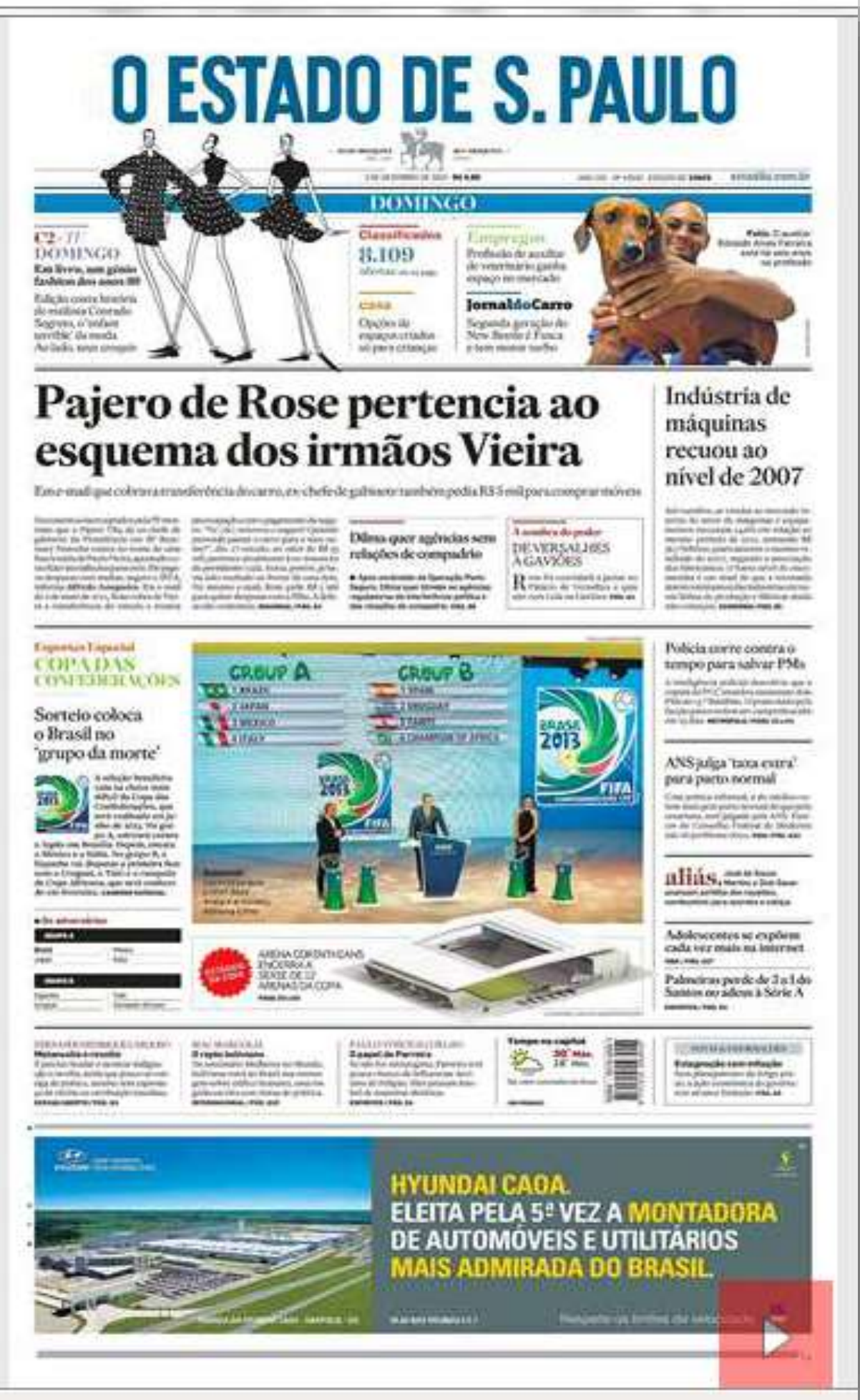


Figura $20 \mid 1^{\mathrm{a}}$ página do caderno "Aliás" - O Estado de São Paulo, 02.12.2012 Fonte: http://acervo.estadao.com.br/

Site consultado em 09.12.2012

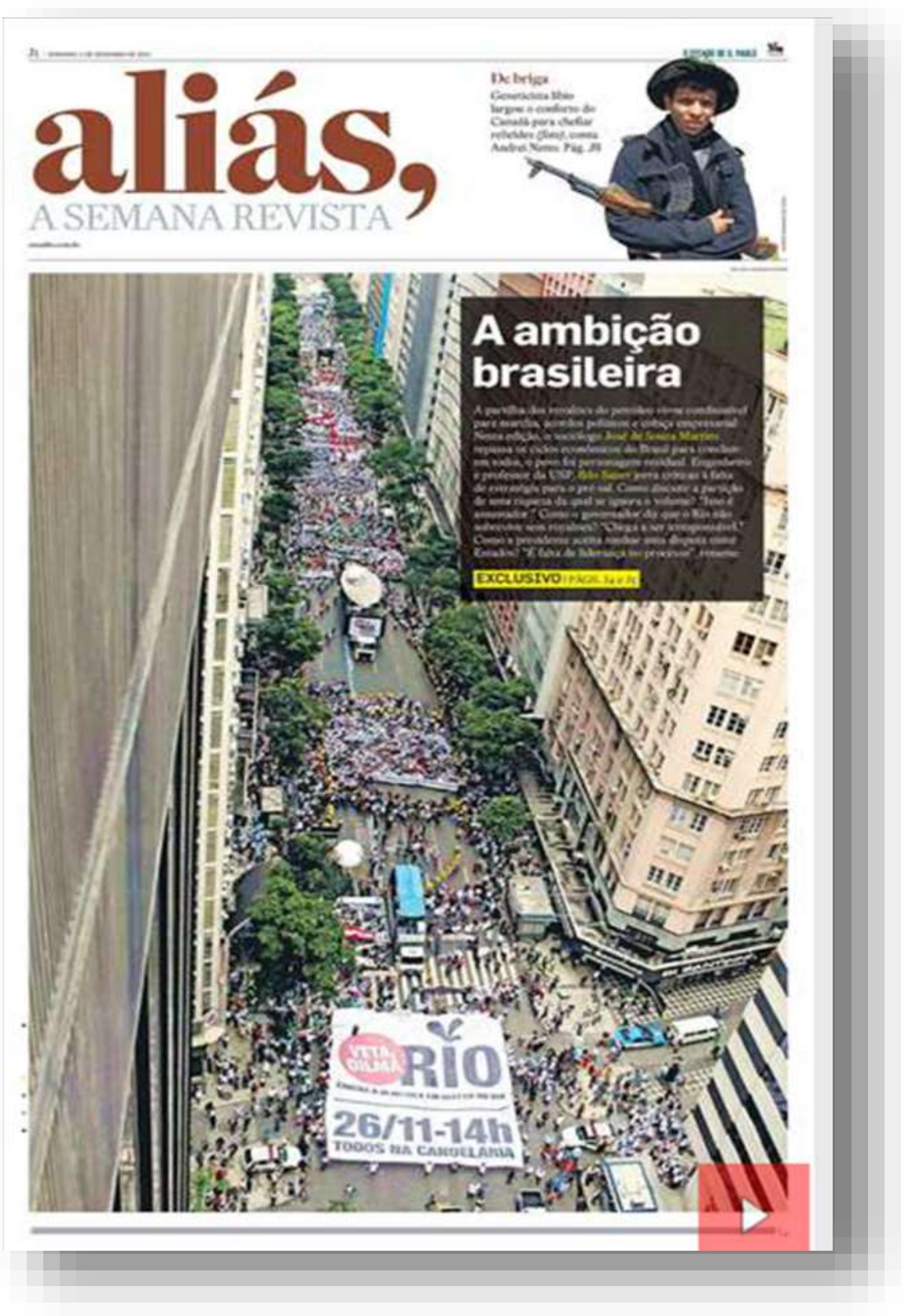

Ao observarmos a transformação dessas páginas, notamos que o texto escrito, predominante nos primeiros exemplos, cede progressivamente espaço à imagem. Vemos também que muitas delas parecem interagir e completar o texto escrito, como gráficos e desenhos. O último exemplo é particularmente interessante, pois relega o 
texto escrito a um plano secundário, complementar: é o texto que complementa a imagem e não mais a imagem, objeto geralmente considerado secundário, que viria ilustrar o texto. Estamos diante de uma inversão histórica entre os papeis do texto e da imagem, que nos lembra uma citação de Joly (2003) em que a autora fala de uma "vingança da imagem" nos dias atuais.

De fato, nosso processo de leitura tornou-se cada vez mais multimodal. No jornal de 2012, além do texto, temos imagens em grandes formatos e gráficos que favorecem a construção do sentido pelo leitor do século XXI. Esse mesmo leitor pode encontrar dificuldades na leitura do jornal da década de 60, composto quase que exclusivamente por textos. Nossos textos atuais multimodais parecem "melhores" que os anteriores, pois estamos acostumados a criar o sentido tendo por base várias ferramentas. No entanto, vale lembrar que talvez o leitor da década de 60 encontrasse dificuldades na leitura de um jornal atual, já que seu processo de leitura não era o mesmo do leitor dos dias de hoje.

A relação entre palavra e imagem mudou e, com ela, mudou também nossa maneira de ler e de construir o sentido a partir desses novos textos. A pesquisadora Ângela Paiva Dionísio (2008) descreve da seguinte forma essa mudança:

Imagem e palavra mantêm uma relação cada vez mais próxima, cada vez mais integrada. Com o advento de novas tecnologias, com muita facilidade se criam novas imagens, novos layouts, bem como se divulgam tais criações para uma ampla audiência. Todos os recursos utilizados na construção de gêneros textuais exercem uma função retórica na construção de sentidos dos textos. Cada vez mais se observa a combinação de material visual com a escrita: vivemos, sem dúvida, numa sociedade cada vez mais visual. Representação e imagens não são meramente formas de expressão para divulgação de informações, ou representações naturais, mas são, acima de tudo, textos especialmente construídos que revelam as nossas relações com a sociedade e com o que a sociedade representa.

(DIONÍSIO, 2008: 119).

A mesma autora afirma que a diversidade de layouts que a escrita vem apresentando na mídia, graças aos avanços tecnológicos, tem como consequência uma reelaboração dos nossos modos habituais de ler um texto. Dionísio (2008) ressalta também a importância do caráter discursivo do texto multimodal, já que ele se encontra inserido em uma sociedade e é compartilhado por um grupo de pessoas. Essa mesma 
visão social do texto multimodal é defendida por Kress e Van Leeuwen (2006), conforme veremos mais adiante.

\subsection{A imagem como texto e discurso visual que exige uma leitura própria}

Kress e van Leeuwen (2006) concebem a imagem como texto e discurso visual, inserido em um grupo social e em suas práticas, como uma mensagem conectada ao texto verbal, mas de forma alguma dependente dele, estando estruturada em si mesma. Desta forma, segundo os autores, a linguagem visual não é universalmente transparente, pois varia de acordo com a cultura do grupo que a criou. As significações construídas a partir de um suporte visual dependem também das crenças e valores do grupo social que o analisa. De onde a importância de considerarmos o "enunciado imagem" sempre inserido e produto de um contexto sociocultural.

Dondis (2007) nos lembra que, para sermos considerados verbalmente alfabetizados, devemos aprender os elementos que compõem a linguagem escrita, ou seja, as letras, as palavras, a ortografia, a gramática e a sintaxe. A autora acredita que um mesmo letramento é necessário para uma educação visual.

Ora, o que vemos frequentemente em sala de aula é a abordagem de elementos visuais tomando-se por base instrumentos que pertencem ao domínio da linguagem escrita. Segundo Michael Hallyday (1984), a linguagem visual exige instrumentos próprios para sua leitura tanto quanto a verbal, solicitando sua própria gramática para ser lida e analisada. É interessante notar que a análise da imagem não aparece como elemento curricular nos cursos de Letras, apesar da crescente utilização do signo visual em textos multimodais. Acreditamos que se esse aspecto não é apresentado aos estudantes em sua formação acadêmica, dificilmente será tratado de forma pertinente quando os mesmos se tornarem professores e passarem a trabalhar com seus alunos a leitura e a produção de gêneros textuais do cotidiano em sala de aula.

Apesar de as imagens estarem presentes nos manuais escolares, o estudo das mesmas como meio legítimo de comunicação parece ainda não ter sido integrado aos sistemas educacionais atuais. Segundo Kress e van Leeuwen (2006) conforme as crianças avançam em seu aprendizado, o sistema educacional tende a sobrepor a análise da linguagem verbal em detrimento da análise da linguagem visual. 
Essa contradição entre a grande quantidade de imagens no mundo atual e o pequeno espaço ocupado pela análise das mesmas nos currículos escolares parece também se refletir nas vertentes mais utilizadas para a análise do código visual. Segundo a pesquisadora Tânia Clemente de Souza (1998), as discussões sobre o processo de significação da imagem estão geralmente restritas a duas vertentes principais:

Ou se toma a imagem da mesma forma como se toma o signo linguístico, discutindo-lhe as questões relativas à arbitrariedade, à imitação, à referencialidade, ou se toma a imagem nos traços específicos que a caracterizam, tais como extensão e distância, profundidade, verticalidade, estabilidade, ilimitabilidade, cor, sombra, textura, etc., buscando-se a definição de que modo se dá a apreensão (ou leitura?) da imagem naquilo que lhe seria específico (cf.: KLEE, 1973 e DAVIDSON, 1984). [...]

No primeiro caso, [...] ao se entender o não verbal através do verbal, ocorre um reducionismo na própria conceituação de linguagem (verbal e não verbal), por ser esta pensada com relação ao signo linguístico. No outro caso, a relação com o linguístico cede lugar à relação com os traços da imagem entendidos a partir de um "olhar técnico" (cf.: AUMONT, 1993, dentre outros). Em ambos os casos, acaba-se por se propor para o estudo do não-verbal uma descrição formal da imagem, não entrando em pauta a materialidade significativa da imagem na sua dimensão discursiva. Ou seja, não se discutem nem os usos que vêm sendo feitos - como na mídia, por exemplo - da imagem, nem as possibilidades de interpretação da imagem social e historicamente determinadas.

(SOUZA, 1998)

A passagem acima reforça o caráter discursivo da imagem que é preconizado também por Kress e van Leeuwen. Ao considerarmos a imagem como texto visual, devemos entender que a mesma requer uma leitura diferente daquela que é utilizada para a linguagem verbal. Ao libertar o texto visual de qualquer dependência à escrita, esses autores opõem-se à visão de Roland Barthes (1964) que defendia que a imagem e outros códigos semióticos estão sempre relacionados com o código verbal.

Outros pesquisadores brasileiros reforçam o caráter próprio da imagem enquanto linguagem. Ao analisar as relações entre texto e ilustração na literatura infantil, Flávia Ramos e Neiva Panozzo (2004) afirmam que a imagem não se encontra em posição subordinada ao texto, uma vez que ela é dotada de uma linguagem própria e que a mesma estabelece um diálogo com outras linguagens. 
Essa noção de diálogo com outras linguagens é particularmente importante na produção de sentido em textos multimodais. Kress e van Leeuwen (2006) afirmam que há uma interatividade entre palavra e imagem nesses tipos de textos. Segundo os autores, as diferentes formas de representação não existem como setores isolados do cérebro ou como áreas isoladas na cultura, mas estão estreitamente ligadas no que os pesquisadores definem como uma nova "semiótica da sinestesia". Os sentidos construídos nesse contexto multimodal são diferentes do que poderiam ser produzidos ao analisar separadamente e de forma independente os códigos verbais e visuais.

\subsection{Ler, interpretar e compreender a imagem.}

Antes de abordarmos a proposta teórica dos autores Kress e van Leeuwen (2006) para uma leitura da imagem com ferramentas que lhe são próprias, parece-nos importante definir dois termos ligados à aprendizagem da língua escrita que têm sido constantemente utilizados na linguagem visual. Trata-se dos termos alfabetização e letramento.

\subsubsection{Alfabetização e letramento na linguagem escrita}

No século passado e, principalmente, nas últimas décadas, as utilizações da língua escrita sofreram mudanças em várias esferas sociais, como no trabalho, na família ou nas relações comerciais. Segundo a pesquisadora Ângela Kleiman (2005), juntamente com essas mudanças houve, na esfera escolar, um questionamento sobre a concepção do que seria "ser alfabetizado" e também do que é necessário atualmente para usar a escrita em diferentes contextos e com diferentes objetivos ao longo da vida.

O desenvolvimento tecnológico, a Internet, a democratização da informação e do ensino trouxeram um aumento e uma mudança no uso dos sistemas de escrita nas sociedades. Segundo a autora, há cem anos, para que um aluno fosse considerado alfabetizado, bastava que ele tivesse o domínio do código alfabético e ortográfico da escrita. Hoje, no entanto, é preciso que esse mesmo aluno consiga se comunicar, por meio da escrita, em uma grande variedade de situações que incluem o campo de práticas do uso da escrita, mas que as ultrapassam. E a escola, muitas vezes, não considera a bagagem cultural que um aluno já possui antes mesmo de ser alfabetizado. 
O professor e pesquisador Brian Street (1984) definiu as práticas de "letramento" ("literacies"), como práticas sociais e culturalmente definidas. Elas assumem, portanto, significados e funcionamentos específicos dos contextos socioculturais onde ocorrem. $O$ letramento aparece assim como uma noção estreitamente ligada às práticas sociais da escrita, ultrapassando, portanto, a simples decodificação da mesma, ou seja, a alfabetização.

Baseando-se em Street (1984) para desenvolver essa definição, Kleiman (2007) afirma que os estudos do letramento concebem a leitura e a escrita como práticas discursivas, com múltiplas funções e inseparáveis dos contextos em que se desenvolvem. Já a autora Magda Soares (2003) distingue da seguinte forma as noções de letramento e alfabetização:

Letramento é palavra e conceito recentes, introduzidos na linguagem da educação e das ciências linguísticas há pouco mais de duas décadas; seu surgimento pode ser interpretado como decorrência da necessidade de configurar e nomear comportamentos e práticas sociais na área da leitura e da escrita que ultrapassem o domínio do sistema alfabético e ortográfico, nível de aprendizagem da língua escrita perseguido, tradicionalmente, pelo processo de alfabetização.

$(\text { SOARES, 2003) })^{17}$

A mesma autora comenta o surgimento desse termo em outros países:

Assim, é em meados dos anos de 1980 que se dá, simultaneamente, a invenção do letramento no Brasil, do illettrisme, na França, da literacia, em Portugal, para nomear fenômenos distintos daquele denominado alfabetização, alphabétisation. Nos Estados Unidos e na Inglaterra, embora a palavra literacy já estivesse dicionarizada desde o final do século XIX, foi também nos anos de 1980 que o fenômeno que ela nomeia [...] tornou-se foco de atenção e de discussão nas áreas da educação e da linguagem [...]

$(\text { SOARES, } 2004: 6)^{18}$

Esses estudos da década de 1980 influenciaram a reflexão sobre a linguagem escrita na escola e contribuíram para a inclusão de vários gêneros textuais na sala de aula

17 Artigo disponível on-line: http://www.scielo.br/pdf/rbedu/n25/n25a01.pdf/ Site consultado em 11.02.2013.

${ }_{18}$ Artigo disponível on-line: http://pt.scribd.com/doc/18892732/Artigo-Alfabetizacao-e-LetramentoMagda-Soares1 Site consultado em 19.05.2013. 
e, consequentemente, no material didático. Campanhas publicitárias, artigos de jornal, reportagens passaram a constituir um material importante para o desenvolvimento do letramento. Sendo assim, o universo textual escolar foi ampliado e o trabalho realizado em sala de aula passou a dialogar cada vez mais com as práticas e as relações sociais reais do cotidiano.

Kleiman (2005) afirma que essa mudança se faz sentir de maneira clara nos materiais didáticos publicados nas últimas décadas. De fato, o texto comum da mídia de hoje - e que está também cada vez mais presente em sala de aula - é um texto multissemiótico, ou seja, um texto no qual, além da linguagem verbal, são usadas também imagens, fotos e gráficos na produção do sentido. Para isso, a autora compara uma abertura de unidade de um livro didático da década de 70, na qual a linguagem escrita reinava absoluta, com uma versão publicada recentemente, na qual o texto tornase multimodal (Figura 21).

Figura 21 | Imagens citadas por Kleiman (2005: 49)

\section{TEXTO 5}

\section{MISSA DO GALO}

Machado de Assis

Nunca pude entender a conversaçāo que tive com uma senhora, hà muitos anos, contava eu dezessete, ela trinta. Era noite de Natal. Havendo ajustado com um vizinho irmos à missa do galo, preferi năo domir, combinei que iria acordáto à meianoite.

A casa em que eu estava hospedado era a do escriväo Meneses, que fora casado, em primeiras núpcias, com uma de minhas primas. A segunda mulher, Conceiçāo, e a māe desta acolheram-me bem, quando vim de Mangaratiba para o Rio de Janeiro, meses antes, a estudar preparatórios. Vivia tranqüilo, naquela casa assobradada da Rua do Senado, $\infty \mathrm{m}$ meus livros. poucas relaçōes, alguns passeios. A familia era pequena, o escrivaa, a mulher, a sogra e duas escravas. Costumes velhos. As dez horas da noite toda a gente estava nos quartos; às dez e meia a casa dormia. Nunca tinha ido ao teatro, e mais de uma vez, ouvindo dizer ao Menezes que ia ao teatro, pedithe que me levasse consigo

\section{RESPONDA}

1. Onononononono nononono nononononon nononon nononon nononon nonono nonononon nonono

2. Ononononono nononono nonono nonononon nono nonon

3. Ononono nononono nonon nonon nonono nononon no

4. Onononono nononono nonono nonononononono nononon

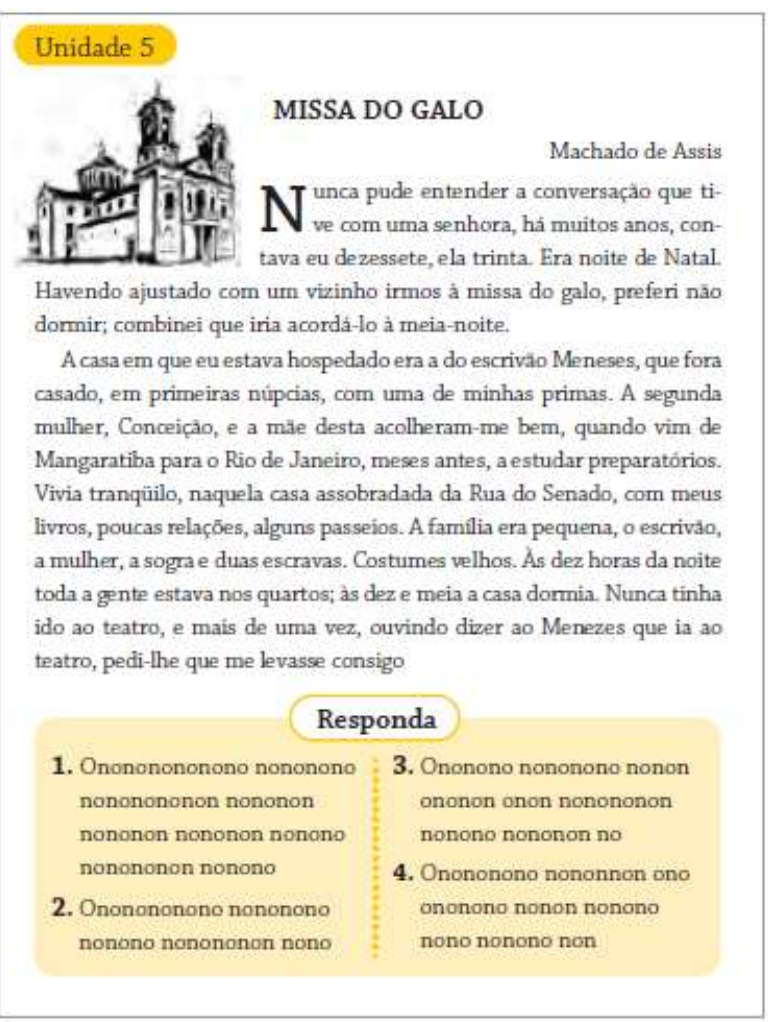

Por esse motivo, a autora insiste na importância de formar alunos "letrados" e não apenas alfabetizados, ou seja, alunos que participem das práticas sociais de uso da 
linguagem em sua comunidade, mesmo que não tenham o domínio individual da escrita, ou seja, mesmo que ainda não tenham sido alfabetizados. Kleiman cita como exemplo uma criança não alfabetizada ou um adulto analfabeto que mora em uma cidade. Ambos podem e devem desenvolver um letramento que se tornará completo com a alfabetização. Esta, no entanto, por si só, não os torna "letrados".

Soares (2004) insiste na importância da inter-relação entre as duas noções:

Dissociar alfabetização e letramento é um equívoco porque, no quadro das atuais concepções psicológicas, linguísticas e psicolinguísticas de leitura e escrita, a entrada da criança (e também do adulto analfabeto) no mundo da escrita ocorre simultaneamente por esses dois processos: pela aquisição do sistema convencional de escrita - a alfabetização - e pelo desenvolvimento de habilidades de uso desse sistema em atividades de leitura e escrita, nas práticas sociais que envolvem a língua escrita - o letramento. Não são processos independentes, mas interdependentes, e indissociáveis: a alfabetização desenvolve-se no contexto de e por meio de práticas sociais de leitura e de escrita, isto é, através de atividades de letramento, e este, por sua vez, só se pode desenvolver no contexto da e por meio da aprendizagem das relações fonema-grafema, isto é, em dependência da alfabetização.

(SOARES, 2004: 6)

A indissociabilidade que Soares propõe para as duas noções no que se refere à linguagem escrita nos parece extremamente pertinente e importante no que diz respeito à formação de professores. A nosso ver, essa análise é coerente com a visão bakhtiniana que adotamos neste estudo, ou seja, a de que o valor de um enunciado não é determinado pela língua como sistema puramente formal, mas sim pelas diferentes interações que ela estabelece dentro de um contexto social.

Acreditamos que essa questão pode suscitar um paralelo interessante com o ensino-aprendizagem de uma língua estrangeira que, por muitas vezes e dentro de diferentes metodologias, privilegiou o aspecto puramente formal da língua, trabalhando-a fora de um contexto sociocultural. No entanto, desde o advento das abordagens comunicativas que propuseram trabalhar a língua estrangeira a partir de documentos e discursos autênticos inseridos em um contexto sociocultural, o professor passou a se preocupar não somente com a "alfabetização" na língua-alvo - 
e por esse termo entendemos exercícios puramente estruturais e descontextualizados, mas também - e talvez sobretudo - com o letramento discursivo e sociocultural em língua estrangeira. Essa abordagem nos parece extremamente rica e pertinente. Ela nos faz acreditar que a alfabetização e o letramento também deveriam estar unidos quando falamos em linguagem visual.

\subsubsection{Letramento visual}

Segundo Dondis $(1973,2007)$, da mesma forma que o advento da imprensa e do livro criou a necessidade de um "alfabetismo verbal universal”, o surgimento da câmera fotográfica - e de todas as suas formas paralelas que não cessam de se desenvolver - criou a necessidade, por sua vez, de um "alfabetismo visual universal”. A obra de Dondis foi publicada antes dos anos 1980, mas sua definição de "visual literacy" aproxima-se bastante, não do termo alfabetização tal como acabamos de defini-lo, mas sim, do termo letramento. O termo "visual literacy" usado pela autora foi traduzido em português como "alfabetismo visual", conforme nota do tradutor que reproduzimos a seguir:

Literacy quer dizer "capacidade de ler e escrever". Por extensão, significa também "educado", “conhecimento", "instrução", etc., termos, porém, que não traduzem o verdadeiro sentido do vocábulo como ele é aqui empregado. Para evitar a introdução de um neologismo de sentido obscuro, como, por exemplo, "alfabetidade", optou-se aqui por "alfabetismo", definido no dicionário Aurélio como "estado ou qualidade de alfabetizado.

Nota do tradutor Jefherson Luiz Camargo (DONDIS, [1973]/2007: 1)

Por acreditarmos que Dondis levantou em sua obra reflexões que anteciparam a questão do letramento visual, utilizaremos esse termo, e não alfabetismo visual, para nos referir a "visual literacy".

Segundo a autora, o letramento significa que um grupo compartilha o significado atribuído a um conjunto comum de informações, o que retoma o aspecto social do termo. Ela considera que o letramento visual deve operar, de alguma forma, dentro desses limites e define da seguinte maneira seus objetivos:

Construir um sistema básico para a aprendizagem, a identificação, a criação e a compreensão de mensagens visuais que sejam acessíveis a todas as pessoas, e não apenas àquelas que foram especialmente treinadas, como o projetista, o artista, o artesão e o esteta.

(DONDIS, [1973]/2007:3) 
Em sua obra, Dondis propõe a análise do conteúdo da forma visual por meio do estudo de elementos individuais simples, como a cor, o tom, a linha, a textura, a proporção. Ela afirma que o letramento significa participação e transforma todos os que o alcançam em observadores menos passivos.

A mesma preocupação com uma democratização do letramento visual é defendida por Kress e van Leeuwen:

Acreditamos que a comunicação visual está se tornando cada vez menos uma área de especialistas, e cada vez mais crucial nas áreas da comunicação pública. Isso levará, inevitavelmente, a novas e mais numerosas regras, e a um ensino mais formal e normativo. Não ser "visualmente letrado" começará a atrair sanções sociais. O "letramento visual" vai começar a ser uma questão de sobrevivência, especialmente no local de trabalho. ${ }^{19}$

(KRESS \& VAN LEEUWEN, $2006: 3$ )

Os autores afirmam também que, seja na mídia impressa ou eletrônica, seja em jornais, revistas ou sites, seja em materiais publicitários ou informativos, a maioria dos textos atuais trazem componentes multimodais de interação entre texto escrito, imagens e gráficos. No entanto, apesar dessa constatação e do papel central desse tipo de texto na sociedade contemporânea, observamos que a habilidade de produzir e de ler textos multimodais não é trabalhada nas escolas.

É justamente com o intuito de trazer respostas a essas questões que os autores propõem uma gramática visual para a análise da imagem, teoria que apresentamos em seguida.

19 Tradução nossa. No original: "We believe that visual communication is coming to be less and less the domain of specialists, and more and more crucial in the domains of public communication. Inevitably this will lead to new, and more rules, and to more formal, normative teaching. Not being 'visually literate' will begin to attract social sanctions. 'Visual literacy' will begin to be a matter of survival, especially in the workplace." 


\subsection{A Gramática do Design Visual de Kress e van Leeuwen}

Kress e van Leeuwen publicaram em 2001 o livro Reading Images, the grammar of visual design, no qual propõem elementos para a análise de uma estrutura visual, ou seja, uma "gramática" do design visual. Com uma segunda edição publicada em 2006, esse livro traz um "kit de ferramentas"2o destinado à compreensão da representação e da comunicação visual. Apesar da comparação constante entre a linguagem visual e a linguagem verbal, Kress e van Leeuwen afirmam que os modelos de análise da primeira aplicam-se somente a ela:

Assim como Ferdinand de Saussure fez no início do último século, vemos a linguística como parte da semiótica; no entanto, não vemos a linguística como a disciplina que pode fornecer um modelo pronto para a descrição de outro modo semiótico que não seja a linguagem.

(KRESS \& VAN LEEUWEN, prefácio da $2^{\mathrm{a}}$ edição, 2006). ${ }^{21}$

Esse trecho mostra que, contrariamente a outros teóricos, esses autores buscaram um método próprio e independente para a análise do código visual. Kress e van Leeuwen afirmam que a maioria dos estudos sobre a linguagem visual baseiam-se em uma perspectiva linguística do léxico, das palavras. Desta forma, a análise da imagem restringe-se aos elementos nela contidos (em suas “palavras”) e não em sua gramática, em sua sintaxe, ou seja, na forma como esses elementos - pessoas, objetos, lugares - se relacionam entre si para a construção de sentidos em uma imagem. Eles concebem a imagem como texto que projeta sentidos por meio de uma gramática própria e propõem uma Gramática do Design Visual (doravante GDV) para a decodificação e o ensino da linguagem não verbal. Os autores pretendem fornecer descrições para a maioria das estruturas composicionais estabelecidas na história da semiótica visual do Ocidente e analisar como as mesmas são utilizadas nos dias de hoje pelos criadores de imagem na produção de sentido.

Kress e van Leeuwen concebem a gramática de uma língua como um inventário de elementos e regras que estão na base de formas culturais específicas da comunicação verbal de um determinado grupo. Essa definição torna a gramática uma questão bem

\footnotetext{
${ }^{20}$ Tradução nossa. No original "Reading images provides the reader (...) with an unvaluable 'toll-kit' for reading images" 2006, contracapa do livro.

${ }^{21}$ Tradução nossa. No original "As Ferdinand de Saussure had done at the beginning of the last century, we see linguistics as a part of semiotics; but we do not see linguistics as the discipline that can furnish a ready-made model for the description of semiotic modes other than language."
} 
mais social, já que ela é vista como um dos conhecimentos e práticas compartilhados por um grupo de pessoas.

Paralelamente, para os mesmos autores, a gramática visual descreve um recurso social de um determinado grupo, seu conhecimento implícito e explícito desse recurso e a maneira como ele é utilizado nas práticas desse grupo. Além disso, eles afirmam também que se trata de uma gramática bastante genérica, pois essa expressão deve abarcar desde uma pintura a óleo até o layout de uma revista. A partir desses dois aspectos, Kress e van Leeuwen definem da seguinte forma a GDV:

Reunindo-se esses dois pontos e tendo em conta a nossa definição social da gramática, diríamos que "nossa" gramática é uma gramática bastante geral de design visual contemporâneo em culturas "ocidentais", um relato sobre os conhecimentos e práticas explícitas e implícitas em torno de um recurso, que consiste em elementos e regras subjacentes a uma forma específica de cultura de comunicação visual.

Optamos deliberadamente por uma definição social, começando com a pergunta "Qual é o grupo? Quais são suas práticas?" buscando, a partir daí, descrever a gramática em questão, em vez de adotar uma abordagem que diz: "Aqui está a nossa gramática. As práticas e conhecimentos deste grupo estão de acordo com ela ou não?".22

(KRESS \& VAN LEEUWEN, 2006: 3).

Segundo os autores, isso mostra, acima de tudo, que não se trata de uma gramática "universal”, já que a linguagem visual - apesar dos pressupostos em contrário - não é compreendida de forma transparente e universal, mas sim dentro de sua especificidade cultural. No entanto, apesar das diferenças regionais e sociais do mundo ocidental, Kress e van Leeuwen acreditam que suas teorias para uma gramática visual podem ser aplicadas a todas as formas de comunicação visual no Ocidente (2006: 4).

\footnotetext{
${ }^{22}$ Tradução nossa. No original : "Drawing these two points together, and bearing in mind our social definition of grammar, we would say that 'our' grammar is a quite general grammar of contemporary visual design in 'Western' cultures, an account of the explicit and implicit knowledge and practices around a resource, consisting of the elements and rules underlying a culture-specific form of visual communication. We have quite deliberately made our definition a social one, beginning with the question 'What is the group? What are its practices?' and from there attempting to describe the grammar at issue, rather than adopting an approach which says, 'Here is our grammar; do the practices and knowledges of this group conform to it or not?' (KRESS, VAN LEEUWEN, $2006: 3$ ).
} 


\subsubsection{Uma teoria social de representação semiótica}

Dentre as diferentes teorias da semiótica, a mais difundida é a peirceana, baseada nos estudos do cientista e filósofo norte-americano Charles Peirce (18391914), considerado o fundador da semiótica moderna. Para Pierce, um signo é aquilo que, sob certo aspecto, representa algo para alguém. Ao dirigir-se a essa pessoa, esse primeiro signo criará em sua mente um segundo signo - equivalente ou mais desenvolvido. Uma vez criado na mente receptora, esse signo recebe a designação de interpretante e o elemento representado recebe o nome de objeto. Signo, Interpretante e Objeto constituem a representação triádica do signo, conhecida também como a tríade semiótica de Peirce.

Kress e van Leeuwen (2006) relembram o contexto que a semiótica percorreu nos últimos 75 anos na Europa, onde três escolas aplicaram ideias da área da linguística em modos não-linguísticos de comunicação.

A primeira delas foi a Escola de Praga nos anos 1930 e no início dos anos 1940. Ela desenvolveu o trabalho de formalistas russos, fornecendo-lhe uma base linguística. Segundo pensadores como Jakobson e Mukarovsky, sistemas semióticos como o cinema, a arte e o teatro poderiam cumprir as mesmas funções comunicativas da linguagem verbal.

A segunda escola foi a Escola de Paris nos anos 1960 e 1970, fundada pelo linguista russo Algirdas Greimas, cuja teoria voltou-se para a questão da narratividade e do estudo do discurso com base na ideia de que uma estrutura narrativa se manifesta em qualquer tipo de texto. Essa escola aplicou ideias oriundas de Saussure e de outros linguistas na pintura (Schefer), na fotografia (Barthes, Lindekens) e na moda (Barthes), entre outras áreas. As ideias desenvolvidas pela Escola de Paris ainda são ensinadas em vários cursos de estudos de mídia, arte e design, muitas vezes sob o título "semiologia".

A terceira escola ainda é recente e aplica elementos da linguística em outros modos de representação, sendo fundamentada nas ideias de Michael Halliday e de sua linguística sistêmico-funcional. A visão dessa terceira escola, à qual pertencem Kress e van Leeuwen, diferencia-se da segunda escola "europeia", dentre outras razões, pelo fato de Saussure ter visto a relação entre significante e significado no signo como arbitrária e convencional, enquanto esses autores acreditam que essa relação é sempre motivada e convencional. 
Kress e van Leeuwen afirmam que precisamos ser capazes de "ler entre as linhas" para compreender a posição discursivo-ideológica que deu origem a um texto. A análise crítica do discurso procura fornecer os meios e ferramentas para esse tipo de análise que tem sido principalmente aplicada aos textos verbais. Os autores buscaram ampliar essa análise crítica do discurso ao fornecer elementos também para o estudo de textos não verbais, tratando as formas de comunicação visual com a mesma seriedade que tem sido aplicada às formas de comunicação linguísticas.

Ao propor ferramentas de análise para esse discurso, os autores afastam-se da posição assumida por Roland Barthes e, consequentemente, da visão da segunda escola europeia que descrevemos anteriormente:

Ao fazer isto, nós nos afastamos da posição tomada por Roland Barthes em 1964 em seu "Retórica da imagem" (1977: 32-51). Nesse ensaio (e em outras obras, como na introdução de "Elementos de Semiologia', Barthes, 1967a), ele afirmou que o significado das imagens (e de outros códigos semióticos, como vestuário, alimentos, etc.) está sempre relacionado e, em certo sentido, dependente, do texto verbal. Por si só, as imagens são, pensou ele, muito "polissêmicas", muito abertas para uma variedade de significados possíveis. Para chegar a um significado definitivo, a linguagem deve intervir. ${ }^{23}$

(KRESS \& VAN LEEUWEN, 2006: 18).

Na visão dos autores, o componente visual de um texto é uma forma organizada e estruturada independentemente do mesmo: a imagem encontra-se conectada ao texto verbal, mas não está de maneira nenhuma maneira dependente dele - e o inverso também é verdadeiro.

\subsubsection{As metafunções da imagem no modo semiótico visual}

O conceito de metafunções foi proposto por Hallyday (1984) dentro da Linguística Sistêmico-Funcional; Kress e van Leeuwen (2006) adaptaram esse mesmo

\footnotetext{
23 Tradução nossa. No original: "In doing so, we have to move away from the position which Roland Barthes took in his 1964 essay 'Rhetoric of the image' (1977: 32-51). In this essay (and elsewhere, as in the introduction to Elements of Semiology; Barthes, 1967a), he argued that the meaning of images (and of other semiotic codes, like dress, food, etc.) is always related to and, in a sense, dependent on, verbal text. By themselves, images are, he thought, too 'polysemous', too open to a variety of possible meanings. To arrive at a definite meaning, language must come to the rescue."
} 
conceito para a criação de uma Gramática Visual propondo uma nova abordagem para as três metafunções definidas por Hallyday - ideacional, interpessoal e a textual - de forma a que se apliquem a todos os modos semióticos, e não são somente à fala e à escrita.

De acordo com esses autores, qualquer modo semiótico tem que ser capaz de representar os objetos e suas relações no mundo fora do sistema representacional. Isso é feito por meio da metafunção ideacional dentro de diferentes maneiras de representação. Dois objetos podem ser representados dentro de um processo de interação que poderia ser realizado visualmente por meio de vetores (Figura 22) ou também num processo de classificação, utilizando-se uma árvore esquemática (Figura 23).

Figura 22 | Kress e van Leeuwen (2006: 42)

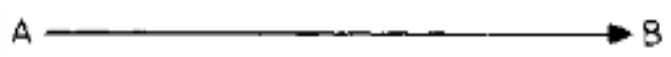

Figura 23 | Kress e van Leeuwen (2006:42)

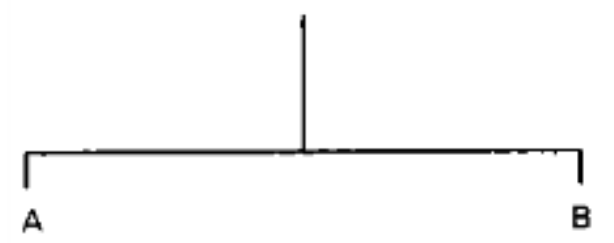

Um modo semiótico também deve ser capaz de projetar as relações entre o produtor e o receptor de um sinal por meio da metafunção interpessoal. Ou seja, ele deve conseguir representar uma relação social particular entre o produtor, o espectador e o objeto representado. 
Qualquer modo semiótico tem que ter a capacidade de formar textos, complexos de sinais que se ligam tanto internamente entre si quanto externamente com o contexto no qual e para o qual foram criados, ao que Halliday chama de metafunção textual.

Segundo a GDV, diferentes composições desses elementos produzem significados diferentes nos textos. De acordo com os autores, estruturas visuais não fornecem uma simples reprodução formal da "realidade", mas podem, pelo contrário, ter uma dimensão ideológica e produzir imagens vinculadas aos interesses das instituições sociais nas quais são criadas, divulgadas e lidas.

Ao analisar um sistema representativo semiótico, Kress e van Leeuwen preferem utilizar o termo "participantes" ao invés de "objetos" ou "elementos". De um lado, essa mudança aponta para a presença de um participante em algo e, por outro, chama a atenção para o fato de existirem dois tipos de participantes: os interativos, que são os produtores e receptores de um ato de comunicação, e os representados, que são o tema da representação (pessoas, lugares ou objetos). No entanto, também é possível que os produtores e / ou os receptores da mensagem estejam representados na mesma, fazendo com que as duas categorias se sobreponham.

No caso de textos visuais abstratos, como diagramas, é mais simples identificar o que ou quem são os participantes. Kress e van Leeuwen citam para isso o famoso modelo de comunicação de Shannon e Weaver (1949). Figura 24.

Figura 24 | Kress e van Leeuwen (2006: 48)

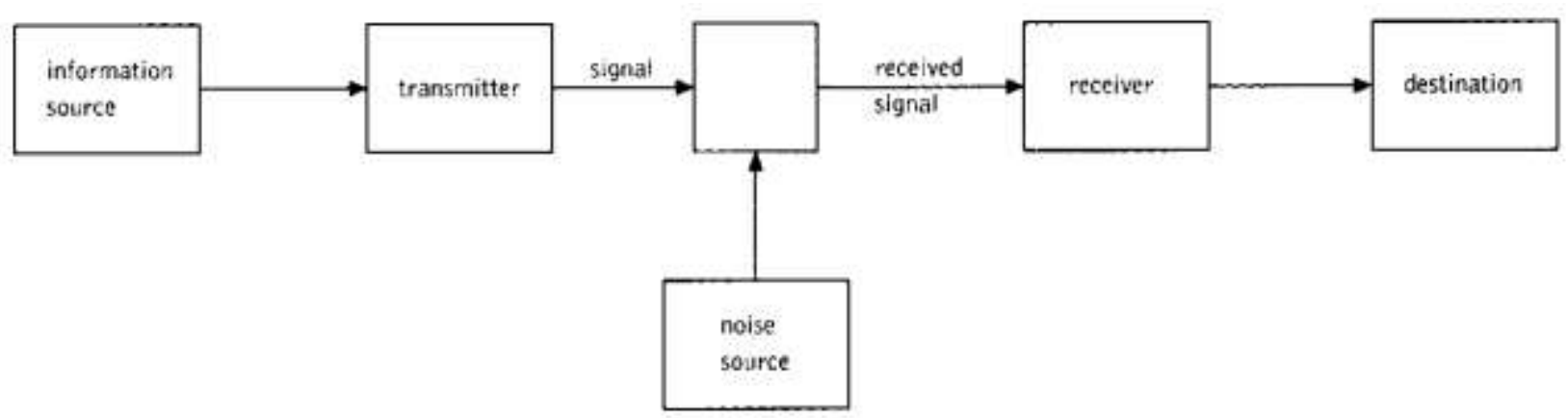


As caixas desse modelo representam os participantes (pessoas e / ou coisas) e as setas, os processos de relação entre os mesmos. Traduzindo isso em linguagem, segundo os autores, seria possível dizer que as caixas representam os substantivos e as setas, os verbos que os colocam em relação. Kress e van Leeuwen acreditam que as imagens naturalistas também podem ser analisadas em termos de participantes e processos, de maneira bem próxima à que é feita em diagramas.

As metafunções definidas por Halliday - ideacional, interpessoal e textual - são retomadas por Kress e van Leeuwen com a seguinte terminologia: metafunções representacional, interacional e composicional. Assim como Halliday, eles utilizam em sua análise os termos "ator" (participante de onde emana o vetor), "objetivo" (participante para onde o vetor aponta) e "transação" (relação entre os dois, ou seja, algo feito pelo "ator" para o “objetivo"). Segundo os autores, “o que em linguagem é realizado por meio de configurações sintáticas de certas classes de substantivos e de verbos é visualmente realizado [...] pelas relações vetoriais entre volumes." ${ }^{24}$ (KRESS \& VAN LEEUWEN, 2006: 50).

\subsubsection{A metafunção representacional}

A metafunção representacional refere-se às representações do mundo e analisa as interações entre pessoas e objetos, ou seja, entre os participantes encontrados em um meio semiótico visual. Esses participantes exercem funções na criação e na construção do significado. Os autores identificam dois tipos de estruturas representacionais: as narrativas e as conceituais.

$\mathrm{Na}$ estrutura de representação narrativa, os participantes estão conectados por um vetor e, desta forma, são representados realizando uma ação, "fazendo algo". Escolhemos, a seguir, uma imagem de um livro didático de FLE (Écho A1) que nos parece representativa dessa estrutura visual (Figura 25).

\footnotetext{
24 Tradução nossa. No original: "what in language is realized by means of syntactic configurations of certain classes of nouns and certain classes of verbs is visually realized [...] by the vectorial relations between volumes."
} 
Figura 25 | Exemplo de estrutura representacional narrativa

PECHEUR, J. ; GIRARDET, J. - Écho A1. Paris : CLE International, 2010.

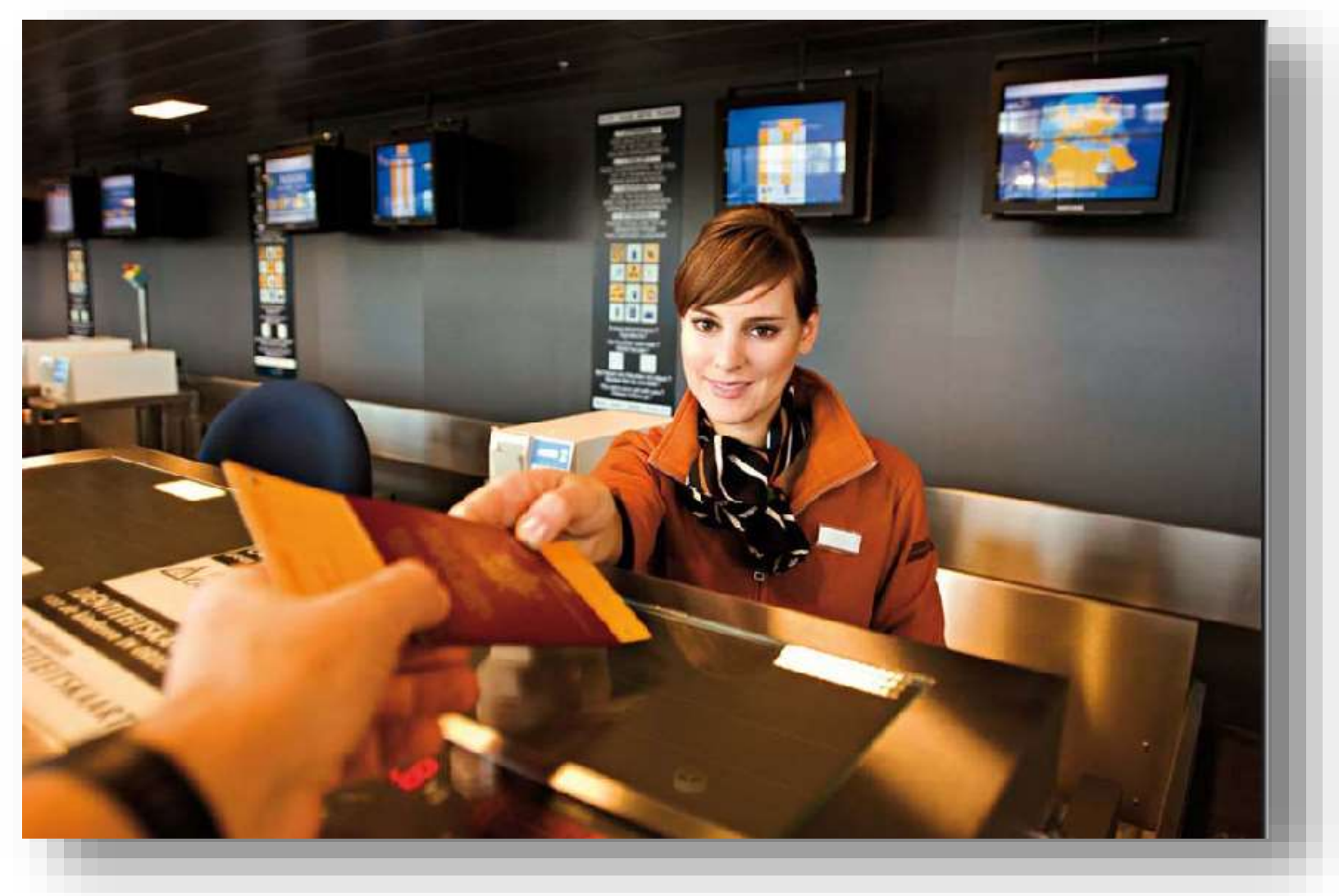

Já as estruturas visuais conceituais são estáticas e desprovidas de ações vetoriais. Os participantes são representados em termos de classe, estrutura ou significado, ou seja, em termos de essência (ser, existir). A seguir, uma imagem de um livro didático de FLE (Écho A1) que nos parece representativa dessa estrutura visual (Figura 26). 
Figura 26 | Exemplo de estrutura representacional conceitual PECHEUR, J. ; GIRARDET, J. - Écho A1. Paris : CLE International, 2010.

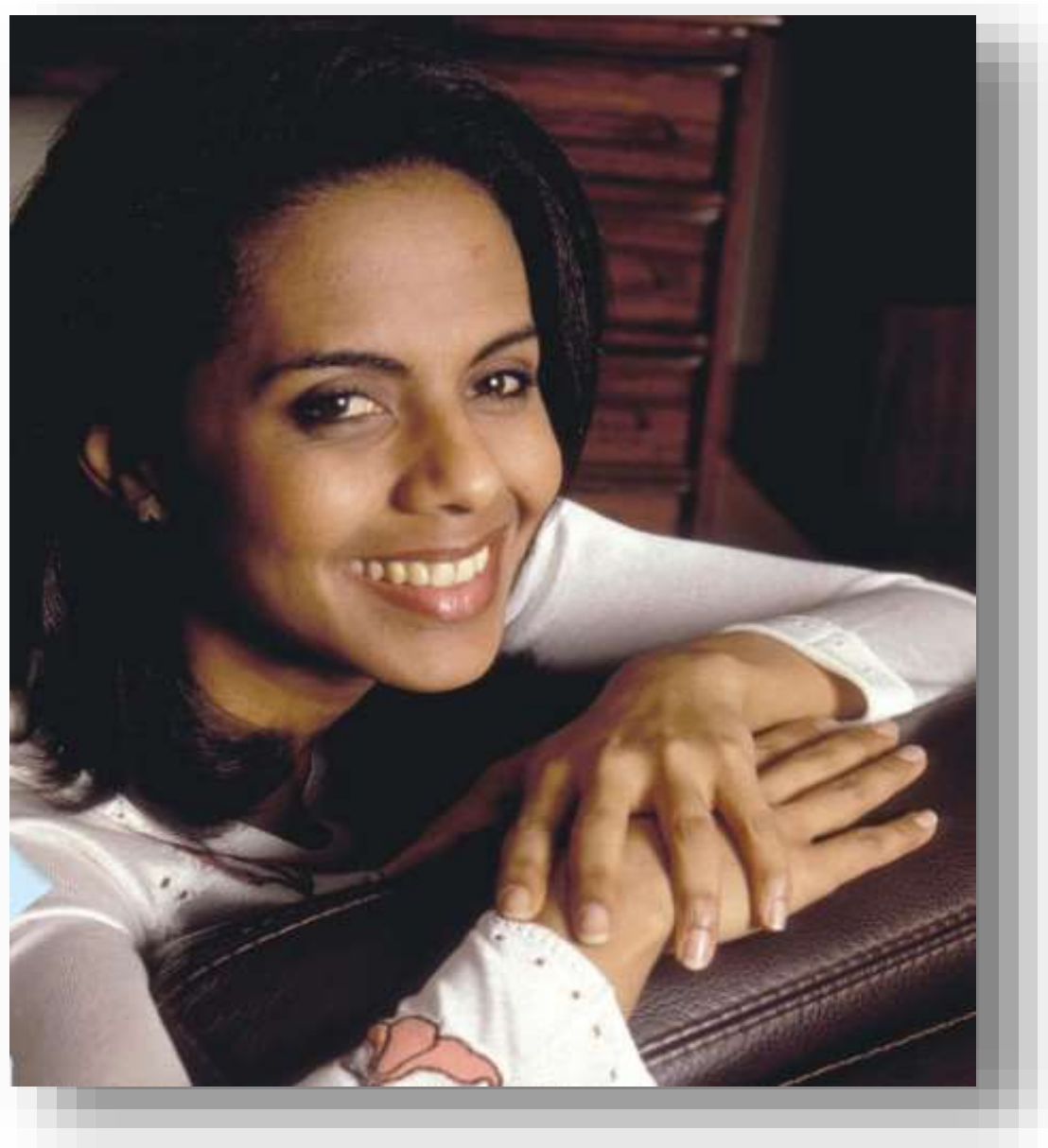

\subsubsection{A metafunção interacional}

A comunicação visual tem recursos para criar e manter a interação não somente entre os participantes, mas também entre o produtor e o espectador da imagem. A metafunção interacional caracteriza-se justamente pelas relações entre o produtor, o produto e o espectador.

Segundo os autores, enquanto a função representativa analisa as interações entre pessoas e objetos encontrados em uma imagem, a função interativa analisa as interações entre o produtor e o observador da mesma. Eles podem estar frente a frente, mas, muitas vezes, não há nenhuma interação direta entre os dois. É preciso que eles compartilhem um mesmo conhecimento social para que a comunicação seja estabelecida apropriadamente. 
Quatro fatores não-verbais compõem a função interacional segundo Kress e van Leeuwen: o primeiro deles é o contato que é determinado pelo olhar do participante/ator.

Os autores afirmam que há uma diferença fundamental entre as imagens em que os participantes olham diretamente para os olhos do espectador e os casos em que isso não acontece. No primeiro caso, os vetores formados pela linha de visão do participante o conectam ao espectador. Fala-se, neste caso de "demanda", pois o espectador é interpelado pelo ator. No segundo caso, fala-se de "oferta".

Uma segunda dimensão da função interacional é a distância social que se traduz pela escolha entre o close-up, o plano médio e o plano geral. De acordo com os autores, as escolhas da distância entre os participantes e os espectadores remetem às diferentes relações sociais entre os mesmos.

O close-up é o plano mais próximo do leitor/espectador, o que cria uma sensação de maior intimidade com o mesmo. Essa relação é menos intensa no plano médio e ainda menor no plano aberto ou geral.

A terceira dimensão da função interacional é a perspectiva, que define o envolvimento e a relação de poder entre o participante e o observador de uma imagem. Essa relação se traduz pelos ângulos adotados na comunicação visual.

Os ângulos horizontais definem as relações entre o participante e o espectador de uma imagem e são classificados por Kress e van Leeuwen como ângulo frontal ou ângulo oblíquo. $O$ primeiro coloca o participante e o espectador em posição de igualdade, enquanto que o segundo traduz um maior distanciamento entre eles. Já os ângulos verticais definem a relação de poder e são classificados em ângulo alto, ângulo baixo e o ângulo do nível do olhar. No primeiro caso, é o participante quem detém o poder com uma visão do alto em relação ao espectador. O contrário acontece no ângulo baixo e, por fim, os dois estão em posição de equivalência de poder, ou seja, de igualdade.

Segundo os mesmos autores, os ângulos compõem a perspectiva subjetiva, ao passo que a perspectiva objetiva é representada de forma estrutural e organizacional em imagens como mapas e placas de trânsito.

A quarta e última dimensão da função interacional é a modalidade ou o valor de realidade que o espectador atribui à imagem. Marcadores como cor, iluminação e brilho definem esse fator. 


\subsubsection{A metafunção composicional}

A metafunção composicional organiza os elementos do texto em seu layout, combinando as estruturas das duas funções que vimos anteriormente e resultando no todo significativo. O sentido é construído graças à maneira como os elementos estruturantes do texto se posicionam entre si dentro do espaço - levando-se em conta parâmetros como esquerda/direita, topo/base, centro/margem - e também a relação dos mesmos com o espectador.

Segundo os autores, essa associação entre os significados representacionais e interativos da imagem é estabelecida por meio de três sistemas inter-relacionados: valor da informação, saliência e enquadramento.

O valor da informação é medido através da disposição no espaço dos elementos de um texto multimodal. Os autores salientam que esses valores são válidos para a cultura ocidental, na qual temos o hábito de ler da esquerda para a direita e de cima para baixo. Kress e van Leeuwen afirmam que as polaridades esquerda/direita contem, respectivamente, a informação dada (já conhecida) e a informação nova, inaugural (que o espectador não conhecia). Já a relação topo/base, situada no eixo vertical, remete, respectivamente, aos valores de ideal e de real. As posições centro/margem produzem, por sua vez, significados ligados ao valor de informação essencial ou periférica (Fig. 27).

Figura 27 | Trípticos horizontais e verticais (KRESS \& VAN LEEUWEN, 2006: 201).
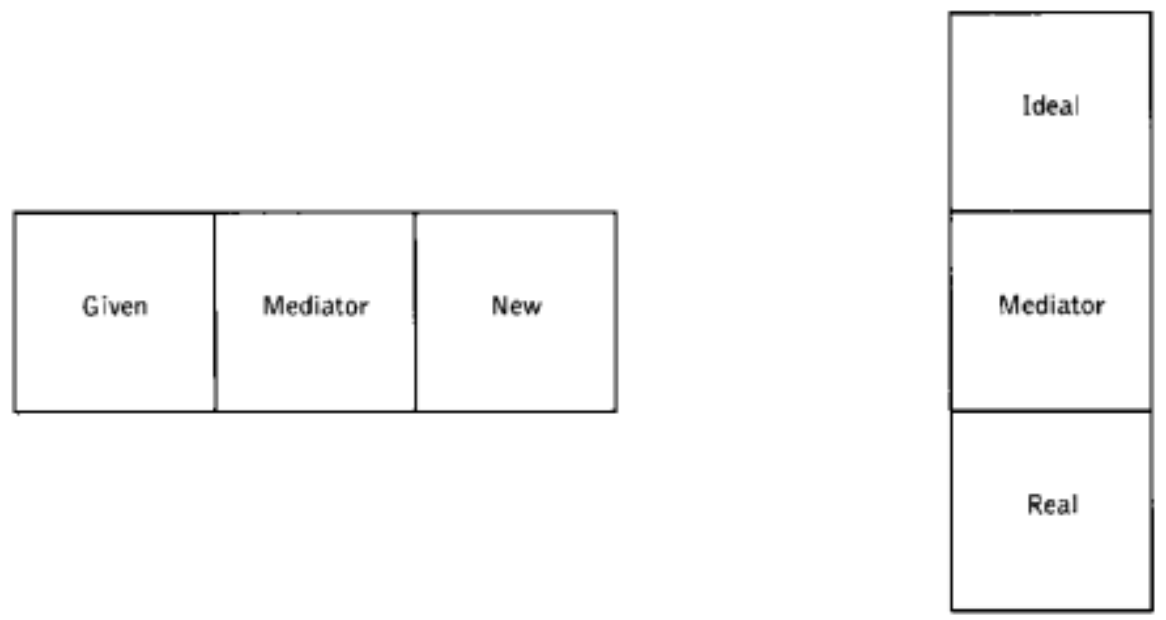

Quanto à saliência, trata-se de um recurso utilizado para atrair a atenção do espectador em diferentes graus por meio, entre outros, da colocação em primeiro ou 
segundo plano, do tamanho relativo, do contraste no valor tonal (ou na cor), das diferenças na nitidez.

Por fim, o enquadramento diz respeito à forma pela qual os diferentes elementos estão conectados ou desconectados da imagem. A estrutura visual pode agrupar esses elementos por meio de recursos como a continuidade das cores, a utilização de vetores e de elementos de repetição que forneçam a ideia de continuidade, ou então afastar os mesmos, por meio de fortes contrastes, espaços em branco e outros fatores que indiquem descontinuidade.

A dupla página abaixo (Figura 28), que identificamos no livro didático Forum 1, representa bem, a nosso ver, a multifunção composicional de um texto multimodal. A informação dada - posicionada na página da esquerda - mostra algumas frases já conhecidas dos alunos e que se ligam à situação de comunicação que será abordada nesta lição, ilustrada na grande foto. Vetores em forma de flechas saem dessa foto em direção a diálogos com elementos linguísticos novos (à direita) que serão trabalhados de forma mais aprofundada durante a lição.

Figura 28 | Forum 1 - pág. 144, 145.
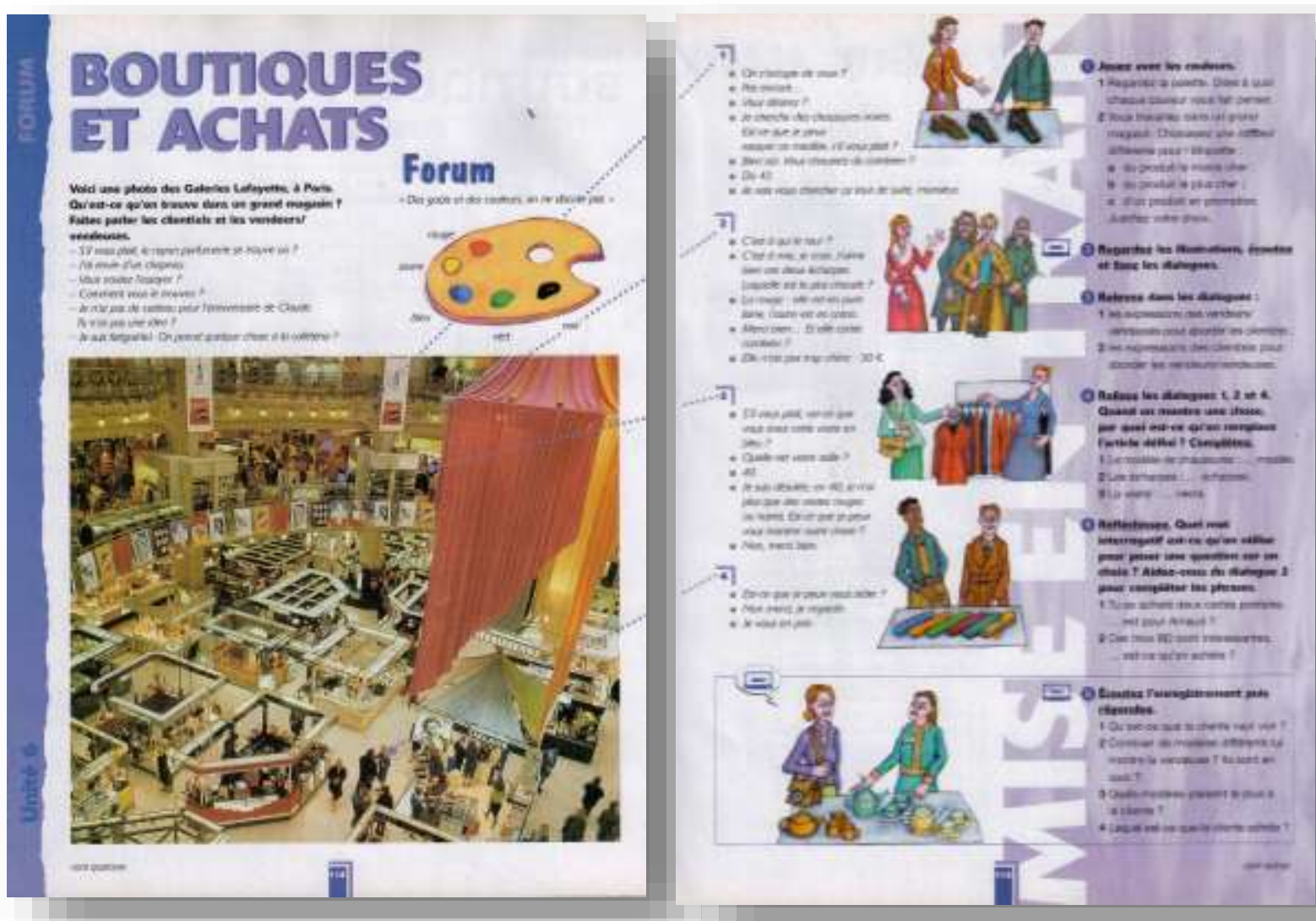
No que diz respeito ao enquadramento, os diferentes elementos da dupla página encontram-se agrupados por meio de recursos como a continuidade das cores (neste caso, o violeta) e a utilização de vetores que ligam a grande foto aos diálogos, a suas ilustrações e a suas transcrições.

Acreditamos que essa noção da composição do texto multimodal no livro didático é muito importante para o professor. De fato, é necessário que ele tenha consciência de que essa dupla página representa um único texto multimodal e que seus diferentes elementos - que interagem entre si na construção do sentido - não devem ser trabalhados de forma segmentada, compartimentada ou isolada.

\section{A importância da metafunção composicional na análise do livro didático}

Segundo os autores, esses três princípios de composição aplicam-se não somente a imagens individuais, mas também a visuais compostos, que combinam texto, imagem e, talvez, outros elementos gráficos, estejam eles em uma página ou em uma tela de computador ou de televisão.

Essa questão é essencial para o contexto do presente estudo, uma vez que, no caso do livro didático, nos deparamos na maioria das vezes não com uma imagem individual, mas sim, com diversos elementos visuais, textuais e gráficos dispostos em uma mesma página ou em uma página dupla, quando esta constitui uma unidade de sequência didática, como acabamos de ver no exemplo de dupla página de Forum 1. Como veremos mais adiante, os livros didáticos atuais são cada vez mais multimodais e uma teoria de análise da imagem que não a insira nesse contexto é menos pertinente para o estudo do uso pedagógico efetivo da mesma. Vejamos a passagem em que Kress e van Leeuwen explicam mais detalhadamente esse ponto:

$\mathrm{Na}$ análise dos textos compostos ou multimodais (e qualquer texto cujos significados são realizados por meio de mais um código semiótico é multimodal), pergunta-se se os produtos dos vários modos devem ser analisados separadamente ou de forma integrada; se os significados do conjunto devem ser tratados como a soma dos significados das partes, ou se as partes devem ser vistas interagindo entre elas e afetando umas às outras. É esse último caminho que vamos seguir neste capítulo. ${ }^{25}$

(KRESS \& VAN LEEUWEN, $2006:$ 177)

\footnotetext{
25 Tradução nossa. No original: "In the analysis of composite or multimodal texts (and any text whose meanings are realized through more than one semiotic code is multimodal), the question arises whether the products of the various modes should be analysed separately or in an integrated way; whether the meanings of the whole should be treated as the sum of the meanings of the parts, or whether the parts should be looked upon as interacting with and affecting one another. It is the latter path we will pursue in this chapter."
} 
Ao analisar um texto multimodal composto por texto e ilustração, os autores afirmam:

Não procuramos ver a imagem como uma "ilustração" do texto verbal, tratando, assim, o texto verbal como preexistente e mais importante, nem tratamos o texto visual e verbal como elementos totalmente distintos. Procuramos ser capazes de olhar para a página inteira como um texto integrado. Nossa insistência em fazer comparações entre linguagem e comunicação visual decorre deste objetivo. Buscamos quebrar as fronteiras disciplinares entre o estudo da língua e o estudo de imagens, e procuramos, na medida do possível, usar uma linguagem e uma terminologia compatíveis para falar sobre ambos, pois na comunicação real os dois, e na verdade muitos outros, se unem para formar textos integrados. ${ }^{26}$

(KRESS \& VAN LEEUWEN, 2006: 177)

Assim, eles definem dois códigos de integração composicional: o modo de composição espacial, descrito anteriormente (valor da informação, saliência e enquadramento) e o modo de composição temporal, presente em textos que se desenrolam ao longo do tempo, como a fala, a música, a dança. Alguns tipos de textos multimodais utilizam ambos, como o cinema e a televisão, apesar de o ritmo ser geralmente o princípio integrativo dominante nesses dois casos.

Nesta tese, nos concentramos na análise da imagem fixa nos manuais de FLE sendo, portanto, o modo de composição espacial nosso foco. De fato, o aspecto composicional formal sobressai em nossas análises, já que as páginas dos livros didáticos de FLE combinam cada vez mais diferentes modos semióticos para a construção do sentido, como texto, fotos, ilustrações, quadros, gráficos. (Figuras 29 e 30).

\footnotetext{
${ }^{26}$ Tradução nossa. No original: "[...] we do no seek to see the picture as an 'illustration' of the verbal text, thereby treating the verbal text as prior and more important, nor treat visual and verbal text as entirely discrete elements. We seek to be able to look at the whole page as an integrated text. Our insistence on drawing comparisons between language and visual communication stems from this objective. We seek to break down the disciplinary boundaries between the study of language and the study of images, and we seek, as much as possible, to use compatible language, and compatible terminology to speak about both, for in actual communication the two, and indeed many others, come together to form integrated texts."
} 
Figura 29 | Écho $A 1$ - página X

\section{o Parcours d'initiation}

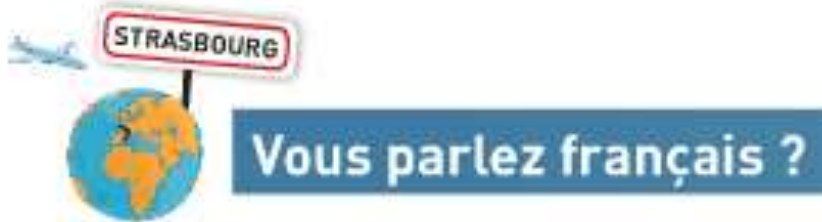

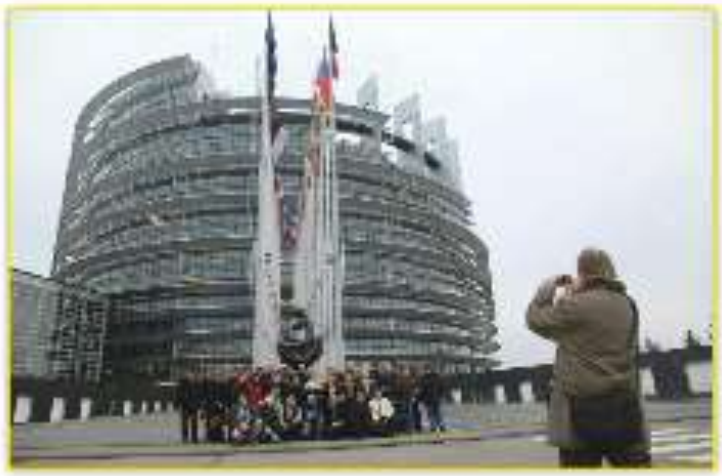

Parlamento vuropeo

European Parllament

Parlamento europeu

Europdisches Parfament

Parlament Europejski

Parlement européen

Eupuntuíkó кoเvoß̧ochiso

Europees Parlement

Европейски парламеит

\section{Liste des participants}

EL. MESSAOUDC Hakim

HSCOIDON Amparm

GRONBERG Dieter

KANDISXI lpor

L.EGALND Vincei:

MARTIN] L I iigi

MENDOZA Adrian

UZUMER AXr

WANG IMU

WILSON Diana
- Excusez-mol vous porved francais

- Nan

- Moi je parle tringais

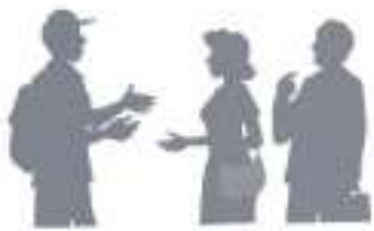

sien Asseciez les mots ti-contre

et les lanques.

$\square$ allemand

$\square$ builgare

$\square$ gres.

$\square$ hollandois

$\square$ polonas

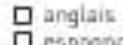

$\square$ espogrio

$\square$ francais

$\square$ ilisien

$\square$ purtugas

ET Lisez la liste des participants.

Imagibez quelle Iangue ills partent.

Evemple a lil parte

- allemapile parte

- atlemanes *angla

- arabe * chinois

- espagaol $\quad$ - francas

- rusere viere

E3: Quelle(s) tanguels] partez-vous?

\section{Parter}

Ie parlefrancais.

Tu paries espagrod

Wuus parkse chinats

a park italien.

Ele parks partugse 
Figura 30 | Écho A1 - página 93

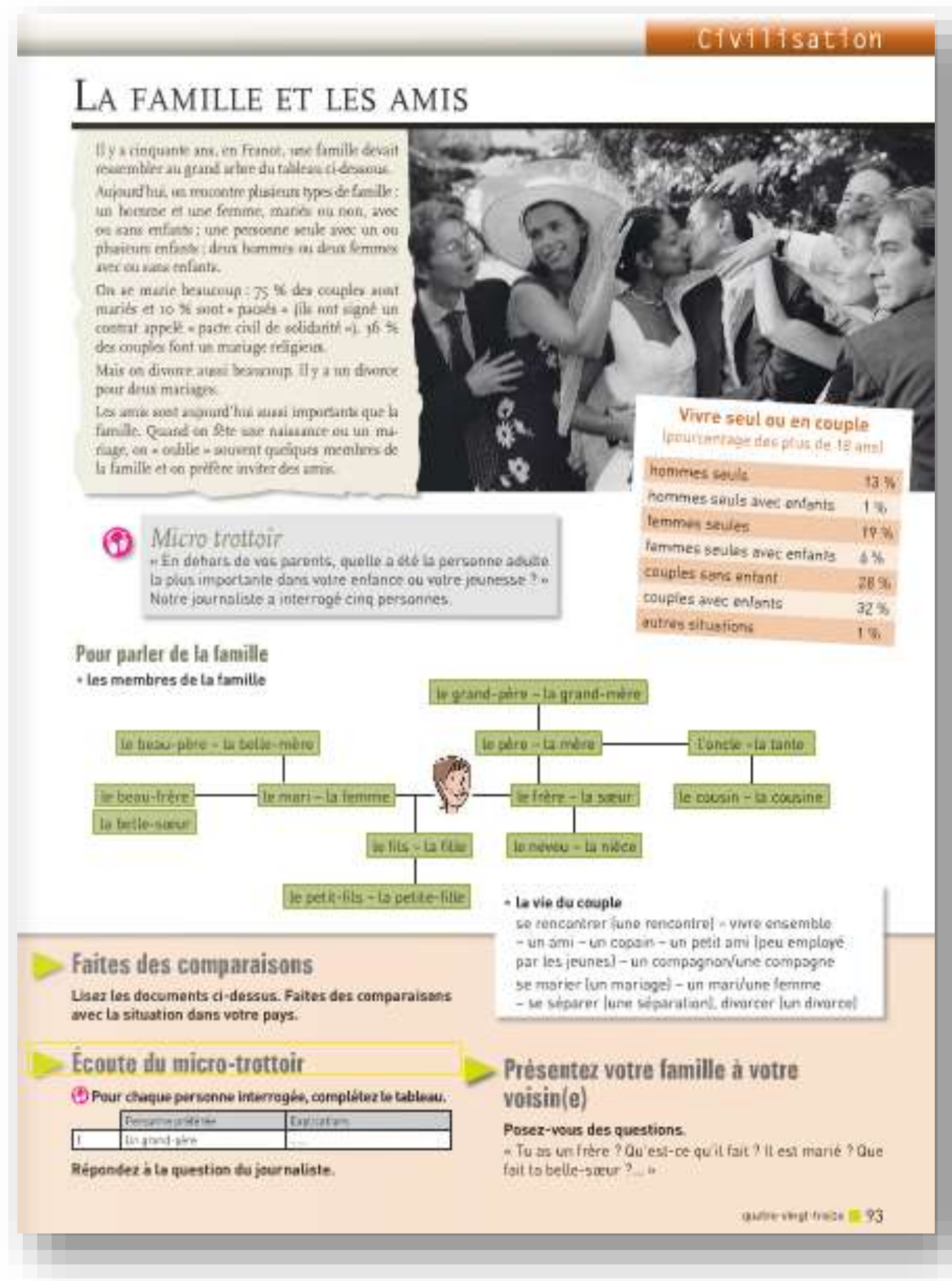

As ferramentas da GDV definidas por Kress e van Leeuwen para a compreensão da imagem e de um texto multimodal nos trazem elementos concretos para a leitura desses suportes também em sala de aula, na exploração de um livro didático. No entanto, segundo importantes referenciais teóricos que nos servem de 
base, ao falarmos de "linguagem" visual, inserimo-nos dentro da visão bakhtiniana de linguagem. Ou seja, concebemos a imagem e o texto multimodal como uma produção dialógica, uma vez que eles são determinados por um conjunto de produções anteriores, dirigem-se a alguém e respondem a demandas socioculturais específicas.

Robert Vion (1992) afirma que essa noção bakhtiniana de dialogismo é um dos componentes da dimensão interativa da linguagem. Ele lembra que os trabalhos da Escola de Palo Alto foram os primeiros a explicitar as diferentes concepções que se pode ter da comunicação. Citando Winkin (1981), Vion afirma que a noção de comunicação não se baseia na ideia de telégrafo ou de ping-pong, ou seja, em um processo que seguiria as seguintes etapas: codificação, envio da mensagem codificada, recepção e descodificação da mensagem. A melhor metáfora para a comunicação não seria então a de um “telégrafo", mas sim a de uma "orquestra” ou a de um balé interativo. De fato, a comunicação é concebida como um sistema de múltiplos canais do qual o ator social - mais do que marcado, construído social e dialogicamente - participa de forma contínua e respondendo às motivações socioculturais do momento da interação. Esse aspecto é abordado por Bakhtin da seguinte forma:

Qualquer que seja o aspecto da expressão-enunciação considerado, ele será determinado pelas condições reais da comunicação em questão, isto é, antes de tudo pela situação social mais imediata. (BAKHTIN, 2004: 112)

Pietraróia (2001), ao analisar aspectos práticos e teóricos da leitura, afirma que conceber a leitura como uma atividade de construção do sentido é dizer que o ou os sentidos não são fornecidos previamente, e nem podem ser "achados" no texto, como se lá tivessem sido fixados pelo autor. Ela ressalta a importância da interação na criação do sentido:

Ler, como bem diz Ítalo Calvino, é «aproximar-se de algo que acaba de ganhar existência» e é nessa aproximação, nas interações por ela criadas, que a leitura passa a ser um processo de construção de sentido, marcado por representações e experiências que se complementam ou se entrechocam, mas sempre inscrito em contextos singulares e significativos.

(PIETRARÓIA, 2001: 98) 
Essa definição para a leitura corrobora com a noção de "orquestra" no processo comunicativo e a mesma é, sem dúvida alguma, válida para a comunicação visual.

Para que o processo de leitura de uma imagem seja desenvolvido e aprofundado, vimos que é preciso dispor de ferramentas específicas para tal, mas sabemos que a construção do sentido da imagem será realizada por meio de interações e de outros fatores que não se encontram inseridos nessa "caixa de ferramentas". Em outras palavras, a leitura da imagem é feita levando-se em consideração as experiências pessoais e socioculturais de cada "espectador" e por seus museus imaginários, por sua biblioteca visual.

Por essa razão, nas análises de livros didáticos de FLE que apresentamos no próximo capítulo desta tese, utilizamos as teorias da gramática do design visual com a ressalva de que se deve levar em conta o repertório cultural do professor que trabalha uma determinada imagem com um aluno, o repertório cultural desse último e o contexto em que esses atores interagem, bem como a relação que estabelecem (em geral hierárquica e marcada ideologicamente) entre si. Dentro desse contexto, não há como não considerarmos uma importante citação de Joly:

Uma boa análise define-se antes de mais pelos seus objetivos. Definir o objetivo de uma análise é indispensável para estabelecer os seus próprios instrumentos, não esquecendo que eles determinam em alto grau o objeto da análise e as suas conclusões. De fato, a análise por si própria não só não se justifica como não tem interesse; ela deve servir um projeto e é este que lhe fornecerá a sua orientação, assim como lhe permitirá elaborar a sua metodologia. Não há método absoluto para a análise, mas sim opções a fazer, ou a inventar, em função dos objetivos.

(JOLY, 2007: 54). 


\section{CAPÍTULO 3 | ANÁLISE DO USO DA IMAGEM EM LIVROS DIDÁTICOS DE}

FLE

“Para que serve um livro sem imagens?”, pergunta Alice. Lewis Carroll, Alice no país das maravilhas 


\section{CAPÍTULO 3 | ANÁLISE DO USO DA IMAGEM EM LIVROS DIDÁTICOS DE FLE}

\subsection{Livro didático: definição, edição, utilizações previstas e efetivas.}

Antes de analisarmos o uso da imagem nos livros didáticos, parece-nos importante fazer algumas considerações sobre esse tipo de publicação. A primeira diz respeito à própria definição desse termo e ao papel que as editoras costumam exercer na concepção desse material. A segunda, que abordaremos mais adiante nesta mesma seção, diz respeito aos usos previstos pelos criadores do material e os usos feitos efetivamente por seus usuários.

\subsubsection{Definição e autoria: a questão do mercado editorial}

O pesquisador francês Alain Choppin (2007) define da seguinte forma as “múltiplas facetas" de um livro didático (doravante LD): um produto industrial e comercial que se insere em um dos principais setores editorias do mercado; um suporte de iniciação à leitura; um vetor poderoso de ideologia e de cultura, participando da construção identitária e da formação das mentalidades coletivas; um suporte de conhecimentos cuja transmissão a gerações mais jovens é considerada essencial por um grupo social; um instrumento de ensino e de aprendizagem comum à maioria das disciplinas escolares; uma publicação que, pela extensão de sua divulgação e pela natureza de seus públicos, constitui um desafio para o poder político.

Choppin (2009) nos lembra que o conceito de livro didático é historicamente recente. Na França, a noção apareceu apenas depois da Revolução. Em outros países ocidentais, várias denominações foram utilizadas em diferentes épocas tentando reagrupar livros escolares com características semelhantes. O mesmo autor (2004) afirma que, após ter sido negligenciada por muito tempo, a pesquisa científica sobre os LDs conhece uma considerável expansão a partir dos anos 1960 e, sobretudo, nos últimos vinte anos. Uma das razões desse interesse é a grande presença de livros didáticos no mundo e, consequentemente, a importância que o setor escolar assumiu na economia do mercado editorial.

Segundo Choppin (2004), as recentes pesquisas históricas sobre os LDs abordam aspectos bastante diversos, podendo, portanto, ser divididas em duas categorias: 
- Aquelas que, concebendo o livro didático apenas como um documento histórico igual a qualquer outro, analisam os conteúdos em uma busca de informações estranhas a ele mesmo (...), ou as que só se interessam pelo conteúdo ensinado por meio do livro didático (...)

- Aquelas que, negligenciando os conteúdos dos quais o livro didático é portador, o consideram como um objeto físico, ou seja, como um produto fabricado, comercializado, distribuído ou, ainda, como um utensílio concebido em função de certos usos, consumido - e avaliado - em um determinado contexto.

(CHOPPIN, 2004:554)

No primeiro caso, o pesquisador não aborda a história dos LDs, mas sim, a história de um tema, de uma disciplina. No segundo caso, ao contrário, o pesquisador coloca sua atenção diretamente sobre os LDs, "recolocando-os no ambiente em que foram concebidos, produzidos, distribuídos, utilizados e 'recebidos', independentemente, arriscaríamos a dizer, dos conteúdos dos quais eles são portadores." (CHOPPIN, 2004:554).

O pesquisador francês afirma que essa distinção é esquemática e que uma pesquisa geralmente participa - ainda que em proporções variáveis - das duas categorias. No entanto, ele lembra que a grande maioria das pesquisas tem se concentrado mais no discurso textual dos LDs do que no seu discurso visual:

As últimas transformações na análise de conteúdo dos livros didáticos referem-se ao próprio material sobre o qual se baseia seu estudo. Por razões que dizem respeito à formação de pesquisadores e à carência de instrumentos apropriados, as análises dos livros didáticos, independentemente de suas problemáticas, ficam tradicionalmente restritas - ao menos no Ocidente - à análise de texto. [...] Foi no final dos anos 1980, com os avanços da semiótica, o impulso da história das mentalidades e o interesse pelas questões de vulgarização das ciências, que recorreu a muitos esquemas e gráficos, que o livro didático deixou de ser considerado um texto subsidiariamente "enfeitado" de ilustrações, e para que a iconografia didática - e a articulação semântica que une o texto e a imagem tenha sido levada em conta.

(CHOPPIN, 2004:559)

As observações de Choppin reforçam a importância não somente de uma análise do discurso visual do LD como também da interação desse discurso com outros meios semióticos, como a imagem. 
Ao trabalharmos com o livro didático, é preciso que tenhamos consciência de que o autor do conteúdo não é o autor do projeto gráfico-editorial, processo no qual se define a disposição, a composição das formas verbais e visuais e - no caso da iconografia - a própria escolha das imagens e dos componentes visuais. Podemos, portanto, afirmar que o LD é fruto de uma coautoria entre autor, designers e editores.

De fato, os autores de um LD nem sempre podem escolher as imagens e a iconografia que acompanharão as atividades por eles concebidas. Muitas vezes, eles descrevem ao designer e ao editor qual a imagem de que precisam para determinada atividade, em outras, escolhem uma determinada imagem esperando que o editor possa adquirir seus direitos autorais, o que não é garantido.

$\mathrm{Na}$ área do livro didático de língua portuguesa, publicações recentes (BUNZEN \& ROJO, 2005; MARSARO, 2011) mostram que o projeto gráfico-editorial de um LD é marcado por uma série de negociações entre autores e editores.

A pesquisadora Deusa Maria de Souza (1999), ao analisar a questão da autoria do LD, afirma que seu autor passará sempre pelo crivo editorial.

O aparato editorial funciona, de forma drástica, para manter determinados padrões em termos de livros didáticos, motivados por uma combinação de razões de ordem ideológica e por razões econômicas - o livro que fará mais sucesso será aquele que venderá mais exemplares.

(SOUZA, 1999: 28)

Um procedimento que tem sido cada vez mais constante no meio editorial é a fragmentação das tarefas na elaboração de um material didático. Muitas vezes, os diferentes componentes de uma coleção didática (livro do aluno, caderno de exercícios, guia pedagógico, etc.) não são concebidos pelo mesmo autor ou pela mesma equipe de autores. Fatores econômicos podem justificar essa escolha: os autores mais célebres e, consequentemente, mais caros, são solicitados apenas para a elaboração do livro do aluno. Seus nomes aparecem em destaque como uma garantia da qualidade do material. Outro autor ou outra equipe de autores menos conhecidos são então contratados para criar o caderno de exercícios. Há também casos em que o guia do professor - que deveria, em princípio, traduzir a orientação pedagógica adotada no livro do aluno - é concebido por outros profissionais. A comunicação entre as duas equipes é, portanto, essencial para a coerência e unidade do material didático. 


\subsubsection{Utilizações previstas, utilizações efetivas.}

A segunda questão sobre o LD que gostaríamos de abordar nesta seção diz respeito aos usos previstos pelos seus criadores (autor, designer, editor) e os usos efetivos feitos pelos professores. Essa questão parece-nos estreitamente ligada ao item anterior, no qual vimos que o livro didático, em sua própria definição, é considerado um objeto depositário de conhecimentos e saberes de um grupo social.

Ao abordar a questão da legitimação do LD, a pesquisadora Maria José Coracini (1999) parte do pressuposto de que todo processo de legitimação provém do reconhecimento de valores que constituem a ética de um grupo social. Dentro desse raciocínio, a legitimação do LD se daria, portanto, na própria escola por meio do uso do material pelo professor:

É nesse contexto que se insere o uso do livro didático pelo professor que, autorizado pela instituição escolar (já que é portador de um diploma legalmente reconhecido), legitima o material comercializado, considerando-o a base para o seu trabalho em sala de aula. Assim, o livro didático funciona como o portador de verdades que devem ser assimiladas tanto por professores quanto por alunos.

(CORACINI, 1999: 33-34)

A autora lembra, no entanto, que com o advento da abordagem comunicativa, o LD passou a ser criticado, sobretudo, por professores de língua estrangeira que passaram a preferir um trabalho com documentos autênticos. De fato, pedagogos e linguistas aplicados concebiam o LD como um material fabricado, artificial que escravizaria o professor, limitando sua criatividade. Coracini ressalta que só bem recentemente houve uma mudança na concepção da utilização do livro didático:

Só bem recentemente voltou-se a admitir que ele ocupa um lugar central no ensino de línguas estrangeiras, tanto quanto nas demais disciplinas, a ponto de nos levar a questionar se o ensino está centrado no aluno, como gostariam pedagogos e professores, ou no livro didático, do qual o professor não seria senão o mediador.

(CORACINI, 1999: 35) 
Essa questão de o professor muitas vezes ser visto como um simples mediador de um material que foi legitimado pela sociedade e pela instituição parece-nos essencial. De fato, dentro desse contexto de pré-legitimação, o professor seria apenas o portador de uma "verdade" que deve ser "transmitida" da maneira mais fiel possível aos alunos.

A pesquisadora Marisa Grigoletto (1999) salienta que na esfera escolar o LD pode funcionar como um dos "discursos de verdade":

Afirmando ser o LD um discurso de verdade, queremos dizer que ele se constitui, no espaço discursivo da escola, como um texto fechado, no qual os sentidos já estão estabelecidos (pelo autor), para ser apenas reconhecido e consumido pelos seus usuários (professor e alunos). [...]

É digno de nota o fato de o livro do professor trazer prefácios curtos, nos quais o autor geralmente não se estende em justificativas sobre a metodologia adotada ou os conteúdos privilegiados, como se tais aspectos já estivessem legitimados a priori. O professor recebe um "pacote" pronto e espera-se dele que o utilize. Ele é visto como usuário, assim como o aluno, e não como analista. Ele é um consumidor do produto segundo as diretrizes ditadas pelo autor. Essa concepção do professor como consumidor e não construtor, como usuário e não analista pode ser inferida também por outra característica do livro do professor [...] que é a de apresentar as respostas a todos os exercícios. Tais procedimentos, que estabelecem o LD como um objeto fechado à interpretação, revelam a concepção, pelo autor e editor do LD e, possivelmente, também pelos seus consumidores, de que o livro seja um lugar no qual os sentidos se fecham, se completam e aparecem de forma transparente ao professor.

(GRIGOLETTO, 1999: 68)

Essa reflexão nos parece importantíssima no trabalho docente. De fato, muitas vezes os próprios professores concebem o LD como um material "fechado", limitandose simplesmente a "aplicar" seu conteúdo em sala de aula. A nosso ver, esse engessamento que permeia a produção e a utilização do LD constitui a causa das principais dificuldades de utilização desse material no ensino-aprendizagem de línguas estrangeiras. Por sua própria origem e missão, o LD deveria "abrir", “criar”, "levar a construir" sentidos e não "fechar" os mesmos. 
Para os estudiosos do trabalho educacional, a atividade docente é caracterizada não somente pela recepção de prescrições oficiais e institucionais, concebidas para todos, como também pela ação que, como sujeito, o professor exerce sobre esse material, reformulando, recriando e adaptando essas prescrições ao seu contexto de trabalho (SAUJAT, 2002). Isso ocorre, por exemplo, quando ele adapta as prescrições do livro didático adotado pela sua instituição em função de seus grupos, de seus alunos. As pesquisadoras Anna Rachel Machado e Eliane Gouvêa Lousada (2010) concebem essa ação do professor como uma transformação de artefatos em instrumentos.

A abordagem instrumental que distingue "artefatos" de "instrumentos" tem sua origem em Vygotsky e foi desenvolvida mais recentemente por Pierre Rabardel (1995, 2003). Na visão desse autor, a noção de ferramenta ou de instrumento é muitas vezes compreendida apenas em seu sentido material, ou seja, como um objeto físico. No entanto, um conceito psicológico se faz necessário para analisar a situação do ponto de vista do homem que exerce uma ação com e sobre essa ferramenta, ou seja, a noção de instrumento.

O artefato é visto portanto como um meio material (martelo, enxada, etc.) ou simbólico (linguagem algébrica, símbolos, etc.) enquanto que a noção psicológica de instrumento inclui as ações e utilizações feitas com e sobre esse artefato pelo sujeito.

De acordo com Machado e Lousada (2010), prescrições oficiais como os Parâmetros Curriculares Nacionais (PCNs) podem ser consideradas artefatos, uma vez que são concebidas como preconizações de trabalho para uma coletividade. As autoras salientam, no entanto, que para que o professor atinja esses objetivos prescritos, é preciso que ele esteja convencido de que os mesmos são bons não apenas para o aluno, mas também para o seu bem-estar. Só assim poderemos falar de apropriação de um artefato pelo trabalhador e de sua consequente transformação em instrumento.

Segundo Rabardel (2003), a criação de instrumentos constitui, portanto, uma atividade feita por "designers" e por "usuários":

A tarefa dos designers é a elaboração de uma proposta de instrumento sob a forma de artefatos e em termos de operações previstas (design para o uso). Os usuários podem tirar proveito dessas propostas (totalmente, parcialmente ou de forma alguma), a fim de desenvolver seus próprios instrumentos - instrumentos estes que preencham suas próprias necessidades, em função da 
organização e das situações nas quais serão utilizados (design em uso). ${ }^{27}$

(RABARDEL, 2003: 643).

De acordo com Lousada (no prelo), no caso do livro didático, o autor enfrenta muitas vezes uma situação conflitante, uma vez que deve se adaptar ao mesmo tempo às prescrições oficiais de educação e às prescrições da editora que, por sua vez, se pautam sobre uma lógica de mercado. Essas duas prescrições são por vezes contraditórias, o que faz com que o material didático seja concebido em uma relação complexa. Segundo a pesquisadora, os responsáveis pelo “design para uso" e pelo “design em uso" deveriam trabalhar conjuntamente e ter autonomia para fazer propostas. Incluir os responsáveis pelo design em uso, ou seja, os professores, na elaboração dos LDs deveria fazer parte das propostas das editoras como uma maneira de realizar artefatos mais eficientes para o uso e que seriam, portanto, mais facilmente transformados em instrumentos.

Essa questão parece-nos importante pois, nesta pesquisa, estudamos justamente os artefatos que constituem os livros didáticos de FLE e buscamos entender, do outro lado e ao mesmo tempo, algumas características dessa apropriação total ou parcial do artefato feita pelo professor, transformando o livro didático em instrumento de trabalho.

Na próxima seção, procedemos à análise prática do uso da imagem nos quatro livros didáticos de FLE identificados:

- Archipel 1, COURTILLON, J. ; RAILLARD, S. Paris : Didier, 1982.

- Espaces 1, CAPELLE, G. ; GIDON, N. Paris : Hachette FLE, 1990.

- Forum 1, BAYLON, C. ; CAMPÀ, A. ; MESTREIT, C. ; MURILLO, J. ; TOST, M. Paris : Hachette, 2000.

- Écho A1, GIRARDET, J. ; PÉCHEUR, J. Paris : CLE International, 2010.

Um espaço de tempo de cerca de 10 anos separa uma publicação da outra e acreditamos que todos esses LDs sejam bem representativos de sua respectiva década.

${ }^{27}$ Tradução nossa. No original: « The task of designers is to elaborate an instrumental proposition in the form of artefacts and in terms of anticipated operations (design for use). Users may take advantage of these propositions (totally, partially or not at all) in order to develop their own instruments - instruments that fulfill their own characteristic needs, depending on the organisation and the situations, where they are to be used (design in use). » 
Nesta análise, levamos em conta os pressupostos teóricos de Kress e van Leeuwen (2006) para uma primeira leitura do texto visual e multimodal. Buscamos também conhecer a quantidade de imagens presentes em cada um dos livros do aluno e o número de menções às mesmas nos respectivos guias do professor. A função pedagógica reservada à imagem no texto multimodal também nos interessará e buscaremos, portanto, encontrar tanto no livro do aluno quanto no guia do professor prescrições para o seu uso.

\subsection{Análise $n^{\circ} 1 \mid$ Archipel 1}

COURTILLON, Janine ; RAILLARD, Sabine. Paris : Didier, 1982.

O livro do aluno Archipel 1 faz parte da coleção Archipel, destinada à aprendizagem do francês língua estrangeira por adultos e grandes adolescentes. Concebido por Janine Courtillon e Sabine Raillard, Archipel marcou sua época e é frequentemente citado como um dos primeiros métodos pertencentes à abordagem comunicativa, apesar de ainda conter alguns elementos da metodologia SGAV, sobretudo no que se refere às repetições e memorizações dos diálogos. Também da metodologia SGAV, Archipel herdou a presença de um filme fixo acompanhando os diálogos. Sua função é descrita da seguinte forma no guia do professor:

Chaque unité comporte en général les matériaux suivants : six à dix courtes situations, constituées de dialogues enregistrées. Elles sont accompagnées d'un film fixe visualisant le lieu de communication et les principales attitudes des personnages. Ces images entretiennent avec le texte un rapport plus lointain que dans les méthodes audiovisuelles classiques. Elles servent de point de départ à la compréhension globale de la situation. Très tôt, l'écoute se substitue à l'image qui s'efface pendant la phase de mémorisation. $[\cdots]$ 


\subsubsection{Análise da capa do livro do aluno Archipel 1}

Trata-se de uma capa bastante sóbria (Figura 31), mas com um apelo importante às cores, o que costumava ser adotado com frequência por outros manuais dos anos 80. O título aparece no alto em preto e remete à ideia bastante difundida na época de que não estamos mais apenas na França continental: a língua francesa toma uma dimensão mais ampla, associando-se à ideia de arquipélago - e não de ilha. Ela ganha espaço e convida a novas descobertas e aventuras. No que diz respeito às cores, o fundo azul apresenta em sua parte inferior um toque de cor quente: o laranja. $O$ aspecto chapado

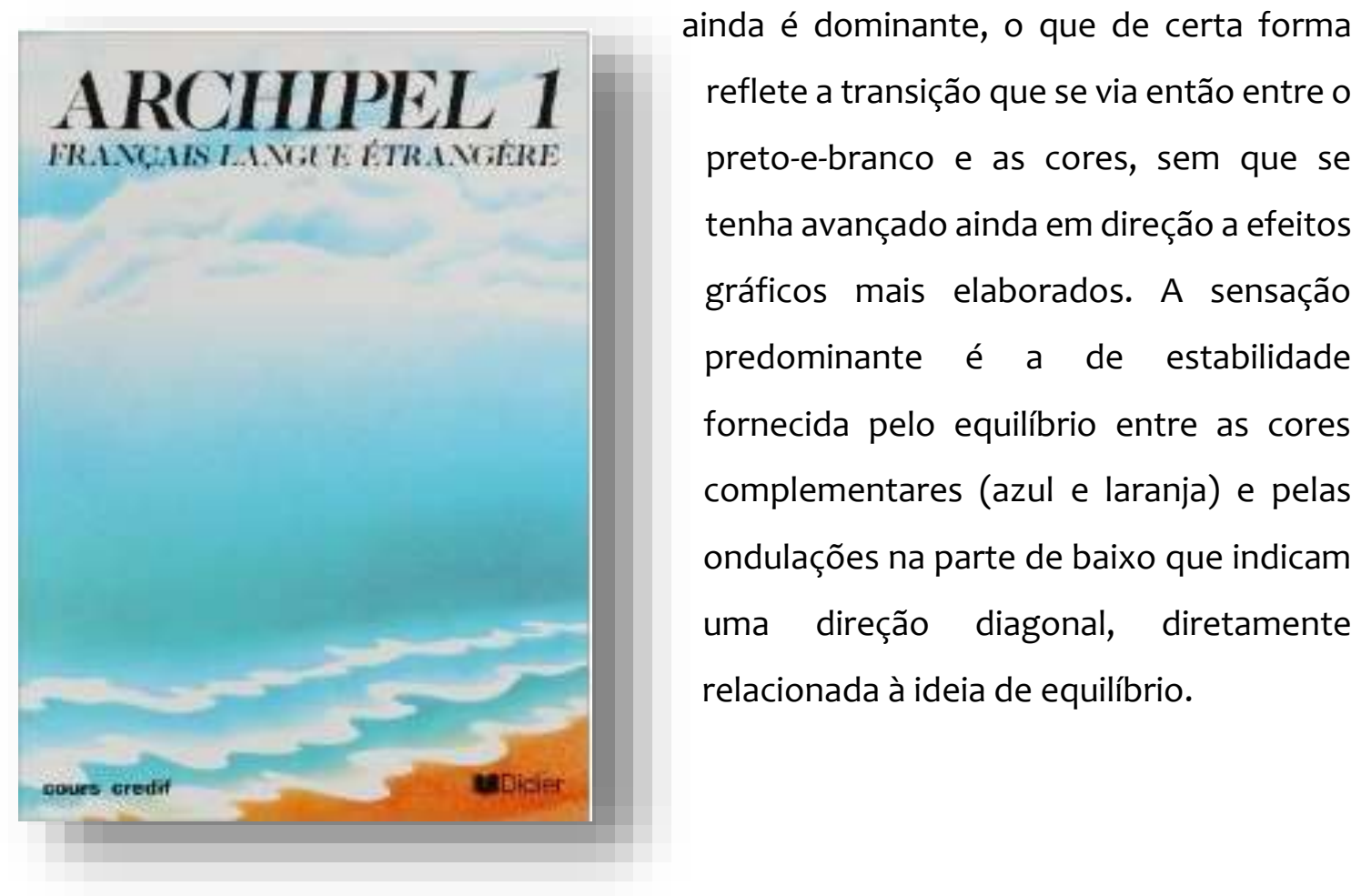

Figura 31 | Archipel 1 - Capa do livro do aluno

\subsubsection{Análise quantitativa das imagens no livro do aluno}

O livro do aluno é constituído exclusivamente por imagens em preto-e-branco. Os tipos de imagens são bastante variados tratando-se, muitas vezes, de documentos autênticos, como fotografias, histórias em quadrinhos, imagens de filmes, ilustrações de obras literárias e de calendários, mapas de cidades, cartazes, pinturas, publicidades, anúncios, menus de restaurante. A publicação traz também ilustrações e desenhos fabricados, concebidos para acompanhar as situações de comunicação apresentadas no livro do aluno. 
Das 162 páginas que compõem as sete unidades do livro do aluno (excluindo-se os anexos com transcrições e correções de exercícios), apenas 65 são constituídas somente por texto, sem o uso da imagem, o que significa que $60 \%$ das páginas do livro Archipel 1 são ilustradas. Além disso, algumas dessas páginas são compostas quase que exclusivamente por imagens.

No que diz respeito à estrutura formal do livro do aluno, encontramos a seguinte descrição no guia do professor:

Le matériel pédagogique est composé des éléments suivants :

1. Un livre de l'élève comportant sept unités composées selon le plan suivant :

«Ambiance »: une image (dessin ou photo) qui illustre le titre et les objectifs fonctionnels de l'unité ;

"Situations ": des séries d'images accompagnées d'un court texte constituant un rappel situationnel ou linguistique de chacune des unités ;

"À lire et à découvrir »: une rubrique que l'étudiant peut parcourir à son gré. Il s'agit tantôt de compléments linguistiques (...), tantôt d'ajouts à caractère culturel ou publicitaire (...). En principe, le professeur n'a donc pas à les exploiter mais à répondre aux questions éventuelles qui pourraient être posées à leur sujet. C'est pourquoi on ne trouvera pas d'indications d'exploitation de cette rubrique dans le livre du professeur ;

"Pratique de la langue »: exercices écrits correspondant au contenu linguistique de l'unité ;

"Pour aller plus loin »: divers documents authentiques (textes publicitaires, journalistiques ou littéraires) à utiliser selon les niveaux et les besoins ;

Les « textes » des dialogues et des exercices liés à la pratique orale de la classe : exercices à choix multiple, canevas et jeux de rôles, activités de production libre.

(COURTILLON; RAILLARD, 1982: 7). Grifo nosso.

As imagens são, portanto, citadas dentro da estrutura do livro nas seções “Ambiente" e "Situações". Os termos utilizados pelo guia pedagógico para descrever a função do suporte visual do livro parecem atribuir ao mesmo um papel secundário e subordinado à linguagem escrita e verbal, como podemos notar por meio do emprego de palavras como "ilustra" e "lembrete situacional". 


\subsubsection{Análise qualitativa e funcional das imagens no livro do aluno}

Analisaremos agora algumas imagens e textos multimodais que compõem cada uma das partes do livro do aluno citadas acima. Comecemos pela "abertura" de cada unidade, a seção Ambiance que, segundo o guia pedagógico, é composta por uma imagem (desenho ou foto) que ilustra o título e os objetivos funcionais da unidade.

$\mathrm{Na}$ figura 32, vemos a página de abertura na unidade 4, que tem os seguintes objetivos funcionais: pedir informações sobre um objeto e informar-se sobre o tamanho, a qualidade e o preço de um produto. As situações da unidade acontecem em lugares públicos, como uma estação de trem, um restaurante, uma farmácia, uma perfumaria, etc. Percebemos que se trata de um texto multimodal no qual o sentido é construído graças ao texto (título do capítulo Que voulez-vous?) e às imagens.

O próprio título do capítulo remete ao tema do consumo, por meio do verbo “vouloir”/ querer. A primeira fotografia à esquerda (Figura 33) nos chama particularmente a atenção já que a mesma é composta também por um texto escrito: um cartaz no qual lemos "Tu te consommes à trop consommer" ("Você se consome consumindo demais.") De acordo com Kress e van Leeuwen (2006), os participantes encontrados em um suporte semiótico visual exercem funções na criação e na construção do sentido do mesmo. 
Figura 32 | Archipel 1, pág.79
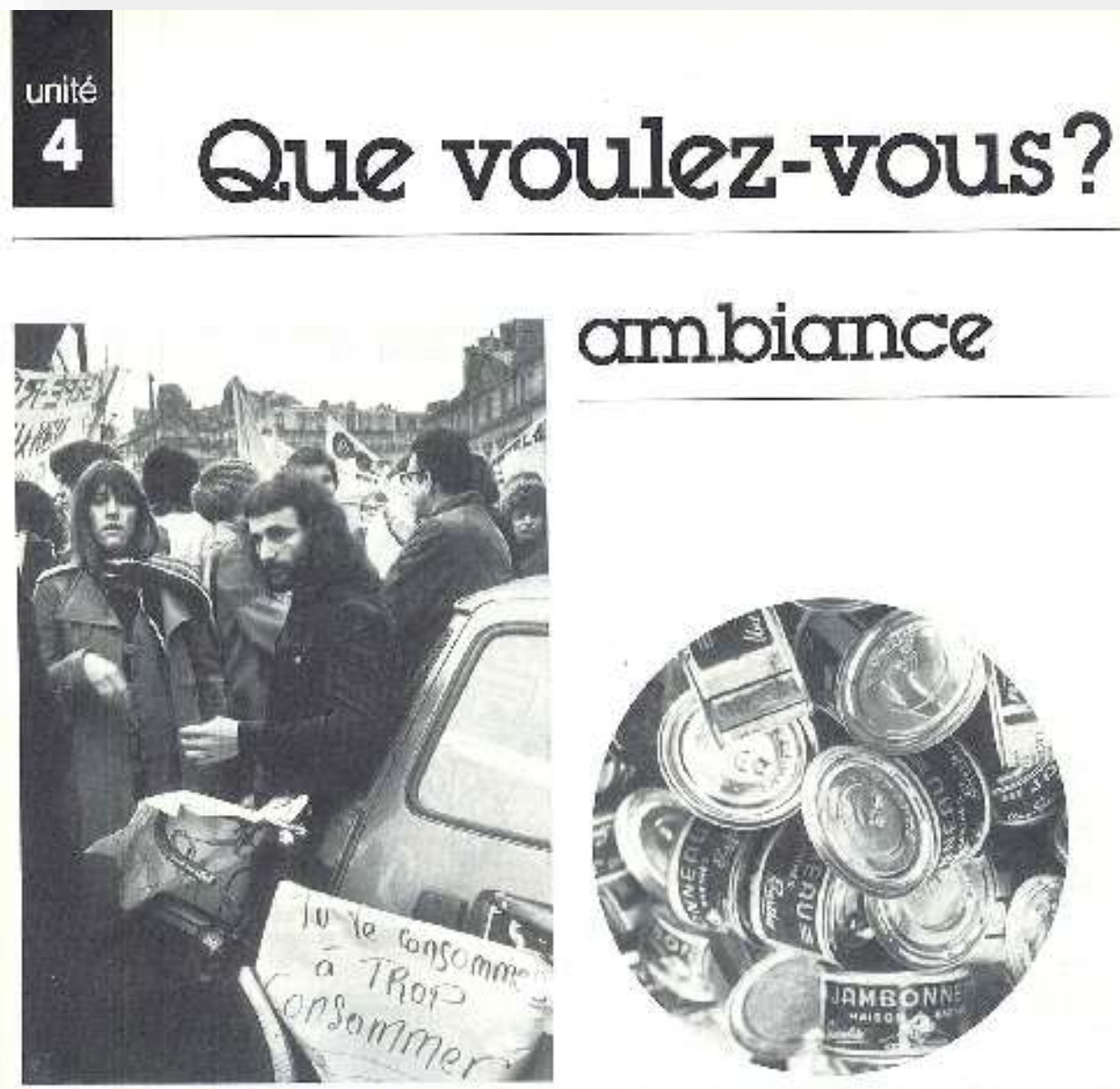

\section{ambiance}

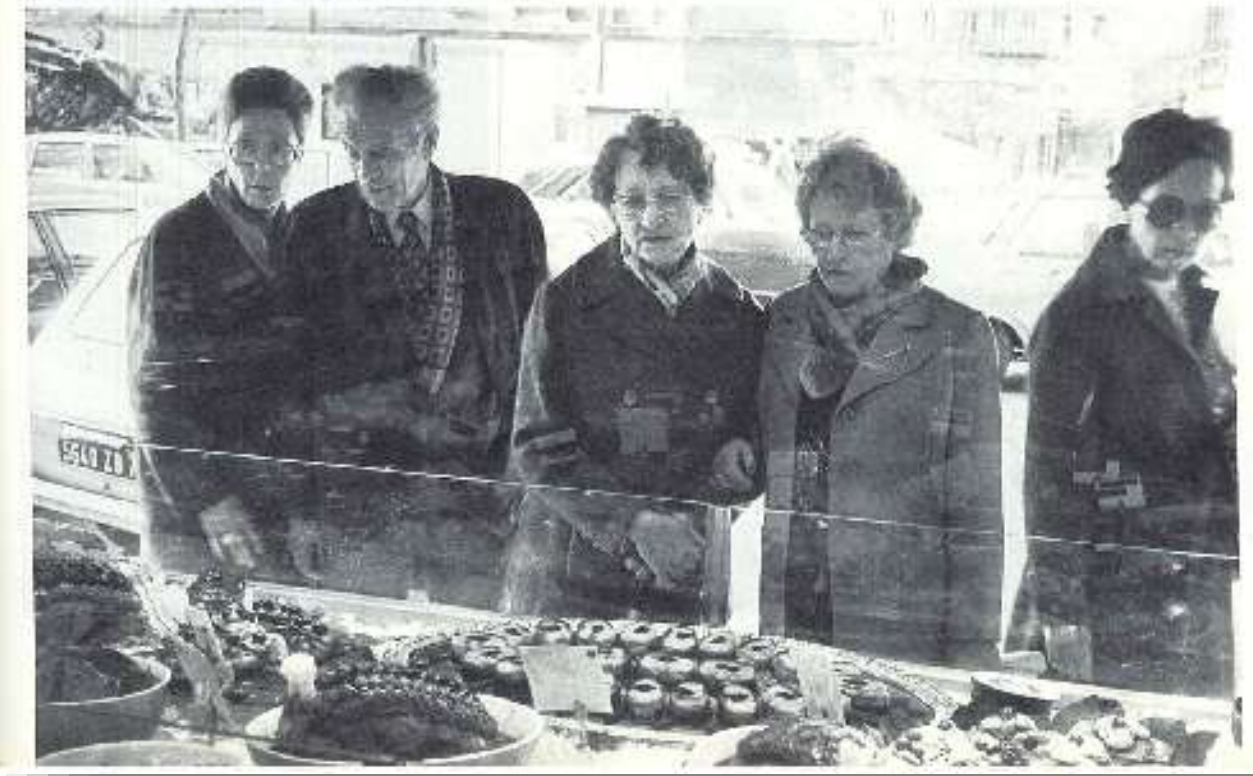


Figura 33 | Archipel 1, pág.79 - Detalhe foto $n^{\circ} 1$

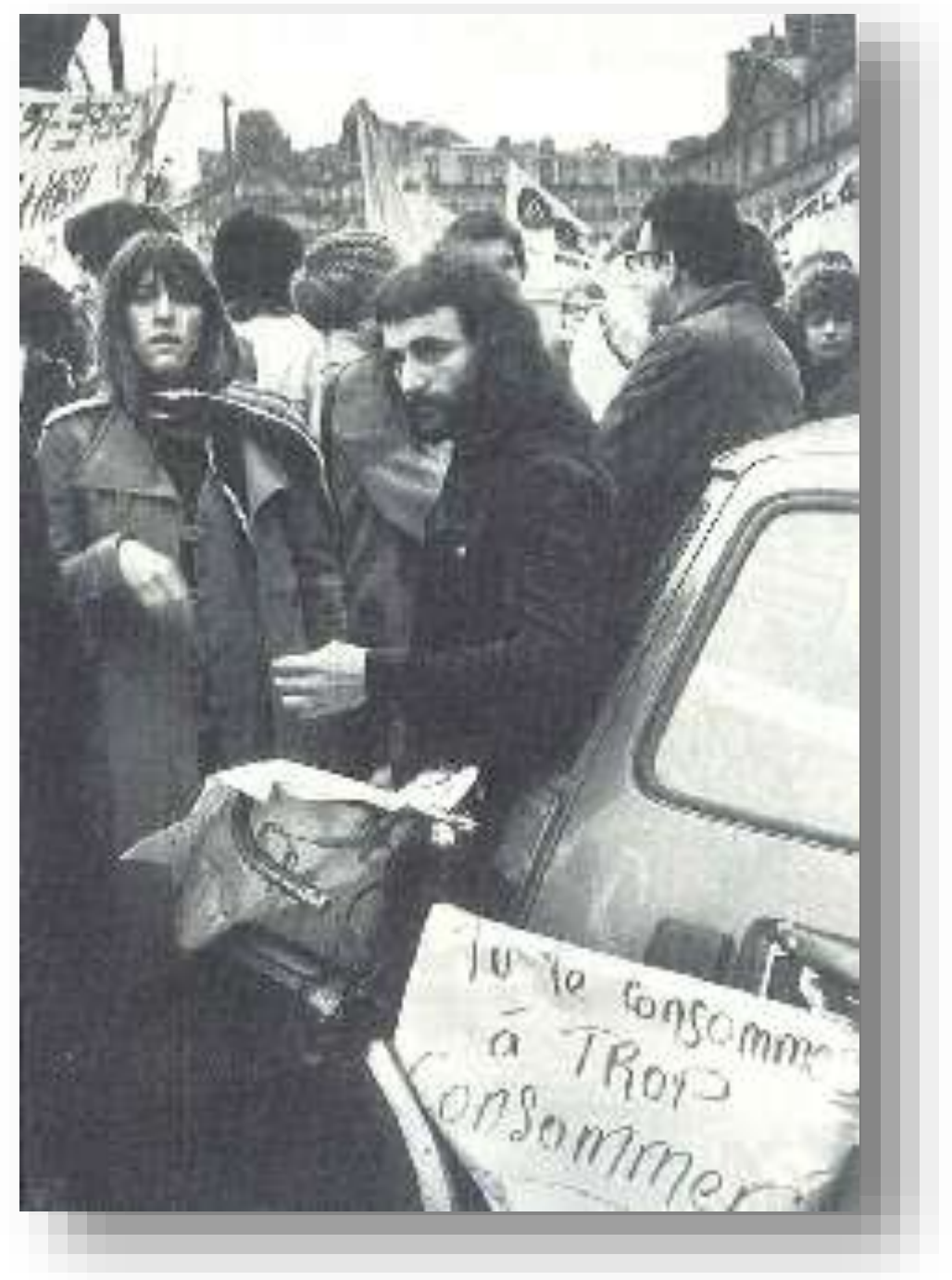

Nessa fotografia, vemos um grupo de pessoas com faixas e cartazes na rua. Dois personagens principais dominam a cena e aparecem realizando uma ação, fazendo algo. Seus braços em movimento criam vetores e podemos dizer que estamos diante de uma estrutura representacional narrativa. Como vimos anteriormente, o propósito dessa página do manual é apresentar os objetivos funcionais da unidade que será abordada. Sabemos que os objetivos funcionais remetem à ação comunicativa a ser realizada pelos alunos e, neste caso, nada mais apropriado do que estruturas representacionais narrativas para ilustrá-las. 
Um aspecto particularmente interessante da imagem, e ao mesmo tempo explicativo da mesma, constitui o cartaz com os dizeres contra o consumo. Não há dúvidas: estamos diante de uma manifestação de rua na qual os participantes defendem um consumo mais racional por parte dos cidadãos.

Analisemos a seguir a mesma imagem sem essa parte de texto para compararmos os processos de criação do sentido. (Figura 34).

Figura 34 | Archipel 1, pág.79 - Detalhe foto ${ }^{\circ}{ }^{1}$



Diante dessa outra versão da mesma imagem, talvez o espectador dissesse que estamos em uma festa de rua ou em um comício. Mesmo se ele evocasse o tema 'manifestação', ele dificilmente evocaria o tema do consumo, ou seja, o motivo da mesma.

Curiosamente, temos nessa página de Archipel uma "mise en abîme" na construção dos sentidos. Ao considerar a página toda como uma unidade, notamos que texto e fotos se relacionam para comunicar uma mensagem. Ao nos determos em um dos elementos desse texto multimodal, ou seja, a fotografia da manifestação, encontramos multiplicidade de códigos em uma unidade visual. De fato, essa imagem 
pode ser considerada por si só um texto multimodal no qual os aspectos visuais e escritos contribuem para a construção do sentido.

No que diz respeito à metafunção interacional e do ponto de vista do contato, ou seja, do olhar do participante em relação ao espectador, sabemos que há uma diferença fundamental entre as imagens em que os participantes olham diretamente para os olhos do espectador e os casos em que isso não acontece. Nessa foto, a jovem à esquerda olha diretamente o espectador, num caso de demanda: o observador é interpelado pelo ator, de onde emana o vetor. Já do ponto de vista da perspectiva, vemos que a jovem é retratada em um ângulo horizontal frontal e no mesmo ângulo de visão vertical do espectador, o que os coloca em posição de igualdade. O espectador se sentirá mais próximo dos manifestantes (e do seu ponto de vista) ao observar essa foto.

Ao analisarmos a metafunção composicional, notamos que essa jovem que interpela o espectador com seu olhar exerce uma função de mediadora entre o mundo real (representado pelo cartaz colado no carro, na parte inferior da imagem e denunciando o excesso de consumo) e o ideal, representado na parte de cima por uma visão geral da manifestação e de seus ideais, como procuramos evidenciar no esquema a seguir (Figura 35).

Figura 35 | Archipel 1, pág.79 - Detalhe foto n¹
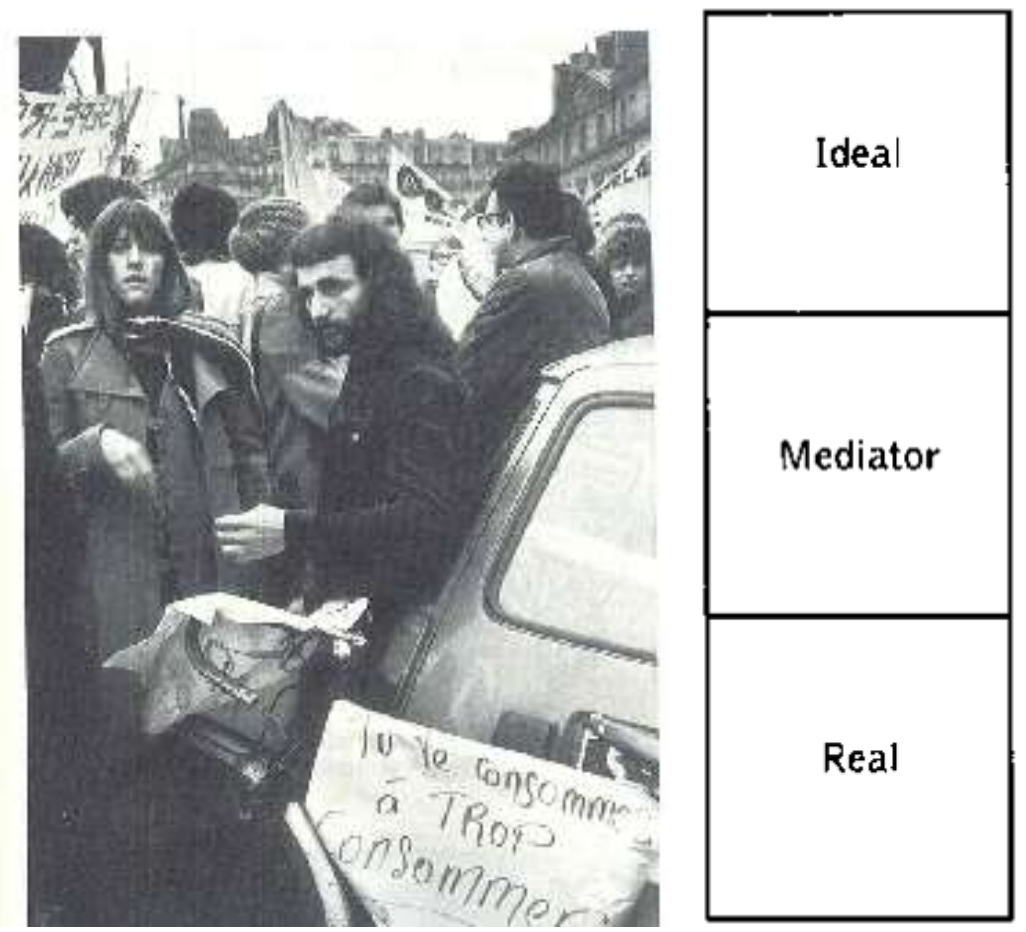
Analisemos agora a imagem que aparece na parte inferior desta mesma página. Ela mostra um grupo de consumidores em uma posição passiva e admirativa diante de uma vitrine. (Figura 36)

Figura 36 | Archipel 1, pág.79 - Detalhe foto $\mathrm{n}^{\circ} 2$

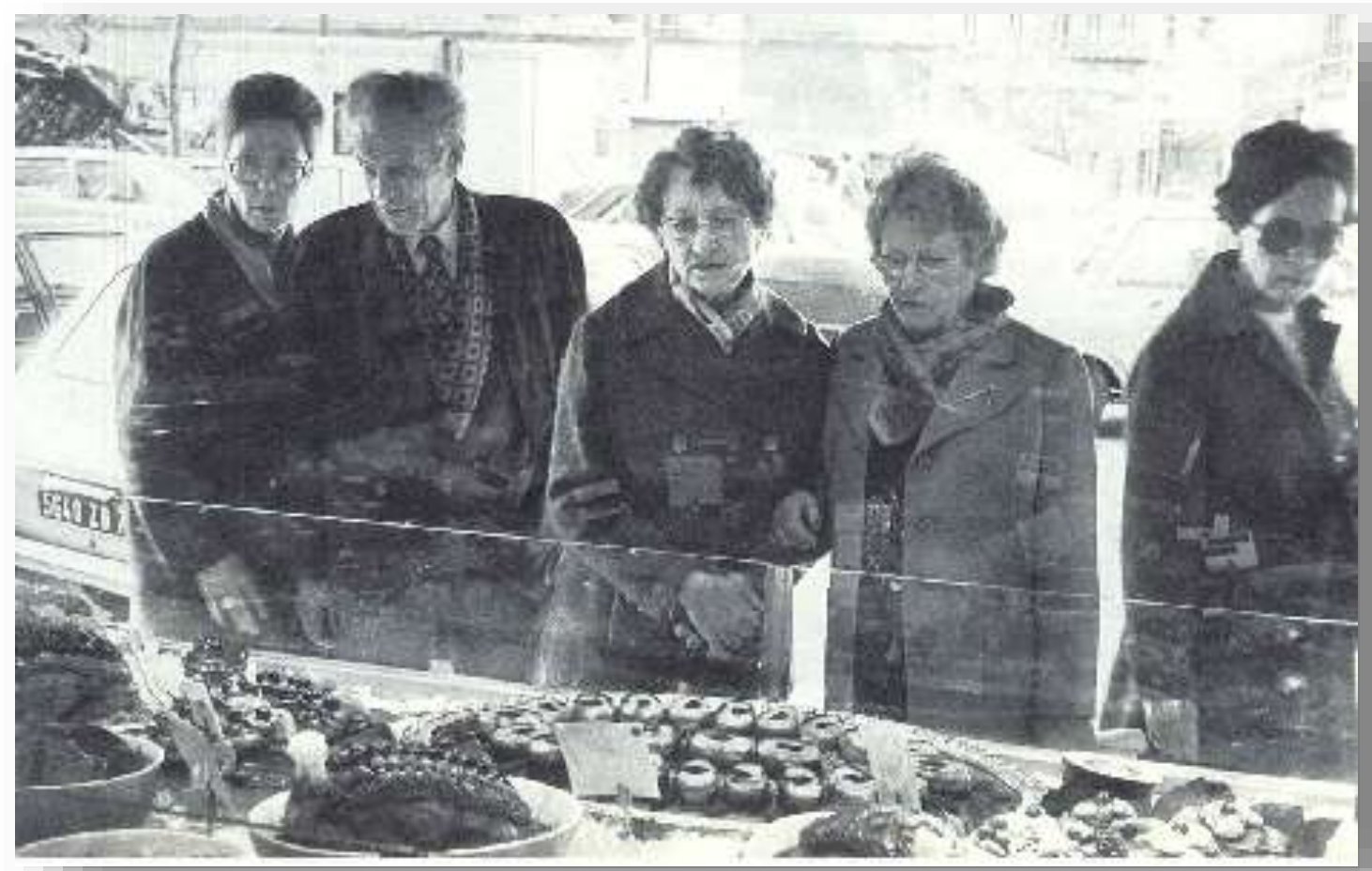

Ao analisarmos a função interacional dessa fotografia, notamos que, do ponto de vista do contato, os participantes não olham diretamente para os olhos do espectador e temos, desta vez, um esquema de oferta e não de demanda como na primeira foto. $\mathrm{O}$ fator interacional da perspectiva nos parece um elemento de análise particularmente importante nessa imagem. Segundo Kress e van Leeuwen (2006), os ângulos verticais definem a relação de poder entre os participantes e o observador. Nessa imagem, o ângulo baixo indica que é o observador quem detém o poder, com uma visão do alto em relação ao participante. Levando-se em consideração o questionamento proposto por esse texto multimodal ao excesso de consumo e a posição passiva dos participantes dessa foto diante da vitrine de um estabelecimento comercial, notamos que o ângulo 
baixo parece também traduzir um olhar crítico (e superior) do espectador em relação a esses participantes "passivamente consumistas".

A combinação das imagens e a inter-relação entre elas contribuem para essa visão crítica à segunda imagem, conforme podemos observar no recorte a seguir (Figura 37):

Figura 37 | Archipel 1, pág.79 - Detalhe foto n²

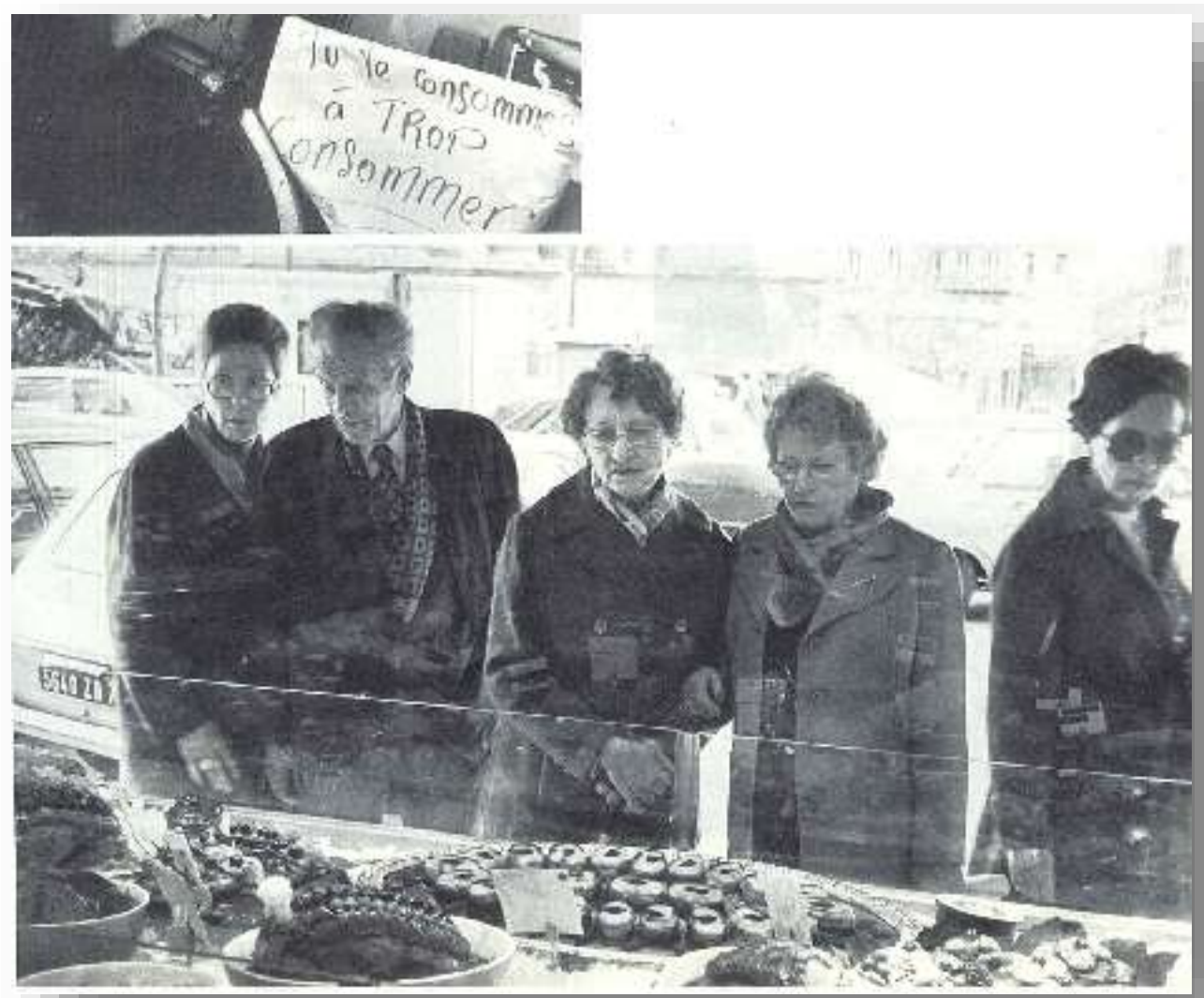

É inegável a influência da imagem superior na inferior, o que confirma a afirmação de Kress e de van Leeuwen (2006) sobre a influência mútua dos componentes de um texto multimodal na criação de significados. Nesse recorte que propomos acima, o cartaz com uma crítica ao excesso de consumo da primeira imagem "Tu te consommes à trop consommer" parece caber como um título para a segunda.

A terceira e última imagem que compõe o texto multimodal dessa página apresenta um amontoado de latinhas, também relacionada à noção de "trop consommer". (Figura 38) 

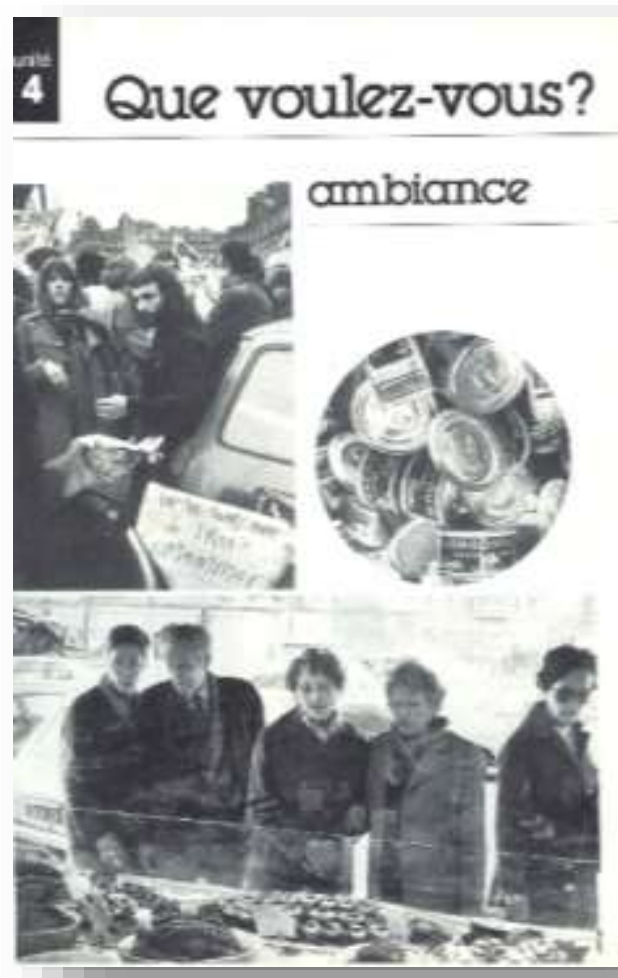

Por todas essas razões, podemos dizer que essa página de abertura da unidade favorece uma postura ativa do aluno em relação ao tema proposto. O título do capítulo o interpela, assim como o olhar da jovem na primeira fotografia analisada. O aluno é convidado a se posicionar frente ao tema a partir dessa interação com o texto multimodal. Curiosamente, esse convite a uma tomada de posição e a uma argumentação não aparece nem no conteúdo linguístico, nem nas imagens que se seguem no capítulo. De fato, nesse capítulo do livro, a aluno aprenderá a estabelecer um contato social em relações comerciais: na farmácia, no restaurante, numa loja. O objetivo comunicativo pode ser traduzido por: pedir um prato num restaurante, se informar sobre o preço de um produto, etc., objetivos estes que estão de acordo com o programa proposto e o nível dos alunos.

No entanto, ao retomarmos a análise do texto multimodal da abertura da unidade, notamos que essa página se presta a um objetivo bem mais ambicioso em termos linguísticos, que poderíamos definir da seguinte forma: tomar posição em relação aos hábitos de consumo, defender e argumentar seu ponto de vista. Ora, esses objetivos não se encaixam em um programa para alunos iniciantes em FLE, como é o caso deste 
livro didático. Concluímos, portanto, que apesar da grande quantidade de imagens presentes nessa página, elas não parecem apropriadas ao objetivo pedagógico e pragmático da unidade. Em outras palavras, podemos afirmar que as imagens e o texto multimodal da abertura desse capítulo não se adaptam aos objetivos do mesmo, o que torna mais difícil seu uso pedagógico, nesse contexto, por parte do professor.

Passemos agora a outra parte do manual, denominada "Situações". Como vimos, o guia pedagógico a apresenta como séries de imagens acompanhadas de um texto curto que constitui um lembrete situacional e linguístico de cada unidade. (Figura 39).

Figura 39 | Archipel 1. Pág. 80, 81

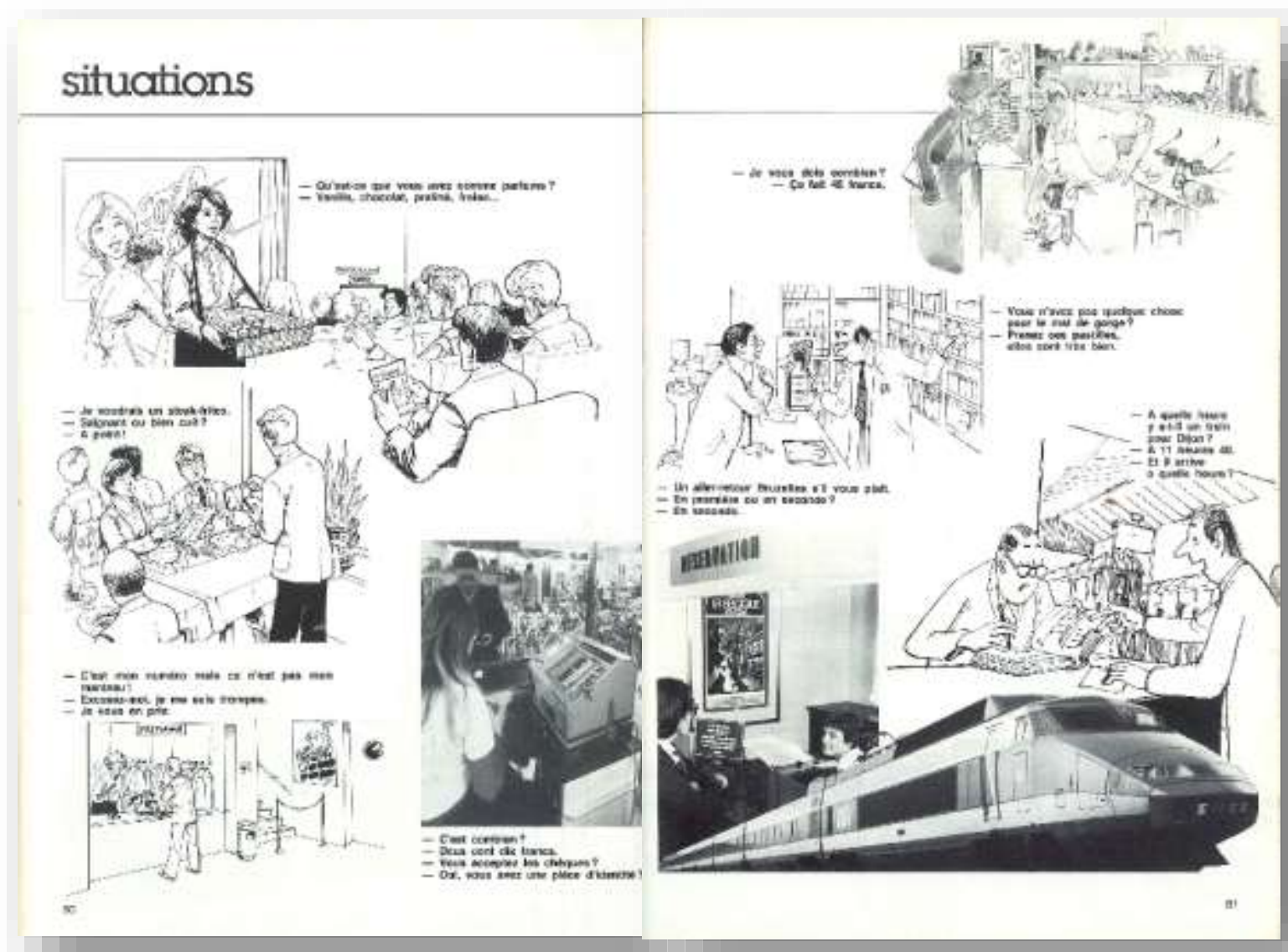

No caso dessa imagem, vemos que se trata, na verdade, de uma dupla página na qual são apresentadas resumidamente as diferentes situações de comunicação da unidade. Essa apresentação é feita de forma multimodal: com pequenas passagens transcritas dos diálogos do livro e imagens que ocupam a quase totalidade do espaço 
gráfico. Apesar da posição física de destaque, a posição funcional pedagógica dessas imagens é secundária. Trata-se, como diz o guia pedagógico, de uma simples ilustração para a situação, ou seja, essa dupla página multimodal é composta por “lembretes” (para se retomar o termo do guia) visuais e escritos para a situação comunicativa trabalhada.

Essa função ilustrativa e subordinada da imagem em relação ao diálogo é citada em outra passagem do guia pedagógico:

" Deux films fixes visualisant globalement les situations dialoguées (une ou deux vues par situation). »

(COURTILLON; RAILLARD; 1982: 7).

Dentro do projeto gráfico-editorial, vale notar também que os tipos de imagens escolhidas (desenhos fabricados e fotos em preto e branco) compõem o texto multimodal de forma pouco harmoniosa. Essas mesmas observações são válidas para outra dupla página "Situations" que observamos a seguir (Figura 40).

Figura $40 \mid$ Archipel 1. Pág. 56, 57

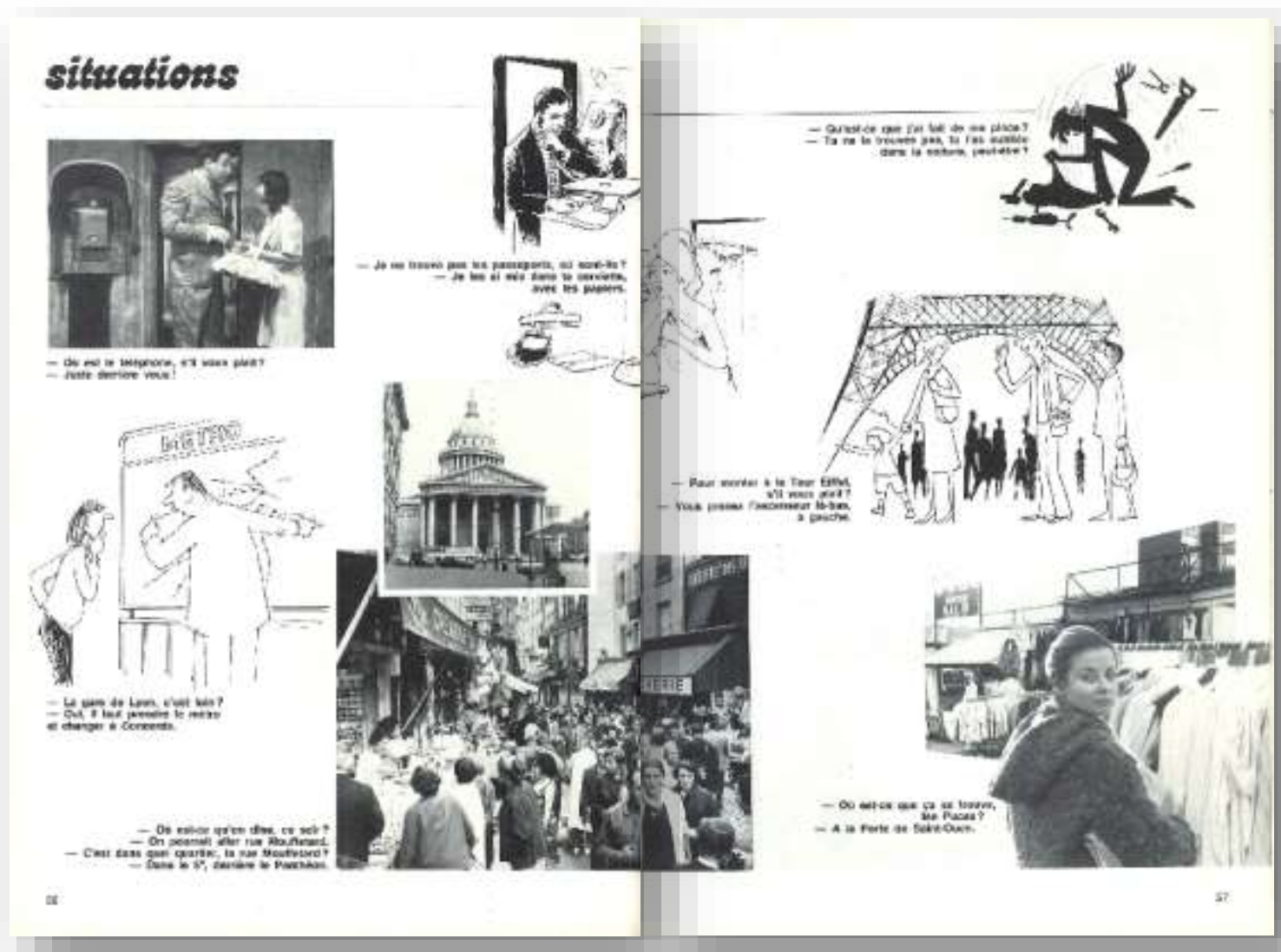


A noção de "dupla página” parece mais intensa nesse exemplo, com imagens que ocupam a parte central entre as duas páginas, reforçando a unidade das mesmas.

Reencontramos pequenos "lembretes" verbais e visuais das situações de comunicação e imagens que parecem heterogêneas e desconexas, mesclando desenhos fabricados e fotografias em preto e branco.

Nos deteremos mais particularmente na foto do canto inferior à direita que mostra uma jovem em um mercado que a legenda indica ser "Les Puces", conhecido mercado das pulgas em Paris. (Figura 41).

Figura 41 | Archipel 1. Pág. 56 - Detalhe

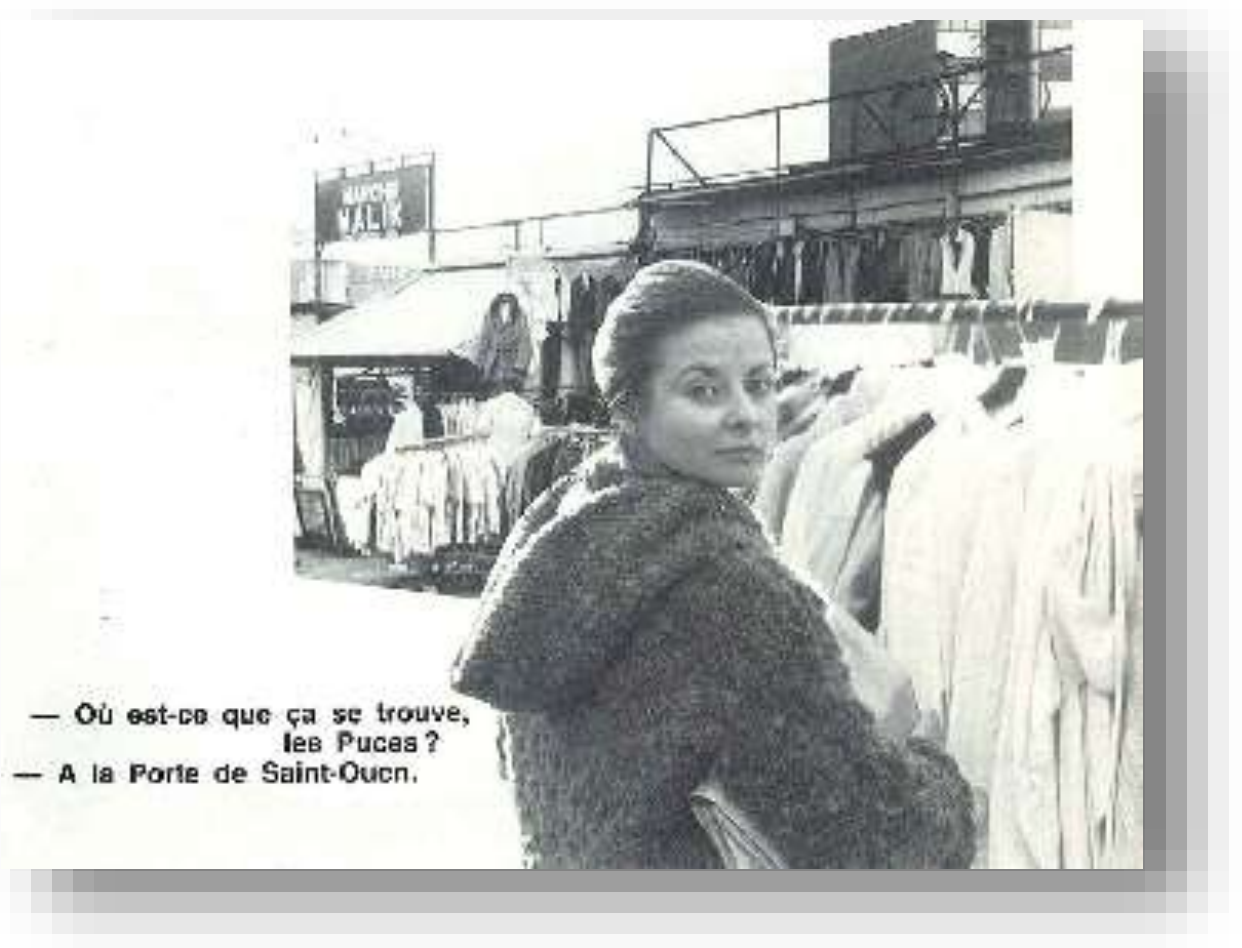

A jovem interpela diretamente o espectador, num esquema interacional de contato que indica demanda. Ela está ligeiramente de costas para o observador e parece ter sido surpreendida pelo mesmo.

Vimos no guia pedagógico que as imagens do manual Archipel têm como função ajudar o aluno a visualizar as situações do diálogo, ou seja, uma função de ilustração da situação de comunicação, podendo servir ao professor como um documento de antecipação ao diálogo, um elemento de "entrada" no mesmo. Desta forma, a imagem 
poderia facilitar a primeira abordagem do diálogo e a emissão de hipóteses por parte dos alunos sobre a situação de comunicação, elementos essenciais para uma primeira compreensão global do documento (Quem são os personagens da situação que iremos abordar? Onde se encontram? O que fazem? Por quê? etc.). Vejamos agora a transcrição do diálogo correspondente a essa imagem:

\section{Situation 6 - LES PUCES}

Au restaurant universitaire, file d'attente.

Étudiante 1 : Elle est jolie ta robe. Où est-ce que tu l'as achetée?

Étudiante 2 : Aux Puces.

Étudiante 1 : Aux Puces ? Dans quelle boutique?

Étudiante 2 : Chez Virginie.

Étudiante $1:$ « Où c'est ça ? »

Étudiante 2 : Tu descends au métro Clignancourt. En sortant, tu prends la première rue en face et c'est tout de suite à gauche.

Étudiante 1 : Je vais y aller. Je veux acheter le même.

Étudiante 2 : Fais bien attention, c'est la deuxième ou troisième boutique sur la gauche.

Ora, notamos que a situação se passa não no Mercado de pulgas, mas sim, na fila de espera de um restaurante universitário e que há dois personagens no diálogo, duas amigas, sendo que uma delas cita o Mercado de pulgas, local onde comprou seu belo vestido. Como podemos ver, a imagem utilizada no livro do aluno não corresponde à situação de comunicação do diálogo que o mesmo pretende ilustrar. Essa distância entre a situação representada visualmente e a situação verbal pode causar estranhamento e confusão na compreensão do diálogo por parte do aluno e também não facilita o trabalho de introdução ao diálogo que será proposto pelo professor. Provavelmente, ele terá que adaptar as perguntas que fará aos alunos para poder utilizar a imagem juntamente com o documento de áudio a fim de poder transformar o "artefato" em “instrumento". (RABARDEL, 2003).

Acreditamos que isso se explique pelo distanciamento que pode ocorrer no mercado editorial entre os autores de um livro didático e os designers que trabalham em seu projeto gráfico, mas essa é uma hipótese que - de qualquer forma - não poupa o 
docente de querer trabalhar com a imagem associada ao diálogo, o que trará dificuldades.

\section{Imagens em Archipel: quantidade, escolha, utilização pedagógica}

As imagens são abundantes no método. Por vezes uma página é composta por muitas delas (Figura 42) e, por vezes, uma única imagem ocupa quase o espaço da página inteira (Figura 43).

Figura 42 | Archipel 1. Pág. 144

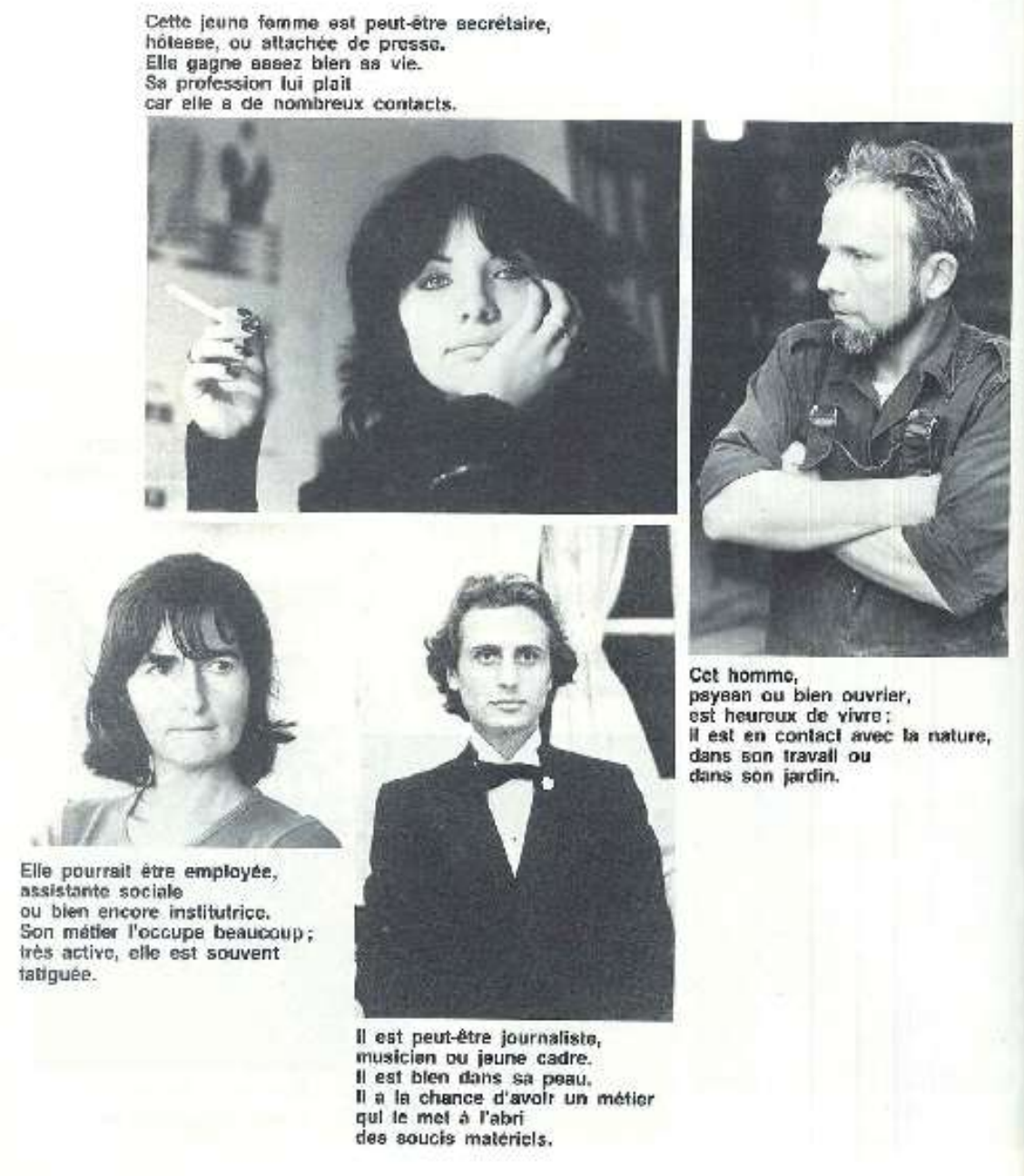


Figura 43 | Archipel 1. Pág. 13

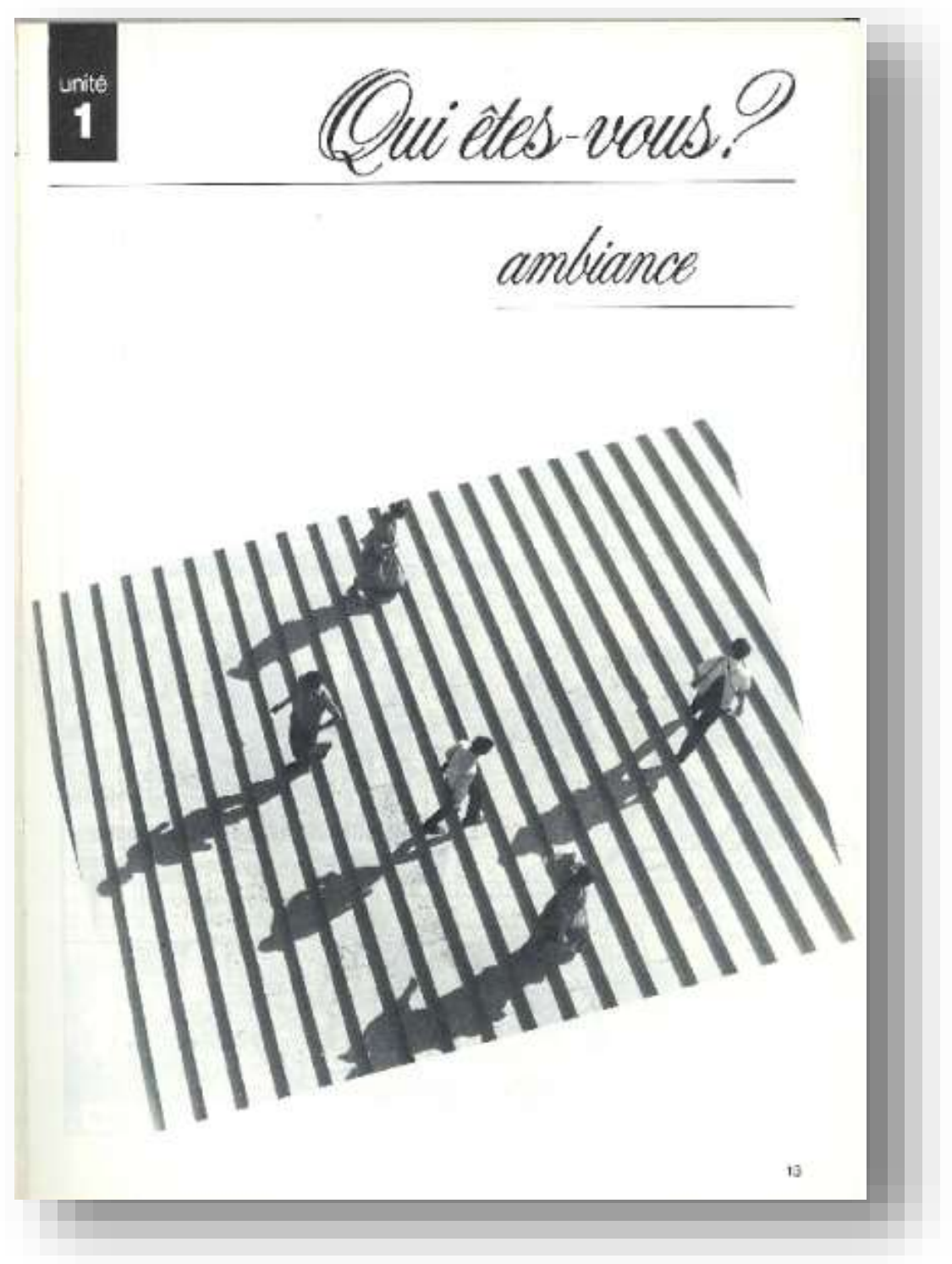

Logo no prefácio do livro do aluno, a grande quantidade de imagens é apresentada pelos autores como uma escolha. Nessa apresentação, a imagem parece ocupar uma posição de igualdade em relação ao texto:

Chaque unité de ce livre présentant un matériel écrit et visuel volontairement abondant, tout ne pourra pas être étudié et abordé en salle de classe.

(COURTILLON; RAILLARD; 1982: 2).

No entanto, ao analisarmos o guia pedagógico, notamos que não há muitas atividades específicas para a exploração didática do suporte visual. Um exemplo disso 
são as próprias páginas intituladas "Ambiance" (Figura 43) que introduzem cada uma das sete unidades do livro. Trata-se de uma página extremamente visual, composta por uma ou várias imagens que "abrem" o capítulo. Essas imagens são muito bem escolhidas e a composição da página multimodal, bastante atraente. No entanto, nenhuma atividade ou orientação é proposta para essas páginas nem para o estudante, no livro do aluno, nem para o professor, no guia pedagógico.

Essa dicotomia entre a grande quantidade de imagens no livro do aluno e as poucas orientações para sua utilização é, no entanto, justificada pelos autores nas páginas de introdução do guia pedagógico:

Bien entendu, l'image est le point de départ de l'explication, mais les images de la méthode n'ont pas été conçues pour une utilisation exhaustive : nous n'avons pas voulu en faire le support principal de la communication. [...] Les images ont donc été conçues essentiellement pour véhiculer des informations de type situationnel et culturel plutôt que référentiel.

(COURTILLON, J ; RAILLARD, S ; 1982 : 15)

Podemos então afirmar que, no método Archipel 1, as numerosas imagens do livro do aluno ocupam uma posição gráfica e espacial de destaque, mas exercem, de fato, um papel secundário no processo pedagógico adotado para a aprendizagem da língua. Esse fato constitui um desejo e uma opção dos autores, como podemos observar nessas duas passagens que citamos anteriormente e que retomamos abaixo, colocando em destaque as palavras que indicam uma escolha:

Un matériel $[\ldots]$ visuel volontairement abondant.

(COURTILLON, J ; RAILLARD, S ; 1982 : 2 - grifo nosso).

Nous n'avons pas voulu en faire (des images) le support principal de la communication. [...] Les images ont donc été conçues essentiellement pour véhiculer des informations de type situationnel et culturel plutôt que référentiel.

(COURTILLON, J ; RAILLARD, S ; 1982 : 15 - grifos nossos).

Com essa afirmação, de alguma forma, os autores parecem antever eventuais críticas sobre a inadequação de certas imagens em relação aos textos que acompanham. A explicação, no entanto, não ajuda o professor a explorar o suporte visual do livro. 


\subsubsection{Preconizações do guia pedagógico para o uso da imagem}

O papel secundário que os autores de Archipel escolheram atribuir ao uso da imagem confirma-se ao analisarmos a quantidade de referências às mesmas no Guia pedagógico. Encontramos no guia do professor referências a apenas quatro páginas ilustradas do livro do aluno, conforme descrevemos a seguir.

As duas primeiras páginas ilustradas comentadas no guia pedagógico constituem, na verdade, uma dupla página intitulada Les Saisons (Figura 44).

Figura 44 | Archipel 1. Pág. 84, 85

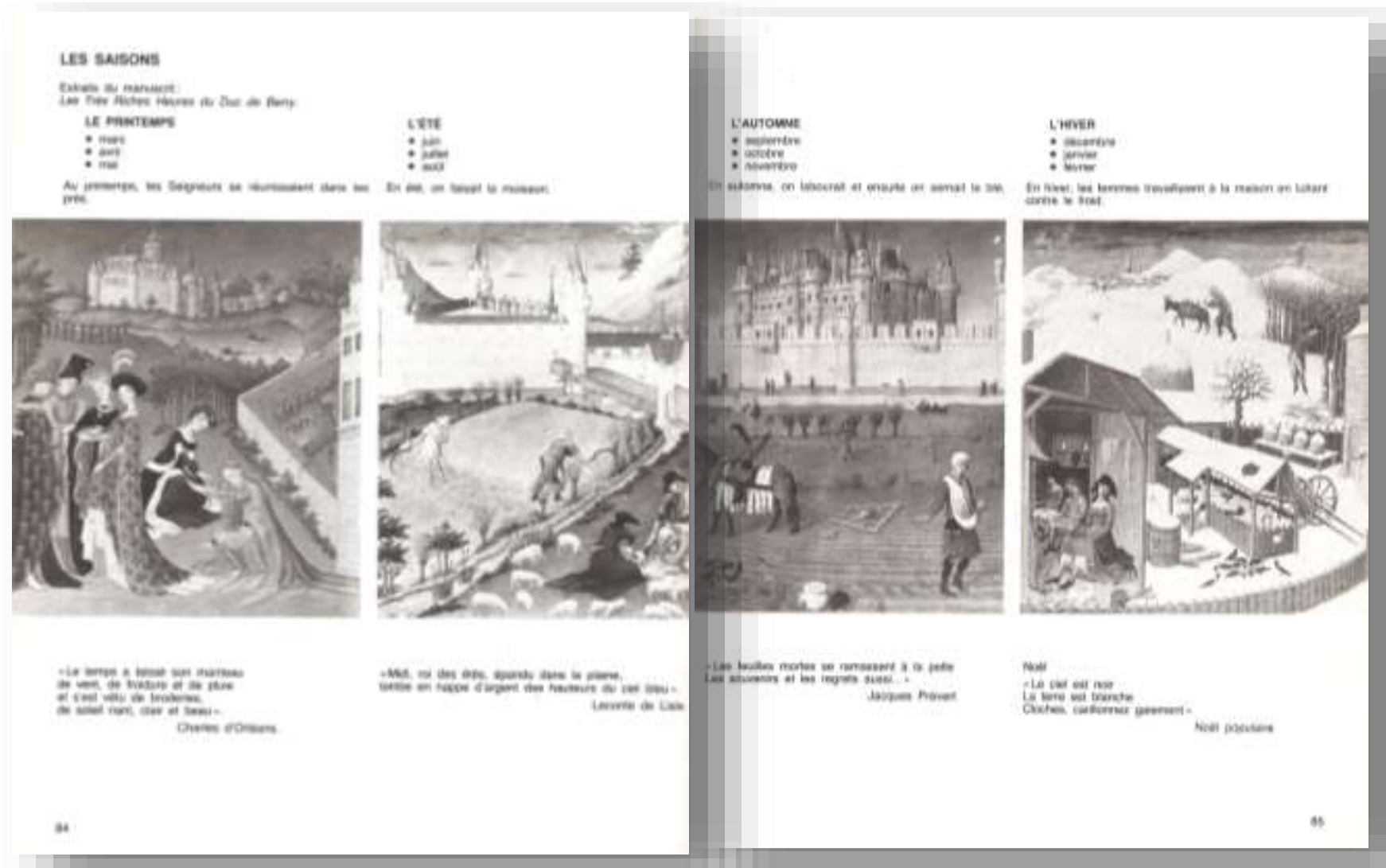

Nessa dupla página, as estações do ano são representadas por iluminuras no manuscrito Les Très Riches Heures du Duc de Berry, realizadas pelos irmãos Limbourg entre 1413 e 1416. O termo iluminura pode ser definido como um conjunto pictórico de carácter decorativo ou ilustrativo que acompanhava os textos manuscritos do período medieval. Neste caso, mesmo se a dupla página é composta por pequenos textos 
referentes a cada estação, a maior parte do espaço é ocupada pelas imagens. Estamos na análise da página 84 do livro do aluno e encontramos, pela primeira vez no guia do professor, uma referência específica a uma imagem do livro didático:

Le professeur pourra relever dans les indications ci-dessous des informations lui permettant de faire un commentaire rapide des enluminures du Livre d'Heures du Duc de Berry, ou de répondre aux questions des élèves.

(COURTILLON, J ; RAILLARD, S ; $1982: 65$ - grifo nosso).

Aparecem, em seguida, informações sucintas sobre o manuscrito e sua história, assim como o nome do museu onde ele se encontra atualmente. As preconizações do guia aconselham o professor a ser breve nos comentários sobre as iluminuras, ou seja, a não se alongar no que tem menos importância: a imagem. Nenhuma atividade específica é solicitada ao aluno. Basta que o professor esteja preparado para "responder às perguntas dos alunos", caso as mesmas venham a ser formuladas. Isso confirma a opção dos autores de conceder à imagem um papel meramente ilustrativo na abordagem pedagógica.

Ainda é bastante comum, nos guias pedagógicos de LDs atuais, e sobretudo quando há reproduções de obras de arte, que o guia traga apenas informações enciclopédicas sobre as obras e os pintores ou escultores em questão, sem fazer uma proposta de exploração pedagógica das mesmas. Isso acontece, por exemplo, nas páginas 74 e 75 do livro didático Écho A1 que cometamos mais adiante.

Uma exceção a esse procedimento, no entanto, nos é fornecida pelo próprio livro Archipel 1, em uma página que tem como título Promenade dans un musée: l'exposition Chardin (Figura 45). 
Figura 45 | Archipel 1. Pág. 133

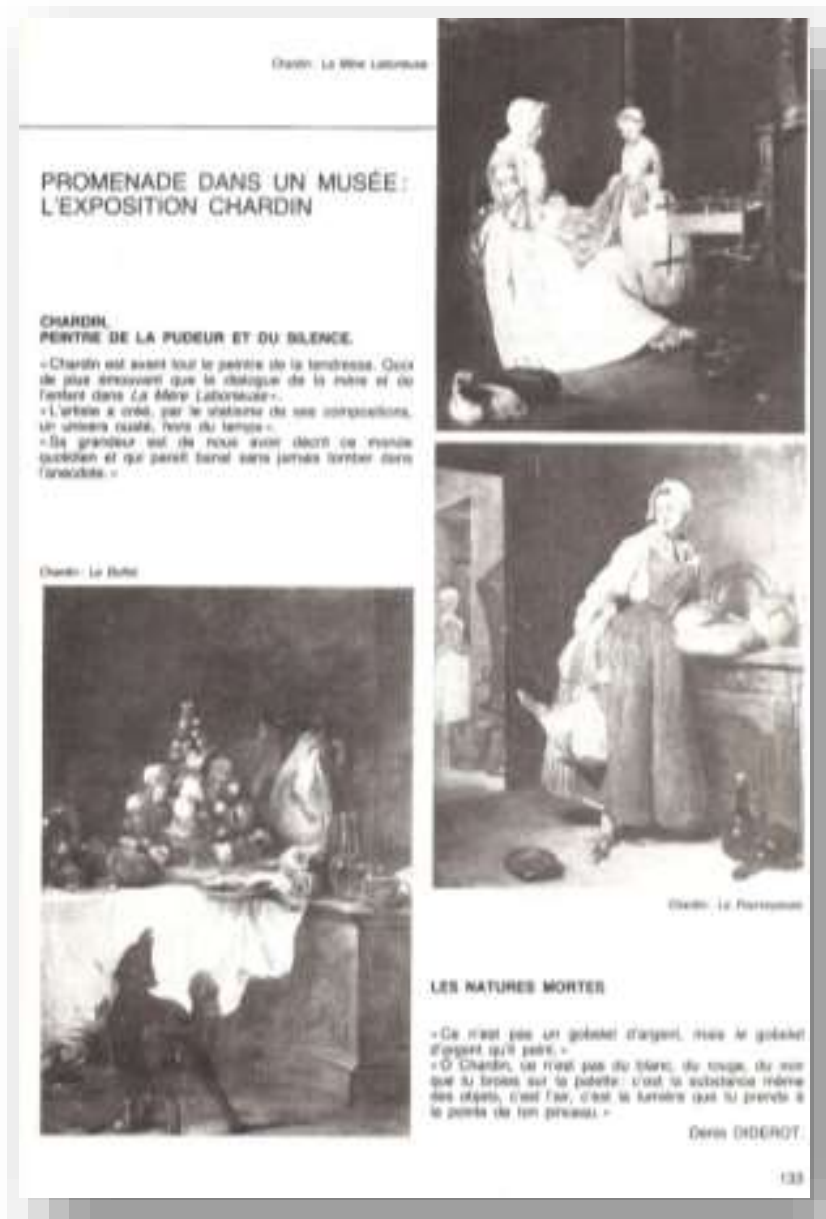

Cerca de 70\% do espaço dessa página é ocupado por imagens de três obras do pintor francês Jean-Baptiste-Siméon Chardin. Há também algumas citações sobre esse pintor barroco, uma delas de autoria de Denis Diderot.

Vejamos as indicações do guia pedagógico para essa página do livro do aluno:

Production d'une saynète. II serait intéressant d'utiliser les reproductions des tableaux de Chardin, ainsi que le texte qui les accompagne pour amener les élèves à produire une saynète satirique. Il s'agirait de replacer les personnages de la scène 3, c'està-dire un personnage naïf et un personnage cultivé et snob devant un tableau de Chardin, et de les faire parler. Le personnage snob pourrait utiliser certaines des appréciations contenues dans le texte pour faire étalage de ses connaissances.

(COURTILLON, J ; RAILLARD, S ; 1982 : 84 - grifo nosso). 
É interessante notar que a imagem, nesse caso, é utilizada como um meio para a prática da língua, no caso, uma atividade de produção oral. Solicita-se do aluno uma posição "atuante" diante da imagem, uma vez que ele tem uma tarefa a fazer que se baseia tanto no suporte visual quanto no suporte escrito. Trata-se da única vez no guia pedagógico de Archipel 1 em que não somente a imagem do livro do aluno é citada como também ela exerce um papel importante - e não periférico - na realização de uma atividade pedagógica. O exemplo é ainda mais interessante pois trabalha de forma conjunta os vários componentes da página multimodal na realização de um objetivo comunicativo.

Acreditamos que esse uso da imagem e do texto multimodal em um LD é extremamente positivo e que, por isso, deveria ser adotado mais frequentemente. Vemos também que o acordo entre os autores e os produtores do projeto gráficoeditorial resulta em propostas interessantes para o professor e, consequentemente, para o aluno.

Passamos, enfim, à última menção sobre uma imagem do livro do aluno feita no guia pedagógico Archipel 1. Trata-se de uma página que propõe uma atividade de produção escrita ("Construisez un texte publicitaire") e que é composta não somente por elementos linguísticos, mas também por imagens representativas do gênero textual em questão, ou seja, um anúncio publicitário. (Figura 46).

Observemos a tarefa proposta ao aluno no próprio livro didático:

Consultez les publicités suivantes (...). En vous inspirant de ces modèles linguistiques, vous essayez d'écrire un texte publicitaire qui mette en valeur les qualités des produits choisis.

(COURTILLON, J ; RAILLARD, S ; 1982). 
Figura 46 | Archipel 1 - pág. 109

\section{pour aller plus loin}

\section{CONSTRUISEZ UN TEXTE PUBLICITAIRE}

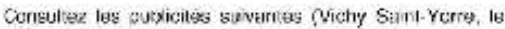

Ln weus inscyant de res modeles linguistiques, yors assavez c'ecrire un texte public taire qu matte en vicur les qualitiés ces: proxuluils chuisis.

Vous pouvez chois parmi les mosshigtès suivartes.

- Bave ris vin

du lait

de l'oau mirncrale

- manger du pair

de la viande

des orangess

- utiliser de l'huile d'olve de l'eau de rowe:

ve la lleur d'manger

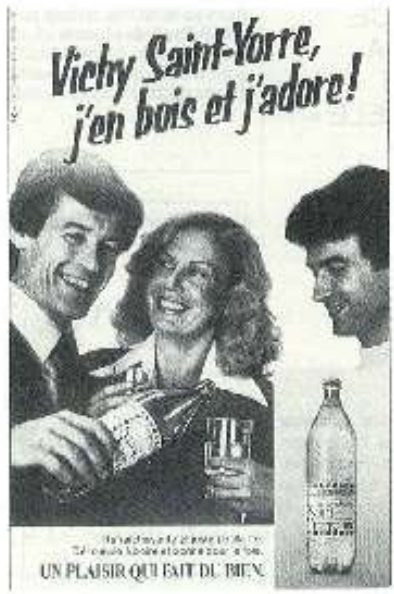

\section{SI VOUS NE BUVEZ PAS DE LAIT, MANGEZ-EN.}

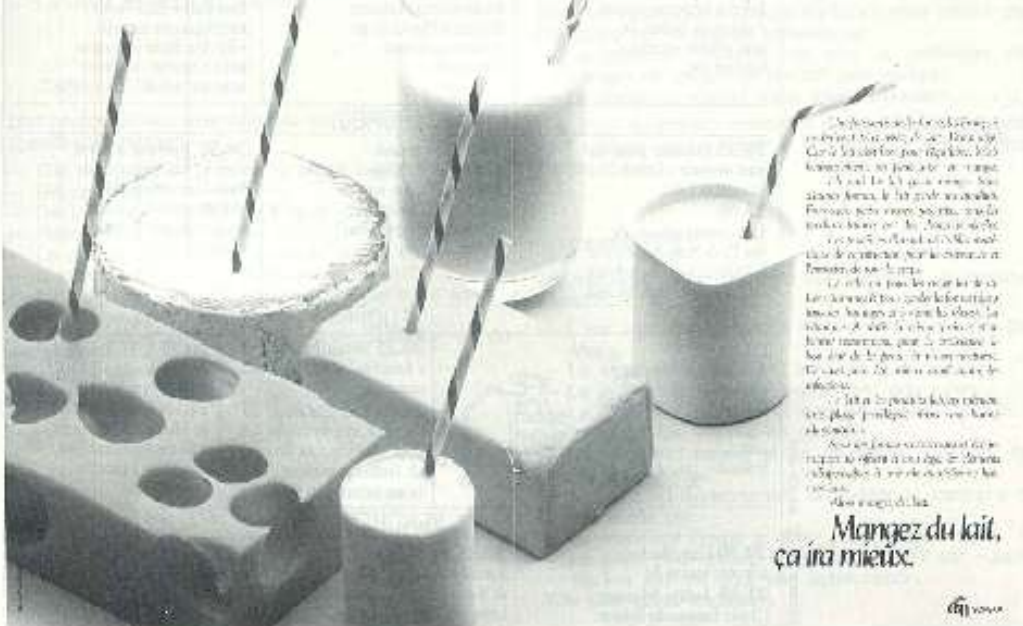

Apesar do aspecto multimodal dos anúncios publicitários propostos, com as características formais e visuais completas do gênero textual em questão, pede-se ao aluno que observe apenas o "modelo linguístico" apresentado. O guia pedagógico também não põe em evidencia o componente formal e visual dessa página que contribui para a construção do sentido, indicando apenas: 
Le professeur demandera aux élèves d'étudier les différentes publicités sur le lait, l'eau minérale, etc. par petits groupes. Les élèves devront reproduire les avantages et les qualités sur lesquels le publicitaire s'est appuyé pour faire vendre le produit : par exemple le calcium pour le fromage.

Ensuite, ils devront repérer les moyens linguistiques qui ont été utilisés pour mettre en valeur le message (principalement l'impératif) et la mise en relief des qualités du produit.

Puis, une fois ce repérage effectué, les élèves choisiront un des produits proposés - ou un produit de leur choix qui respecte les données sur lesquelles ils sont en train de travailler - et ils construiront ensemble une courte publicité accompagnée d'indications de visualisation, par exemple :

Si vous voulez avoir des muscles, faites de la bicyclette (ceci pourrait constituer le slogan de base). Quelques courtes phrases vantant les avantages de la bicyclette : c'est écolo de faire du vélo ou encore faire de la bicyclette, c'est chouette, etc.

Un des intérêts de cet exercice est de faire comprendre aux élèves comment jouer avec le langage.

(COURTILLON, J.; RAILLARD, S; 1982 : 73)

Apesar de uma discreta menção a uma possível indicação de visualização na produção escrita, em nenhum momento a linguagem visual - aspecto essencial nos anúncios publicitários utilizados como exemplo - foi indicada para ser trabalhada com os alunos.

No entanto, é preciso ressaltar que, mesmo se esse aspecto formal, estrutural e visual do gênero discursivo não foi tratado pelo guia pedagógico, Archipel 1 tem o mérito de ter introduzido um gênero discursivo da vida cotidiana, no caso, um anúncio publicitário, em um LD. Os documentos autênticos, apreciados pela abordagem comunicativa, trazem uma importante riqueza visual e sociocultural ao material didático, por meio da utilização de diferentes gêneros textuais. Vale lembrar que adotamos neste estudo a noção de gênero textual/discursivo definida por Bakhtin (1997) como tipos "relativamente estáveis" de enunciados elaborados pelas mais diversas esferas da atividade humana.

Esse mesmo aspecto positivo de incluir gêneros textuais do cotidiano no material didático permanece com a metodologia que se seguiu, a perspectiva acional. De fato, para o QECR, o grande objetivo do ensino-aprendizagem de uma língua estrangeira é justamente o agir social do cidadão, usuário e falante da língua na sociedade em que ela é praticada. Por essa razão, é importante também que os textos produzidos por essa 
sociedade sejam integrados ao processo de ensino-aprendizagem. Pesquisas recentes têm ressaltado a importância do ensino de línguas por meio dos gêneros textuais (DOLZ e SCHNEUWLY, 2004; LOUSADA, 2005, 2008):

Na realidade, poucos são os livros didáticos que abordam o desenvolvimento da competência para produzir textos de diferentes gêneros, o que é necessário mesmo em LM (língua materna), quando temos geralmente um maior domínio da língua. [...] É exatamente essa realidade de que mesmo certos gêneros em LM [...] têm que ser aprendidos, que prova a importância e a necessidade de ensiná-los de maneira formal/institucional quando se trata de LE (língua estrangeira).

(LOUSADA, 2005).

O professor e pesquisador brasileiro Luis Antônio Marcuschi (2008) considera que, quando dominamos um gênero textual, não dominamos uma forma linguística, mas sim uma forma de realizar linguisticamente objetivos específicos em situações particulares. Essa noção nos parece próxima da definição da perspectiva acional fornecida pelo QECR e que citamos no início deste trabalho:

A perspectiva privilegiada aqui é, de um modo geral, de tipo acional no sentido em que ela considera antes de tudo o usuário e o aprendiz de uma língua como atores sociais que têm tarefas a realizar (tarefas que não se referem somente à linguagem) em circunstâncias e em um ambiente determinado, no interior de uma área de ação particular. Se os atos de fala realizam-se dentro de atividades da linguagem, estas inscrevem-se por sua vez no interior de ações em contexto social que lhes dão seu sentido pleno.

(CONSELHO DA EUROPA, 2001: 15 - tradução nossa)

Ao cruzarmos as duas considerações e aplicando-as a nosso contexto de trabalho e pesquisa, parece-nos claro que o objetivo principal do ensino-aprendizagem de uma língua estrangeira não deve ser norteado por elementos linguísticos desconectados de sua aplicação, de seu contexto e, consequentemente, de seu sentido. $O$ trabalho sobre os gêneros textuais permite justamente que objetivos específicos - ou tarefas, para retomar o termo usado do QECR - sejam alcançados por meio da linguagem dentro de um contexto sociocultural e em determinadas situações.

Marcuschi (2008) ressalta que o estudo dos gêneros textuais é uma fértil área interdisciplinar, com atenção especial para o funcionamento da língua e para as 
atividades culturais e sociais. Já os pesquisadores Dolz e Schneuwly (2004) afirmam que é por meio dos gêneros que as práticas de linguagem se materializam nas atividades dos alunos.

O tema interessa-nos particularmente - e por isso nos detemos um pouco mais sobre ele neste momento - pois a maioria dos gêneros textuais reproduzidos em livros didáticos de FLE são, na verdade, textos multimodais. E eles estão cada vez mais presentes: por vezes, são documentos autênticos - como artigos de imprensa, cartazes, fotografias - em outras vezes, trata-se de documentos "realistas", ou seja, documentos fabricados, mas que seguem a estrutura formal, visual e discursiva de um determinado gênero textual.

Como já dissemos anteriormente, para Kress e van Leeuwen (2006), a disposição do texto escrito, a sua diagramação e a sua interação com o suporte visual compõem a estrutura multimodal de um texto e influenciam a construção de sentidos. Dionísio (2008) também afirma que a tipografia e o layout exercem um papel importante no texto multimodal. De acordo com a mesma autora, não só as fotografias e ilustrações, mas também a disposição gráfica deve ser considerada um elemento visual em um texto multimodal:

Importante mencionar que ao conceber os gêneros textuais como multimodais, não estou atrelando os aspectos visuais meramente a fotografias, telas de pintura, desenhos, caricaturas, por exemplo, mas também à própria disposição gráfica do texto no papel ou na tela de computador.

(DIONÍSIO, $2008:$ 123)

Em resumo, sabemos que gêneros discursivos multimodais, quando inseridos em uma aula de língua estrangeira, contribuem fortemente para o aprendizado, o desenvolvimento e a aquisição - também social - da língua. Mesmo assim - e talvez devido a eventuais imposições trazidas por um vasto programa curricular - ainda é raro, em um livro didático, que se proponha aos alunos a produção completa de um gênero textual específico em sala de aula. Isso pode ocorrer um pouco mais frequentemente em livros didáticos mais recentes, baseados na perspectiva acional e que propõem a realização de projetos pedagógicos. 


\subsubsection{Balanço quantitativo e qualitativo}

Chegamos, portanto, às seguintes estatísticas para Archipel 1 no que se refere à quantidade de imagens no livro do aluno e à quantidade de menções à exploração das mesmas no guia pedagógico (Figura 47).

- Número de páginas do livro do aluno - excluindo-se os anexos: 162 páginas

- Número de páginas ilustradas no livro do aluno - excluindo-se os anexos: 97 páginas

- Número de páginas para as quais há uma menção ao trabalho sobre a imagem no guia pedagógico: 4 páginas.

Figura 47 | Gráfico - Presença quantitativa da imagem em Archipel 1

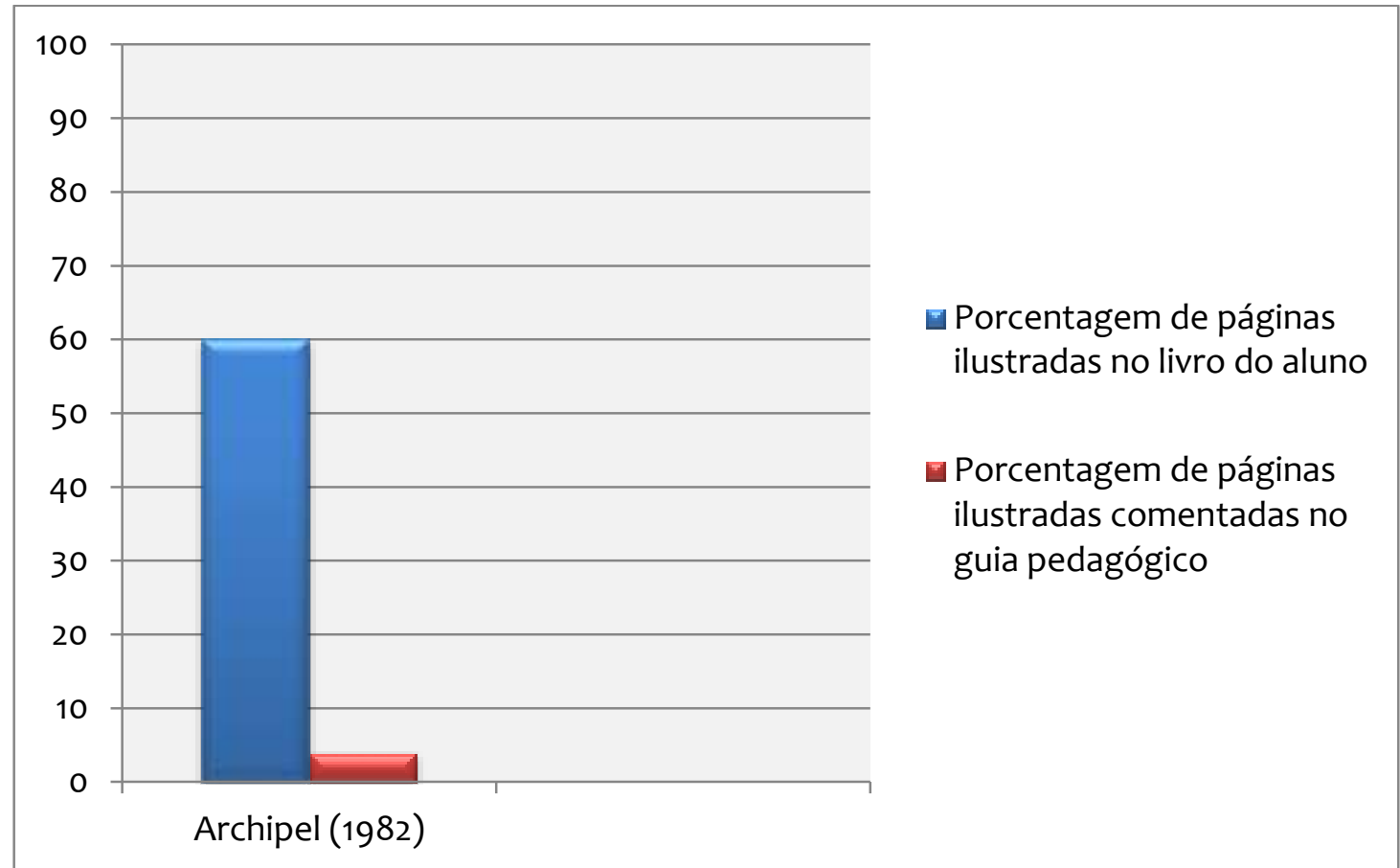

Como conclusões importantes, vimos que Archipel 1 é um livro didático que apresenta uma grande riqueza na variedade de imagens e também em sua quantidade. A imagem tem um espaço físico de destaque no livro do aluno - algumas páginas são mesmo compostas quase que exclusivamente por elas. No entanto, os autores optaram por não atribuir ao suporte visual um papel de destaque nas atividades pedagógicas e de comunicação. De fato, mesmo se bastante presente no livro, a imagem é muito pouco comentada e quase não há prescrições para a sua exploração pedagógica no guia do professor. 


\subsection{Análise $n^{\circ} 2 \mid$ Espaces 1}

CAPELLE, Guy ; GIDON, Noëlle. Paris : Hachette FLE, 1990.

Composto por três volumes (Espaces 1, Espaces 2, Espaces 3), Espaces é uma coleção de livros didáticos para a aprendizagem do francês língua estrangeira destinada a adultos e grandes adolescentes. A coleção é apresentada da seguinte forma na contracapa do livro do aluno:

ESPACES, un ensemble pédagogique de trois niveaux, pour apprendre :

- à communiquer en français, oralement et par écrit ;

- à maîtriser progressivement le fonctionnement de la langue ;

- à découvrir la France et le monde francophone.

Publicados em 1990, os livros didáticos dessa coleção foram adotados pela Aliança Francesa de São Paulo em 1992, em substituição ao livro didático Archipel que analisamos anteriormente. Apenas oito anos separam uma publicação da outra, mas as diferenças em relação à qualidade das imagens são bastante significativas. Se em Archipel, $100 \%$ das ilustrações e fotos eram em preto e branco, passamos nesse curto espaço de tempo ao extremo oposto: todas as ilustrações e fotos do livro Espaces 1 são em cores. Uma curiosidade: mesmo as páginas compostas apenas por textos levam um toque de cor, seja no título ou nas tabelas coloridas (Figura 48). 


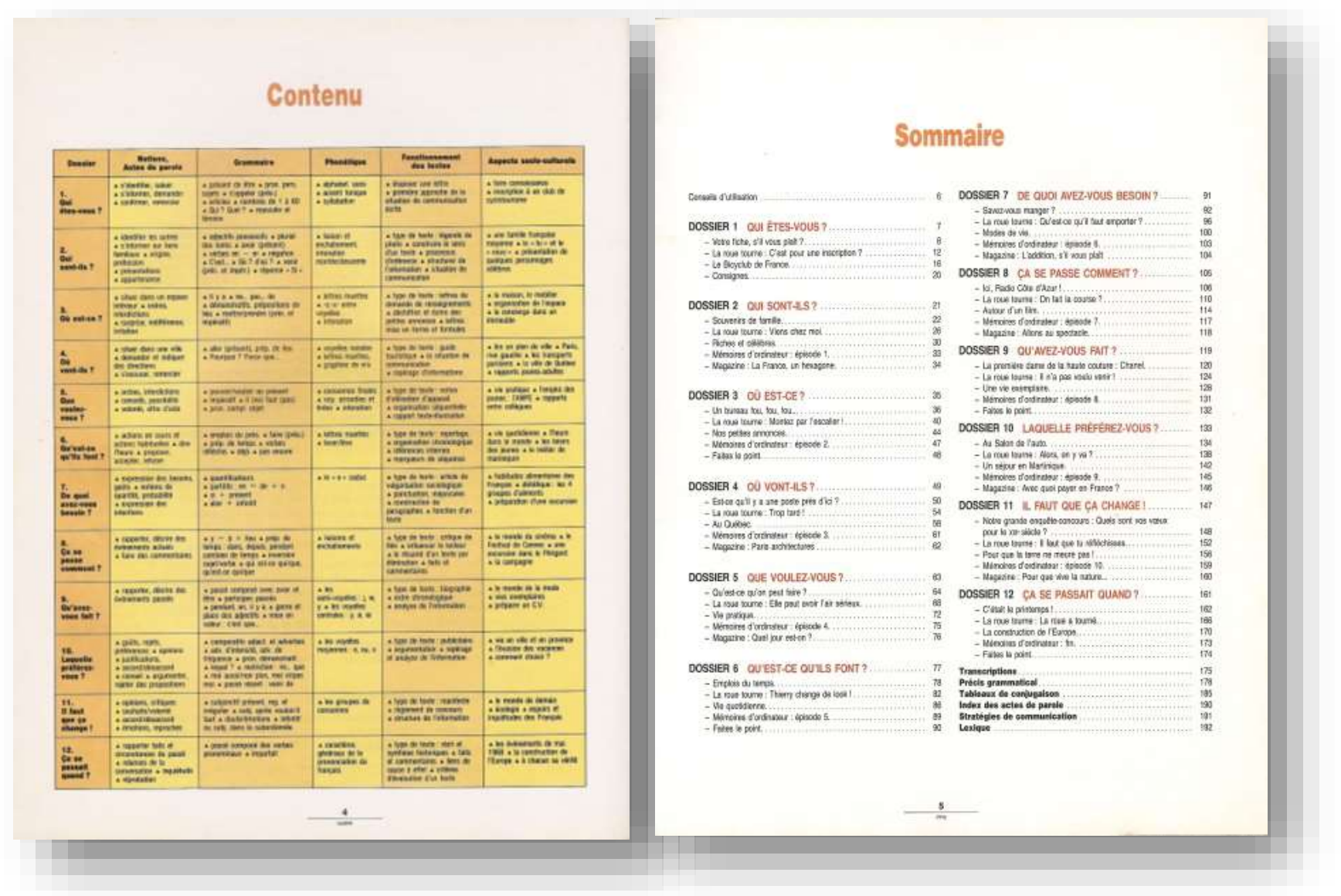

Outra curiosidade: a utilização de ícones ao longo de todo o LD para a identificação de atividades da linguagem ${ }^{28}$ como, por exemplo, produção escrita, compreensão escrita e compreensão oral (Figura 49). A imagem aparece como sinalizador das atividades da linguagem não somente para o aluno, mas também para o professor já que os mesmos ícones são utilizados no guia pedagógico.

\footnotetext{
${ }^{28}$ Utilizamos aqui, ao invés do termo "competências", a noção de "atividades de linguagem" (activités langagières) definidas pelo Quadro Europeu Comum de Referência (CONSELHO DA EUROPA, 2001): recepção, produção, interação e mediação.
} 
Figura 49 | Espaces 1 - Pág. 6

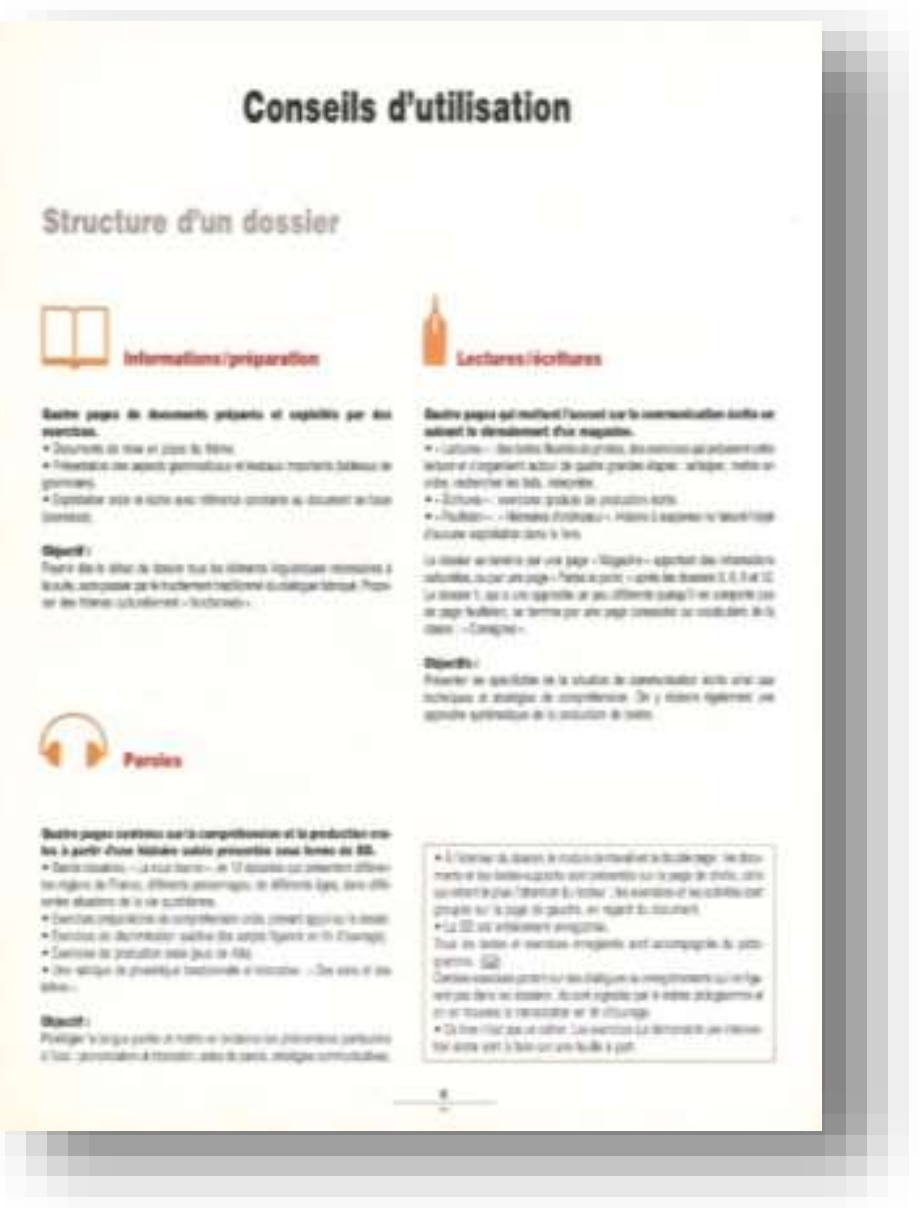

\subsubsection{Análise da capa do livro didático Espaces 1}

Uma capa igualmente sóbria (Figura 50) que utiliza, curiosamente, as mesmas cores do LD que analisamos anteriormente, Archipel : laranja na parte de baixo e azul na parte de cima. Porém, o caráter ilustrativo da capa de Archipel é substituído pelo realismo da fotografia.

A sensação predominante também é a de estabilidade graças ao equilíbrio entre as cores complementares azul e laranja. O título permanece em destaque na parte superior e um efeito gráfico na letra "A" traz um toque de modernidade à capa dessa publicação. Os tons fortes da capa anunciam a proposta visual interna: cores intensas estão presentes e de forma abundante nas páginas desse livro didático.

Mais uma vez, o título Espaces remete a algo maior do que um território continental e parece convidar o aluno a descobrir - e a ocupar - novos espaços. 


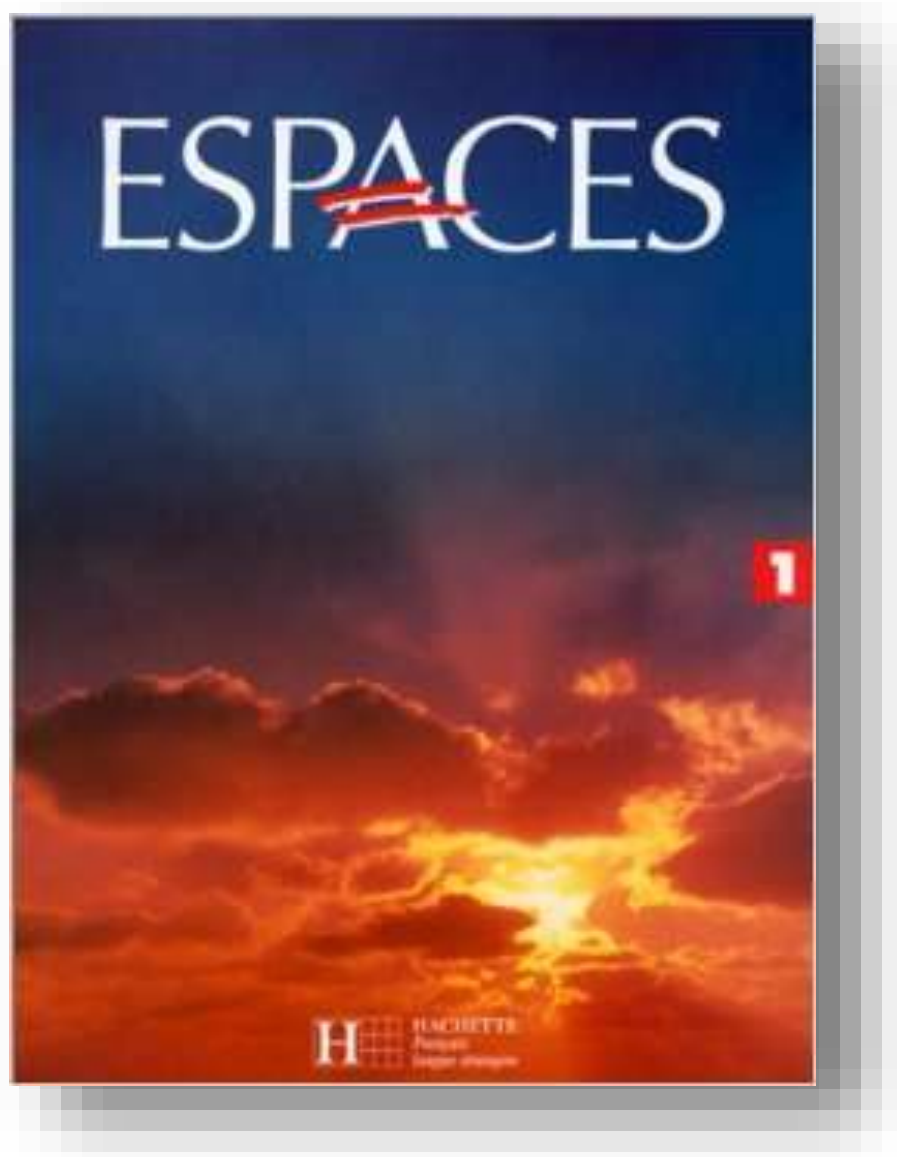

\subsubsection{Análise quantitativa das imagens no livro do aluno}

O livro do aluno é constituído exclusivamente por imagens em cores. A tipologia dessas imagens é bastante variada, já que encontramos uma boa quantidade de documentos autênticos, como fotografias, imagens de quadros/pinturas, logotipos, painéis de sinalização, fotos e cartazes de filmes, desenhos de moda, mapas de cidades, anúncios imobiliários acompanhados de imagens, calendários, charges, menus de restaurante.

O livro do aluno apresenta também ilustrações e desenhos fabricados, isto é, concebidos especialmente para acompanhar as situações de comunicação apresentadas no livro, como plantas do interior de um imóvel, desenhos e ilustrações. 
Uma história em quadrinhos (doravante $\mathrm{HQ}$ ) fabricada, intitulada La roue tourne, é apresentada em forma de episódios ao longo dos 12 dossiês do livro. Contrariamente ao que verificamos em outros métodos - e também em outras páginas deste mesmo livro nas quais os desenhos ilustram um diálogo - o fato de a situação de comunicação ser agora apresentada sob a forma de uma história em quadrinhos cria uma relação entre imagem e diálogo bem mais intrínseca. A transcrição do diálogo já não vem mais separada da ilustração, cada uma em um canto da página. Desta vez, texto e imagem encontram-se unidos por meio de um gênero multimodal por excelência, a HQ. (Fig. 51)

Figura 51 | Espaces 1 - página 13

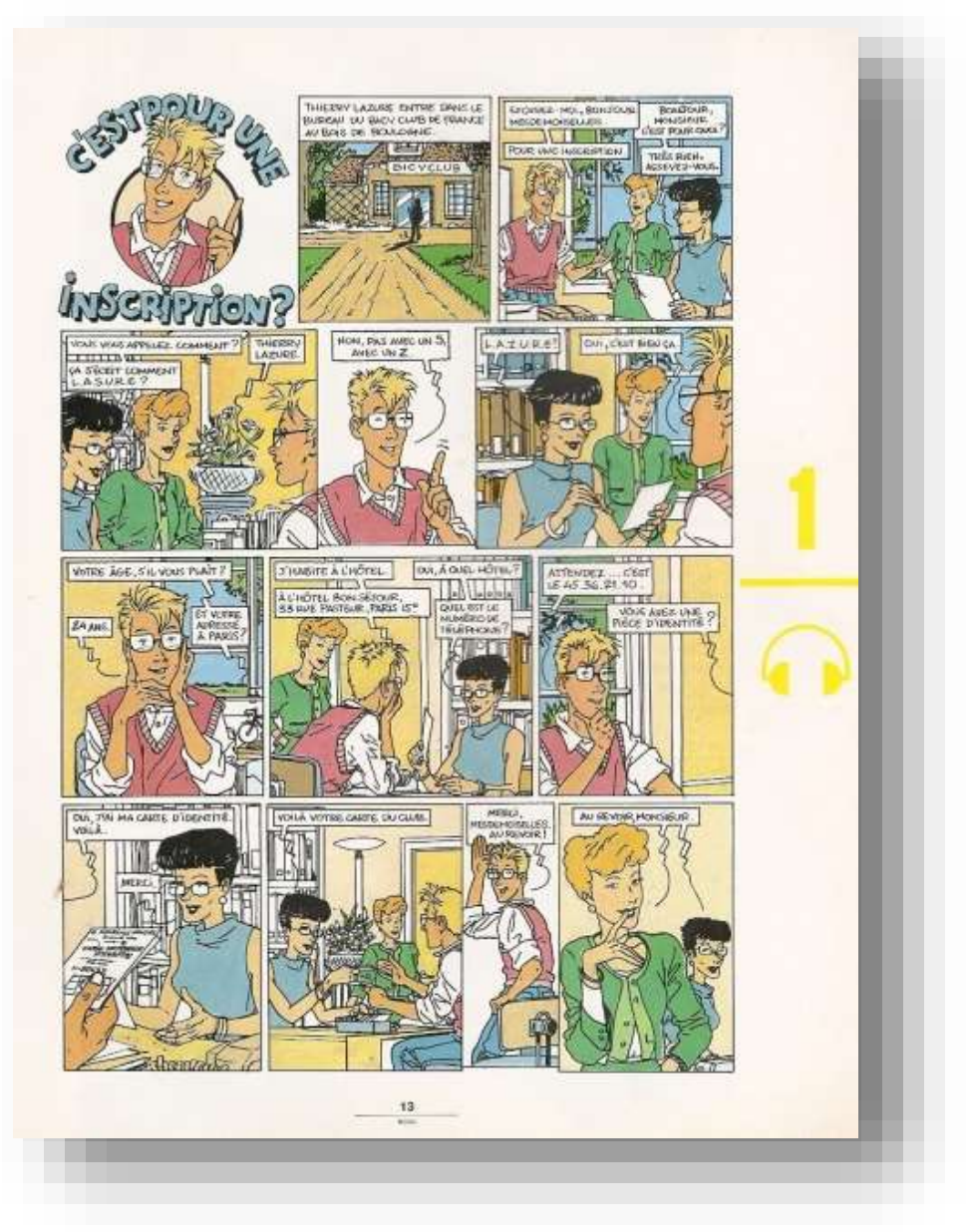

Das 168 páginas que compõem os 12 dossiês do livro (excluindo-se o sumário e os anexos com transcrições e índices de gramática e de vocabulário), apenas duas não recorrem ao uso da imagem: as páginas 22 e 92 . No entanto, apesar de não conterem ilustrações específicas, essas páginas apresentam quadros gramaticais coloridos e com efeitos de sombra, o que pode ser considerado um elemento visual. (Figura 52) 
Figura 52 | Espaces 1 - Página 22

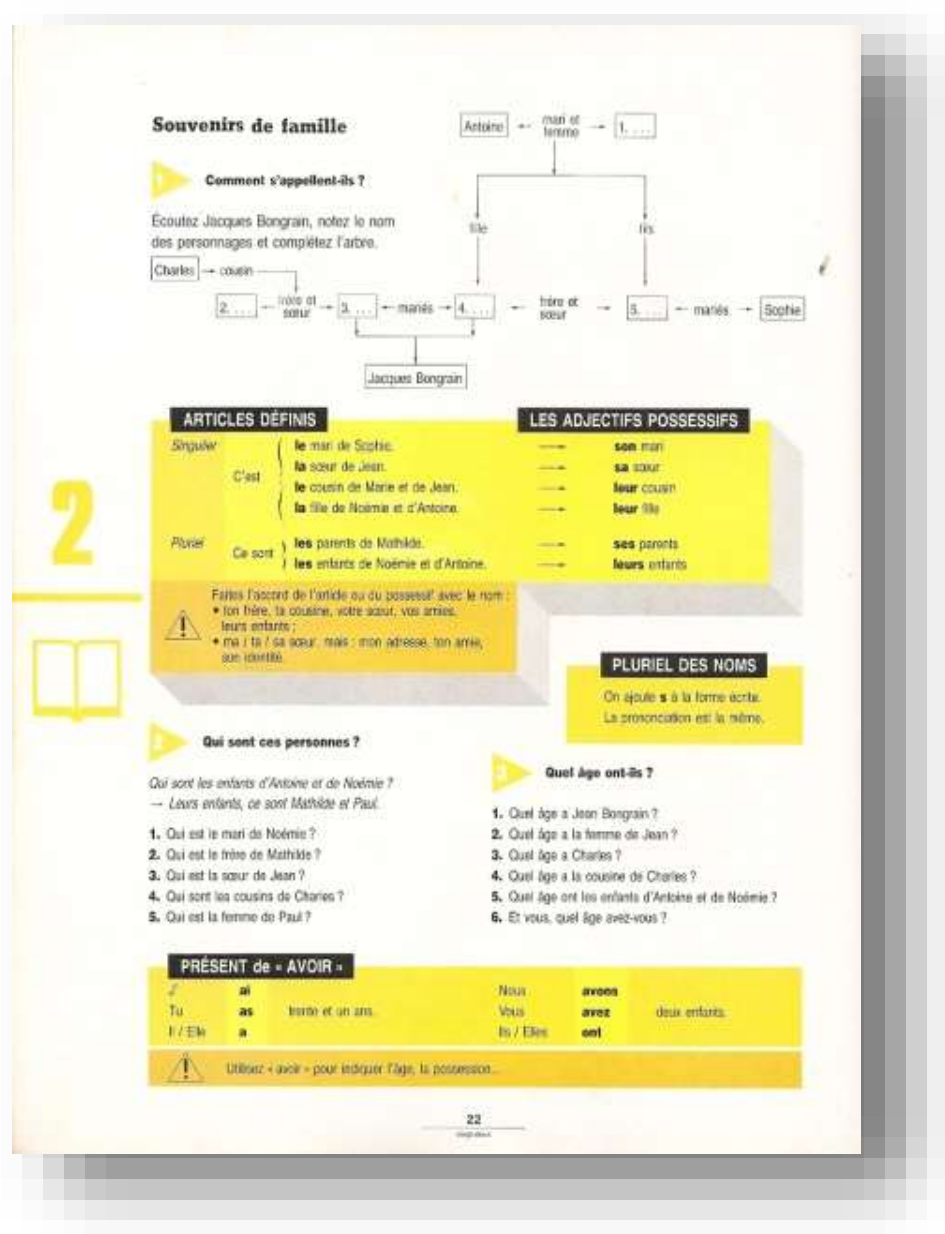

Sendo assim, podemos afirmar que 100\% das páginas do livro do aluno Espaces 1 são ilustradas. Lembramos que no livro didático Archipel 1, a porcentagem era de $60 \%$. Uma progressão importantíssima em quantidade e também em qualidade, já que todas as ilustrações são agora em cores. No que diz respeito à estrutura formal do livro do aluno, notamos que cada um dos doze dossiês é introduzido por uma imagem, com o título apresentado verticalmente, em forma de questão temática, à direita da página (Figura 53).

Curiosamente, o título da lição neste caso é o mesmo da que vimos em Archipel 1, ou seja, Que voulez-vous ? A expressão - bastante direta e pouco usada nas relações sociais de comércio - e a imagem correspondente não ajudarão o professor a introduzir o tema da lição: situações de comunicação em restaurantes, lojas, etc. 


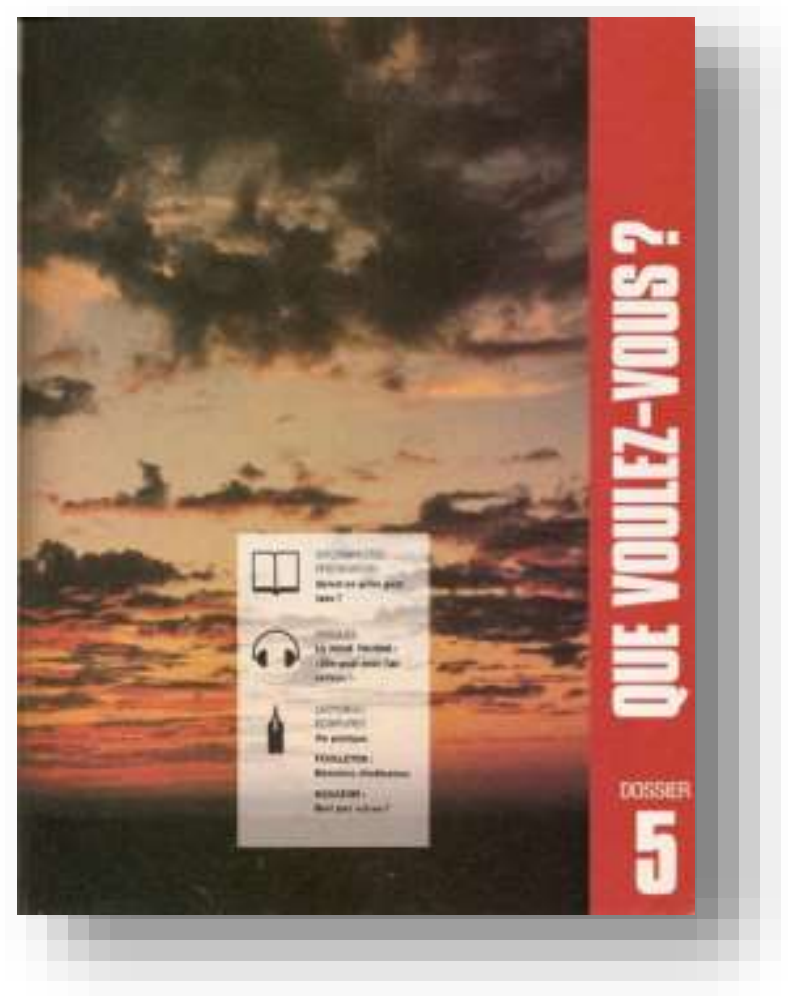

Figura 53 | Espaces 1 - Pág. 63

De fato, contrariamente ao que vimos em Archipel, as imagens aqui não remetem ao título do dossiê, ou seja, à questão que guia o conteúdo. Trata-se de imagens de nuvens, em diferentes momentos do dia e em diferentes cores, que parecem fazer sempre uma referência à imagem da capa do livro didático. Um trabalho temático de abordagem de cada dossiê por meio da imagem parece, consequentemente, descartado. Esse fato cria certa dicotomia entre o grande espaço físico que o livro consagra à imagem e à pequena importância pedagógica que lhe é atribuída nessas páginas de abertura das unidades.

\subsubsection{Análise qualitativa e funcional das imagens}

Analisaremos agora algumas imagens e textos multimodais presentes em Espaces 1 e buscaremos nos enunciados das atividades do livro do aluno e no guia pedagógico pistas para definir a função pedagógica da imagem nas sequências didáticas.

Ao observarmos a estrutura visual deste LD, vemos que as imagens aparecem de forma recorrente ao longo dos doze dossiês. Uma dessas recorrências refere-se à história em quadrinhos, La roue tourne, que se desenrola em doze episódios ao longo dos doze dossiês do livro, sempre na seção Paroles, dedicada às situações orais de comunicação. A 
escolha de um gênero multimodal para se trabalhar a compreensão e a expressão orais em um livro didático de FLE merece nossa análise. Como citamos anteriormente, a história em quadrinhos é um gênero multimodal por excelência e, neste caso, ele tornase ainda mais multimodal, já que temos também o documento áudio com a leitura/interpretação dos diálogos da história. Três recursos semânticos atuam simultaneamente para a construção do sentido: o suporte visual das imagens, o suporte do texto escrito e o suporte do texto oral, o que permite ao aluno uma leitura verdadeiramente multimodal, baseada nas relações texto-imagem-som. (Figura 54).

Figura 54 | Espaces 1 - Página 13

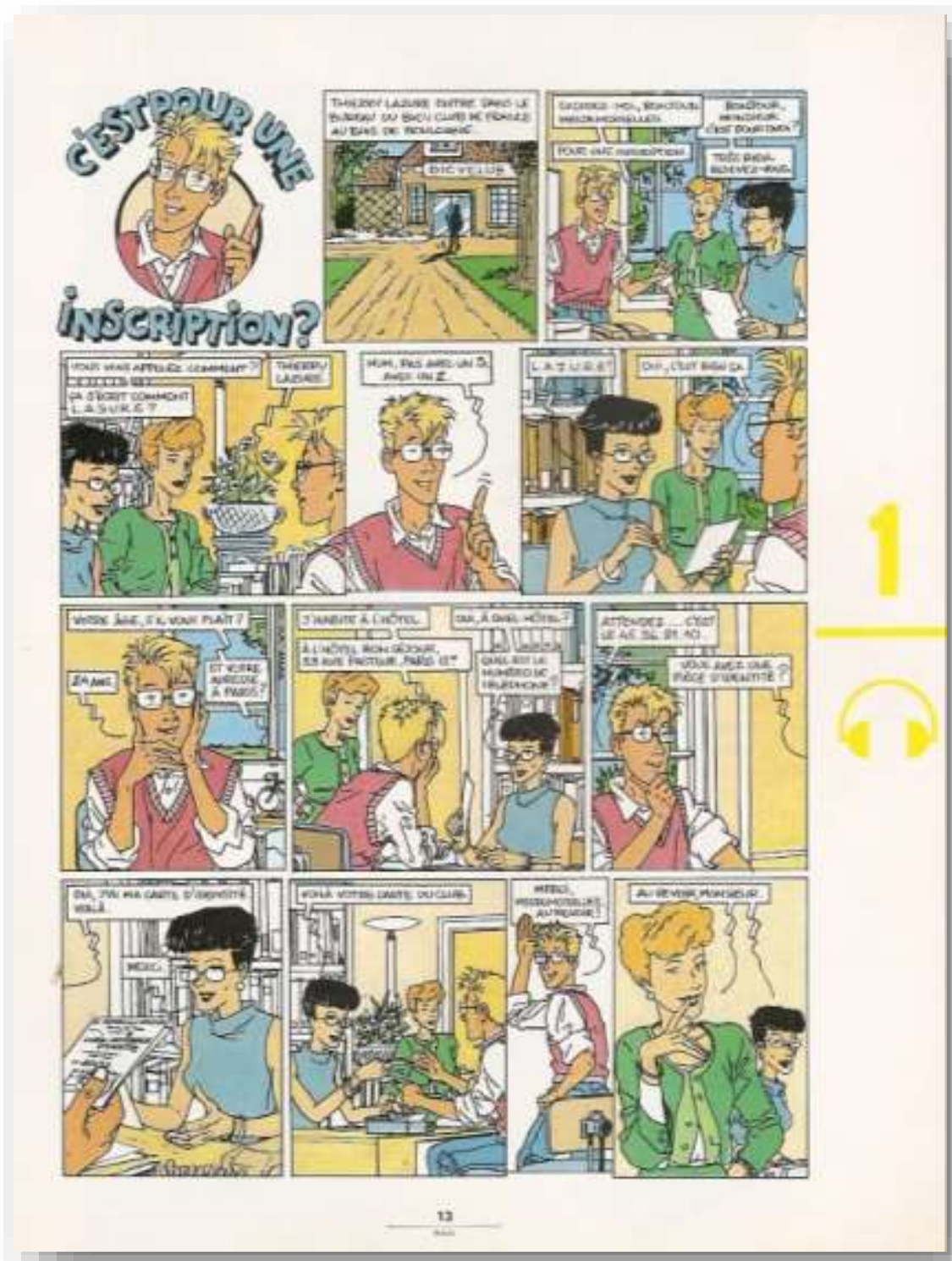


Jean-François Boutin (2012), professor da Universidade do Québec em Rimouski, afirma que, contrariamente às ideias pré-concebidas que associam facilidade de leitura às histórias em quadrinhos, as mesmas exigem, na realidade, uma leitura bastante complexa. Seu leitor deve compreender vários modos de expressão e de comunicação, tais como o textual, o visual, o gestual, o sonoro e os modos mistos. Por essa razão, segundo Boutin (2012), a história em quadrinhos constitui um texto múltiplo, um “multitexto", que exige por sua vez uma leitura múltipla, uma "multileitura”. Essa multileitura gera de forma interativa uma compreensão múltipla e, idealmente, uma integração múltipla dos diferentes elementos que a compõem:

"Lire » de la bande dessinée (la déchiffrer, l'interpréter et l'assimiler), c'est donc lire un texte, lire des images, lire un texte/images, lire des sons, lire des gestes, lire une mise en scène, etc. ; « lire » de la bande dessinée, c'est nécessairement se confronter à un message narratif d'une complexité certaine et beaucoup plus dense que ne le laissent présager les apparences. Or tellement peu d'enseignants, de pédagogues, de communicateurs, de linguistes et d'autres formateurs soupçonnent cette réalité. En fait, toute forme textuelle multimodale (dont évidemment la bande dessinée) demeure encore suspecte, sinon coupable, de distraction, d'égarement, de facilité, d'oisiveté....

(BOUTIN, $2012:$ 40,41)

No caso do livro didático Espaces 1, podemos nos perguntar de que forma a imagem e o texto (escrito e oralizado pela gravação de áudio) da história em quadrinhos são integrados na proposta pedagógica do livro. Trata-se de um suporte com imensas possibilidades que o professor poderá explorar de acordo com seus objetivos e com o seu público. No entanto, ao analisarmos as indicações do guia pedagógico, vemos que há poucas pistas de exploração pedagógica para esse gênero multimodal. O texto geral dessa parte da unidade/dossiê, apresenta a história em quadrinhos nos seguintes termos:

Section Paroles : elle est axée sur la pratique de l'oral. Le document de référence est une histoire en bande dessinée qui se déroule tout au long des douze dossiers : « La roue tourne ». [...]

La première partie de la section est centrée sur la compréhension orale qui est facilitée par les dessins, la mise en situation et la connaissance des personnages qui s'affermit au fil des dossiers.

Guia pedagógico, pág. 11 - grifo nosso. 
Como vemos, o grande objetivo dessa página é trabalhar a compreensão oral. No entanto, o texto multimodal da HQ não aparece como um elemento múltiplo de significados, mas sim, de forma segmentada e hierarquizada: o desenho é um "facilitador" ao acesso ao objetivo principal da seção, a compreensão oral. A expressão é curiosa pois condiz exatamente com a observação de Boutin (2012) sobre a falta de profundidade na exploração didática de recursos extremamente ricos como a história em quadrinhos.

Ao analisarmos as passagens do guia pedagógico específicas para a exploração de cada capítulo da HQ, observamos que, por vezes, a imagem aparece realmente em um papel reduzido de "facilitadora" para a compreensão oral:

Afin de préparer l'écoute, il convient d'amener les élèves à repérer, d'après les images, qui sont les personnages, ce qu'ils font, où et quand ils le font. [...] En travaillant sur les images, on fera en sorte [...] d'enseigner quelques mots et expressions clés du dialogue.

Guia pedagógico, pág.33.

Observer les dessins, définir les situations de communication (qui, à qui, à propos de quoi, où, quand, pourquoi) et imaginer l'histoire.

Guia pedagógico, pág. 67.

A maioria das indicações do guia pedagógico propõe, portanto, para essa página um trabalho não muito diferente do que é feito com os tradicionais desenhos que costumam acompanhar os diálogos de um livro didático: observação, antecipação do conteúdo, emissão de hipóteses sobre o documento oral antes da escuta.

Há, no entanto, propostas didáticas mais ricas para alguns capítulos das HQ, nas quais o suporte multimodal é explorado com mais profundidade, como vemos a seguir nesta atividade de antecipação:

Observer les dessins, définir les situations de communication (qui, à qui, à propos de quoi, où, quand, pourquoi) et imaginer I'histoire.

Guia pedagógico, pág.75. 
Mesmo se nessa atividade o papel da imagem ainda está bastante ligado à ilustração de uma situação de comunicação, a ideia de recortar a HQ em seus quadros (talvez recorrendo a fotocópias da página do livro que serão recortadas pelo professor) preserva-se com mais coerência o aspecto multissensorial do suporte, acrescentando um aspecto lúdico à atividade.

É importante ressaltar que, apesar da falta de atividades pedagógicas que explorem mais profundamente as possibilidades oferecidas pela HQ, Espaces 1 tem o mérito de ter proposto esse gênero textual para as situações de comunicação oral de cada dossiê, o que confere originalidade ao projeto gráfico-editorial e pedagógico do livro didático. Assim como Archipel 1 teve o mérito de incluir anúncios publicitários, menus de restaurante e outros documentos autênticos em suas páginas, mesmo não os tendo explorado profundamente, o mesmo mérito deve ser dado a Espaces 1, pela escolha da HQ, ainda que não tenha havido mudança significativa na forma de explorar o suporte visual que acompanha os diálogos.

O pesquisador norte-americano Richard E. Mayer (2009: 223), que estuda a utilização de textos multimodais na área da educação, afirma que "as pessoas aprendem melhor a partir de palavras e de imagens do que somente por meio de palavras" 29 . Acreditamos plenamente nessa afirmação, por isso, consideramos que a simples inclusão de uma HQ em um LD já é um fato extremamente positivo.

Acreditamos, portanto, que a utilização de textos multimodais na educação e no ensino de línguas estrangeiras é essencial por duas razões. A primeira, já evocada nesta pesquisa, diz respeito à necessidade social de preparar os alunos a diferentes práticas de letramento: é necessário que eles sejam capazes de ler, de compreender e de interpretar esses textos compostos por diferentes suportes semióticos e que estão cada vez mais presentes na sociedade. A segunda razão decorre da afirmação de Mayer (2009) que diz ainda que quando palavras e imagens são apresentadas conjuntamente, os alunos têm a oportunidade de construir modelos verbais e visuais e de estabelecer conexões entre ambos.

No caso da HQ do livro didático Espaces 1, além do suporte escrito e do suporte visual, há também o suporte sonoro, uma vez que os diálogos da HQ são gravados e constituem os documentos a serem trabalhados na compreensão oral. Essa

\footnotetext{
29 Tradução nossa. No original : "People learn better from words and pictures than from words alone."
} 
multiplicação de modalidades no texto, mesmo se sua exploração pedagógica ainda é limitada, nos parece extremamente positiva.

Como vimos, a quantidade de imagens presentes no livro do aluno Espaces 1 é significativamente superior às do livro Archipel 1, publicado cerca de dez anos antes. As mesmas observações que fizemos anteriormente neste trabalho ao analisarmos a transformação das páginas de jornais nas décadas de 1980 e de 1990, são válidas quando passamos de uma década a outra nos LDs de FLE. O texto escrito cede progressivamente espaço a mensagens visuais e interage melhor com elas, como podemos observar na imagem a seguir. (Figura 55).

Figura 55 | Espaces 1 - Página 9

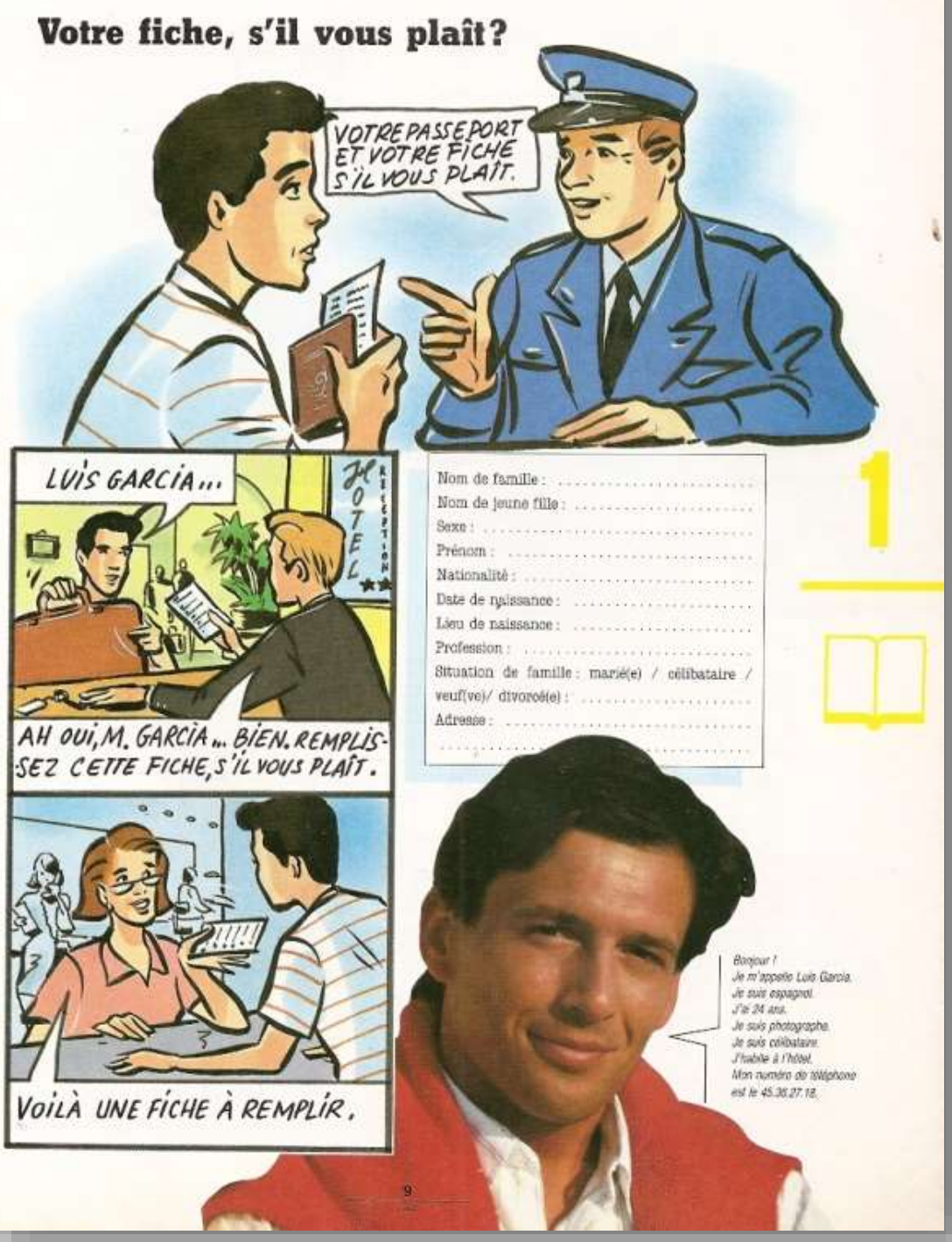


A interação texto/imagem é bastante clara nesse exemplo. Havíamos dito que certas mensagens visuais nos jornais pareciam interagir e completar o texto escrito, como gráficos e desenhos. Nessa página em particular do livro Espaces, temos como situação de comunicação o preenchimento de uma ficha de cadastro e como ato de fala ${ }^{30}$, apresentar-se (dizer seu nome, seu endereço, sua data de nascimento, etc.). Ao analisarmos a proporção da mensagem visual em relação à mensagem escrita, podemos dizer, não que o desenho ilustre o texto, mas sim que as imagens - maiores representantes neste caso da situação de comunicação - são "ilustradas" pelo texto escrito, uma pequena ficha de hotel. Talvez em uma nova "vingança da imagem", retomando a citação de Joly (2003).

No entanto, mais uma vez nesse LD, notamos que essa "vingança”" da imagem se faz em termos de quantidade, ou seja, em termos do espaço físico que lhe é atribuído nas páginas do livro e não no que se refere a um eventual aumento de sua importância no tratamento pedagógico.

De fato, ao analisarmos as preconizações do guia pedagógico para essa mesma página, composta de cerca de $75 \%$ de imagens, notamos uma única frase que faz referência às ilustrações:

L'examen des illustrations de la page 9 permet de prendre conscience des situations, parallèlement à l'écoute des dialogues.

Guia pedagógico, pág. 19

Podemos novamente nos perguntar se a escolha das ilustrações foi feita pelos próprios autores do livro, dentro de uma proposta pedagógica ou se foi inserida de forma ilustrativa no projeto gráfico-editorial, de forma um tanto dissociada do processo de concepção pedagógica - o que limitaria, portanto, as possibilidades e, consequentemente, as preconizações para a exploração didática do suporte visual.

Analisemos agora uma dupla página de Espaces 1, ou seja, uma sequência pedagógica, tomando por base as teorias de Kress e van Leeuwen (2006). Logo no início do livro, as páginas 10 e 11 (Figura 56) abordam conjuntamente os seguintes objetivos comunicativos: cumprimentar alguém e apresentar alguém. Texto verbal e texto visual

30 Utilizamos aqui a noção de "Speech acts", termo definido inicialmente por J. L. Austin (1962) e adotado na abordagem comunicativa. 
integram-se em duas páginas multimodais compostas por textos, exercícios, transcrições de diálogos, fotos e desenhos.

Figura 56 | Espaces 1 - Pág. 10, 11
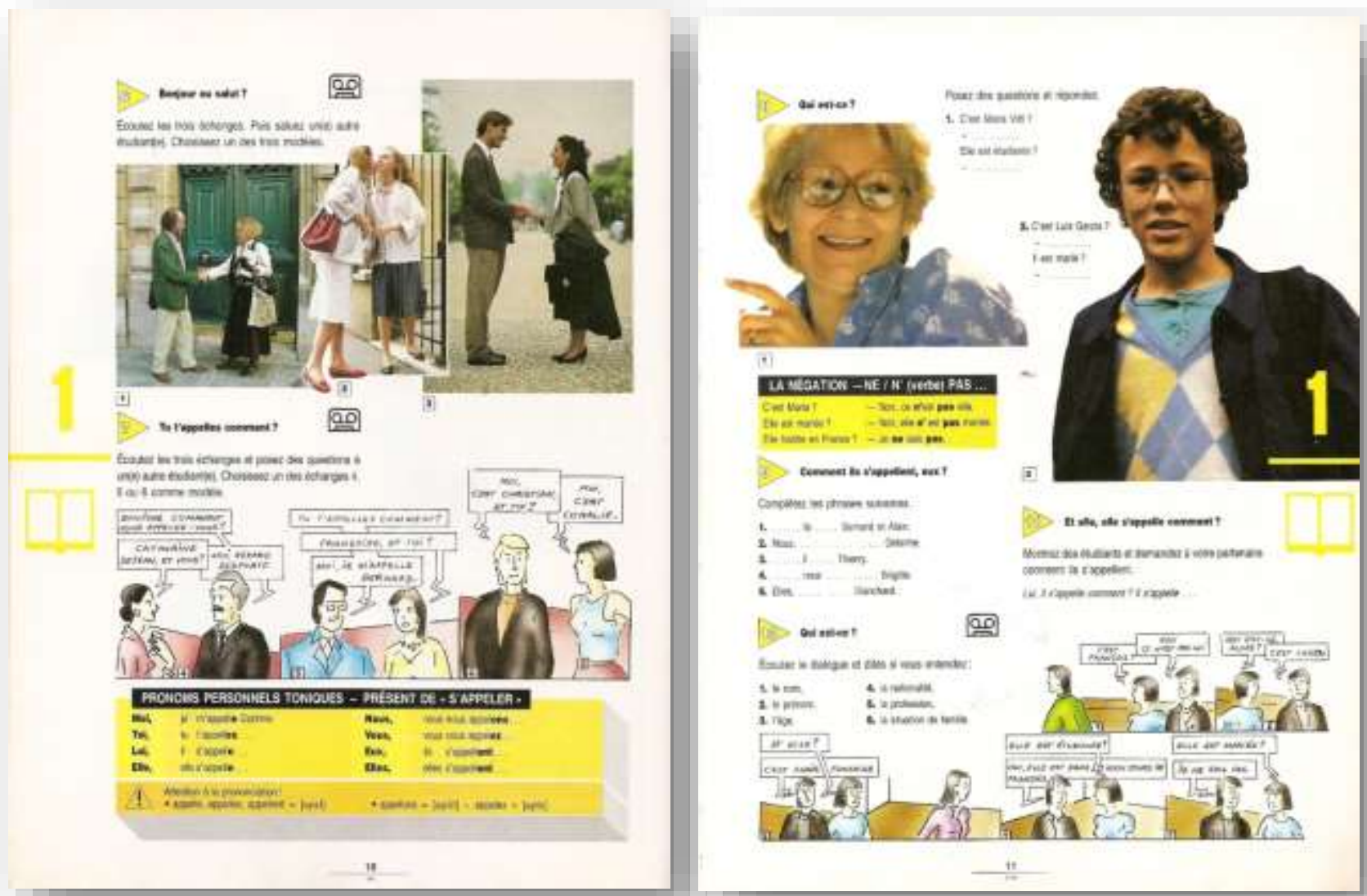

A página à esquerda trata, sobretudo, do primeiro objetivo comunicativo: cumprimentar alguém. Encontramos no texto escrito dessa página fórmulas utilizadas para se cumprimentar alguém em francês, formal e informalmente. As três fotos que compõem a parte superior da página apresentam uma estrutura representacional narrativa, ou seja, os participantes estão conectados por um vetor e são representados realizando uma ação, no caso, cumprimentando-se. Como espectadores das imagens, não conhecemos esses personagens, não sabemos seus nomes ou profissões. Esse distanciamento é reforçado pelo plano adotado, o plano geral que caracteriza a função interacional de distância social da imagem. 
O segundo grupo de imagens da mesma página, composto por três ilustrações, acrescenta ao texto visual e escrito o segundo objetivo comunicativo da dupla página, apresentar-se. Os personagens não apenas se cumprimentam, como na primeira sequência de fotos, mas se apresentam, dizem seu nome e fazem a mesma pergunta. Essa aproximação dos personagens é marcada também pela função interacional de distância social, já que eles nos são apresentados por meio de um plano médio, ainda dentro de uma função representacional narrativa.

Ao passarmos para a página seguinte, o tema abordado concentra-se totalmente no segundo objetivo comunicativo: apresentar alguém. Contrariamente às fotos da página anterior, as duas grandes imagens da página à direita apresentam uma função representacional conceitual, já que os personagens são apresentados em termos de essência (ser, existir), o que é reforçado pelo título da atividade "Qui est-ce ?" Dois personagens, Maria Vitti e Luís Garcia, são apresentados ao espectador / ouvinte / leitor. Este fica sabendo quais são os seus nomes, suas profissões e estado civil, dentro do ato de fala "apresentar alguém". A aproximação dos personagens é reforçada pela função interacional de distância social, já que eles nos são apresentados por meio de um closeup, ou seja, pelo plano que cria a maior sensação de intimidade com o leitor/espectador.

No caso específico da grande foto do rapaz à direita, podemos também analisar a metafunção interacional e o ponto de vista do contato, ou seja, o olhar do participante em relação ao espectador. Nessa foto, o jovem olha diretamente o espectador, num caso de demanda: o observador é interpelado pelo ator, de onde emana o vetor. Já do ponto de vista da perspectiva, vemos que o jovem é retratado em um ângulo horizontal frontal e no mesmo ângulo de visão vertical do espectador, o que coloca os dois em posição de igualdade e reforça, consequentemente, o convite para que o aluno, ao final da sequência, tome a palavra e se apresente. Pode-se imaginar que muitos alunos tenham a mesma idade do jovem da foto e sejam, portanto, passíveis de se identificar com ele.

Ao retomarmos o percurso feito pelo leitor/espectador ocidental, da esquerda até a direita, vemos que o grau de aproximação aumenta tanto no conteúdo quanto na estrutura das formas / imagens apresentadas nessa dupla página.

A última composição de imagens, embaixo da página à direita e sob a forma de uma história em quadrinhos, retoma de forma mais completa os dois atos de fala da sequência (cumprimentar e apresentar alguém) em um único contexto, com imagens nem tão distantes como nas primeiras fotos, nem tão próximas quanto nas fotos 
anteriores. O aluno, com a ajuda do professor e desse percurso multimodal, terá passado nessa dupla página do geral para o detalhe para, enfim, reagrupar todos os elementos abordados dentro de uma produção única e contextualizada, numa retomada multimodal e multissensorial de um percurso didático com objetivos comunicativos precisos e progressivos.

Quanto à metafunção composicional, vale destacar o enquadramento, ou seja, a forma pela qual esses diferentes elementos (textos, desenhos, fotos, etc.) estão agrupados em uma sequência única por meio da cor, no caso, o amarelo que aparece em toda a dupla página nos quadros gramaticais e nos números dos exercícios.

Encontramos também em Espaces uma função para a imagem muito utilizada nos livros didáticos de francês: a imagem associada ao léxico. Nesse caso, a imagem aparece como ilustração de um novo vocabulário. Setas ligam as imagens às palavras correspondentes com o intuito de ajudar o aluno a adquirir um novo vocabulário, como podemos ver na ilustração abaixo (Figura 57).

Figura $57 \mid$ Espaces 1 - Página 82, detalhe

\section{Thierry change de look.}

Comment est-il habillé avant et après?

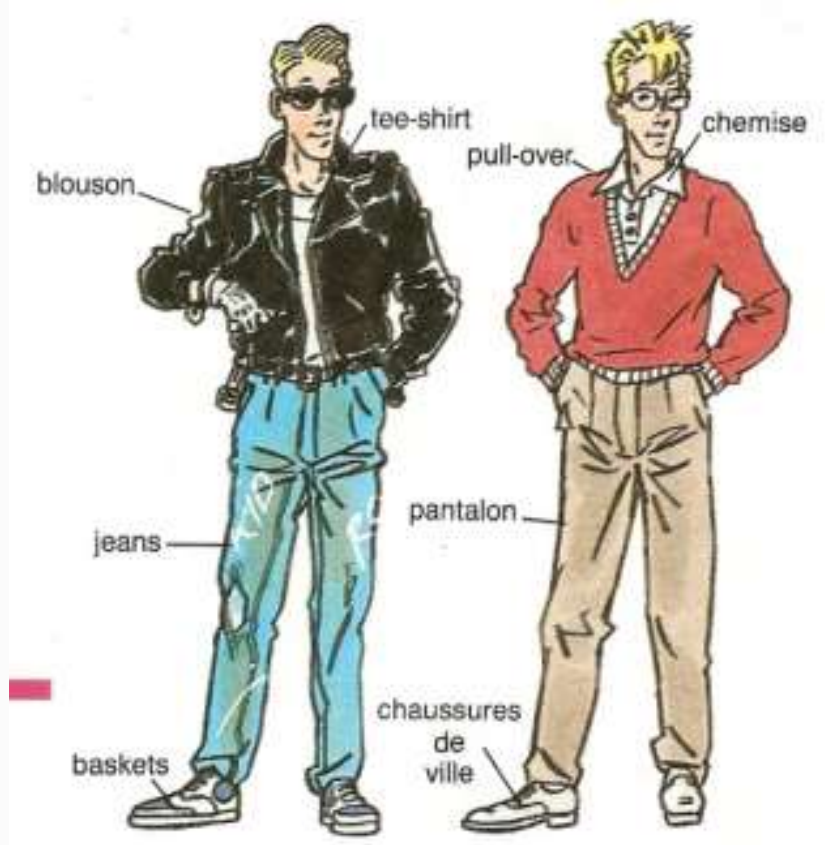


Essa mesma função da imagem como representação de um novo vocabulário aparece na página 93 do livro, dedicada aos alimentos (Figura 58). Eles são divididos em quatro grupos alimentares, com setas indicando as correspondências lexicais para cada imagem.

Figura 58 | Espaces 1 - Página 93

\section{Savez-vous manger?}

Pour être en bonne santé nous avons besoin d'un régime alimentaire equilibre et d'environ 2000 a 2500 calories par jour. Mais savez-vous ce que vous mangez?

On peut classer les aliments en 4 grands groupes:
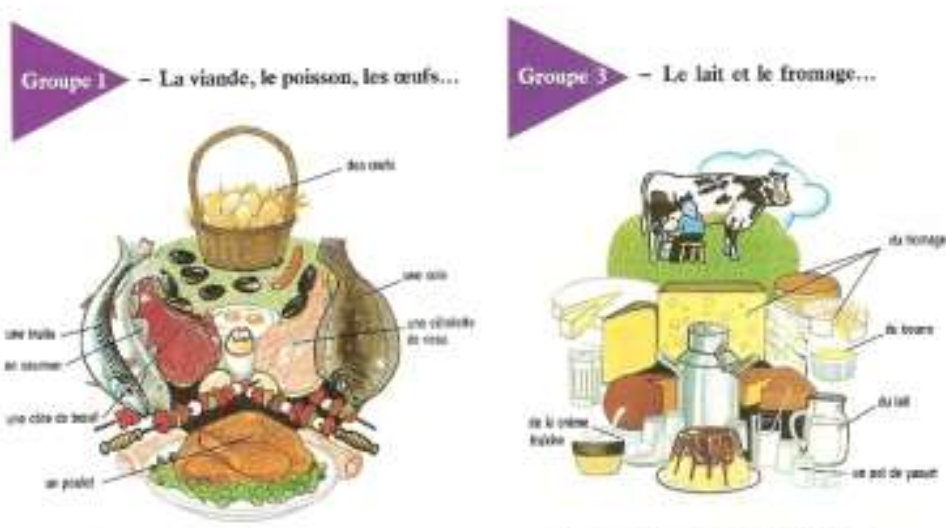

t.t. soat riches en protétios.

i. conticnnent beaucoup de vitamines.
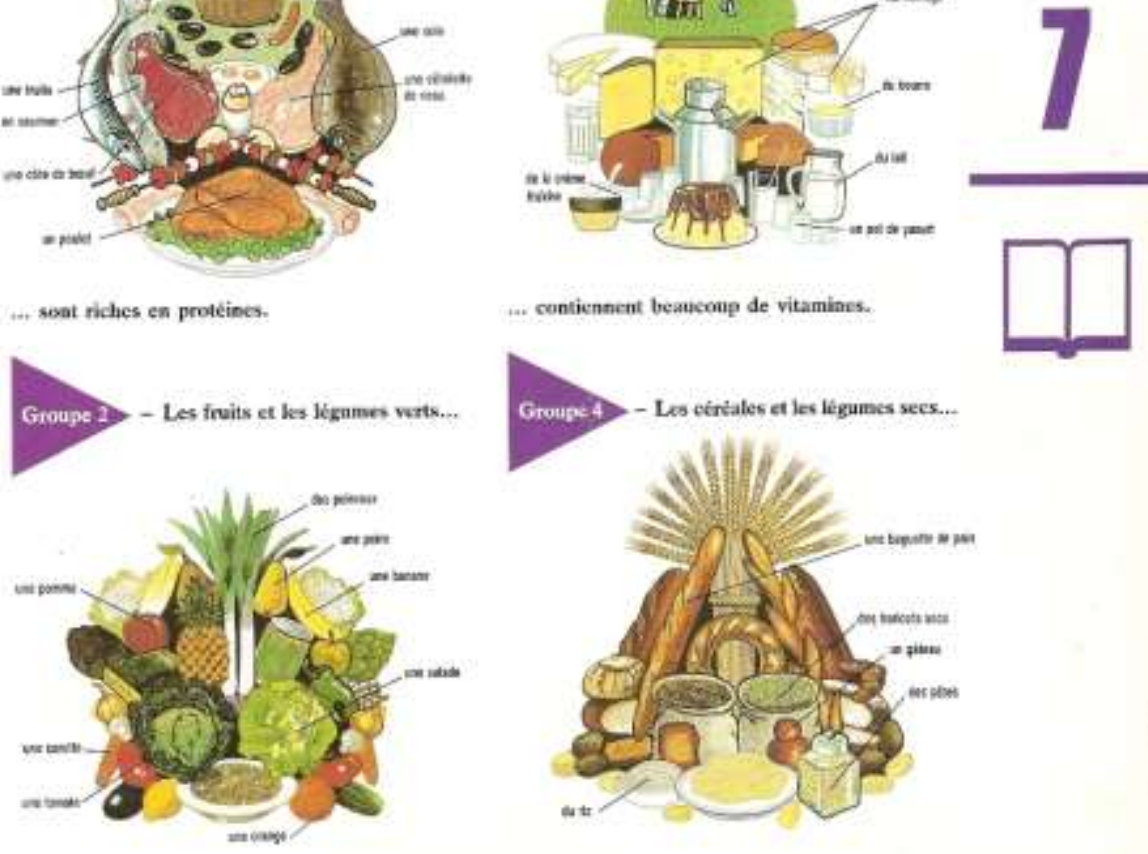

H. contiennent beauceup de vitamines.

... sont riches en proteines.

93

Apesar da importância espacial da ilustração nessa página, nenhuma menção a um trabalho específico com essas imagens aparece no guia pedagógico. 


\subsubsection{Preconizações do guia pedagógico para o uso da imagem}

Analisaremos agora o guia pedagógico de Espaces 1, buscando em seu texto referências às imagens do livro do aluno. Para isso, retomamos a seguir alguns trechos do guia em que palavras como illustrations, images, dessins são citadas e que são representativos dos tipos de preconizações adotadas para o uso da imagem. Nosso objetivo será identificar a quantidade de indicações para o uso da imagem no guia pedagógico e também os termos associados à sua exploração.

Page 9 - Examen des illustrations

L'examen des illustrations de la page 9 permet de prendre conscience des situations, parallèlement à l'écoute de courts dialogues.

Guia pedagógico. Pág. 19 - grifo nosso.

Page 10

À partir des dessins et des dialogues, faire prendre conscience de la distinction entre tu et vous et entre deux niveaux de langue (familier/plus soigné) selon les rapports entre les interlocuteurs.

Guia pedagógico. Pág. 21 - grifo nosso.

As páginas 9 e 10 que vimos anteriormente são plenamente ilustradas (Figuras 55, 56). O guia pedagógico, no entanto, confere às imagens um papel apenas de introdução e de ilustração das situações de comunicação. Vejamos agora alguns exemplos de orientação pedagógica para a exploração da HQ:

Page 13 - Bande dessinée « La roue tourne »

\section{Avant l'écoute}

Quelle est la situation?

Présenter les 3 personnages. Regarder les dessins et faire repérer les personnages, le lieu (le bureau) et les types d'interaction (qui parle à qui ? pourquoi ?).

Guia pedagógico. Pág. 23 - grifo nosso.

Ex. 5 - Les dessins suggèrent des actes de parole utilisés dans le dialogue.

Guia pedagógico. Pág. 24 - grifo nosso.

Page 27 - Bande dessinée "La roue tourne »

Examen de la BD (pré-sensibilisation - anticipation)

Regardez la bande dessinée. 
Afin de préparer l'écoute, il convient d'amener les élèves à repérer, d'après les images, qui sont les personnages, ce qu'ils font, où et quand ils le font.

En travaillant sur les images, on fera en sorte, surtout dans les débuts, d'enseigner quelques mots et expressions clefs du dialogue (ici, par exemple : faire du vélo, venir, travailler afin de fournir des points d'appui supplémentaires pour la compréhension.

Guia pedagógico. Pág. 33 - grifo nosso.

Como havíamos anunciado anteriormente, nas páginas referentes à HQ La roue tourne, o papel da imagem consiste em ajudar na identificação da situação de comunicação, preparar a escuta do diálogo, antecipar o vocabulário. A grande maioria das orientações para o uso da HQ seguem esses objetivos, como no exemplo abaixo, correspondente à figura 59.

\section{Page 139 : Examen de la BD et anticipation}

Combien de scènes différentes y a-t-il ? Qui sont les personnages ? Quel est le personnage central de l'épisode ? Où sont les personnages?

Guia pedagógico. Pág. 109.

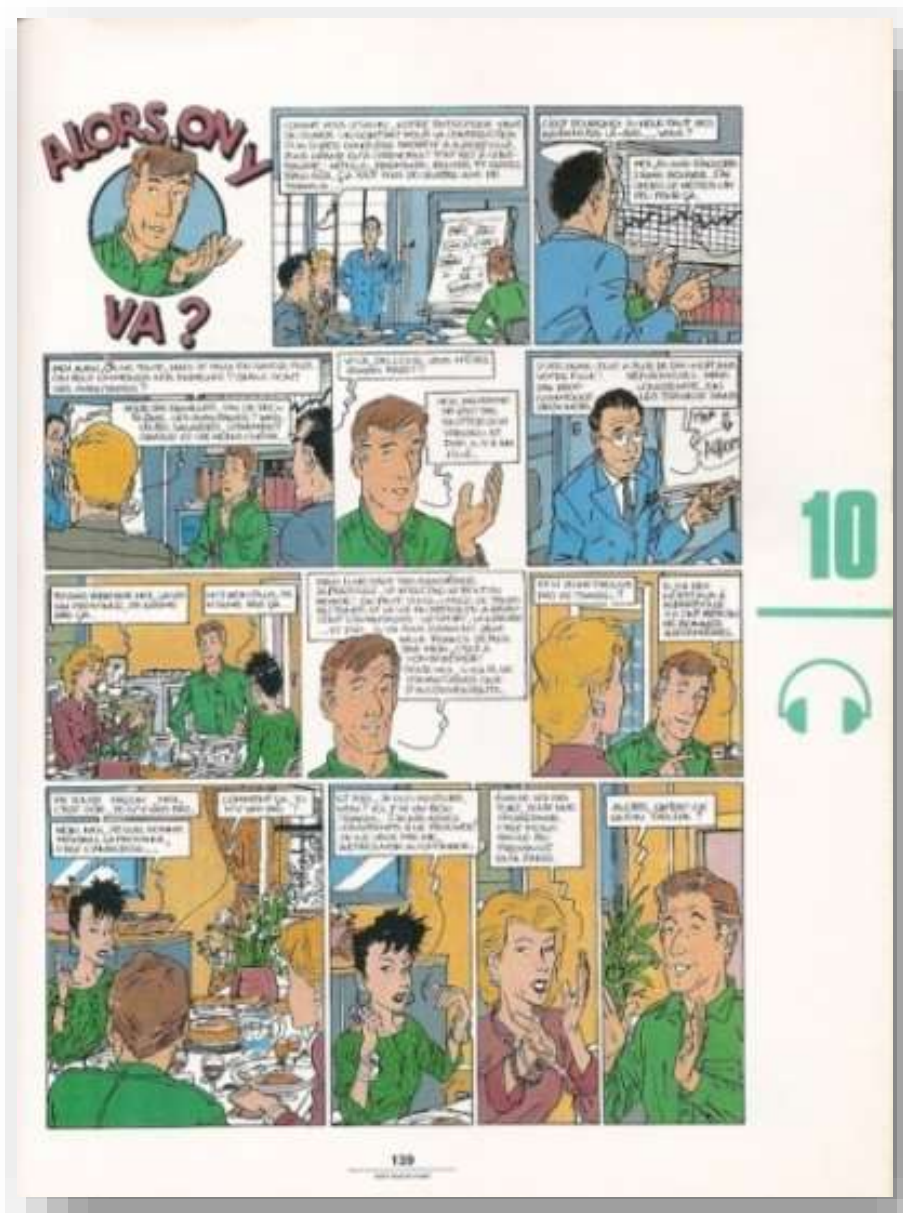

Figura 59 | Espaces 1 - Pág. 139 
Há, no entanto, uma orientação específica que nos parece interessante e que vale a pena ressaltar:

\section{Page 153 hésitante, heureuse, en colère? \\ (Enseigner : « avoir l'air » + adjectif) \\ Que se passe-t-il à la fin ?}

Observer le visage d'Émilie. Elle a l'air contente, inquiète,

Guia pedagógico. Pág. 117.

Consideramos bastante positivo o fato de a expressão gestual da personagem ter sido explorada na proposta didática, já que se trata de um componente visual essencial do gênero HQ.

Por sua vez, a dupla página abaixo (Figura 60) merece destaque pela qualidade de seu projeto gráfico-editorial, que integra texto, imagem, juntamente com um trabalho sobre a tipologia das frases, ao reproduzir alguns slogans de Maio de 1968.

Figura 60 | Espaces 1 - Pág. 162, 163

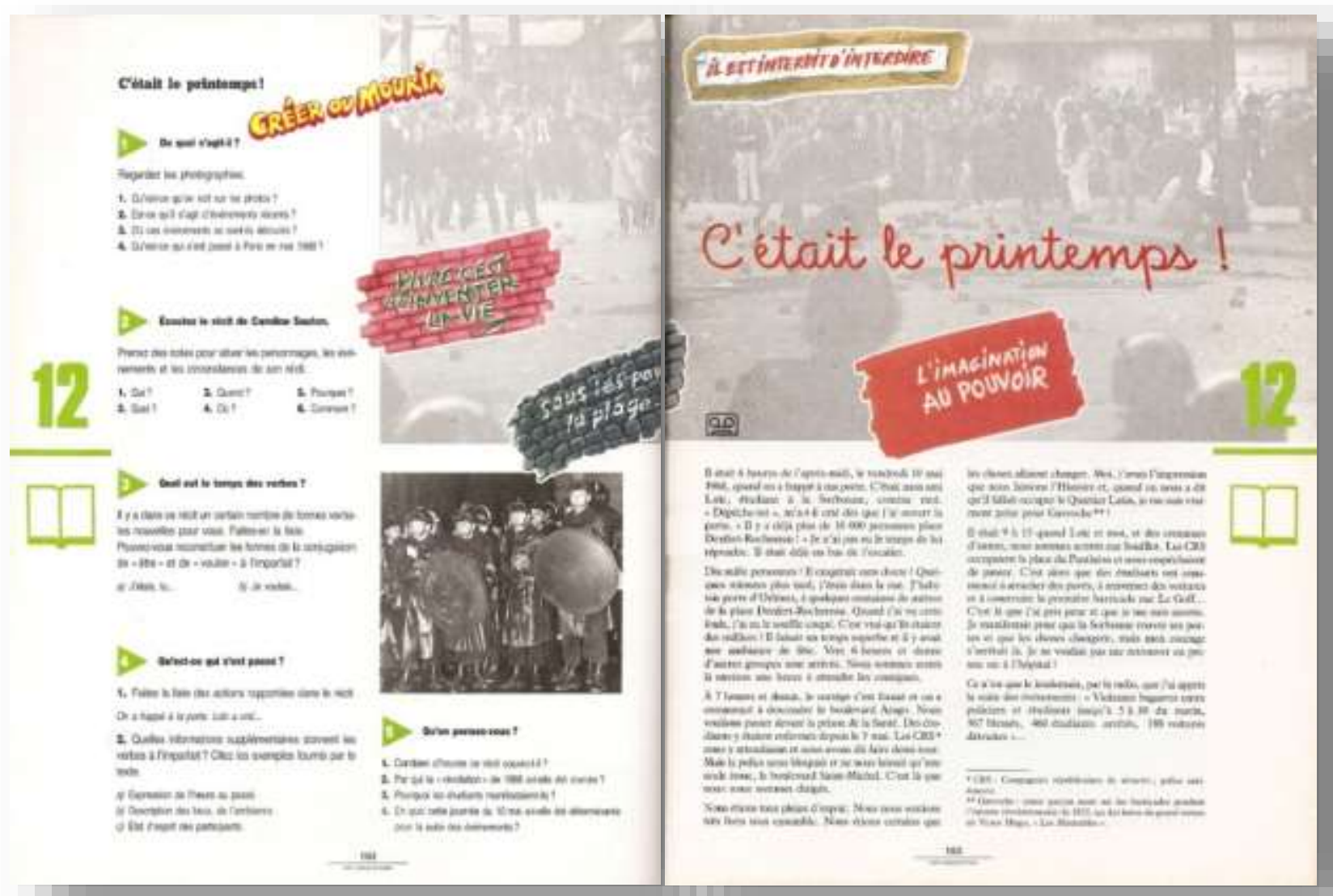


Acreditamos que a escolha gráfica desse texto multimodal favoreça a construção do sentido pelo aluno. No entanto, apesar da potencialidade do suporte para exploração em sala de aula, as indicações do guia do professor para esse conteúdo visual resumemse a uma única frase que copiamos abaixo:

C'était le printemps ! Pages 162-163

Décrire les illustrations. Introduire : CRS, foule, arracher des pavés, barricade.

(Guia pedagógico, pág. 122)

Confirma-se, portanto, que a grande quantidade de imagens presentes no livro, muitas vezes inscritas em um belo projeto gráfico-editorial, estão raramente acompanhadas de uma proposta mais aprofundada de exploração.

E como que para provar que há exceções a essa ausência de um trabalho mais específico sobre o texto multimodal nesse livro didático, analisamos, a seguir, uma proposta pedagógica que nos parece extremamente pertinente. Trata-se da dupla página 52-53 representada na figura a seguir (Figura 61).

Figura 61 | Espaces 1 - Pág. 52, 53

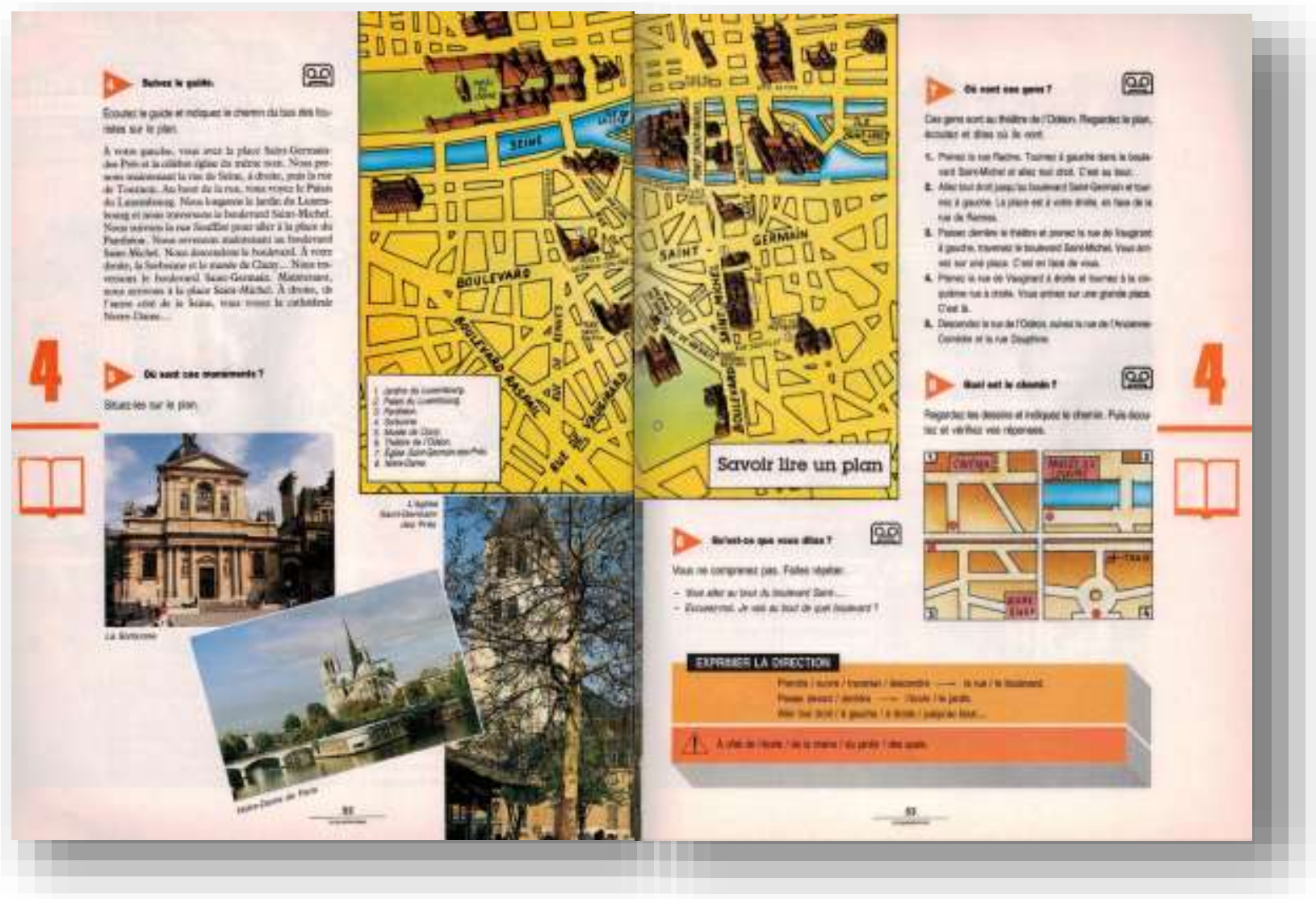


Essa dupla página multimodal é composta por um mapa de Paris, por fotos de três monumentos turísticos parisienses e por um documento sonoro que reproduz a voz de um guia turístico dentro de um ônibus que circula por esse local da cidade. O guia turístico indica o caminho seguido, os nomes das ruas pelas quais passa o ônibus e os monumentos que podem ser vistos à esquerda, à direita, etc. A transcrição do diálogo completa a página multimodal.

O posicionamento do mapa de Paris entre as duas páginas cria uma sensação de unidade entre elas e contribui para a interação de seus diferentes componentes. No entanto, além do projeto gráfico-editorial interessante, o que nos chama a atenção é a proposta de atividade feita pelos autores para a compreensão oral do documento (um guia turístico que descreve o caminho de seu ônibus pelas ruas de Paris). Pede-se ao aluno que desenhe sobre o mapa da cidade o caminho indicado pelo documento oral e que situe, em seguida, e também no mesmo mapa, os monumentos de Paris representados nas fotos da página.

Essa proposta nos parece extremamente interessante pois não somente integra os diferentes elementos que compõem a dupla página, mas também - e sobretudo porque propõe ao aluno que realize uma atividade com a imagem. Ele deverá atuar, interagir sobre a imagem e realizar uma tarefa a partir dela e com ela, o que nos parece indicar uma possibilidade de proposta de exploração do texto multimodal extremamente pertinente, mas, infelizmente, extremamente rara - não somente nesse livro, mas também em livros didáticos publicados mais recentemente, como veremos mais adiante.

\subsubsection{Balanço qualitativo e quantitativo}

\section{- Balanço qualitativo das preconizações para o uso da imagem:}

Os termos utilizados pelo guia pedagógico para se referir às imagens são os seguintes: illustrations, dessins, photos, bande dessinée, carte. Os verbos associados às mesmas costumam ser: observer, regarder, examiner, décrire, definir, faire correspondre.

Em todos os casos, a análise da imagem aparece como uma antecipação ao trabalho sobre a sequência didática, como provam as palavras: pré-sensibilisation, anticipation que acompanham constantemente as indicações sobre o momento em que a imagem deve ser trabalhada. 
Podemos, portanto, dizer que a imagem é trabalhada no livro didático Espaces 1 como um apoio à situação de comunicação. Ela acompanha os diálogos, os textos, mas raramente ocupa uma importância igual ou maior do que eles, pois está geralmente a serviço dos mesmos.

\section{Balanço quantitativo das preconizações para o uso da imagem em Espaces 1:}

- Número de páginas do livro do aluno - excluindo-se os anexos: 168 páginas.

- Número de páginas ilustradas no livro do aluno - excluindo-se os anexos: 168 páginas (100\%).

- Número de páginas para as quais há uma menção ao trabalho sobre a imagem no guia pedagógico: 19 páginas (11,3\%).

Ao compararmos esses dados quantitativos com os dados obtidos na análise do livro didático Archipel 1, chegamos ao seguinte gráfico comparativo:

Figura 62 | Gráfico - Balanço comparativo Archipel 1/ Espaces 1

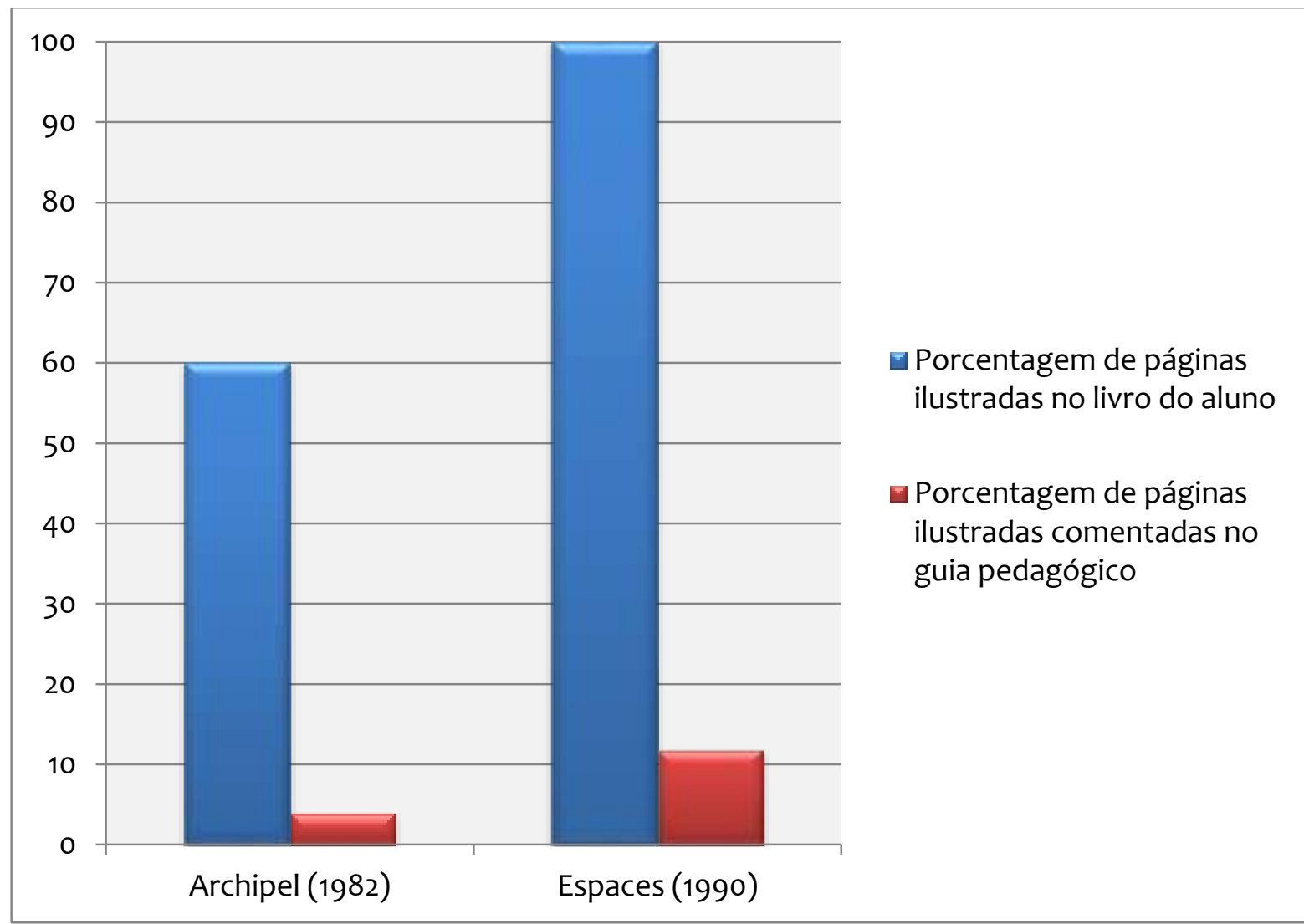




\subsection{Análise $n^{\circ} 3 \mid$ Forum 1}

BAYLON, Christine ; CAMPÀ, Angels ; MESTREIT, Claude ; MURILLO, Julio ; TOST, Manuel. Paris : Hachette, 2000.

Composto por três volumes (Forum 1, Forum 2, Forum 3), Forum é um livro didático de FLE publicado em 2000 pela editora Hachette e destinado a adultos ou a grandes adolescentes. Logo no prefácio do livro do aluno, afirma-se que esse é o primeiro método a integrar elementos de reflexão desenvolvidos pelo QECR.

Os livros didáticos dessa coleção foram adotados pela Aliança Francesa de São Paulo em 2004, em substituição a Le nouvel Espaces, uma edição atualizada do LD Espaces que analisamos anteriormente.

A coleção Forum 1 é composta, além do livro do aluno, por um caderno de exercícios, um guia pedagógico, dois CDs de áudio para o professor e um site Internet com exercícios autocorretivos para um trabalho em autonomia. Além disso, o livro do aluno é acompanhado por um Carnet de route no qual o próprio aluno cria seu memento de gramática e de vocabulário. Dentro dos anexos, o livro propõe também um portfolio de auto avaliação seguindo as orientações do QECR. Essa prática viria a ser adotada frequentemente nas publicações posteriores em FLE, na maioria das vezes, no entanto, sob o formato de uma brochura encartada no livro do aluno.

$\mathrm{Na}$ introdução do guia pedagógico de Forum 1, reforça-se a importância do aspecto afetivo da utilização e da aprendizagem de uma língua. Esse aspecto - e também os conhecimentos culturais prévios do aluno - aparecem ligados, entre outros, aos documentos visuais propostos pelo livro didático, como vemos a seguir:

Cette composante affective inhérente à toute communication parlée [...] est ici doublement mise en jeu :

- par les relations qu'entretiennent les personnages. Ces relations se manifestent dans les dialogues et documents présentés dans le livre, et s'expriment par des moyens linguistiques (vocables, expressions figées, métaphores, etc.) ou paralinguistiques (gestes, intonations, exclamations, etc.) fournissant à l'apprenant les instruments qui lui permettent de comprendre et de produire la «parole authentique »;

- à travers les réactions que ce matériau - sonore, visuel, écrit ou iconique - suscite chez l'apprenant, en fonction de son vécu et de 
ses connaissances préalables, qui ont de ce fait, une forte charge affective.

(CAMPÀ, MESTREIT, MURILLO, TOST, 2000; 6-7)

De fato, ao analisarmos os documentos iconográficos desse LD, veremos que são reproduzidos um bom número de exemplos de gêneros textuais do cotidiano como cartões de visita, mapas, formulários, passagens de trem, etc. (Figura 63). Essa identificação de um gênero textual já conhecido pelo aluno facilita a aprendizagem, trazendo referências de sua própria experiência de vida em sua língua e cultura maternas.

Figura 63 | Forum 1 - Pág. 44

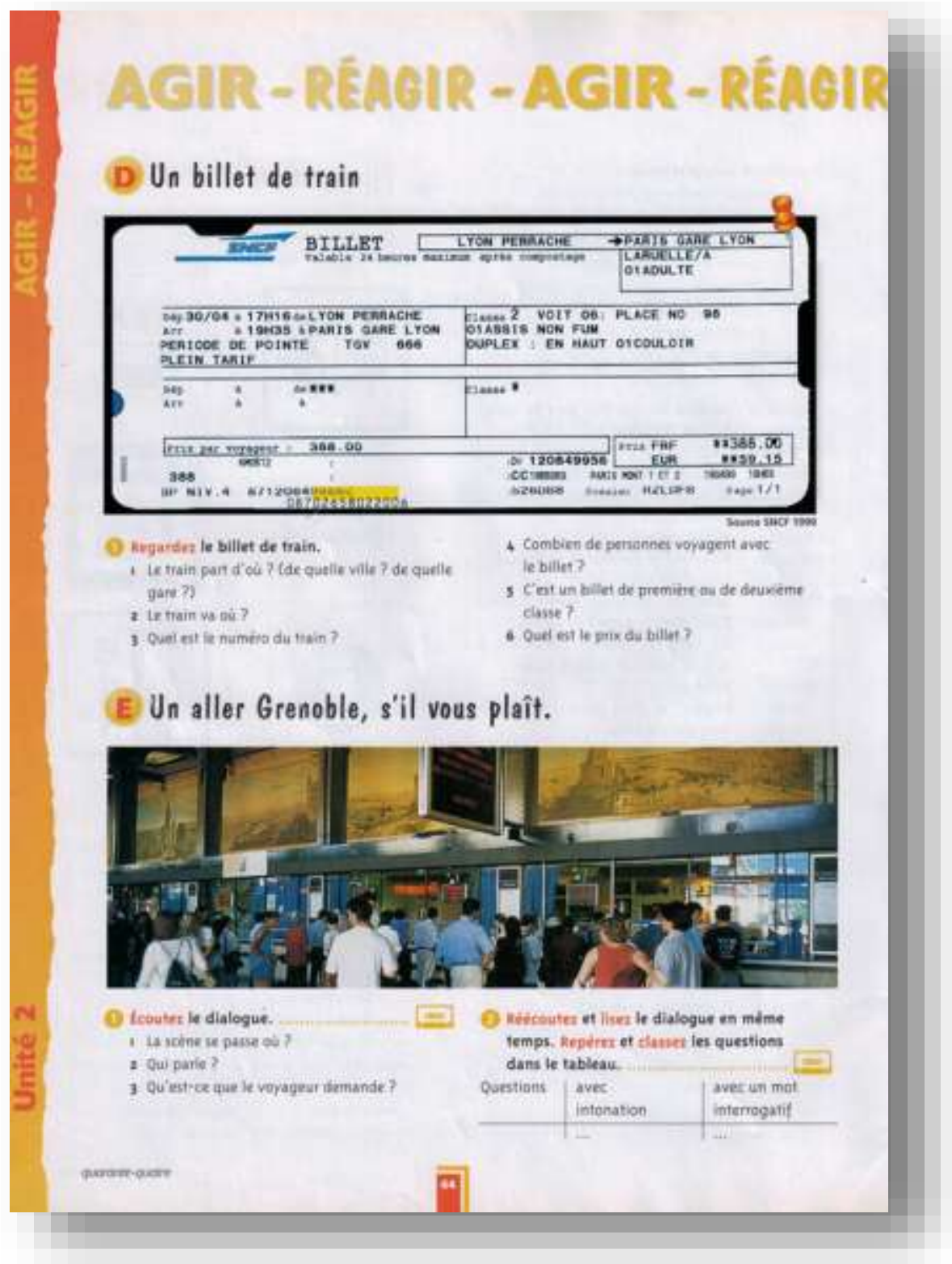


Como no livro didático Espaces, ícones específicos são utilizados como referência a atividades de linguagem, mas eles são bem menos frequentes desta vez: a imagem de uma fita cassette indica a presença de um documento sonoro correspondente e a imagem de uma máscara de teatro indica uma atividade de expressão oral. (Figura 64)

Figura 64 | Forum 1 - Pág. 171 - Detalhe

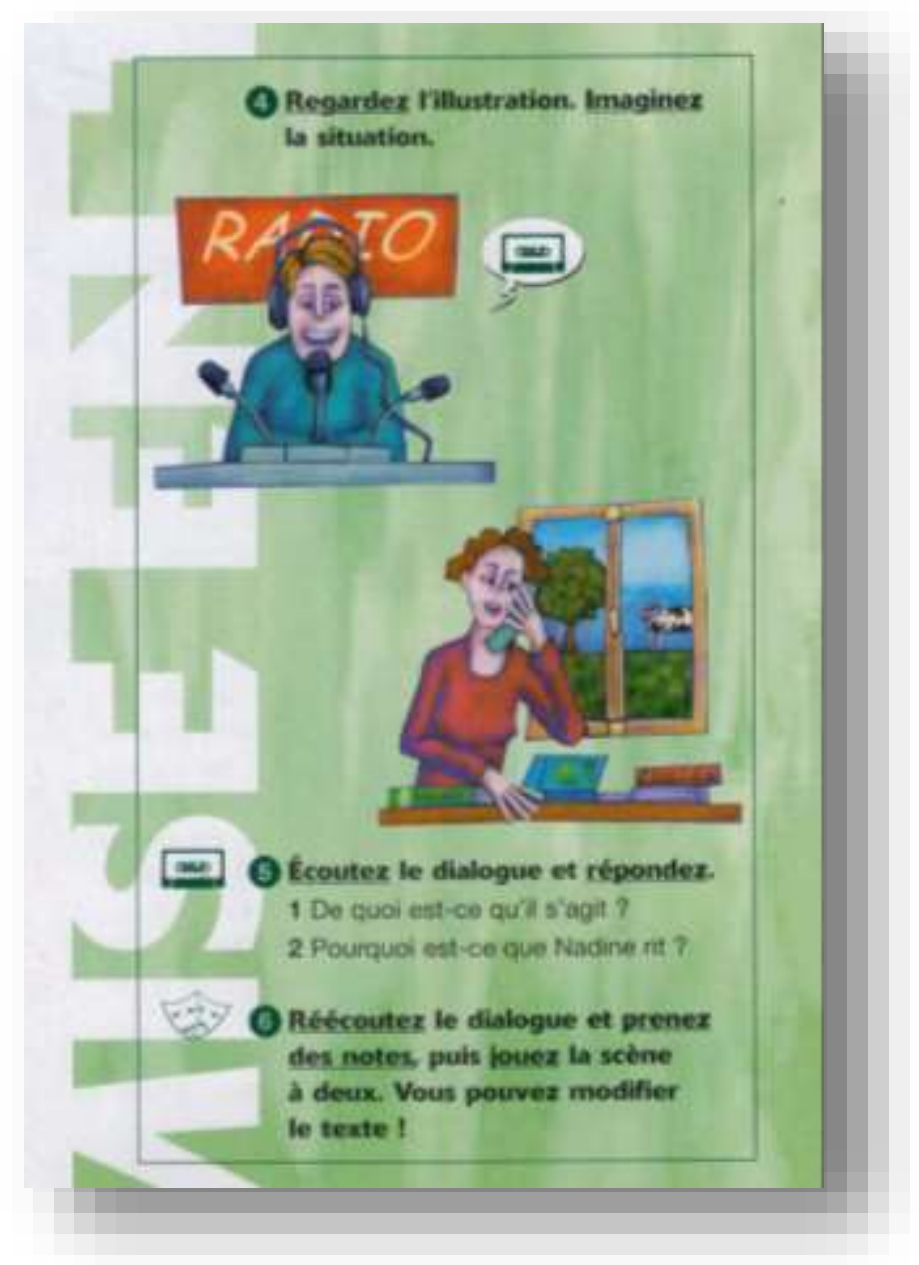

\subsubsection{Análise da capa do livro didático Forum 1}

Trata-se de uma capa sóbria e ao mesmo tempo moderna (Figura 65). A sobriedade vem da escolha do fundo preto e do uso de uma paleta de cores limitada. A modernidade vem de certo aspecto digital evocado pelos quadrados coloridos que lembram pixels de um computador. O próprio nome do livro pode ser relacionado ao vocabulário da Internet e à questão da interação. 
Essa associação não se encontra apenas no léxico pois, na verdade, trata-se de um dos primeiros métodos de FLE a propor um site Internet complementar para o aluno. Ainda não estamos na época dos livros didáticos digitais, mas essa proposta constitui um primeiro passo para o que se vê cada vez mais no mundo da edição de livros de FLE: a complementaridade digital para o LD impresso. Este aparece cada vez mais como um elemento - ainda central, é verdade - dentro de uma ampla oferta de suportes complementares para o ensino-aprendizagem da língua. As editoras criam para cada nova publicação didática, além do livro do aluno impresso, sites de acompanhamento, livro e caderno de exercícios em versão digital na qual já se inclui o material sonoro e visual, atividades interativas e autocorretivas complementares em DVDs ou em plataformas específicas para o aluno com a possibilidade de mediação do professor, além de aplicativos específicos. Forum parece indicar um primeiro passo na busca desses complementos digitais.

Figura 65 | Forum 1 - Capa do livro do aluno

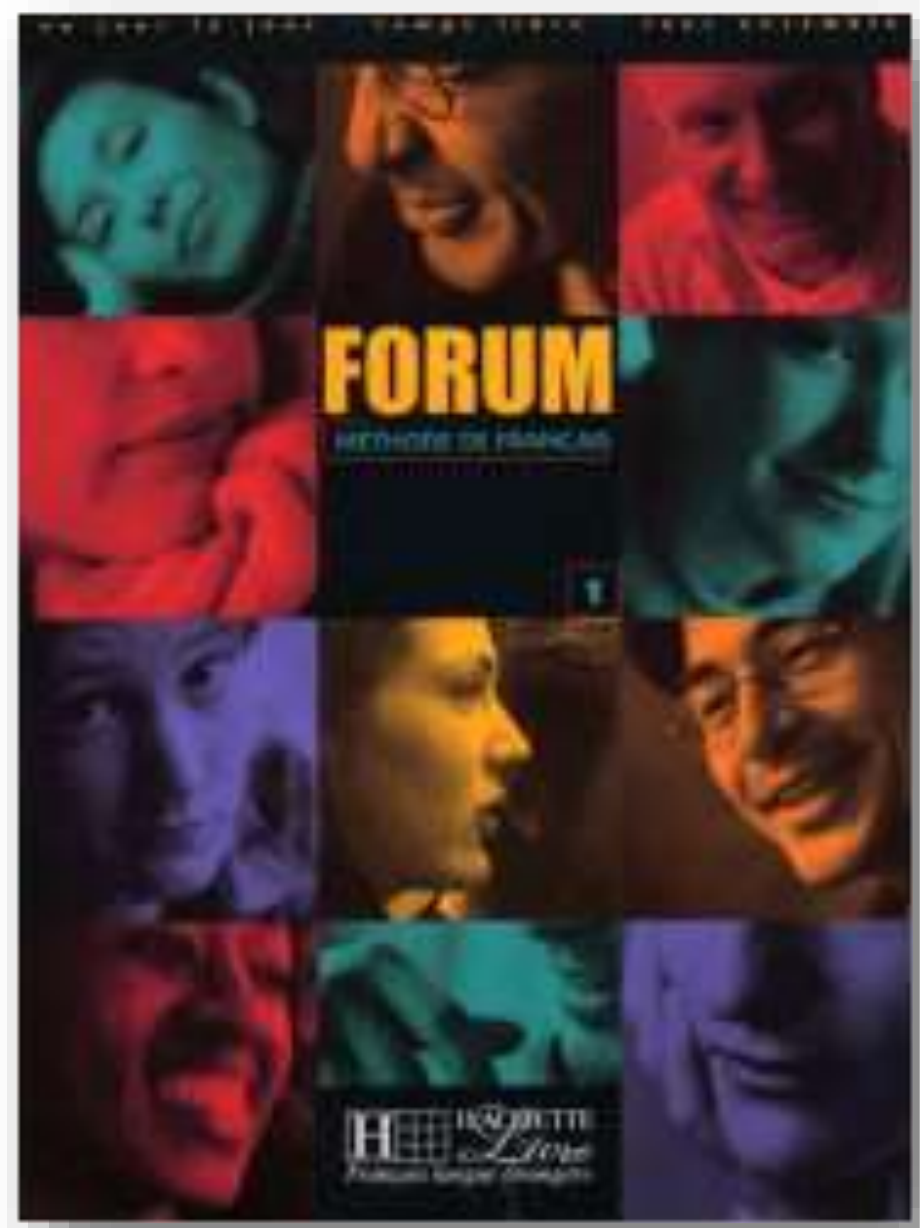


Existe outro aspecto importante da capa que parece indicar uma tendência a partir de então: a utilização de fotos de pessoas em capas de livros didáticos de FLE. Essa opção tem sido adotada desde então por diferentes editoras, como podemos notar nos exemplos da figura a seguir (Figura 66).

A diversidade étnica tem sido respeitada nessas capas, mas o mesmo não se pode dizer quanto às faixas etárias representadas, já que elas são exclusivamente jovens. A exceção fica por conta justamente de Forum 1 que propõe a foto de uma pessoa com mais de 40 anos, o que não tem sido repetido em publicações mais recentes.

Figura 66 | Capas dos livros Alter Ego, Écho, Saison

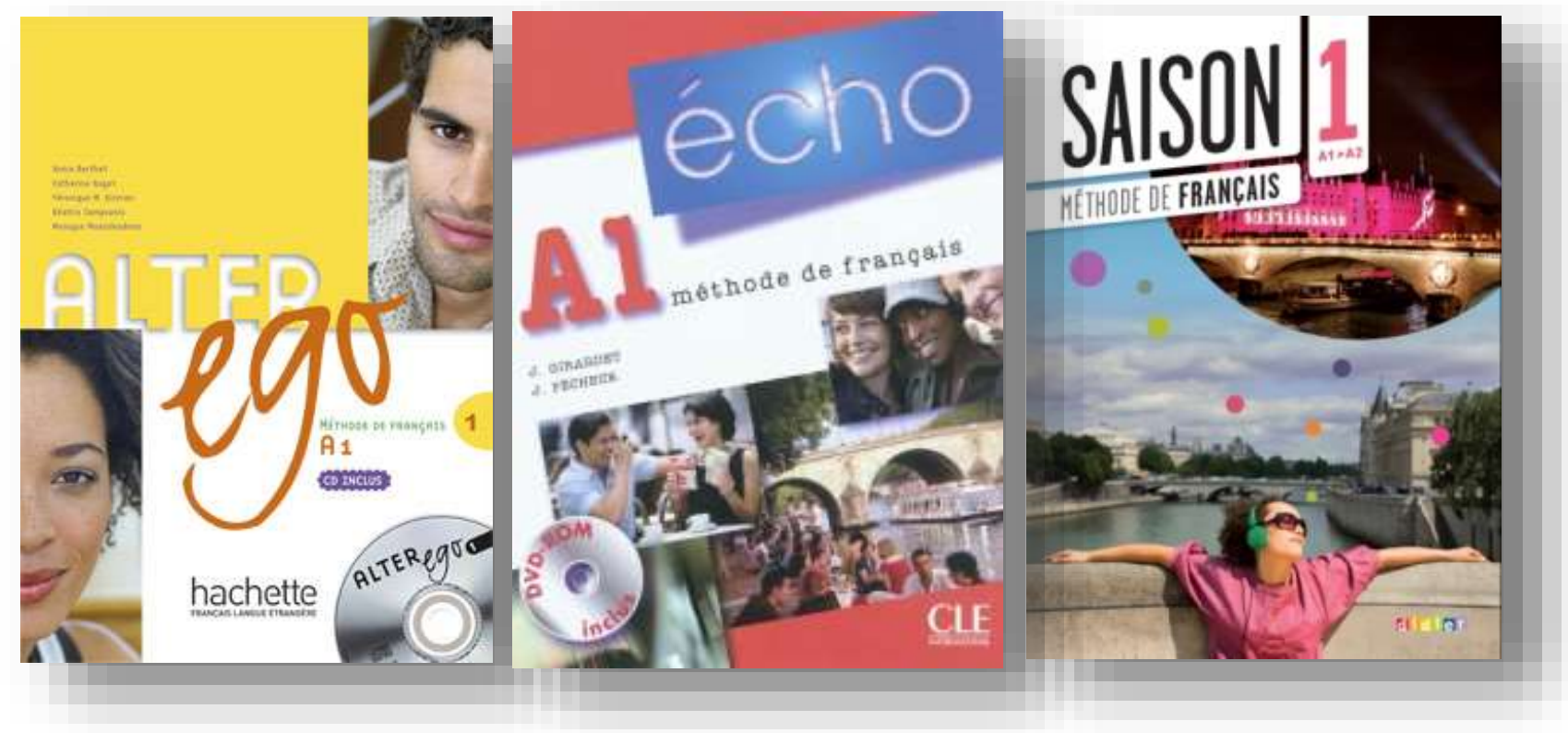

\subsubsection{Análise quantitativa das imagens no livro do aluno Forum 1}

As páginas do livro didático Forum 1 são bastante coloridas e amplamente ilustradas. Os tipos de imagens são bem diversos: fotos, desenhos, reproduções de gêneros textuais bem variados como cartazes de filmes, mapas de cidades ou de países, receitas de cozinha, cartões de visita, páginas de sites da Internet, menus de restaurante, bilhetes de trem, calendários, agendas, anúncios de emprego, anúncios publicitários, pictogramas... Em alguns casos, trata-se de documentos autênticos. O manual traz também ilustrações e desenhos fabricados, concebidos, sobretudo, para acompanhar as situações de comunicação apresentadas no livro. 
Das 180 páginas que compõem as nove unidades do livro (excluindo-se os anexos), apenas 13 são constituídas apenas por texto escrito, sem o uso da imagem. 0 que significa que $93 \%$ das páginas do livro Forum 1 são ilustradas.

As cores exercem um papel importante na estrutura do livro do aluno, uma vez que cada uma das nove lições é caracterizada por uma cor diferente. Dentro dessa unidade, os elementos gráficos, o fundo das páginas e os títulos das diferentes rubricas são apresentados nessa mesma cor. Além disso, as páginas pares do livro apresentam em sua borda exterior uma faixa vertical na cor de referência da unidade o que possibilita um acesso visual às mesmas, já que essas faixas criam bordas coloridas no próprio livro.

Figura 67 | Forum 1 - Pág.28

Cor de referência: laranja

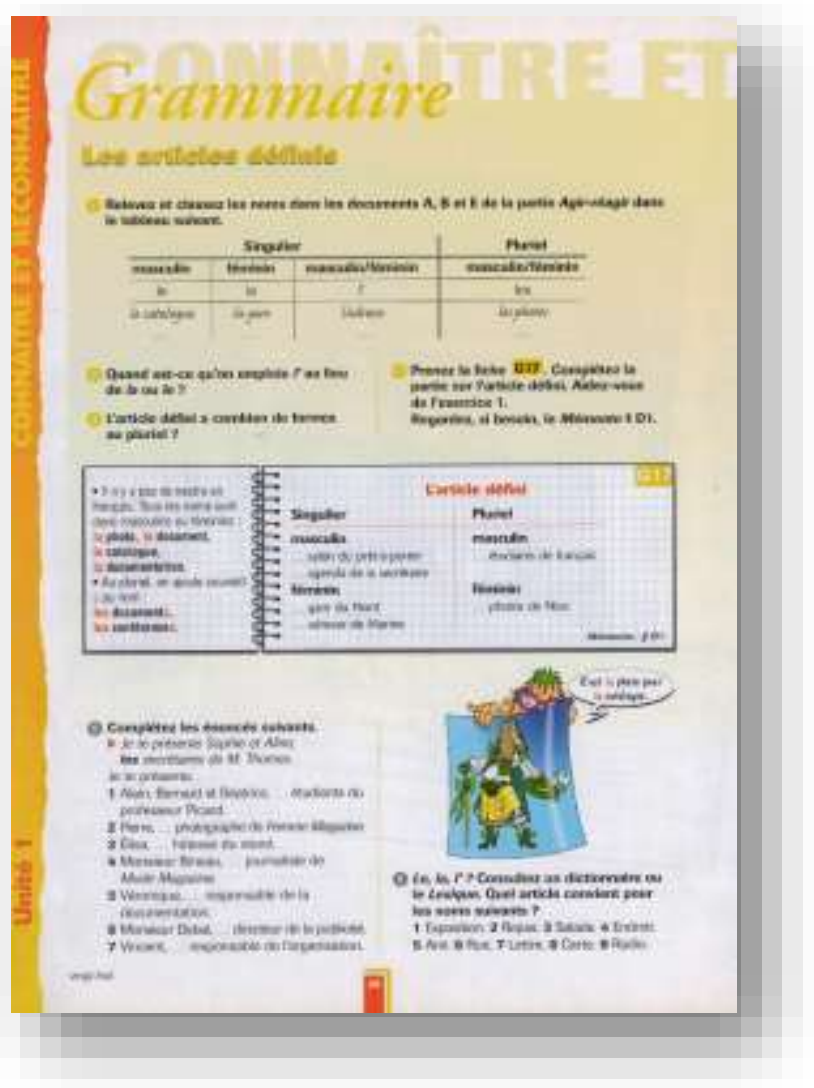

Figura 68 | Forum 1 - Pág.86

Cor de referência: azul

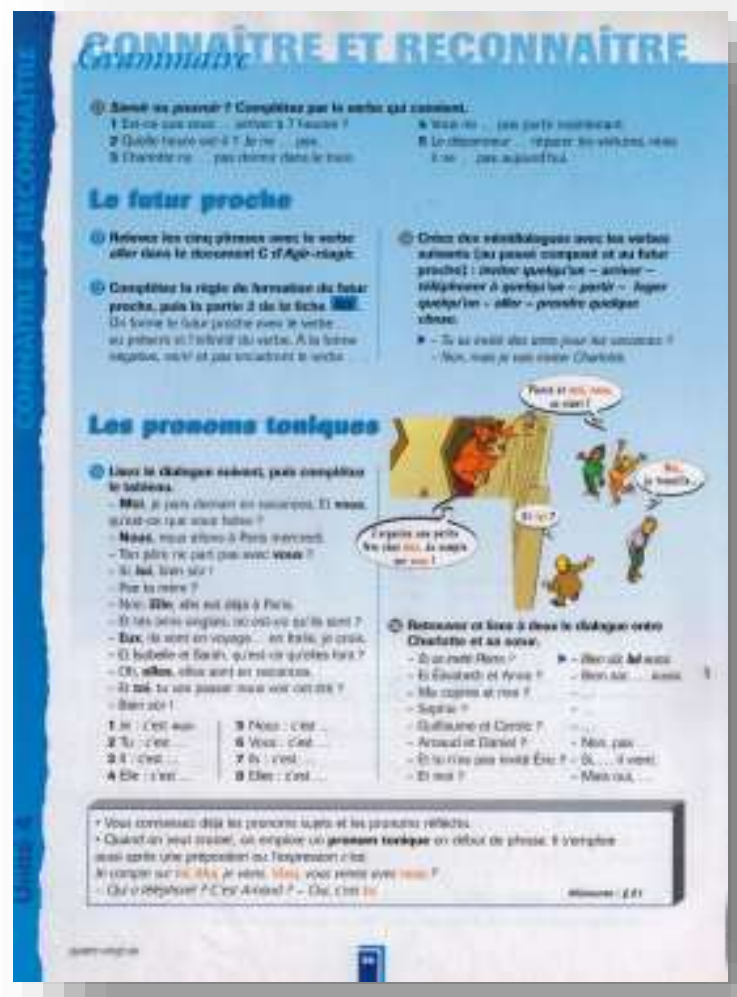


Figura 69| Forum 1 - Pág.140

Cor de referência: verde

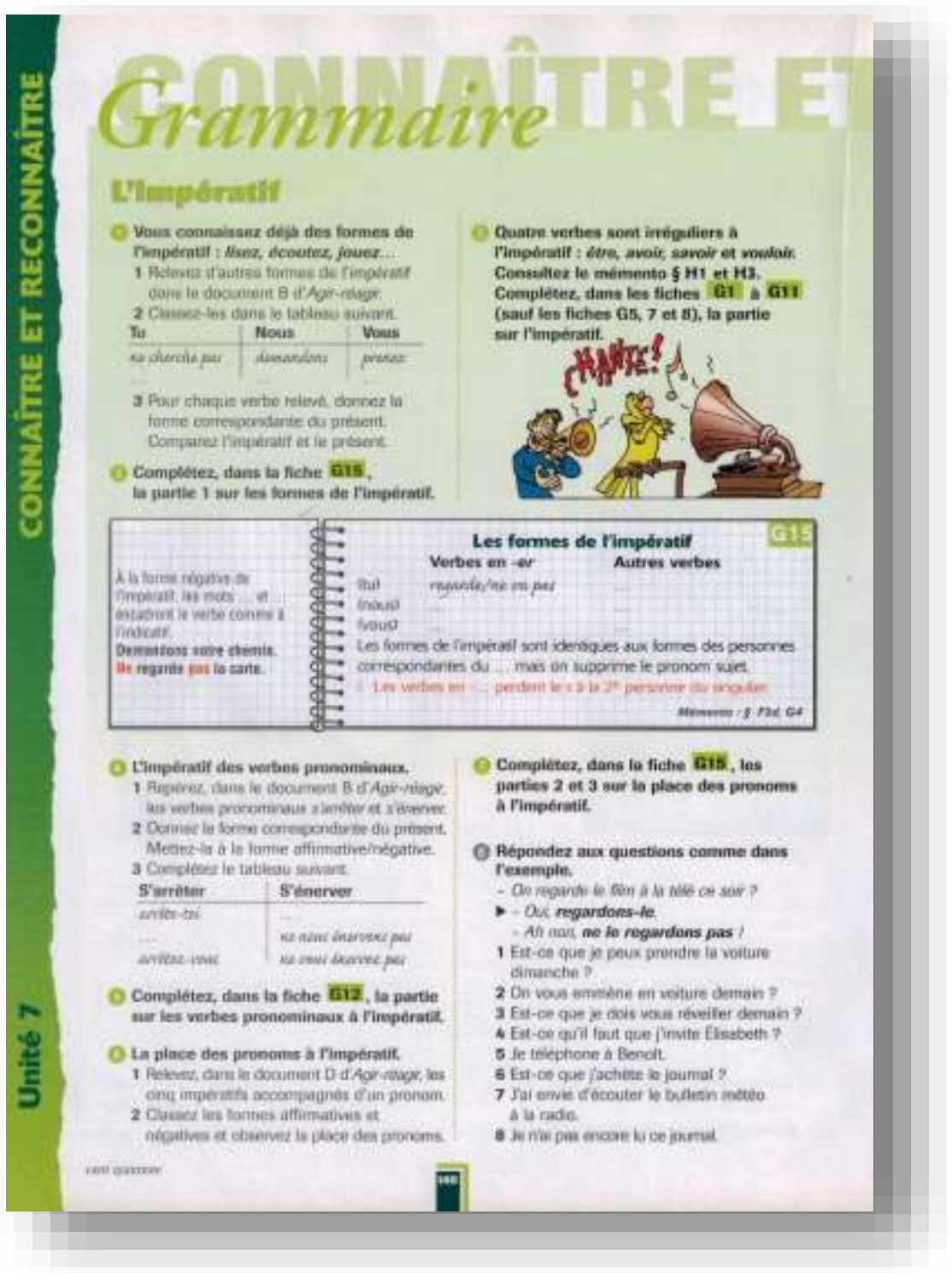

Essa utilização referencial das cores tem sido adotada com frequência nas publicações mais recentes em FLE. Alguns LDs optam por associar uma cor a cada objetivo linguístico ou atividade de linguagem. É o caso, por exemplo, do livro didático Saison 1 (COCTON, 2014) publicado pela editora Didier, que segue o seguinte código de cores (Figura 70) em todos os suportes (impressos ou digitais):

- $\quad$ Léxico = azul;

- Fonética = verde;

- Gramática = laranja. 
Figura 70 | Saison 1 - Pág.100, 101

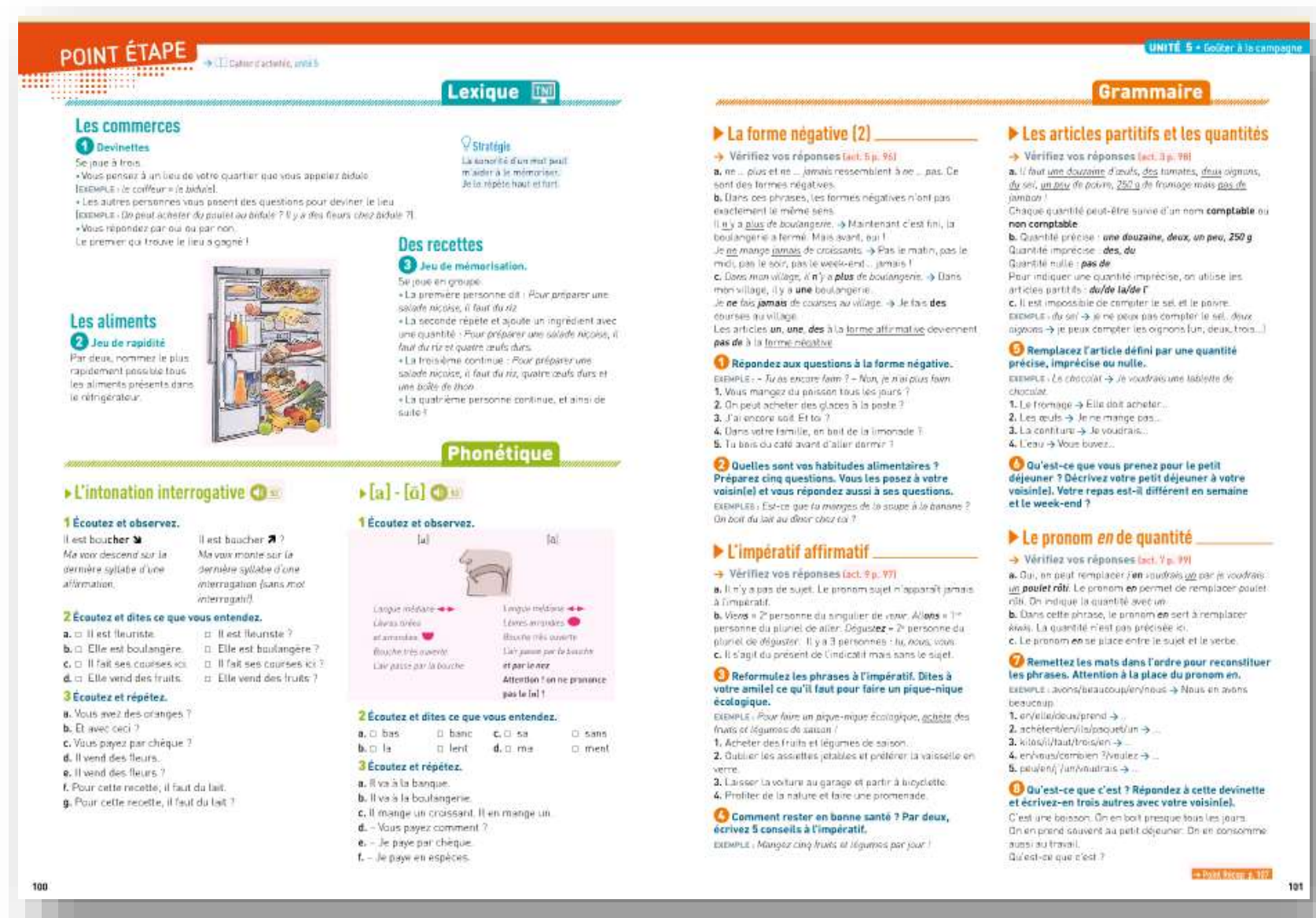

3.4.3. Análise qualitativa e funcional das imagens

\section{Análise da utilização das imagens no livro do aluno e das respectivas orientações no guia pedagógico.}

Analisamos agora alguns textos multimodais presentes em Forum 1 e buscamos nos enunciados das atividades e no guia pedagógico pistas para definir a função pedagógica da imagem nas sequências didáticas.

De acordo com o guia pedagógico (pág.7), cada unidade do livro didático Forum 1 possui um percurso fundamental de aprendizagem e um perfil de aprofundamento, como vemos a seguir. 


\section{Percurso fundamental de aprendizagem}

- Contrat d'apprentissage : uma página de apresentação dos objetivos comunicativos, linguísticos e culturais da unidade. Curiosamente, trata-se do único tipo de página que não recorre ao uso da imagem;

- Forum : duas páginas com uma grande foto situacional à esquerda e pequenos diálogos ligados às situações de comunicação desse contexto;

- Agir-Réagir : quatro páginas com diálogos e documentos que apresentam, de forma contextualizada, elementos de gramática e vocabulário que serão sistematizados nas páginas seguintes. Um mesmo grupo de personagens são os protagonistas de uma história apresentada ao longo de três unidades (o equivalente a um módulo do livro do aluno);

- Connaître et reconnaître : três páginas para um reconhecimento, sistematização e reemprego de conteúdos gramaticais e lexicais;

- S'exprimer : quatro páginas com objetivos variados - fonética, ferramentas para a produção oral e escrita.

\section{Percurso de aprofundamento (Pour aller plus loin...)}

- Pause-jeux : uma página com jogos e atividades lúdicas;

- Interculturel : uma página dedicada à interculturalidade - termo que substitui, com vantagens, a antiga nomenclatura "civilisation";

- Point-DELF: atividades de preparação a esses exames.

Nas primeiras páginas do guia pedagógico, há um texto de apresentação geral de cada uma dessas etapas que compõem o percurso de aprendizagem das unidades do livro do aluno. Mesmo se praticamente todas essas etapas são sempre compostas por imagens (única exceção: contrat d'apprentissage), elas são pouco comentadas nesse texto de apresentação do guia do professor. Dentre as oito etapas do percurso evocadas acima (Contrat d'apprentissage, Forum, Agir-réagir, Connaître et reconnaître, S'exprimer, Pause-jeux, Interculturel, Point-DELF), é na parte Forum que o guia mais se refere ao uso das imagens: 
Le Forum est une mise en train pour démarrer l'unité. Il est composé :

- d'une grande photo fonctionnelle qui suggère le cadre général de l'unité ;

- de petits documents écrits et de quatre ou cinq minidialogues enregistrés, à caractère authentique, qui sont extraits de scènes situées dans le cadre de la grande photo. Les mini-dialogues sont souvent des formes stéréotypées d'échanges rituels (brèves salutations, interactions dans la vie courante, etc.);

- d'un appareil d'exploitation pédagogique léger pour aborder les documents (photos et minidialogues);

- d'un exercice de compréhension orale d'un dialogue non reproduit, s'appuyant sur un dessin.

Le Forum présente, sur le vif, une vue d'ensemble d'une « macrosituation de communication » sur laquelle on a représenté de manière réaliste un espace où les gens parlent entre eux. Grâce aux connaissances acquises dans les unités précédentes, les apprenants peuvent « faire parler des personnages », décrire la scène et se poser des questions.

De cette "scène vécue " (qui correspond à une situation courante dans laquelle pourrait se trouver toute personne en France) sont extraits quatre ou cinq mini-dialogues, enregistrés, où l'on trouve déjà certaines nouveautés linguistiques.

Ce sont de simples échanges " anonymes ", ce qui explique que les dessins soient très stylisés. Ces échanges contiennent des expressions figées du français, des répliques stéréotypées, que l'on pourra facilement retenir et réutiliser telles quelles.

Forum 1. Guia pedagógico (CAMPÀ, MESTREIT, MURILLO, TOST, $2000: 10$ ).

Analisamos, a seguir, um exemplo de dupla página dessa parte Forum (Figura 71). Trata-se de uma página bastante atrativa do ponto de vista visual, com cores fortes e um espaço importante dedicado à imagem. À esquerda, uma grande foto de uma cena do cotidiano acompanhada de uma descrição específica do local representado e de perguntas que convidam o aluno a se expressar utilizando frases aprendidas na unidade anterior: Observe a foto. É o Salão do prêt-à-porter. Faça os personagens se comunicarem utilizando as seguintes expressões $[. . .]^{31}$

\footnotetext{
${ }^{31}$ Tradução nossa. No original: Regardez la photo. C'est le Salon du prêt-à-porter. Faites parler les
} personnes. Aidez-vous des expressions suivantes [...]. 


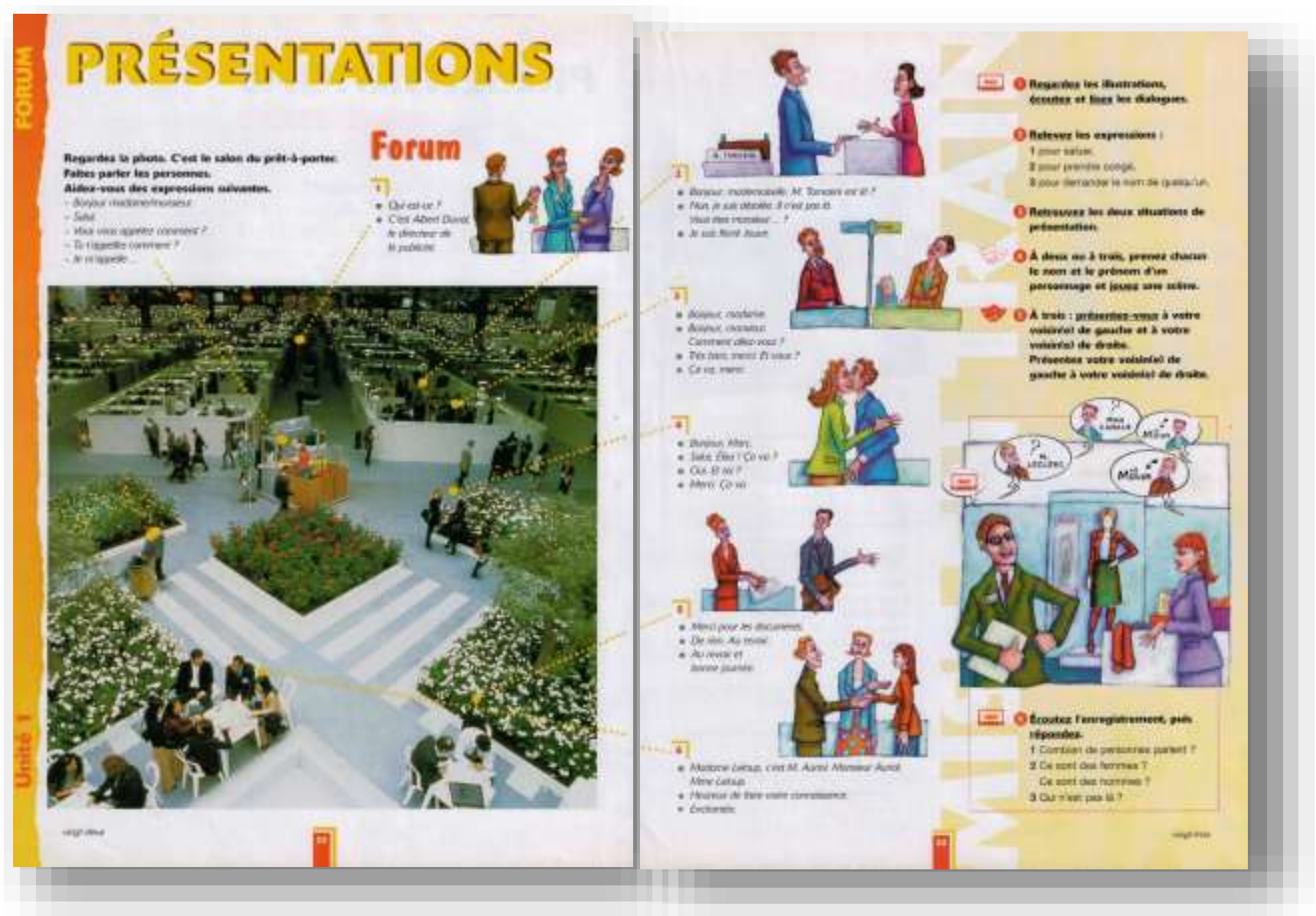

A proposta pedagógica parte, portanto, de uma grande foto situacional na qual os alunos trabalharão elementos e enunciados já conhecidos. Flechas saindo dessa grande imagem levam, em seguida, a mini diálogos com suas respectivas transcrições e acompanhados, cada um, por uma pequena ilustração. Esta também é situacional, como a foto maior, mas ilustra situações de comunicação mais detalhadas e precisas, daí a ideia de uma aproximação, de um “zoom” sobre diferentes pontos captados na grande foto.

Passamos do conhecido ao desconhecido, do ponto mais abrangente ao mais detalhado, o que facilita a aquisição de novos elementos linguísticos e culturais. Ao analisarmos essa dupla página servindo-nos das teorias de Kress e van Leeuwen (2006), vemos que se trata de um rico texto multimodal, composto por diferentes tipos de imagem (foto, desenho e elementos gráficos), por textos (com títulos e sub-títulos 
coloridos) e por ícones como as fitas cassette que remetem a outro suporte que integra a página: os documentos sonoros.

No que diz respeito ao enquadramento, notamos que os diferentes elementos da dupla página (foto, textos, desenhos, flechas, ícones) estão integrados do ponto de vista composicional em uma sequência única, com o apoio da unidade de cor, o amarelo alaranjado. É interessante notar como as flechas que saem da grande foto em direção aos diálogos e ilustrações reforçam a inter-relação de todos esses componentes, resultando no todo significativo.

Dentro da metafunção composicional definida por Kress e van Leeuwen (2006), sabemos que o valor da informação é medido através da disposição no espaço dos elementos de um texto multimodal. As polaridades esquerda/direita contem, respectivamente, a informação dada (já conhecida) e a informação nova, inaugural (que o espectador não conhecia). Passamos do conhecido (grande foto e sugestões de enunciados de unidades anteriores) ao desconhecido (pequenos diálogos com novos pontos linguísticos), do ponto mais abrangente ao mais detalhado, o que facilita a aquisição de novos elementos linguísticos e culturais.

Essa mesma estrutura - e essas mesmas qualidades - são encontradas nas outras partes do livro intituladas Forum, que abrem cada uma das nove lições do LD, como podemos observar neste outro exemplo a seguir (Figura 72). 


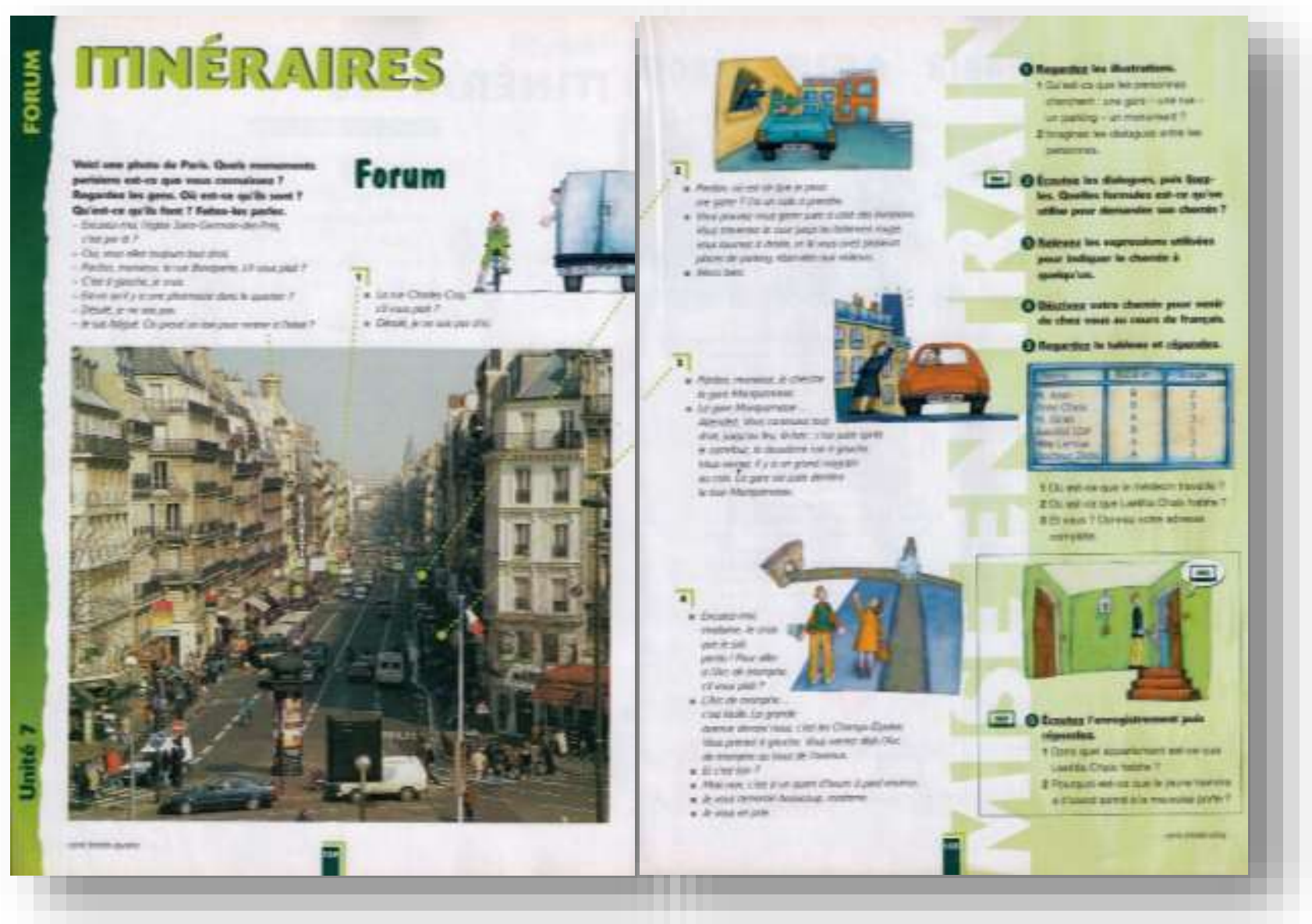

Encontramos novamente uma grande foto situacional à esquerda, com questões que fazem a transição entre a esta lição e a lição anterior. Da grande foto, flechas direcionam a pequenos diálogos, acompanhados por desenhos situacionais. Passamos novamente do mais conhecido (esquerda) ao menos conhecido (direita), terminando a lição por um diálogo sem a transcrição e também acompanhado por um desenho. Essa opção se repete em praticamente todas as duplas páginas Forum. Mais uma vez, observamos nessa dupla página multimodal a função unificadora da cor, verde desta vez, e dos elementos gráficos que unem a grande foto aos diálogos e desenhos.

Após essa dupla página Forum, encontramos em todas as lições quatro páginas Agir-Réagir. Elas são compostas geralmente por quatro diálogos e cada um deles encontra-se acompanhado de uma imagem situacional. É interessante notar como imagem, diálogo e texto escrito (transcrição do documento sonoro) compõem harmoniosamente a mensagem multimodal. Não podemos dizer que a imagem seja mais importante que o texto ou vice-versa, mas sim, que todos interagem na composição da 
mensagem multimodal. Para isso, o método utiliza, por vezes, além da ilustração situacional, uma foto de um documento autêntico ou realista, isto é, com grande semelhança a um documento autêntico. Esse documento suplementar contribui para a construção do sentido, como podemos ver nos exemplos abaixo (Fig. 73, 74).

Figura 73 | Forum 1 - Pág.25

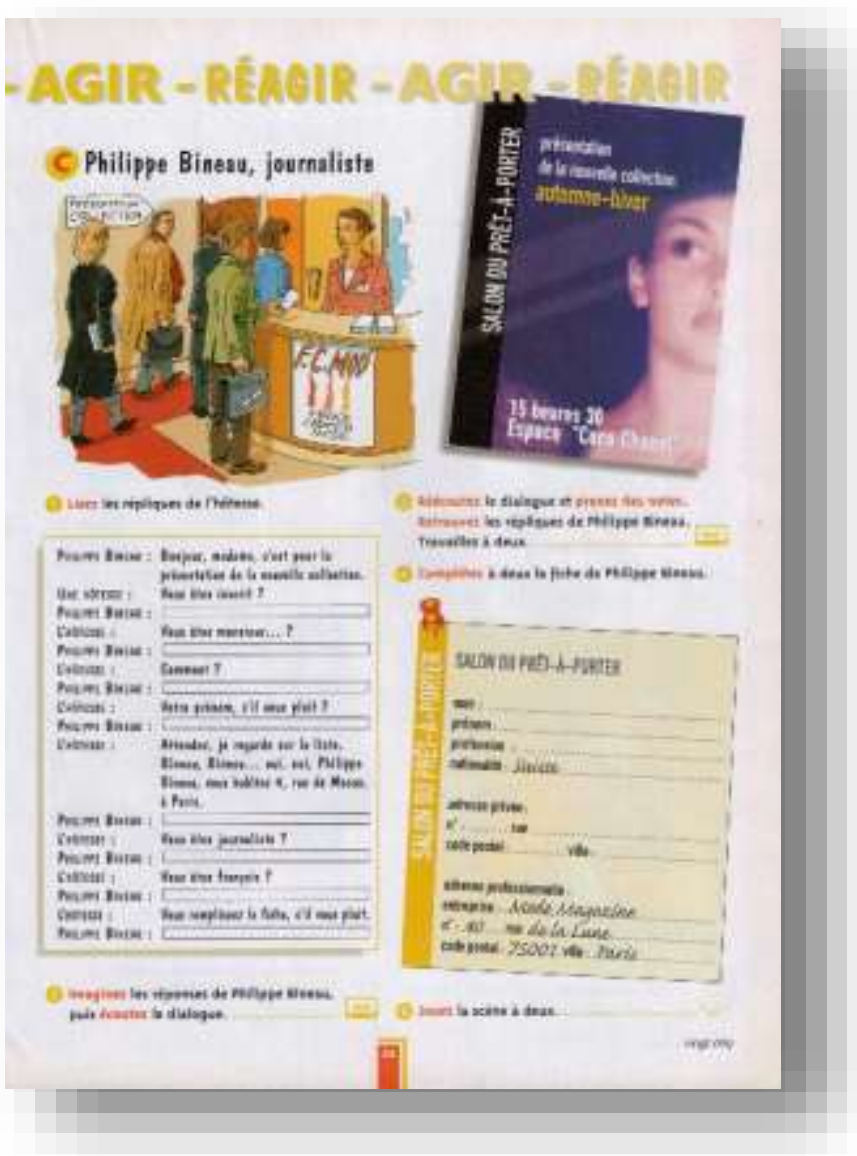

Figura 74 | Forum 1 - Pág.137

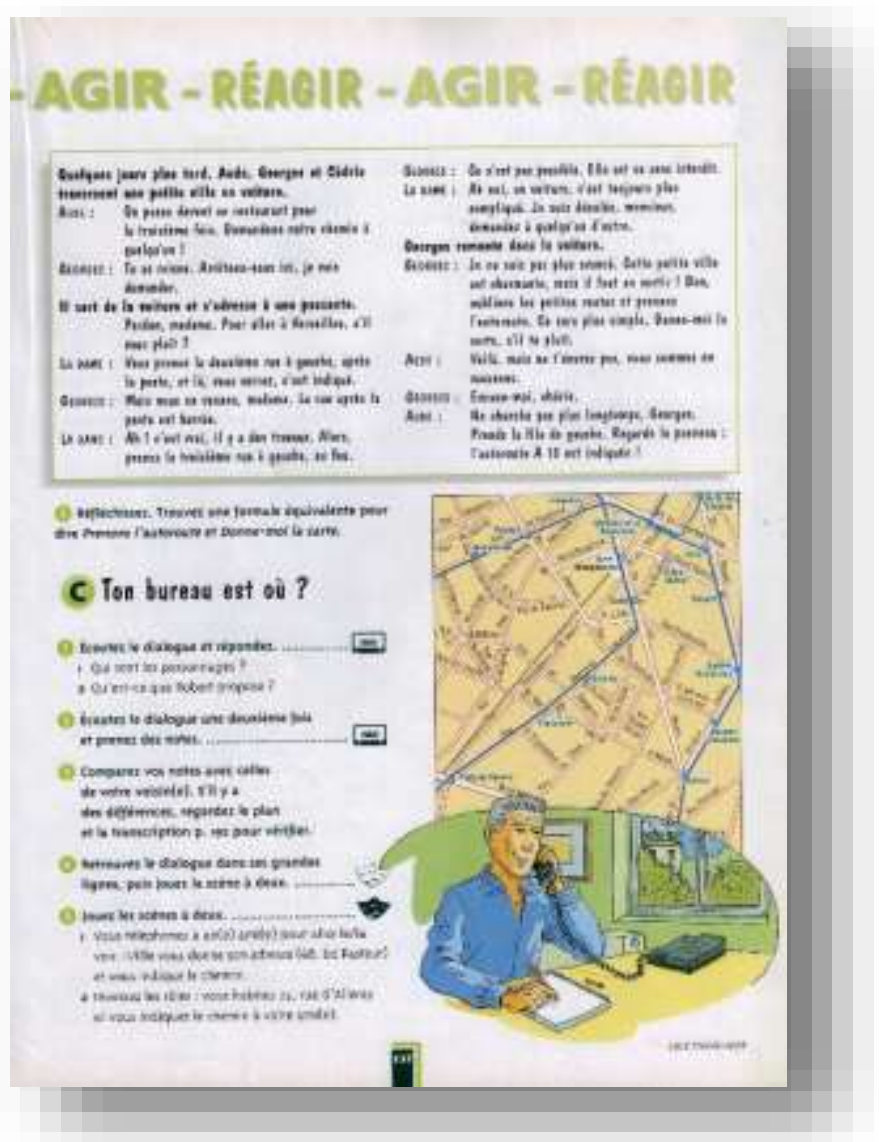

Passamos agora a uma segunda parte da estrutura da lição, intitulada S'exprimer e composta por quatro itens: Vocabulaire, Phonétique, Production orale, Production écrite. Todas elas são geralmente ilustradas, mas o item que mereceu uma menção ao uso da imagem no texto geral de apresentação do guia pedagógico foi apenas a Production orale :

La rubrique Production orale s'appui d'une part sur des dessins ou documents qui donnent le cadre de la situation, d'autre part sur des 'Outils', qui présentent les expressions les plus usuelles pour la réalisation des actes de parole étudiés.

Forum 1. Guia pedagógico (CAMPÀ, MESTREIT, MURILLO, TOST, 2000 ; 10). 
Apesar de o espaço físico dedicado às imagens nessa página de produção oral ser geralmente reduzido, elas podem representar o instrumento principal para a realização de uma atividade, como vemos no exemplo a seguir (Figura 75). Neste caso, o aluno deve comparar as vestimentas dos dois personagens ilustrados no desenho utilizando, para isso, o léxico correspondente e a expressão de comparação.

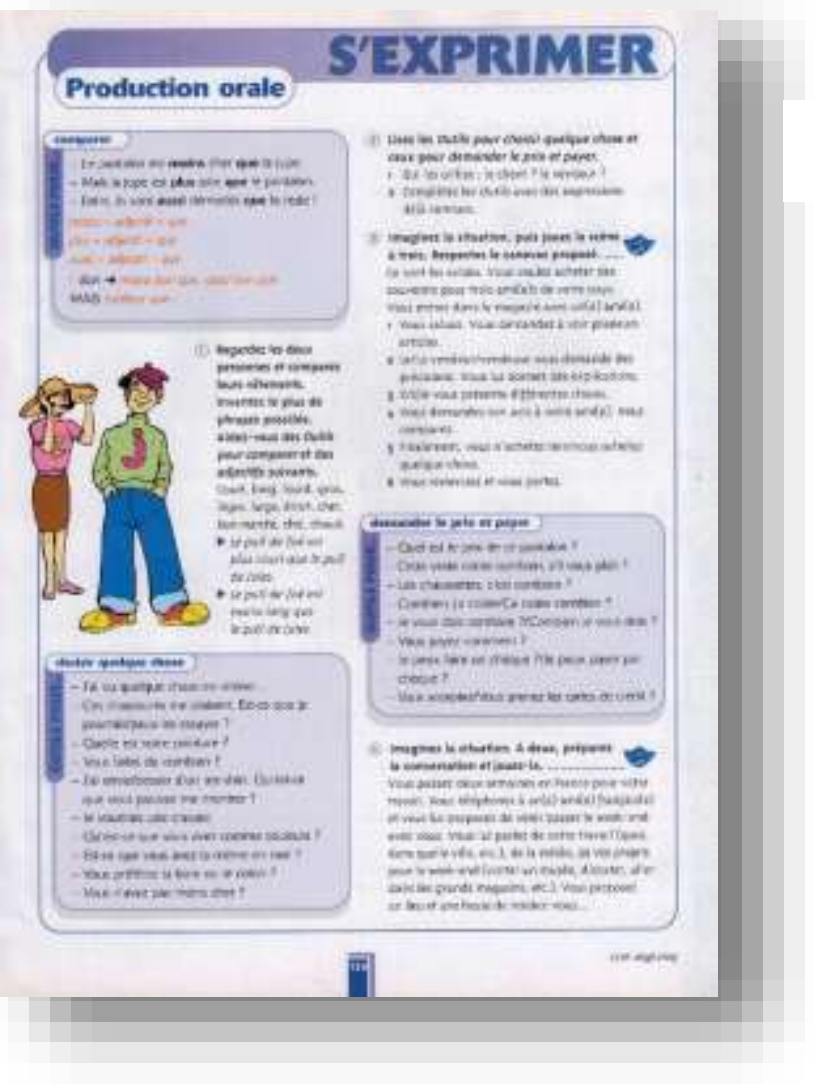

Em outros casos, no entanto, não há atividades baseadas nas imagens e estas ocupam um papel meramente ilustrativo (Figura 76).
Figura 75 | Forum 1 - Pág.125

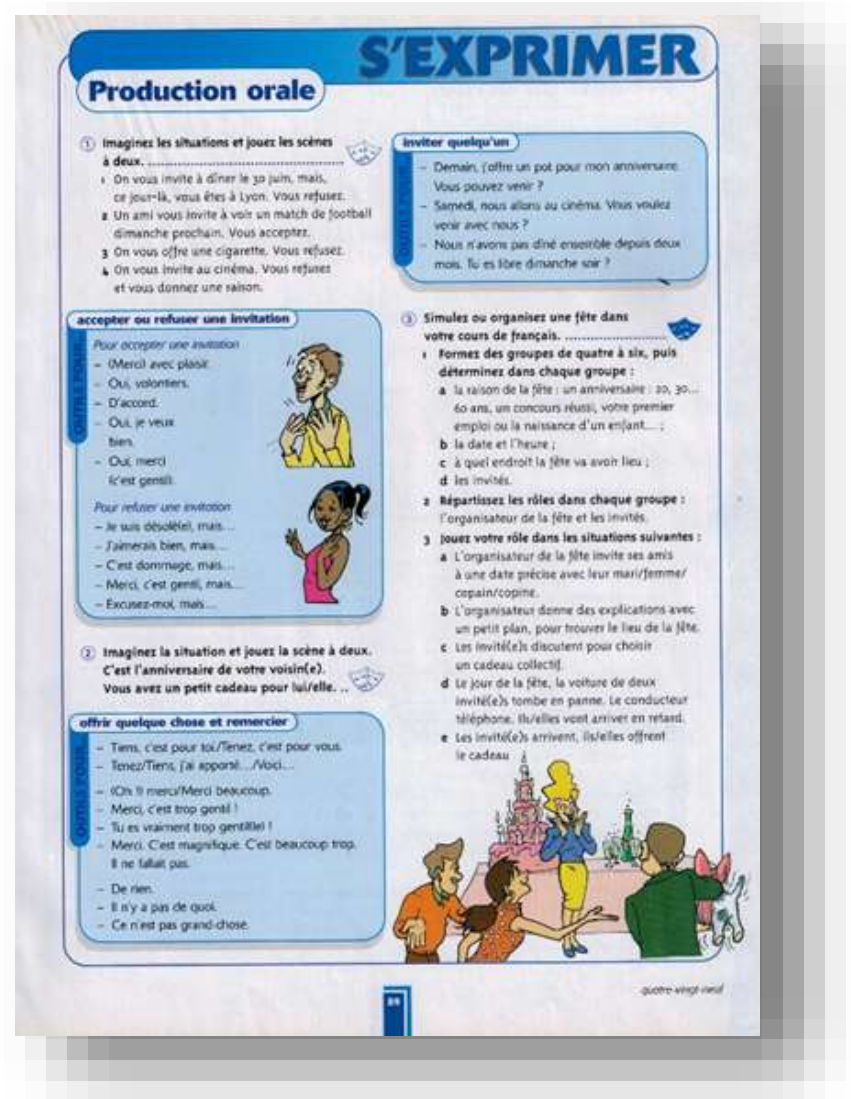


No que diz respeito às páginas dedicadas à produção escrita, é interessante notar que elas fazem quase sempre referência a um gênero textual da vida real: cartão de visita, e-mail, formulário de encomenda de um produto, receita de cozinha, convite (Figuras 77, 78). Muitas vezes, há uma foto representativa desse gênero textual. É interessante notar que essa imagem constitui um exemplo representativo não somente de um conteúdo típico desse gênero, mas também de sua forma. Acreditamos que essa representação do gênero textual pela imagem levará os alunos a realizarem produções escritas mais ricas e mais próximas das que encontramos na vida real.

Figura 77 | Forum 1 - Pág.34

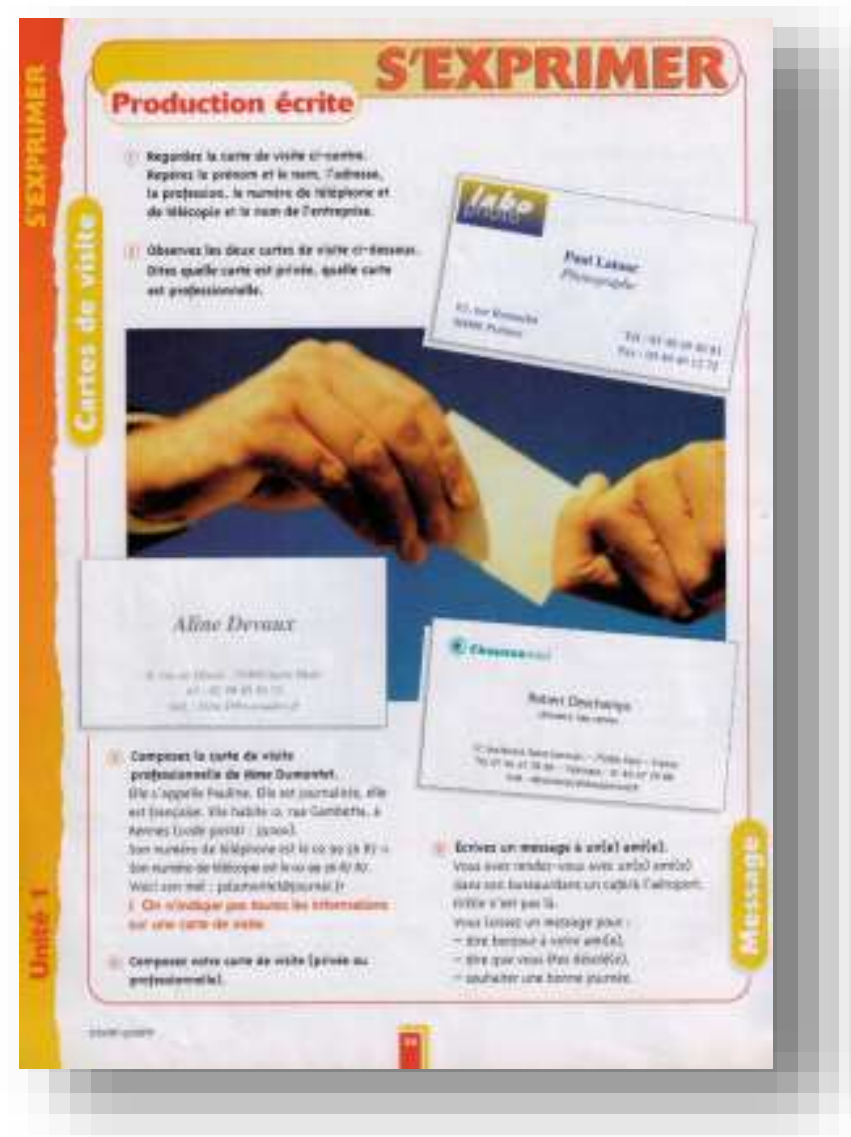

Figura 78 | Forum 1 - Pág.90

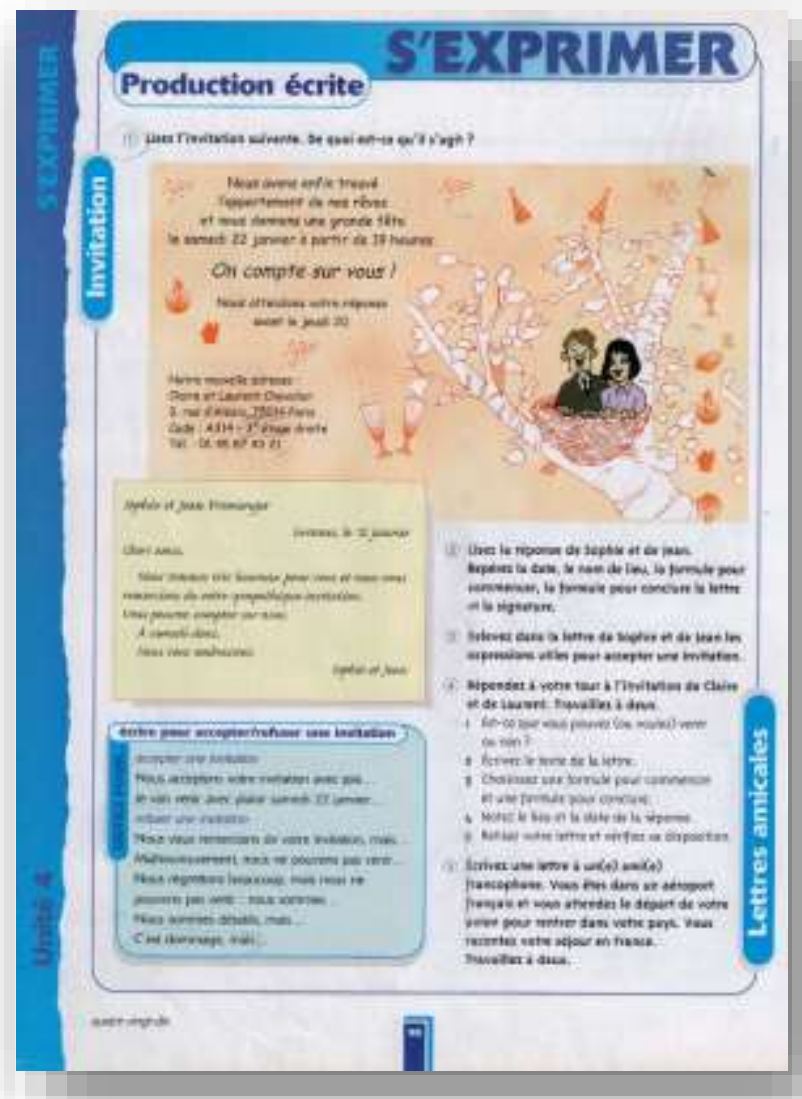

Ao analisarmos as páginas de Forum 1 dedicadas ao vocabulário, vemos que elas são quase sempre ilustradas. A função mais comum dessas imagens é a de representar pelo signo visual o vocabulário temático da lição. Frequentemente, as ilustrações - ou detalhes das mesmas - são associadas às palavras correspondentes por meio de flechas. 
(Figuras 79, 80). Trata-se de um procedimento já empregado por Comenius em seu livro Orbis sensualium pictus e que vimos no LD analisado anteriormente.

Figura 79 | Forum 1 - Pág.88

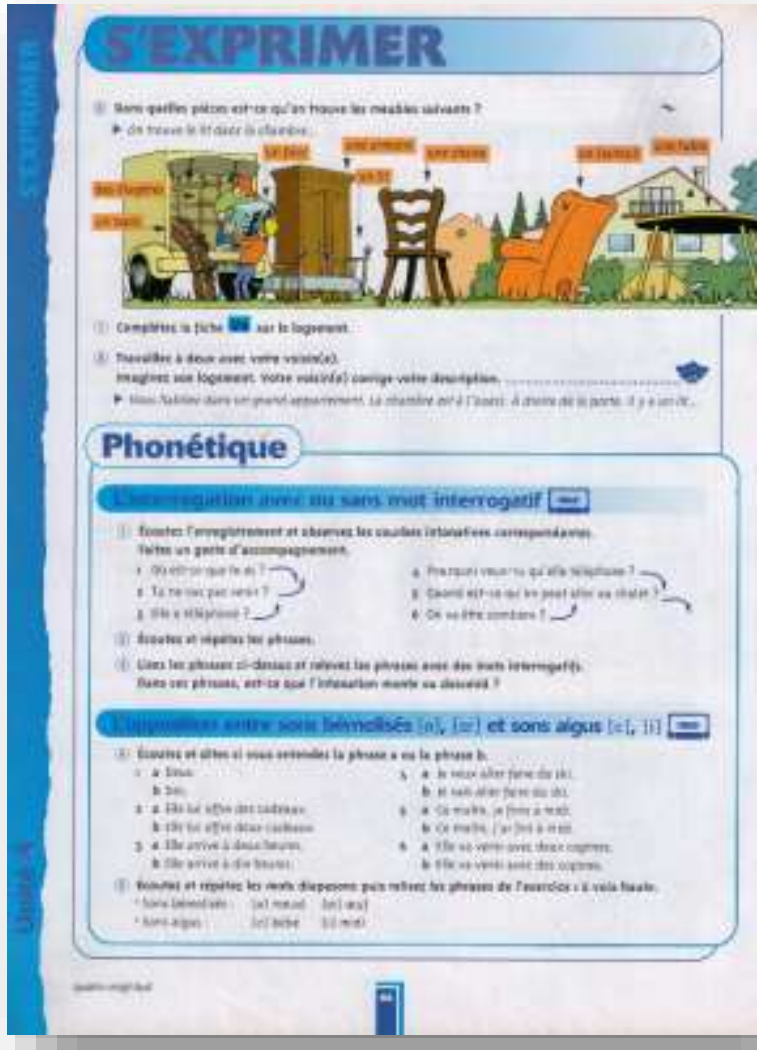

Figura 80 | Forum 1 - Pág.123

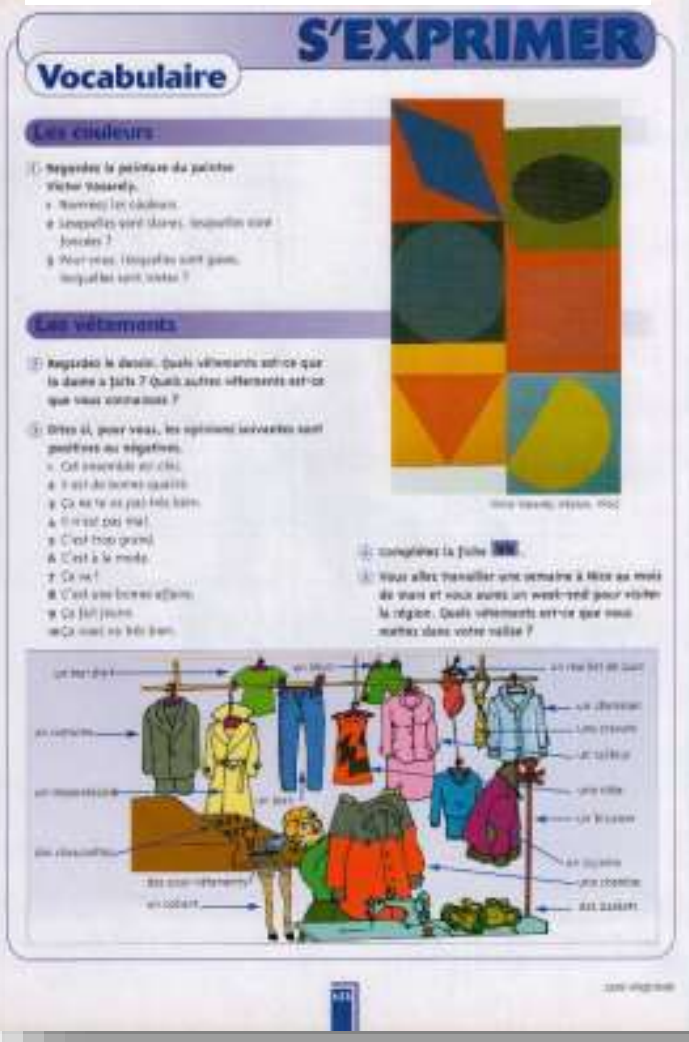

Em certas páginas de vocabulário, porém, as imagens exercem um papel de introdução ao léxico e não de representação explícita do mesmo. Podemos ver um exemplo desse uso na página 31 do livro do aluno na qual são trabalhados os temas da nacionalidade, das profissões e suas respectivas declinações de gênero - masculino / feminino (Figura 79).

Nessa página, o uso das imagens referentes às profissões é preconizado da seguinte forma no guia pedagógico:

Objectifs : familiarisation avec les formes des noms masculins et féminins.

Partir des illustrations, pour motiver visuellement la notion de genre.

(Guia pedagógico, pág. 34 - grifo nosso) 
Figura 81 | Forum 1 - Pág.31

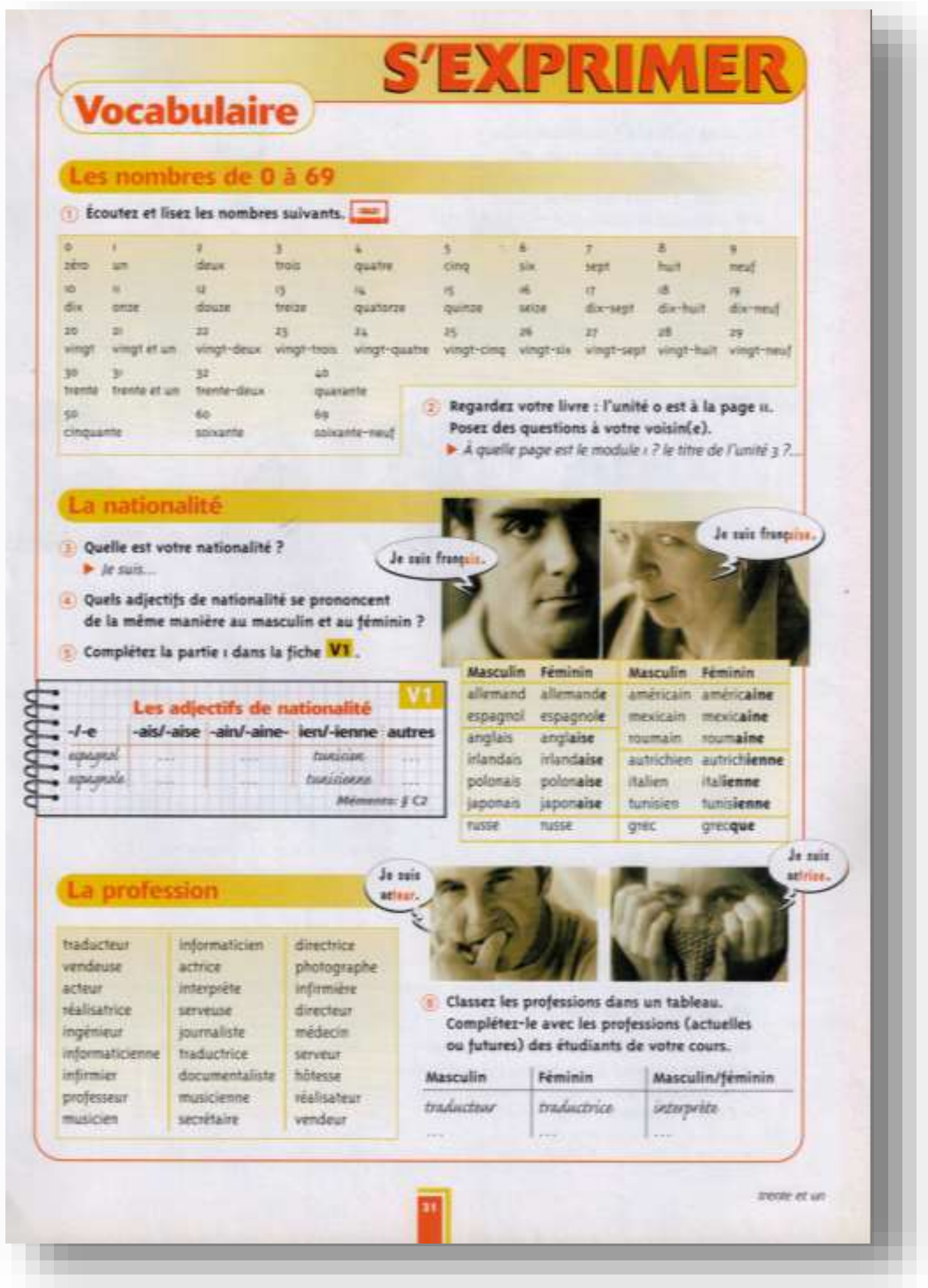

A função de motivar visualmente o aluno, apesar de frequente nesse e em outros livros didáticos, é raramente explicitada nos guias do professor. Quando a orientação não está presente, cabe ao professor incluir, às vezes de forma intuitiva, esse trabalho preliminar de motivação e sensibilização por meio da imagem. 


\subsubsection{Preconizações do guia pedagógico para o uso da imagem}

Analisamos agora o guia pedagógico de Forum 1, buscando em seu texto referências às imagens presentes no livro do aluno. Para isso, retomamos a seguir alguns trechos do guia em que palavras como illustrations, images, dessins são citadas.

- Referências à página 11 do livro do aluno:

Photos et dessins. Images d'un casting, situation de présentation par excellence.

Objectif : compréhension globale de la situation, association du message audio/écrit à l'illustration.

Guia pedagógico, pág. 22.

- Referências às páginas 22/23 do livro do aluno (Figura 82):

Photo : la photo est un déclencheur. C'est une vue générale du Salon du prêt-à-porter. La photo montre différents groupes de personnes, dans des situations de communications diverses. Des extraits discontinus relient les situations à des illustrations et à des minidialogues.

Dessins : ils reprennent, en les grandissant, des situations de communication de la vue panoramique du salon. [...]

Faire l'activité en deux temps : d'abord, observation des illustrations ; ensuite, écoute et lecture simultanée des dialogues. Observer les gestes des personnages. Deviner, grâce aux illustrations, les rapports entre les interlocuteurs (tutoiement ou vouvoiement, distance ou familiarité) et les actes de parole réalisés.

Guia pedagógico, pág. 27.

Figura 82 | Forum 1 - Pág.22, 23

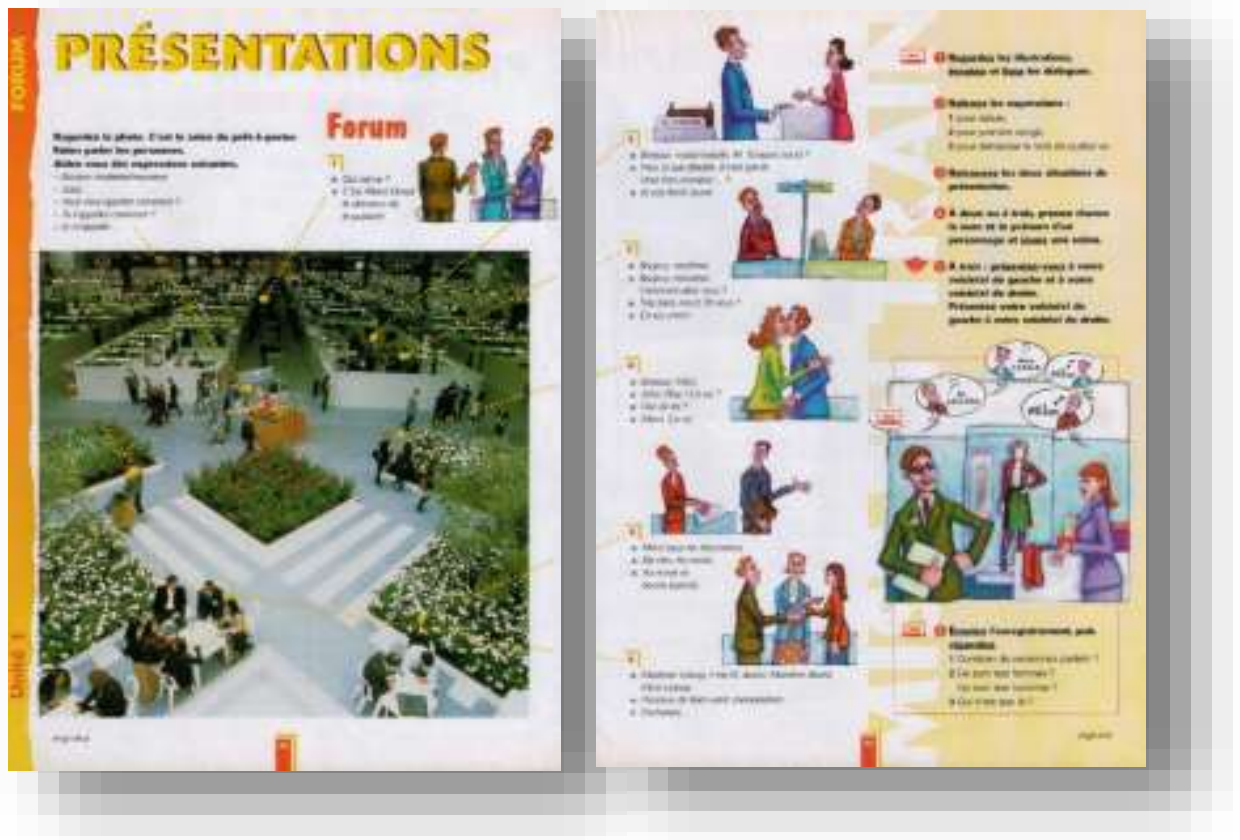


Essas duas passagens são particularmente interessantes pois em ambas propõese um trabalho de associação das mensagens escrita, sonora e visual, ou seja, dos diferentes componentes deste texto multimodal, o que é extremamente positivo a nosso ver, conforme afirmamos anteriormente. No último caso, o componente visual traz elementos para uma análise sociolinguística e sociocultural, como a utilização de uma linguagem mais formal ou informal, a questão da proximidade e familiaridade dos interlocutores.

Em relação ao último desenho da página à direita, que fecha essa dupla página, mais uma vez, o papel da imagem é reforçado como um indicador da situação de comunicação que será abordada no diálogo: "Regarder le dessin. Faire identifier la situation de demande de renseignements". (Guia pedagógico, pág.28. Grifo nosso)

- Referência à página 63 do livro do aluno:

E / Vacances à la Martinique.

Objectif : compréhension orale et écrite. Interprétation d'éléments textuels.

Écoute du dialogue. S'appuyer sur l'illustration pour identifier la situation et comprendre le sens.

(Guia pedagógico, pág.56. Grifo nosso)

Nessa página, assim como em outras dedicadas aos diálogos e à compreensão oral, a imagem aparece como um "apoio" ao texto oral/escrito. Esse termo revela a função secundária da imagem em relação ao texto: ela é usada para facilitar o acesso ao mesmo. Vimos anteriormente que a imagem já foi vista como algo que "distraía” o leitor do que realmente "importa": o texto escrito. No caso da página 56 que vimos acima, a imagem aparece como um elemento facilitador já que ela contribui para o acesso ao sentido. No entanto, o ponto de referência permanece o mesmo: o texto oral/escrito.

No guia pedagógico, esse papel "situacional” das imagens que acompanham os diálogos do livro é reforçado por expressões como: "Observer le dessin. Expliquer la situation” (pág.104) ; “Observer le dessin avant d'écouter le dialogue (cacher celui-ci si nécessaire). » (pág.105); « Observer la photo et les dessins. Imaginer les micro-situations que les énoncés donnés permettent d’amorcer. » (pág.129). 


\subsubsection{Balanço qualitativo e quantitativo}

\section{Balanço qualitativo das preconizações para o uso da imagem em Forum 1 :}

Os termos mais comumente associados à exploração das imagens no guia pedagógico são: “observer" et "décrire". Mais uma vez, a imagem aparece frequentemente como uma antecipação ao trabalho sobre a sequência didática, como podemos notar nesta passagem referente a um diálogo na página 60 do livro do aluno:

\section{B/ On déjeune ensemble?}

Objectif : compréhension orale et écrite. Interprétation du texte. Réemploi des acquis.

Déclencheur « complet » qui répond aux principes de base de la démarche préconisée par la méthode : six étapes (six exercices) précédés de l'observation de l'image-situation : lecture des questions pour faciliter l'écoute (exercice 1), écoute (exercices 2 et 3), question de compréhension globale (exercice 3), lecture de vérification (exercice 4), élucidation d'un point précis (exercice 5), appropriation de l'acte de parole présenté, invitation (exercice 6).

(Guia pedagógico, pág.55. Grifo nosso)

A imagem é trabalhada nesse LD como um apoio à situação de comunicação, como uma facilitadora da mesma. Ela acompanha os diálogos, os textos, mas não ocupa uma importância igual ou maior do que eles, pois está a serviço dos mesmos.

\section{Balanço quantitativo das preconizações para o uso da imagem em Forum 1 :}

- Número de páginas do livro do aluno - excluindo-se os anexos: 180 páginas.

- Número de páginas ilustradas no livro do aluno - excluindo-se os anexos: 167 páginas (93\%).

- Número de páginas para as quais há uma menção ao trabalho sobre a imagem no guia pedagógico: 36 páginas (21,5\%).

Ao compararmos esses dados quantitativos com os dados obtidos nas análises anteriores, chegamos ao seguinte gráfico comparativo (Figura 83). 
Figura 83 | Gráfico - Balanço comparativo Archipel 1 / Espaces 1 / Forum 1

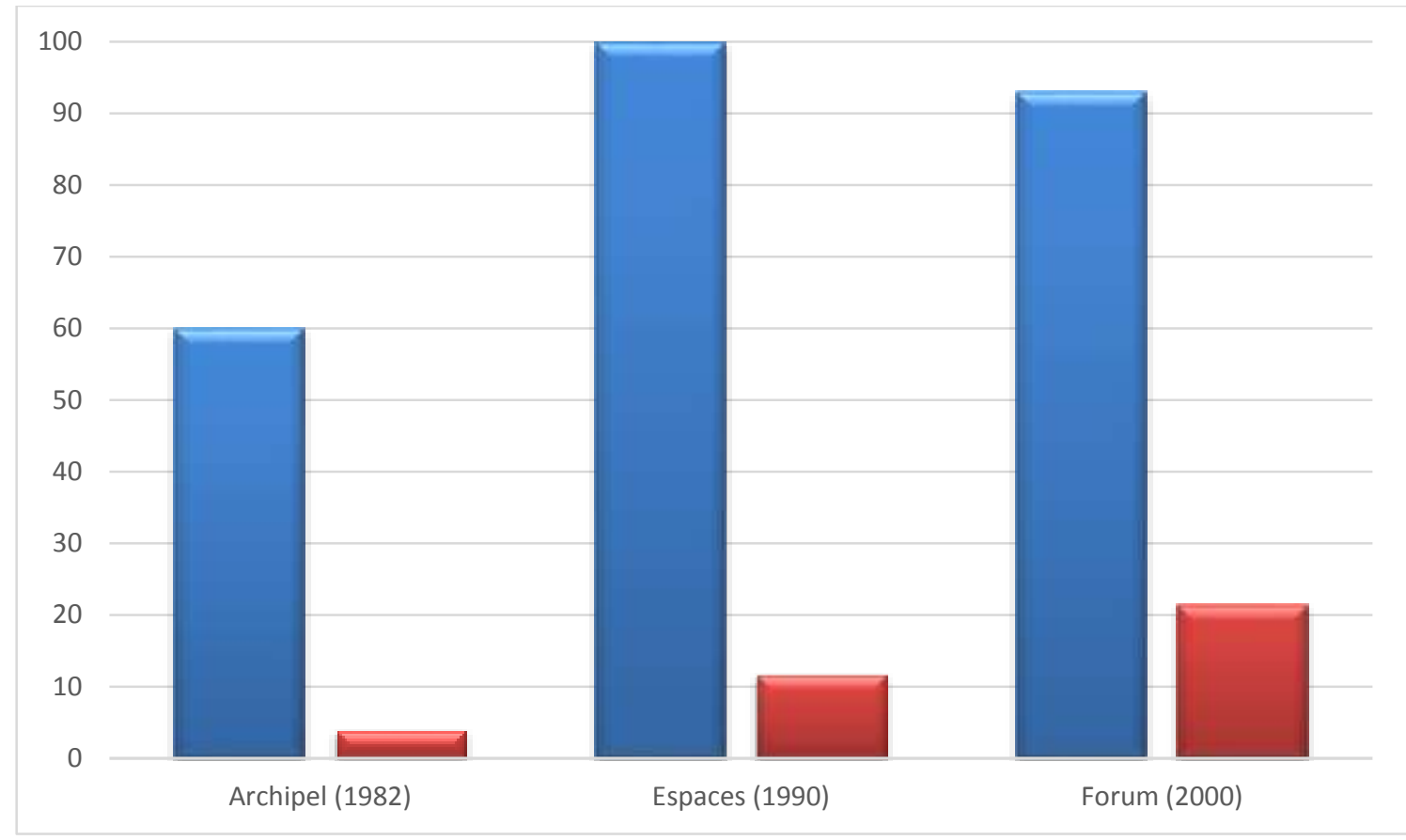

Porcentagem de páginas ilustradas no livro do aluno

Porcentagem de páginas ilustradas comentadas no guia pedagógico

\subsection{Análise $n^{\circ} 4 \mid$ Écho $A 1$}

GIRARDET, Jacky ; PÉCHEUR, Jacques. Paris : CLE International, 2010.

A coleção Écho de livros didáticos de FLE é composta pelos seguintes volumes: Écho A1, Écho A2, Écho B1 - volume 1, Écho B1 - volume 2 e Écho B2. Publicada em 2010 pela editora CLE International, essa coleção destina-se a adultos ou a grandes adolescentes e foi adotada em 2011 pela Aliança Francesa de São Paulo, em substituição ao livro didático Tout va bien! da mesma editora.

Foi uma mudança importante, pois alteramos não apenas o LD adotado, mas também a denominação de todos os nossos cursos de acordo com os seis níveis do QECR. Os antigos cursos denominados básico, intermediário, avançado e superior passaram, desde então, a ter as seguintes nomenclaturas: A1.1, A1.2, A2.1, A2.2, A2.3, B1.1, etc. As 
subdivisões e a carga horária de cada nível aumentam de acordo com a progressão exponencial de conteúdo prevista pelo QECR.

A coleção Écho faz referência em seus quatro títulos aos quatro primeiros níveis do QECR, uma opção contestável, já que ao final do primeiro volume (Écho A1, unidade 3, composta por quatro lições), encontramos conteúdos linguísticos do nível seguinte, o mesmo acontecendo na unidade 3 do livro Écho A2, como os próprios autores reconhecem nos portfolios de Écho A1 e de Écho A2:

ÉCHO A1 permet d'atteindre le niveau A1 du Cadre Européen à la fin de la troisième unité [...] N.B. Dans certains cours qui utilisent du matériel complémentaire à la méthode, il est possible que le niveau A1 soit atteint à la fin de l'unité 2 de ÉCHO A1.

ÉCHO A1 - Portfolio, page 1 ; grifo nosso.

ÉCHO A2 permet d'atteindre le niveau A2 du Cadre Européen à la fin de la deuxième unité.

ÉCHO A2 - Portfolio, page 1 ; grifo nosso)

Como nas análises anteriores, nos concentramos no primeiro volume da série de livros didáticos da coleção. O livro Écho A1 é composto por três unidades, cada uma delas compreende quatro lições, totalizando 12 lições. Écho A1 é composto por um livro do aluno acompanhado de um portfólio e de um DVD-ROM, por um caderno de exercícios acompanhado por uma brochura com as correções e por um CD de áudio, por um livro do professor, por um livreto de avaliações e por um livro digital para ser usado pelo professor em uma lousa digital interativa.

De fato, trata-se de um dos primeiros LDs que propuseram uma versão digital, prática cada vez mais recorrente desde então. Nesta análise, no entanto, estudamos apenas a versão impressa do livro, e isto por duas razões:

- para guardar a homogeneidade nas análises, já que os outros livros estudados não possuíam esse suporte digital;

- pelo fato de as diferenças entre a versão impressa e digital serem mínimas no que diz respeito ao conteúdo. Como se trata ainda da primeira geração de livros didáticos digitais, as atividades suplementares interativas são pouco numerosas. O conjunto corresponde mais a uma versão digitalizada das páginas impressas, com a possibilidade, no entanto, de se aumentar uma imagem, de acessar diretamente um áudio ou um vídeo. 
A coleção Écho também propõe um site compagnon para cada livro com atividades interativas on-line e documentos complementares sonoros e escritos.

\subsubsection{Análise da capa do livro didático Écho A1}

Trata-se de uma capa bastante tradicional que opta pela simplicidade nos efeitos gráficos e também no jogo de cores: duas cores predominantes por nível, sobre um fundo branco (Figura 84). A composição completa-se com algumas fotos de pessoas em diferentes contextos situacionais. A representatividade de origens étnicas diferentes está garantida, mas não a representatividade de diferentes faixas etárias. Como na maioria das imagens presentes nas capas e no interior dos LDs de FLE, é o público jovem que se encontra representado.

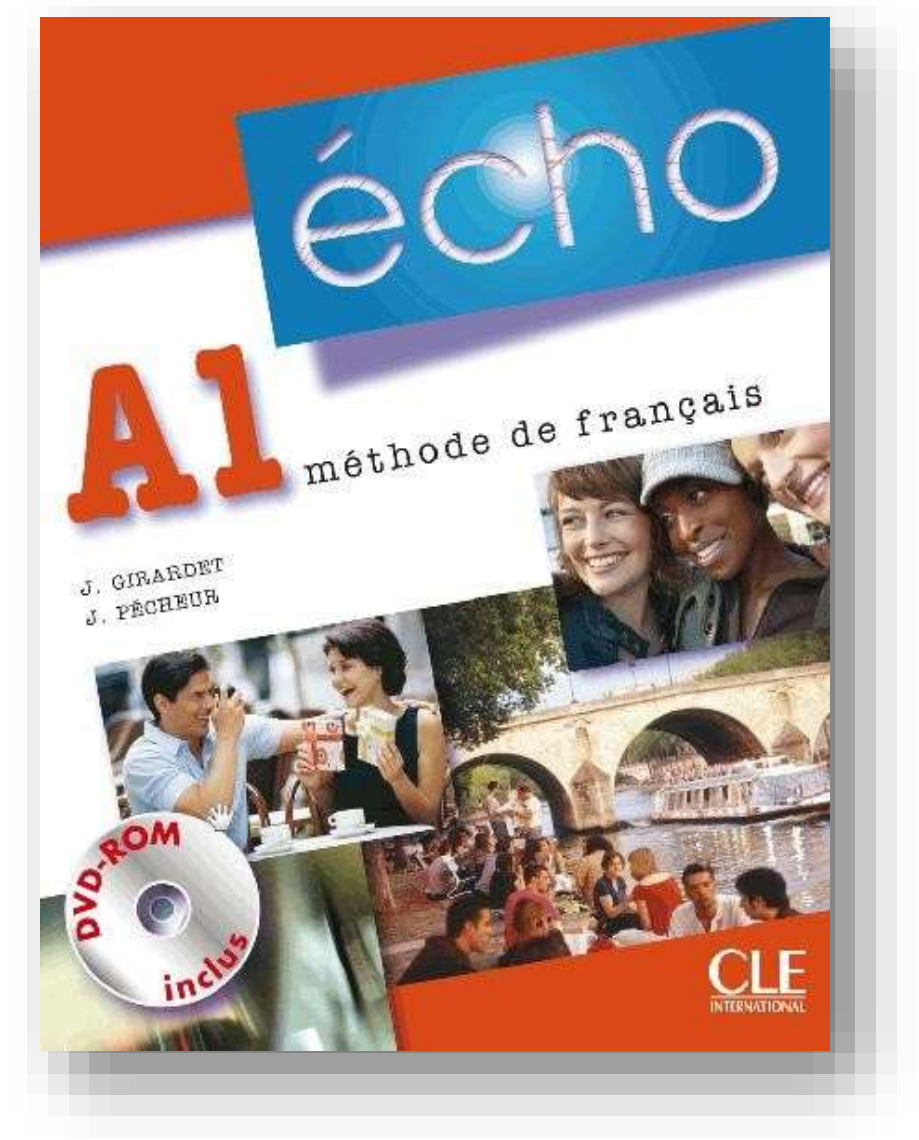

Figura 84 | Écho A1

Capa do livro do aluno

Como em outras coleções de livros didáticos de FLE, a mesma estrutura gráfica é retomada nos níveis superiores, optando-se pela mudança de cores e de fotos. Essa retomada garante a unidade visual da coleção (Figura 85). 
Figura 85 | Capa dos livros didáticos da coleção Écho
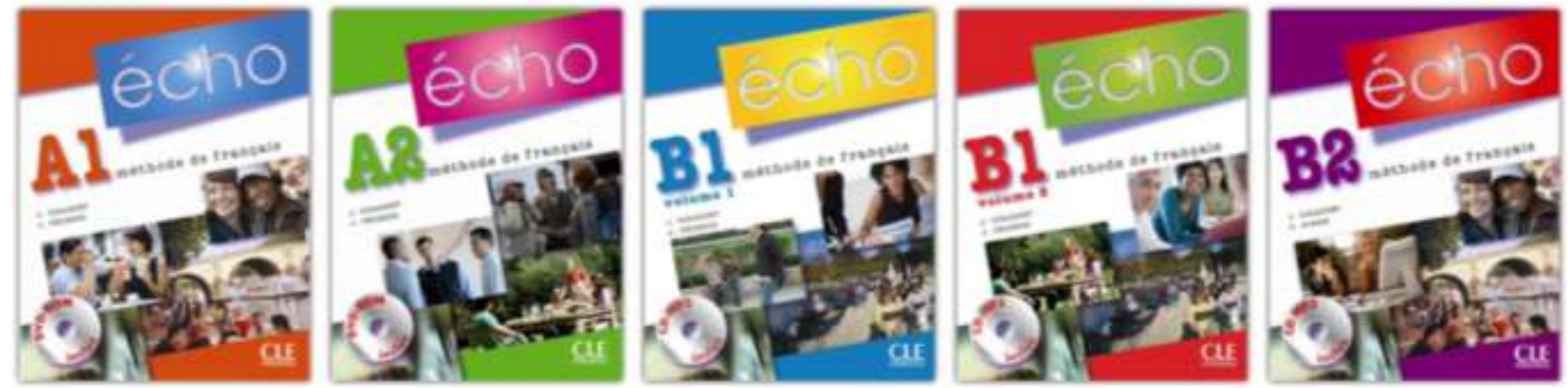

3.5.2. Análise quantitativa das imagens no livro do aluno

As páginas do livro didático Écho A1 são amplamente ilustradas, com uma tipologia variada de imagens composta por fotos, desenhos, reproduções de um determinado gênero textual: cartazes de filmes, de peças de teatro, de associações, capas de livros, mapas de cidades ou de países, receitas de cozinha, cartões de visita, páginas de sites da Internet, menus de restaurante, calendários, pictogramas... Em alguns casos, trata-se de documentos autênticos, em outros, de documentos realistas pois, mesmo não sendo autênticos, respeitam a forma e o conteúdo de um determinado gênero textual, como um menu de restaurante ou um formulário de uma agência imobiliária (Fig. 86, 87).

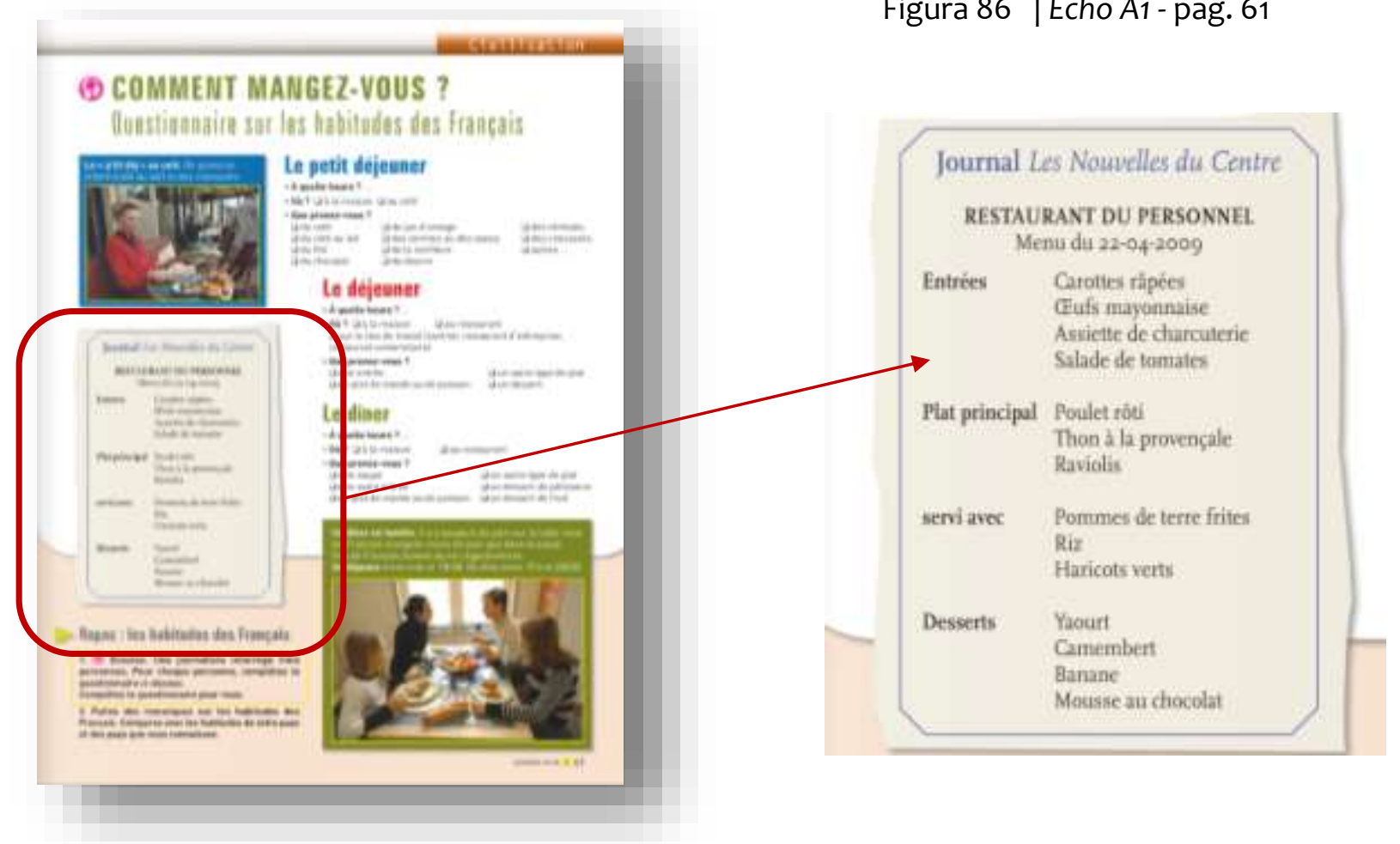


Figura 87 | Écho A1 - pag. 70

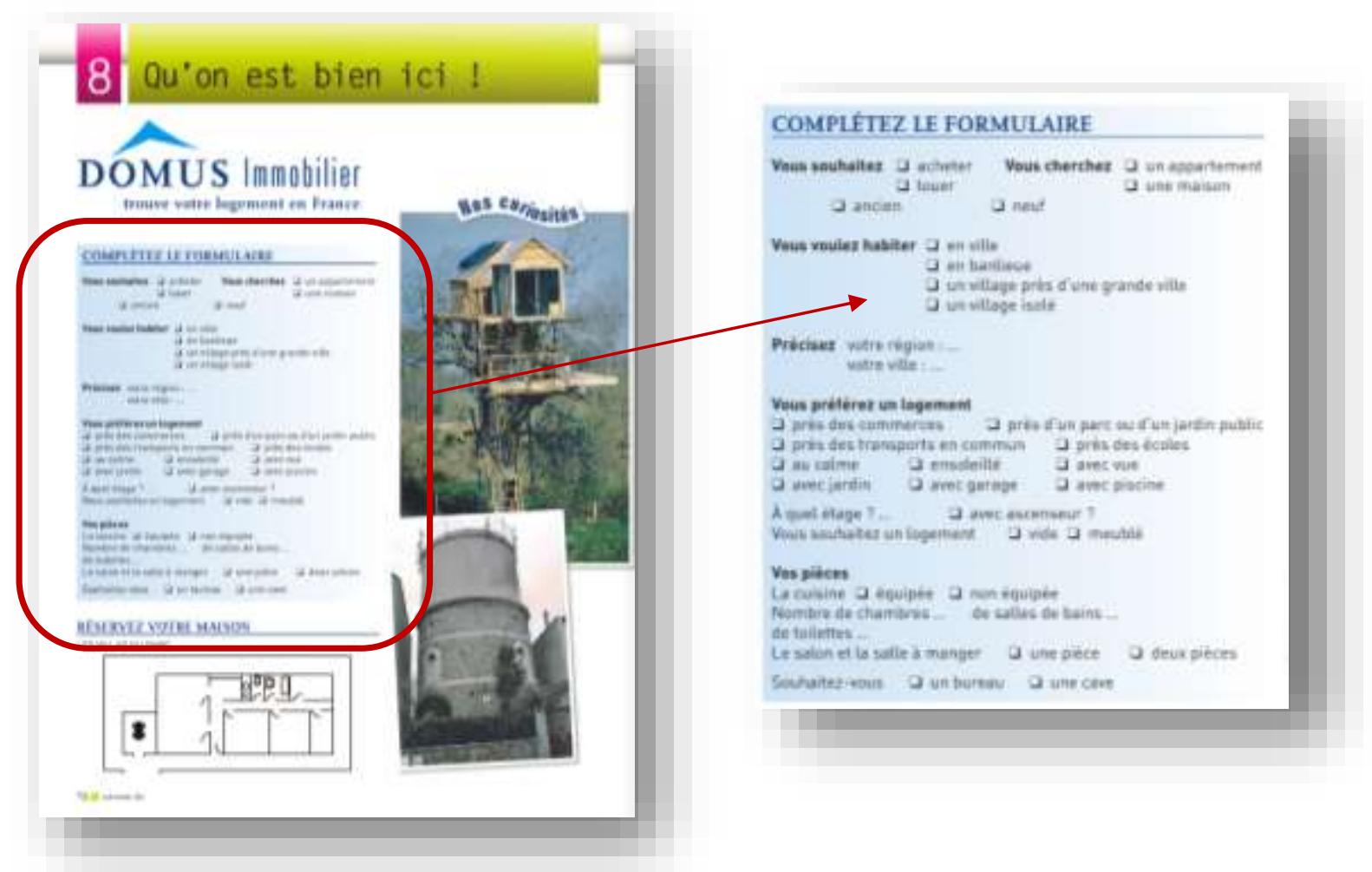

O livro traz também ilustrações fabricadas. Trata-se sobretudo de desenhos, concebidos para acompanhar as situações de comunicação apresentadas (Figura 88) e também para introduzir um ponto linguístico nas páginas de gramática, sob a forma de sketches situacionais (Figura 89).

Figura 88 | Écho A1 - pag. 50

5. Bon voyage!

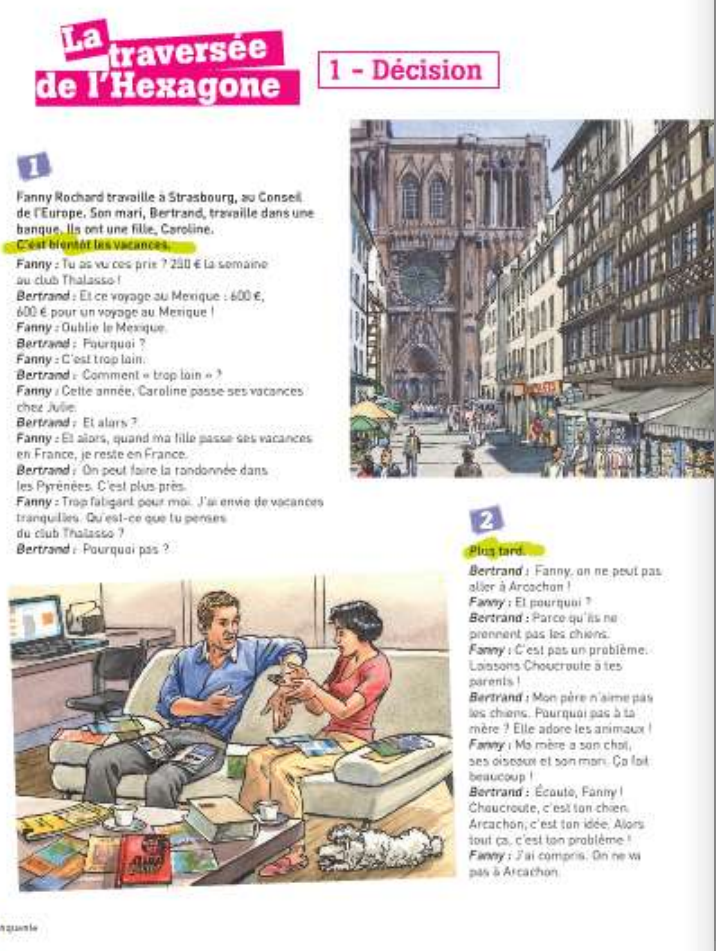


Figura 89 | Écho A1 - pag. 56, 57

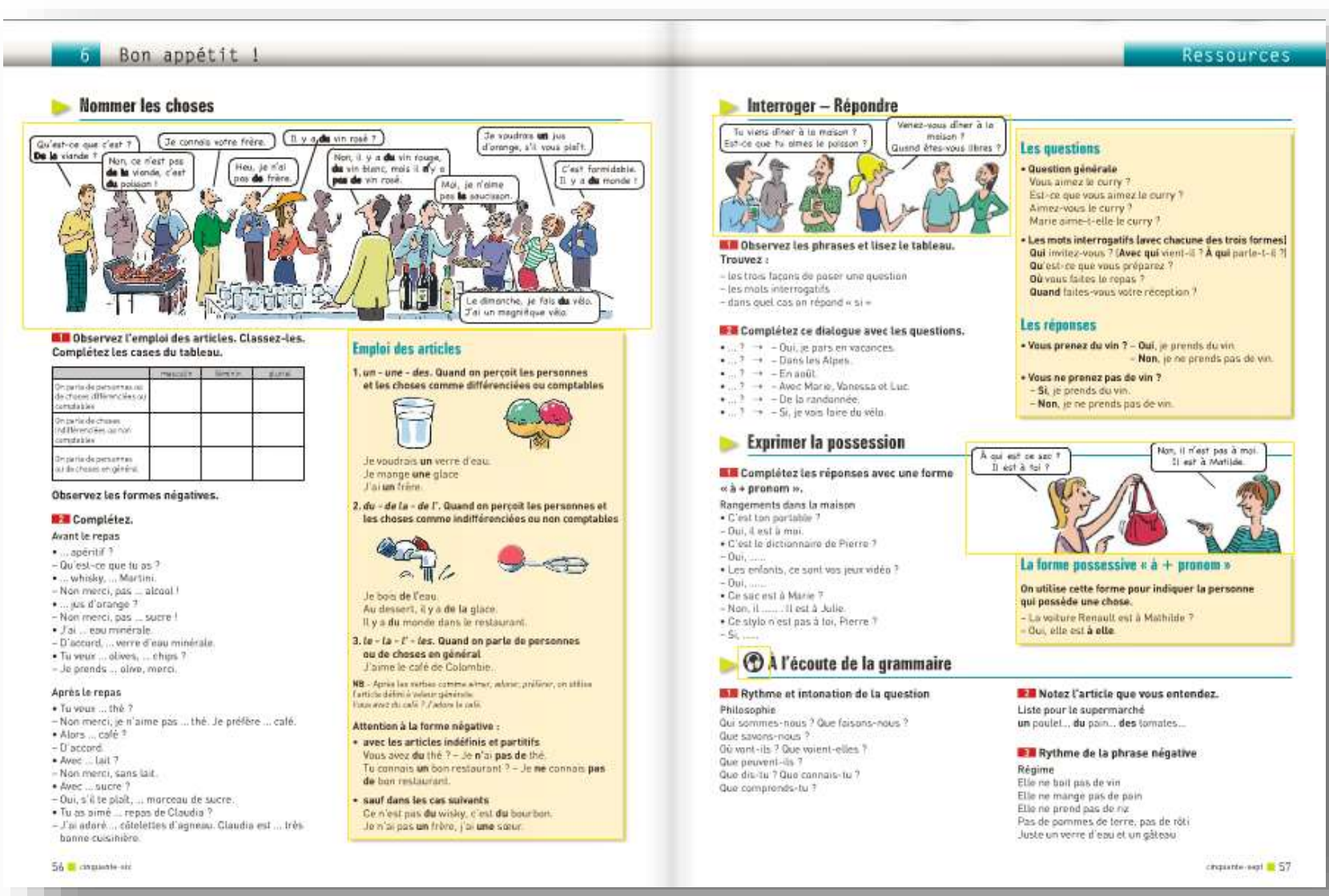

Das 128 páginas que compõem as doze unidades do livro do aluno (excluindo-se os anexos), apenas 6 não recorrem ao uso da imagem. O que significa que $95 \%$ das páginas do livro Écho A1 são ilustradas.

As cores estão associadas à estrutura do livro do aluno, mas com uma importância menor do que no livro Forum 1, que analisamos anteriormente. Se em Forum cada lição estava inteiramente associada a uma única cor, visível também na borda do livro e, portanto, sinalizadora para o aluno, já em Écho A1, as cores estão associadas às diferentes partes que compõem uma lição: dupla página Interactions sinalizada em rosa, dupla página Ressources em verde, dupla página Simulations em violeta, página Écrits em azul e página Civilisation em laranja. Em todos os casos, as respectivas cores aparecem apenas em uma barra no alto da página de forma indicativa e nem sempre essas mesmas cores são predominantes na página, já que os títulos e elementos gráficos podem aparecer em outra cor. Mesmo se essa composição se repete em cada unidade, a cor nesse LD parece ter uma função mais estética do que estrutural, como no caso de Forum. 
Figura 90 | Écho A1 - Pág.36, 37

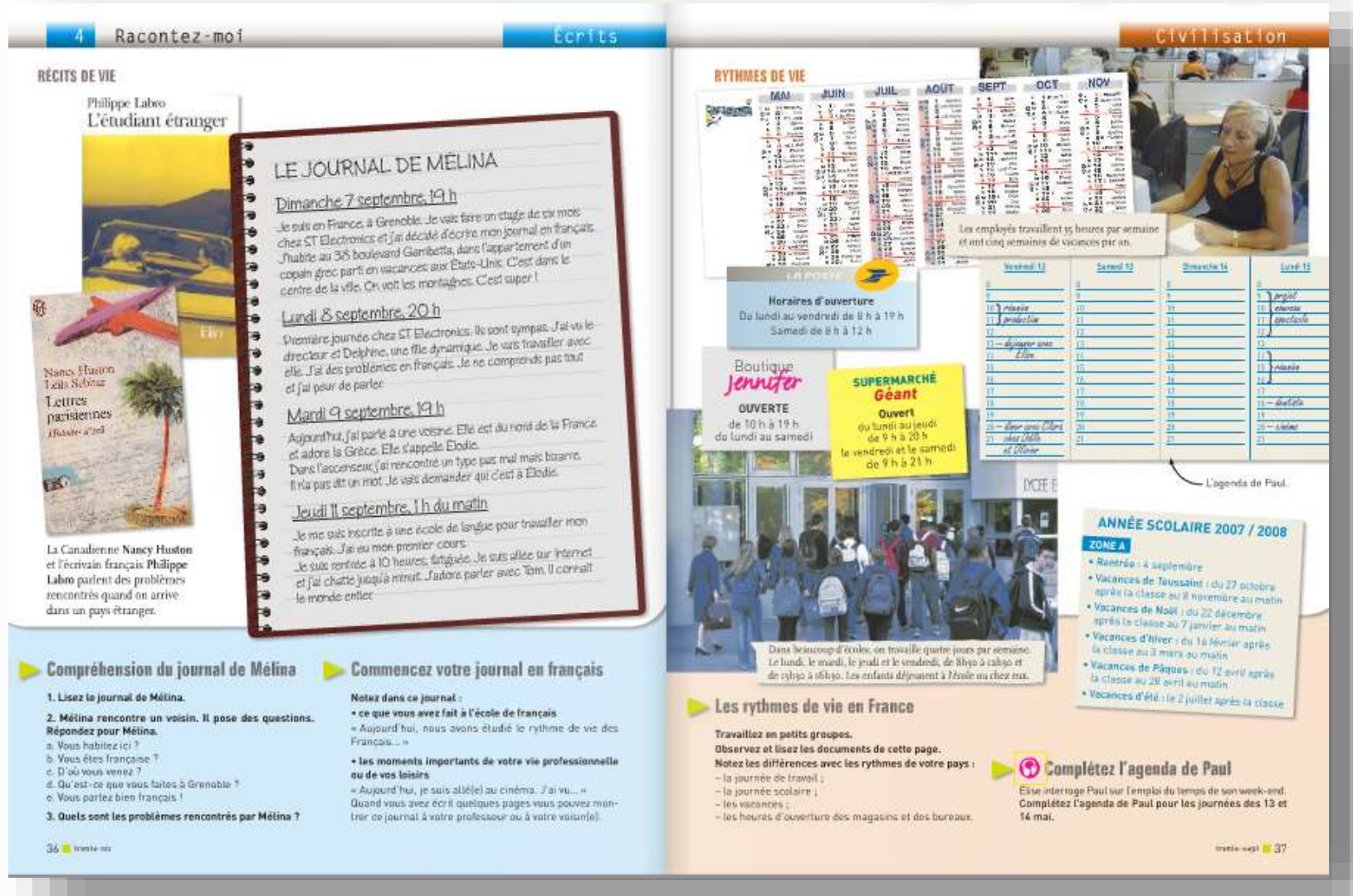

3.5.3. Análise qualitativa e funcional das imagens

Analisamos agora alguns textos multimodais presentes em Écho A1 e buscaremos no guia do professor pistas para definir a função pedagógica da imagem nas respectivas sequências didáticas.

O guia pedagógico inicia-se com uma vista panorâmica das diferentes duplaspáginas que compõem cada lição (Figura 91). Apesar de elas serem todas amplamente ilustradas, ainda não há referências ao uso da imagem nos respectivos textos de apresentação. 
Figura 91 | Écho A1 - Guia pedagógico, pág. IV e V

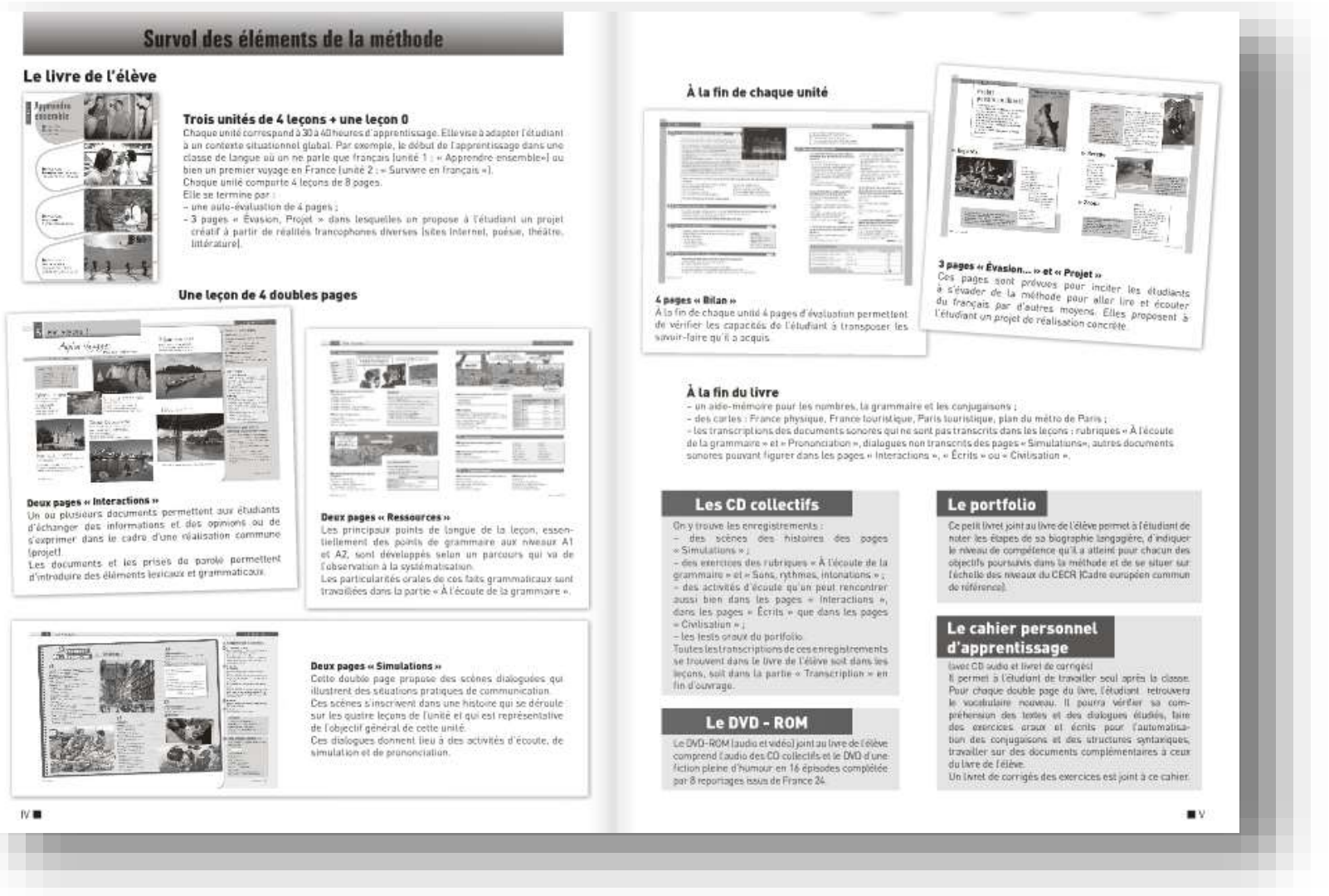

Em seguida, passa-se a uma apresentação da escolha metodológica. Um texto de quatro páginas intitulado Une approche actionnelle explica de que forma essa abordagem do QECR foi adotada no livro do aluno e também no caderno de exercícios. O texto aborda sobretudo questões como a noção de "tarefas" (tâches, no original) proposta pelo Quadro Europeu, o papel das simulações no LD, avaliações, progressão linguística, francofonia. Não há nenhuma referência à utilização das imagens e nenhuma palavra do campo semântico da ilustração (imagens, desenhos, fotos, ilustrações...) é utilizada nessa apresentação de quatro páginas sobre a metodologia do livro.

\section{Imagem: um gigante invisível nos guias pedagógicos}

Quarenta anos após a publicação do livro didático Archipel 1, nos deparamos com uma situação curiosa. Havíamos notado que, apesar da grande quantidade de imagens presentes no livro do aluno Archipel 1 (60\% de páginas ilustradas), a exploração pedagógica das mesmas parecia bastante restrita. Restrição essa que foi justificada pelos autores nas páginas de introdução do guia pedagógico: 
Bien entendu, l'image est le point de départ de l'explication, mais les images de la méthode n'ont pas été conçues pour une utilisation exhaustive : nous n'avons pas voulu en faire le support principal de la communication. [...] Les images ont donc été conçues essentiellement pour véhiculer des informations de type situationnel et culturel plutôt que référentiel.

Archipel 1. Guide pédagogique, pág. 15.

Ora, ao analisarmos agora as páginas introdutórias de Écho A1, cujo livro do aluno é composto em 94\% por páginas ilustradas, vemos que o uso pedagógico da imagem não é sequer citado nas páginas que explicam a metodologia adotada. Fica a impressão de que a imagem nos livros didáticos de FLE se agiganta e se multiplica fisicamente, permanecendo, no entanto, praticamente invisível quando a questão é a exploração pedagógica da mesma.

\section{Composição das lições do livro do aluno Écho A1}

Como vimos anteriormente, a estrutura de cada lição se repete ao longo do livro. Após a descrição da metodologia adotada, o guia pedagógico Écho A1 apresenta uma descrição de cada uma das partes das lições em um texto intitulado Écho, mode d'emploi:

- Páginas de abertura das unidades: apresenta de forma resumida e "muito ilustrada" - nas palavras do guia e em uma primeira referência à utilização das imagens. A página exerce também a função de contrato de aprendizagem (Figura 92). 


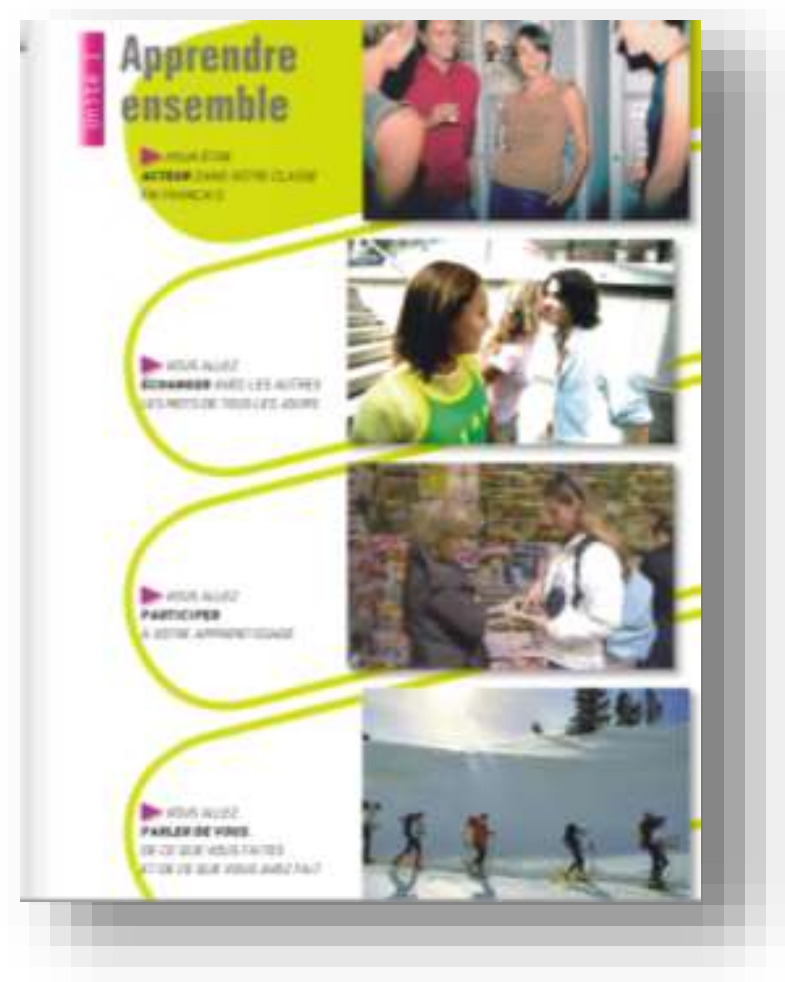

Figura 92 | Écho A1 - Pág. 5

- Dupla página Interactions : página de abertura da lição, ela é geralmente composta em boa parte por imagens (Figura 93). De acordo com o guia, a função dessa dupla página é a de desencadear a expressão oral e escrita por meio de documentos variados como questionários, sondagens, etc.

Figura 93 | Écho A1 - Pág. 46,47

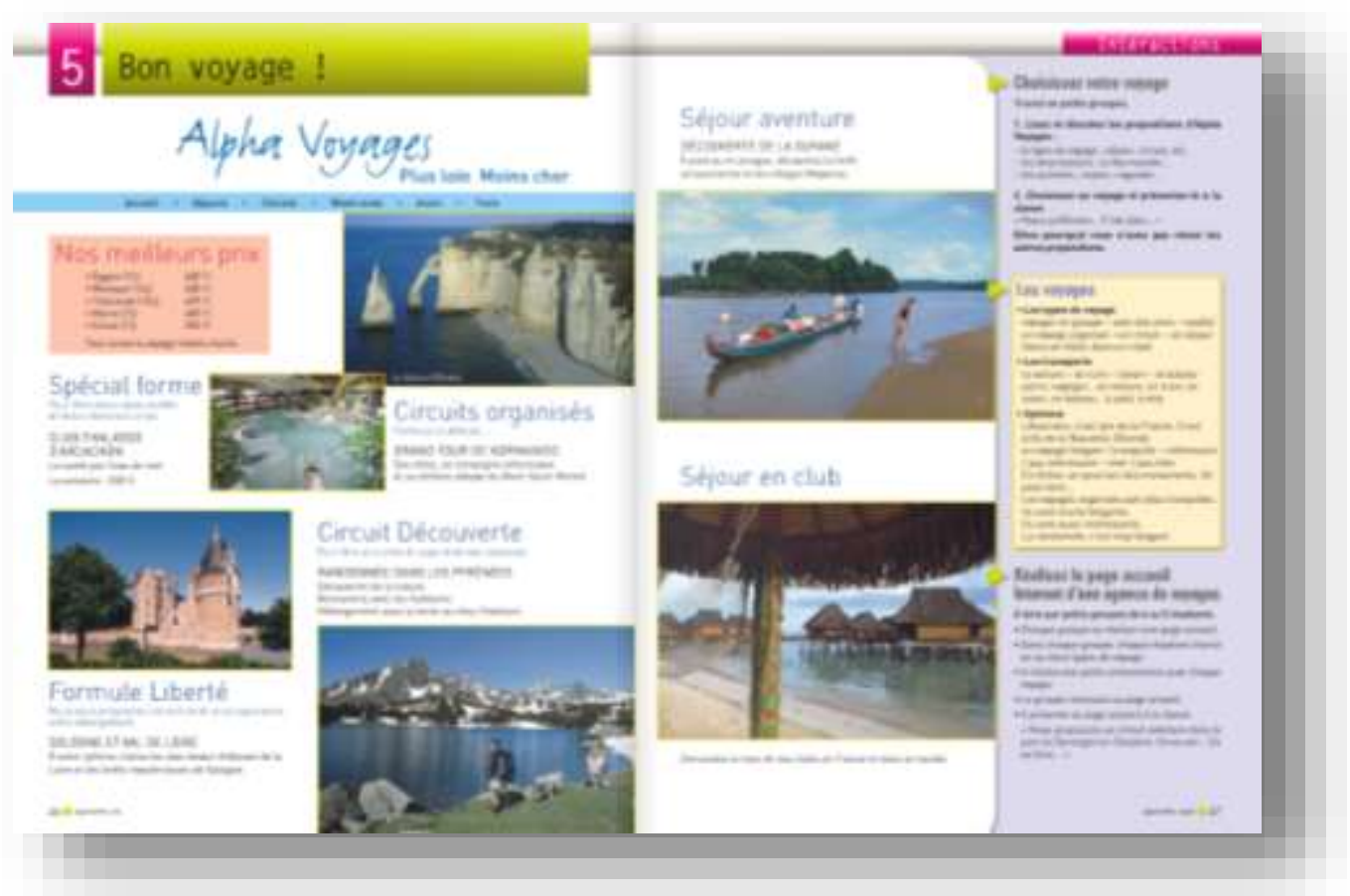


- Dupla página Ressources: dedicada ao conteúdo linguístico da lição. Sketches situacionais introduzem o ponto linguístico (Figura 94). Curiosamente, é parte em que mais se faz referência à imagem na apresentação do guia pedagógico:

Un dessin humoristique proposant un corpus d'expressions qui va permettre l'observation du point de la langue (les deux ou trois dessins de la double page sont liés par une trame narrative).

Ce dessin est suivi d'une activité de découverte (grille à remplir, mots à rechercher, etc.) qui permet de conceptualiser, de classer, d'introduire des règles du système de la langue.

Écho A1. Guide pédagogique, pág. XII

Figura 94 | Écho A1 - Pág. 56,57

Dupla página Ressources

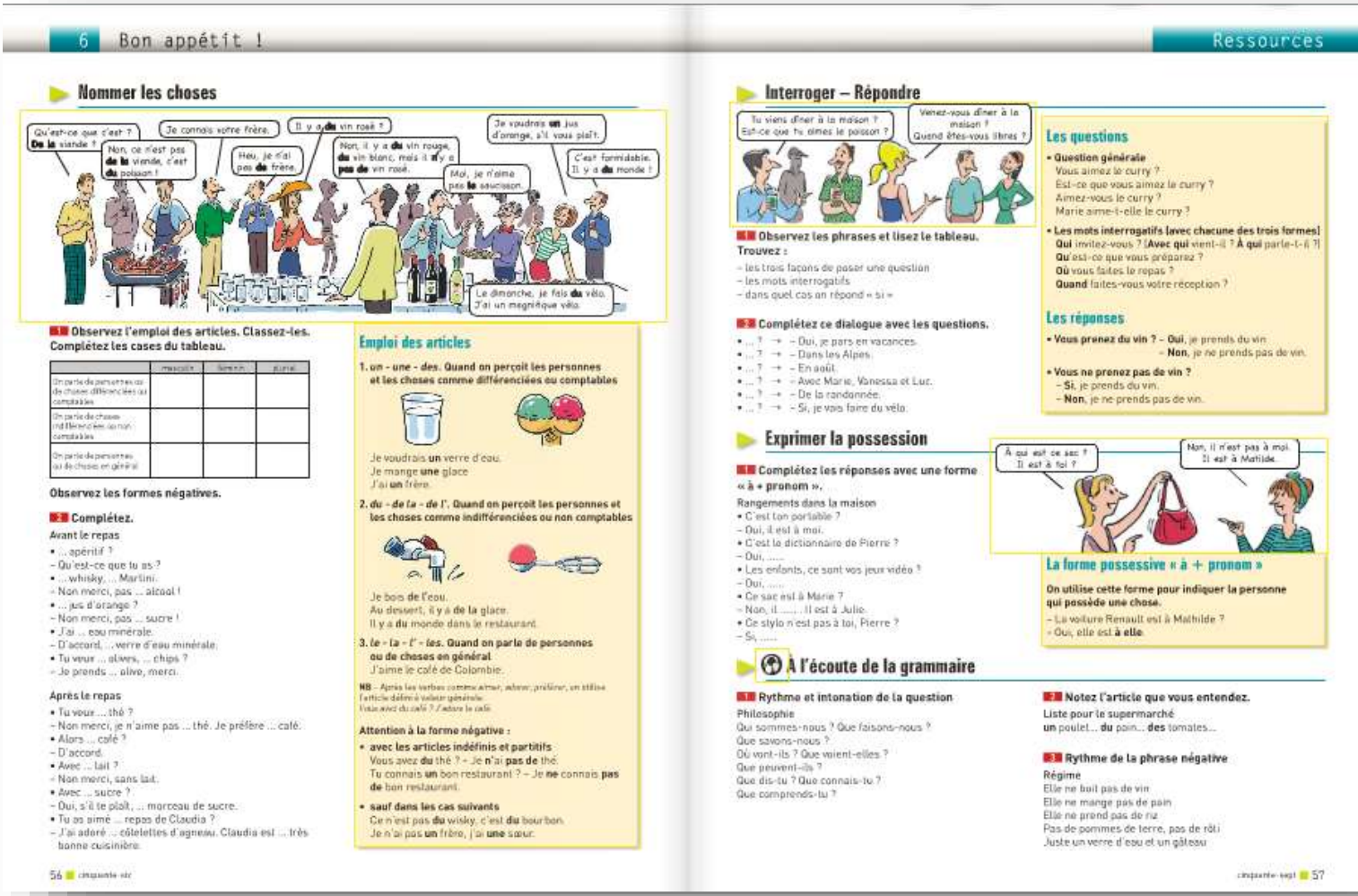

- Dupla página Simulations: diálogos situacionais que se encadeiam dentro da mesma unidade, lição após lição, para contar uma história (Figura 95). Os diálogos retomam situações da vida cotidiana em um contexto preciso. O guia pedagógico traz, nesse mesmo texto de apresentação, orientações para se trabalhar os diálogos: “Técnicas para 
trabalhar com um documento de áudio" (Guia pedagógico, página XIII). Seis etapas compõem essa orientação e a imagem é citada apenas na primeira: "Hipóteses sobre o conteúdo do diálogo a partir de elementos situacionais", com a sugestão de “observação da imagem" e da emissão de hipóteses sobre o conteúdo do diálogo. Trata-se, como vimos também em análises anteriores, de uma imagem com um objetivo situacional.

Figura 95 | Écho A1 - Pág. 58,59

Dupla página Simulations

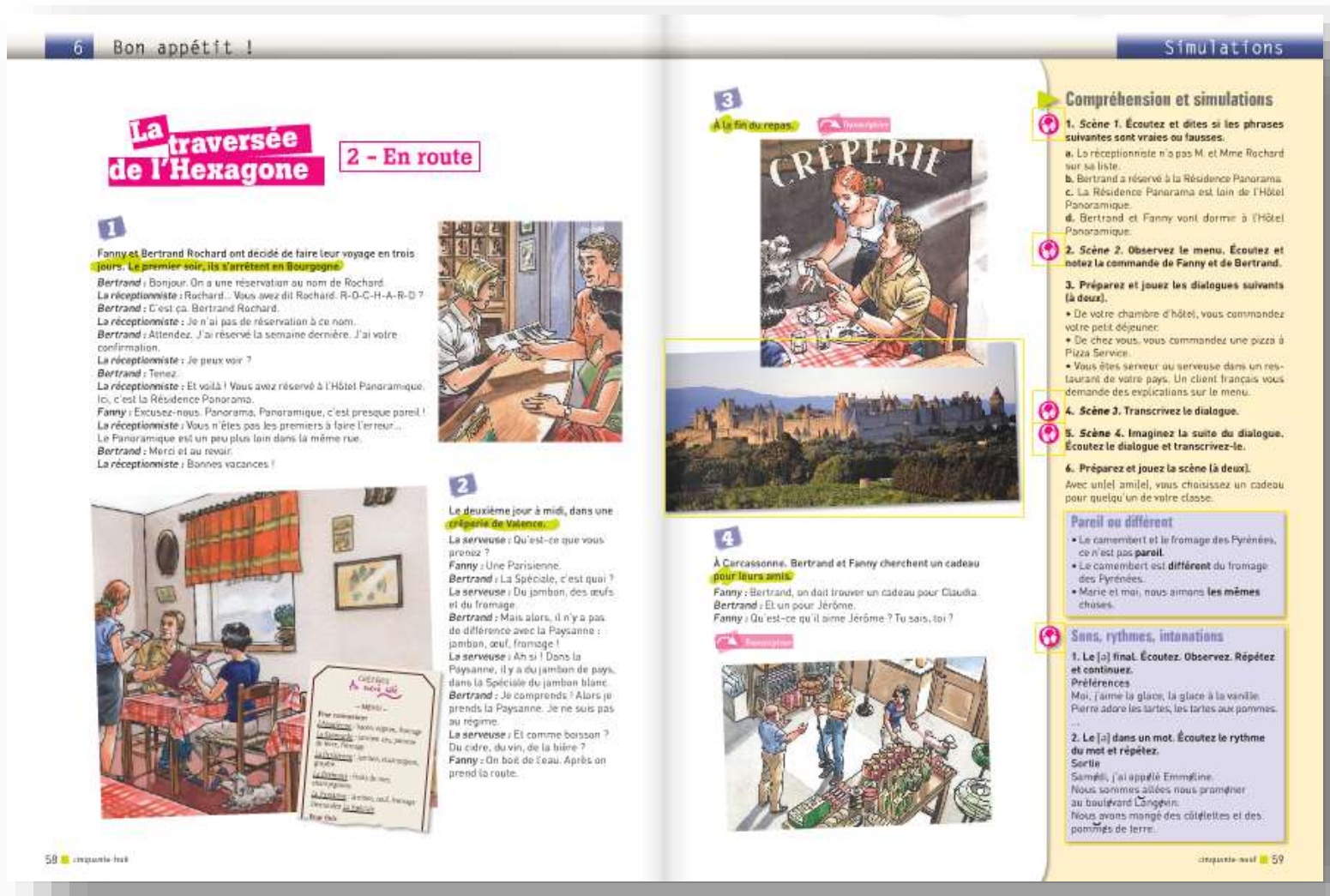

Temos ainda duas páginas que "fecham" a lição: Écrits dedicada à compreensão e à produção escrita e Civilisation, dedicada a temas interculturais. Ao final de cada unidade, ou seja, ao final de quatro lições, o livro propõe a realização de um projeto, dentro de uma perspectiva mais voltada à ação, seguindo o QECR.

\subsubsection{Preconizações do guia pedagógico para o uso da imagem}

Analisamos, a seguir, alguns exemplos dessas páginas multimodais de Écho A1. Comecemos pela análise de uma dupla página Interactions (Figura 96). 
Figura 96 | Écho A1 - Pág. 6,7

Dupla página Interactions

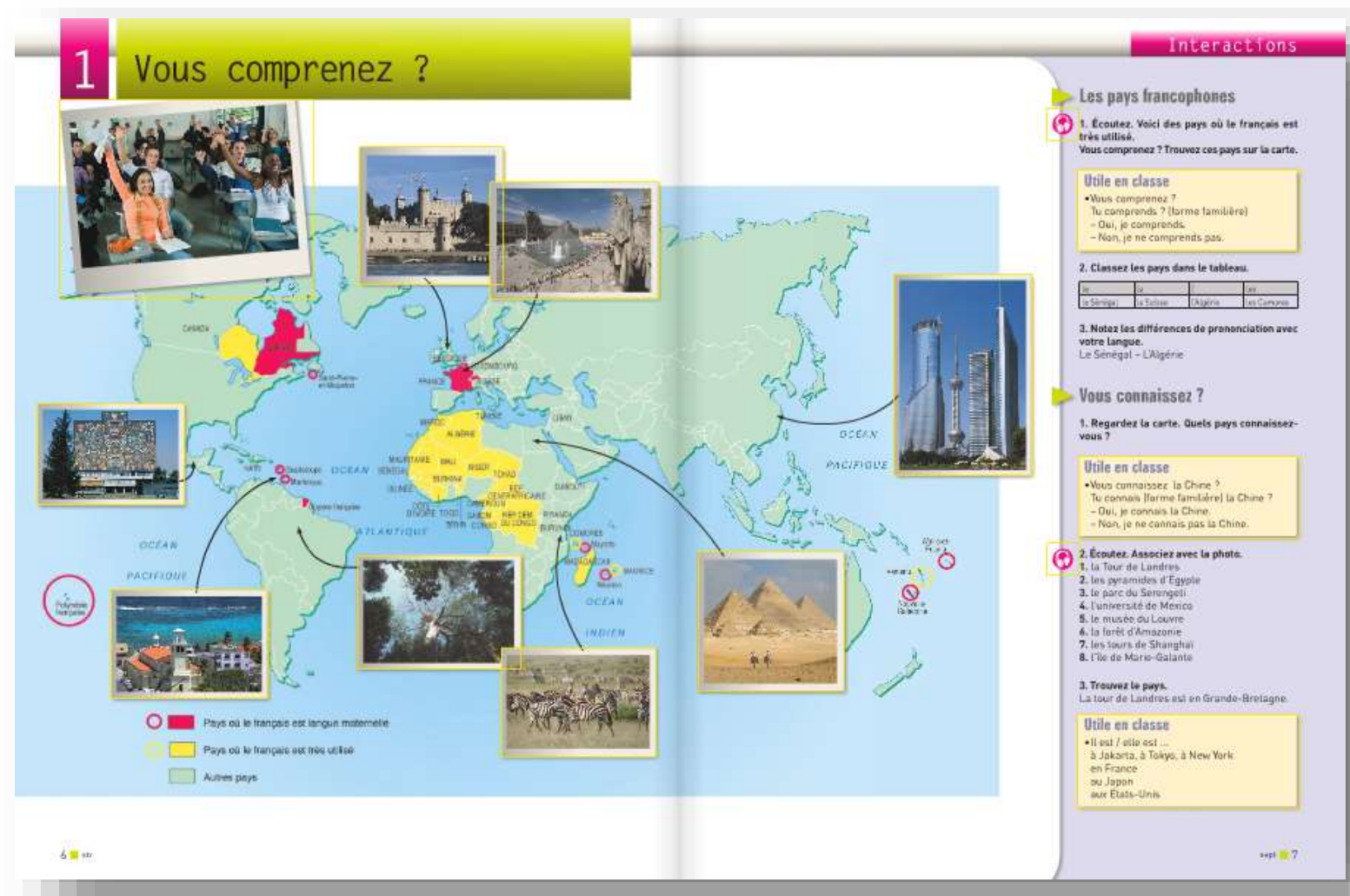

Como vimos anteriormente, o objetivo dessa dupla página que abre a unidade é introduzir o tema principal da lição e desencadear a expressão oral e/ou escrita. A imagem costuma ocupar um papel importante nessa dupla página, mesmo se ela é pouco citada tanto no livro do aluno quanto no guia pedagógico:

Exercício 1 / Livro do aluno: "Regardez la carte. Quel pays connaissez-vous?"

Exercício 1 / Guia pedagógico: « Observation de la carte et identification de quelques pays connus des étudiants. » photo";

Exercício 2 / Livro do aluno: "Écoutez. Associez avec la

Exercício 2 / Guia pedagógico: “Écoute du document. À chaque nom de lieu, poser la question : 'Vous comprenez, etc. ». Les étudiants associent les noms de lieu avec la photo.

Écho A1. Livro do aluno, pág. 7. Écho A1. Guia pedagógico, pág. 18.

Esses dois exemplos são particularmente significativos pois ilustram um aspecto bastante comum quando buscamos no guia do professor referências ao uso pedagógico 
da imagem: raramente o guia traz elementos ou pistas para o trabalho sobre a imagem. Como no caso acima citado, as referências do guia à imagem são praticamente uma reprodução com outras palavras dos enunciados que já estavam presentes no livro do aluno, sem orientações suplementares ou mais aprofundadas para o professor. Consequentemente, o professor terá menos instruções para explorar as imagens do livro e tenderá a fazer um uso superficial das mesmas. A nosso ver, isso explica também porque muitos professores não consultam com frequência o guia pedagógico. É como se eles já soubessem o que vão encontrar em suas páginas e, por essa razão, o consultam menos para obter informações sobre tratamento pedagógico do conteúdo do LD e mais para buscar um conhecimento enciclopédico específico sobre, por exemplo, uma obra de arte ou um pintor citado no livro do aluno.

A dupla página em questão (Figura 96) é bastante atrativa do ponto de vista visual, já que três quartos da mesma são ocupados por imagens. Trata-se de um rico texto multimodal, composto por diferentes tipos de imagem (um grande mapa, pequenas fotos e elementos gráficos), por textos (tanto no mapa com o nome dos países e legendas quanto à esquerda, na parte dedicada à exploração pedagógica) e por ícones de fones de ouvido que indicam outro suporte na composição do sentido: os documentos de áudio.

O layout dessa dupla página mostra que o sentido é construído graças à maneira como os elementos estruturantes do texto se posicionam entre si dentro do espaço. Levando-se em conta parâmetros como esquerda/direita, válidos para a cultura ocidental, notamos que essas polaridades contêm, respectivamente, a informação dada (já conhecida) e a informação nova, inaugural (que o espectador não conhecia). A informação nova aparece à direita, sob a forma de quadros que retomam os novos pontos linguísticos abordados.

No que diz respeito à metafunção composicional, vale notar que os diferentes elementos da dupla página (mapa, fotos, textos, flechas, ícones) estão integrados do ponto de vista composicional em uma sequência única, com o apoio da unidade de cor e dos vetores, no caso, as flechas que religam as fotos ao mapa. O quadro com texto na parte direita também se encontra unido à imagem por meio das pequenas flechas verdes e dos ícones de áudio sobrepostos de forma a unir as duas partes da dupla página em um único texto multimodal. A barra superior cinza sobre toda a dupla página também 
contribui para a conexão dos diferentes elementos, trazendo unidade ao enquadramento.

As outras duplas páginas Interactions seguem essa mesma estrutura, com três quartos da página (à esquerda e na parte central - informação mais conhecida) compostos por imagens de diferentes tipologias e pequenos textos unidos a elas por vetores, e um quarto da página (à direita - informação menos conhecida) - com quadros explicativos dos novos pontos linguísticos abordados.

Figura 97 | Écho A1 - Pág. 86, 87

Dupla página Interactions

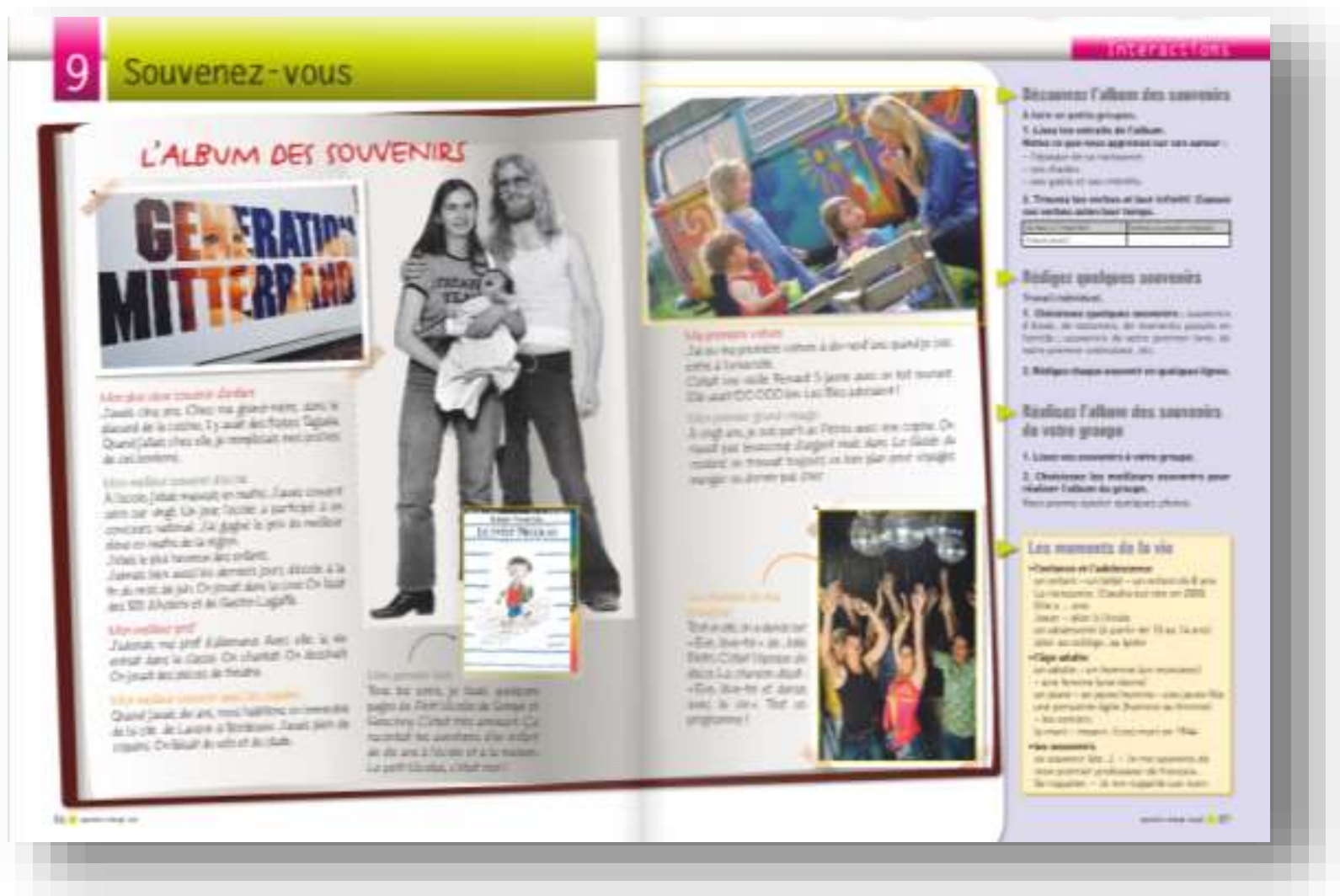

Na dupla página acima, curiosamente, nenhuma referência às imagens é feita no livro do aluno nem no guia pedagógico. Tanto nos enunciados dos exercícios no livro do aluno quanto nas orientações do guia do professor, aborda-se diretamente e unicamente o texto que compõe a página multimodal:

Exercice 1/ Livro do aluno: "Lisez les extraits de l'album. Notez ce que vous apprenez sur son auteur [...] Trouvez les verbes et leur infinitif" 
Exercice 1 / Guia pedagógico : "Lecture collective du premier souvenir. Repérer les circonstances (âge, de l'enfant, lieu, etc.) [...] Observer les verbes. Retrouver l'infinitif."

Écho A1. Livro do aluno, pág. 87. Écho A1. Guia pedagógico, pág. 60.

A única referência à imagem aparece, não na exploração da dupla página, composta em sua maioria por ilustrações, mas no enunciado de produção escrita que propõe a redação coletiva do álbum de lembranças do grupo:

Livro do aluno : "Choisissez les meilleurs souvenirs pour réaliser l'album du groupe. Vous pouvez ajouter quelques photos."

Guia pedagógico : " Ils (les élèves) peuvent poursuivre leur travail en dehors de la classe et pour la séance suivante rapporter des photos, des articles, etc. »

Écho A1. Livro do aluno, pág. 87. Grifo nosso. Écho A1. Guia pedagógico, pág. 60. Grifo nosso.

Mais uma vez, temos a impressão de que a imagem nos livros didáticos de FLE, apesar do grande espaço físico que ocupa, permanece invisível quando o assunto é a sua exploração pedagógica.

Analisamos agora a dupla página Ressources na qual, segundo a apresentação do guia pedagógico que vimos anteriormente, os desenhos/sketches permitem a observação do ponto linguístico que será estudado. De fato, nesses desenhos alguns personagens - anônimos, pois não são os mesmos das histórias nos diálogos do livro utilizam expressões ou o vocabulário que será estudado na unidade. As frases aparecem dentro de balões, o que torna esse texto multimodal semelhante a uma charge ou a uma história em quadrinhos. (Figura 98).

Trata-se de uma dupla página bastante carregada do ponto de vista de conteúdo linguístico, com vários pontos novos de gramática e/ou de vocabulário e quadros com conjugações verbais. Os desenhos talvez tenham sido escolhidos com a intenção de tornar a página mais agradável visualmente, mais leve. No entanto, essa leveza visual acaba por se tornar um ponto negativo nesse contexto, visto que o corpus apresentado é extremamente reduzido e, o que é mais problemático, descontextualizado e não conectado a um gênero textual específico. 
Figura 98 | Écho A1 - Pág. 24, 25

Dupla página Ressources

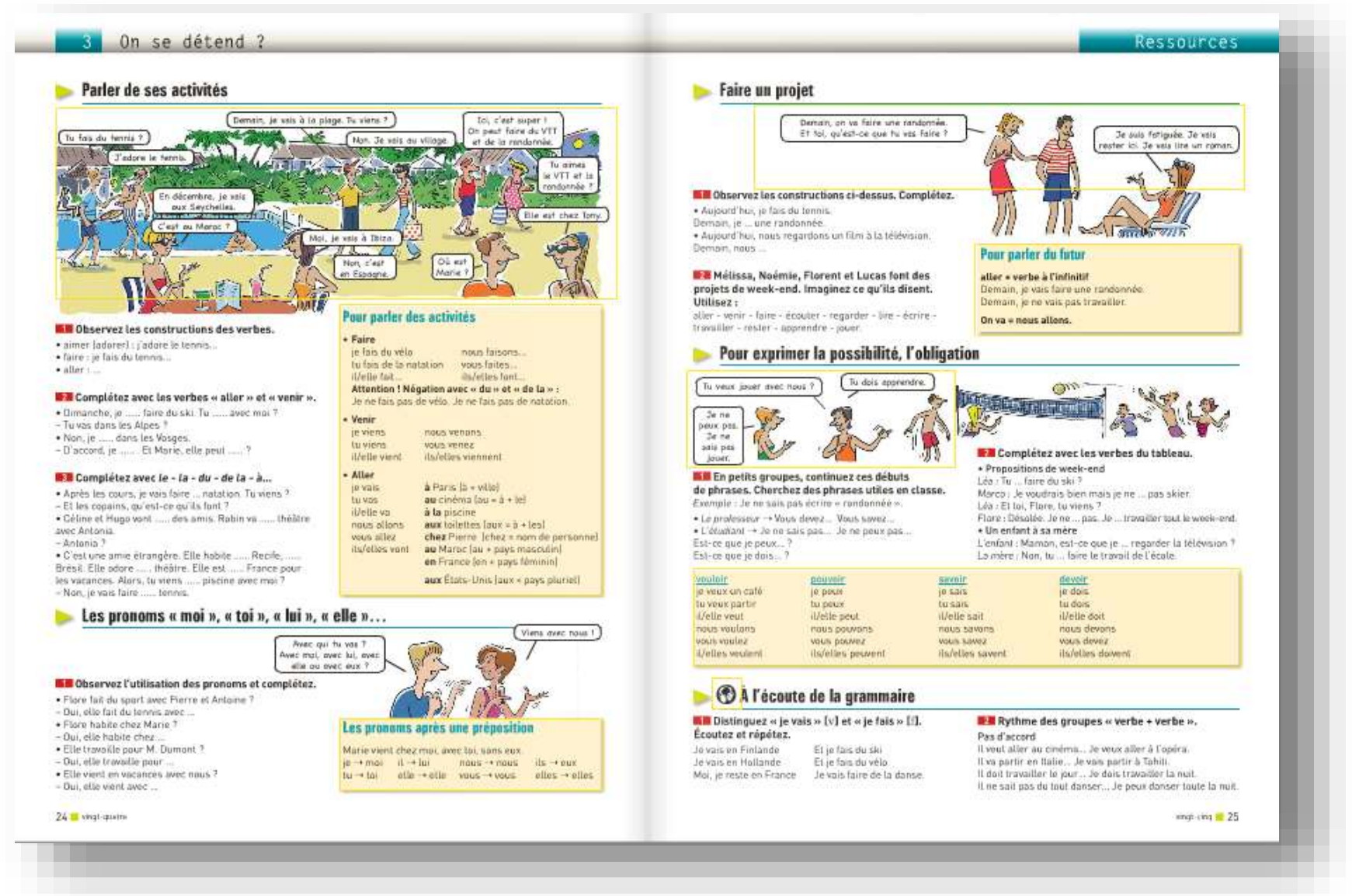

Quanto à exploração das imagens, as mesmas frases são utilizadas em todo o guia pedagógico para essas duplas páginas: "Observar os desenhos. / Observar os balões do desenho. / Ler os balões do desenho." Por vezes, vemos esta frase: "Observação das frases do desenho" (guia pedagógico, pág. 65). Ela é interessante, pois mostra que o desenho é praticamente ignorado, a primeira indicação de exploração da página aborda - não o desenho - mas "as frases do desenho", ou seja, o que é realmente "importante": o texto escrito. De fato, passa-se, em seguida, diretamente ao ponto linguístico em questão. O mesmo procedimento é adotado nos enunciados dos exercícios do livro do aluno e, por vezes, a palavra “desenho" não é nem mesmo citada, como nas páginas 24 et 25, ilustradas acima: “Observe a construção dos verbos/ Observe a utilização dos pronomes e complete.” (pág. 86). “Observe as construções acima e complete” (pág. 87). 
Analisamos agora a dupla página Simulations (Figura 99), que apresenta diálogos acompanhados por imagens constituídas, em sua maioria, por desenhos que ilustram a situação de comunicação. É comum também que uma foto representativa de um espaço, de uma região ou de um gênero textual específico venha completar a página multimodal e contribuir para a construção de sentido.

No exemplo abaixo, quatro desenhos acompanham quatro diálogos. Os desenhos contribuem para a definição da situação de comunicação e para a construção do sentido. $\mathrm{O}$ mesmo acontece com as duas fotos que representam um gênero textual evocado no diálogo $\mathrm{n}^{\circ} 2$ (menu de restaurante) e a cidade de Carcassonne onde se encontram os personagens da história no diálogo $n^{\circ} 4$. Apesar da importância que as imagens ocupam nessas duplas páginas, as referências a elas no guia são extremamente restritas, resumindo-se, quase sempre, à expressão: “Observar o desenho".

Figura 99 | Écho A1 - Pág. 58, 59

Dupla página "Simulations"

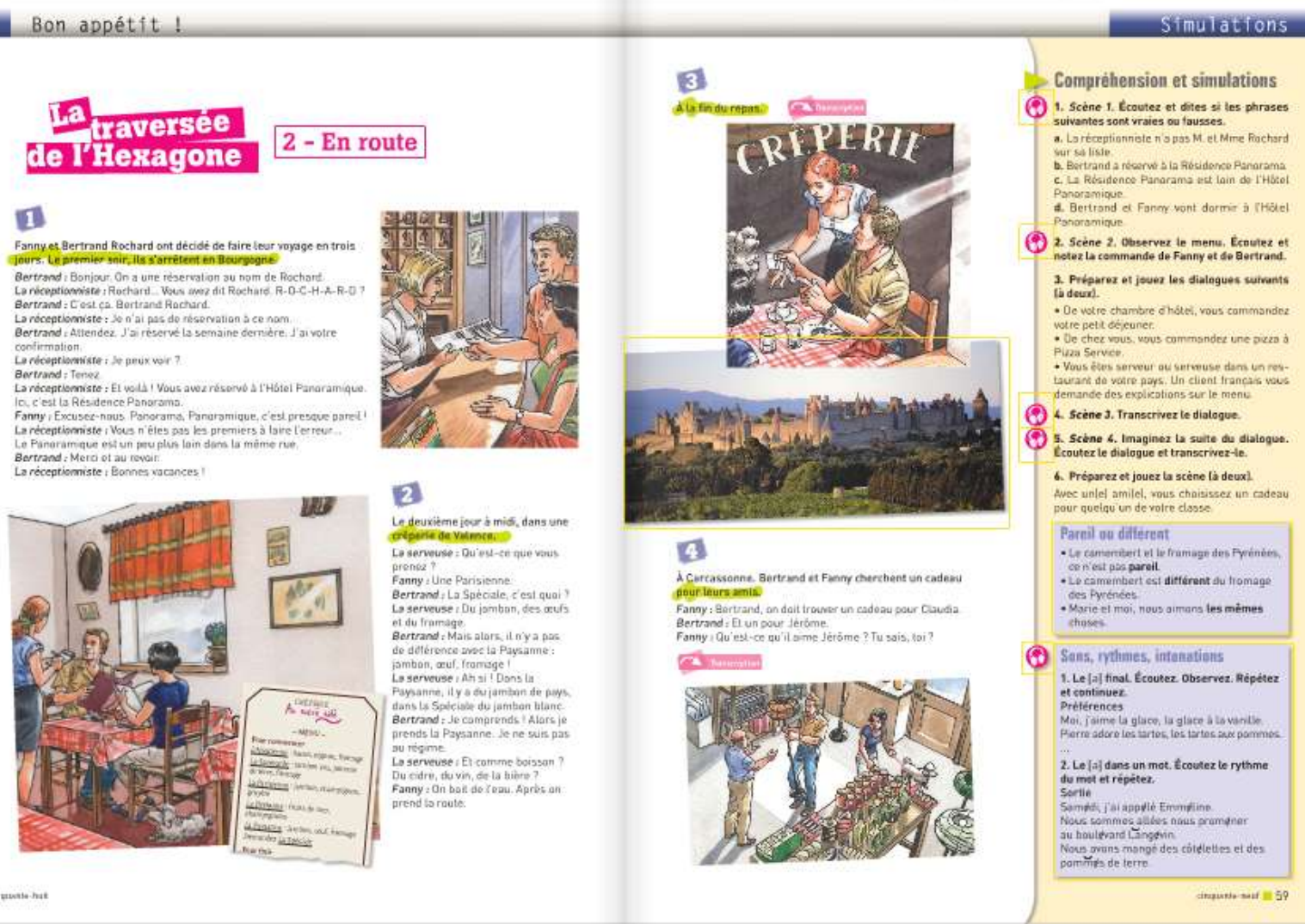


No caso dessa dupla página específica, essa mesma expressão é repetida três vezes no guia pedagógico, cada vez para um desenho diferente, mas sem nenhum outro comentário ou orientação para a utilização das imagens.

Ao analisarmos agora a página Écrits, dedicada à compreensão e à produção escrita, vemos que ela é sempre composta por texto e imagens. Vejamos o exemplo que segue (Figura 100).

Figura 100 | Écho A1 - Pág. 76

Página Écrits

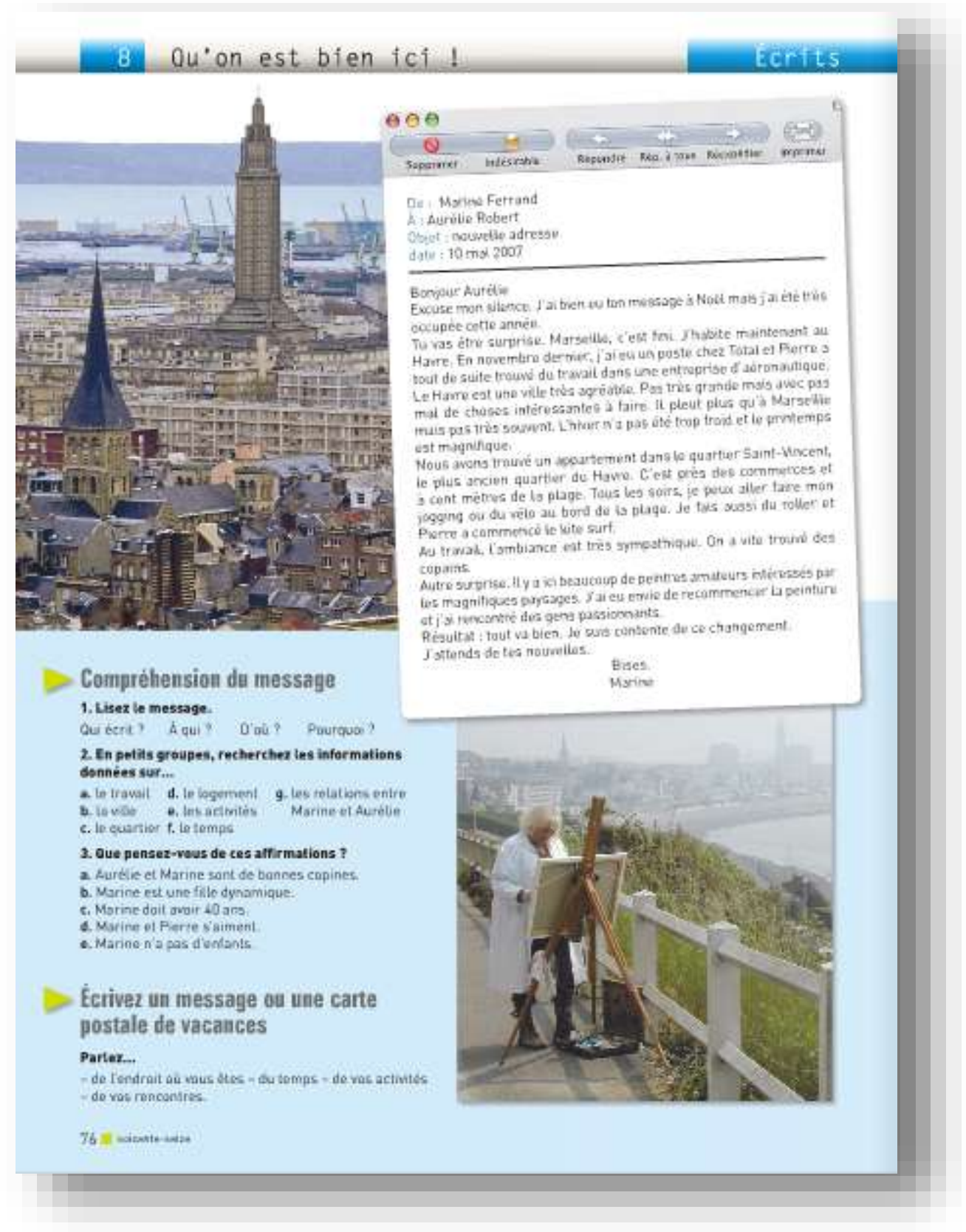


Assim como vimos nas páginas Simulations, aqui também imagens de tipologias diferentes interagem entre si e com o texto escrito na construção do sentido. Nesse exemplo (Figura 100), o documento principal - um e-mail pessoal - serve também como modelo visual e estrutural para a produção escrita que será proposta: "Escrever uma mensagem para falar de suas férias". As fotos que compõem a página são representativas de lugares (a cidade Le Havre) e atividades (a pintura) descritas no texto. Os diferentes elementos interagem e se completam para a construção da mensagem do texto multimodal. No entanto, nenhuma referência às imagens é feita nem no livro do aluno nem no guia pedagógico. Enquanto o livro do aluno começa a atividade pela frase “Leia a mensagem”, o guia pedagógico utiliza esta orientação: “Fazer uma primeira leitura para determinar os parâmetros da situação de comunicação" (Guia pedagógico, pág.54). Ora, boa parte desses parâmetros poderia ser identificada primeiramente pelo estudo das imagens. O guia pedagógico, no entanto, “pula” completamente a etapa de observação da mensagem visual, do aspecto formal e estrutural do gênero textual em questão. Passa-se diretamente à leitura do texto e às atividades de compreensão escrita.

Mais uma vez, notamos um grande distanciamento entre as possibilidades de exploração oferecida pela riqueza dos textos multimodais nos livros didáticos de FLE e a exploração efetiva dos mesmos proposta nos respectivos guias pedagógicos.

\subsubsection{Balanço qualitativo e quantitativo}

\section{- Balanço quantitativo das preconizações para o uso da imagem em Écho A1:}

A imagem permanece com uma função de "iluminura", ou seja, como um acompanhamento para o texto. Não se perde muito tempo com a imagem e passa-se rapidamente aos pontos linguísticos como vimos em orientações como: "Observar os desenhos. / Observar os balões do desenho. / Ler os balões do desenho. / Observação das frases do desenho".

\section{- Balanço quantitativo das preconizações para o uso da imagem Écho A1:}

- Número de páginas do livro do aluno - excluindo-se os anexos: 128 páginas.

- Número de páginas ilustradas no livro do aluno - excluindo-se os anexos: 122 páginas (95\%).

- Número de páginas para as quais há uma menção ao trabalho sobre a imagem no guia pedagógico: 43 páginas (35\%). 
Ao compararmos esses dados quantitativos com os dados obtidos nas análises anteriores, chegamos ao seguinte gráfico:

Figura 101 | Gráfico - Balanço comparativo Archipel 1/ Espaces 1 / Forum 1 / Écho A1

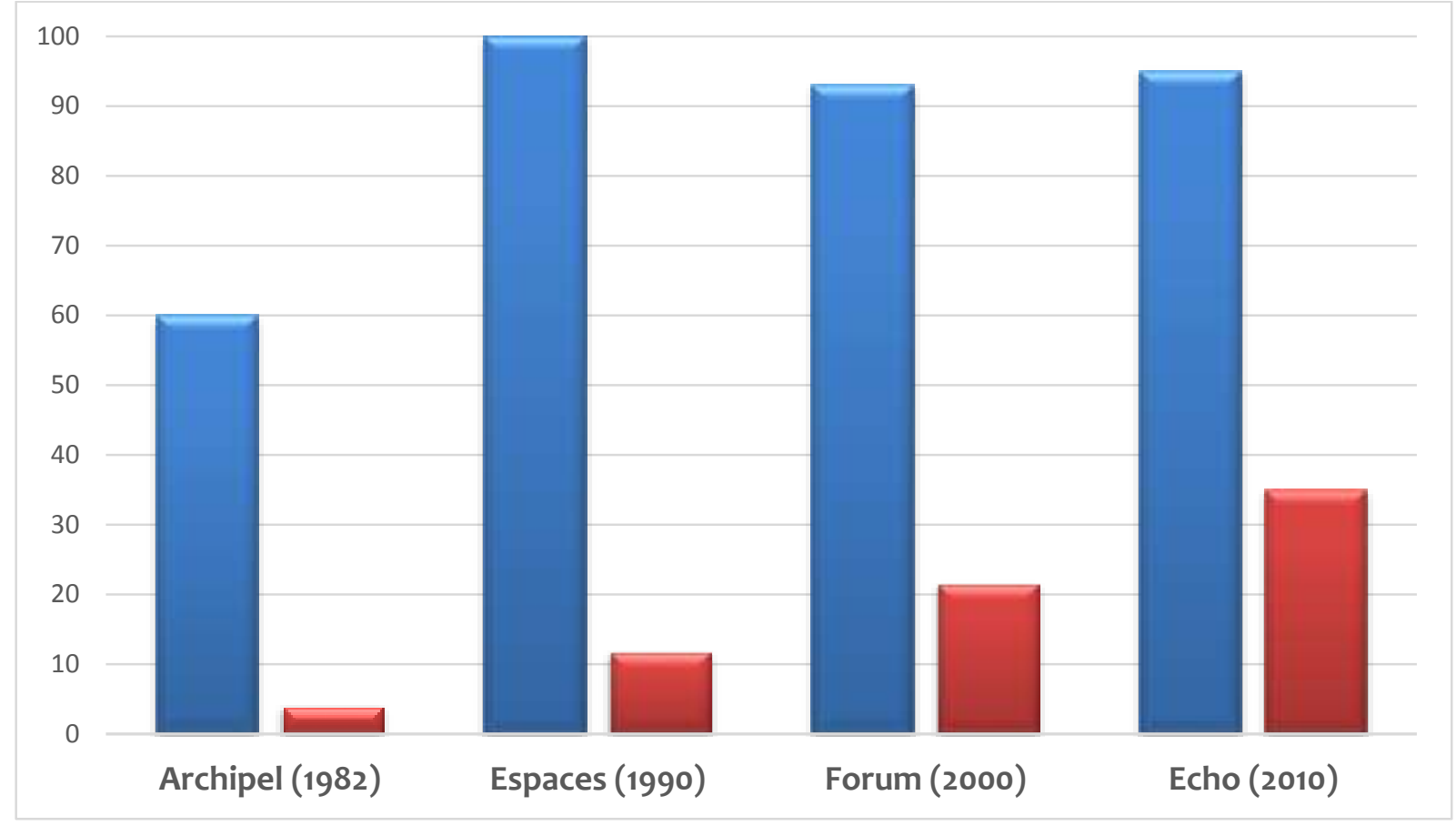

Porcentagem de páginas ilustradas no livro do aluno

Porcentagem de páginas ilustradas comentadas no guia pedagógico

Como conclusão desta análise do livro didático Écho A1, podemos afirmar que, apesar do aumento quantitativo de referências às imagens no guia do professor, a exploração pedagógica das mesmas pouco mudou. As frases de referência ao componente visual permanecem lacônicas, restritas, pouco informativas, pouco orientadoras e, resumem-se, na maioria das vezes, na expressão "Observe o desenho" ou "Observe a foto". Passa-se rapidamente em seguida ao objetivo principal da página multimodal: “Escute o diálogo" em páginas dedicadas sobretudo à compreensão oral e “Leia o texto" em páginas dedicadas sobretudo à compreensão escrita. 


\subsection{Considerações ao final desta etapa}

Ao chegarmos ao final desta etapa do trabalho, parece-nos pertinente fazer algumas considerações. Retomando os resultados dessa primeira parte da análise, acreditamos ter elementos concretos de resposta para algumas das questões que guiaram nosso estudo como, por exemplo, a questão de um eventual aumento do espaço reservado à imagem nos LDs de FLE publicados nas últimas décadas e a questão da transformação ou não do tratamento pedagógico preconizado para as mesmas nessas publicações.

As ferramentas da GDV mostraram-se eficazes e importantes para uma melhor compreensão da estrutura da imagem e do texto multimodal. No caso específico de uma página ou de uma dupla página de um LD, o conhecimento dessas ferramentas certamente ajudará o professor de FLE a explorar de forma mais consciente as imagens do livro e a estrutura do texto multimodal e o levará a explorar com mais propriedade os documentos autênticos multimodais que ele ou os alunos trouxerem para a sala de aula, em complemento ao livro didático.

No entanto, ao retomarmos nossas perguntas de pesquisa neste ponto do trabalho, identificamos um aspecto importante para o qual ainda não obtivemos elementos de resposta satisfatórios. Trata-se da identificação das funções previstas para a imagem nos livros didáticos de FLE e das funções possíveis para a mesma no ensino-aprendizagem da língua. As metafunções definidas pela GDV nos forneceram elementos estruturais importantes para a compreensão da imagem o do texto multimodal nas diferentes produções criadas pela sociedade contemporânea, principalmente a ocidental. Porém, para entender as funções da imagem no contexto específico do ensino-aprendizagem de uma língua estrangeira e, ainda mais especificamente, dentro de um LD dessa língua, devemos continuar nossa pesquisa criando métodos de análise específicos para a mesma. De fato, na citação de Joly (2007), a pesquisadora afirmava que os instrumentos de uma análise devem ser determinados em função dos objetivos da mesma e que "não há método absoluto para a análise, mas sim opções a fazer, ou a inventar, em função dos objetivos." 
Portanto, a fim de buscarmos mais informações sobre as funções previstas para a imagem nos livros didáticos de FLE, analisaremos no próximo capítulo os seguintes aspectos:

- Elementos estruturais geralmente comuns às unidades/lições que compõem um livro didático e a tipologia da imagem adotada prioritariamente para cada elemento dessa estrutura;

- Justificativas para a escolha desse tipo de imagem a partir da função reservada pelo livro didático para a mesma.

Propomos, em seguida, uma classificação nossa para possíveis usos da imagem no ensino-aprendizagem do FLE. Essa classificação, não exaustiva, tem um duplo objetivo:

- Repertoriar possíveis usos pedagógicos para a imagem de forma a contribuir para um uso mais constante e consciente da imagem pelos professores em sala de aula;

- Incentivar os professores a buscar, em suas próprias práticas docentes, outros usos e outras funções para a imagem que não foram descritos neste trabalho. 


\section{CAPÍTULO 4 | A IMAGEM NO ENSINO- APRENDIZAGEM DO FLE: UTILIZAÇÕES PRECONIZADAS, UTILIZAÇÕES POSSÍVEIS}

A pintura deve desafiar o espectador [...] e o espectador, surpreendido, deve ir ao encontro dela como se entrasse em uma conversa.

Roger de Piles. Cours de peinture par principes, 1676. 


\section{CAPÍTULO 4 | A IMAGEM NO ENSINO-APRENDIZAGEM DO FLE: UTILIZAÇÕES PRECONIZADAS, UTILIZAÇÕES POSSÍVEIS}

Fotografias, desenhos, mapas, ícones, figuras geométricas, gráficos, tabelas, reproduções de gêneros textuais do cotidiano como sites da Internet, cartas, convites, etc. Vários são os tipos de imagem utilizados nos livros didáticos de francês e a escolha por cada um deles não se faz de forma aleatória. Por que os LDs privilegiam fotografias em certas etapas de uma sequência didática e ilustrações/desenhos em outras? Quais tipos de imagem são mais utilizados para cada etapa? Quais funções são atribuídas explícita ou implicitamente a essas imagens? Como vimos até agora, poucas menções são feitas à utilização das imagens do livro do aluno nos guias pedagógicos. Mais raras são as justificativas da escolha de uma determinada tipologia visual para um determinado objetivo. Buscamos neste capítulo respostas para essas questões e, para isso, apresentamos agora uma análise transversal entre os diferentes livros didáticos analisados neste estudo com os seguintes objetivos:

- Identificar uma estrutura comum na composição dessas publicações, ou seja, identificar os diferentes componentes de uma unidade/lição de um LD de francês língua estrangeira;

- Para cada um desses componentes estruturais de uma lição, identificar se há uma tipologia dominante na escolha das imagens, como, por exemplo, fotos nas páginas dedicadas aos aspectos culturais e civilizacionais, desenhos na parte dedicada aos diálogos situacionais, e assim por diante.

\subsection{A imagem na capa dos livros didáticos}

Comecemos pela análise dos livros didáticos e pelo primeiro item estudado na análise anterior: a capa do livro do aluno. Ao fazermos uma análise transversal e cronológica das capas de LDs de FLE dos últimos 40 anos, notamos que os elementos gráficos e desenhos reinavam absolutos na década de 80 e de 90 não somente na coleção Archipel (1982), mas também em outras publicações de grandes editoras do FLE, como Bonne route, publicado pela Hachette em 1988, e Panorama, publicado pela CLE International em 2000. Mesmo se essa opção continua aparecendo em livros didáticos publicados nos anos 2000, como em Tout va bien !, publicado pela CLE Internacional em 2004, os lançamentos mais recentes parecem indicar uma nova tendência: a utilização de 
fotos, além dos elementos gráficos na capa de um livro didático de FLE. A capa do LD Bonne route mostra a silhueta longínqua do Mont Saint-Michel, um destino turístico sempre desejado, mas um pouco inatingível nessa época que precedeu a grande mobilidade internacional dos dias atuais.

Figura 102 | Bonne Route 1

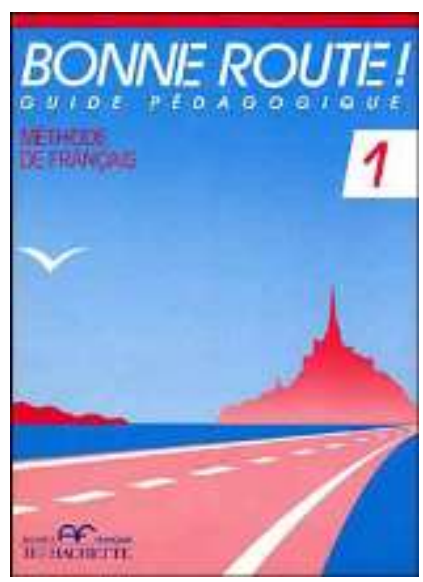

Figura 103 | Panorama 1

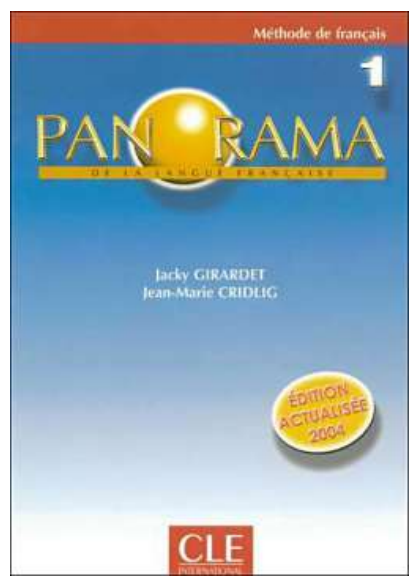

Figura 104 | Tout va bien ! 1

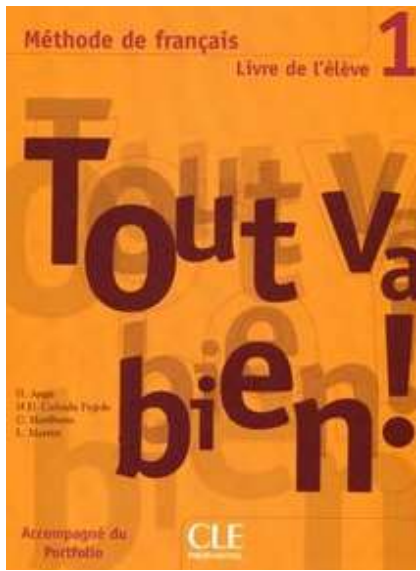

A capa do livro Espaces (1990) pode ser considerada representativa dessa passagem entre a utilização de desenho gráfico e fotos. Temos ainda uma foto na capa, mas ela aparece ainda associada a elementos gráficos comuns a outras publicações de sua época, o que podemos observar na edição Le Nouvel Espaces (2000) que acrescenta efeitos gráficos à mesma foto da edição anterior.

Figura 105 | Espaces 1

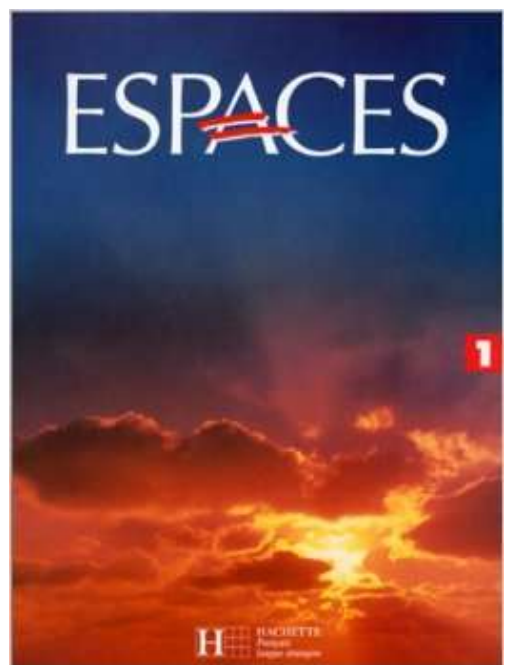

Figura 106 | Le Nouvel Espaces 1

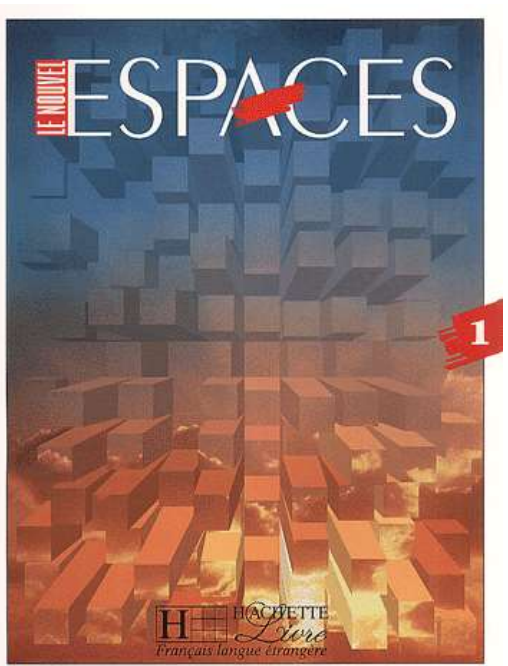


Como vimos anteriormente, a capa do livro didático Forum 1 (2000) parecia inovadora em sua época pois indicava uma tendência que se confirmaria nos anos seguintes: a utilização de fotos na capa do LD de FLE e, sobretudo, de fotos de pessoas em cenas do cotidiano, como podemos ver em alguns exemplos abaixo e no próprio livro Écho A1, publicado dez anos mais tarde e também analisado neste trabalho.

Figura 107 | Forum 1

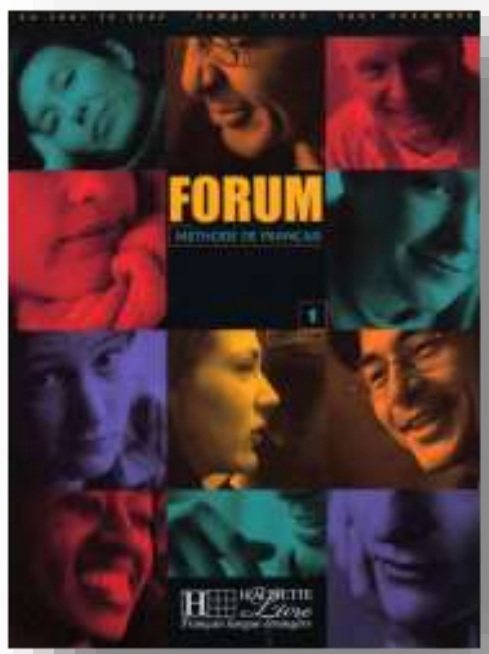

Figura 108 | Écho A1

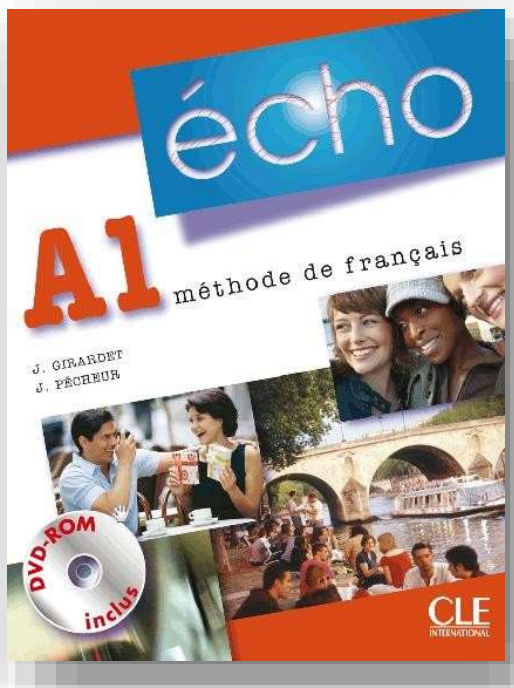

Figura 109 | Alter Ego+1

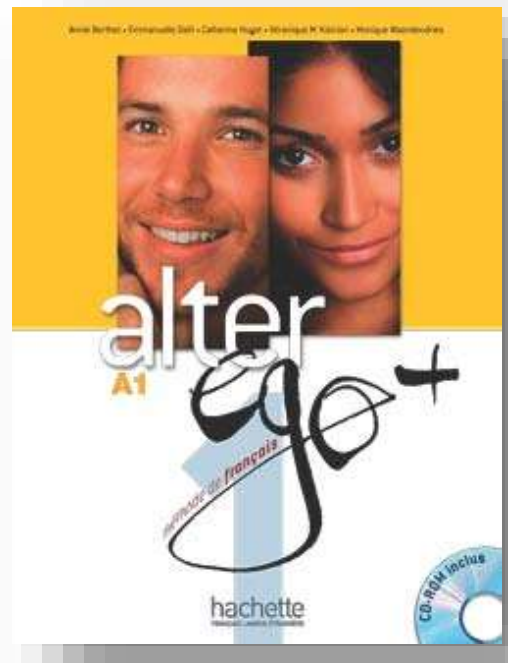

Tal tendência se impôs nos livros didáticos publicados após 2005, momento em que o QECR reforçou sua influência nas publicações de FLE. As editoras passaram não somente a indicar os níveis do QECR nas capas de seus livros, mas também a adaptar seu conteúdo, anunciando "tarefas" e "projetos" que evocam a perspectiva acional proposta pelo QECR, mesmo que os mesmos nem sempre solicitem uma participação ativa por parte do aluno. Ora, o que podemos perceber, é que, assim como o QECR concebe o aluno como um ator social que é ao mesmo tempo aprendiz, cidadão e usuário efetivo da língua em um contexto social, essa relação com o mundo real não poderia ser deixada de lado pelas publicações de FLE. Ela passa a ser levada em conta no próprio conteúdo do LD, que propõe tarefas "acionais", mas também na capa da publicação já que ela representa, por meio de fotografias, esses mesmos atores sociais em ação, em um determinado contexto. De fato, o aprendizado da língua não pode estar dissociado do contexto social em que ela é utilizada, nem da sociedade em que o aluno vive e a 
utiliza - seja em uma viagem ou mesmo sem sair de seu ambiente de trabalho ou de sua casa, graças às interações possíveis pela Internet.

Ao compararmos, portanto, a capa do livro didático Panorama (2000) com a de outro livro mais recente como Agenda (2010), vemos que o ensino-aprendizagem do FLE parece - também por meio da imagem e nas capas de seus LDs - deixar de lado o aspecto escolar e caminhar em direção a uma imersão sociocultural no mundo real.

Figura $110 \mid$ Panorama 1

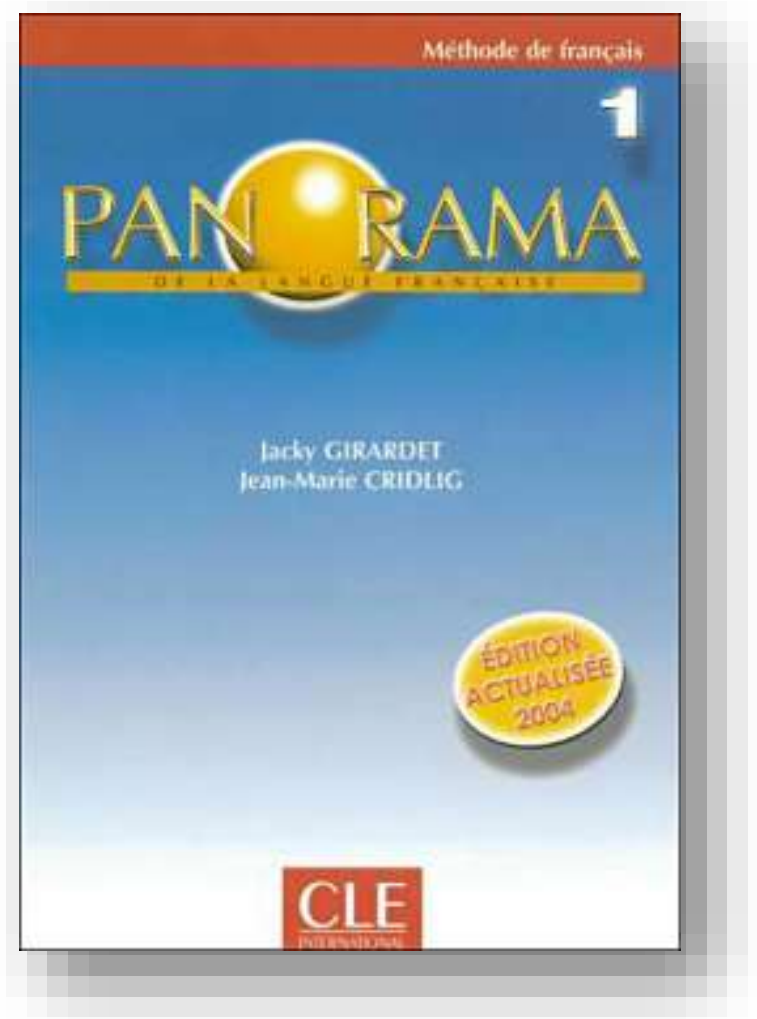

Figura 111 | Agenda 1

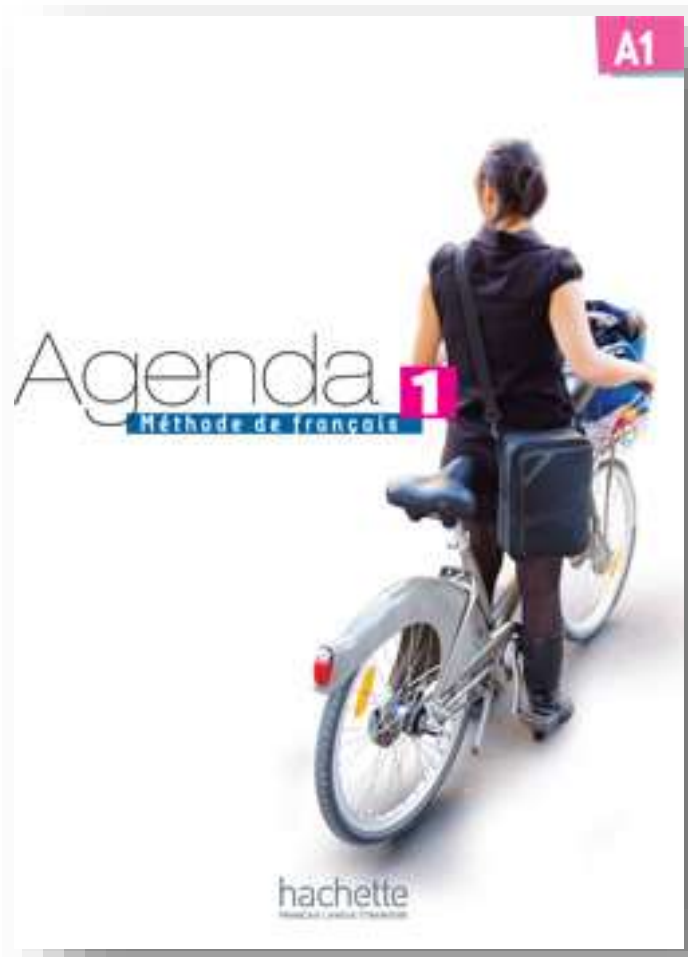

\subsection{A imagem na página de abertura de uma lição ou de um conjunto de lições}

Em alguns métodos, como Archipel e Espaces, essa página aparece na abertura de cada lição do livro do aluno que, como vimos, pode também levar o nome de "dossier" ou "unité", mas que representa, em todos os casos, uma unidade de conteúdo e temática, construída em torno de objetivos comunicativos, linguísticos e socioculturais comuns. Em outros livros didáticos, como Forum e Écho A1, apenas a página de abertura dos "módulos", compostos por três ou quatro lições, é ilustrada. 
A descrição fornecida pelo guia pedagógico de Archipel para essa página explica sua função de forma bastante adequada para os outros LDs estudados: "Uma imagem (desenho ou foto) que ilustra o título e os objetivos funcionais da unidade." (Archipel 1 Guia pedagógico, pág. 7). Por vezes, esses objetivos também são descritos em um pequeno texto.

Os quatro LDs que estudamos utilizam fotografias para a composição dessa página, sendo Archipel o único que, por vezes, utiliza também desenhos. Ao observarmos, no entanto, publicações mais recentes (Figuras 114 a 117), vemos que essa opção pela fotografia se confirma.

Figura 112 | Archipel 1 - pág.101

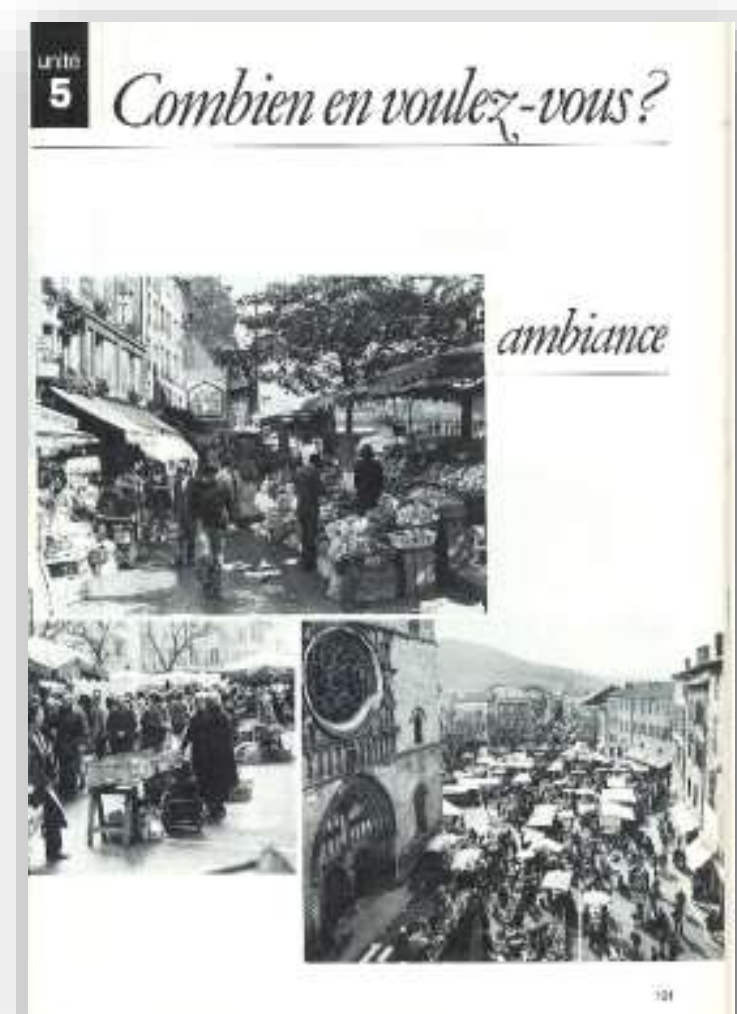

Figura 113 | Archipel 1 - pág.55

\section{Ois allez-vors?} ambiasce 
Figura 114 | Espaces 1 - pág. 63

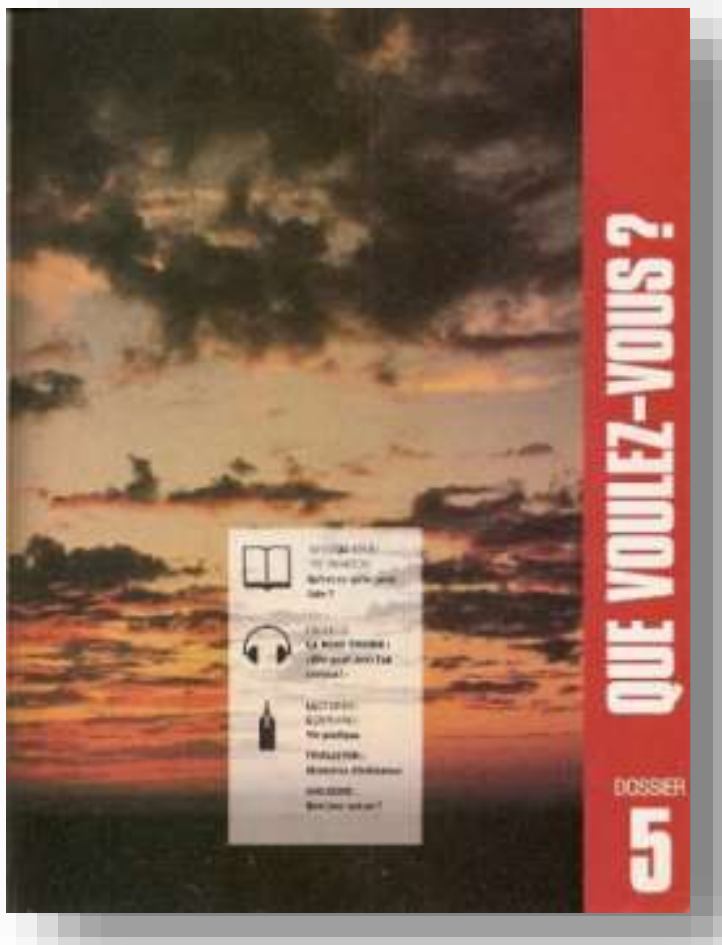

Figura 116 | Écho A1 - pág. 85

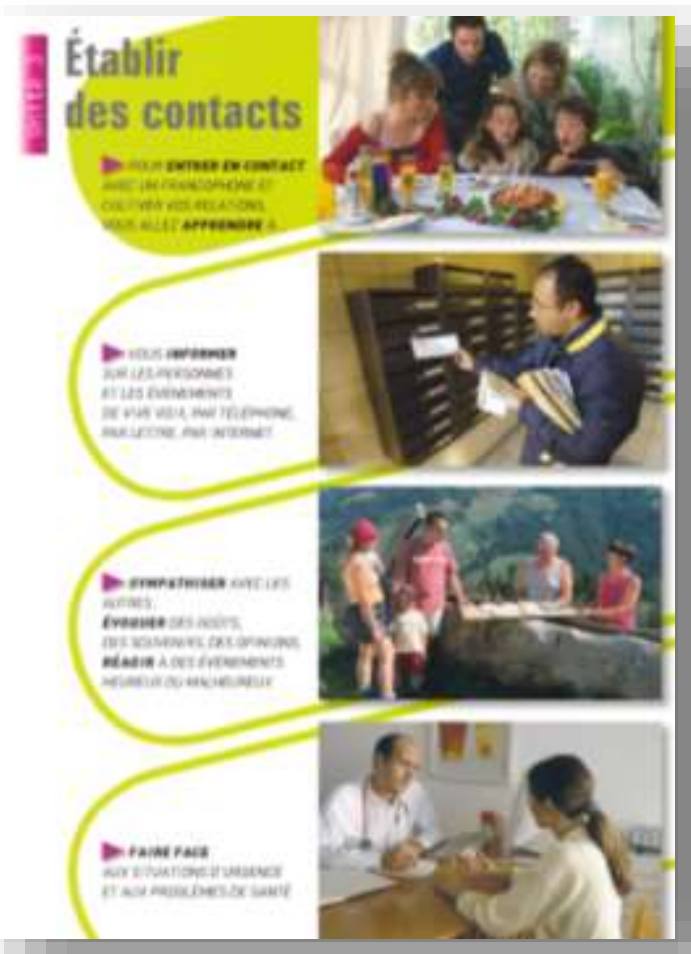

Figura 115 | Forum 1 - pág. 19

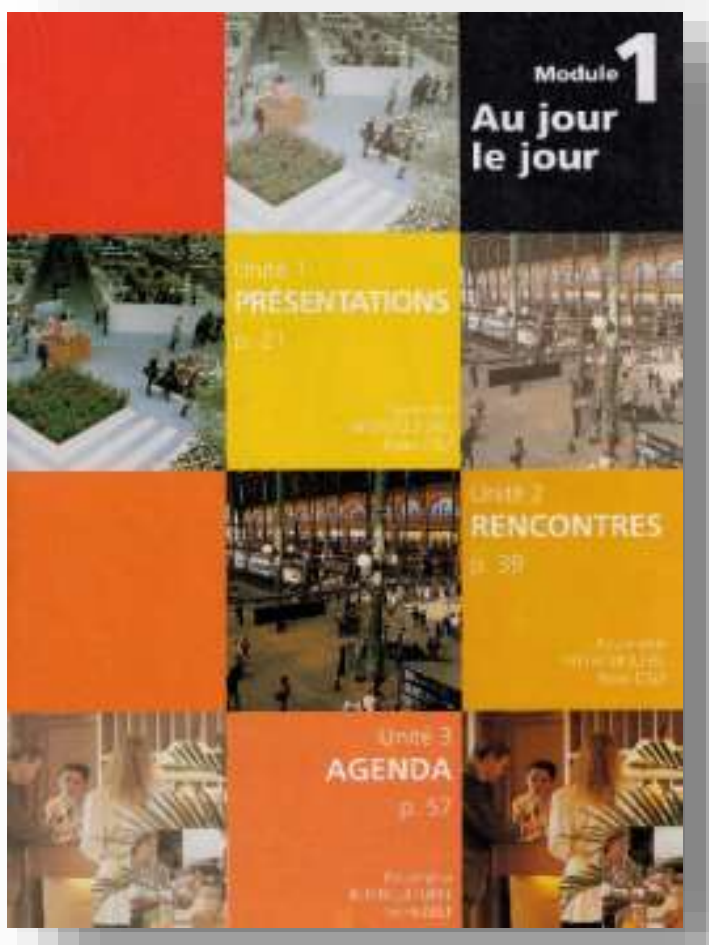

Figura 117 | Alter Ego+ 1 - pág. 85

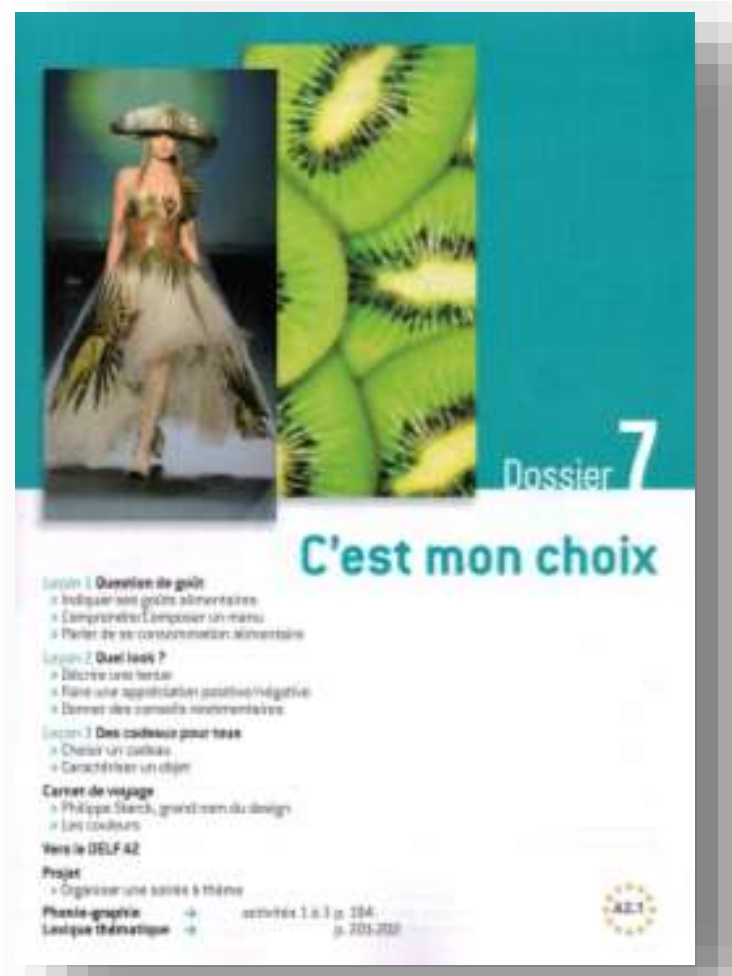


Essa página de abertura tem como finalidade trazer situações da vida cotidiana do aluno para dentro da sala de aula. Partimos do conhecido, do real, do sentido global e passaremos aos poucos - e dentro de cada lição - ao menos conhecido, ao mais específico, às novas formas linguísticas. Nada mais coerente, portanto, do que a escolha do tipo de imagem mais representativo do "mundo real": a fotografia.

Com exceção do livro didático Espaces, essas fotografias fazem referência a situações de comunicação que serão abordadas nas páginas seguintes do livro do aluno: situações cotidianas em um restaurante, em um mercado, em uma estação de trem, em um hotel, etc.

Os objetivos comunicativos, linguísticos e interculturais também são descritos nessa mesma página associando-se, assim, o texto escrito à imagem. Nos livros didáticos mais recentes, que costumam ter por base teórica o QECR, é comum que esses objetivos apareçam sob forma de tarefas que o aluno será capaz de cumprir ao final de cada lição ou de um projeto que será realizado pelo grupo ao final de um conjunto de lições. Como em outras páginas multimodais, as imagens interagem com o texto na composição do sentido.

\subsection{A imagem e as situações comunicativas}

Um componente que costuma estar presente nos livros didáticos de FLE é a página ou dupla página com diálogos situacionais e atividades de compreensão oral. Nos LDs analisados neste estudo, vimos que esse componente da lição pode se apresentar sob duas formas:

- Em situações mais amplas de comunicação com textos orais ou escritos sempre acompanhados por imagens, geralmente em um tamanho maior do que outras imagens utilizadas no livro. Essas situações "abrem" a unidade de forma mais ampla e introduzem alguns pontos linguísticos;

- Em situações mais precisas de comunicação com diálogos para o treinamento da compreensão oral e a introdução e desenvolvimento de pontos linguísticos mais precisos. Esses diálogos trazem, por vezes, personagens próprios do LD dentro de uma história que se desenrola ao longo das lições. Eles trazem um corpus importante para o trabalho sobre a estrutura da língua (gramática, léxico, fonética), uma vez que os elementos linguísticos a serem trabalhados estão inseridos em um contexto situacional. 
Analisamos, a seguir, a presença da imagem nesses dois tipos de situações comunicativas.

\subsubsection{Situações mais amplas para uma abertura temática da lição}

Trata-se da opção adotada pelos livros didáticos Espaces 1, Forum 1 e Écho A1. Nesses livros, a primeira dupla página é destinada a uma situação de comunicação mais ampla. Uma grande foto costuma ocupar um lugar de destaque trazendo elementos representativos de diferentes situações de comunicação. Textos escritos e/ou orais completam a página e são acompanhados por atividades de compreensão escrita e/ou oral. Alguns pontos linguísticos podem ser ressaltados em pequenos quadros em forma de lembretes linguísticos, como vemos nos exemplos a seguir.

Figura $118 \mid$ Espaces 1 - pág. 78, 79

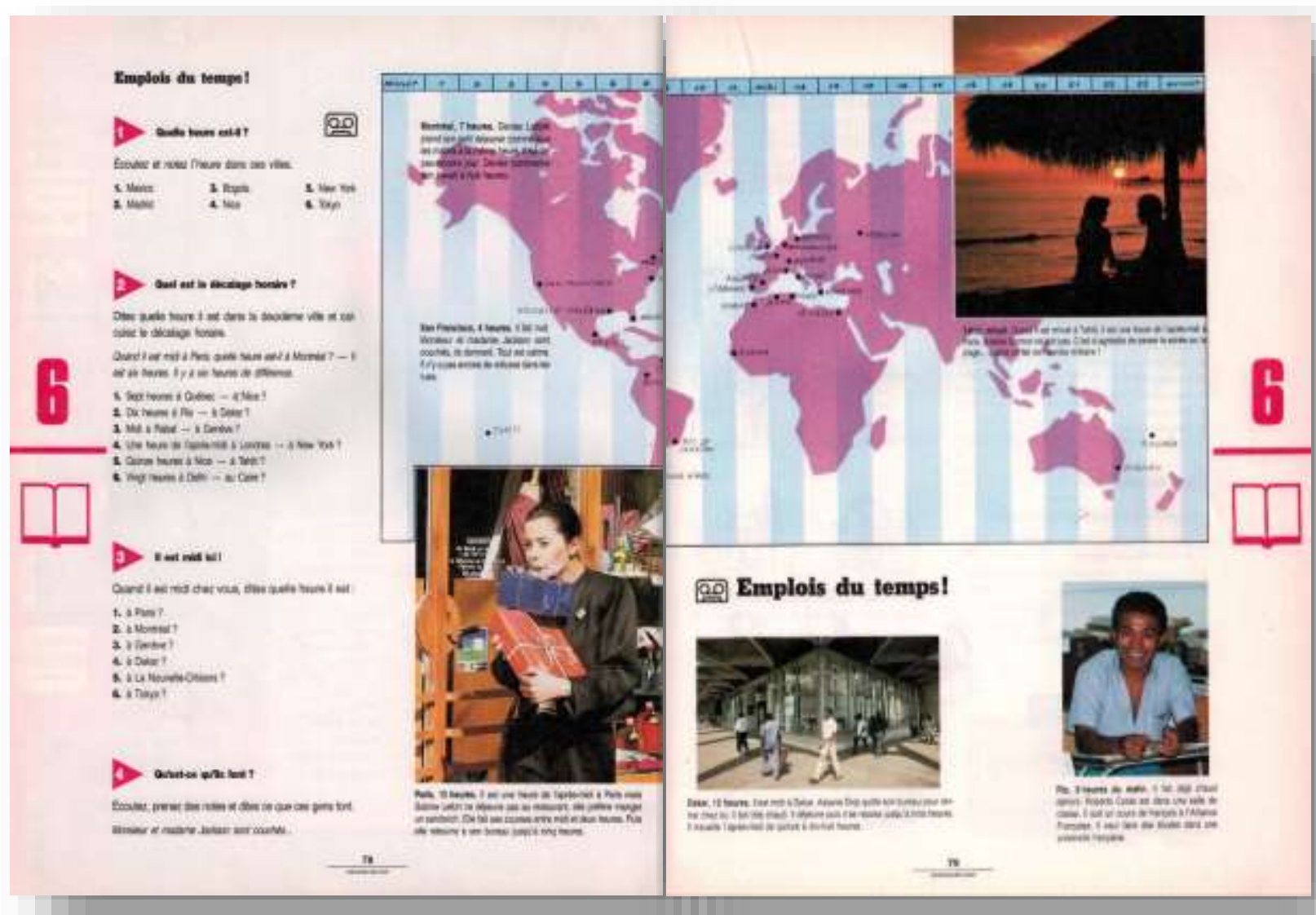


Figura 119 | Écho A1 - pág. 62,63

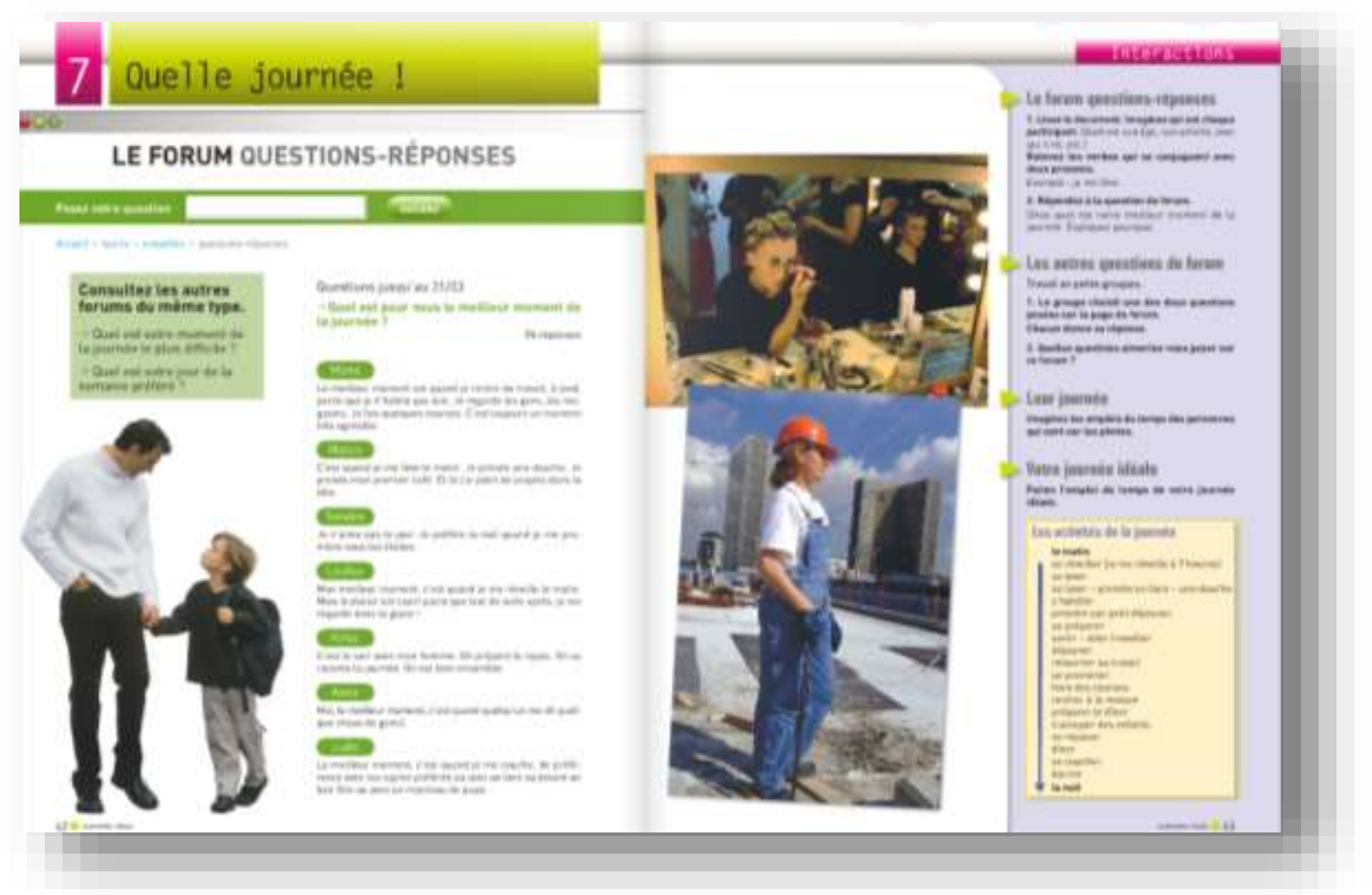

No que diz respeito à tipologia das imagens, é interessante notar o papel de destaque da fotografia nessas páginas de introdução. Assim como na página de abertura da lição, os livros didáticos parecem buscar nas referências cotidianas dos alunos elementos de introdução a uma primeira situação de comunicação. A fotografia - em imagens que retratam instantâneos do cotidiano - é, portanto, a escolha mais comum para essas páginas. Curiosamente, da mesma forma que conteúdo abordado é amplo, pois ainda não estamos no estudo preciso de um ponto linguístico, as imagens também possuem dimensões maiores do que em outras páginas e parecem acompanhar essa intenção de se partir do global para o mais preciso, do mais conhecido para o menos conhecido, como veremos adiante ao estudarmos outras duplas páginas que costumam constituir uma unidade didática.

No caso do LD Forum 1, essa progressão do mais amplo para o mais específico é particularmente clara logo nessa primeira dupla página. Como vimos anteriormente, ela é composta por uma grande fotografia situacional descrita no guia pedagógico como uma "foto funcional que sugere o ambiente geral da unidade" (Guia pedagógico, pág. 10). 


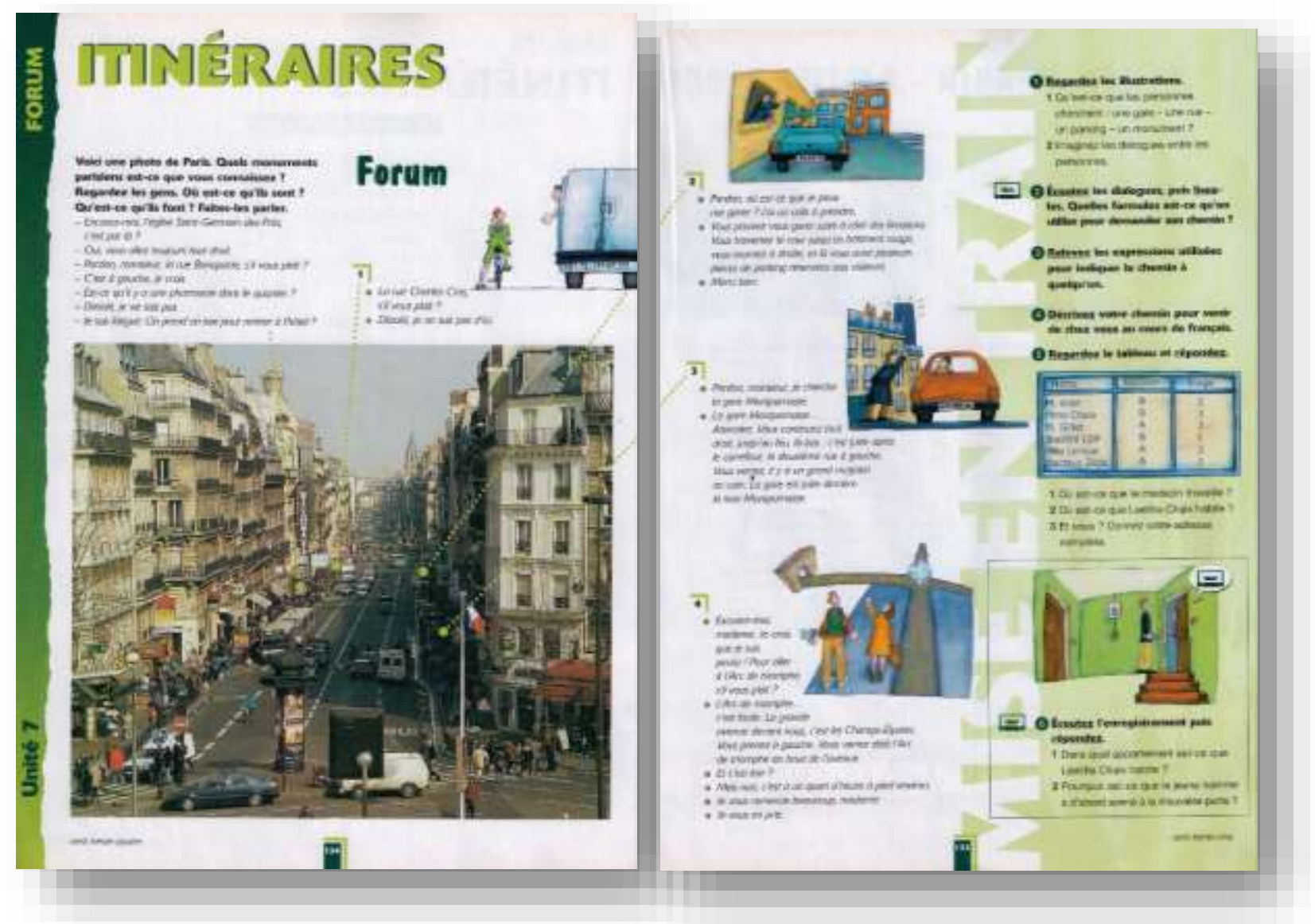

A partir dessa foto, partem vetores em formas de flechas que conduzem a situações de comunicação mais específicas e, desta vez, ilustradas por desenhos. Esses pequenos desenhos também são mais específicos pois representam situações de comunicação mais particulares, acompanhadas por diálogos e suas respectivas transcrições. Mais uma vez, passamos do mais conhecido (grande foto à esquerda) ao menos conhecido (pequenos desenhos à direita), retomando as teorias da GDV para a cultural ocidental.

A utilização da imagem segue esse mesmo percurso de aproximação, já que começamos a sequência didática por uma grande fotografia ilustrativa da vida cotidiana com um ângulo de visão mais amplo e passamos aos detalhes, aos diálogos que estariam por trás dessa grande imagem. Ao passarmos ao diálogo, ou seja, ao mais específico, a imagem mais utilizada nos livros didáticos passa a ser o desenho, como vimos nesse exemplo de transição entre uma etapa e outra e como veremos no item a seguir. 


\subsubsection{Diálogos situacionais para compreensão oral}

Trata-se de uma parte bastante comum nos livros didáticos de FLE: pequenos diálogos situacionais, acompanhados pela transcrição correspondente e por imagens, na grande maioria das vezes, desenhos, como podemos constatar nas figuras a seguir. A escolha por desenhos justifica-se pelo fato de muitos LDs optarem pela criação de uma história própria, com seus próprios personagens. O aluno acompanha a progressão narrativa dessa história ao longo do livro. Dos quatro livros didáticos analisados neste trabalho, três optam pela criação de personagens e de uma história que é ilustrada por desenhos: Espaces 1, Forum 1 e Écho A1. No caso do LD Espaces, a proposta é mais original pois optou-se pela criação de uma história em quadrinhos (Figura 122) ao invés de desenhos separados de sua transcrição, como é o caso dos outros livros didáticos (Figuras 121, 123, 124).

Figura 121 | Archipel 1, pág. 80, 81

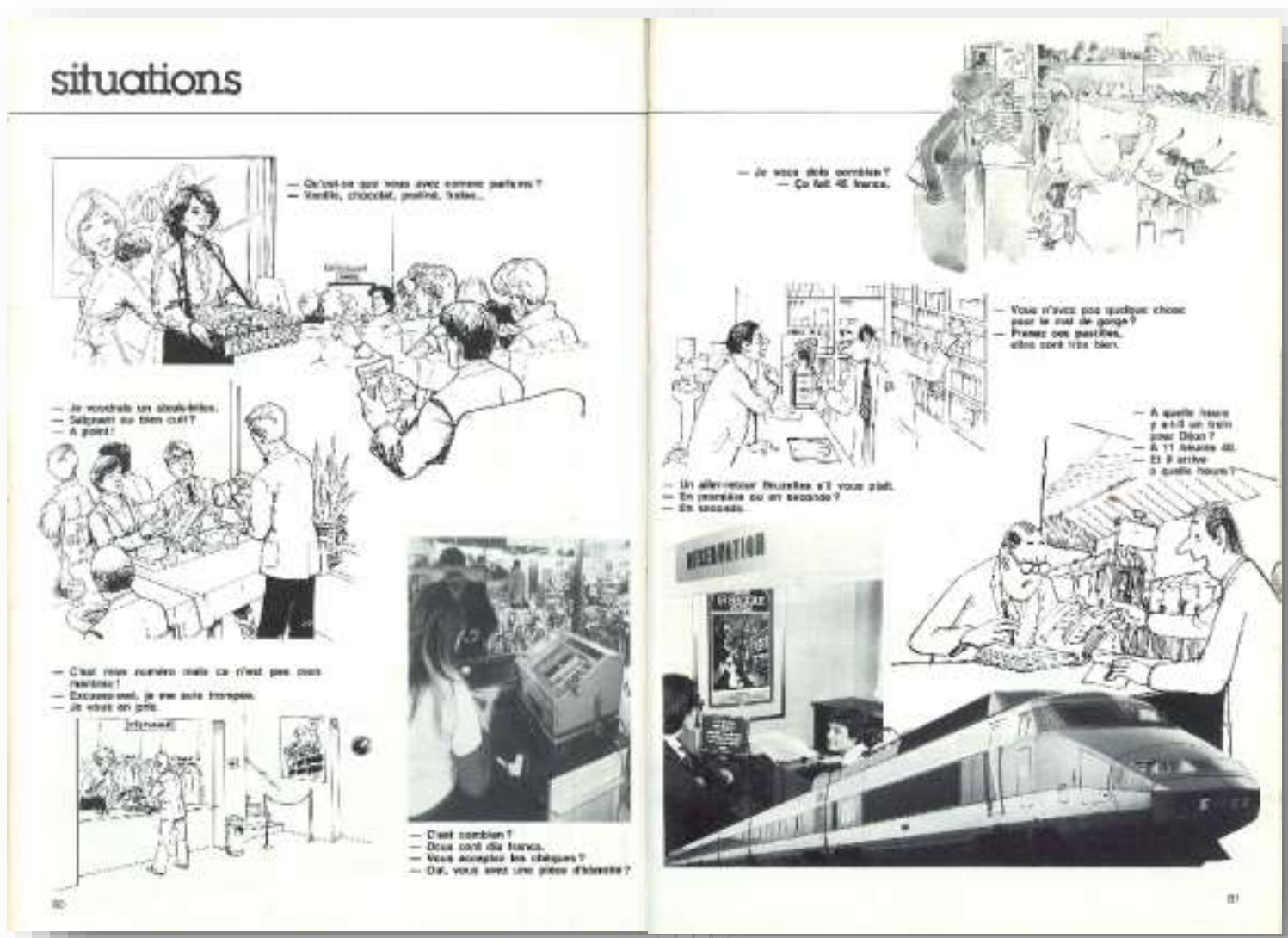


Figura 122 | Espaces 1 - pág. 82, 83

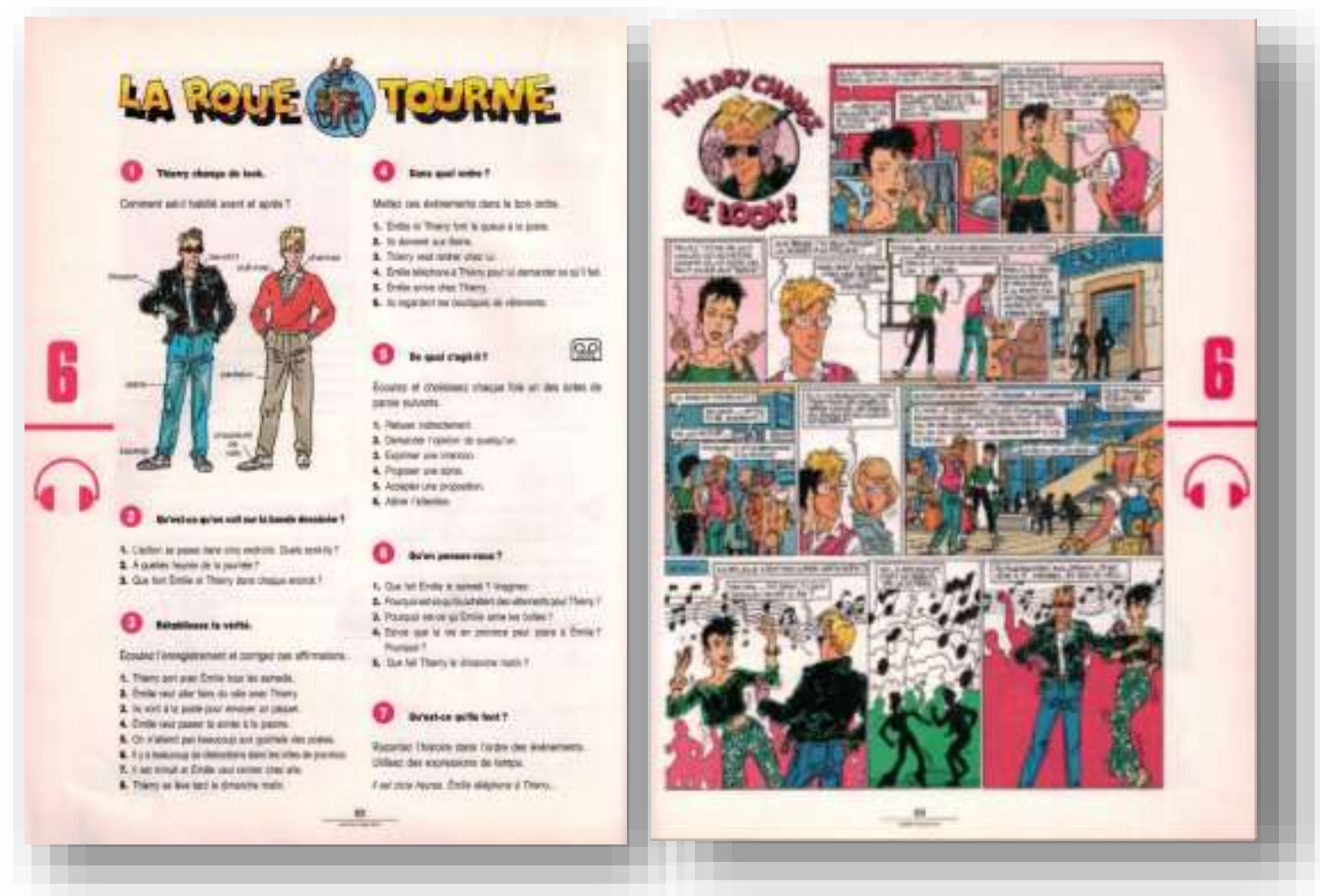

Figura 123 | Forum 1 - pág. 80, 81

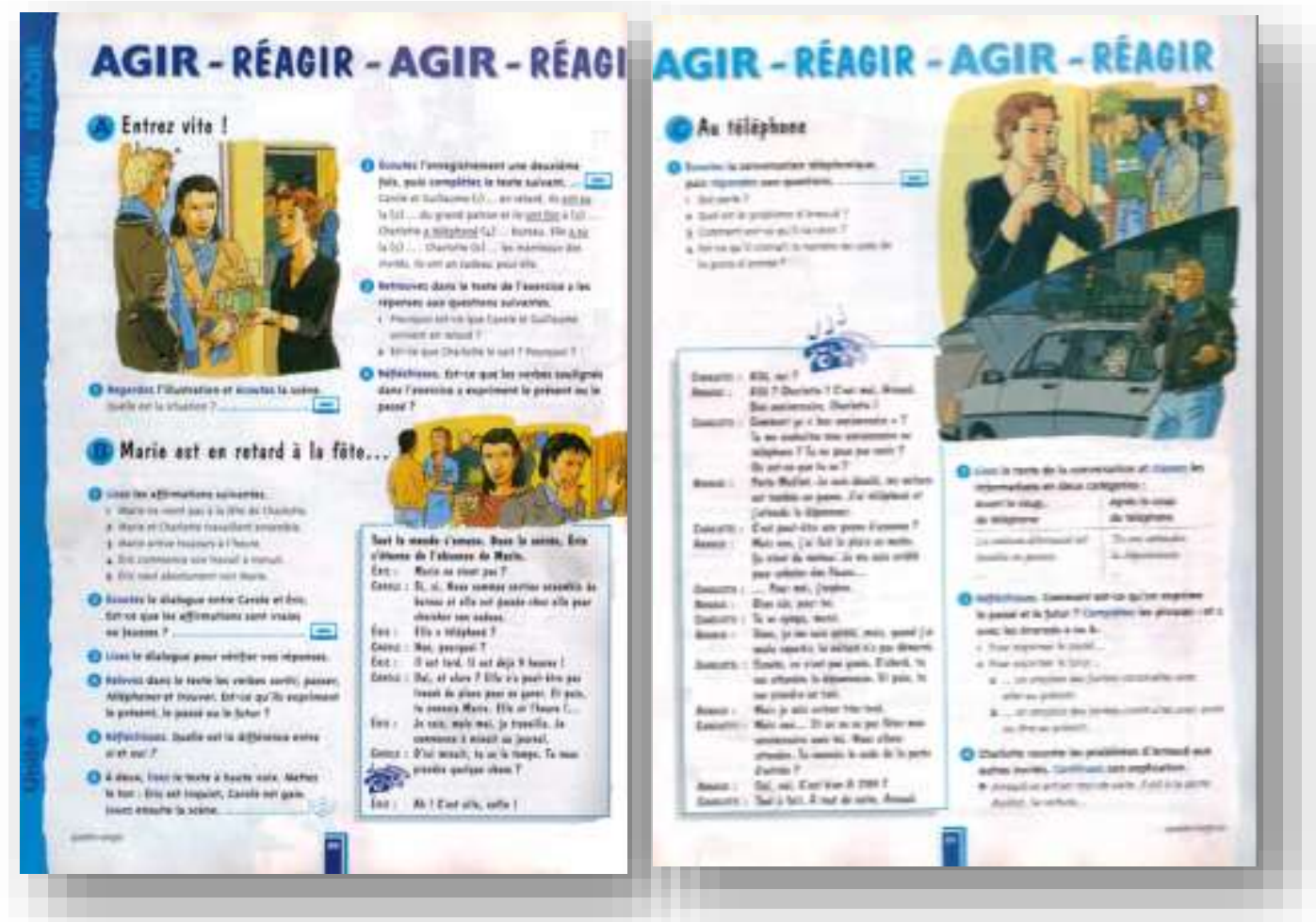




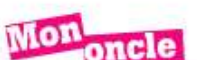
de Bretagne

\section{(11)}

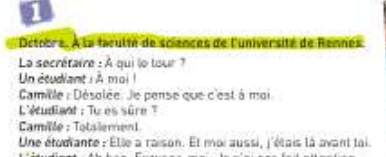

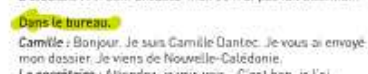

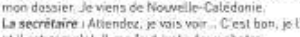

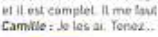
ound camile sort du burease

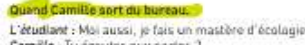

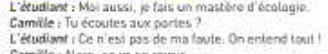

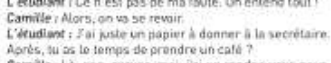

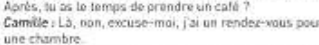

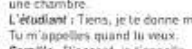

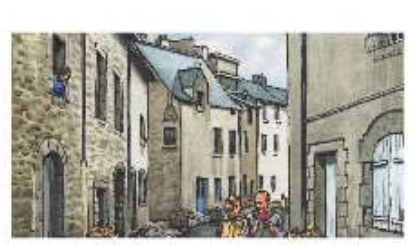

\section{2- Enquète à Saint-Malo}

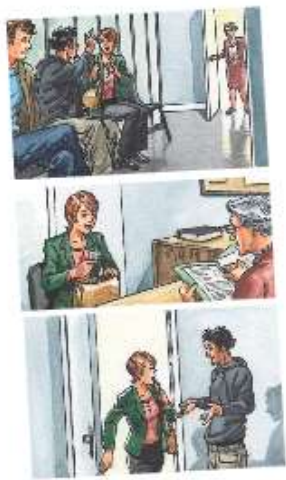

\section{2}

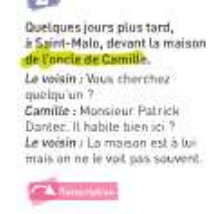

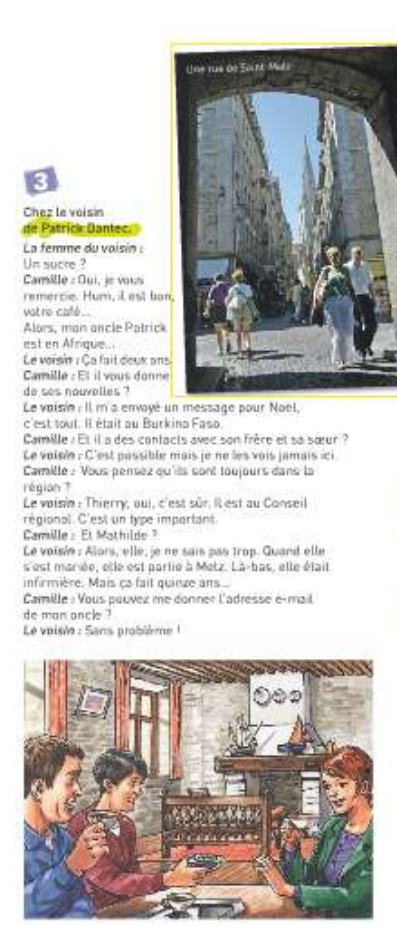

Comprèiension et simulations Q1. Scene 1 . Que s'est-a passe depuis répisode précedent

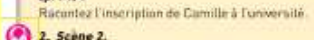
Transerivaz lo dialogue. au'apprend-on ser 3. hevez la scéne la seuxl.

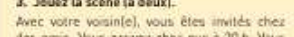

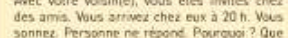

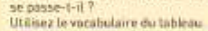
Paur exprimer ane opinian

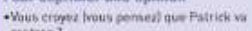

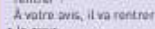

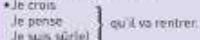

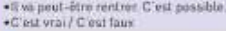
(9) Sccemes. sonnages de rhistoire.

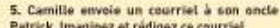

(6) Soms, nthmes, intonatimns

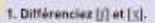

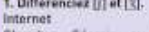

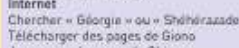

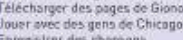

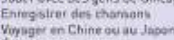

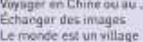
2 Ditterenciez $|s|-|z|-10|-| z \mid$.

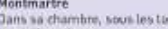

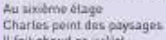
Eilit neige en jamier

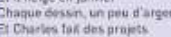
al Cheres tor des praps:
hwoc sie harmanto wisine

Os professores de FLE conhecem tão bem essa estrutura que utilizam frequentemente a mesma metodologia de trabalho para sua exploração: pedir aos alunos que observem a imagem, que descrevam o ambiente situacional da mesma (quem são os personagens, onde estão, em que momento do dia, o que fazem, etc.). Por vezes, os professores pedem aos alunos que formulem hipóteses para o conteúdo do diálogo antes da escuta - de que assunto os personagens estão falando? O que pretendem fazer? etc. - em uma tentativa de prepará-los para a compreensão oral e, ao mesmo tempo, de suscitar o interesse pela escuta do documento sonoro. O próprio LD costuma propor questões de compreensão oral global e, após uma segunda escuta, questões de compreensão oral mais detalhada. Quando essas atividades não aparecem explicitamente no livro do aluno, o próprio professor costuma criá-las de modo a explorar plenamente a compreensão do sentido global para poder, em seguida, trabalhar sobre as novas estruturas linguísticas presentes no respectivo diálogo. 
Em todos os livros didáticos que analisamos, a imagem tem o papel de "facilitar" a compreensão oral. Isso acontece no procedimento que acabamos de descrever, no qual ela é utilizada na antecipação do diálogo, e é confirmado pelos próprios guias pedagógicos que analisamos. O guia de Archipel é um pouco mais explícito nesse ponto quando propõe a seguinte orientação ao professor:

Chaque unité comporte en général les matériaux suivants ; Six à dix courtes situations, constituées de dialogues enregistrés. Elles sont accompagnées d'un film fixe visualisant le lieu de communication et les principales attitudes des personnages. Ces images [...] servent de point de départ à la compréhension globale de la situation. Très tôt, l'écoute du texte se substitue à l'image qui s'efface pendant la phrase de mémorisation. » [...]

Guide pédagogique, pág. 13. Grifo nosso.

Mais de quarenta anos mais tarde, a abordagem prevista pelos guias pedagógicos para os desenhos que acompanham os diálogos ainda é a mesma. Em Écho A1, por exemplo, a única referência às imagens das páginas 98 e 99 (Figura 124) aparece no início da explicação da sequência didática, com a seguinte frase para o primeiro diálogo: “Observer le dessin et écouter le dialogue." Nenhuma outra referência às imagens aparece nem no guia pedagógico nem no livro do aluno para essa dupla página. Todas as outras atividades direcionam-se exclusivamente para a compreensão dos diálogos. Ao final da sequência didática, por vezes há uma sugestão de produção oral ou escrita como um prolongamento da situação de comunicação. No caso específico dessa dupla página de Écho A1, propõe-se uma produção escrita na qual a personagem da história escreverá um e-mail para seu tio. $\mathrm{O}$ aluno deverá redigir a mensagem. Como vimos anteriormente, esse "abandono" da imagem logo após a sua descrição acontece mesmo no livro didático Espaces 1 que opta, no entanto, por uma história em quadrinhos. As atividades que se seguem após uma primeira observação dos desenhos concentram-se exclusivamente na compreensão escrita e oral do documento, já que os diálogos da história em quadrinhos são também gravados.

Outro tipo de imagem pode também acompanhar os diálogos do livro, reforçando o aspecto multimodal dessas páginas. Observemos a figura a seguir (Figura 125). 


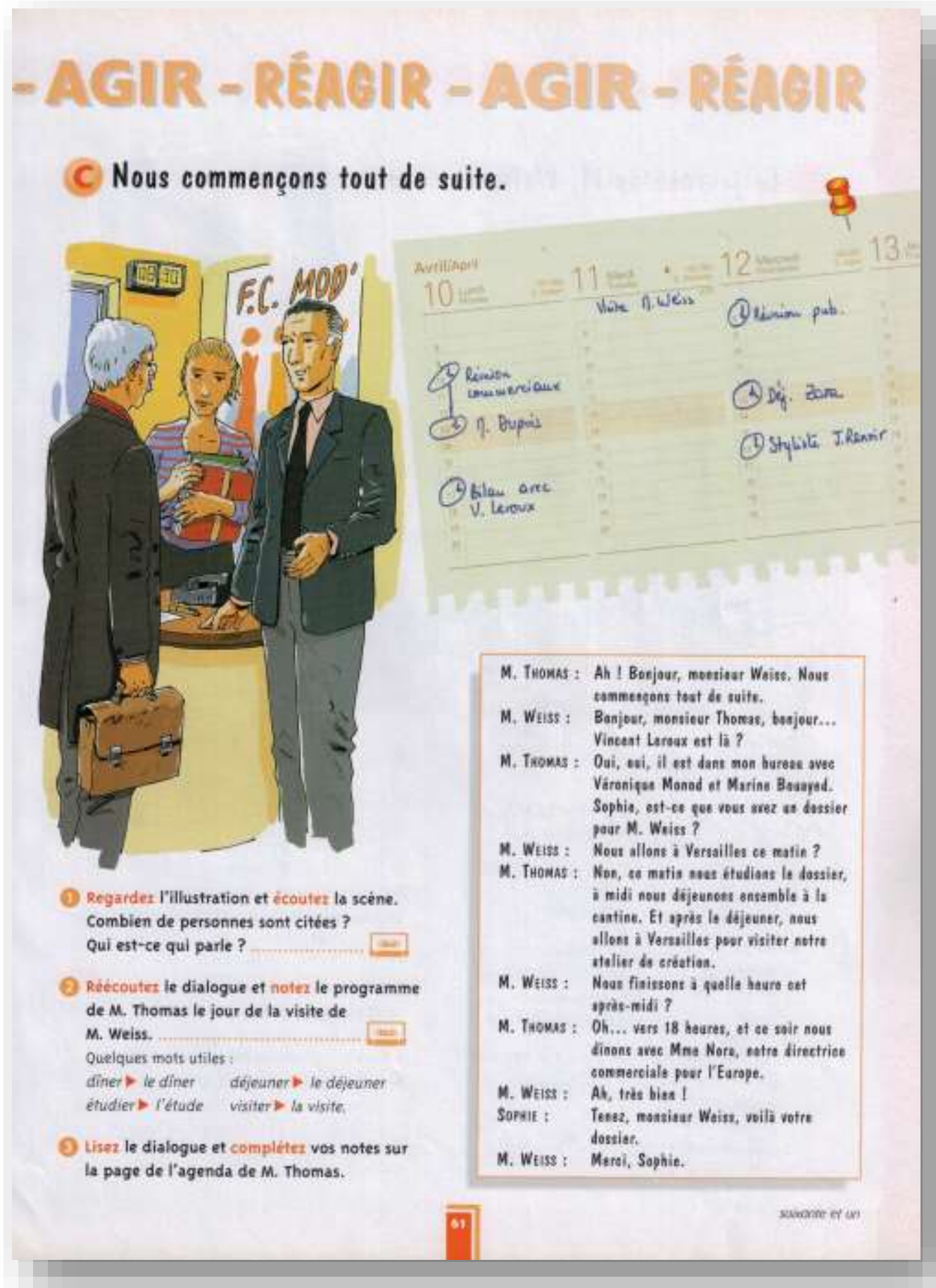

No que diz respeito à imagem, a leitura e a construção do sentido dessa página são feitas por dois suportes visuais: um desenho que ilustra os personagens na situação de comunicação do diálogo, como na maioria dos livros, mas também a imagem de uma agenda com os compromissos da semana.

Esses compromissos são citados no diálogo que, por sua vez, contribuirá para a construção do sentido por meio de componentes sonoros e também escritos 
(transcrição do diálogo). Essa multiplicidade de fontes, de suportes e de tipologias da imagem favorece uma multiplicidade de leituras pelo aluno e, consequentemente, uma melhor apropriação do conteúdo comunicativo, linguístico e cultural pelo mesmo. Ainda que essa riqueza não seja comentada ou explorada no guia pedagógico correspondente, acreditamos que o professor de FLE deve estar atento para explorar cada uma delas em toda a sua complexidade.

O mesmo acontece na composição das páginas multimodais das figuras abaixo, nas quais a ilustração de um gênero textual específico completa a construção do sentido:

Figura 126 | Écho A1 - pág. 58, 59

Gênero textual representado:

Menu de restaurante

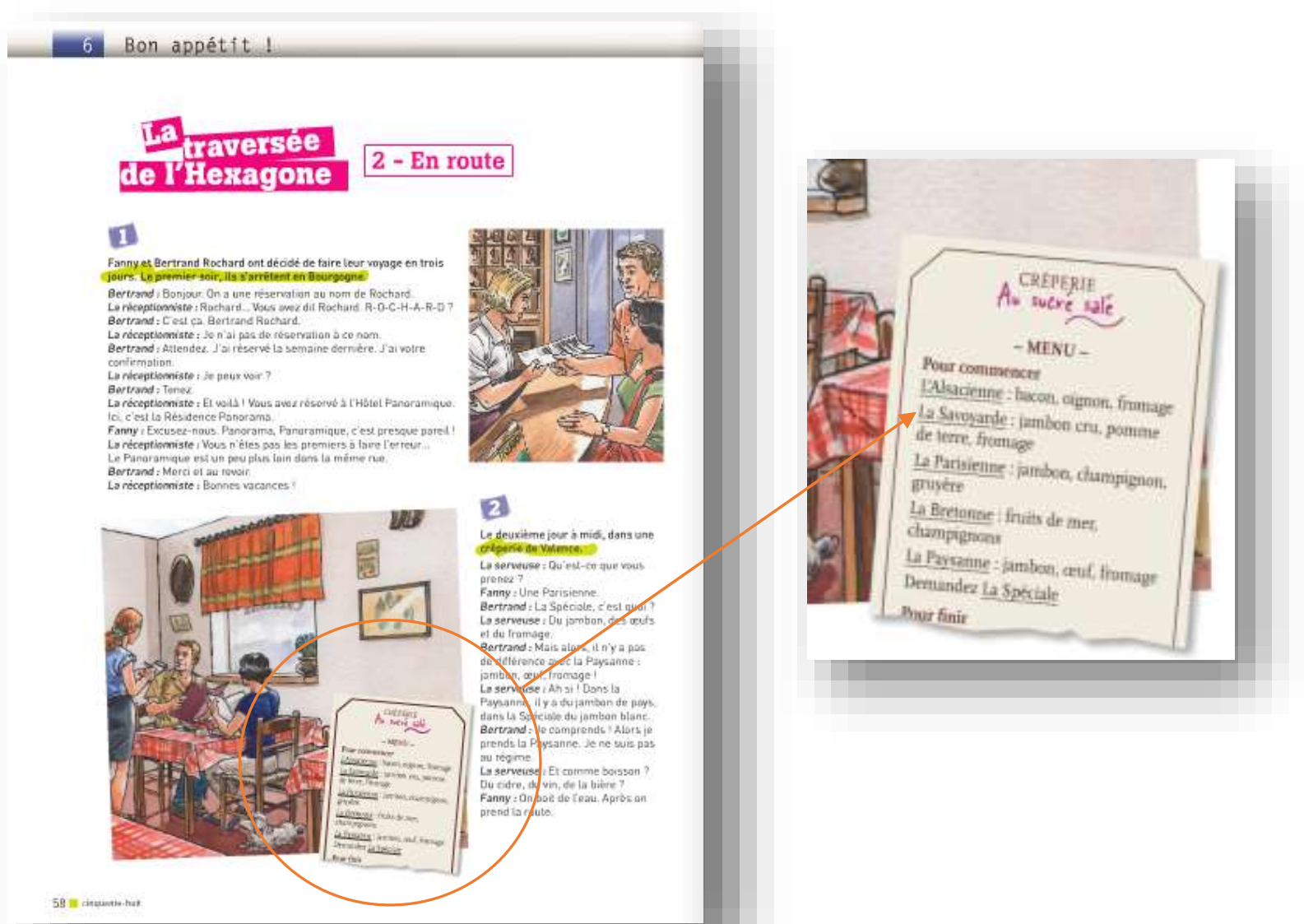


Figura 127 | Forum 1 - pág. 154

Gênero textual representado:

Um guia cultural semanal

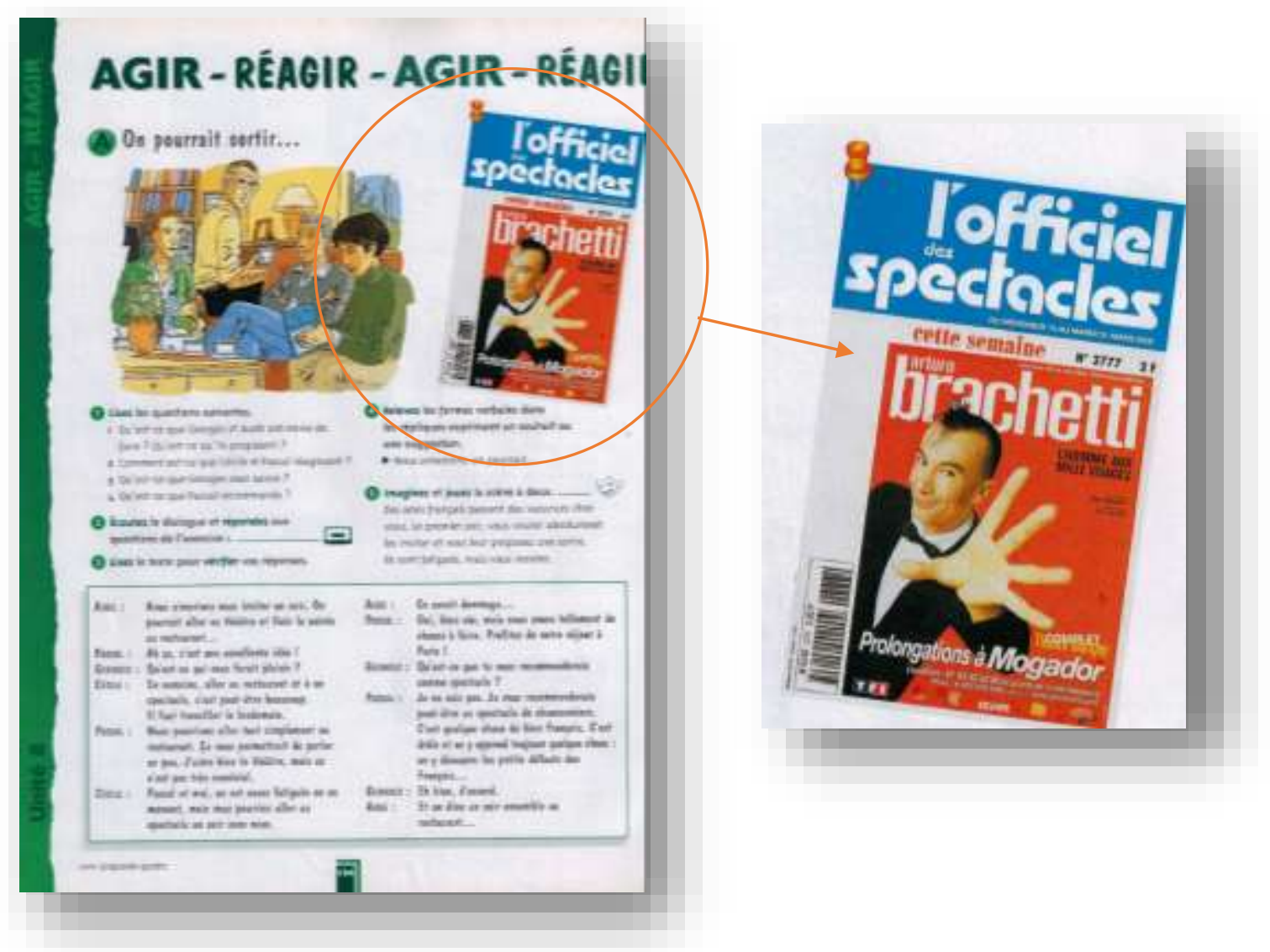

Como os diálogos são fabricados, assim como os desenhos dos personagens concebidos exclusivamente para o LD, essa fotografia de um gênero textual do cotidiano traz mais autenticidade ao diálogo do livro, estreitando sua relação com o mundo real, além dos aspectos culturais e do enriquecimento que eles trazem à sequência didática no caso acima, com uma foto da capa do guia L'officiel des spectacles que não é citado no diálogo, mas que contribui com um importante acréscimo cultural à construção de sentido da página.

\subsubsection{Atividades de produção oral}

Como vimos anteriormente, as atividades de produção oral costumam ser propostas ao final dos dois tipos de duplas páginas que vimos acima. No primeiro caso, elas estarão 
mais associadas à fotografia situacional que apresenta de forma mais ampla o conteúdo temático da lição e, no segundo caso, a produção oral aparece mais associada aos desenhos das situações e ligadas a determinados personagens. Pede-se, por exemplo, que os alunos interpretem outras versões para a mesma cena ou imaginem a cena seguinte da história. As propostas de simulações e de "jeu de rôles" permanecem nos livros didáticos mais recentes, teoricamente mais próximos da perspectiva acional do que da abordagem comunicativa, metodologia na qual esse tipo de atividade era bastante solicitado.

\subsection{A imagem e o conteúdo linguístico}

O conteúdo linguístico de uma lição pode ser apresentado em páginas específicas para esses objetivos ou integrados às páginas das situações de comunicação, por meio de tabelas e quadros que compõem - juntamente com textos escritos, orais e imagens as páginas multimodais.

Os quatro livros didáticos que analisamos neste trabalho possuem páginas específicas para a abordagem do conteúdo linguístico de cada lição. Essas páginas costumam aparecer após as páginas de situações de comunicação orais e escritas que vimos anteriormente e antes de partes dedicadas à produção escrita e/ou aos aspectos culturais.

Veremos, a seguir, que tipo de imagem costuma ser associada nos LDs de FLE à gramática, ao léxico e à fonética.

\subsubsection{A imagem e a gramática}

Os famosos "quadros gramaticais" ou tabelas reinam absolutos como o tipo de imagem mais associado à gramática nos livros didáticos de FLE. Conjugações verbais, artigos, pronomes, advérbios, diferentes pontos linguísticos são retomados de forma resumida e bastante esquemática em tabelas gramaticais como as das figuras a seguir. 
Figura 128 | Forum 1 - pág. 103 (detalhe)

A limperatif aftimatif, le pronom objat me devient moi et le pronom objet te devient toi

Donne-moi la carte. Arreatte-toi.

Ne me donne pas la carte. Ne I'arrête pas.

\section{La place du pronom à l'impératif}

A rimpératif affimatif, le pronom se place .... le verbe. II y a toujours un ... entre le verbe et le pronom. A rimpératif négatif, le pronom se place .... le verbe, comme a rindicatif. La négation ... se place avant le pronom, et la négation ... aprés le verbe Suivez la riviere Longez-la. Ne la traversez pas. Ametons-nous. Ne nous énervans pas Midmente : F EIa-b

Figura129| Écho A1 - pág. 88 (detalhe)

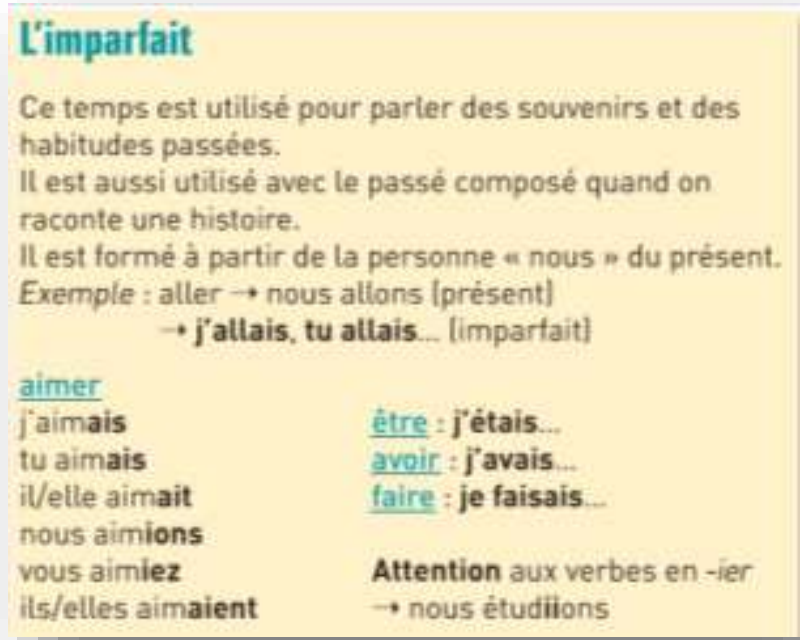

A tipografia é particularmente importante nesses quadros: a utilização do negrito e de cores diversas facilitam a visualização de terminações verbais, de artigos e outros pontos gramaticais. Naturalmente, essas páginas também são compostas por exercícios de gramática o que pode torná-las pesadas aos olhos de alguns alunos. Talvez para quebrar essa possível impressão de austeridade - ou de uma eventual dificuldade da língua - opta-se inúmeras vezes pelo desenho na composição das mesmas e, em muitos casos, por desenhos com um toque humorístico, como vemos nos exemplos a seguir. 
Figura 130 | Espaces 1 - pág. 108, 109

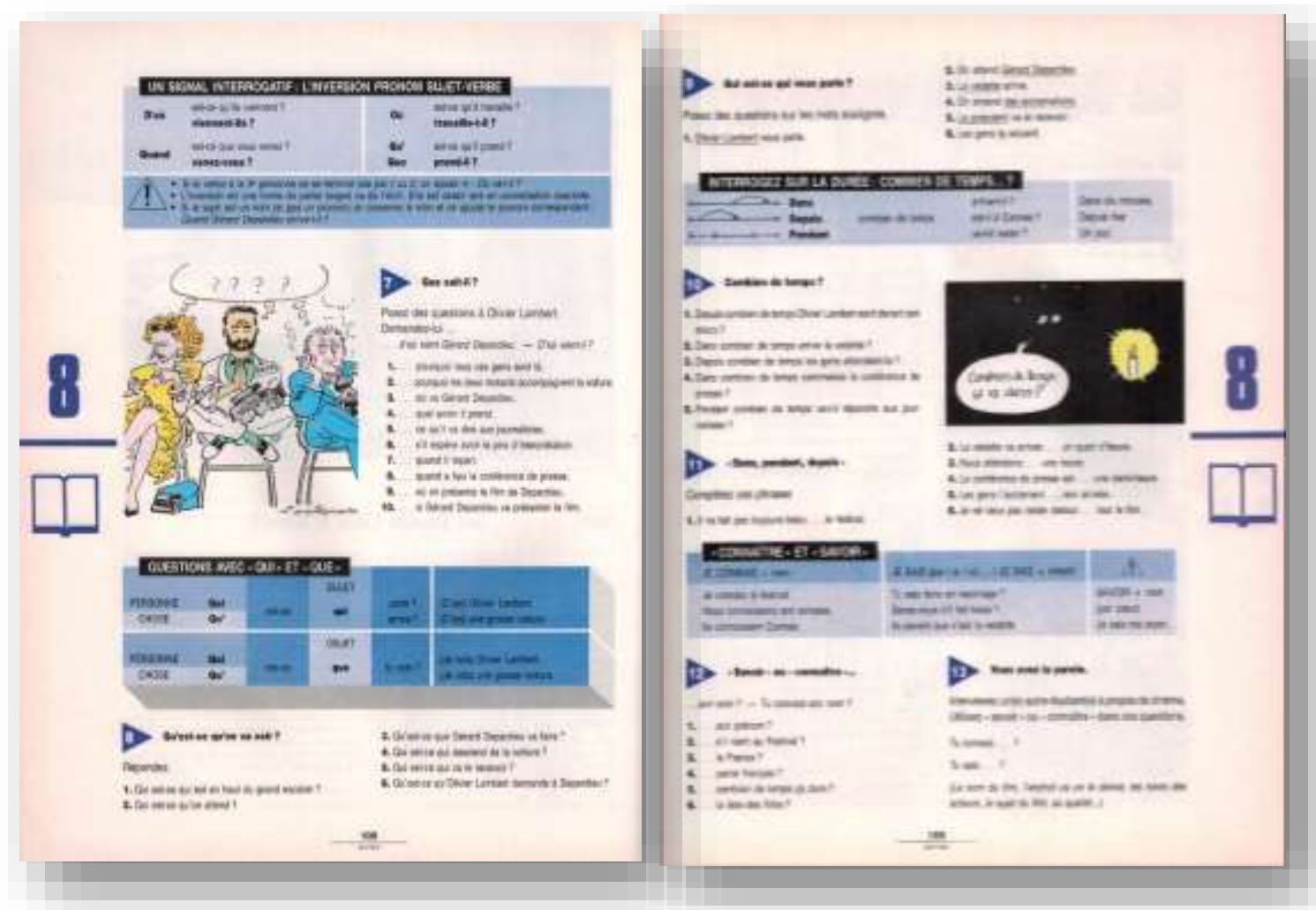

Figura 131 | Forum 1 - pág. 140, 141
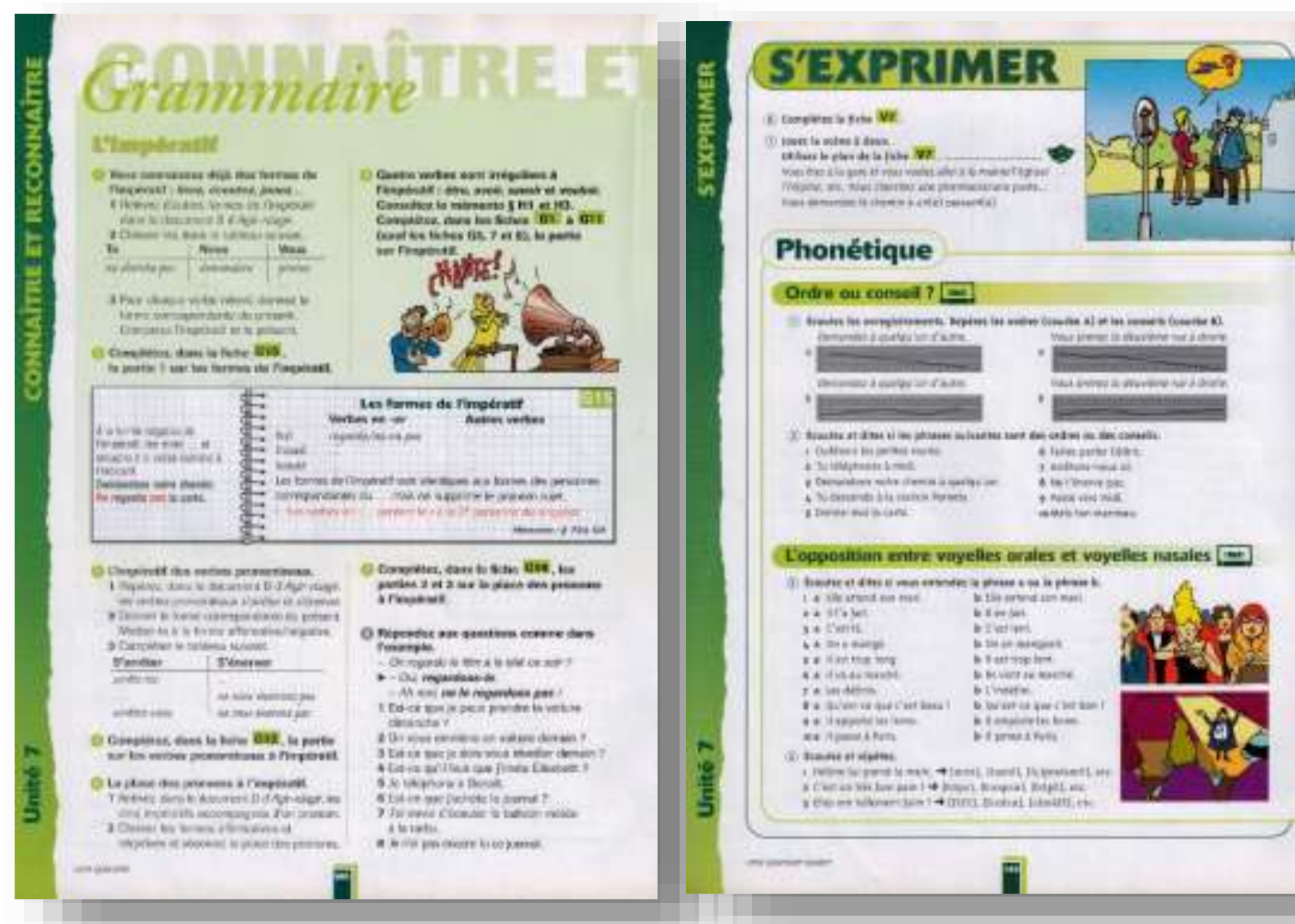

\section{Phonétique}

Ordin ou consel ? [D]

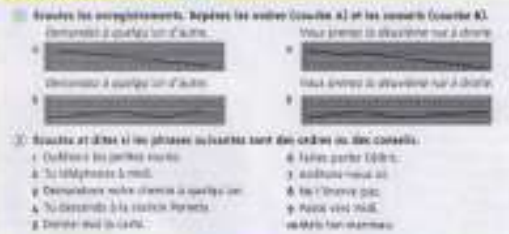

Copgosisin mitre veyelies orales et voyeles nasaies

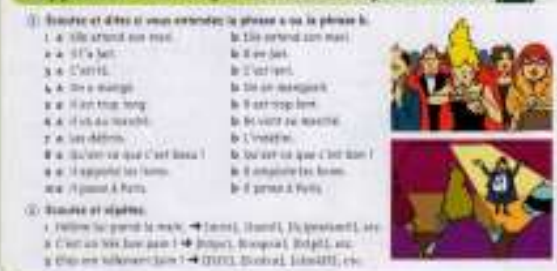

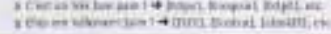


Figura 132 | Écho A1 - pág. 16, 17

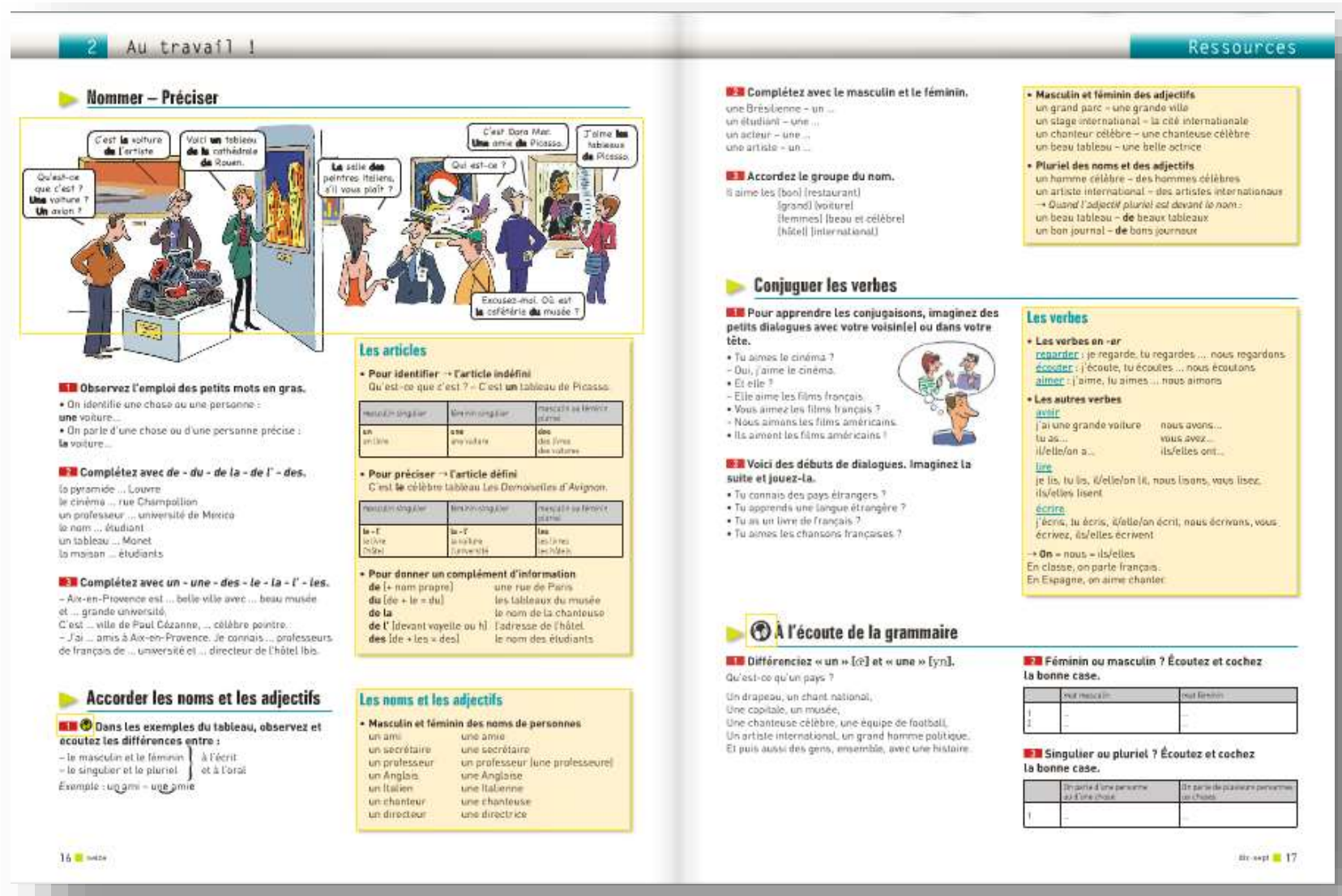

Muitas vezes, os personagens dos desenhos têm suas falas representadas em balões, fazendo com que a ilustração se aproxime mais de um "sketch" (termo utilizado pelo guia pedagógico de Écho A1), de uma charge ou de uma HQ.

Ao abordar a gramática, após o estudo de uma situação de comunicação, aproximamo-nos da forma, de um ponto linguístico específico. A fotografia dificilmente responderia a essa necessidade de comunicação visual. Mais uma vez, é por meio do desenho fabricado que as editoras conseguem expressar a gramática pelas imagens. $\mathrm{E}$ por se tratar de um aspecto formal da língua, as figuras gráficas como tabelas e quadros tornam-se essenciais na organização do sentido. O uso de tabelas com cores fortes, bastante comum na parte dedicada à gramática nos LDs, traz também um pouco de humor e alegria a um tema considerado difícil e austero pela maioria dos alunos. 


\subsubsection{A imagem e o léxico}

Tradicionalmente, o léxico sempre foi o ponto linguístico mais comumente associado à imagem tanto no ensino-aprendizagem da língua materna quanto no de língua estrangeira. Como vimos anteriormente, o pensador tcheco Jan Amos Comenius (1592-1670), publicou em 1658 Orbis Pictus, considerado hoje o primeiro livro didático ilustrado. Comenius uniu linguagem visual e linguagem escrita em um livro que nomeia, mostra e escreve sobre diversos assuntos, como afirma o pesquisador Carlos Eduardo Albuquerque Miranda:

Assunto e aquisição da linguagem não estão separados. As imagens não são meras ilustrações do texto escrito: são apresentações figurativas do assunto comentado. $[\ldots]$

Orbis Pictus possui 150 unidades didáticas que vão da natureza à religião, passando pelo homem, por seu corpo e por suas atividades produtivas e societárias. A aprendizagem da linguagem - imagem e escrita - e a aprendizagem do conhecimento, os assuntos de cada unidade didática, articulam-se na construção de uma visão de mundo.

(MIRANDA, 2011: pág. 198)

De fato, como podemos ver na figura a seguir, correspondente à unidade que aborda os instrumentos musicais, a imagem aparece como suporte primordial para a construção do sentido. Cada instrumento musical é acompanhado de um número e sua definição encontra-se no texto escrito correspondente. Podemos afirmar que a imagem "apresenta" visualmente o sentido do texto escrito, não estando de forma alguma submissa a ele nem exercendo um papel de representação ou de simples ilustração temática do mesmo. As duas linguagens se articulam e interagem na construção do sentido. 
Figura 133 | Orbis Pictus

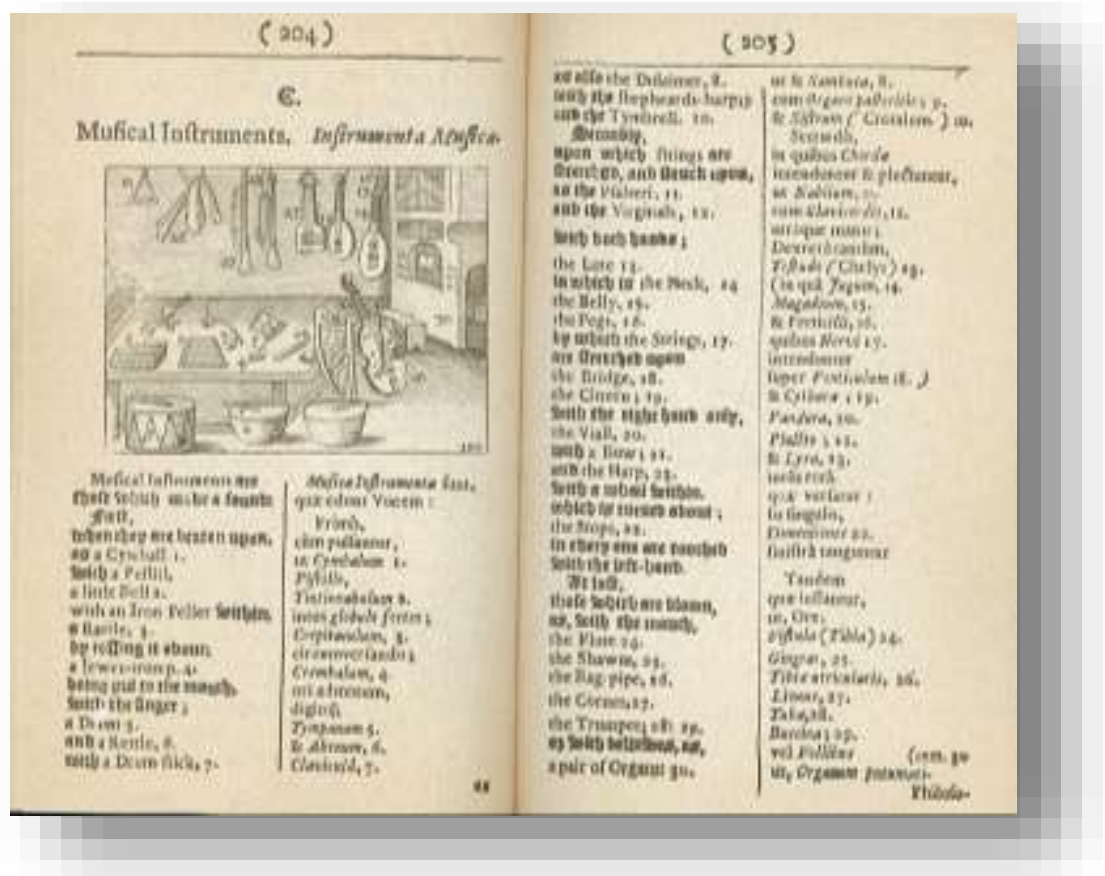

A força da imagem na aquisição lexical é intensa e os LDs de língua estrangeira têm recorrido constantemente a ela ao longo dos séculos. Nos livros didáticos de FLE que estudamos neste trabalho, o uso da imagem no ensinoaprendizagem do léxico também é bastante comum e a escolha do tipo de imagem recai sobre o desenho, como podemos comprovar nas figuras a seguir.

Figura 134 | Espaces 1 - pág. 68 (detalhe)

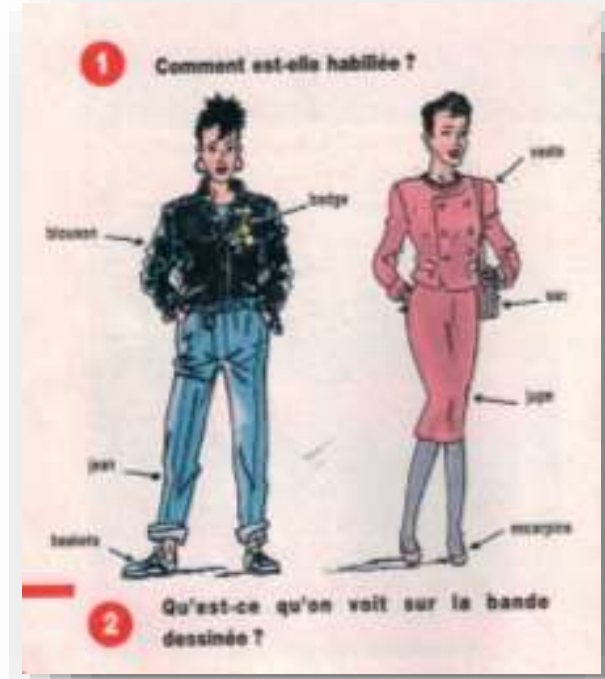

Figura 135 | Espaces 1 - pág.93 (detalhe)

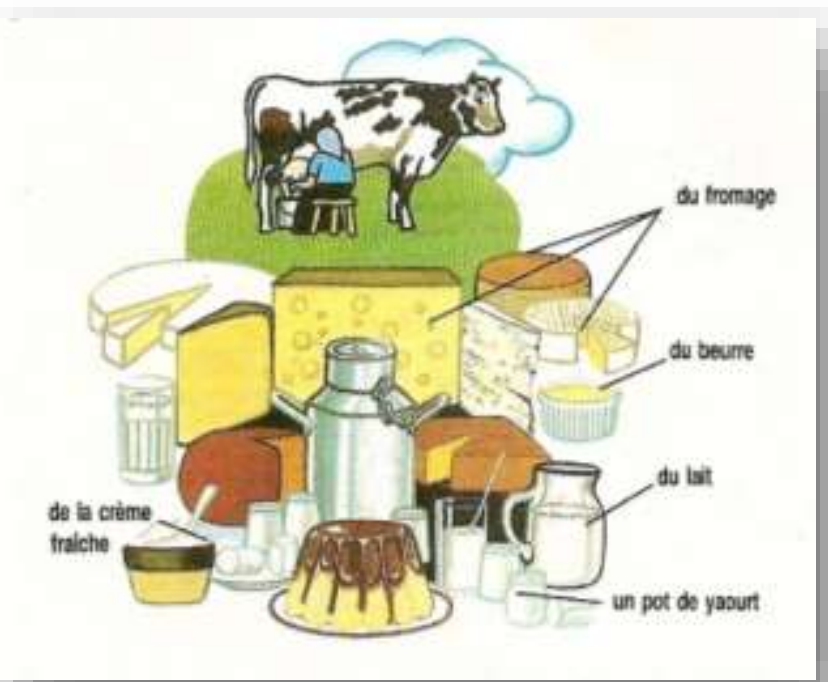


Figura 136 | Forum 1 - pág. 88 (detalhe)

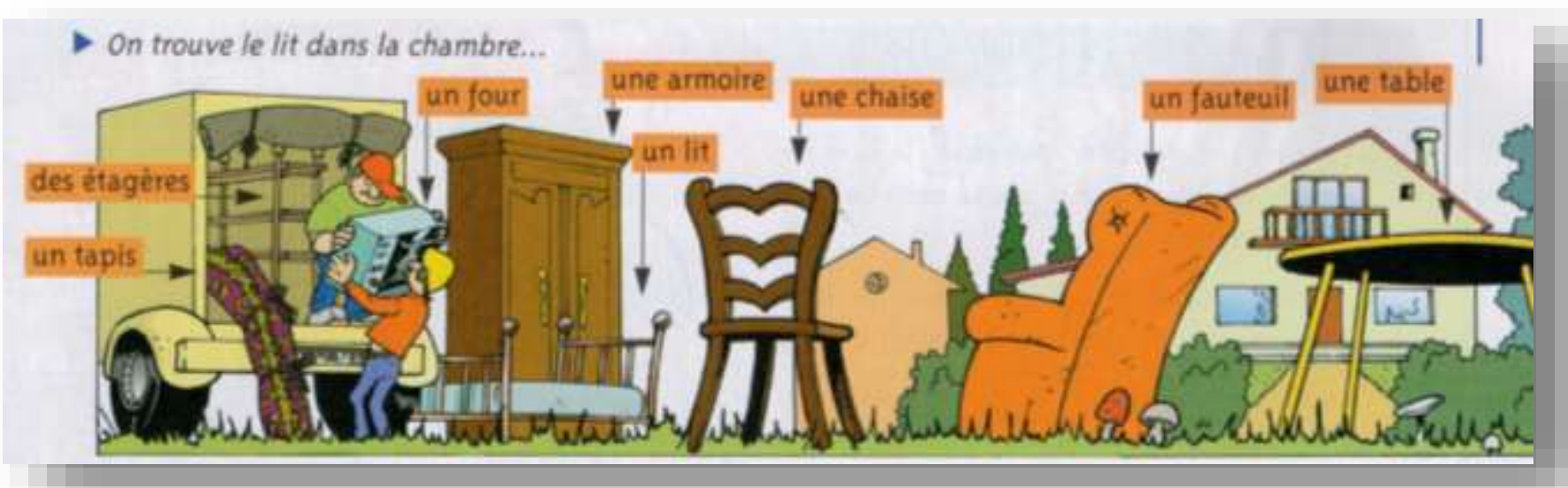

Figura 137 | Forum 1 - pág. 123 (detalhe)

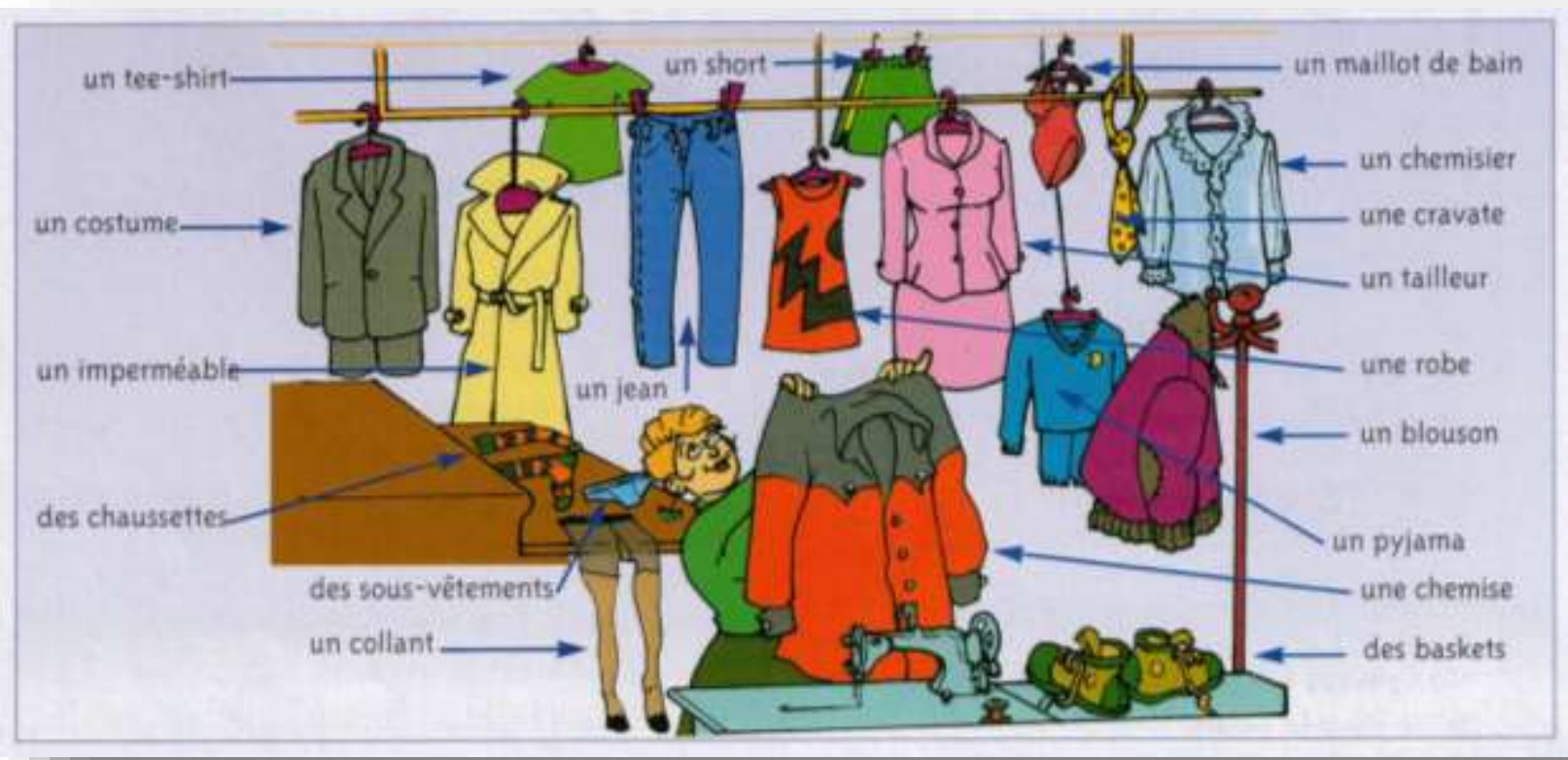


Figura 138 | Écho A1 - pág.109 (detalhe)

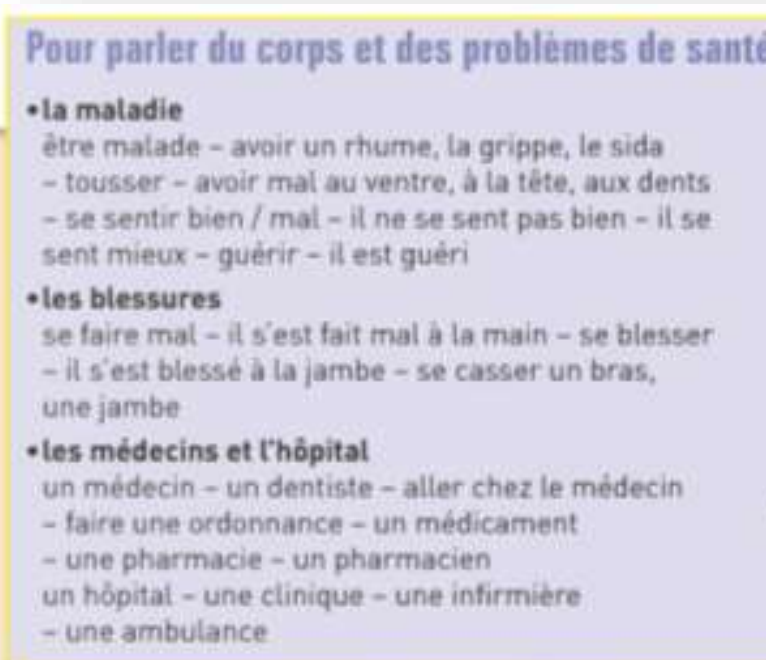

Pour parler du corps et des problèmes de santé

- La maladie

ètre malade - avoir un rhume, la grippe, le sida

- tousser - avoir mal au ventre, a la tête, aux dents

- se sentir bien / mal - il ne se sent pas bien - il se

sent mieux - guèrrir - il est quêri

- les blessures

se faire mal - il s'est fait mal à la main - se blesser

- il s'est blessé a la jambe - se casser un bras.

une jambe

- Les médecins et thôpital

- une pharmacie - un pharmacien

- une ambulance

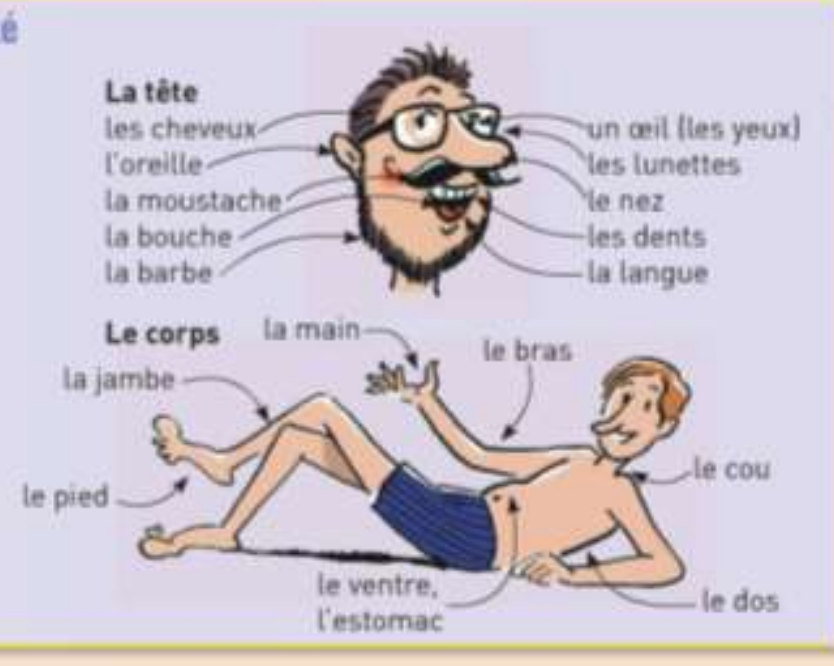

A justificativa para essa escolha pelo desenho parece, a nosso ver, retomar os motivos que citamos para explicar o uso desse tipo de imagem nas análises feitas anteriormente:

- A possibilidade de o desenho retratar de forma mais específica, esquemática e didática um conteúdo particular;

- O aspecto lúdico das cores e do próprio suporte que contribuem para o processo de aprendizagem.

Esse último ponto é interessante, pois foi a intenção principal de Comenius ao colocar imagens em Orbis Pictus: como se tratava de um LD para crianças, esse aspecto lúdico foi buscado e valorizado pelo autor.

O que nos chama a atenção, no entanto, é o quão pouco essa abordagem do léxico pela imagem nos livros didáticos mudou ao longo do tempo. Ao compararmos capítulos de Orbis Pictus (1658) com livros didáticos de FLE dos séculos 20 e 21, veremos que, apesar do grande progresso técnico na qualidade das imagens, poucas mudanças ocorreram do ponto de vista da exploração pedagógica das mesmas, como podemos observar nas imagens comparativas a seguir. 
Figura 139 |Orbis Pictus - Ervas e legumes

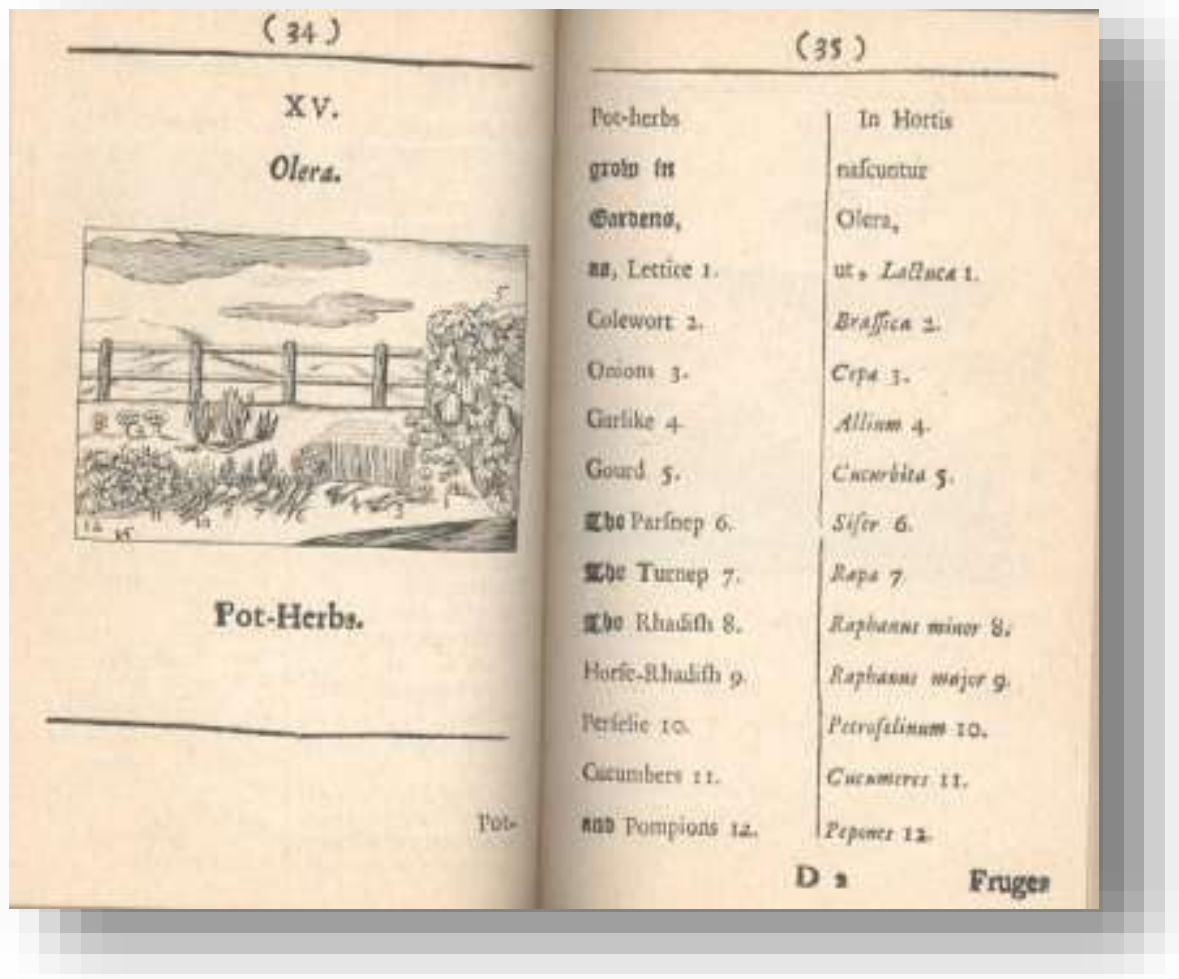

Figura 140 | Espaces 1: pág.93 (detalhe) - Frutas e legumes

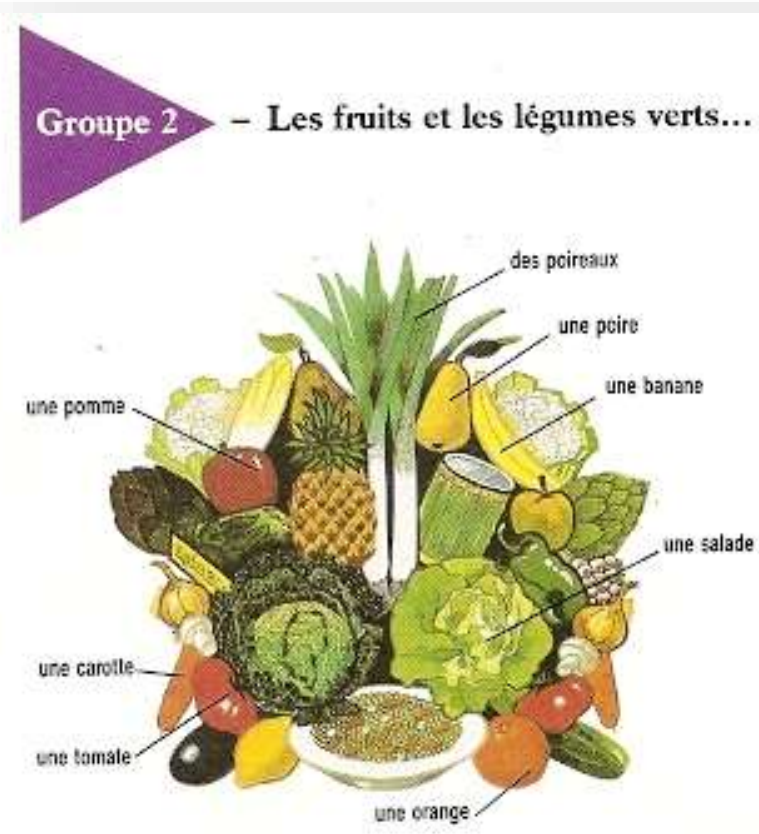

... contiennent beaucoup de vitamines. 


\section{Figura 141 | Orbis Pictus - Árvore genealógica (1658)}

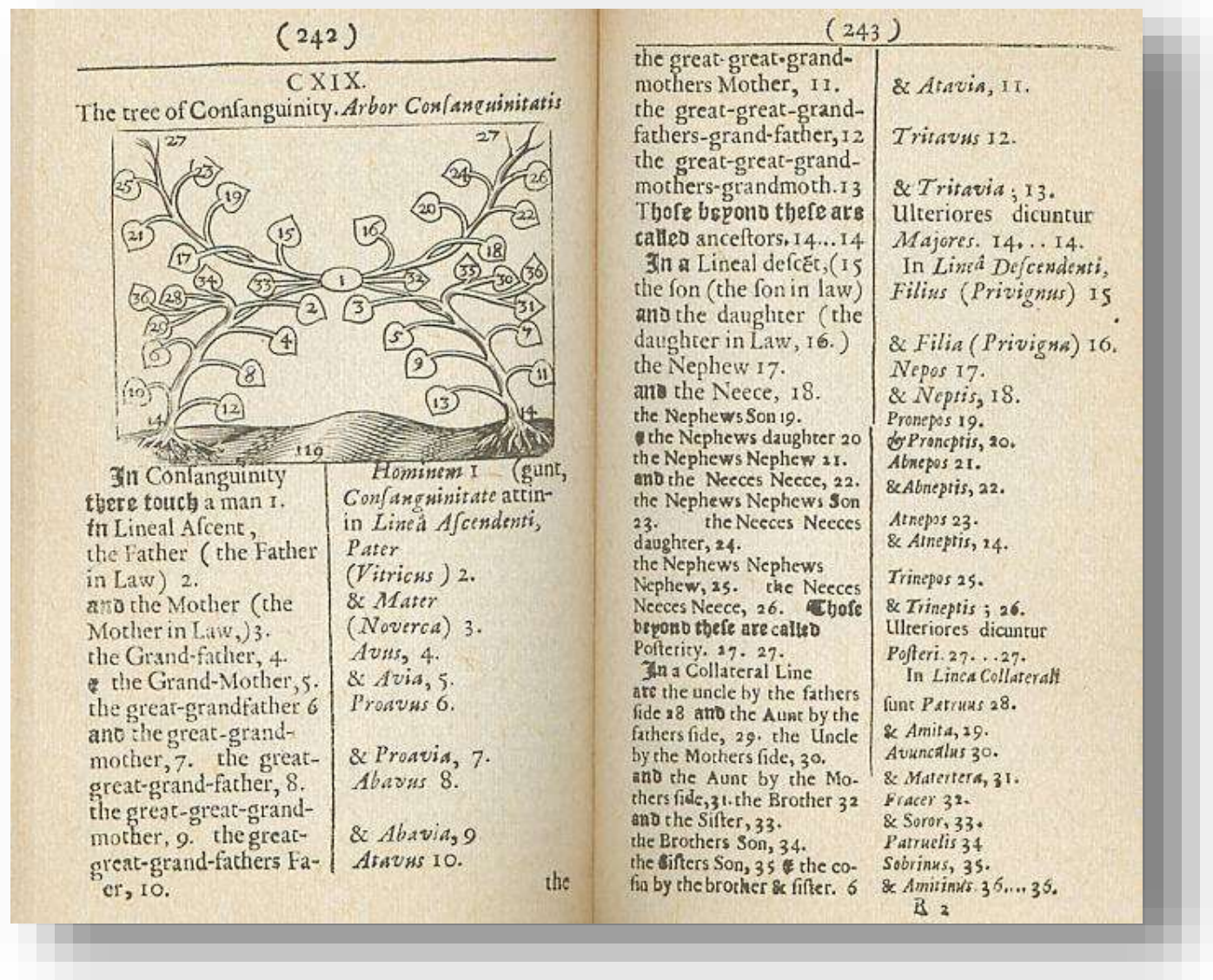

Figura 142 | Écho A1 - A família

\section{Pour parler de la famille \\ - les membres de la famille}

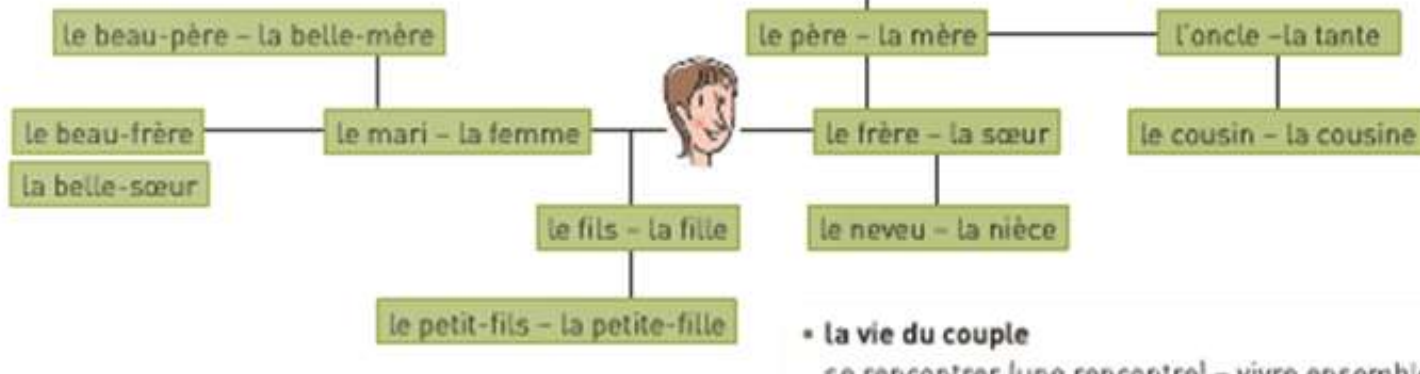

se rencontrer lune rencontrel - vivre ensemble
- un ami - un copain - un petit ami fpeu employe

Faites des comparaisons

Lisez les documents ci-dessus. Faites des comparaisons avec la situation dans votre pays. par les jeunes] - un compagnon/une compagne se marier (un mariage] - un mari/une fernme

- se séparer (une séparationl, divorcer lun divorcel 
É evidente que a imagem tem uma grande importância no ensino-aprendizagem do léxico em uma língua estrangeira, mas acreditamos que a aquisição e apropriação desse vocabulário não se façam com uma simples observação de uma imagem associada a palavras. Se esperamos que um LD aborde o léxico apenas pela associação de imagens a suas definições, uma busca em "Google images" pode se mostrar mais rápida e mais eficiente. A nosso ver, essa associação é extremamente válida para a compreensão do léxico, mas não para a sua aquisição pelo aluno. Acreditamos que os livros didáticos de FLE trazem, de modo geral, poucas atividades para a manipulação desse léxico e também para a sua reutilização em um contexto situacional da vida real.

Uma proposta de associação da utilização da imagem na aquisição lexical que nos parece mais pertinente aparece no livro didático Espaces 1. Ao invés das famosas "flechas" que ligam imagem e vocabulário - por vezes fora de contexto - o livro optou por trabalhar o léxico dos materiais de escritório em uma situação de comunicação que se passa em uma papelaria. Ao observarmos a figura abaixo, vemos que há também essa associação entre a imagem e sua definição, mas isso é feito dentro de um conceito bem mais próximo do que encontramos na vida real: na vitrine de uma papelaria, o nome e o preço do produto são indicados em uma etiqueta.

Figura 143 | Forum 1 - pág. 88 (detalhe)

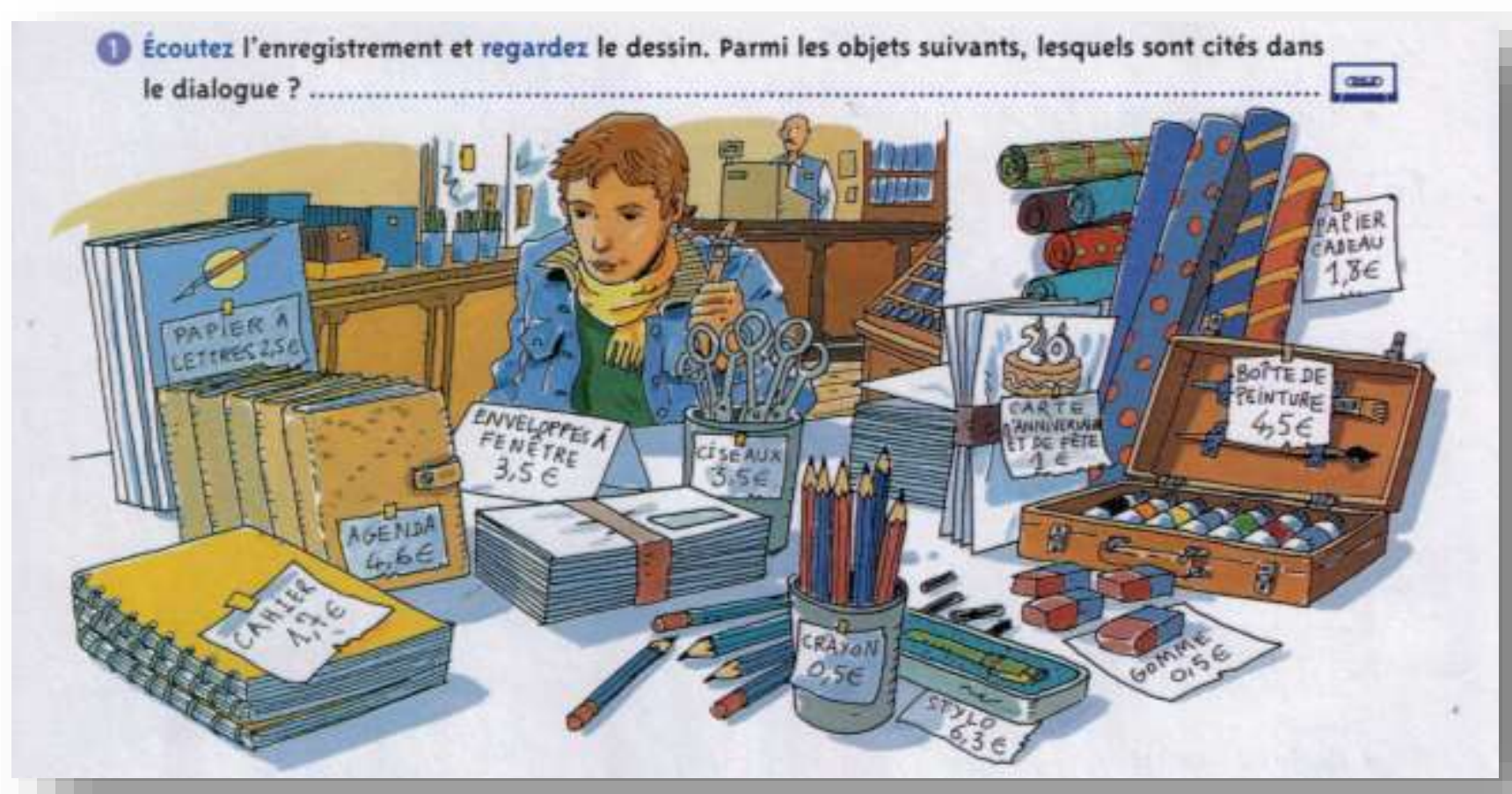


A página multimodal completa é composta por um diálogo e por sua transcrição, além de atividades de compreensão e de produção orais. Acreditamos que o trabalho sobre esse vocabulário será bem mais proveitoso e eficaz, já que o aluno estará construindo o sentido por meio de três suportes diferentes: imagem, texto e som. A multimodalidade possibilita diferentes leituras que se fazem de forma simultânea e interativa e que enriquecem, graças a essas diferentes vias, a capacidade de construção e de memorização do sentido.

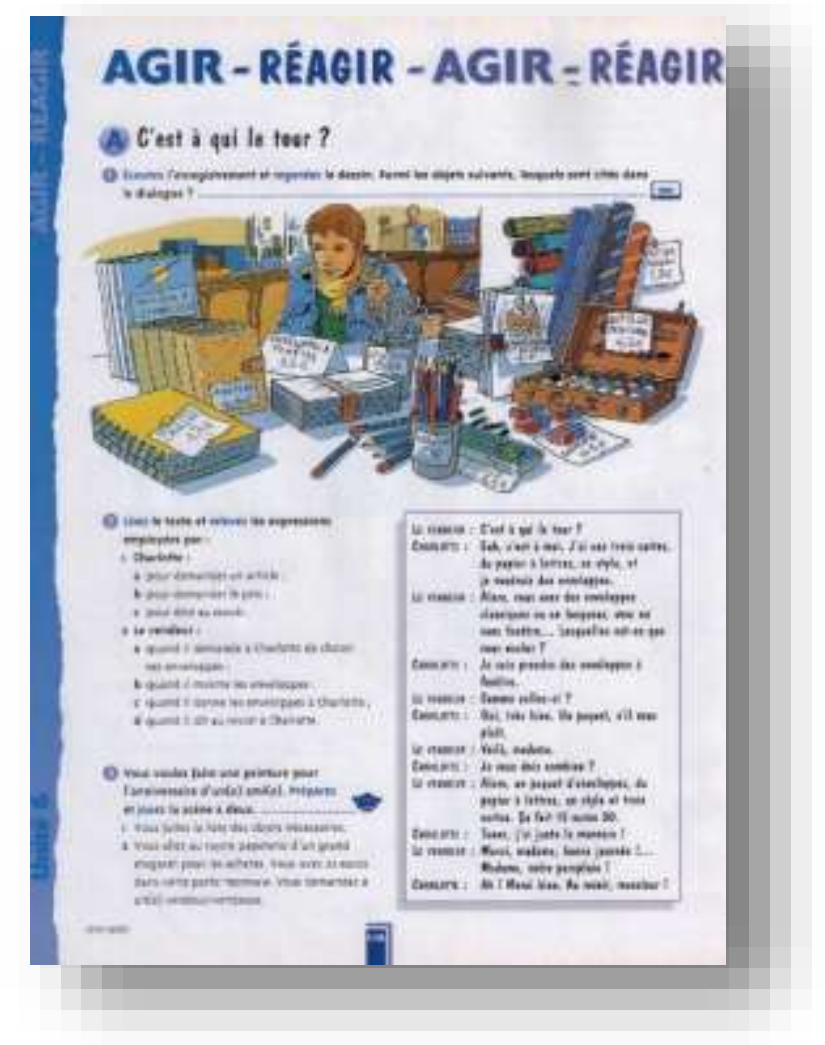

Figura 144 | Forum 1 - pág. 88

A atividade de produção oral, baseada nas simulações orais da abordagem comunicativa, propõe aos alunos o famoso "jeu de rôle" entre um vendedor e um cliente, neste caso, em uma papelaria. O "cliente" dispõe de um valor limitado em dinheiro (22 euros) para comprar produtos de pintura com o intuito de fazer um quadro para o aniversário de um(a) amigo(a). A atividade propõe um contexto real de reutilização do léxico e uma tarefa suplementar em relação ao valor máximo a ser gasto, elemento que também é bastante apreciado na perspectiva acional. Acreditamos que se trata, por todas essas razões, de uma atividade interessante e eficaz para a aquisição do léxico, já que ela traz estratégias confirmadas pelas duas metodologias mais recentes para o ensino-aprendizagem do FLE - que podem conviver harmoniosamente - e, ao mesmo tempo, tira partido dos diferentes componentes do texto multimodal. 


\subsubsection{A imagem e a fonética}

Dos três pontos linguísticos frequentemente tratados em um livro didático de FLE - a gramática, o léxico e a fonética - esta última é a que costuma ocupar menor espaço nas páginas das publicações. Talvez pelo fato de as dificuldades com determinados fonemas dependerem da língua materna do aluno, enquanto que as grandes publicações de FLE destinam-se a estudantes de todo o planeta.

Dos quatro LDs que analisamos, três preveem um quadro específico para a fonética em cada lição: Espaces 1, Forum 1, Écho A1. Em todos eles, o tipo de imagem mais utilizado são os recursos gráficos: linhas contínuas ou pontilhadas para marcar uma "liaison" ou um "enchaînement", curvas que indicam a entonação ascendente ou descendente e um trabalho importante de tipografia. É comum que alguns sons ou pronúncias específicas sejam ressaltados com a utilização do negrito no texto, o que produz uma associação interessante entre imagem, texto escrito e som. No livro Espaces 1, esse quadro intitula-se Des sons et des lettres e o componente visual caracteriza-se, sobretudo, por linhas contínuas e pontilhadas e pelo uso do negrito em fonemas específicos, como vemos na figura a seguir (Figura 145).

Figura 145 | Espaces 1 - pág.169 (detalhe)

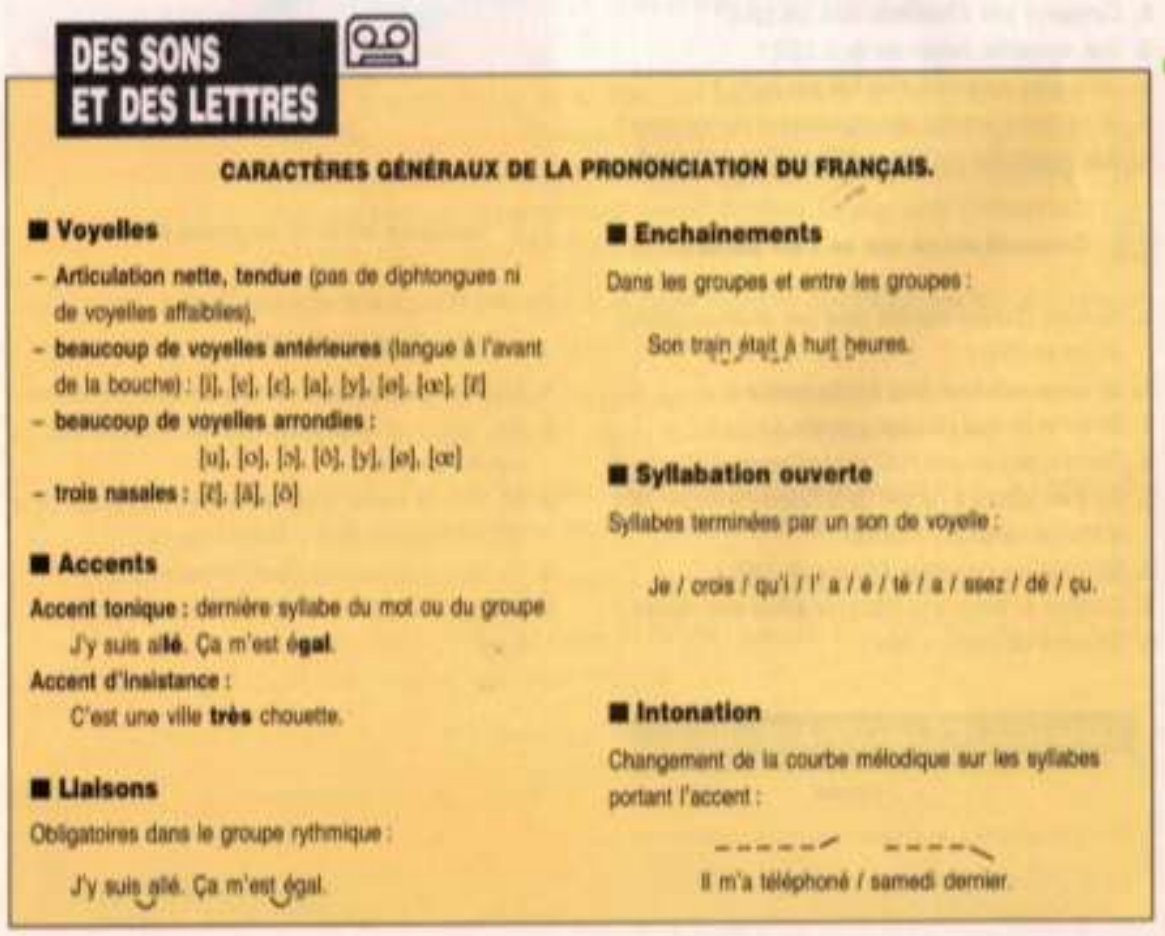


Em Forum 1, esse quadro dedicado à fonética apresenta os mesmos recursos gráficos como componente visual. No entanto, por vezes, encontramos também o uso do desenho, mas com uma função meramente ilustrativa das frases utilizadas para se praticar a pronúncia, como vemos a seguir.

Figura 146 | Forum 1 - pág.144

\section{Phonétique}

\section{Ordre ou conseil ?}

(1) Ecoutez les enregistroments, Reptrex les ordres (courbe A) et les consils (courbe B).

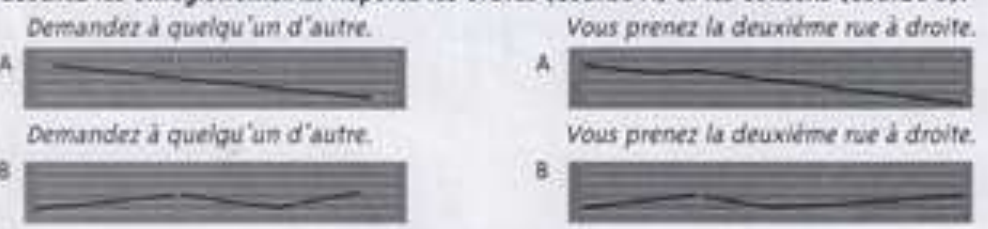

(2) tcouter et dites si les phrases sulvantes sont des ordres ou des conseils.

1. Oublions les petites routes.

2. Tu teléphones i midi.

3 Demandons notre chemin a quelqu' un.

6 Fahes parler Cédric

7 Arrattons-nous iki.

8 Ne t'enerve pas.

4 Ta descends a la station Pernety

9 Passe vers midi.

5 Donne-moi la caste

10 Mets ton manteas.

\section{Lopposition entre voyelles orales et voyelles nasales}

(3) Ecoutez et dites si vous entender la phrase a ou la phrase b.
1 a tlie attend son mani.
b tlle entend son mari.
2 a II ra fait.
b II en fait.
3 a C'est lia.
b C'est lent.
4 a On a masgé.
5 a II est trop long
$b$ On en margeait.
6 a Il va aa marché.
b II est trop lent.
7 a tes definis.
b is vont au marcket.
b c'indefini:
8. Qu'est-ce que c'est besu!
9. II apporte les livies.
b quiest-ce que c'est bon!
10a II passe a Daris.
b il emporte les livres.
b il pense d Paris.

(4) icoutez et répéter.

1. Helène lui prend ta main, $\rightarrow$ imenl. flame1, flqipralamel, ete. a C'est un tres bon pain $1 \rightarrow$ [ospe], [bospen], [bspe], etc

3 Elles ont tellement faim I $\rightarrow$ Irerth. Ifenfenl. felmastL, etc.

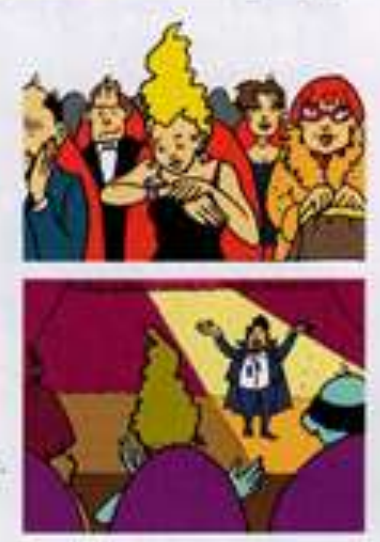


No livro Écho A1, o quadro de fonética intitula-se "Sons, rythmes et intonations" (Figura 147). O quadro é bastante restrito e apresenta menos recursos visuais. Permanecem, no entanto, alguns elementos gráficos e a utilização do negrito.

Figura 147 | Écho A1 - pág.11 (detalhe)

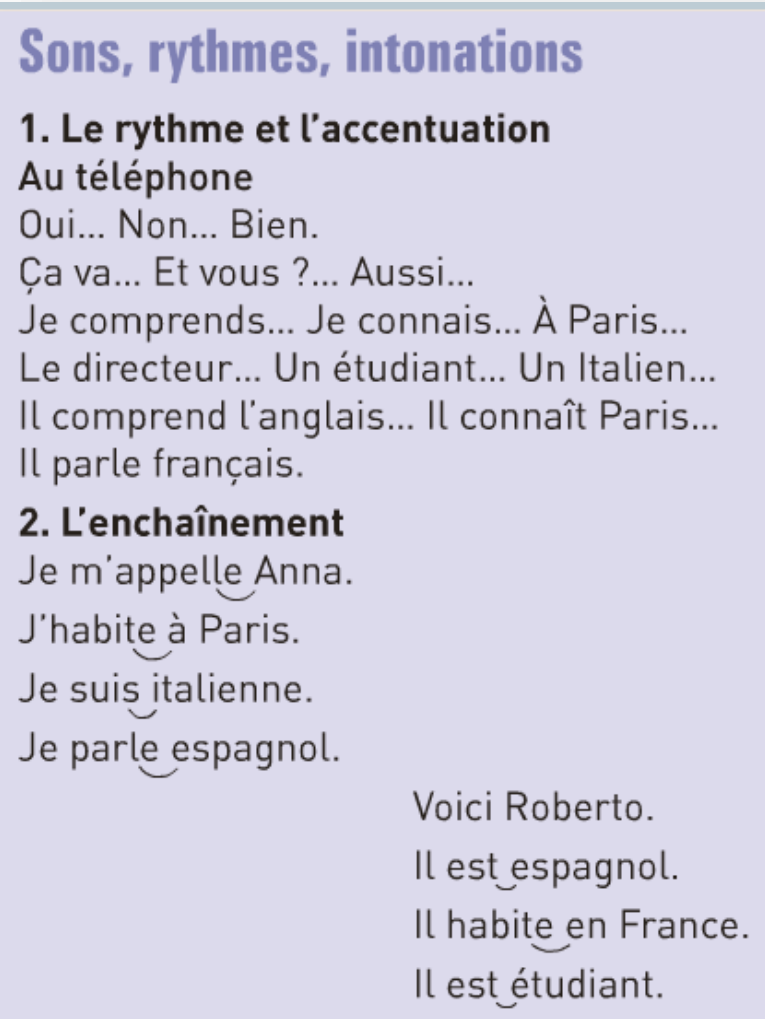

Alguns livros didáticos como Saison 1 (COCTON, 2014) recorrem a desenhos do aparelho fonador e de suas articulações (Figura 148) para a composição desse ponto de fonética. É curioso notar que cada vez mais a imagem móvel é associada à aprendizagem da pronúncia de uma língua estrangeira. Vários sites da Internet propõem closes da boca de um usuário da língua em questão pronunciando diferentes fonemas. 
Figura 148 | Saison 1 - pág.46 (detalhe)

\section{Phonétique}

\section{Le - les (41028)}

1 Écoutez et observez.

le

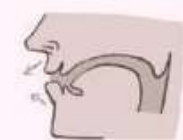

Langue en avant

Lèvres arrondies

2 Écoutez et dites ce que vous entendez.

a. $\square$ le $\square$ les

b. $\square$ le voisin $\square$ les voisins

c. $\square$ le locataire $\square$ les locataires

d. $\square$ le propriétaire $\square$ les propriétaires

3 Écoutez et mettez au pluriel.

$\begin{array}{ll}\text { a. Le logement } & \text { c. Le salon } \\ \text { Transformez. } & \text { Transformez. } \\ \text { b. Le studio } & \text { d. Le placard } \\ \text { Transformez. } & \text { Transformez. }\end{array}$

\section{- La liaison (10) 29}

\section{1 Écoutez et observez.}

Lesjnformations

Au pluriel, on fait la liaison entre l'article et le nom quand il commence par une voyelle lou par un $h$ muet). On entend [z] entre les deux mots.

[Les-zin-for-ma-tions]

2 Écoutez et notez les liaisons.

a. Des appartements

b. Les entrées

c. Les immeubles

d. Des hôtels

3 Écoutez et répétez.

a. Je veux visiter des appartements.

b. Ce sont des immeubles modernes.

c. Ce sont des habitations originales.

d. Il y a des annonces sur ce site.

\subsection{A imagem e a compreensão e produção escritas}

Uma parte bastante recorrente nos livros didáticos de FLE, a compreensão e a expressão escritas costumam aparecer juntas em uma única página ou em uma página dupla. Os quatro LDs que estudamos neste trabalho apresentam uma página dedicada a essas atividades da linguagem.

Em sua grande maioria, essas páginas são compostas por fotografias que representam, muitas vezes, um gênero textual específico, como um anúncio publicitário, um formulário, um cartaz, etc. Podem ser documentos autênticos no caso de fotos, ou então, e o que é bem comum nos níveis iniciantes, pode se tratar de um documento fabricado, com ar realista. De fato, esse tipo de documento é bastante útil e apreciado pelas editoras pois se evita o uso de datas e o envelhecimento do mesmo. Esse tipo de documento respeita não só o conteúdo, mas - o que nos interessa particularmente neste estudo - o formato, a estrutura visual e a diagramação de um determinado gênero textual. Vejamos alguns exemplos do uso da imagem associada à compreensão e à produção escrita nos livros didáticos que analisamos. 
O livro Archipel 1 utiliza fotografias autênticas de publicidades com os seguintes objetivos comunicativos para o aluno: compreender e construir um anúncio publicitário. O próprio trabalho de análise do conteúdo e da forma a partir de um documento autêntico guiará o aluno em sua própria produção escrita.

Figura 149 | Archipel 1 - pág.109

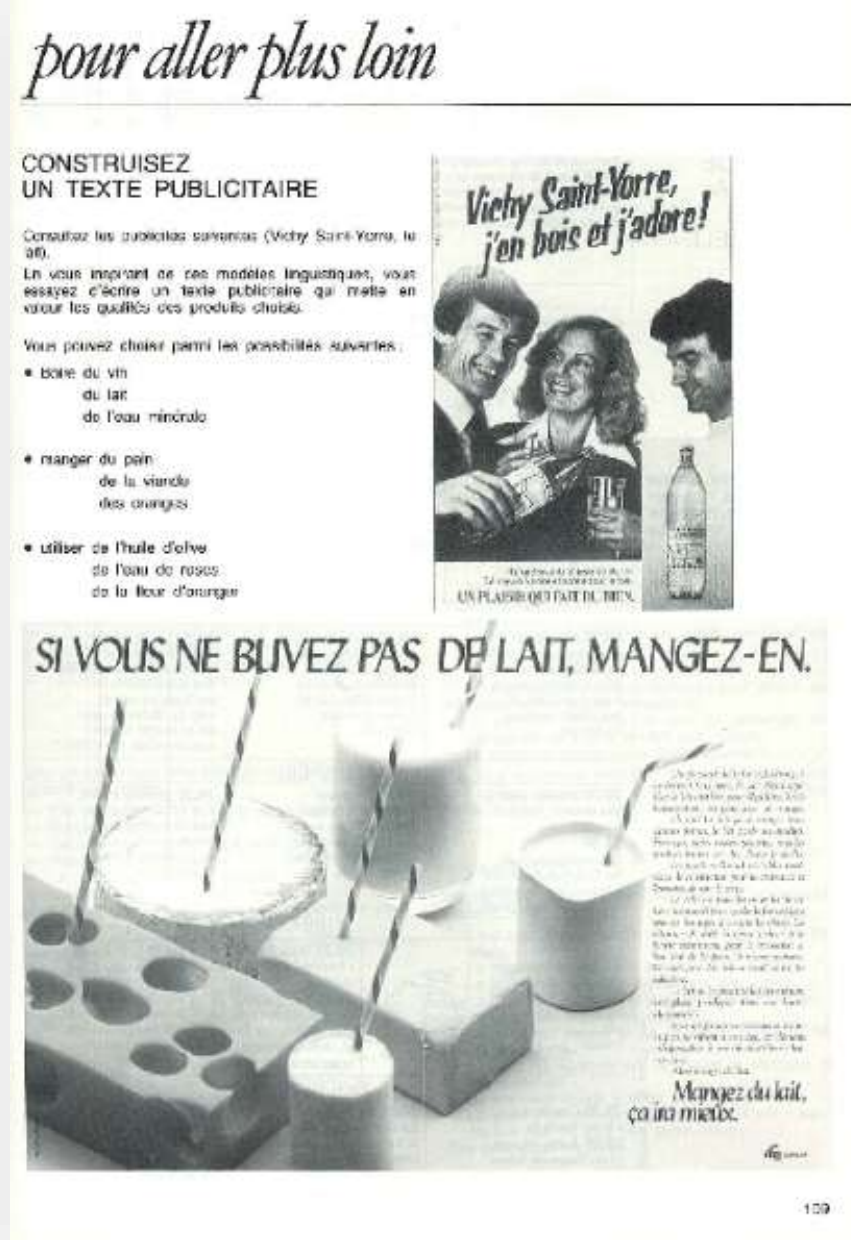

Os livros didáticos Espaces 1, Forum 1 e Écho A1 utilizam esse mesmo recurso para propor ao aluno a compreensão e a criação de gêneros textuais diversos como, por exemplo, convites, e-mails, cartas, artigos, sites da Internet, pequenos anúncios, receitas de cozinha, etc. 

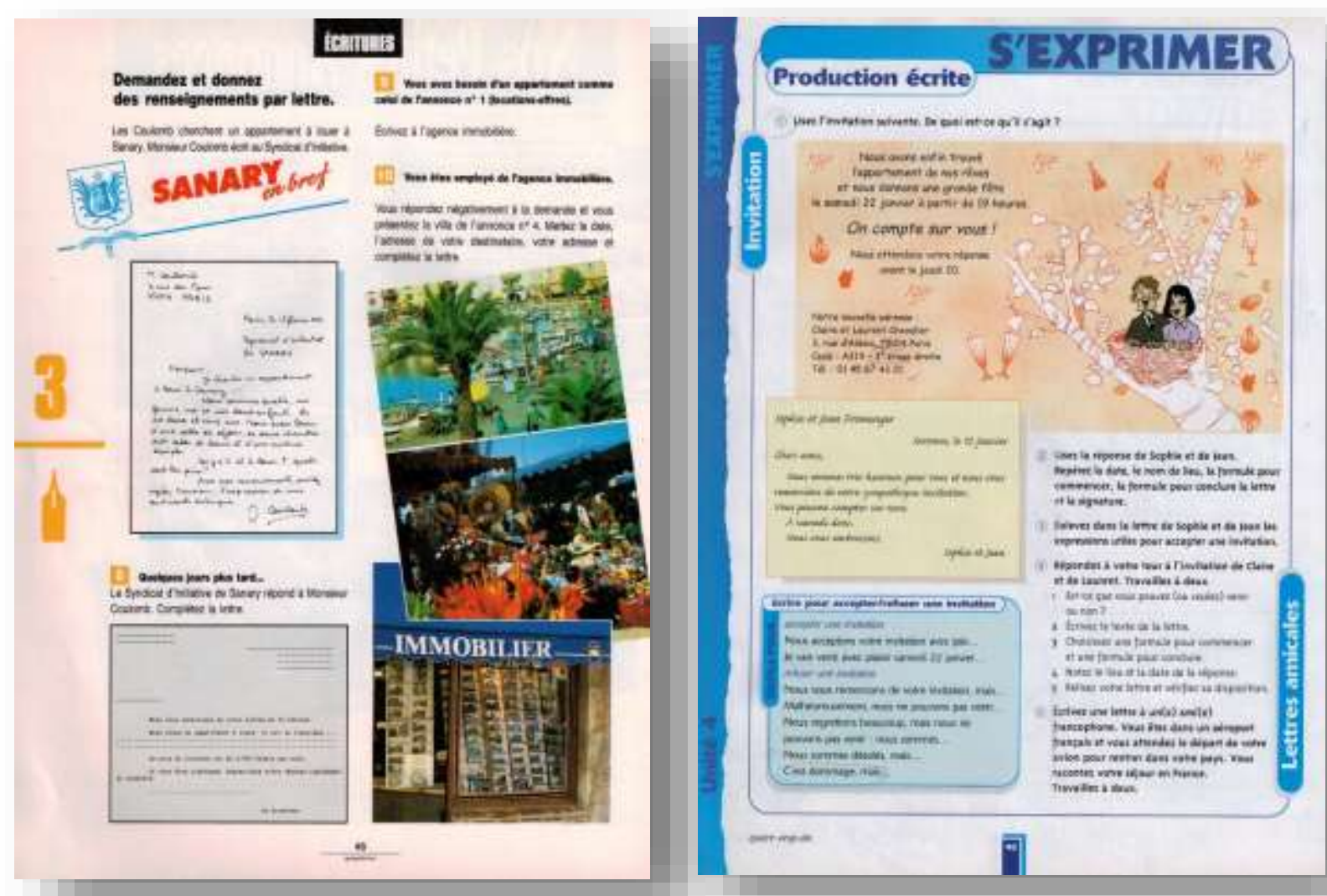

É interessante notar que, mesmo quando se trata de documentos fabricados, a estrutura visual e formal do gênero é respeitada (uso de títulos, subtítulos em artigos; diagramação apropriada em uma carta ou convite, estrutura específica de um formulário, de um cartaz, etc.). Esse aspecto é extremamente importante, mas pouco comentado no livro do aluno ou no guia pedagógico como vimos anteriormente. Caberá ao professor, tanto na compreensão quanto na produção de um determinado gênero textual escrito, explorar o aspecto estrutural e visual do mesmo. Esse mesmo cuidado deve ser tomado quando o professor fizer um "copiar-colar" da Internet, de forma a preservar a estrutura visual do texto de origem. Como vimos anteriormente, é importante lembrar que o aluno possui um letramento visual em sua língua materna desenvolvido pelo contato com os diferentes gêneros textuais do cotidiano. Cabe ao professor estimular o uso desses conhecimentos prévios para uma melhor compreensão e produção em uma língua estrangeira. 


\subsection{A imagem e o conteúdo sociocultural}

Chamada por muito tempo de "Civilisation", um termo que persiste ainda em alguns LDs, essa parte costuma aparecer no final de cada lição. Poderíamos nos perguntar por que ela é relegada a um espaço teoricamente menos importante, por que ela não poderia, ao contrário, integrar todas as outras partes de cada lição do livro. No que se refere ao título da página, alguns livros didáticos mais recentes têm preferido nomes como "Interculturel/Objectifs interculturels", o que nos parece mais apropriado em um contexto de valorização do plurilinguismo e do multiculturalismo.

Os quatro LDs que estudamos neste trabalho dedicam uma página aos aspectos culturais da sociedade francesa. Por vezes, aspectos de outras sociedades francófonas também são evocados, mas em quantidade bem mais restrita. Os temas são variados: transportes em comum, lazeres, gastronomia, hábitos alimentares, sistema escolar, trabalho, festividades, etc. Em todos os casos, sem exceção, a fotografia reina em absoluto como tipo de imagem mais utilizada.

Figura 152 | Forum 1 - pág. 37

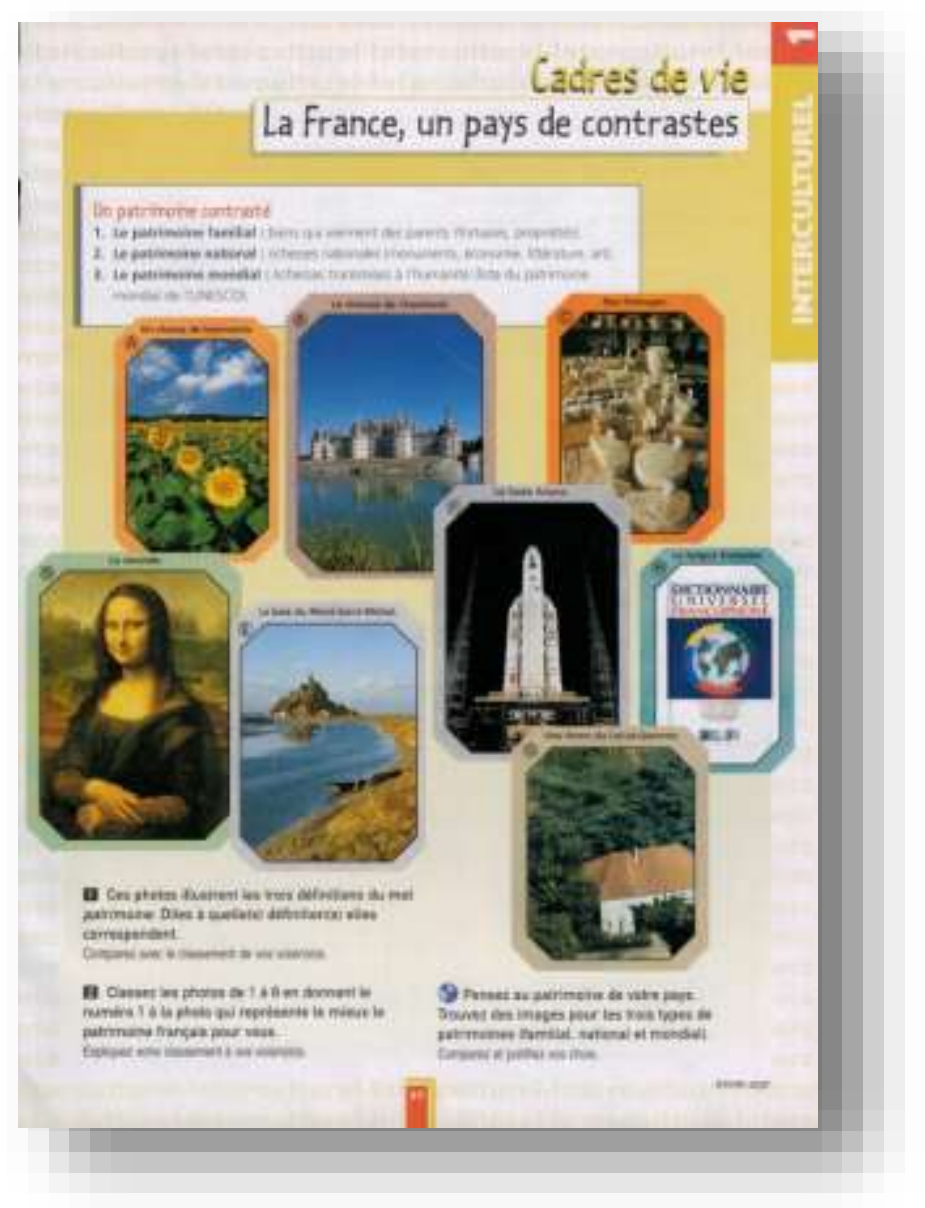


Figura 153 | Écho A1 - pág. 101

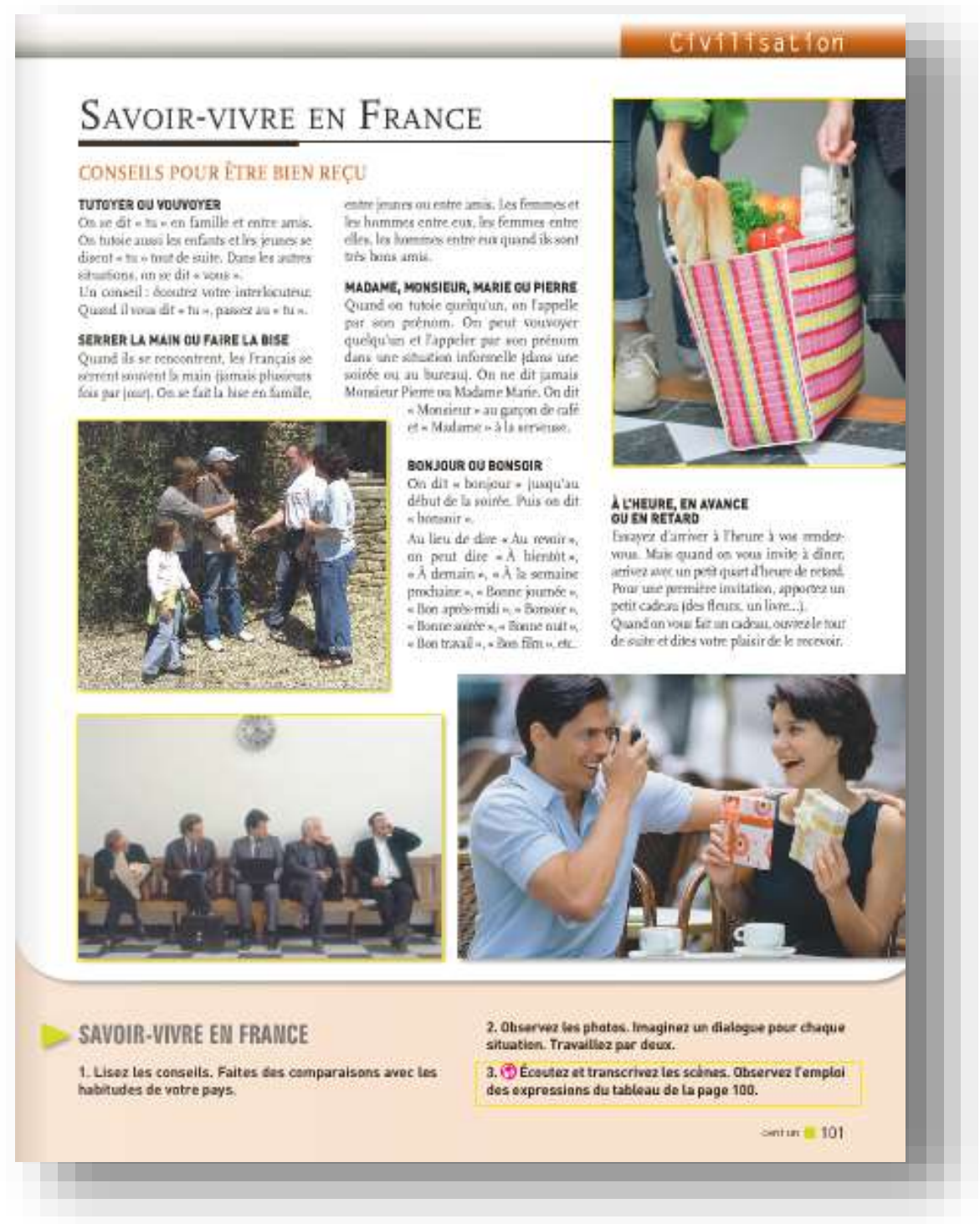

A justificativa para um uso tão intenso da fotografia nessas páginas pode ser explicada pelo próprio objetivo da mesma: trazer retratos da sociedade francesa e de sua cultura para uma página da lição, para dentro da sala de aula, mas de forma rápida e dentro de uma visão geral. Na categoria de imagens fixas, nada melhor do que um “instantâneo”, ou seja, uma fotografia para atingir esse objetivo.

4.7. Conclusões sobre os tipos de imagem mais utilizados

As análises realizadas neste capítulo nos permitiram conhecer melhor os tipos de imagem que costumam compor os livros didáticos de FLE e também algumas 
justificativas para essas escolhas. Chegamos, assim, à seguinte tabela para os tipos de imagem mais utilizados em livros didáticos de FLE.

Figura 154 | Tipos de imagem mais utilizados em cada componente do LD

\section{Componentes}

Capa

Tipos de imagens fixas predominantes

Fotografias

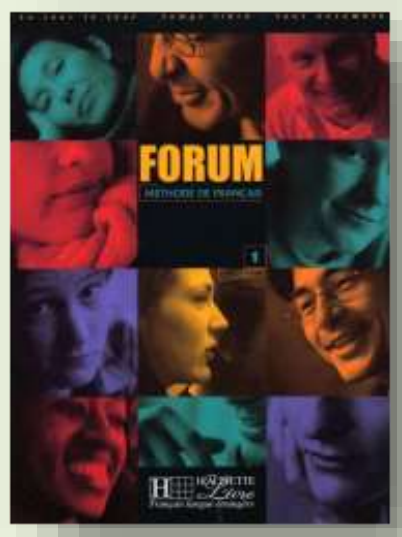

Página de abertura da lição (ou de conjunto de lições)

Situações amplas de comunicação, Fotografias abertura temática da lição
Fotografias

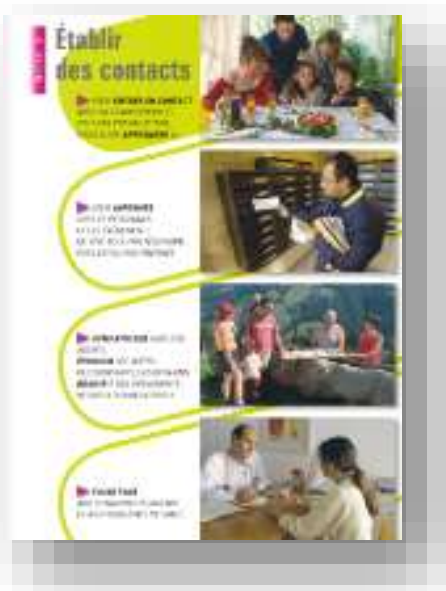

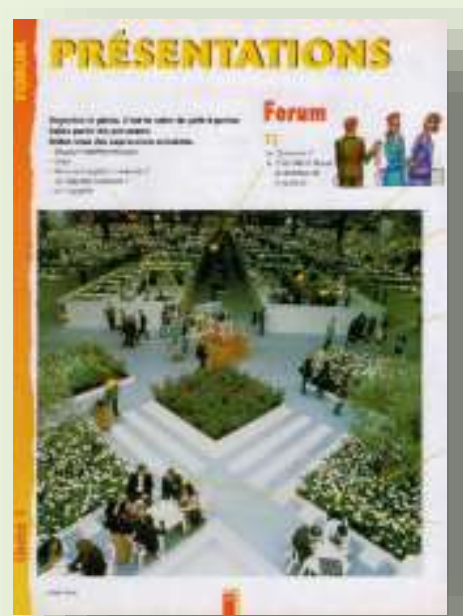


Componentes

Diálogos situacionais de

compreensão oral

Atividades de produção oral
Tipos de imagens fixas predominantes

Desenhos, por vezes, acompanhados de imagens de gêneros textuais

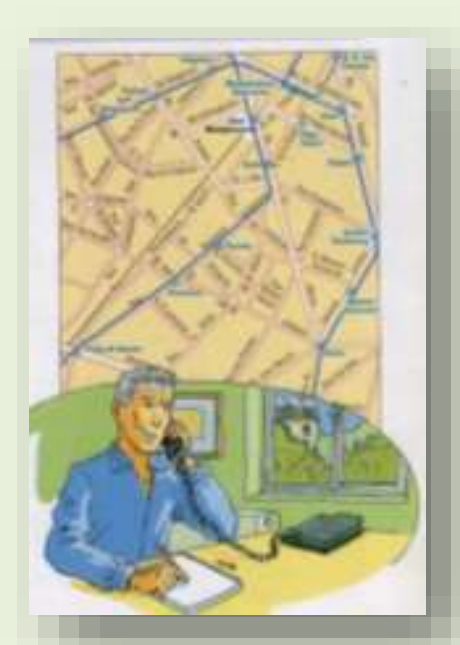

\section{Gramática}

Léxico
- Tabelas

- Elementos gráficos

- Tipografia

(negrito)

- Desenhos

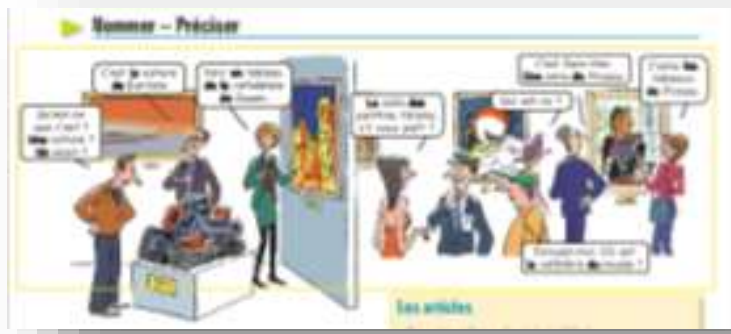

Desenhos

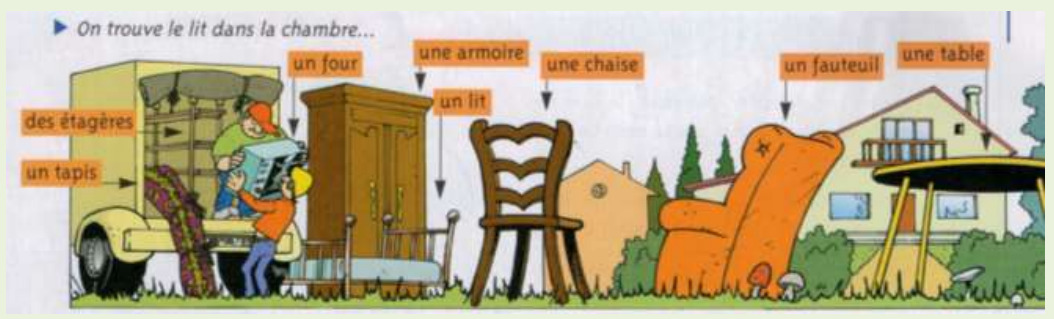


Componentes

Fonética

Compreensão e produção escritas
Tipos de imagens fixas predominantes

- Elementos gráficos

- Tipografia (negrito)

- Desenhos

Fotografias de gêneros textuais.

No caso de documentos fabricados, a estrutura e a tipografia do documento são característicos do gênero textual em questão.

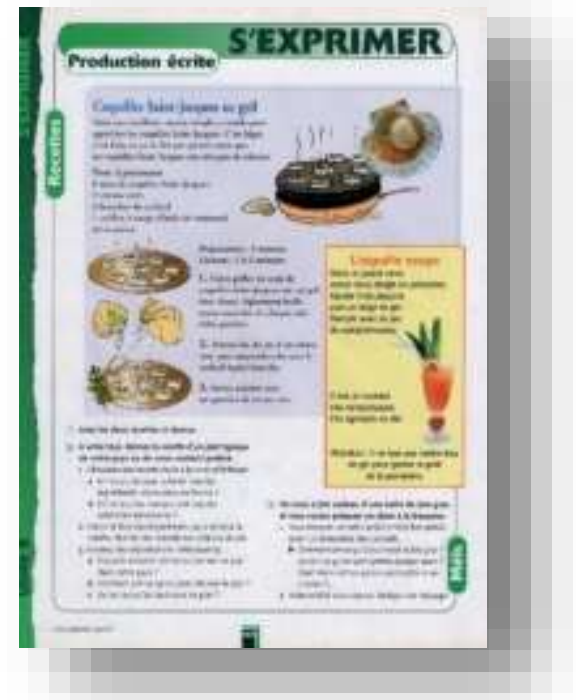

Interculturalidade Civilização
Sons, rythmes, intonations

1. Le rythme et l'accentuation

Au téléphone

Oui... Non... Bien.

Ça va... Et vous ?... Aussi...

Je comprends... Je connais... À Paris..

Le directeur... Un étudiant... Un Italien

Il parle français.

2. L'enchaînement

Je m'appelle Anna.

J'habite à Paris.

Je suis italienne.

Je parle espagnol.

Voici Roberto.

Il est espagnol.

Il habite en France.

Il est étudiant.
Il comprend l'anglais... Il connaît Paris.. 


\subsection{Funções possíveis para a imagem no ensino-aprendizagem do FLE}

\section{Funções prescritas e não prescritas, funções possíveis}

Nesta parte do capítulo, interessamo-nos especificamente pelas funções que as imagens de um livro didático de FLE podem exercer no meio para o qual essa publicação foi concebida, ou seja, a sala de aula. Esse ponto constitui a penúltima pergunta de pesquisa de nosso trabalho. Acreditamos que, para uma melhor utilização e exploração das imagens no ensino de FLE, é preciso que o professor esteja consciente das diferentes funções que as mesmas podem exercer, sobretudo, em um texto multimodal. A nosso ver, essa conscientização e maior clareza das diferentes funções possíveis para as imagens em sala de aula ajudarão o professor não somente a explorar melhor os textos multimodais quando faltam indicações nos LDs, mas também a criar mais conscientemente suas próprias atividades na elaboração de uma sequência didática.

Propomos, portanto, a definição de algumas funções para a imagem fixa no ensino-aprendizagem do FLE utilizando, para isso, os diferentes elementos de análise e os aportes teóricos trazidos em nossa pesquisa. Levamos em conta não somente as utilizações previstas para a imagem nos livros didáticos de FLE analisados neste trabalho, mas também nas utilizações possíveis para o suporte visual em sala de aula, mesmo que elas não tenham sido preconizadas pelo guia pedagógico. Definimos nesta tese quatro grandes funções para a imagem no ensino-aprendizagem do FLE: a situacional, a conceitual, a atuante e a expressiva.

\subsubsection{Função situacional}

A imagem com função situacional tem como objetivo introduzir o aluno/usuário da língua em um determinado universo de comunicação. Podemos estar nos referindo a um universo de comunicação mais amplo, como um universo temático em torno do qual será construída uma lição do LD, ou de uma situação de comunicação mais particular, como as que aparecem frequentemente nos diálogos situacionais do livro. As imagens com função situacional podem, portanto, declinar-se em diferentes tipos, como:

- Fotos de abertura temática de uma lição: geralmente de grandes dimensões, elas introduzem uma unidade. A situação de comunicação - oral ou escrita - costuma ser mais abrangente. Estamos ainda em uma abordagem ampla das situações de comunicação que serão tratadas de forma mais precisa no interior das unidades. 
- Desenhos que acompanham os diálogos das situações de comunicação do livro didático. Eles representam os personagens e as ações narrativas do diálogo em questão.

- Imagens ou sequências de imagens que mostram uma situação de comunicação ou que narram uma história. Exemplo: charges ou histórias em quadrinhos.

A seguir, alguns exemplos de imagens com função situacional:

Figura 155 | Forum 1 - pág. 22, 23

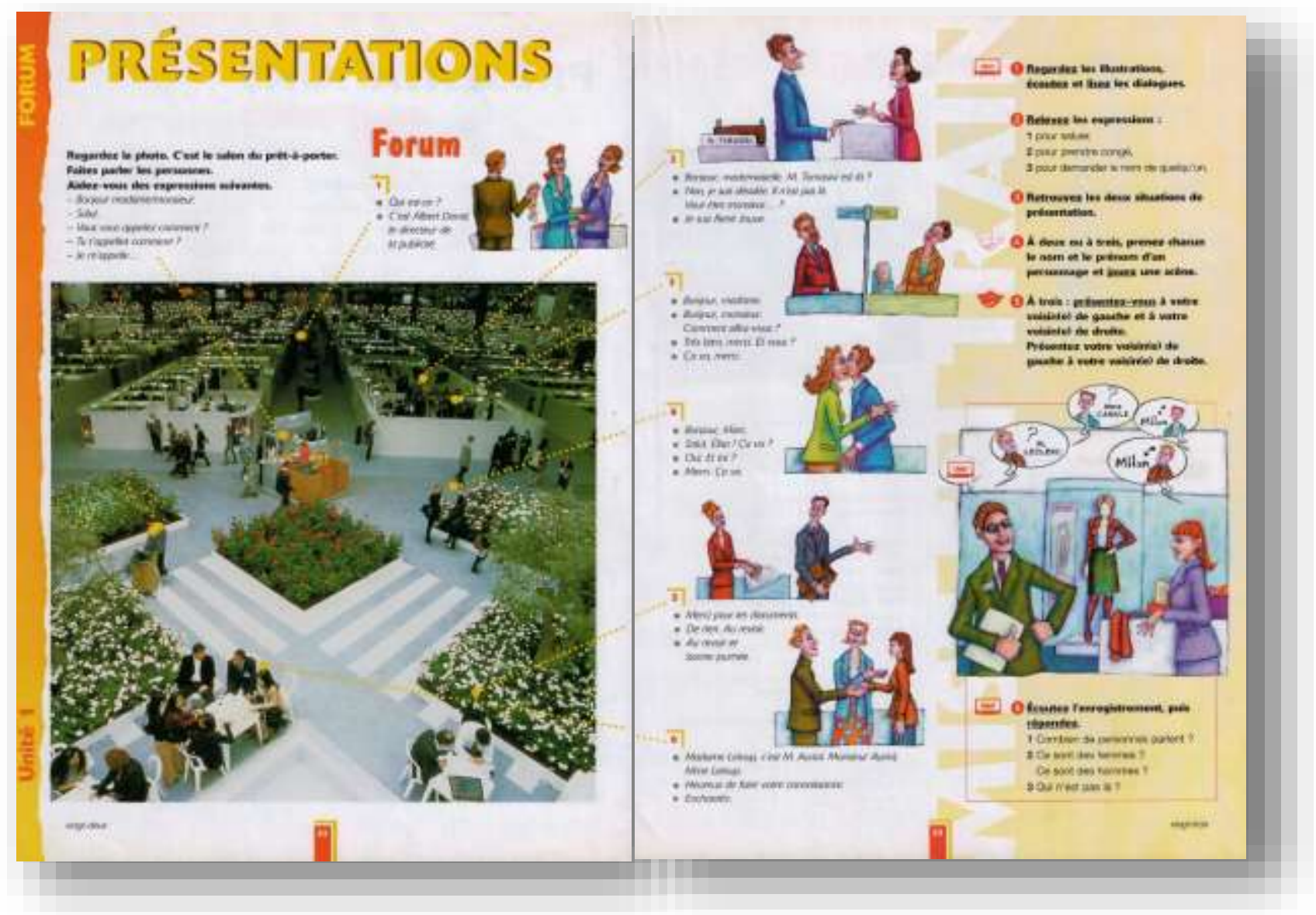

No exemplo acima vemos, à esquerda, uma grande foto de abertura temática e situacional da lição e, à direita, desenhos para situações de comunicação mais específicas. 
Figura 156 | Archipel 1 - pág. 80

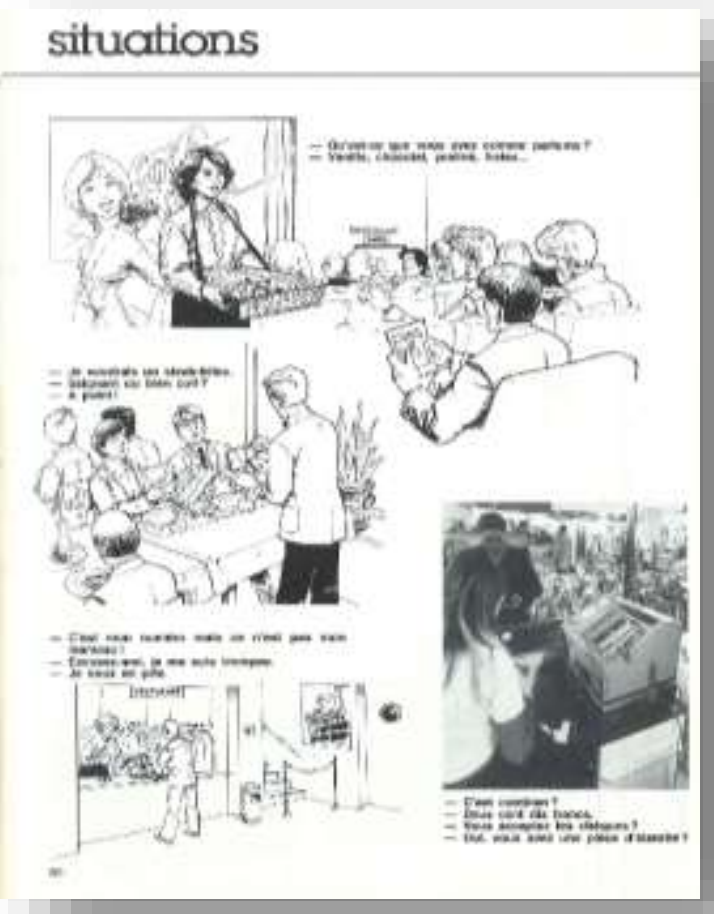

Figura 157 | Espaces 1 - pág. 13

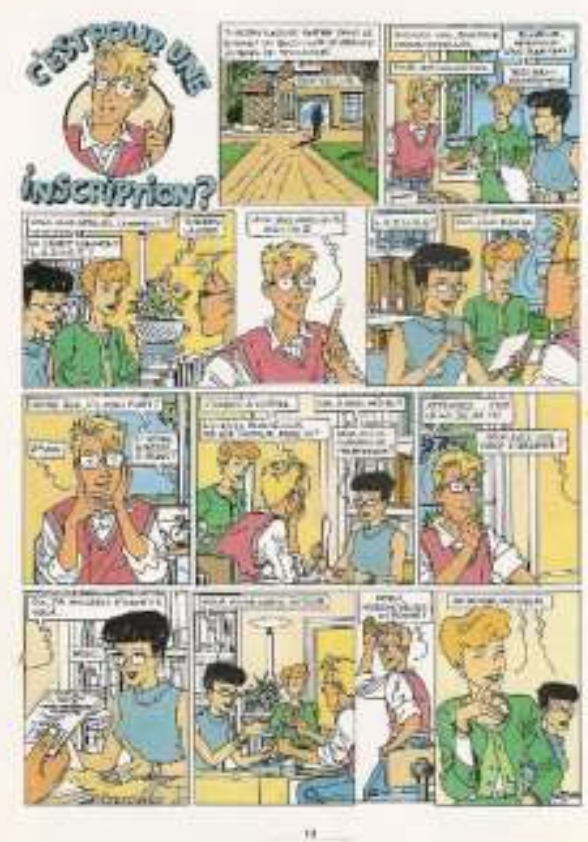

Figura 158 | Écho A1 - pág. 34, 35

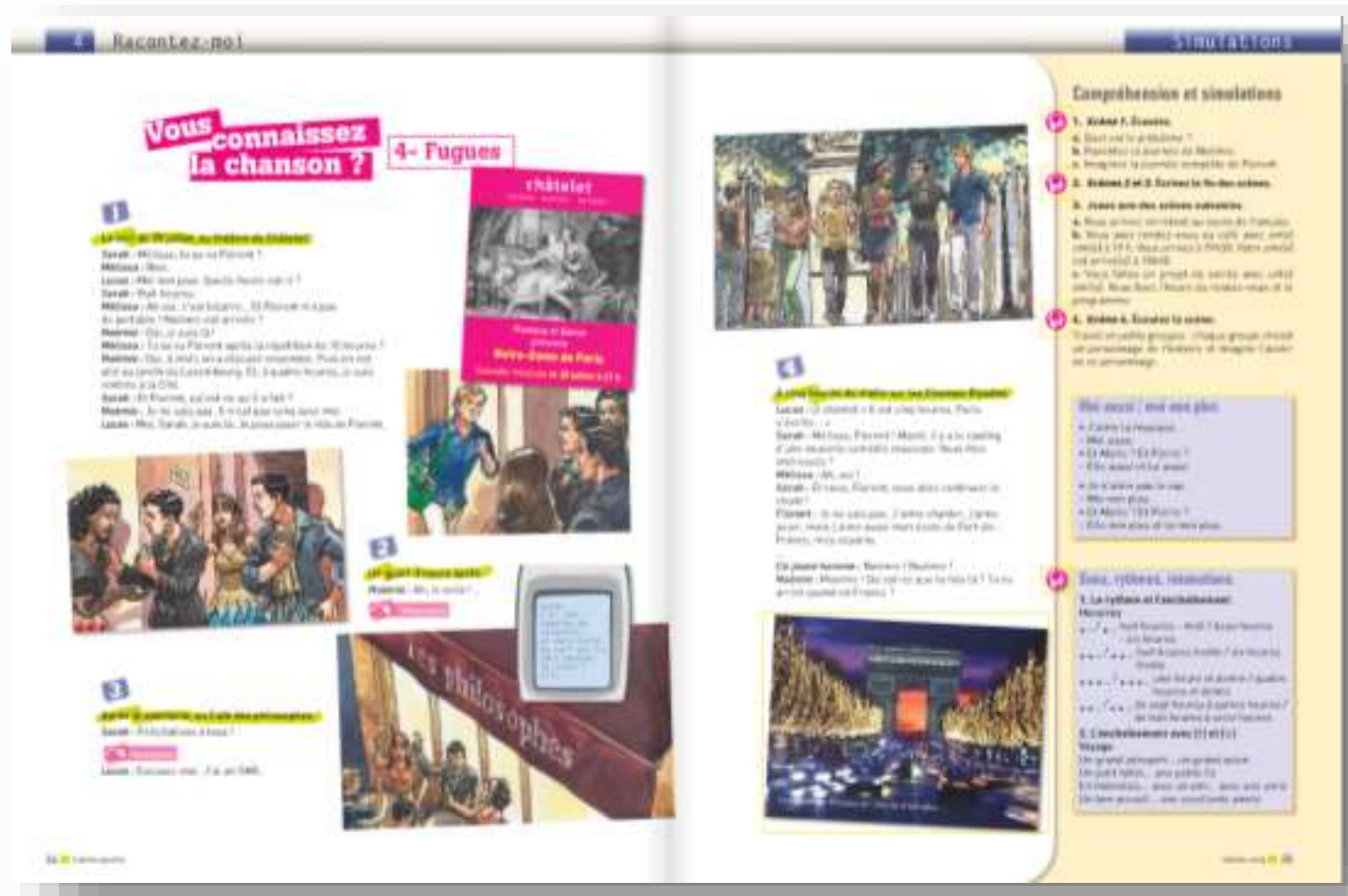




\subsubsection{Função conceitual}

A imagem com função conceitual tem como objetivo apresentar, representar ou evocar:

- Um vocabulário específico como, por exemplo, o léxico da alimentação, das frutas, legumes, etc.;

- Uma noção específica como, por exemplo a noção de trabalho, de guerra ou de paz. Vale ressaltar que a leitura e a interpretação dessa imagem estarão diretamente relacionadas com o contexto sociocultural do aluno.

- Um determinado gênero textual pelo aspecto visual e formal do discurso da imagem: cartões de visita, e-mails, sites da Internet, receitas de cozinha, anúncios publicitários, folders turísticos, etc.

- Aspectos socioculturais ligados a uma língua-cultura e a seu patrimônio cultural. Exemplo: uma foto da Torre Eiffel ou de outro monumento francês, a foto de uma baguette ou de uma boulangerie francesa na parte do livro didático dedicada aos aspectos interculturais. Caberá ao professor estar vigilante para relativizar as noções pré-concebidas que as imagens podem eventualmente evocar nos alunos. Isso é válido, a nosso ver, não só para as imagens presentes no livro, mas também para as imagens mentais da cultura-alvo que cada aluno já traz consigo ou constrói em seu "museu imaginário particular".

A seguir, alguns exemplos de imagens com função conceitual. 
Figura 159| Archipel 1 - pág. 109

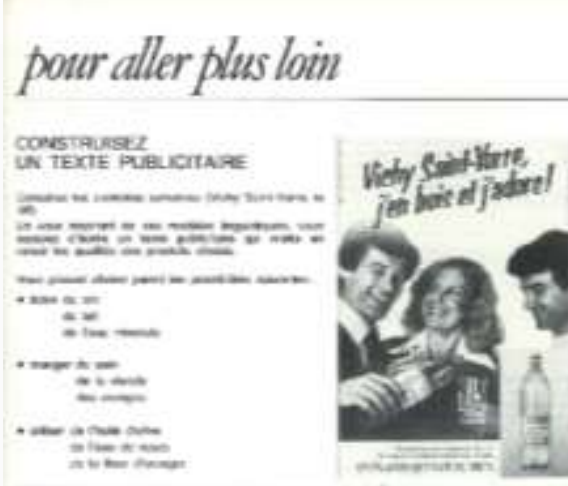

SIVOUS NE GUNEZ PAS DE LAIT. MANGEZ-EN

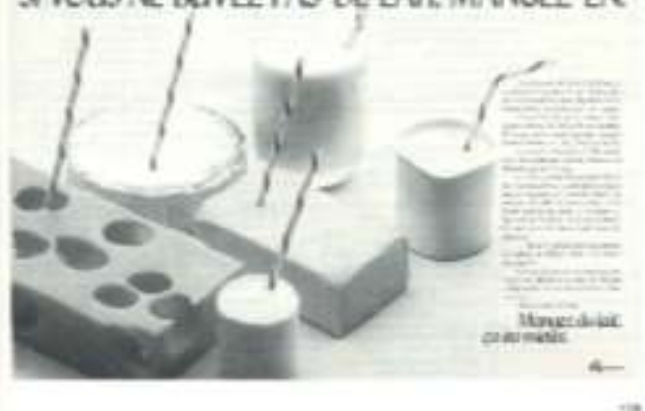

Figura 160| Espaces 1 - pág. 93

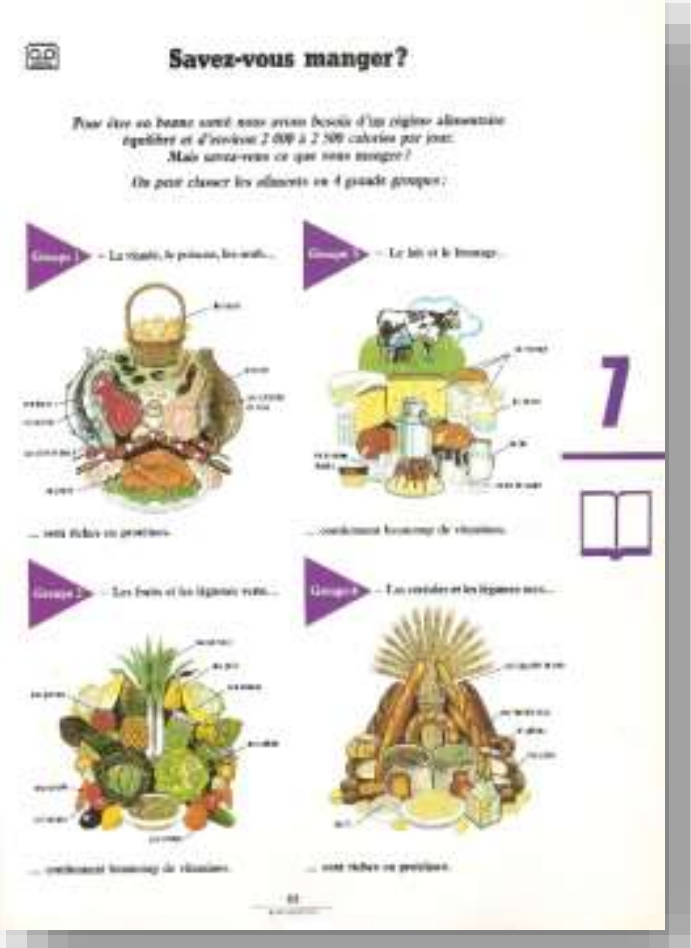

Figura 161 | Forum 1 - pág.37

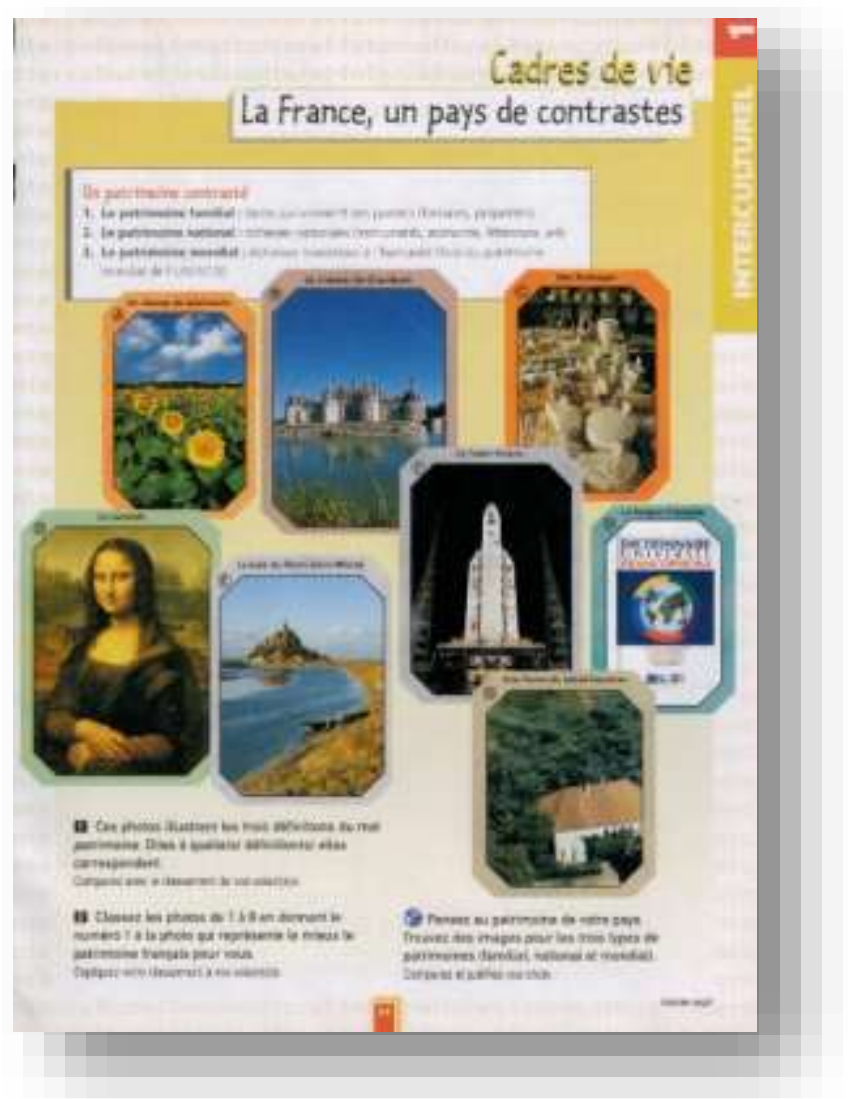




\subsubsection{Função atuante}

Neste caso, a imagem é utilizada - pelo livro didático ou pelo professor - como ferramenta para a realização de uma ação ou de uma tarefa pelo aluno. Pede-se ao aluno bem mais do que uma observação passiva da imagem. Na verdade, ele deve realizar uma tarefa a partir da mesma. Essa tarefa estará frequentemente associada aos outros suportes semióticos que compõem o texto multimodal. Alguns exemplos de tarefas associadas à imagem que o livro didático - ou o professor - poderá solicitar ao aluno:

- Comparar duas imagens, identificando diferenças e pontos em comum (estilos, cores, personagens, épocas, locais, etc.);

- Após apagar textos de alguns balões de uma história em quadrinhos, o professor pede aos alunos para completá-los;

- Após recortar os desenhos de uma história em quadrinhos, pedir aos alunos para os colocarem em uma ordem lógica. O mesmo pode ser feito com desenhos que representam diferentes etapas/fases de uma situação de comunicação narrativa;

- Pedir aos alunos que associem imagens a documentos sonoros;

- Pedir aos alunos que escolham, dentre uma série de imagens, aquela que melhor corresponde a um determinado diálogo;

- Pedir aos alunos que escolham, dentre uma série de imagens, aquela que melhor corresponde a um texto escrito ou a um artigo e, eventualmente e em função do nível dos alunos e da dificuldade do exercício, que justifiquem a escolha.

- Inúmeras outras atividades que podem ou não estar previstas no livro do aluno ou no guia pedagógico.

Trata-se de uma função suplementar que é atribuída à imagem pelo professor ou pelo material didático. Utilizamos o termo "suplementar" pois as imagens podem ter, em sua origem, uma função situacional ou conceitual. Por exemplo: quando pedimos aos alunos que coloquem em ordem os desenhos de uma história em quadrinhos, estamos acrescentando uma função atuante a uma imagem que tem em sua origem uma função situacional. Acreditamos que esse acréscimo da função atuante a uma imagem favorece a aprendizagem pois aumenta a interação e a profundidade da leitura que o aluno faz do suporte visual. 
Mostramos, a seguir, dois exemplos de funções atuantes que foram acrescentadas à imagem em um livro didático. No primeiro caso, a função foi prescrita pelo próprio LD. No segundo, trata-se de uma possibilidade a ser explorada pelo professor. O primeiro caso corresponde à atividade prevista pelo livro didático Espaces 1 na dupla página 52-53 que analisamos anteriormente nesta pesquisa.

Figura 162 | Espaces 1 - pág. 52, 53

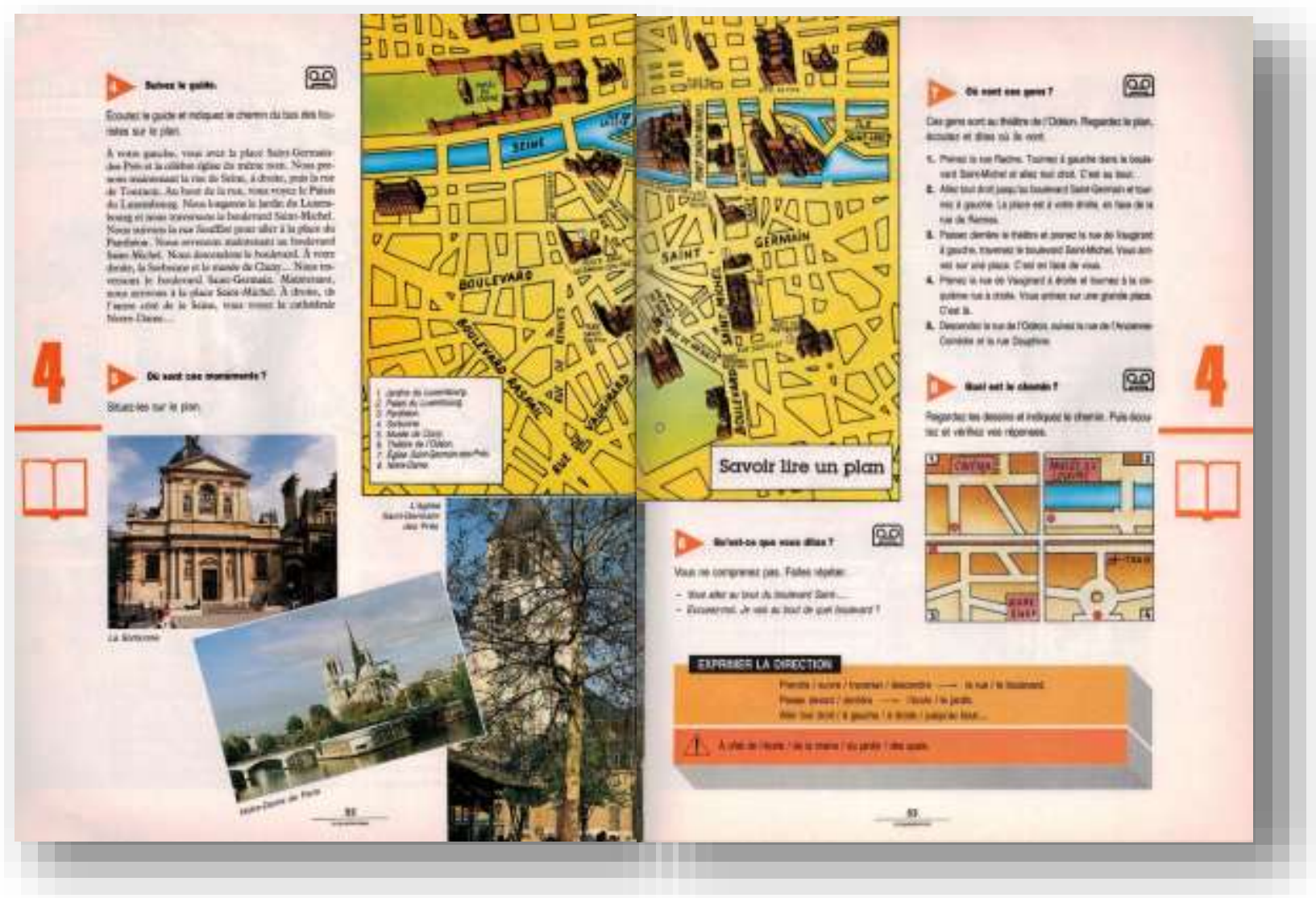

A função das imagens poderia ser apenas conceitual, uma vez que elas representam um mapa e monumentos de Paris. O livro didático, no entanto, acrescenta uma função atuante às imagens ao associá-las ao documento sonoro, pedindo que o aluno desenhe no mapa o caminho feito pelo ônibus de turistas e que situe também no mesmo mapa os monumentos que aparecem nas pequenas fotos. Acreditamos que essa proposta é extremamente interessante e pertinente pois coloca em interação todos os recursos da página multimodal (visuais, sonoros e escritos), explorando-os de forma coerente, interligada e simultânea. Essa interação conjunta na leitura dos suportes é 
importante, pois evita que eles sejam segmentados ou compartimentados como se não compusessem a mesma mensagem, o que não é o caso do texto multimodal.

Evita-se assim uma abordagem pedagógica fragmentada de textos multimodais que, infelizmente, ainda é bastante comum nos dias de hoje. Nela, o professor (ou o livro didático) pede ao aluno que, primeiramente, observe a imagem. Em seguida, que ouça o diálogo e que faça as atividades de compreensão oral. Nesse momento, a imagem já foi completamente abandonada e esquecida, assim como o diálogo será esquecido na atividade posterior dentro da mesma página multimodal.

Várias outras funções atuantes podem ser acrescentadas às imagens de um texto multimodal, mesmo quando isto não tenha sido previsto pelo livro didático. A facilidade trazida pelas novas tecnologias na manipulação das imagens ajuda o professor a criar novas funções para a imagem de maneira a explorar melhor um texto multimodal. No exemplo abaixo, do livro Écho A1, um texto sobre saúde e bem-estar (documento fabricado) reproduz a forma visual e o tipo de discurso de um artigo de revista sobre esse assunto. Nenhuma atividade é prevista para as imagens (uma foto e desenhos de posições para relaxar). Há apenas atividades de compreensão escrita:

Figura 163 | Écho A1 - pág. 108

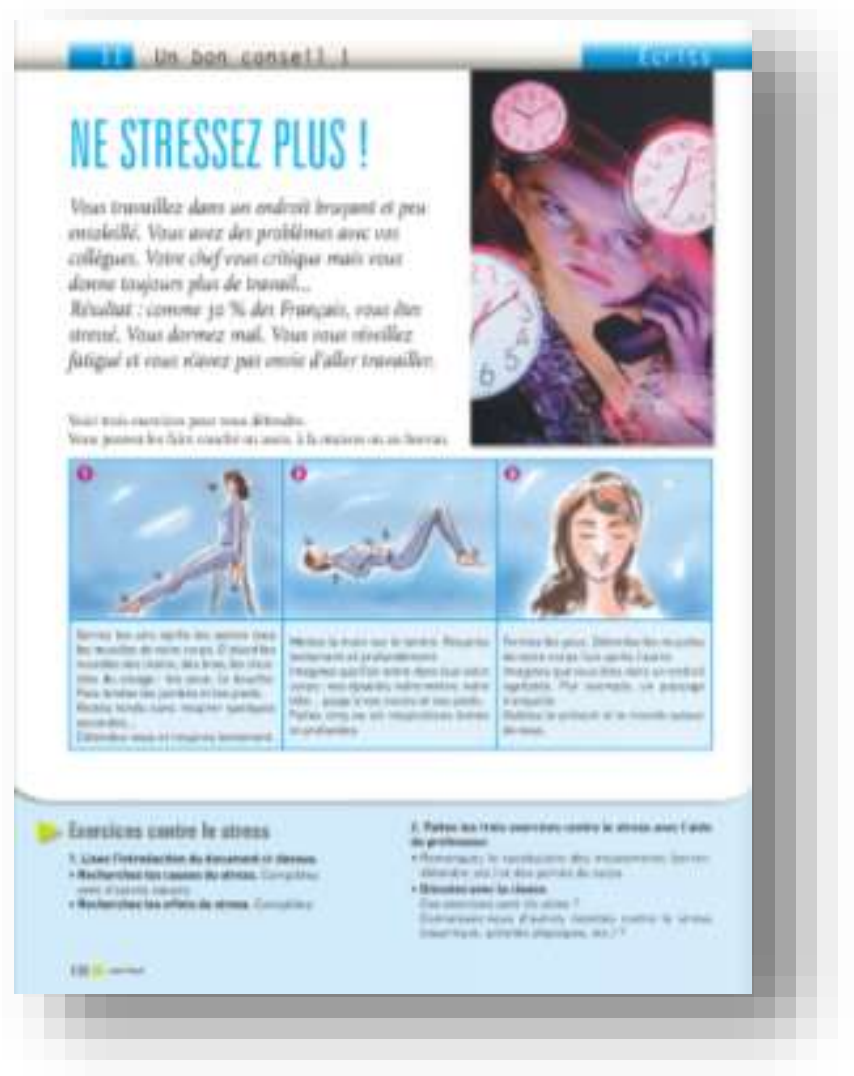


Mesmo que não haja orientações específicas para o uso da imagem e da associação imagem-texto escrito, as possibilidades de se criar uma função atuante para a mesma são muito grandes e, cada vez mais fáceis de serem concebidas graças às tecnologias Algumas possibilidades simples de exploração podem valorizar o discurso visual, multiplicar os tipos de leitura, aprofundar a compreensão do texto e, consequentemente, a aprendizagem da língua, mesmo em um nível básico de aprendizagem (os alunos encontram-se, nesse ponto do livro, no início do nível A2 do QECR). Vejamos algumas opções para acrescentar uma função atuante a essas imagens.

Opção 1. Introduzir o tema apenas pela imagem principal, sem mostrar ainda a página multimodal. Pedir aos alunos que observem a imagem, que descrevam os elementos que a compõem, suas cores, sua estrutura. Que associem algumas palavras (substantivos ou adjetivos) a essa imagem e sentimentos à personagem da foto. Que pensem em um tipo de publicação na qual essa imagem poderia ser inserida.

Figura 164 | Écho A1 - Pág. 108 - detalhe

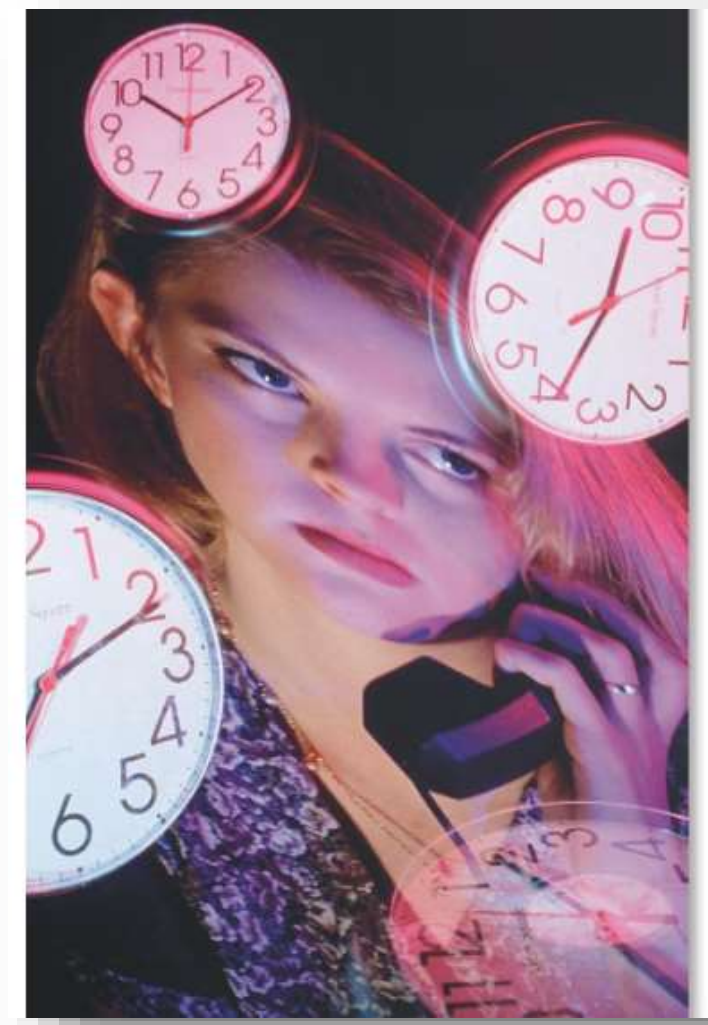


Opção 2. Esconder as partes principais do texto. Apenas com o título e com as imagens, pedir aos alunos que imaginem qual o tipo de publicação, a que público o texto se destina (idade, sexo, etc.) e com que objetivo foi escrito. Pedir também que identifiquem o tema que será tratado e que imaginem o conteúdo do texto para as partes $\mathrm{n}^{\circ} 1$ e $\mathrm{n}^{\circ} 2$ (Figura 165).

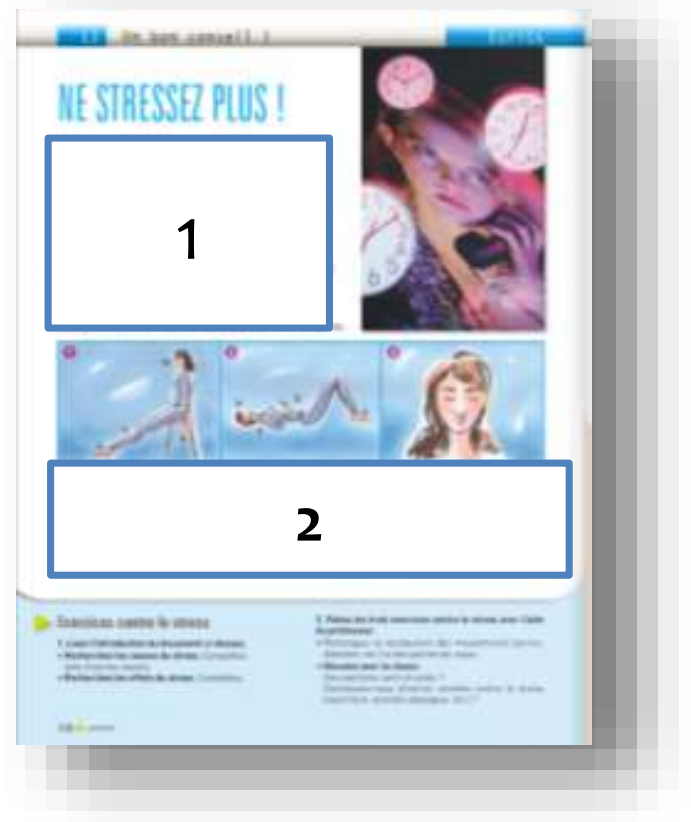

Figura 165 | Écho A1 - Pág. 108

Opção 3: Esconder os desenhos ilustrativos e fornecê-los em desordem aos alunos. Eles deverão associar cada um deles aos pequenos textos correspondentes. Cada texto descreve uma posição de relaxamento ilustrada nos desenhos.
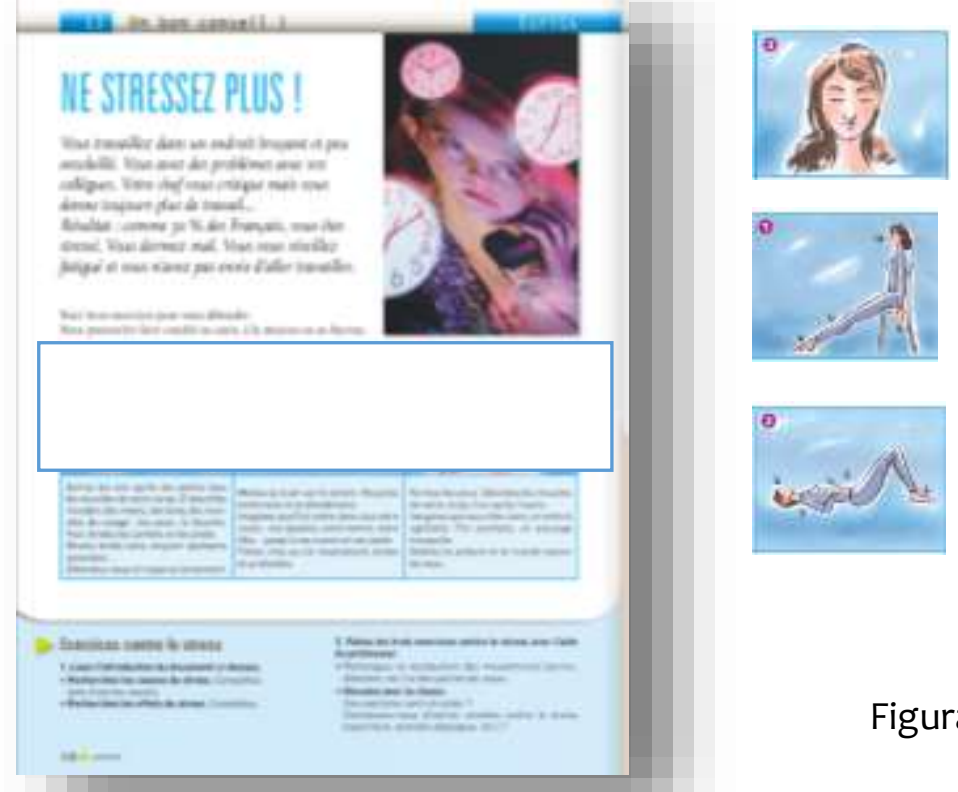

Figura 166 | Écho A1 - Pág. 108 
Após as atividades completas de compreensão escrita, por que não propor como atividade de produção escrita que os alunos contribuam para a revista indicando novas posições de relaxamento? Em grupos de dois ou três pessoas, os alunos redigiriam um pequeno texto para descrever uma quarta posição de relaxamento e trocariam os textos entre os grupos constituídos. Cada grupo se encarregaria, em seguida, de desenhar uma imagem correspondente ao texto recebido. O grupo criador do texto daria seu aval final para dizer se o desenho produzido estava ou não coerente com a posição de relaxamento que havia sido descrita inicialmente.

\subsubsection{Função expressiva}

Sabemos todos o quanto o processo de criação e de criatividade é importante no processo de ensino-aprendizagem de uma língua tanto para o aluno quanto para o professor. A função expressiva é a função trazida pela imagem que o próprio aluno escolheu - ou criou - para sua produção oral ou escrita. Até agora havíamos visto imagens trazidas pelo livro didático ou pelo professor. O aluno, em seu processo de criação, expressa-se também pelos recursos visuais e estes devem ser previstos e valorizados no processo de aprendizagem. Acreditamos que dois tipos de expressão visual podem e devem ser previstos e solicitados pelos professores.

O primeiro ponto diz respeito ao aspecto visual e formal de um gênero textual. Se estamos trabalhando um gênero textual específico, um estudo sobre sua estrutura característica e seu aspecto visual deve compor a sequência didática. De fato, um gênero possui não somente um discurso textual, mas também um discurso visual. A análise da estrutura recorrente desses dois discursos - tanto na recepção do texto quanto na produção do mesmo - é extremamente importante dentro das práticas de ensinoaprendizagem de uma língua estrangeira.

O segundo ponto, que não deixa de estar ligado ao primeiro, é a importância para o aluno de poder trazer algo de si mesmo, algo que lhe seja próprio, para as produções realizadas. Esse "algo" pode ser sua facilidade para o desenho, para a informática, para a diagramação, uma citação que ele aprecia particularmente e que será acrescentada ao seu trabalho, fotos que ele tirou durante uma viagem, fotos de sua autoria, imagens de autoria de outras pessoas, fotógrafos, artistas que ele aprecia e que ele acrescentará à sua produção escrita criando assim, por sua vez, seu próprio texto multimodal. 
Em meu contexto de trabalho, propus em 2010 a criação de um blog destinado à publicação dos trabalhos dos alunos da Aliança Francesa de São Paulo, o Blog da Francofonia32. O objetivo era o de valorizar as produções feitas pelos alunos e, consequentemente, o trabalho dos professores, já que são eles que criam as condições necessárias para que essas produções sejam realizadas. O blog está on-line há cinco anos e nos chama a atenção o fato de que praticamente todas as produções enviadas para publicação contêm, além de texto escrito, uma ou mais imagens. Acreditamos que essas imagens que compõem os textos multimodais criados pelos alunos cumprem justamente o papel de tornar a produção mais pessoal por meio de um outro canal de expressão que não deve ser negligenciado.

\subsubsection{Multifunções e multileituras}

Gostaríamos de salientar que as quatro funções da imagem aqui propostas não são, evidentemente, excludentes, mas, ao contrário, completam-se de acordo com os objetivos da sequência didática criada pelo LD ou pelo professor. Desta forma, vemos as seguintes possibilidades de combinações e de leitura:

\section{Uma página multimodal composta por imagens de diferentes funções.}

Isto ocorre, por exemplo, na página multimodal representada a seguir (Figura 167), composta por duas imagens, um diálogo cujo texto está transcrito na mesma página e por um texto escrito. As imagens têm funções diferentes: o desenho tem uma função sobretudo situacional pois mostra o personagem do diálogo em seu escritório ao telefone. No diálogo, ele pergunta a um colega seu endereço. A segunda imagem, um mapa de uma cidade, tem uma função sobretudo conceitual pois representa um gênero textual específico. As duas imagens interagem com o diálogo e com o texto na construção do sentido multimodal. 


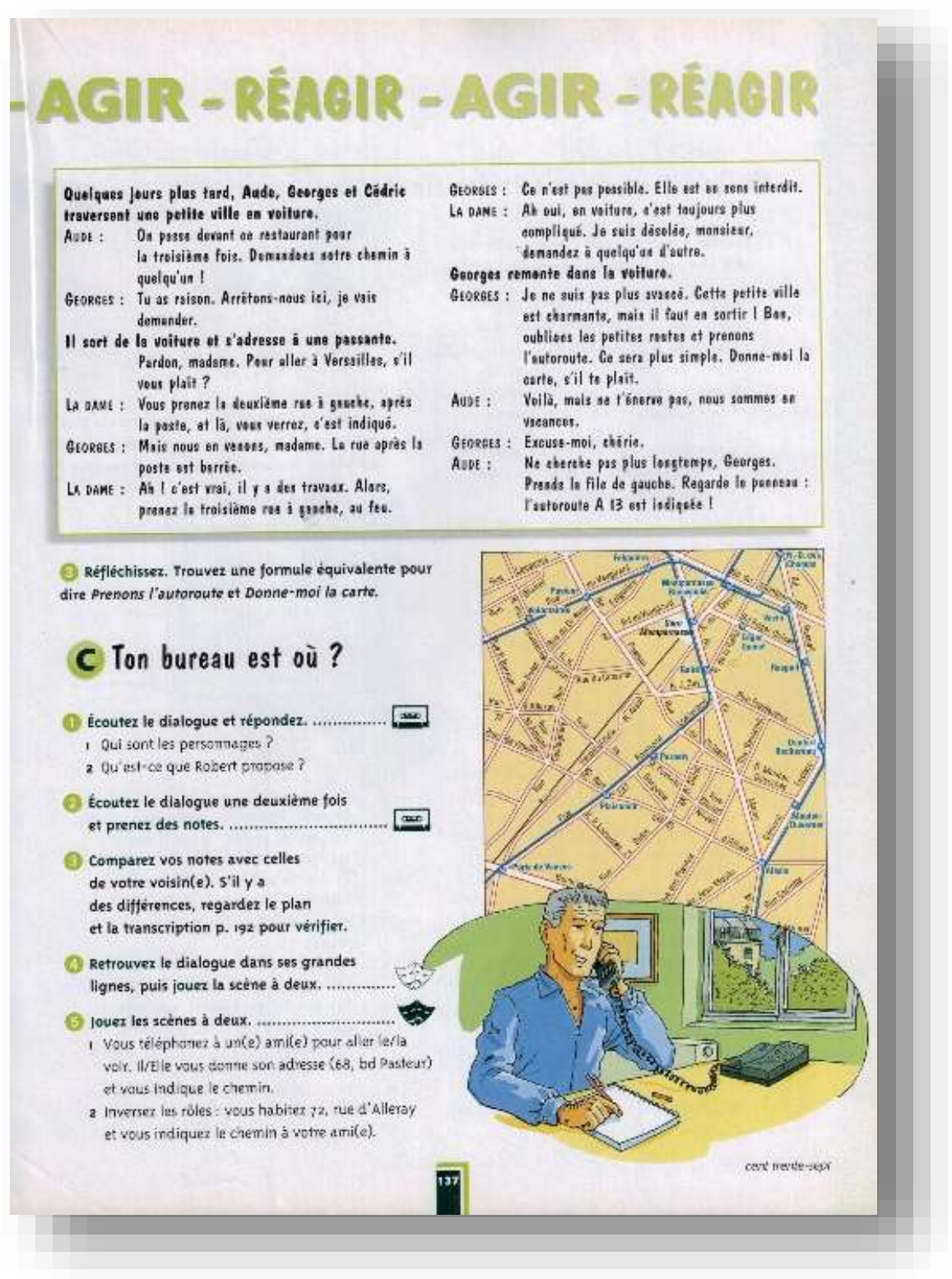

Já no exemplo a seguir, do livro didático Écho A1 (Figura 168), a situação de comunicação está acompanhada de duas imagens de tipos e funções específicas: o desenho tem função situacional e representa os personagens do diálogo. Já a foto, de uma rua de Saint-Malo, tem uma função conceitual, pois traz uma informação visual sobre a cidade onde os personagens se encontram. Mais uma vez, diferentes suportes semióticos com diferentes funções contribuem para uma maior riqueza e a profundidade da leitura e da construção do sentido. 
Figura 168 | Écho A1 - pág. 99

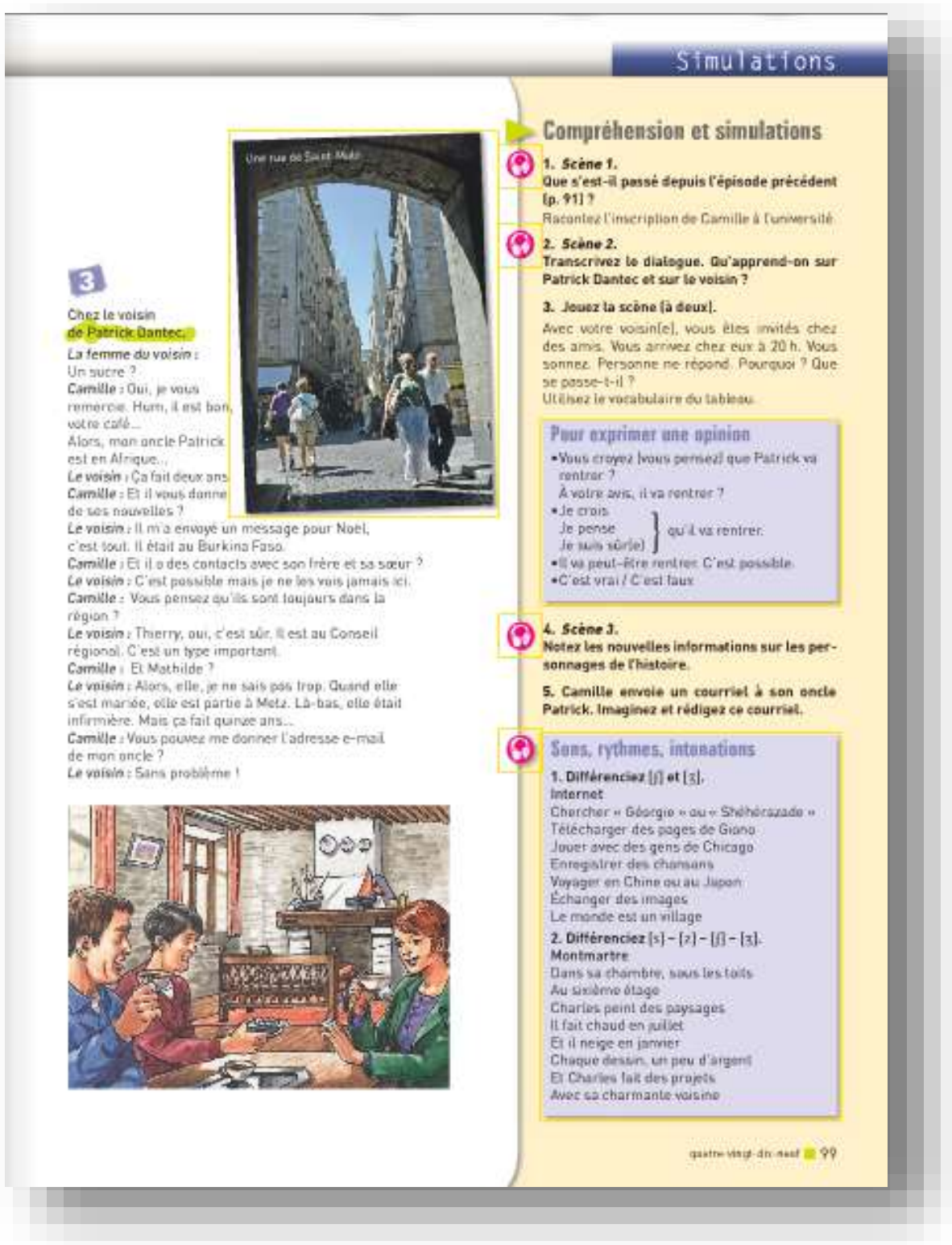

\section{Uma mesma imagem com diferentes funções.}

Já vimos que a função atuante pode se sobrepor à função situacional ou conceitual de uma imagem. Mas é importante lembrar também que uma imagem pode ser situacional e conceitual ao mesmo tempo. A função a ser explorada em prioridade, quando há um acúmulo de funções, dependerá dos objetivos pedagógicos a serem atingidos. 
Observemos abaixo uma dupla página multimodal do livro didático Forum 1:

Figura 169 | Forum 1 - Pág. 114, 115.

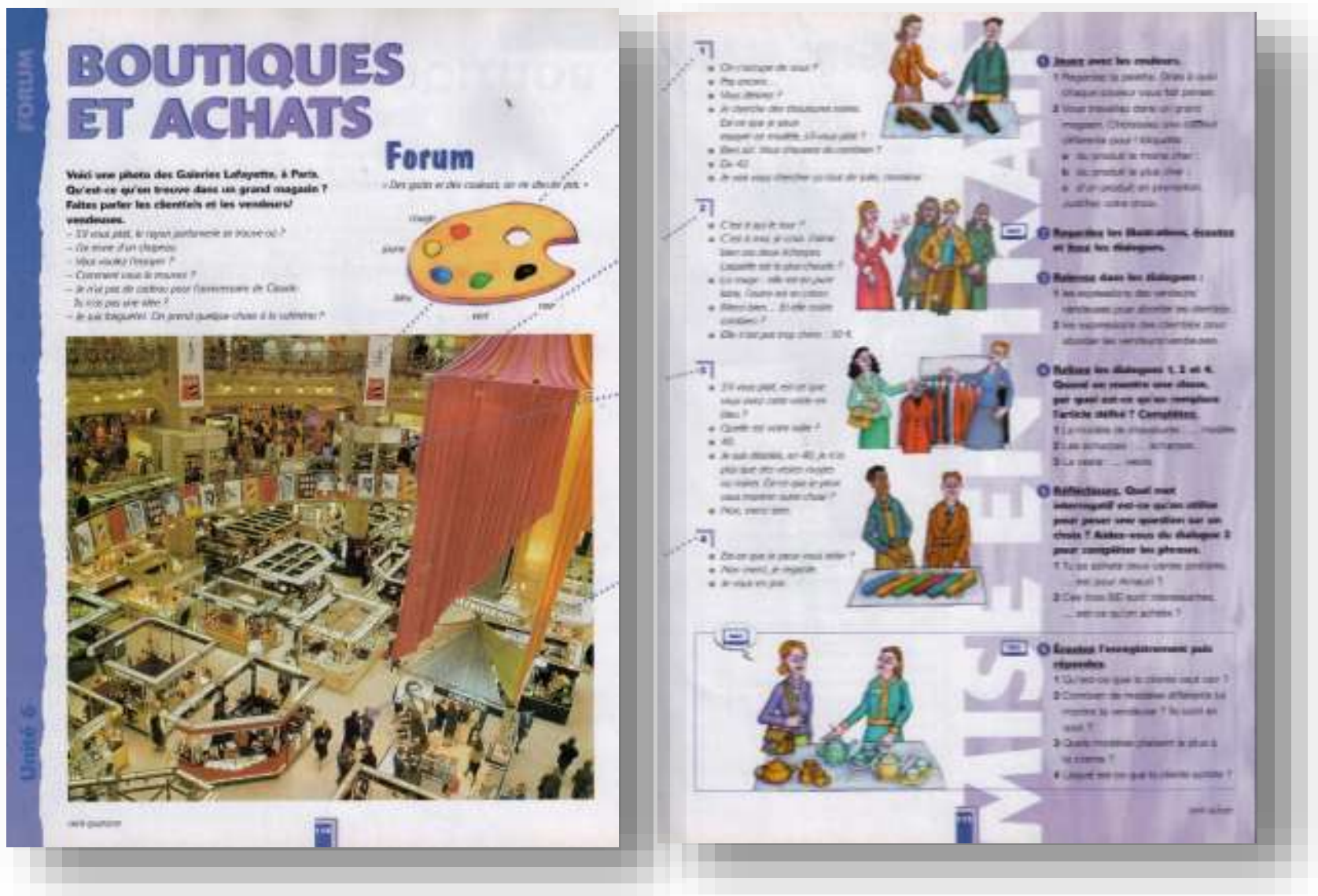

A grande foto situacional à esquerda mostra uma imagem das Galeries Lafayette em Paris. Os diálogos trabalhados nessas páginas preparam o aluno para o objetivo comunicativo “comprar um produto em uma loja”. Dentro desse objetivo serão abordados temas linguísticos como o léxico das vestimentas, das cores, as expressões para se perguntar o preço de um produto, a frase interrogativa, etc. O LD acorda a essa grande foto uma função situacional, como podemos ver no enunciado do texto:

Voici une photo des Galeries Lafayette, à Paris. Qu'est-ce qu'on trouve dans un grand magasin? Faites parler les client(e)s et les vendeurs/vendeuses. 
O professor poderá, no entanto, em função de seus objetivos e do perfil de seu grupo, trabalhar também a função conceitual dessa mesma foto. Ela é rica em aspectos socioculturais, sobretudo no que diz respeito aos grands magasins de Paris, à importância que eles tiveram no desenvolvimento da cidade e ao fascínio que exercem até hoje em muitos turistas.

Acreditamos, portanto, que a função pedagógica de uma imagem não é prédeterminada pela sua estrutura, por seu tipo ou por seu formato. Claro, vimos anteriormente que as fotos geralmente se prestam bem à exploração de funções culturais, por exemplo. No entanto, cremos que uma mesma imagem pode ser utilizada para públicos de contextos e de níveis linguísticos diferentes, trabalhando-se funções visuais diversas, desde que a proposta de exploração pedagógica da mesma esteja adaptada aos objetivos que o professor e/ou o livro didático queiram atingir.

Estamos convencidos da riqueza de possibilidades de leitura que nos propõem os textos multimodais e também da importância de sua presença com uma exploração adequada em sala de aula. A nosso ver, a capacidade de leitura de uma imagem aumenta conforme aumentam as funções que lhe atribuímos durante o processo de ensinoaprendizagem de uma língua. Quanto mais a imagem for trabalhada em sala de aula, quanto mais atividades forem propostas para sua leitura e interpretação, maior será a interação entre os diferentes recursos semióticos do texto multimodal - e também entre os alunos - e, consequentemente, melhor será a aprendizagem e a aquisição de uma língua-cultura.

É necessário, portanto, que o professor de FLE esteja atento não só às funções que o LD prevê para a imagem em sala de aula, mas também - e o que é mais difícil - às possibilidades de exploração oferecidas pelo suporte mas que não estão descritas ou preconizadas pelo mesmo.

Por essa razão, propusemos a definição de quatro funções básicas para a exploração pedagógica da imagem em um texto multimodal no ensino-aprendizagem do FLE: a situacional, a conceitual, a atuante e a expressiva. A nosso ver, o simples fato de conhecer essas funções, já permitirá ao professor um olhar mais crítico para qualquer imagem que ele for trabalhar em classe. Isso lhe permitirá não somente explorar melhor as imagens do livro didático com o qual trabalha, mas também criar suas próprias atividades, com suas próprias imagens, utilizando ele próprio a função expressiva desse suporte. 
Na busca por caminhos possíveis para a exploração da imagem em um texto multimodal, vimos a importância da interação entre os diferentes signos semióticos na construção de significados e também a importância de se propor atividades que permitam trabalhar diferentes meios semióticos simultaneamente, exigindo uma posição atuante por parte do aluno. De fato, se quisermos trabalhar a multimodalidade com mais propriedade e preparar nossos alunos a agir socialmente na língua-alvo, é necessário propor não só uma recepção multimodal mas também uma produção multimodal no ensino-aprendizagem da língua.

O que notamos muitas vezes é que, apesar de vivermos em uma sociedade cada vez mais marcada pela multiplicidade de signos, de textos e de leituras, as atividades realizadas em aula de FLE ainda parecem "compartimentadas" e "segmentadas" entre as famosas "quatro competências", como eram chamadas essas atividades antes da publicação do QECR: a compreensão oral, a compreensão escrita, a produção oral, a produção escrita. Muitas vezes passamos de uma “competência” a outra em sala de aula, sem associá-las e sem deixá-las interagir simultaneamente como acontece na leitura de textos multimodais da vida real. Evidentemente, não nos opomos a um trabalho específico sobre a compreensão escrita ou oral, por exemplo, em determinado momento de uma aula ou de um programa de FLE. O que queremos dizer é que não devemos perder de vista a importância exercida pela interação entre os diferentes elementos semióticos na construção de sentidos. 


\section{CAPÍTULO 5 |A VOZ DO PROFESSOR}

Une photographie est réussie lorsque l'observateur s'approprie l'image et construit sa propre symbolique, sa narration personnelle.

Vincent Fillon 


\section{CAPÍTULO 5 | A VOZ DO PROFESSOR}

\subsection{Metodologia para a coleta de dados: o questionário}

Nesta etapa do trabalho, após termos definido funções prescritas e funções possíveis para a imagem no ensino-aprendizagem do FLE, buscamos conhecer o ponto de vista do "mediador" entre o livro didático e os alunos, ou seja, o professor de FLE.

De fato, interessa-nos saber quais usos os professores preveem para a imagem em sala de aula, já que são eles os principais destinatários dos guias pedagógicos e os principais leitores de suas preconizações. Precisamos saber se as orientações dos LDs Ihes parecem claras, coerentes, fáceis de serem postas em prática e adaptadas a seu público. Gostaríamos de saber se eles sentem ou não falta de orientações mais precisas e/ou aprofundadas sobre o uso das imagens dos livros didáticos. É importante sabermos também se as orientações presentes no guia pedagógico e no livro do aluno são seguidas estritamente pelos professores de FLE ou se eles sentem necessidade de adaptá-las, de modificá-las, de criar novas atividades para a exploração da imagem de acordo com seus objetivos pedagógicos e com o perfil de seu público.

Buscamos conhecer o perfil cultural desse professor e entender o papel que as imagens exercem em sua vida, sua relação com elas e seu interesse pelo suporte visual dentro e fora da vida profissional.

Para obter respostas a essas perguntas sobre a prática docente dos professores de FLE passamos à coleta de dados. A busca de observáveis foi feita por meio da concepção e da aplicação de um questionário on-line que foi respondido por professores de FLE de forma virtual e anônima. Justificamos, a seguir, a escolha desse método para a coleta de dados.

De acordo com as autoras Marina Marconi e Eva Lakatos (2011), como qualquer instrumento de coleta de dados, o questionário apresenta vantagens e desvantagens. Dentre as vantagens, as autoras citam, por exemplo, a rapidez de aplicação, o grande número de dados, a liberdade das respostas em razão do anonimato e a imparcialidade pela não-influência do pesquisador. No caso específico deste estudo, pelo fato de eu trabalhar na escola de FLE citada nesta pesquisa e de estar em contato direto com os cerca de 70 professores da instituição, pareceu-nos possível minimizar - pelo menos em parte - as seguintes desvantagens citadas pelos autores: porcentagem pequena dos 
questionários que voltam, impossibilidade de ajudar o informante em questões mal compreendidas, exigência de um universo mais homogêneo.

Por se tratar de um suporte que apresenta em sua maioria perguntas fechadas, ou seja, perguntas às quais o informante responde por meio de alternativas fixas, os questionários são um instrumento de pesquisa bastante adequado à quantificação, já que eles facilitam a realização posterior de gráficos e tabulações. No entanto, segundo a autora Elisabete de Pádua (2002), as perguntas abertas, ou seja, aquelas às quais o informante responde livremente, trazem informações importantes para uma análise qualitativa, já que nem todas as respostas podem ser previstas pelo pesquisador. No caso específico deste estudo, os pontos evocados de forma espontânea pelos professores nas respostas às perguntas abertas nos forneceram, de fato, informações bastante úteis para uma análise qualitativa.

\subsubsection{Forma e conteúdo do questionário}

A fim de aumentar a eficácia e viabilidade do questionário, observamos em sua elaboração as seguintes normas citadas por Marconi e Lakatos (2011):

- Organizar uma lista de temas ligados ao objetivo geral e específico a fim de elaborar, para cada um deles, duas ou três questões;

- Limitar a extensão do questionário - ele deve conter de 20 a 30 perguntas e demorar cerca de 30 minutos para ser respondido;

- Codificar as questões a fim de facilitar, mais tarde, a tabulação.

Trabalhamos em torno de 5 grandes temas e preparamos algumas questões para cada um deles na elaboração do questionário (apêndice 1). Começamos pelos temas ligados às práticas culturais pessoais dos professores e passamos progressivamente a temas mais diretamente ligados ao trabalho cotidiano do professor com as imagens. No total, chegamos a 30 questões, abrangendo os seguintes aspectos:

A. Dados pessoais (nome, faixa etária, sexo) e contexto de trabalho (escolaridade, instituição de ensino, número de anos de experiência no ensino do FLE)

B. Práticas culturais: relação com a imagem na vida pessoal e no trabalho, representações em relação à imagem.

C. Possibilidades para o uso da imagem em uma aula de FLE importância conferida ao papel da imagem no ensino do FLE, temas para os quais o professor mais utiliza 
a imagem em aula: léxico, gramática, fonética, objetivos culturais e interculturais, compreensão (escrita/oral), produção (escrita/oral), interação (escrita/oral), desenvolvimento de estratégias de aprendizagem, jogos e atividades lúdicas.

D. Preconizações dos guias pedagógicos para o uso da imagem nos livros didáticos de FLE Objetivos principais acordados à imagem pelo guia/livro didático com o qual o professor trabalha, quantidade e qualidade das orientações do guia para o uso das imagens, contribuição das orientações para que os objetivos sejam alcançados.

E. Utilizações efetivas da imagem em uma aula de FLE Objetivos principais para o uso da imagem, necessidade de adaptação das orientações do guia, necessidade de criar atividades complementares, necessidade de formação para o professor trabalhar a imagem em aula de FLE.

No que diz respeito aos tipos de perguntas, adotamos as seguintes opções:

- Perguntas abertas: para que o professor pudesse responder livremente, expressando suas opiniões;

- Perguntas fechadas: em busca de respostas mais objetivas e que facilitassem a tabulação. Seguindo as preconizações dos autores citados, evitamos nesse tipo de pergunta a menção a uma única alternativa no texto, o que poderia induzir a resposta do informante. Com o mesmo objetivo, evitamos também perguntas enunciadas de forma negativa;

- Perguntas de múltipla escolha, por vezes combinadas com uma questão aberta. Buscamos assim unir a facilidade de tabulação à possibilidade de obter mais informações sobre o assunto.

Ao retomarmos abaixo as perguntas de pesquisa que guiam este trabalho, vemos que o questionário foi elaborado de forma a buscar elementos de resposta para a nossa última pergunta de pesquisa, a de $n^{\circ} 5$, voltada especificamente para o trabalho do professor em sala de aula:

1. Qual espaço físico os livros didáticos de FLE reservam para a imagem do ponto de vista estrutural, ou seja, na composição de suas páginas? A evolução tecnológica na qualidade da imagem acompanhou-se também do aumento de sua presença nos livros didáticos? 
2. Que espaço pedagógico é previsto para as imagens nesses livros didáticos e em seus respectivos guias para o professor?

3. Em caso de aumento da presença da imagem nos livros didáticos, houve também mudanças no tratamento pedagógico reservado ao suporte visual?

4. Que funções estão previstas para a imagem nos livros didáticos de FLE? Que funções a imagem pode exercer no ensino-aprendizagem do FLE? Como favorecer o desenvolvimento de letramentos múltiplos nos alunos de FLE capacitando-os a interagir em diferentes situações sócio discursivas?

5. Qual a opinião dos professores sobre as imagens dos livros didáticos e as respectivas preconizações para o seu uso? Quais utilizações os professores de FLE preveem para a imagem e realizam efetivamente em sala de aula?

\subsubsection{Público-alvo, contexto e etapas de aplicação do questionário}

O questionário foi elaborado pela Internet por meio do dispositivo "Google docs" e enviado por e-mail ao seguinte público-alvo:

- Professores da Aliança Francesa de São Paulo - grande maioria dos participantes;

- Professores de FLE que haviam realizado o Curso de didática de FLE da Aliança Francesa de São Paulo entre 2012 e 2014. Eles são, em sua maioria, professores particulares de francês e também da rede particular. Uma porcentagem pequena dos professores que responderam ao questionário trabalha na rede pública. Especificaremos, na análise de dados, a porcentagem de cada um desses perfis.

Trata-se de um público razoavelmente homogêneo que tem o hábito de trabalhar de forma cotidiana com livros didáticos de FLE e que demonstra grande interesse por formações na área do ensino-aprendizagem do FLE.

De fato, a grande maioria dos respondentes trabalha na Aliança Francesa de São Paulo. É importante levar em consideração que se trata também da minha instituição de trabalho, onde ocupo a função de Adjunta ao Diretor de Ensino. Alguns cuidados suplementares foram, portanto, tomados na elaboração e na aplicação dos instrumentos de coleta de dados para evitar que o professor tivesse a impressão de estar sendo "avaliado" no que diz respeito a seus conhecimentos pedagógicos e/ou às suas práticas de ensino. Temos plena consciência de que esse receio de uma possível avaliação comprometeria a espontaneidade das respostas e o resultado da pesquisa. 
É essencial que o professor se sinta à vontade para expressar livremente sua opinião, suas facilidades e dificuldades em relação ao material didático e às práticas de sala de aula. Um dos cuidados que tomamos diz respeito à escolha do vocabulário utilizado no questionário de forma a evitar qualquer termo que pudesse dar a impressão de uma avaliação ou de um julgamento do trabalho do professor.

Como vimos anteriormente, uma das nossas necessidades, por exemplo, é saber se o professor segue ou não as orientações do guia pedagógico e por quê. De modo algum para testar sua "obediência” a algo que seria um guia intocável e detentor de todo o saber, mas sim, obviamente, para entender se as orientações desse guia lhe parecem pertinentes e realizáveis, dentro de sua realidade e de seu contexto de trabalho.

Analisemos, como exemplo, uma eventual pergunta sobre esse tema que poderia ter sido formulada da seguinte forma no questionário: "Você respeita as orientações do guia pedagógico para o uso da imagem?”. É evidente que o caráter inquisitório da interrogação, reforçado pelo verbo "respeitar" faria com que qualquer professor se sentisse um fora-da-lei ao responder “não”. A própria formulação da interrogação, reforçada pelo contexto da pesquisa (relação pesquisadora-respondentes) que salientamos acima, induziria a um grande número de respostas positivas.

Evidentemente, não é o professor que está sendo julgado nesta pesquisa, mas sim, o material didático que temos à nossa disposição para o ensino do FLE, seus pontos positivos, negativos e as eventuais necessidades de adaptação a um determinado contexto. O que nos interessa, portanto, é conhecer a opinião e a utilização que o professor faz do material didático em seu dia-a-dia. Por essa razão, a pergunta acima foi formulada da seguinte maneira: "As orientações do guia pedagógico para o uso da imagem lhe parecem pertinentes?".

Além disso, dois outros fatores contribuíram, a nosso ver, para uma maior veracidade das respostas dos professores da instituição no que se refere ao uso do material didático adotado:

- O fato de o questionário ser anônimo;

- O fato de a mensagem de e-mail com o convite para participar da pesquisa esclarecer que se tratava de uma solicitação pessoal feita aos colegas e que a mesma não estava, portanto, de forma alguma vinculada a nosso contexto comum de trabalho;

- O fato de a coordenação pedagógica da Aliança Francesa de São Paulo ter se manifestado contra a adoção do atual livro didático quando da escolha de um novo 
método em 2010. No entanto, o mesmo acabou sendo adotado devido a uma decisão tomada em rede nacional. Nunca deixamos, desde então, de orientar localmente nossos professores quanto às dificuldades que o livro poderia apresentar em nosso contexto de trabalho e de buscar soluções em conjunto.

A aplicação do questionário foi feita em duas etapas. A primeira ocorreu entre o final do mês de Agosto e o início do mês de Setembro de 2014, quando realizamos um pré-teste. Uma mensagem de e-mail foi enviada a cinco professores da Aliança Francesa de São Paulo, com o link correspondente para o questionário on-line e um termo de consentimento livre e esclarecido. Um encontro individual com esses professores após a realização do teste confirmou a viabilidade do questionário. Os professores mostraramse interessados pelo assunto e afirmaram que foi positivo ter refletido sobre essas questões e que as mesmas não são debatidas frequentemente. Eles afirmaram, no entanto, que levaram mais do que os 20 minutos previstos para responder a todas as questões, já que algumas exigiam que eles consultassem o livro didático e/ou o guia pedagógico para uma resposta mais precisa. Como ajuste, aumentamos o tempo indicado de realização do questionário para 30 minutos.

A partir de então, temos a segunda etapa de aplicação do questionário que ocorreu entre os meses de Setembro e Outubro de 2014. Um novo convite foi feito a cerca de 60 professores em uma mensagem de e-mail na qual se apresentava rapidamente o contexto e os objetivos da pesquisa e se especificava o caráter anônimo e voluntário da participação.

Passamos, a seguir, à apresentação e à análise dos dados obtidos. Mostraremos, em uma primeira seção, os resultados quantitativos e qualitativos obtidos, por meio de porcentagens, gráficos e também recopiando algumas respostas obtidas. Na seção seguinte, procedemos a uma análise geral dos dados coletados e aqui reportados.

\subsection{Dados quantitativos e qualitativos obtidos nos questionários}

No total, 35 professores responderam ao questionário. Retomamos abaixo as perguntas formuladas, a tabulação dos resultados por meio de gráficos e tabelas e recopiamos as principais respostas obtidas. 
PARTE A. Dados pessoais (nome, faixa etária, sexo) e contexto de trabalho

- Faixa etária - duas faixas etárias se destacam como maioria: a faixa de 26 a 35 anos (32\%) e a de 46 a 55 anos (32\%). Nenhum professor escolheu a opção "menos de 25 anos".

\section{Figura 170 | Gráfico - Faixa etária}

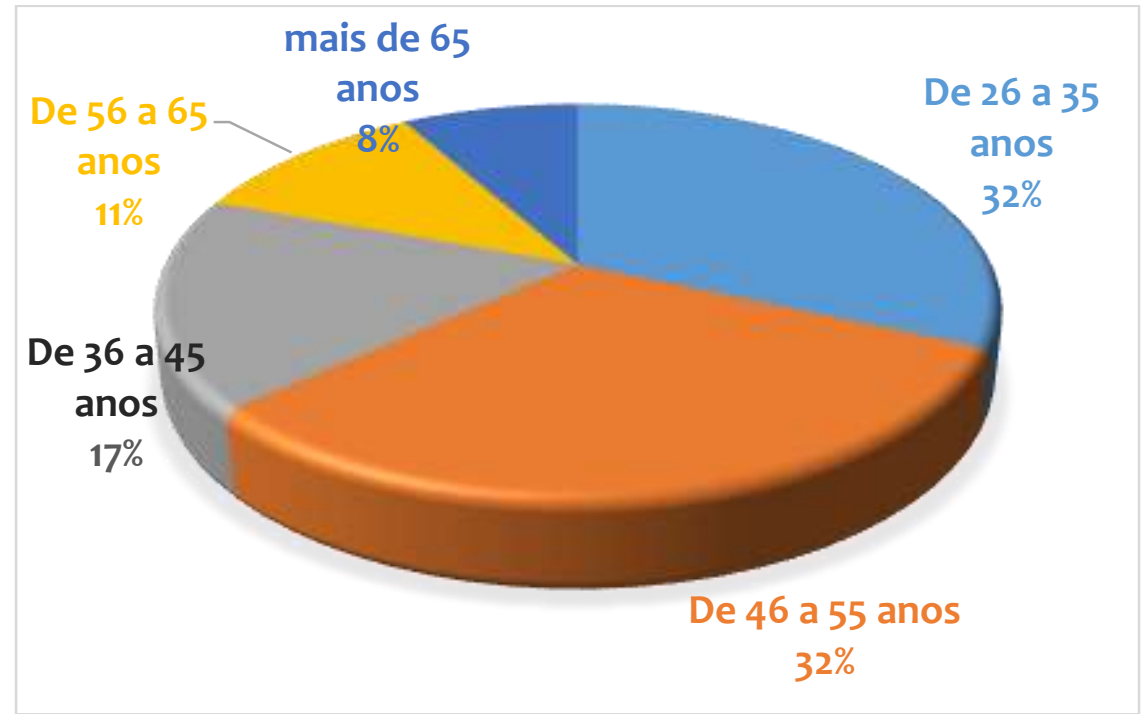

- Sexo: $77 \%$ feminino e $23 \%$ masculino, o que condiz com a imagem majoritariamente feminina que se tem da profissão.

Figura 171 | Gráfico - Sexo

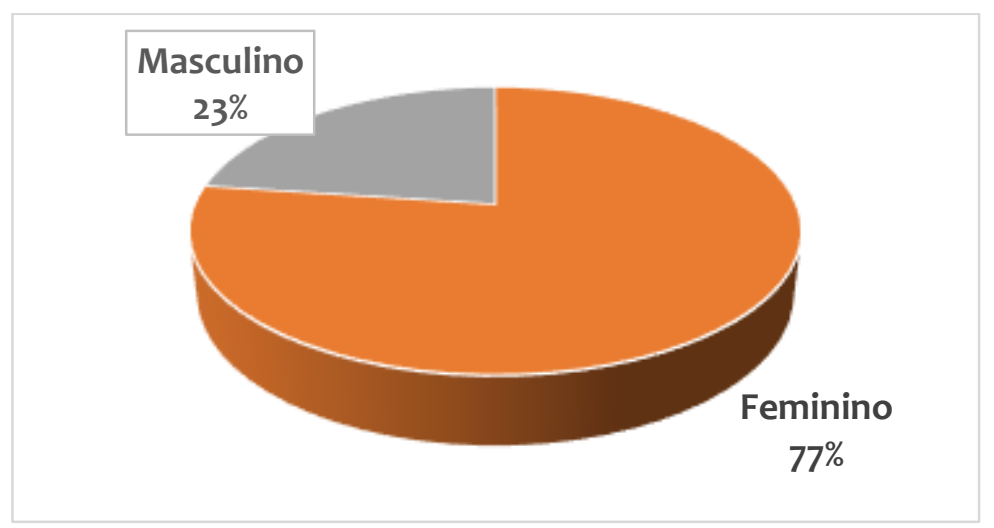

- Formação: todos os respondentes afirmaram ter formação em nível superior, de acordo com a seguinte proporção:

- Graduação: 22 professores (63\%)

- Mestrado: 12 professores (34\%)

— Doutorado: 1 professor (3\%) 


\section{- Há quantos anos você é professor de FLE?}

Figura 172 | Gráfico - Anos de experiência no ensino

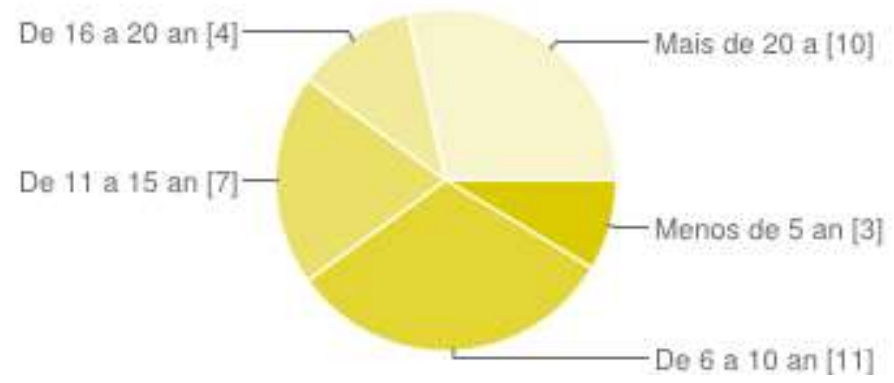

$\mathrm{N}^{\circ}$ prof. $\quad \%$

Menos de 5 anos

$3 \quad 8 \%$

De 6 a 10 anos

$11 \quad 31 \%$

De 11 a 15 anos

$7 \quad 19 \%$

De 16 a 20 anos

$4 \quad 11 \%$

Mais de 20 anos $\quad 10 \quad 28 \%$

Em outras palavras, 92\% dos professores que responderam ao questionário têm mais de 6 anos de experiência no ensino do FLE e 58\%, ou seja, a maioria deles, têm mais de 11 anos de experiência na profissão.

- Instituição de ensino: como precisamos anteriormente, a grande maioria dos respondentes (74\%) trabalha na Aliança Francesa de São Paulo. Podemos dizer que a quase totalidade dos respondentes (94\%) trabalha na rede particular de ensino do FLE em São Paulo.

Figura 173 | Gráfico - Instituição de Ensino

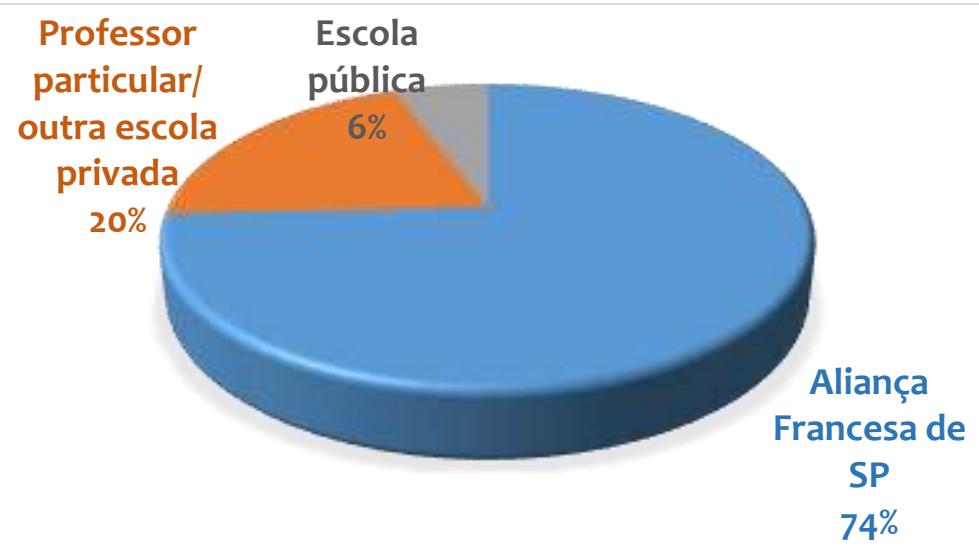


Em resumo, nessa primeira parte do questionário, identificamos que temos um grupo de respondentes majoritariamente feminino, com formação universitária e com bastante experiência no ensino do FLE.

\section{PARTE B. PRÁTICAS CULTURAIS}

1. Em sua vida cotidiana, você procura se informar e se formar sobre a imagem?

A grande maioria dos professores (77\%) afirmou buscar essa formação no dia-a-dia.

Figura 174 | Gráfico - Busca de (in)formação sobre a imagem no dia-a-dia

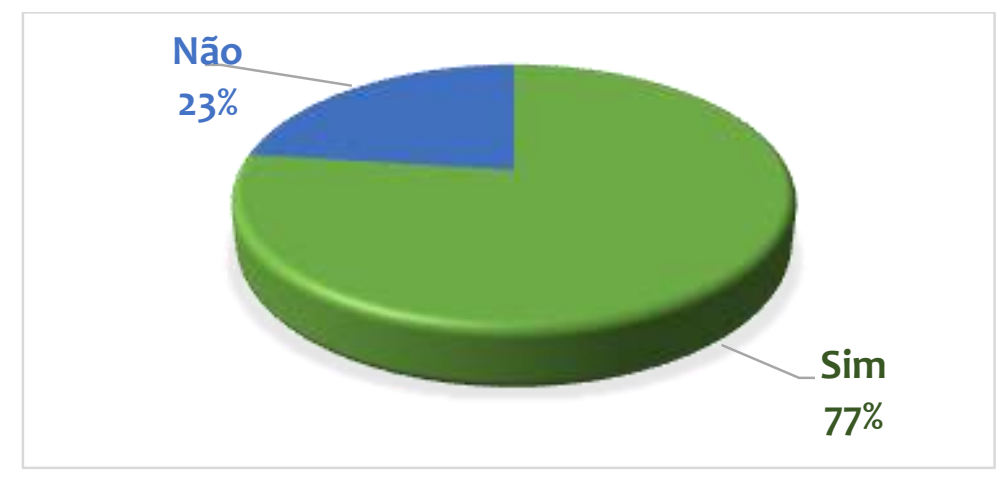

\section{- Em caso afirmativo, especifique de que forma você busca essa informação.}

Como se tratava de uma pergunta aberta, havia bastante margem para a expressão livre do professor. Dos 26 respondentes que preencheram esse campo, 15 deles, ou seja, $57 \%$ citaram espontaneamente a Internet como fonte de formação e de informação sobre a imagem. Integramos nesse termo não somente as respostas com menções específicas à palavra "Internet”, como também outras palavras que referentes a esse mesmo universo como, por exemplo, "sites", "blogs", sites de vídeo como YouTube, Vimeo, Dailymotion, redes sociais como facebook e redes sociais de compartilhamento de fotos, como Pinterest.

Apesar de a Internet prevalecer como o meio mais utilizado para a busca de (in)formação, os professores também citaram atividades culturais como frequentar exposições de arte, de fotografia, assistir a filmes, documentários, curtas, desenhos e também a observação da natureza como elementos formadores para a análise da imagem. Vários professores citaram também a troca de informações com colegas artistas como um elemento formador. 
Alguns professores, tendo citado "Google Imagens" e "Pinterest", parecem ter compreendido a questão como: "De que forma você busca imagens no seu dia-a-dia?" e não "De que forma você busca se informar sobre a imagem no dia-a-dia?" Talvez porque a busca de imagens seja, em seu cotidiano, bem mais comum do que a busca de informações sobre as imagens ou sobre sua leitura. No entanto, não podemos fazer essa afirmação, pois ela dependeria de uma explicação mais precisa da parte do professor, o que não nos permite a reposta de que dispomos pelo questionário.

De modo geral, essa busca pela formação e pela informação sobre a imagem se mostra frequente, múltipla, ou seja, feita através de vários canais do cotidiano. $\mathrm{Na}$ maioria das vezes, ela é feita de maneira autônoma, sem que haja a busca por uma formação mais precisa ou mais formal. Poucos professores afirmaram ter seguido cursos ou comprados livros específicos sobre o assunto.

Retomamos abaixo algumas respostas que resumem esses diferentes pontos citados. Recopiamos as respostas completas, tal como foram formuladas pelos professores, corrigindo apenas alguns erros de digitação.

a) Uma aprendizagem realizada majoritariamente em autonomia e de forma "natural":

- "Internet, livros, exposições, criação pessoal, propagandas, revistas, catálogos, fotografias."

- "Através de exposições e apreciações que vão desde o Clássico até a Arte Contemporânea mas, sobretudo, Fotografia, em particular Doisneau e Salgado."

- "Assistindo filmes, curtas, desenhos, fazendo cursos sobre fotografia, vídeo, utilizando internet, youtube, vimeo, facebook, dailymotion, com amigos fotógrafos, jornalistas, escritores, pintores, fotógrafos, etc."

- "Não se trata de uma formação acadêmica ou sistemática. Como tenho amigos que trabalham com moda, artes, propaganda e comunicação, áreas em que a imagem desempenha um papel importante, eventualmente conversamos sobre o tema. Eles me mostram diferentes maneiras de interpretá-las e me dão conselhos de leitura."

- "Observando a natureza; observando lugares; observando fotos, cores, buscando o equilíbrio, o fio condutor entre as formas e as informações verbais que as acompanham..." 
b) No entanto, as respostas mostram também que alguns professores do grupo, assim como os teóricos que guiam este estudo, não veem a capacidade de ler imagens como algo transparente ou natural, mas sim, como algo que exige um estudo próprio e ferramentas próprias para ser realizado:

- "Já fiz alguns cursos de história da arte, de história da pintura no Brasil, ateliers de preparação a visitas de exposições no MAM, na Pinacoteca do Estado de SP e no MASP. Sempre que posso frequento exposições e galerias. Leio sobre pintura e fotografia e converso com arquitetos e artistas que conheço."

- “A imagem está constantemente presente em nossa sociedade, é preciso estudá-la e analisá-la."

- "Comprei vários livros sobre o assunto; fiz e faço muitas e muitas pesquisas na internet sobre metodologia e sistemática do uso da imagem em aula de FLE"

De forma geral, acreditamos que os respondentes estão bem conscientes da importância da imagem e de sua compreensão na sociedade atual. No entanto, a busca por informação é feita sobretudo por meio de atividades culturais do dia-a-dia, com conversas com amigos e pela Internet. O interesse por (ou a necessidade de) uma formação mais específica e mais formal sobre a leitura da imagem não foi identificado(a) na maioria dos respondentes.

- De que forma a imagem está mais presente em sua vida? (Várias respostas possíveis).

$\begin{array}{lcc} & \begin{array}{c}\mathbf{N}^{\mathbf{0}} \\ \text { prof. }\end{array} & \% \\ \begin{array}{lcc}\text { Exposições de artes } \\ \text { visuais }\end{array} & \mathbf{2 5} & 71 \% \\ \text { Fotografia } & \mathbf{2 9} & 83 \% \\ \text { Sites da Internet } & \mathbf{3 2} & 91 \% \\ \text { Publicidade } & \mathbf{2 5} & 71 \% \\ \text { Livros } & \mathbf{2 0} & 57 \% \\ \text { Livros didáticos } & \mathbf{2 9} & 82 \% \\ \text { Revistas } & \mathbf{2 4} & 68 \% \\ \text { Jornais } & \mathbf{1 8} & 51 \% \\ \text { Outros } & \mathbf{1 1} & 31 \%\end{array}$


Figura 175 | Gráfico - Forma como a imagem está mais presente em sua vida

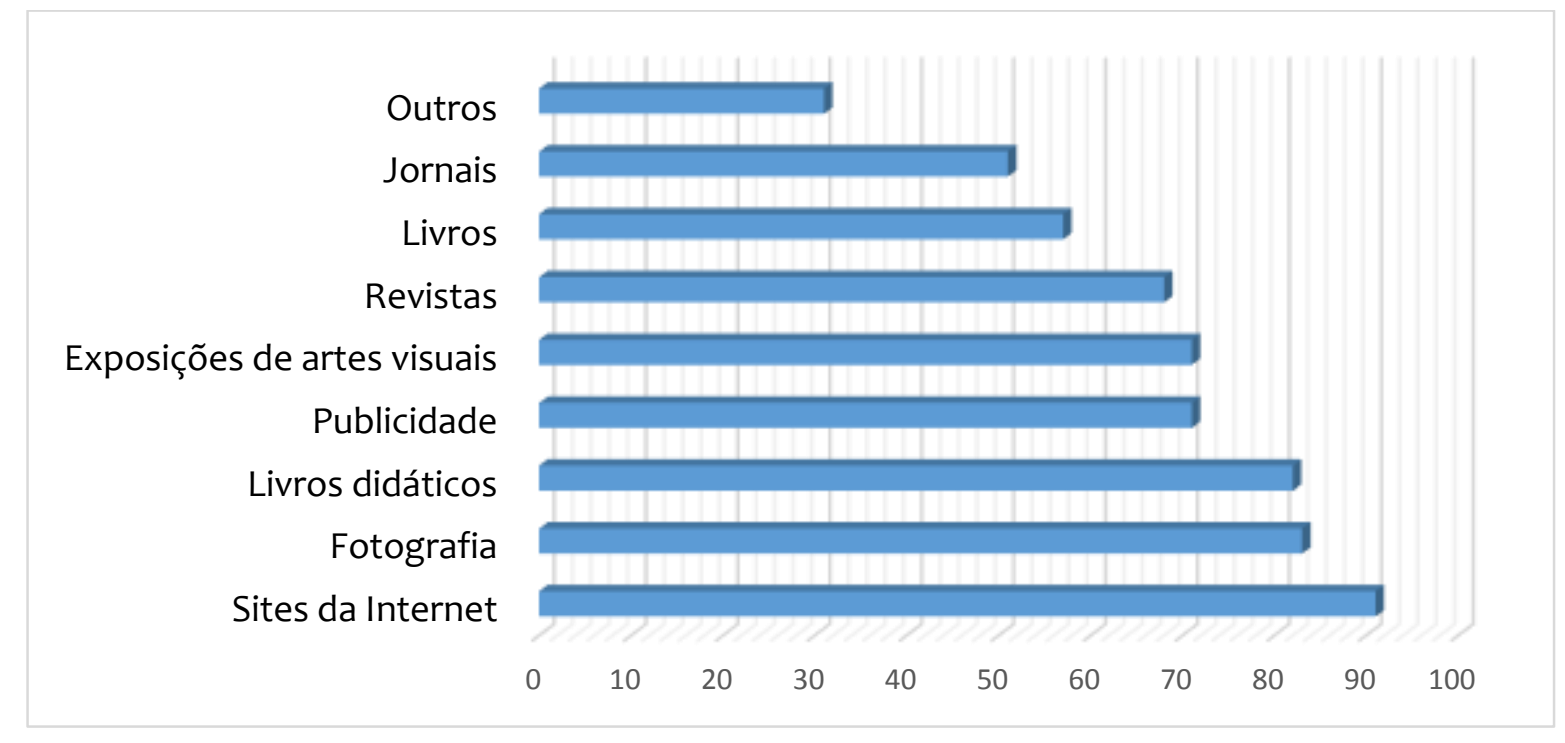

$\mathrm{Na}$ parte "outros", um mesmo professor citou: "Moda, arquitetura, urbanismo, decoração, folhetos, criação pessoal, Pinterest, livros de fotografia, BD, poesia, jogos, dança, natureza." A menção à criação pessoal parece-nos importante e remete à função da imagem que definimos como expressiva.

A grande importância da Internet e de outros meios de comunicação como fotografia e exposições reforçam as respostas obtidas à questão anterior. Em outras palavras, podemos afirmar que os meios nos quais a imagem está presente no dia-adia do professor coincidem com os meios nos quais ele busca informações sobre a mesma. Uma formação que se faz no dia-a-dia, nas atividades cotidianas, como se a leitura da imagem fosse um processo "natural", bastando observá-lo para compreendê-lo.

\section{- Como leitor, você aprecia o fato de um texto estar acompanhado por uma imagem?}

Figura 176 | Gráfico - Apreciação de texto acompanhado por imagem

$\begin{array}{lrr}\text { Nunca } & \mathbf{0} & 0 \% \\ \text { Raramente } & \mathbf{0} & 0 \% \\ \text { Às vezes } & \mathbf{1 4} & 39 \% \\ \text { Frequentemente } & \mathbf{1 2} & 33 \% \\ \text { Sempre } & \mathbf{9} & 25 \%\end{array}$

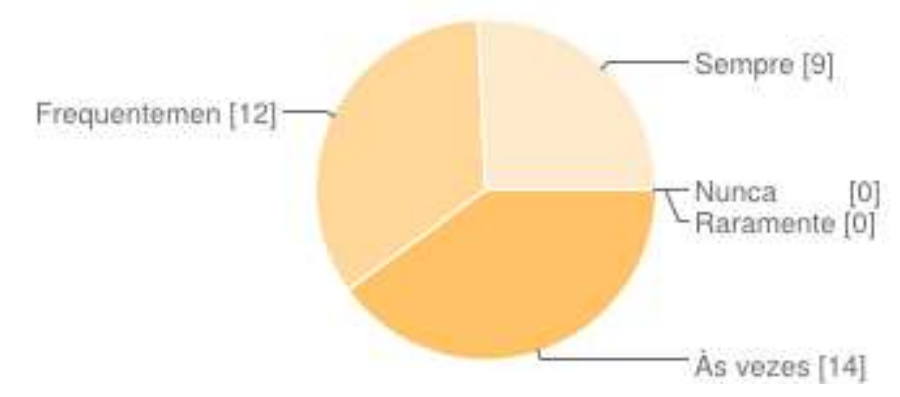


- Em quais desses gêneros textuais você prefere, como leitor, que o texto esteja acompanhado por uma imagem? (Várias respostas possíveis)

Figura 177 | Gráfico - Preferências de gêneros textuais com imagem (em \%)

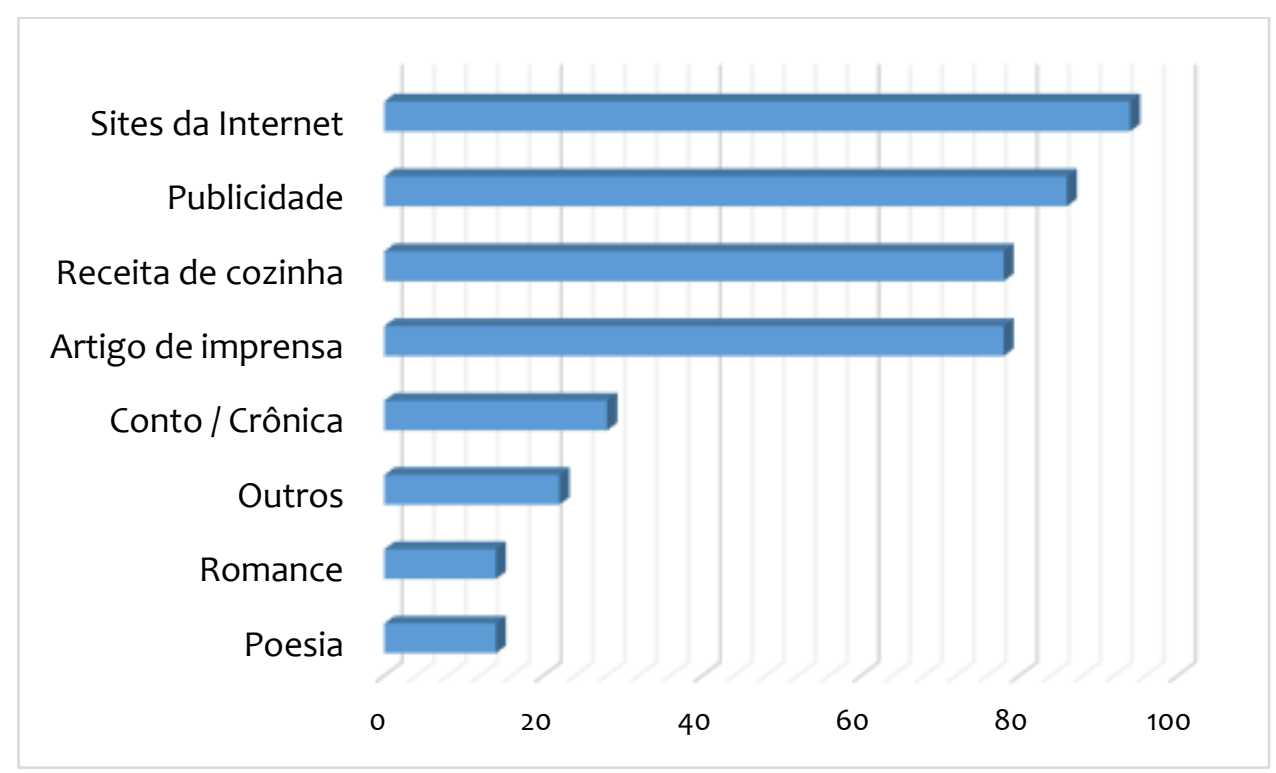

Outros: livro didático, relatos de viagem, capa de $C D$, livros infantis, acho que sempre é bom se ter imagens.

\section{- A imagem exerce um papel importante em sua vida cotidiana?}

Sim: $100 \%$

Não: $0 \%$

\section{Justifique.}

Dentre as respostas mais comuns, o fato de estarmos rodeados continuamente por imagens, o fato de o professor em questão ter uma "memória visual", a rapidez da mensagem transmitida pela imagem, o prazer estético. No que diz respeito ao primeiro ponto, a sociedade de imagens, alguns veem esse aspecto como algo positivo e outros, negativo ou inevitável:

- Sou muito visual, acabando guardando mais as coisas quando vejo a imagem.

- Como tenho memoria visual, registro meu conhecimento através das imagens.

- Nem que queiramos, podemos prescindir da imagem, nos nossos dias. 
- A imagem está presente em quase tudo que vemos no dia-a-dia e acredito que sua importância está no fato de que elas transmitem informações mais rápido do que a grande maioria dos textos, são informações quase imediatas.

- Acredito que a imagem faz parte da nova geração e estamos cada vez mais habituados a representações por imagens substituindo algumas vezes as palavras

- Não por opção, e sim de maneira passiva. Apenas pelo fato de morar em São Paulo e estar imersa em redes sociais, a imagem se impõe. A imagem narra a vida privada, pública, profissional, etc.

- Televisão, computador, celular, "outdoors", etc. nos invadem com inúmeras e variadas imagens o tempo todo do dia. Impossível ficar imune ou passivo. Mais difícil é trabalhar um espírito crítico diante da invasão mencionada 24 horas por dia.

- Sou movida por imagens e aprendo muito com elas. Imagens fazem parte das minhas estratégias pessoais de aprendizado.

- Adoro fotos e trabalho com a imagem nas aulas como professor.

A resposta de um professor nos permite compreender porque, na questão anterior, a maioria dos respondentes não sente necessidade da imagem ao ler um gênero literário:

- A imagem é ilustrativa, resume e retrata, de forma mais direta e sucinta, uma informação. No âmbito da literatura, não creio que a imagem seja importante, na medida em que a literatura é um espaço, na minha opinião, onde a imaginação exerce papel fundamental e penso que, nesse caso, a imagem seja um tanto limitante.

Outras respostas traduzem - de forma positiva e reveladora - a experiência da leitura multimodal, com a imagem associada ao texto escrito:

- Por ser uma linguagem em si, frequentemente autônoma ou paratexto, exercendo uma função complementar e enriquecedora a um texto. Por traduzir melhor alguns estados sutis ou não verbais.

- Uma imagem melhora, altera, completa, aperfeiçoa, explica, reforça, modifica etc... um texto !!!!!

- Ela dá colorido ao que leio.

Alguns termos utilizados nessas respostas, como "função complementar" e “colorido ao que leio" denotam que para alguns professores a importância do texto escrito prevalece sobre o texto visual. 
A imagem é associada a sentimentos e emoções:

- A imagem informa mostra assuntos objetiva e subjetivamente. Possibilita o entendimento, o sentimento e ainda a dúvida. Pode despertar o interesse sobre um determinado tema ou artista ou ainda nos afastar para que sigamos adiante.

- Gosto de cinema pois além do texto, toda uma série de informações culturais são passadas através de imagens; A imagem do GPS, por exemplo, confirma o meu entendimento da mensagem de voz. No whatsApp o envio de imagens põe emoção nas palavras. [...] Imagens humanizam, contextualizam, asseguram, contam histórias que as palavras não dão conta de dizer.

A imagem é associada à criatividade:

- "Uma imagem vale mais que mil palavras", gosto dessa frase, já clichê, mas ela traduz bem o poder de uma imagem. A imagem é mais subjetiva, sugestiva e reflexiva do que a palavra, é mais aberta e nos faz refletir mais, de forma mais ativa e criativa.

- Pelo prazer estético de conhecer e/ou rever assim como apreciar obras de arte, - para o preparo e desenvolvimento das minhas aulas. Gosto muito também de elaborar álbuns e pastas pessoais de imagens sobre os mais variados assuntos: artes, sociedade, história...

\section{- Complete livremente a frase abaixo: Uma imagem para mim é...}

O objetivo dessa pergunta era conhecer as representações dos professores em relação à imagem. Dentre as 28 respostas, a palavra "facilitador(a)" apareceu em três (10\%), o que mostra uma representação ainda um pouco submissa da imagem:

- um facilitador de ideias e pensamentos

- um facilitador para a imaginação

- facilitadora

A grande maioria das respostas, no entanto, conferem à imagem uma posição mais autônoma, atribuindo-lhe poderes ou possibilidades específicas:

- o que a palavra não diz 
- fator de aprendizado

- é essencial; às vezes vale mais que o texto

- a tradução de um mundo de possibilidades

- uma síntese ou um caminho

- eloquência não-verbal

- expressão

- poder ir além de uma simples mensagem, é poder ver através das cores e formas e poder criar outras referências, sensações e possibilidades

- um suporte (mídia) para decodificar e, sobretudo, codificar o mundo.

- expressão de sentimentos

- essencial

- uma mensagem

- informação, formação, diálogo, conexão, confissões...

\section{POSSIBILIDADES PARA O USO DA IMAGEM EM UMA AULA DE FLE}

Todas as perguntas deste questionário referem-se ao ensino de Francês língua estrangeira (FLE) para um público ADULTO.

- Dentro do processo de ensino-aprendizagem do Francês língua estrangeira (FLE), você considera que a imagem pode exercer um papel importante?

$100 \%$ dos professores responderam afirmativamente à essa questão.

Justifique.

A imagem é portadora de informações, cores, gestos, expressões de personagens, de coisas, etc...

Exatamente por completar, alterar, modificar, explicar, esclarecer, etc. em relação a um texto!

Importantíssimo papel, auxiliando na compreensão, tornando um assunto menos árido, introduzindo humor, dando uma dimensão física para determinados assuntos (como as preposições de lugar e indicações de caminho), mostrando a arte e a cultura, imprimindo beleza e prazer de leitura no material didático...

Quando estudamos uma língua estrangeira, as imagens são essenciais para a compreensão de um texto, de novas palavras, sem a necessidade da tradução. 
Trata-se de uma maneira de induzir o aluno a ser mais ativo, criativo e produtivo, do que simplesmente usar um texto.

A meu ver, a imagem é essencial. Seria a primeira etapa para a compreensão de um documento escrito ou oral. Se bem elaborada e conectada com o documento em questão, a maior parte das vezes, restringe o campo semântico, facilitando a compreensão e mesmo uma produção oral ou escrita. Outra função da imagem, do meu ponto de vista, é instigar o aluno, levando-o a procurar comunicar-se de forma oral ou escrita. O prazer que uma imagem pode suscitar (como a de pano de fundo para este questionário!) torna a utilização do manual didático mais agradável.

Em diferentes momentos e em várias atividades realizadas em classe, a imagem tem papel importante. Primeiramente, para a compreensão dos documentos sonoros. Se a imagem é bem escolhida, ela ajuda a antecipar o conteúdo da mensagem oral, decifrar o contexto em que se dá a interação entre as pessoas e a compreender novas palavras e expressões, dispensando a tradução. Ela também contribui para evidenciar informações importantes que são transmitidas por atitudes e gestos, facilitando a assimilação dos aspectos culturais do francês. Quanto ao ensino do vocabulário, os desenhos e fotos são quase que indispensáveis para a criação de atividades lúdicas e eficientes para a aprendizagem do léxico. Se considerarmos, ainda, tabelas e esquemas como imagens, elas também podem otimizar as atividades de descoberta e de sistematização de conteúdos gramaticais.

A imagem exerce um papel fundamental no ensino do idioma: ajuda, por exemplo, na melhor compreensão de um documento sonoro, quando se faz um trabalho de antecipação do conteúdo do documento; ilustra muito do que se quer dizer, no que se refere a documentos relativos a aspectos de civilização e cultura francófonas, etc...

Como disse, penso que através de imagens (dadas pelo professor, livro didático ou até criadas na imaginação pelos alunos) a aprendizagem se desenvolva. Não sei tratar de vocabulário, dados de cultura ou mesmo gramática sem recorrer a imagens (a velha casinha do passé composé, por exemplo...)

\section{Com que frequência você utiliza A IMAGEM em sala de aula para trabalhar com seus alunos os objetivos abaixo?}

Respostas em porcentagem de recorrências.

Figura 178 | Gráfico - Objetivos linguísticos: LÉXICO

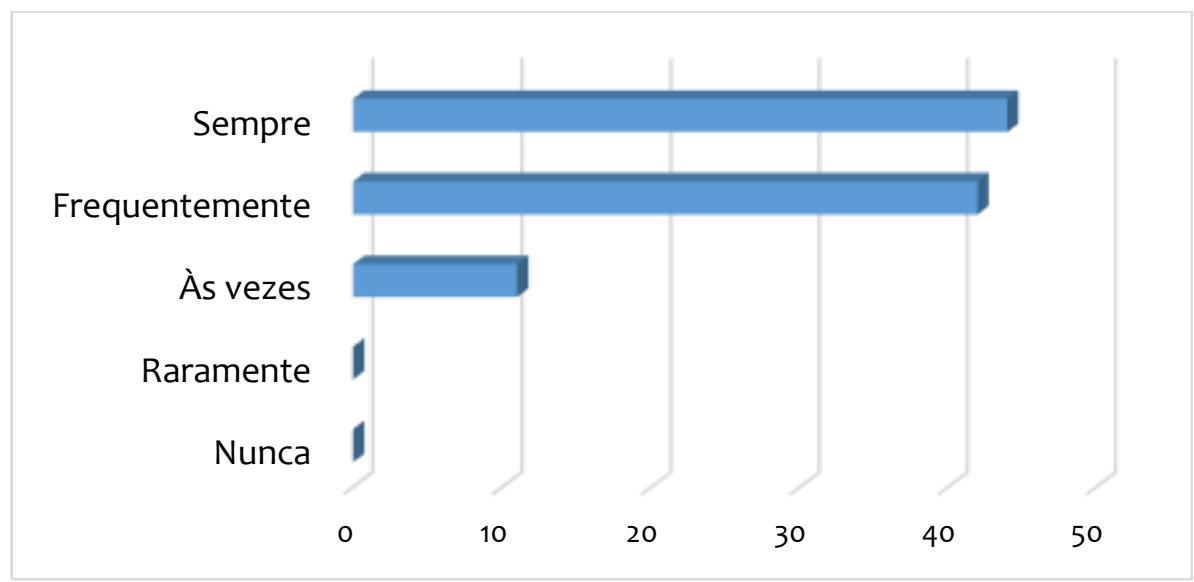


Figura 179 | Gráfico - Objetivos linguísticos: GRAMÁTICA

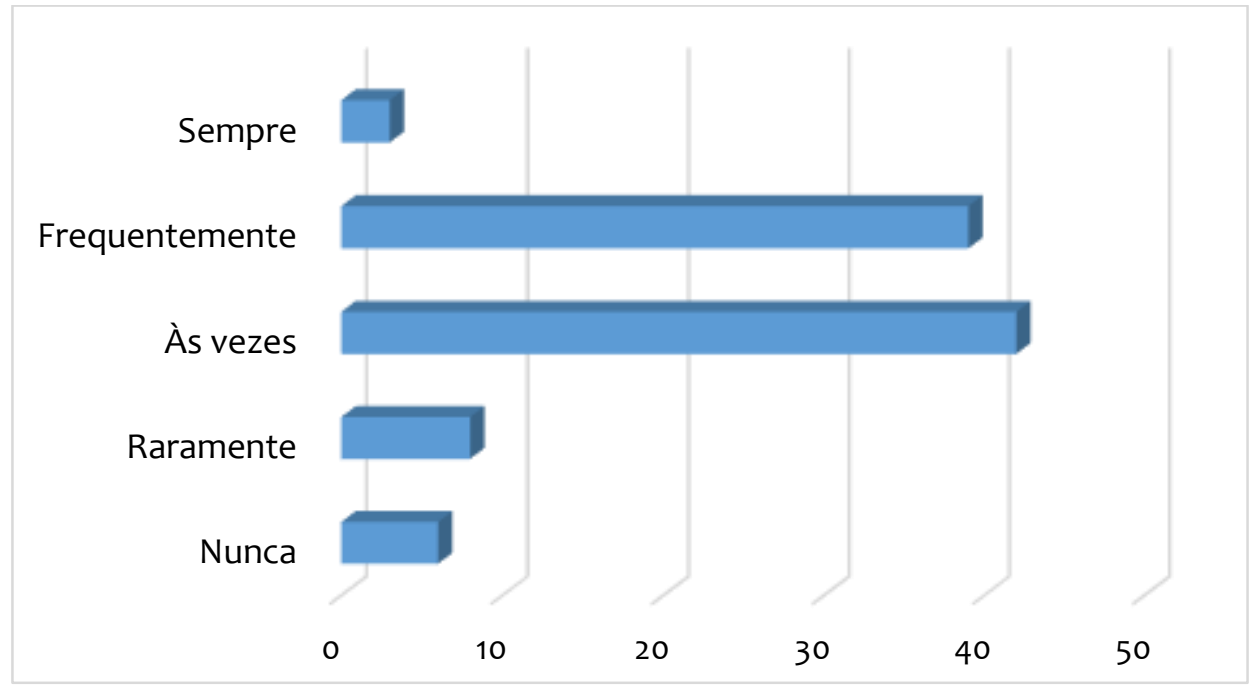

Figura 180 | Gráfico - Objetivos linguísticos: FONÉTICA

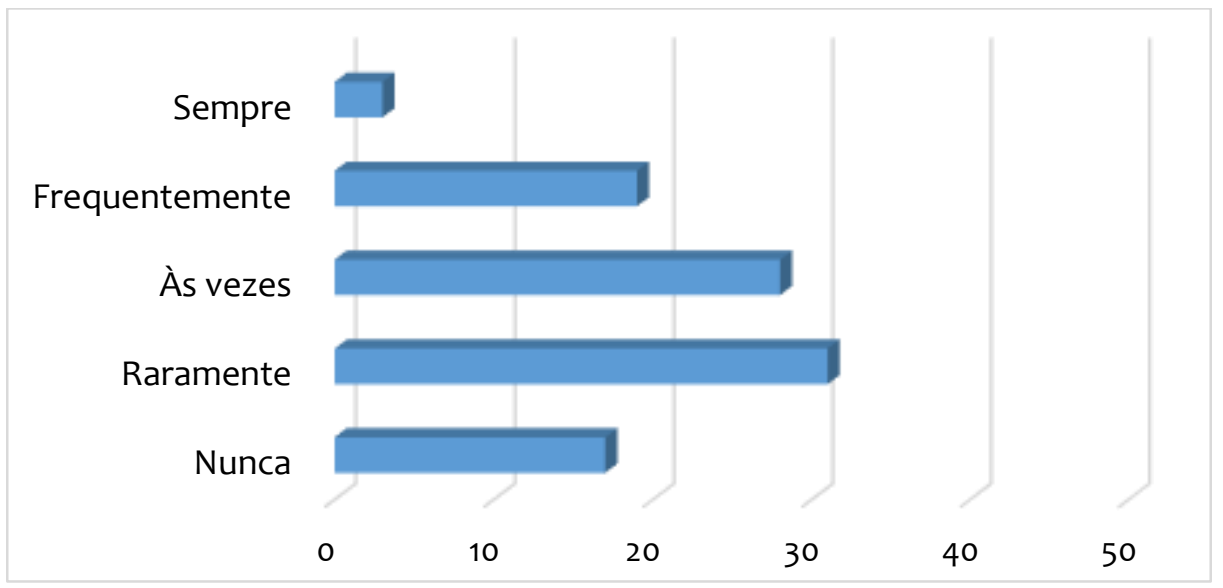

Figura 181 | Gráfico - Objetivos CULTURAIS E INTERCULTURAIS

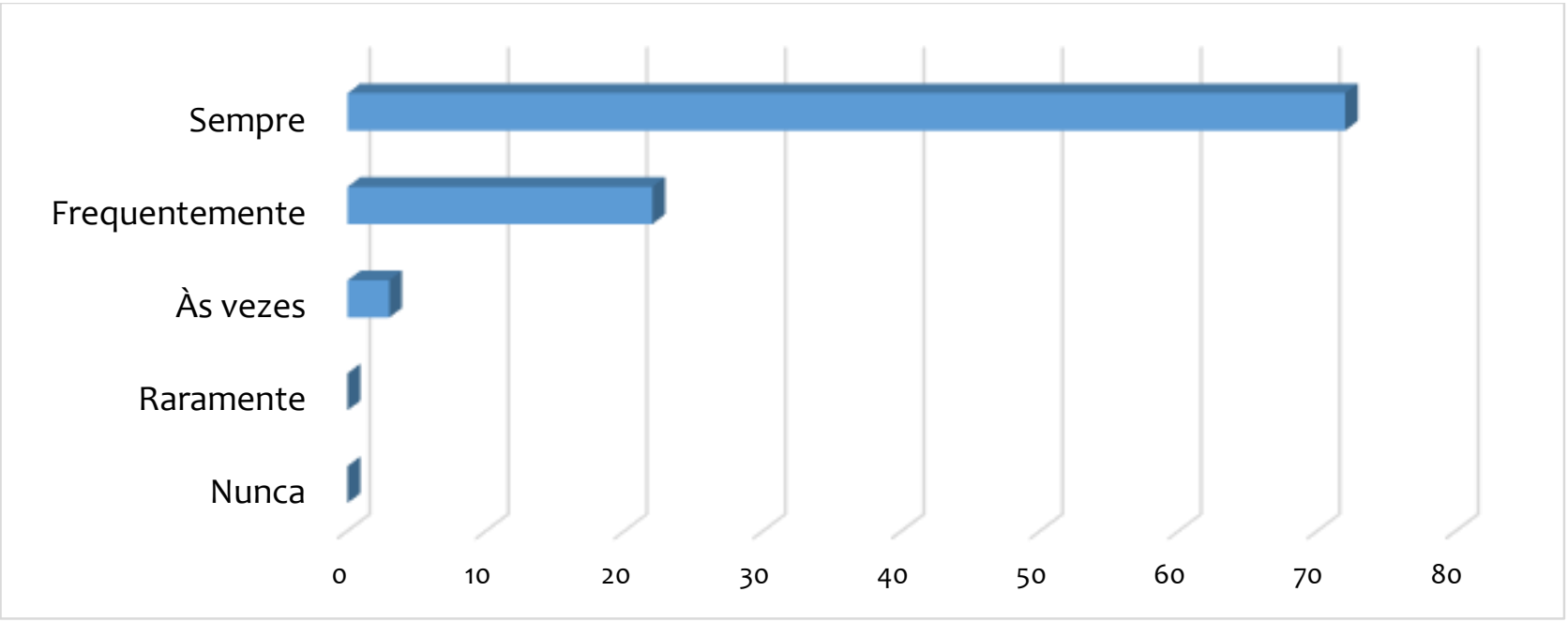


Figura 182 | Gráfico - Objetivos comunicativos: COMPREENSÃO (ESCRITA/ORAL)

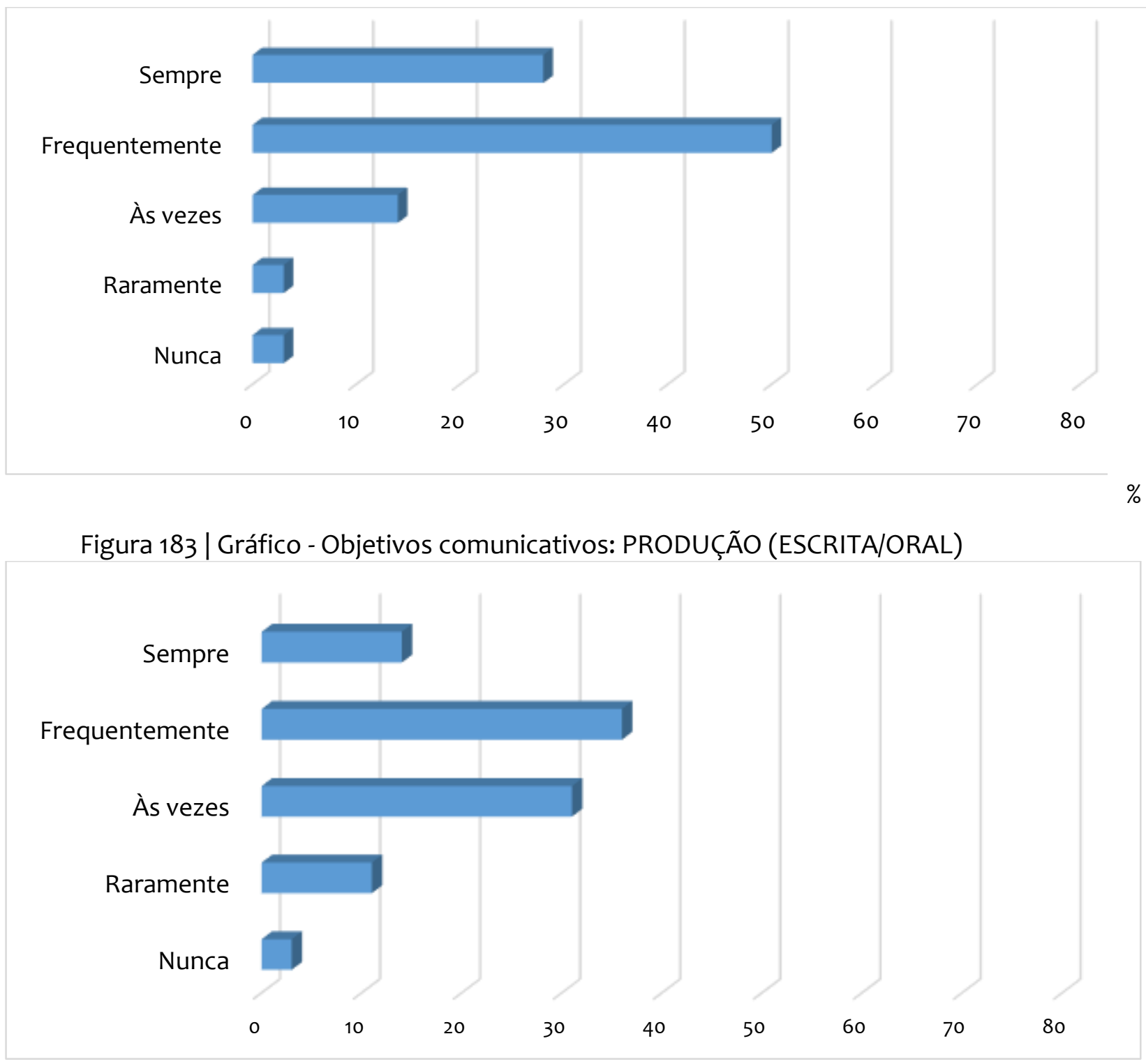

Figura 184 | Gráfico - Objetivos comunicativos: INTERAÇÃO EM SALA DE AULA (ESCRITA/ORAL)

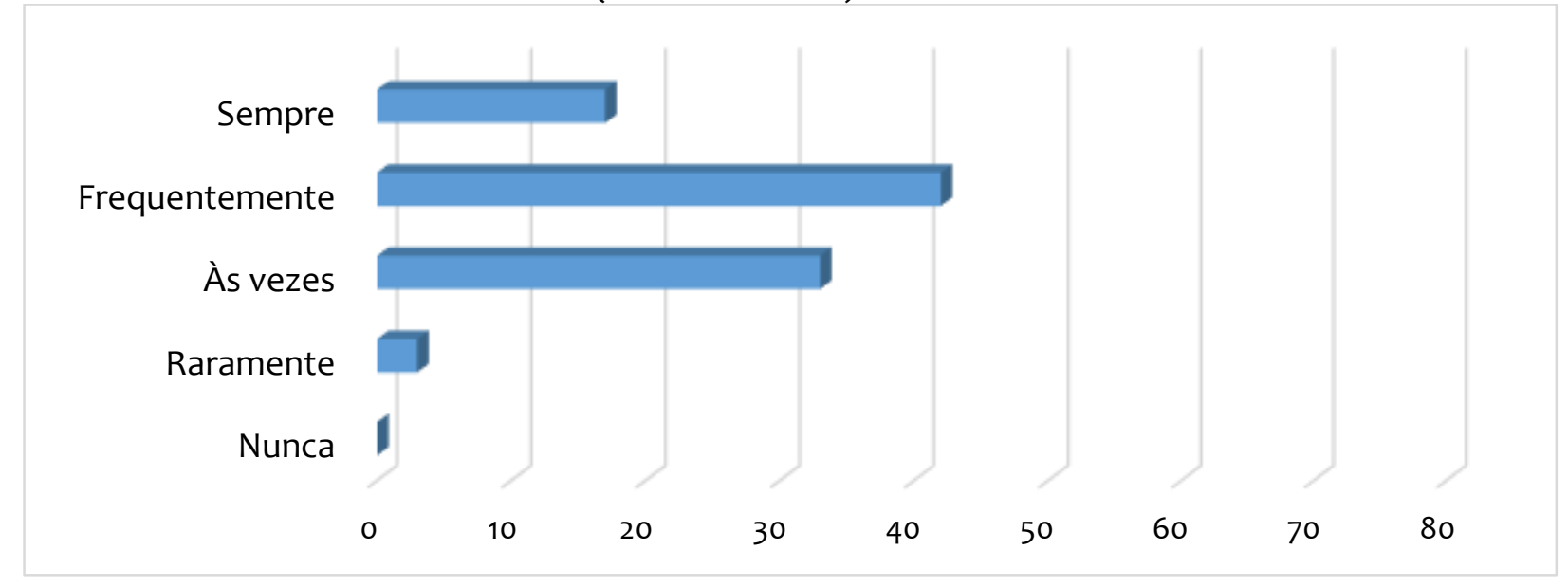


Figura 185 | Gráfico - Ajudar a desenvolver ESTRATÉGIAS DE APRENDIZAGEM

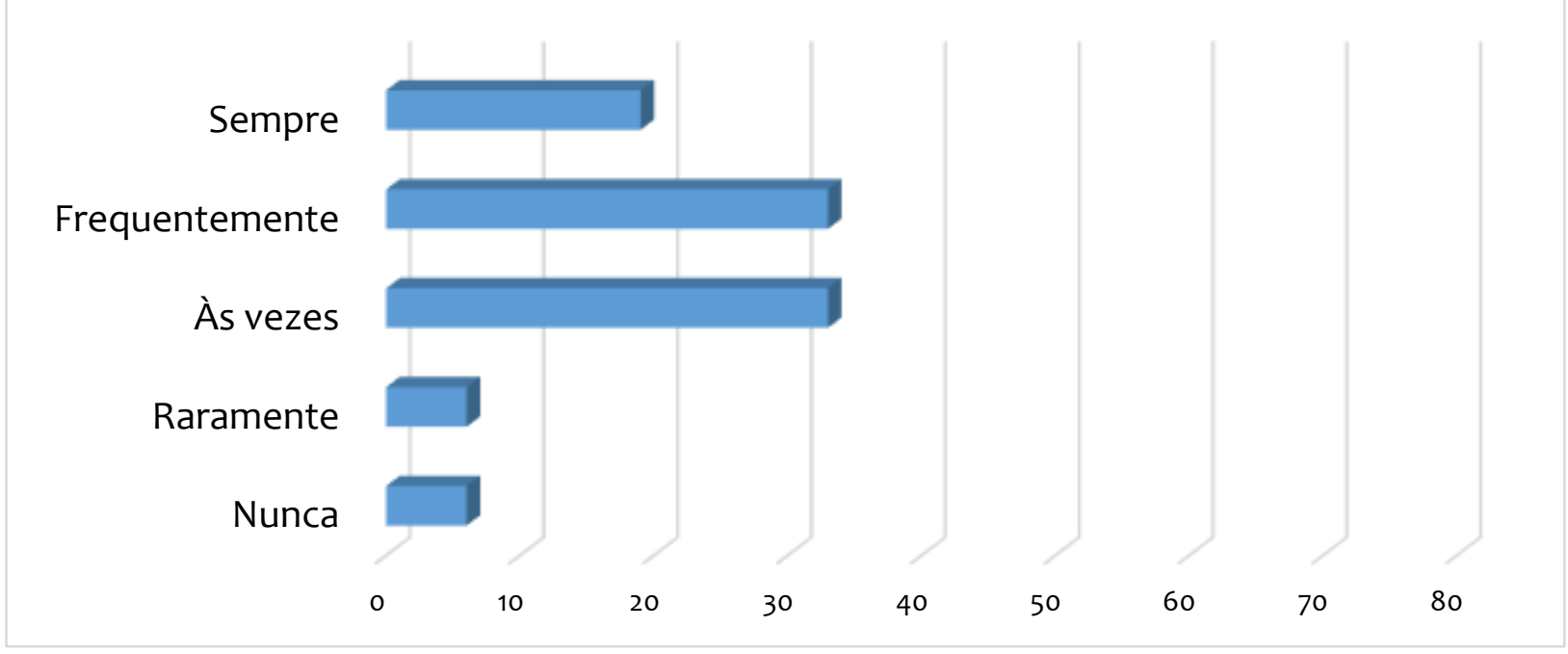

Figura 186 | Gráfico - Para a realização de JOGOS E DE ATIVIDADES LÚDICAS

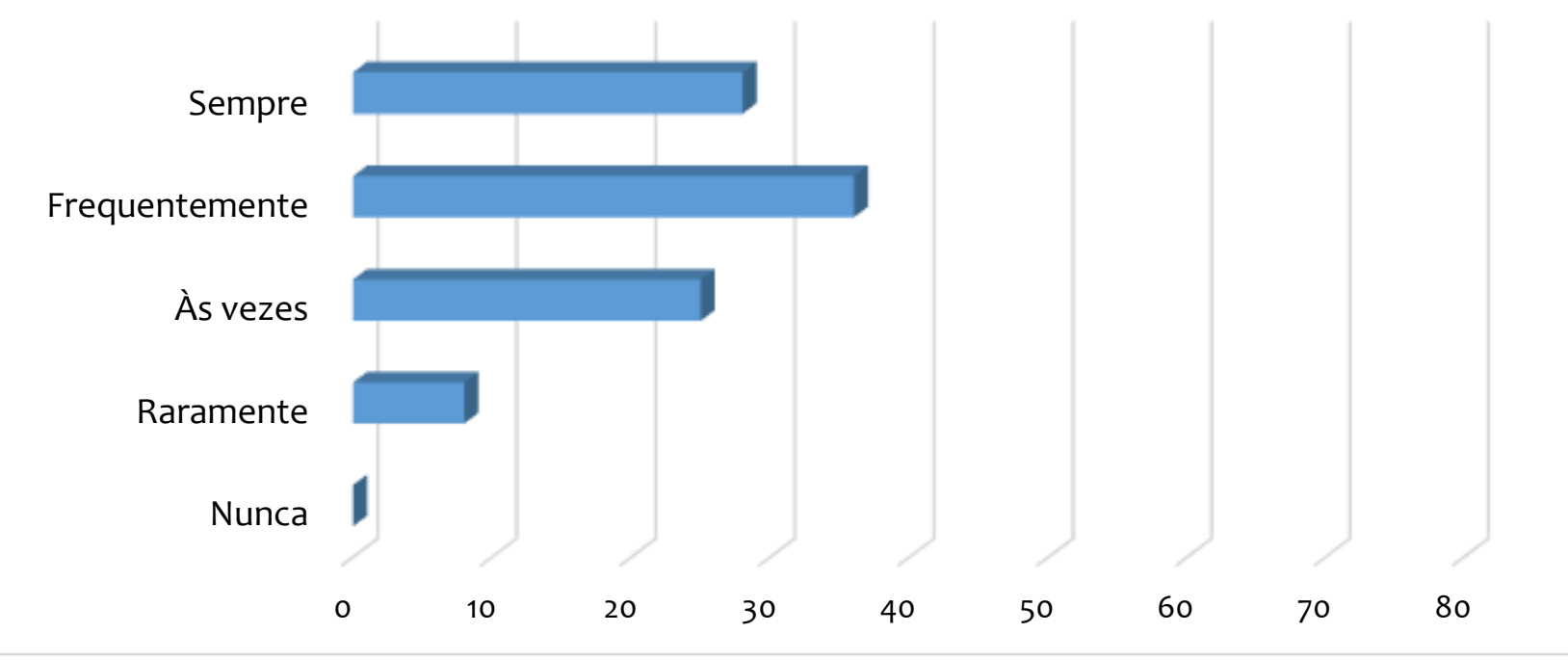

\section{Outros objetivos citados:}

- Cognitivo - observação de gestos para desenvolver ou analisar um diálogo + análise de obra de arte.

- Para ajudar a criar uma cumplicidade, entre alunos.

- Antecipação de um tema.

- Intrigar, instigar, incitar a falar e divertir...

Comentários dos professores sobre as questões acima. 
- As questões acima me fizeram pensar sobre o que é a imagem e como faço uso dela.

- Nunca me veio à mente, trabalhar a imagem associada à fonética. Não saberia bem como fazê-lo. Talvez mostrar o posicionamento dos lábios, da língua na produção de sons.

- Acho que imagens enriquecem a aula, tem que saber tirar o máximo das mesmas.

- Nossos alunos pertencem majoritariamente à geração " $Y$ ": estão conectados e interagindo em tempo integral. Até os alunos que vêm da civilização escrita estão sendo obrigados a entrar neste novo mundo; aliás, acho formidável que os mais jovens alunos se disponham a ajudar os mais velhos, assim como acho fantástico que os mais velhos tenham a humildade de solicitar ajuda. Isto desenvolve um verdadeiro dialogo, espírito de equipe e de camaradagem inter geracional, o professor que não fizer uso permanente da riqueza e das potencialidades da imagem fixa, cinética e sonora está cometendo um total suicídio profissional.

- Muitas vezes, a imagem cria percepção similar ou próxima que envolve vários alunos, isto participa a criar uma aproximação entre pessoas que estudam um idioma.

\section{PRECONIZAÇÕES DOS GUIAS PEDAGÓGICOS PARA O USO DA IMAGEM NOS LIVROS}

\section{DIDÁTICOS DE FLE}

Assinale o livro didático de FLE (público adulto) que você utiliza com mais frequência.

Figura 187 | Gráfico - Livro didático mais utilizado

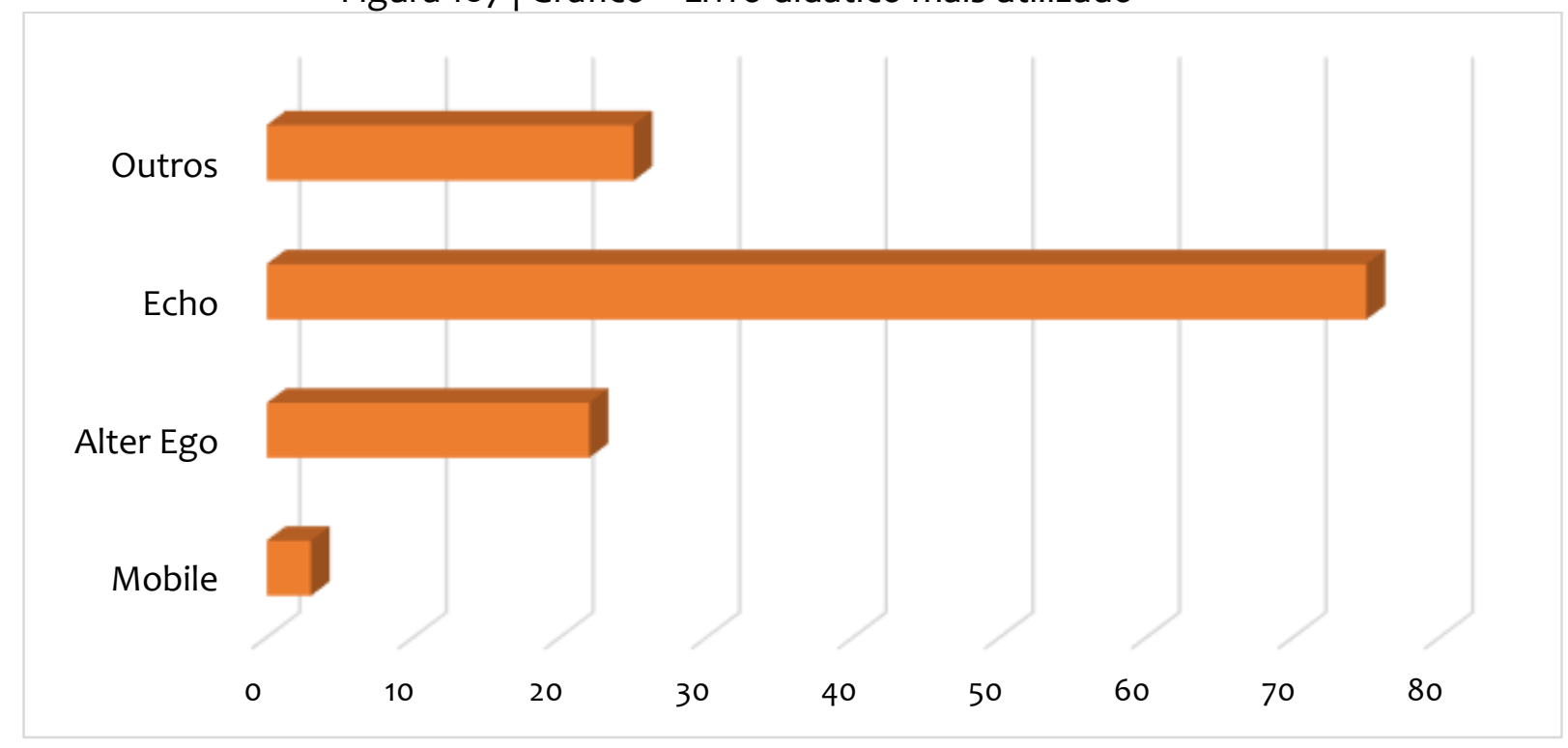

Outros livros didáticos citados: 
Forum, Tempo, Taxi, Tout va bien, Latitudes, Édito, Vite et bien.

Temos assim livros representativos de três grandes editoras francesas: CLE International, Hachette FLE et Didier.

\section{No guia pedagógico correspondente, o uso da imagem é preconizado com que} objetivo? (Várias respostas possíveis):

Figura 188 | Gráfico - Objetivos para o uso da imagem

Na recepção, análise e produção de um gênero textual

Para ilustrar um contexto

Para o reemprego de um conteúdo comunicativo, linguístico ou cultural

Para a memorização/ aquisição de um conteúdo comunicativo, linguístico ou cultural

Para introduzir um conteúdo comunicativo, linguístico ou cultural

Outros

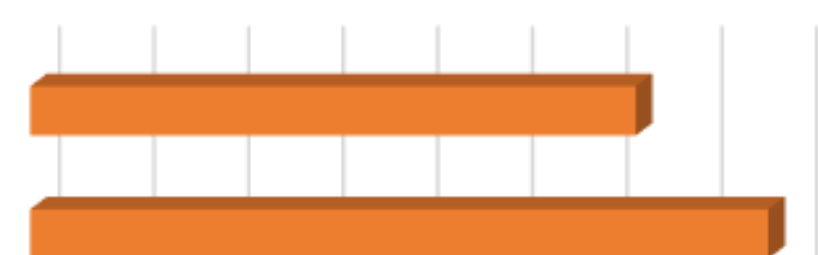

Qual sua opinião sobre a QUANTIDADE de orientações do guia pedagógico para O USO

DAS IMAGENS presentes no livro do aluno?

Figura 189 | Gráfico - Quantidade de orientações

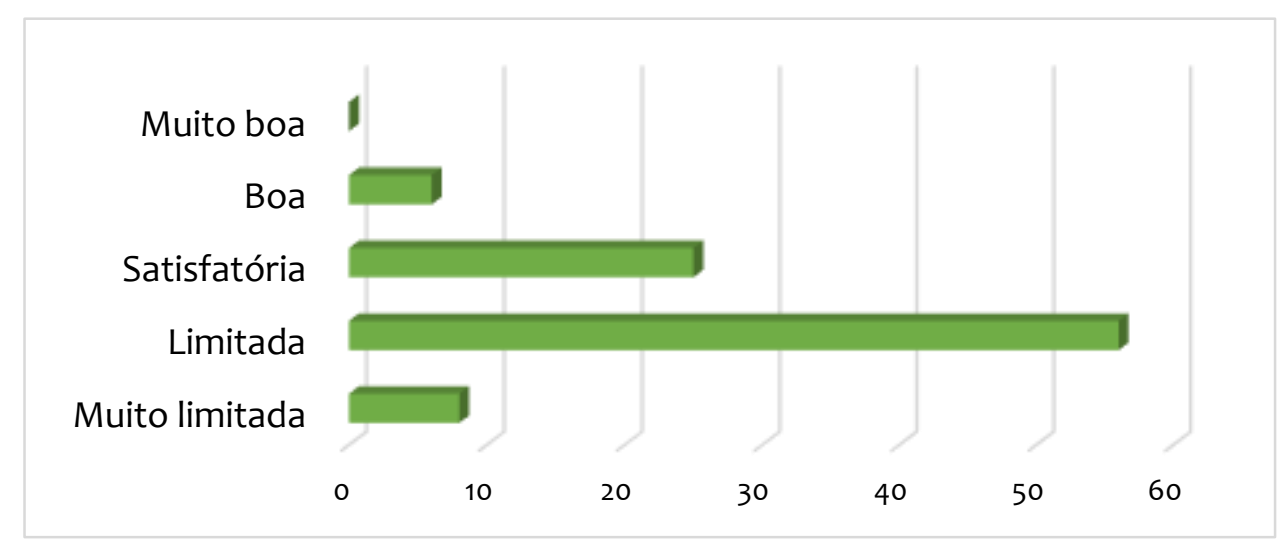


Qual sua opinião sobre a QUALIDADE das orientações do guia pedagógico para O USO DAS IMAGENS presentes no livro do aluno?

Figura 190 | Gráfico - Qualidade das orientações

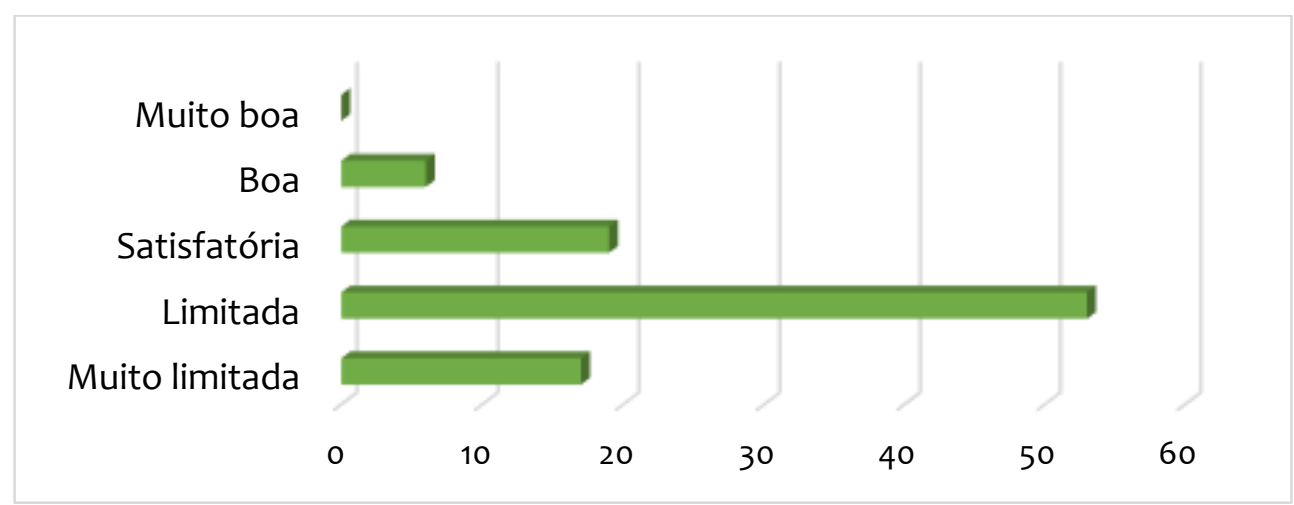

Essas orientações lhe parecem claras e pertinentes?

Figura 191 | Gráfico - Clareza e pertinência

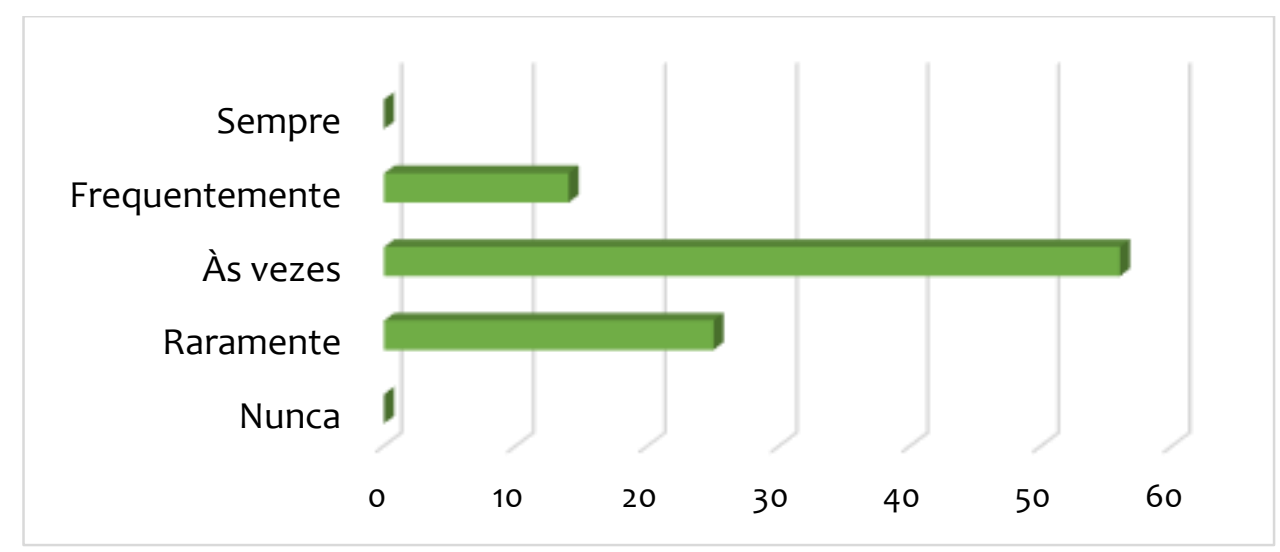

As orientações do guia pedagógico para o USO DAS IMAGENS contribuem para que os objetivos didáticos sejam atingidos em sala de aula?

Figura 192 | Gráfico - Contribuição para os objetivos didáticos

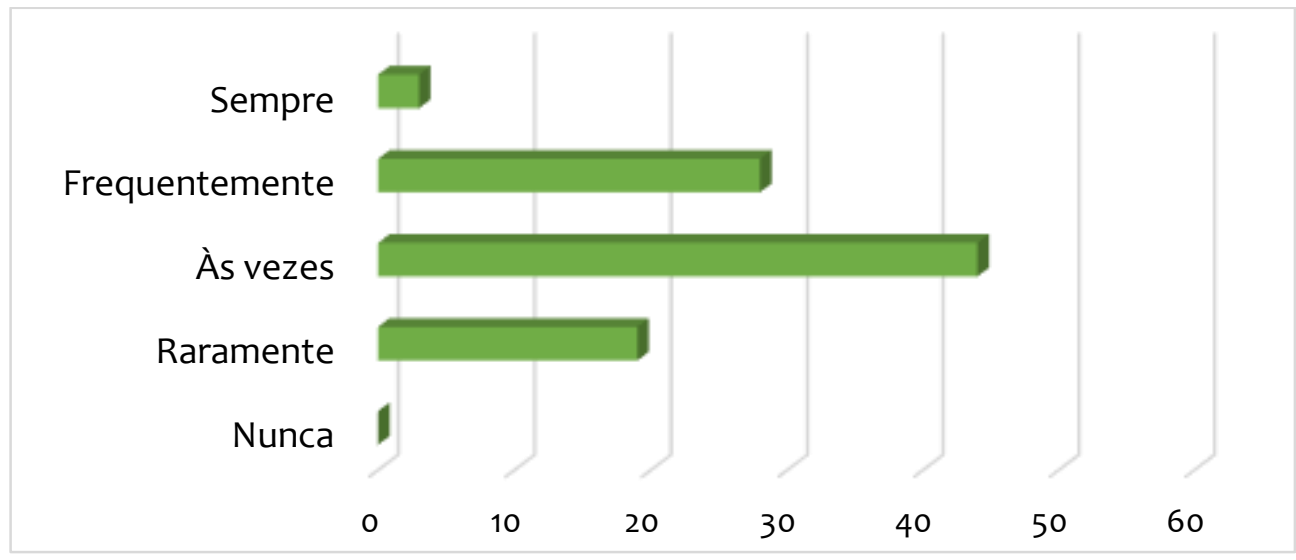


Indique uma página do livro didático com o qual você trabalha mais frequentemente na qual o uso da imagem lhe parece particularmente bem sucedido e explique por quê. Cite o nome do livro.

No caso específico desta questão, apresentaremos os dados coletados na próxima seção (5.3.Análise de dados), pois faremos ao mesmo tempo a análise dos mesmos, juntamente com a imagem das páginas citadas pelos professores.

\section{E. UTILIZAÇÕES EFETIVAS DA IMAGEM EM UMA AULA DE FLE}

Você costuma incluir imagens quando cria uma sequência didática? $100 \%$ dos professores responderam afirmativamente a essa questão.

Em caso afirmativo, você trabalha mais frequentemente a imagem com seus alunos (várias respostas possíveis):

Figura 193 | Gráfico - Objetivos para o uso da imagem

Na recepção, análise e produção de um gênero textual

Para ilustrar um contexto

Para o reemprego de um conteúdo comunicativo, linguístico ou cultural

Para a memorização/ aquisição de um conteúdo comunicativo, linguístico ou cultural

Para introduzir um conteúdo comunicativo, linguístico ou cultural

Outros

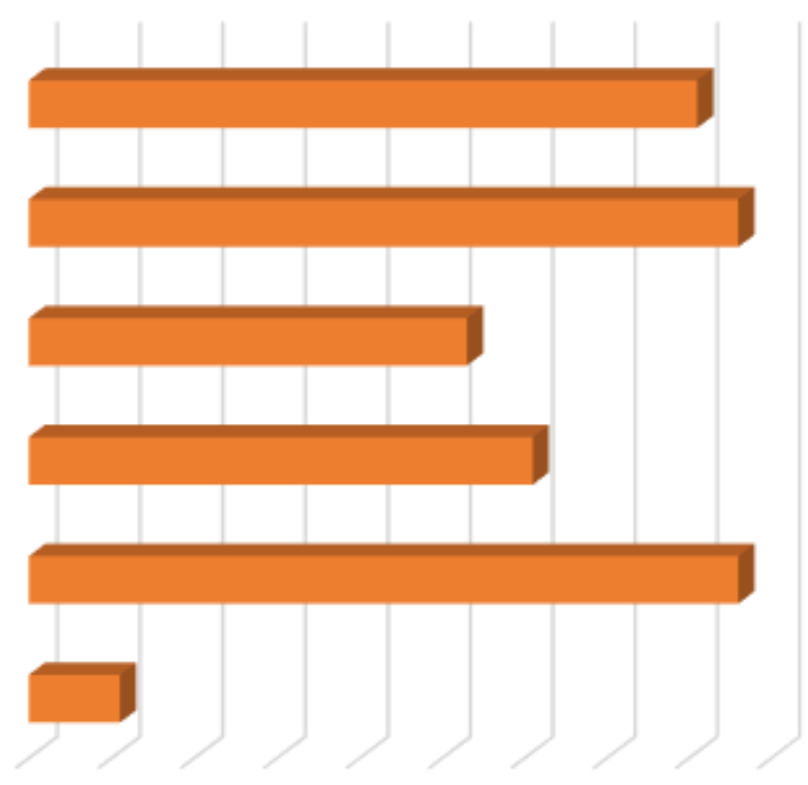

$\begin{array}{llllllllll}0 & 10 & 20 & 30 & 40 & 50 & 60 & 70 & 80 & 90\end{array}$

Outros: Favorecer curiosidade, motivação e provocar pesquisas dos alunos. 


\section{Você poderia citar um exemplo de adaptação de uma atividade para trabalhar uma imagem?}

- Em todos os livros da série Écho, não há (ou quase não há) trabalho sobre as ilustrações dos diálogos das lições. Realizo SEMPRE o exercício de exploração da imagem antes da compreensão oral, ainda que o livro não o peça.

- Localização de lugares que aparecem nos livros didáticos no mapa, por exemplo... Isso explica muito sobre o lugar e ajuda a contextualizar uma situação.

- Nas páginas 62/63 do Écho A1 trabalham-se as atividades da rotina diária das pessoas. Preferi trabalhar a rotina imaginada para cada uma das pessoas que aparece na foto. Cada aluno se imaginava no papel de cada uma das pessoas das fotos e criava seu nome, seu perfil e sua rotina, podendo acrescentar detalhes inesperados ou engraçados sobre cada um.

Figura 194 | Écho A1 - pág. 62, 63

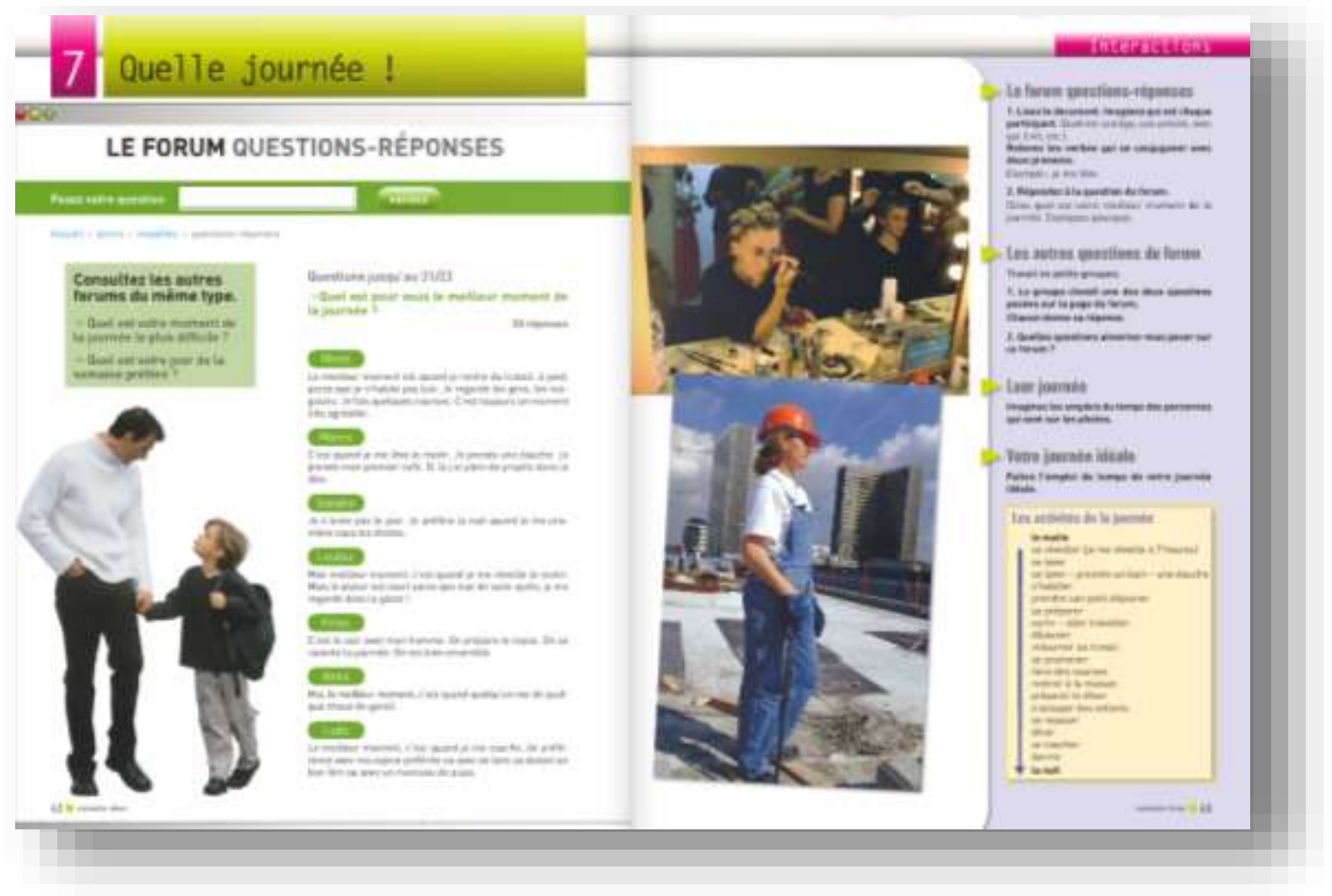

- J'aime bien travailler à partir d'infographies pour des activités à l'oral. À partir d'une image et de données très simples, les apprenants doivent comprendre et commenter une situation, comparer avec leur pays, etc.

- Para introduzir os "faits divers" no B1.2 (livro Écho B1.1) busquei na internet imagens de faits divers e publicações desse gênero (revistas, jornais) e mostrei essa seleção aos alunos antes de qualquer explicação para levantar ideias sobre o que é um fait divers. As imagens do livro não dariam conta de fazer com que os alunos inferissem isso. 
- Localização de lugares que aparecem nos livros didáticos no mapa, por exemplo... Isso explica muito sobre o lugar e ajuda a contextualizar uma situação.

- Trabalhar com hipóteses e depois confirmar a exploração que fizemos da imagem através da escuta.

- Para qualquer imagem, podem ser criadas atividades que estimulem a imaginação e a inserção de um determinado assunto por meio de questões hipotéticas.

Dentro de seu contexto de trabalho, você identifica uma necessidade em formação de professores para trabalhar a imagem em aula de FLE?

Figura 195 | Gráfico - Necessidade em formação

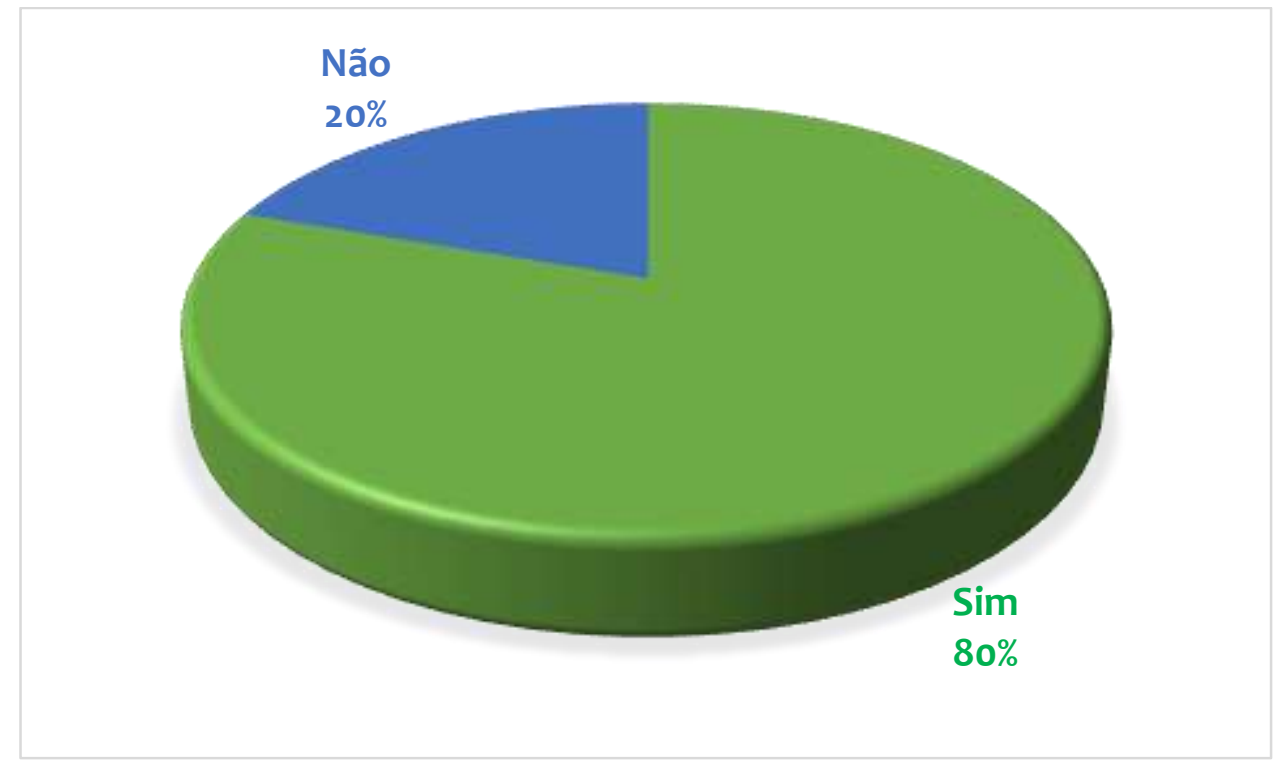

A grande maioria dos professores identifica a necessidade de uma formação. Veremos por que na seção seguinte, durante a análise de dados.

\subsection{Análise dos dados coletados}

A análise dos dados coletados divide-se em cinco seções diferentes (A, B, C, D, E) correspondentes às cinco partes do questionário.

\section{PARTE A. Dados pessoais.}

Os 35 professores que responderam ao questionário constituem um grupo com várias características em comum. Trata-se de um grupo majoritariamente feminino (77\%), 
que trabalha, sobretudo, na Aliança Francesa de São Paulo (74\%) e quase totalmente (94\%) na rede particular de ensino do FLE em São Paulo.

As faixas etárias mais citadas são as de 26 a 35 anos (32\%) e a de 46 a 55 anos (32\%). A totalidade dos respondentes tem formação superior e a grande maioria deles (92\%) têm mais de 6 anos de experiência no ensino do FLE. O total de professores com mais de 11 anos de experiência chega a 58\%, ou seja, a maioria dos respondentes. Estamos, portanto, diante de um grupo que provavelmente já trabalhou com diferentes livros didáticos de FLE e que também já deve ter desenvolvido suas próprias práticas para trabalhar as imagens com os alunos. Essa experiência será notada em suas respostas, já que eles evocam não somente LDs utilizados anteriormente, mas também, vários exemplos das atividades que eles mesmos criam para trabalhar a imagem em sala de aula, quando as orientações dos guias não lhes parecem suficientes.

\section{PARTE B. PRÁTICAS CULTURAIS}

Nosso objetivo com essa parte do questionário era conhecer o perfil cultural desses professores. Sabemos que muitos professores se interessam naturalmente e pessoalmente pela imagem, enquanto que, para outros, a mesma pode ser menos atraente. Alguns professores citaram, de fato, o argumento de serem "mais visuais" ou de terem uma "memória visual” para justificar seu interesse pelas imagens. Imaginamos que professores com graus de interesse diferentes em relação à imagem trabalharão a mesma em sala de aula de forma também diversa.

A grande maioria dos professores (77\%) afirmou buscar se formar ou se informar sobre a imagem no seu no dia-a-dia. Essa busca pela (in)formação é feita por canais bastante variados como visitas a exposições de arte e de fotografia, publicidade, revistas, conversa com amigos. No entanto, o grande canal de (in)formação citado pelos professores foi a Internet, citada por $91 \%$ dos respondentes. Os mesmos canais de (in)formação (Internet, exposições, revistas, etc.) são citados na resposta à pergunta “De que forma a imagem está mais presente em sua vida?".

Portanto, os respondentes que buscam formação e informação sobre a imagem costumam fazê-lo, em grande parte, por meio de suas próprias atividades culturais do cotidiano. No entanto, identificamos duas posições diferentes em relação ao tipo de formação/informação necessária para a leitura e compreensão das imagens: 
a) A maioria dos respondentes busca essa (in)formação de maneira autônoma e informal. Esses professores parecem mostrar, não uma falta de interesse por uma formação mais específica, mas sim uma falta de convencimento quanto à necessidade da mesma, como mostra este testemunho:

- "Não se trata de uma formação acadêmica ou sistemática. Como tenho amigos que trabalham com moda, artes, propaganda e comunicação, áreas em que a imagem desempenha um papel importante, eventualmente conversamos sobre o tema. Eles me mostram diferentes maneiras de interpretá-las e me dão conselhos de leitura."

b) Para outros, no entanto, uma formação própria para a análise da imagem se faz necessária, como vemos no testemunho abaixo:

- “A imagem está constantemente presente em nossa sociedade, é preciso estudá-la e analisá-la."

Concordamos com essa última observação. Assim como os autores que fornecem as bases teóricas para este estudo (JOLY; KRESS \& VAN LEEUWEN, 2006), acreditamos que o excesso de imagens presentes no nosso dia-a-dia não nos capacita naturalmente a analisá-las. Como estamos imersos em um mundo de imagens, sobretudo por meio da Internet, meio de comunicação citado por mais de $90 \%$ dos respondentes, temos a impressão de que essa simples convivência nos capacita a compreendê-las e a analisá-las. No entanto, a nosso ver, nós vemos muitas imagens em nosso dia-a-dia, mas enxergamos e analisamos poucas, sobretudo na nossa área de trabalho, o ensino-aprendizagem de uma língua estrangeira. A imagem está extremamente presente em nossa sociedade e também nos livros didáticos de FLE, mas ela é muito pouco observada e muito pouco estudada. Acreditamos que o discurso visual é construtor de significados e que, por essa razão, ele deve ser estudado e analisado mais profundamente tanto na própria sociedade quanto em sala de aula de FLE.

A imagem exerce um papel importante no cotidiano de 100\% dos respondentes. As respostas para justificar essa importância são variadas e bastante ricas. Identificamos abaixo 4 tipos principais: 
a) A imagem como facilitadora da compreensão do texto. Uma percepção próxima à da imagem-iluminura, submissa ao texto e que contribui para a compreensão do mesmo;

b) A imagem como informação e também como informação instantânea - a rapidez da mensagem que agrada às novas gerações;

c) A imagem com poderes, linguagem e possibilidades próprias, diferentes das do texto escrito;

d) A imagem como fonte de prazer estético;

e) A imagem como fonte inspiradora para a imaginação e para a criação.

A frase de um professor parece reagrupar todas essas possibilidades: "Para mim, uma imagem é... uma síntese ou um caminho.". Essa frase nos parece interessante e permite diferentes leituras. Segue a nossa: por "síntese", compreendemos a concepção da imagem como ilustração, como representação e como informação instantânea (itens “a" e "b"). Por "caminhos" entendemos todas as outras possibilidades evocadas nos outros itens e também aquelas que não foram evocadas nem pelos professores respondentes, nem em nosso trabalho. Ou, como disse um outro respondente, "A imagem para mim é... a tradução de um mundo de possibilidades."

\section{PARTE C. POSSIBILIDADES PARA O USO DA IMAGEM EM UMA AULA DE FLE}

Antes de passarmos à análise dos dados dessa parte do questionário, é importante salientar que os professores foram informados de que todas as perguntas se referiam ao ensino do FLE para um público adulto.

$100 \%$ dos professores afirmaram considerar que a imagem pode exercer um papel importante dentro do processo de ensino-aprendizagem do FLE. Mais uma vez, os professores forneceram uma grande variedade de respostas e riqueza de argumentos para justificar essa opinião. Dentre os principais pontos evocados para o uso das imagens no ensino do FLE, os professores afirmaram que as imagens...

- possibilitam a associação aos conceitos, muitas vezes abstratos;

- abrem as portas da imaginação;

- facilitam a aprendizagem e a memorização;

- são portadoras de informações, gestos, expressões;

- introduzem um tema;

- incitam a expressão oral e a interação entre os alunos; 
- estimulam o interesse do aprendiz em transformar o que ele vê em frase e palavra; - facilitam o caminho para o que se quer: expressar-se;

- completam, alteram, esclarecem um texto;

- mais do que o texto, permitem o contato imediato com o outro (Instagram, selfies, etc.);

- suscitam uma reação imediata;

- ilustram uma explicação;

- têm um aspecto estético importante, captando mais do que o texto a atenção do aluno;

- podem estimular a aprendizagem da língua;

- auxiliam na compreensão oral;

- são indispensáveis para a criação de atividades lúdicas e eficientes para a aprendizagem do léxico;

- podem otimizar as atividades de descoberta e de sistematização de conteúdos gramaticais.

- tornam alguns assuntos menos áridos, introduzindo humor;

- induzem o aluno a ser mais ativo, criativo e produtivo;

- dão uma dimensão física para determinados assuntos (como as preposições de lugar e indicações de caminho), mostrando a arte e a cultura, imprimindo beleza e prazer de leitura no material didático...

Vemos que as justificativas abordam tanto funções bem pragmáticas, como o auxílio na compreensão oral de um documento ou na compreensão do sentido de uma palavra, quanto funções mais ligadas aos sentimentos, às motivações e às emoções.

No que diz respeito à utilização da imagem para objetivos linguísticos, vemos que a maior frequência de utilização do suporte visual se dá no tratamento do léxico. $42 \%$ dos professores afirmaram fazer esse uso "frequentemente" e $44 \%$, "sempre". Somando esses dois resultados, podemos dizer que a utilização da imagem para um trabalho sobre o léxico ocorre frequentemente para $86 \%$ dos respondentes.

Ao somarmos as respostas para esses dados (sempre/frequentemente) nas perguntas referentes ao uso da imagem para a gramática e para a fonética, chegamos ao gráfico a seguir. Nele, podemos ver a porcentagem de respondentes que afirmaram trabalhar frequentemente a imagem para cada um desses objetivos. 
Figura 196 | Gráfico - Frequência da utilização da imagem em aula de FLE

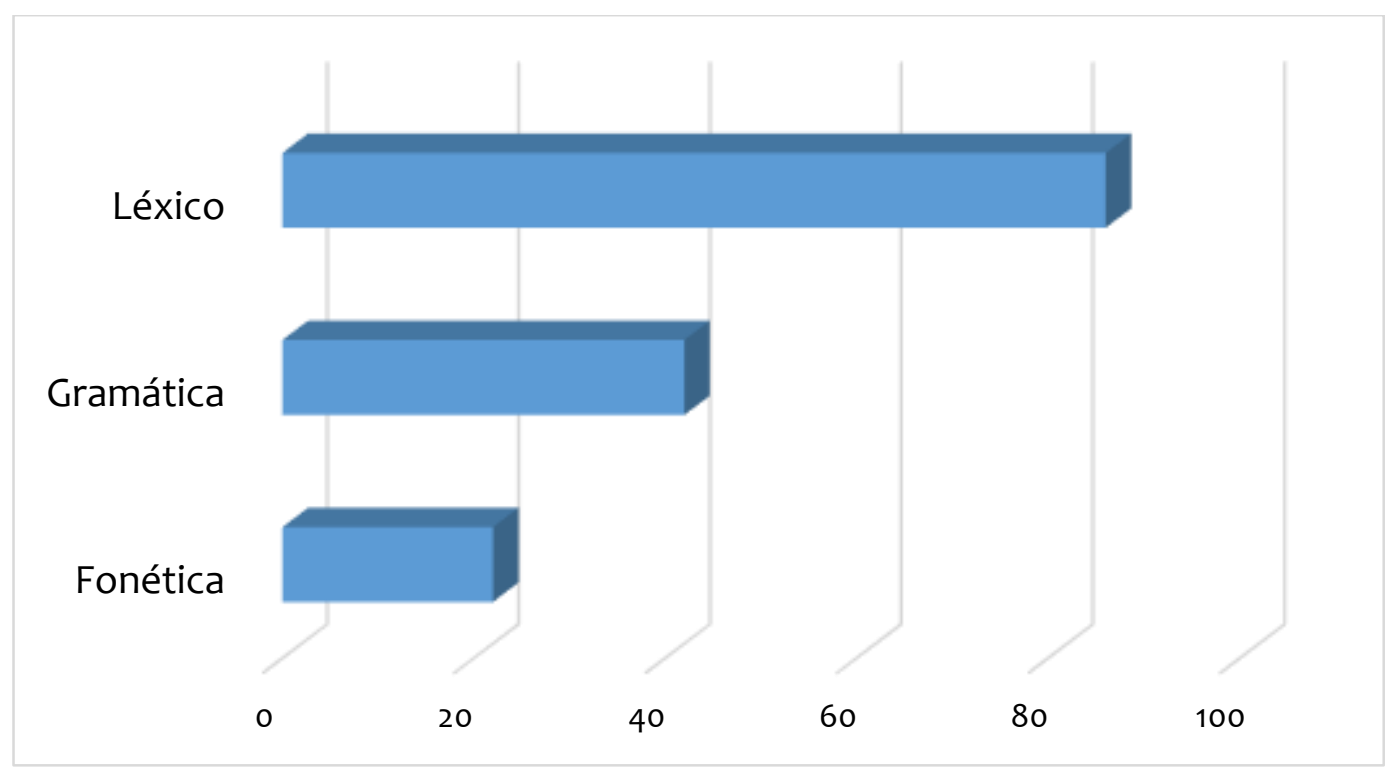

Trata-se de um resultado bastante esperado pois o léxico é, de fato, o ponto linguístico mais comumente associado ao ensino da língua, desde a época de Comenius. As utilizações da imagem para o ensino-aprendizagem da gramática e da fonética são menos conhecidas e, portanto, menos frequentes.

Quanto aos objetivos comunicativos desenvolvidos em sala de aula, os professores afirmaram utilizar mais a imagem em atividades de compreensão (oral e escrita) do que em atividades de produção. Uma prática também desenvolvida pela maioria dos livros didáticos.

Nas demais perguntas, o destaque ficou para a importância do uso da imagem associada a objetivos culturais e interculturais. A quase totalidade dos professores afirmou recorrer "sempre" ou "frequentemente" à imagem para esse objetivo.

\section{PARTE D. PRECONIZAÇÕES DOS GUIAS PEDAGÓGICOS PARA O USO DA IMAGEM NOS LIVROS DIDÁTICOS DE FLE}

As perguntas nesta parte referiam-se à satisfação dos professores em relação ao tratamento pedagógico para a imagem proposto pelo livro didático/guia do professor com o qual eles trabalham mais frequentemente. 
Apenas $6 \%$ dos respondentes consideraram que a quantidade de orientações do guia pedagógico para o uso das imagens era "boa" ou “muito boa". Isso corrobora com o resultado de nossa análise de livros didáticos na qual vimos que essa quantidade de orientações, apesar do grande número de imagens no livro do aluno, é bastante limitada.

No que diz respeito à qualidade dessas orientações, o índice de respostas positivas permanece o mesmo: $6 \%$. Nos dois casos, a maioria dos professores qualificou essas orientações como "limitadas" (56\% no primeiro caso e $53 \%$, no segundo).

O termo "limitado" é, de fato, o mais adequado para definir a opinião dos professores sobre as propostas do guia pedagógico para o uso das imagens. A opção "às vezes" também foi a mais assinalada (56\%) em resposta à clareza das informações do guia e em relação à contribuição das orientações para atingir os objetivos da sequência didática (44\%).

Na pergunta seguinte, pedia-se ao professor que citasse uma página do livro didático em que o uso da imagem lhe parecesse particularmente bem sucedido. Como a grande maioria dos respondentes trabalha com o livro didático Écho, esse foi o livro mais citado tanto nos aspectos positivos quanto nos problemas evocados. Os professores mostraram apreciar particularmente as imagens das partes de "Civilisation", dedicada à interculturalidade, e também as da parte "Simulations", dedicada sobretudo à compreensão oral, com diálogos entre os personagens do livro.

Vejamos alguns exemplos citados:

Écho A1 pág.46 e pág.47 - Lição 5 "Bon voyage !": as fotos apresentadas como sugestões de viagens de uma agência virtual são bem variadas, bonitas $e$ proporcionam a possibilidade de associação com lugares conhecidos e a discussão sobre diferentes tipos de viagem. E se houver tempo elas podem ser complementadas com outras de sites turísticos ou simplesmente do Google imagens. 
Figura 197 | Écho A1 - pág. 46, 47

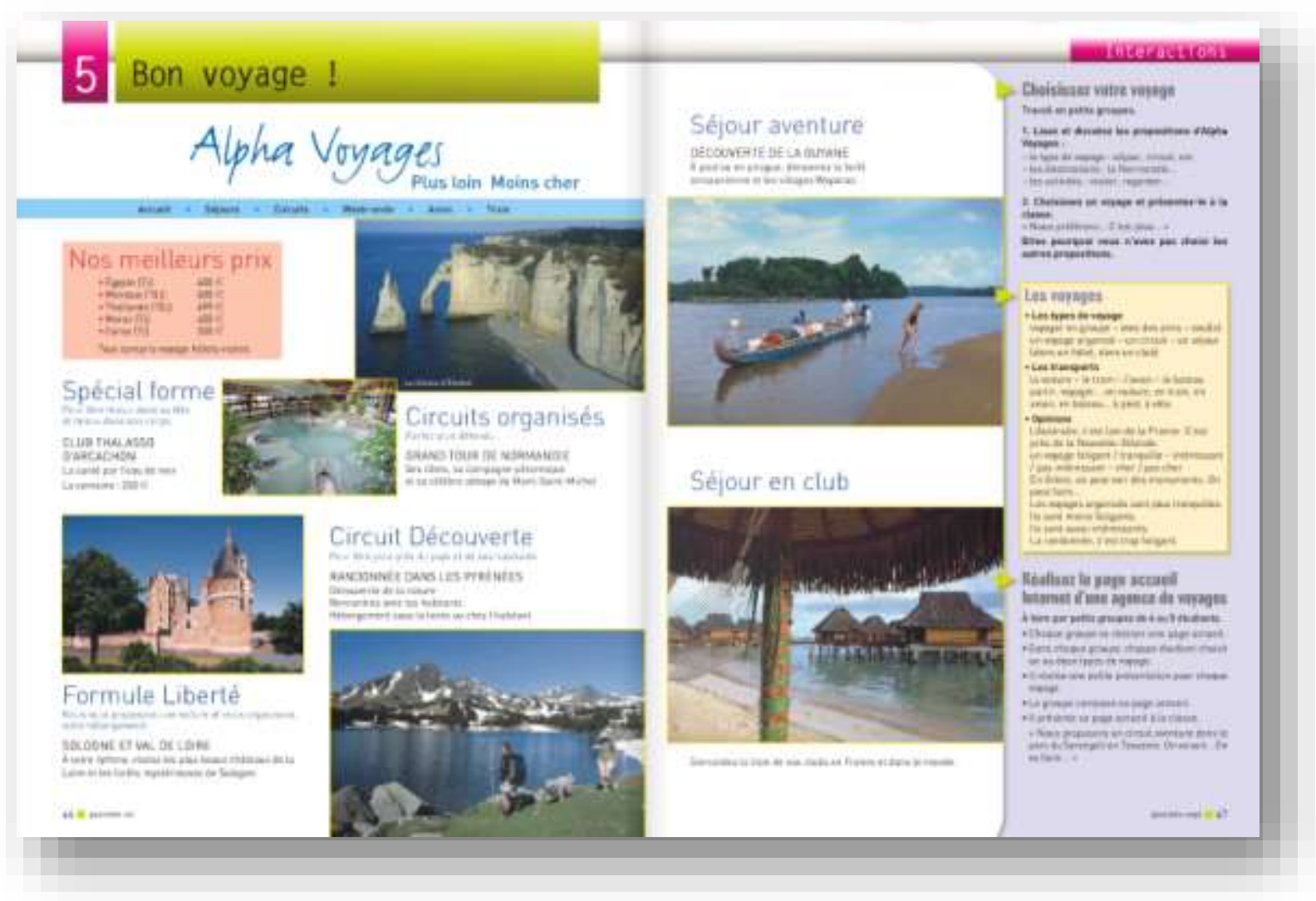

De fato, é uma dupla página com um belo projeto gráfico. Trata-se da página de abertura da lição e, conforme comprovamos anteriormente, nessa parte costuma haver uma grande utilização de fotos para uma inserção temática. Segundo o livro do aluno e as indicações do guia pedagógico, os alunos devem ler os circuitos de viagem e escolher seu destino preferido. O verbo "ler" é interessante pois é o único verbo que aparece no enunciado do livro do aluno e no guia pedagógico. Vejamos as orientações no livro do aluno - página 47, ex. 1 e 2:

1. Lisez et discutez les propositions d'Alpha voyages

- Le type de voyage : séjour, circuit, etc.

- Les destinations : la Normandie...

- Les activités : visiter, regarder...

2. Choisissez un voyage et présentez-le à la classe : 'Nous préférons, c'est plus... » Dites pourquoi vous n'avez pas choisi les autres propositions.

Vejamos agora as orientações do guia pedagógico para essa mesma dupla página (Figura 198). 
Figura 198 | Écho A1 - Guia pedagógico - página 38.

\section{Choisissez votre voyage}

1. Faire identifier le document.

Expliquer: Plus loin - Moins cher. Introduire les comparatifs à l'aide de la liste des prix. On peut aussi utiliser la rubrique «Comparer les choses » de la page 48.

Découvrir le vocabulaire de la rubrique «Opinions» de l'encadré de vocabulaire.

2. Travail en petits groupes. Chaque petit groupe explore le document de l'agence Alpha Voyages. Il peut s'aider du dictionnaire. Il choisit une destination de voyage.

3. Mise en commun. Chaque groupe présente le voyage qu'il a choisi et dit pourquoi.

Chaque présentation est l'occasion pour l'enseignant de faire une mise au point sur la compréhension du vocabulaire du document. On présentera notamment :

- le type de voyage (séjour, circuit, etc.]

- la destination (situer sur les cartes)

- les lieux visités (falaises d'Étretat, abbaye du Mont-SaintMichel, etc.)

- les activités (découvrir, se détendre, visiter, rencontrer, etc.)

4. Introduire le vocabulaire des transports en faisant appel aux préférences des étudiants (Pour aller de ... à ... je préfère prendre le train]

Como podemos verificar nos dois suportes dedicados à explicação das atividades para essa dupla página, não há nenhuma indicação ao trabalho com as imagens. Os exercícios são bem mais focados no trabalho sobre os textos que acompanham as imagens, pois há questões de compreensão escrita e a menção à utilização de um dicionário se houver dúvidas. Nem mesmo o verbo "observer" para as fotos é citado pelo livro ou pelo guia.

As atividades descritas pelo professor para essa dupla página foram, portanto, e talvez sem que ele se tenha dado conta - criadas por ele mesmo e não estavam prescritas no material didático. O professor identificou um projeto gráfico bem feito, com imagens de qualidade e, de forma natural e intuitiva, explorou as imagens pedindo aos alunos que a associassem com lugares conhecidos. Ele também complementou as imagens mostrando sites turísticos e "foi além" como disse outro professor ao se referir a outra página do livro em que a utilização da imagem era bem sucedida:

"Na página 100 dá para tirar muitas coisas das imagens e ir além." 
Acreditamos tratar-se de um bom exemplo da transformação de um "artefato" em um "instrumento". Os professores identificam frequentemente possibilidades de exploração nos livros didáticos que, por vezes, não foram explicitadas pelos autores.

O mesmo acontece ao observarmos estes outros testemunhos:

- No livro Écho utilizo as imagens para os diálogos. Por exemplo, na página 50 utilizo a imagem para explicação da cidade onde os personagens moram e também o diálogo entre o casal antes de colocar a escuta.

- Écho - Nas páginas de "Simulations", em geral, as imagens me parecem bem adaptadas ao conteúdo e permitem, em geral, gerar hipóteses, por parte dos alunos, coerentes com o documento oral.

Figura 199 | Écho A1 - pág. 50, 51

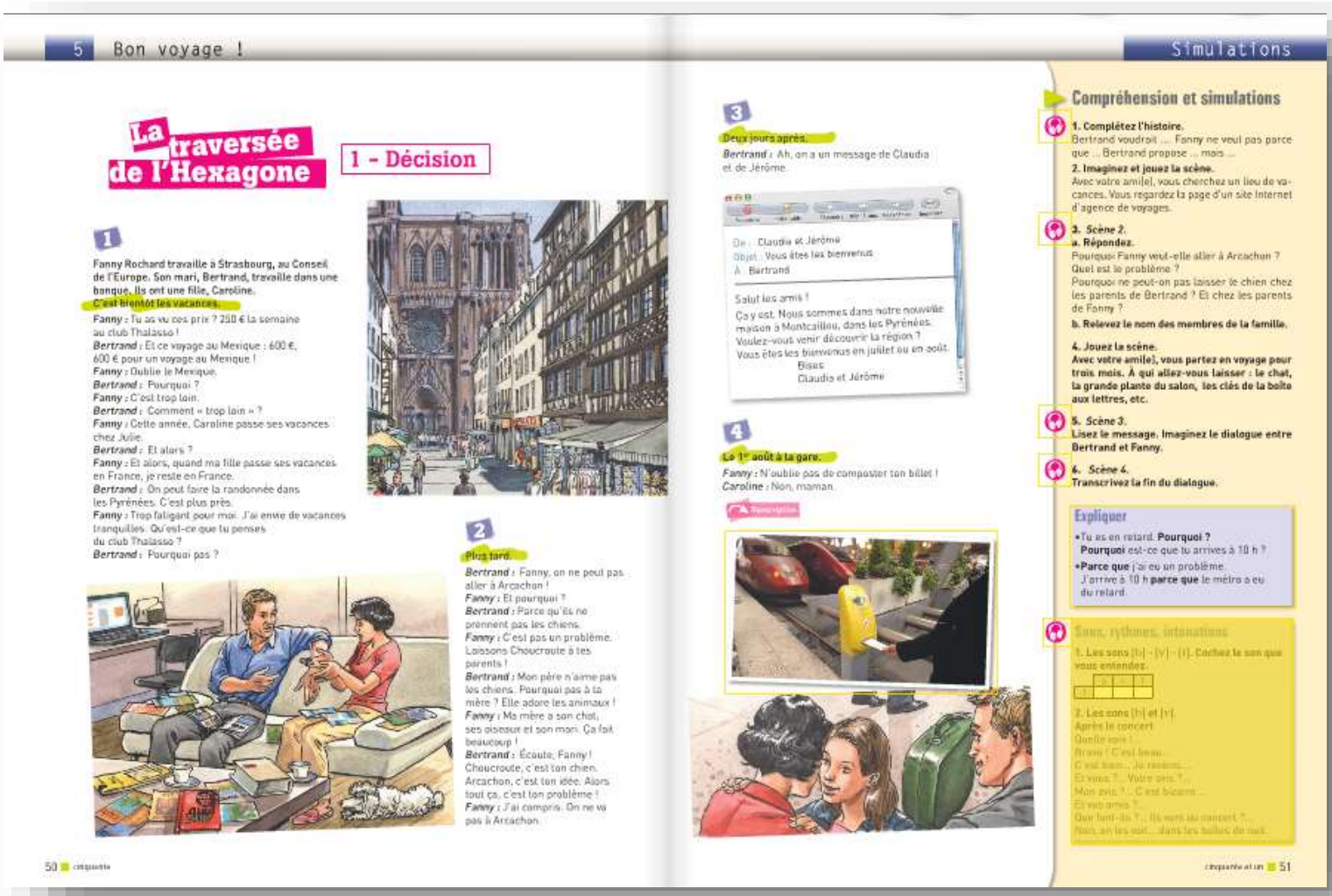

As atividades descritas pelos professores como, por exemplo, "gerar hipóteses" antes da escuta não estão prescritas nem no livro do aluno, nem no guia pedagógico. Os professores, no entanto, identificaram o bom potencial das imagens para atingir seus objetivos e as exploram adequadamente. 
O mesmo pode ser dito em relação a este outro testemunho:

Écho B2 - p 29 - "Le point sur... l'esprit cartésien". A imagem permite aqui uma análise que anuncia muito bem o texto.

O professor faz referência à imagem abaixo, que acompanha um texto intitulado "Le point sur... l'esprit cartésien". No entanto, nenhuma referência à esta imagem é feita nem no livro do aluno, nem no guia pedagógico.

Figura 200 | Écho B2 - pág.29

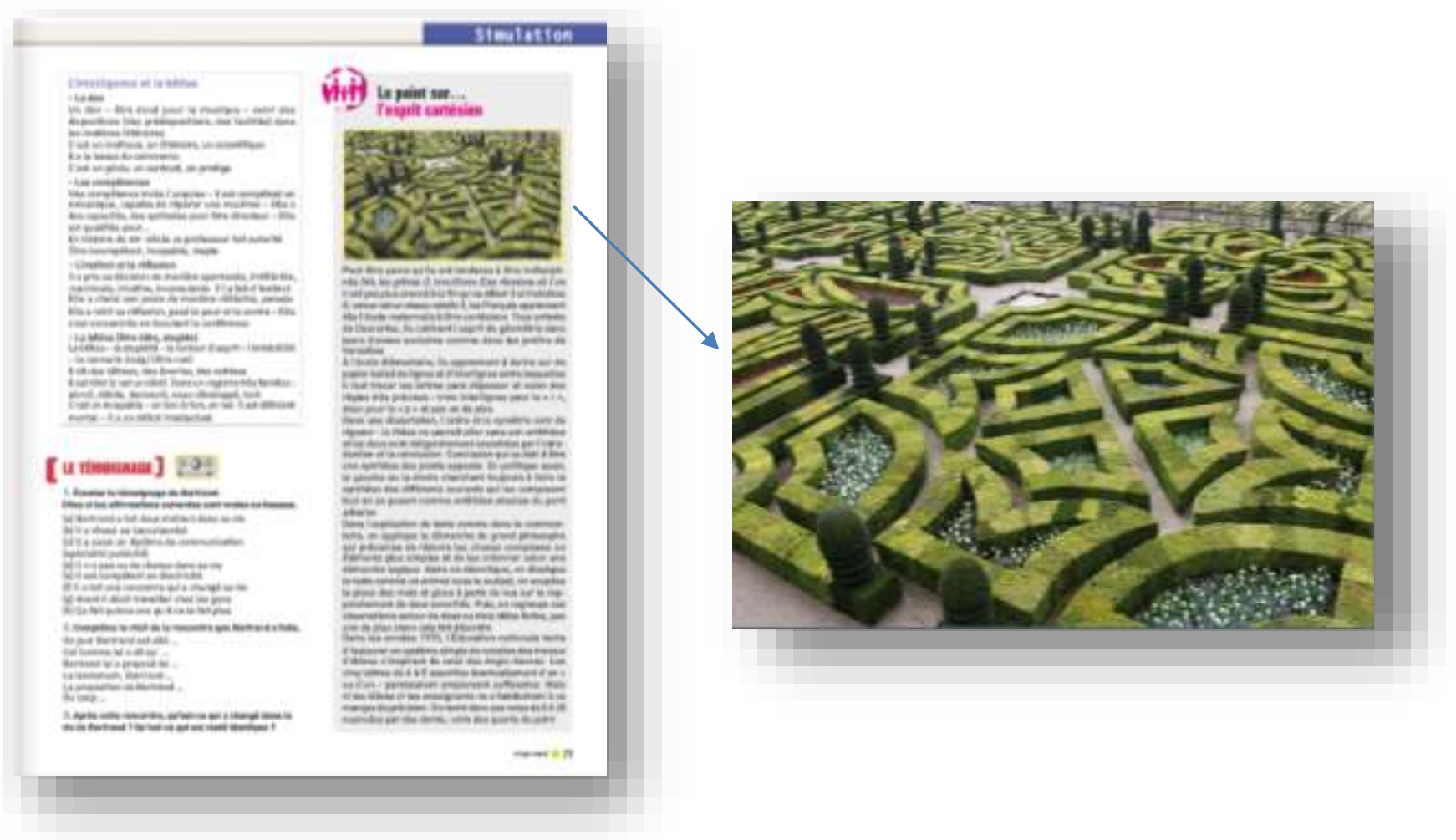

Diante desses fatos, alguém talvez pudesse afirmar que orientações específicas para o uso pedagógico da imagem não são necessárias em um livro didático de FLE, já que os professores sabem intuitivamente como utilizá-las e que os editores/autores dos livros esperam que os professores tomem efetivamente essas decisões. Bastaria, portanto, um projeto gráfico de qualidade e imagens escolhidas em coerência com o texto para que a exploração adequada fosse feita em sala de aula. Acreditamos, no entanto, que essa afirmação não é válida por duas razões principais: a primeira será vista ainda nesta seção, quando um professor afirma não utilizar as belas fotos de uma dupla página pois não sabe como poderia utilizá-las. A segunda diz respeito à importância da 
exploração dos diferentes componentes de uma página multimodal para uma aprendizagem mais efetiva.

Ainda dentro das páginas identificadas pelos professores como um exemplo de sucesso de uso da imagem, há uma atividade que foi citada por dois professores e que propõe, efetivamente, uma proposta de exploração específica para a imagem, com a imagem e, o que é também muito importante, em ligação com os outros suportes semióticos do texto multimodal. Vejamos o que dizem os professores:

- Página 53 do livro Écho A1 para se trabalhar a atividade de compreensão oral, associando cada pequeno diálogo com uma fotografia (esta atividade é comumente bem-sucedida).

- Pág.53 du livre Écho Voyager en France. On doit observer les images et les associer à des situations. On peut déduire plusieurs informations de l'image. À partir de cette analyse, on peut faire imaginer un dialogue aux apprenants avant de réaliser l'écoute.

Figura 201 | Écho A1 - pág. 53

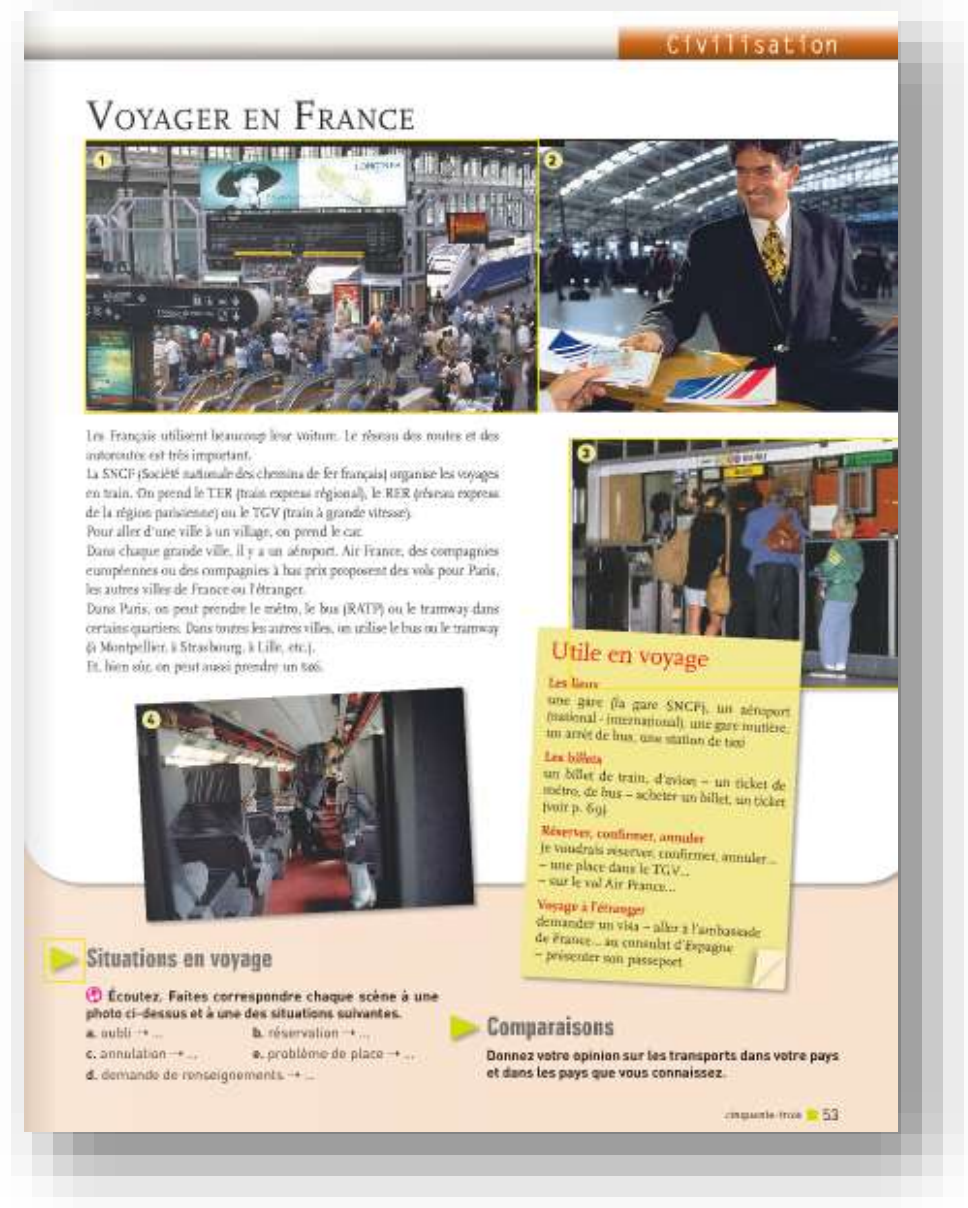


Acreditamos fortemente na pertinência desse tipo de atividade. A imagem pode ser explorada pelo aluno não só como observação, mas há também uma ação que se espera do aluno em relação às imagens. Ela tem, portanto, uma "função atuante" que foi proposta pelo próprio LD. O aluno deve escutar os diálogos, associá-los a uma imagem específica e ainda dizer qual situação corresponde a um pedido de informação, a um pedido de reserva, etc.

Ele tem, portanto, uma tarefa a cumprir em relação às imagens e, o que é mais interessante, essa tarefa está associada a um exercício de escuta e de leitura. Acreditamos que essa multiplicação de formas de leitura solicitada pelo livro favoreça a construção do sentido e a aprendizagem.

\section{PARTE E. UTILIZAÇÕES EFETIVAS DA IMAGEM EM UMA AULA DE FLE}

Antes de analisarmos os dados coletados nesta parte do questionário, achamos que seria importante relativizar a expressão "utilizações efetivas" já que sabemos que nem sempre as utilizações relatadas em um questionário correspondem às utilizações efetivas de um suporte. Primeiramente porque, mesmo que o questionário seja anônimo, sabemos que muitas vezes o entrevistado diz aquilo que acredita que seja esperado que ele diga, a resposta julgada “correta”. E em segundo lugar, pois sabemos que vários fatores interferem entre o que o professor previu realizar e o que ele pôde realizar efetivamente, dentre os quais podemos citar o perfil dos alunos, as reações dos mesmos, as intervenções que surgiram durante a aula, o imprevisto, etc. Apesar dessa ressalva, acreditamos que as respostas dos professores nos oferecem elementos importantes para compreendermos melhor as atividades que eles preveem e realizam com seus alunos em torno da imagem e o porquê de suas escolhas.

100\% dos professores afirmaram incluir imagens quando criam uma sequência didática. A nosso ver, essa resposta reitera outra função importante da imagem, que definimos como "função expressiva”. Ela é válida não somente para o aluno mas também para o professor: a possibilidade de criar, a possibilidade de trazer algo de si para a sala de aula, a possibilidade de se expressar por meio das imagens. 
Perguntamos aos professores quais seus principais objetivos ao incluir a imagem em uma sequência didática. Propusemos as seguintes opções de resposta:

- Para introduzir um conteúdo comunicativo, linguístico ou cultural;

- Para a memorização/aquisição de um conteúdo comunicativo, linguístico ou cultural;

- Para o reemprego de um conteúdo comunicativo, linguístico ou cultural;

- Para ilustrar um contexto;

- Na recepção, análise e produção de um gênero textual (anúncios publicitários, emails, receitas de cozinha, blogs, etc.);

- Outros:

Todos os objetivos foram assinalados pelos respondentes com destaque para: “recepção, análise e produção de um gênero textual (anúncios publicitários, e-mails, receitas de cozinha, blogs, etc.)" e "ilustração de um contexto".

Em relação à pergunta sobre a necessidade de adaptar as orientações do guia para o uso da imagem ou a necessidade de criar outras atividades, a maioria dos respondentes (44\% para as duas questões) afirmou que isso ocorre "frequentemente". Dentro os exemplos de adaptações que eles afirmaram ter feito, a maioria refere-se ao fato de a exploração pedagógica não ser explicitada pelo guia:

- Não há (ou quase não há) trabalho sobre as ilustrações dos diálogos das lições. Realizo SEMPRE o exercício de exploração da imagem antes da compreensão oral, ainda que o livro não o peça.

- Trabalhar com hipóteses e depois confirmar a exploração que fizemos da imagem através da escuta.

- Localização de lugares que aparecem nos livros didáticos no mapa, por exemplo... Isso explica muito sobre o lugar e ajuda a contextualizar uma situação.

- Para qualquer imagem, podem ser criadas atividades que estimulem a imaginação e a inserção de um determinado assunto por meio de questões hipotéticas.

Esses testemunhos reforçam o ponto que havíamos visto anteriormente, ou seja, o fato de muitos professores criarem de maneira quase intuitiva atividades de exploração para a imagem. E nos leva também àquela questão sobre a necessidade ou não de essas 
propostas estarem descritas no material didático. Acreditamos que sim e ilustramos nossa posição com o testemunho abaixo:

- Não sei se poderia chamar de adaptação de atividade, na medida em que não há nenhuma orientação no guia do professor (pág. 66) para explorar as imagens do livro do aluno Écho A1 (pág. 74). Existem apenas informações sobre as fotos. Quando trabalho essa double page, às vezes, desconsidero completamente as fotos; às vezes, acabo substituindo-as por outras que mostram mais claramente diferentes traços de personalidade (sportif, cultivé, généreux, élégant, etc.).

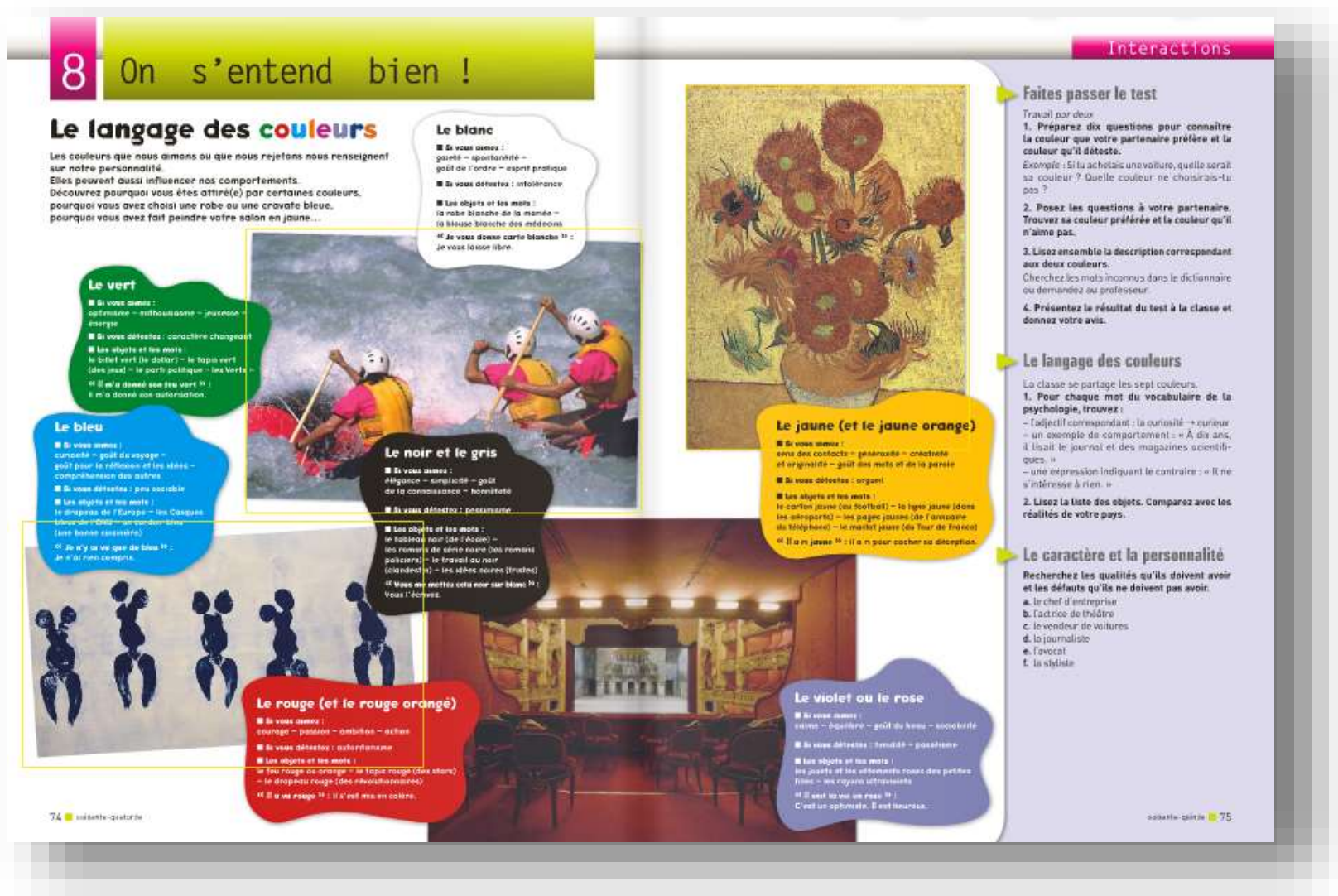

Apesar de as imagens estarem bem ligadas ao tema das cores, o ponto principal do vocabulário são os diferentes tipos de personalidade. Ao ler o texto correspondente a sua cor preferida, o aluno descobre traços de sua personalidade. O professor em questão teve dificuldades para associar os temas às imagens do livro pois não havia indicações para o seu uso, apesar de as mesmas comporem cerca de dois terços da dupla página. Acreditamos, portanto, que essa falta de informação/orientação pode ser prejudicial ao professor e, consequentemente, ao processo de ensino-aprendizagem da 
língua. Mesmo que o professor não adote a prescrição do livro, acreditamos que o simples fato de se ter uma proposta de exploração pedagógica para a imagem e de se tomar conhecimento da mesma é essencial para o trabalho de preparação da aula com textos multimodais.

A última pergunta do questionário dizia respeito à necessidade ou não de uma formação de professores para trabalhar a imagem em aula de FLE. Como vimos, a grande maioria dos professores $(80 \%)$ respondeu afirmativamente a essa questão.

Vejamos agora as justificativas.

1/ Justificativas evocadas pelos que não sentem necessidade de uma formação ao uso da imagem para os professores:

- Acredito que os colegas com os quais trabalhamos já o fazem bem. Temos compartilhado experiências e atividades e elas preconizam a exploração de imagens, quando podem.

- Não vejo necessidade de uma formação específica para isso. Vejo a imagem como um suporte que vai se formando e melhorando a cada aula.

- Não tenho certeza de que isso é uma necessidade pois acredito que a maioria dos professores já usa imagens em sala de aula. Uma formação nesse sentido poderia ser interessante, mas não sei se é tão necessária.

Como podemos observar, as justificativas para a resposta negativa mostram não uma falta de interesse pelo tema, mas sim, a impressão de uma "falta de necessidade" de tal formação pois o tema já seria dominado pelos professores. Essa posição retoma a questão que vimos anteriormente sobre o fato de muitas pessoas julgarem que esse aprendizado à leitura da imagem ser algo "transparente" ou "natural”.

2/ Justificativas para as respostas afirmativas. Optamos por recopiar um número maior de respostas, pois elas retomam e também ilustram - como imagens - diferentes pontos abordados neste trabalho:

- Penso o professor, hoje, como um "concepteur" de sequências pedagógicas. A rigor, ele pode abdicar de algumas imagens propostas nos manuais e/ou buscar novas imagens, mais belas e criativas, na Internet, a fim de melhorar a qualidade 
de seu trabalho e, assim, alcançar resultados mais interessantes, para ele mesmo $e$, especialmente, para seus alunos.

- Como em todo aspecto didático, o uso da imagem requer conhecimento teórico e prático, renovação constante, adaptação, etc.

- Pode ajudar a ter novas ideias de trabalho.

- Acho muito instigante para os alunos trabalhar com imagens, mas temos pouca formação sobre o tema, seria interessante e enriquecedor uma formação sobre esse tema.

- Nem sempre conseguimos explorar de maneira satisfatória todo o potencial da imagem em sala de aula. Seriam, portanto, pertinentes e necessárias formações com esse objetivo.

- O trabalho com a imagem é parte essencial de nosso curso e de nosso cotidiano. A partir dela, podemos tomar vários rumos. Não me lembro de ter tido alguma formação específica sobre o assunto e faço meio instintivamente. Acho que estamos em uma sociedade da imagem, saber tirar proveito de tal fato em sala de aula é um grande trunfo.

- As imagens nos permitem criar atividades múltiplas e, assim, muitas vezes, torna-se difícil adaptá-las ao contexto da aula de forma eficaz e produtiva. Com a ajuda de pesquisas sobre o assunto e com a formação de professores, acredito que esta tarefa de preparação diária de aula ficará mais fácil e mais apropriada no que concerne o uso das imagens.

- Porque, muitas vezes, como as imagens contribuem no processo de aprendizagem e os livros didáticos as trazem em profusão, sinto que se poderia saber usá-las e inseri-las de uma maneira mais efetiva em todas as aulas, como mais uma ferramenta a serviço do aprendizado.

- Difícil responder pois não conheço bem o trabalho dos outros professores para trabalhar a imagem em aula FLE. Mas, pelo trabalho que eu tive e tenho para domínio desta atividade e preparo das minhas aulas, acho que seria de grande necessidade e utilidade profissional.

- Para intercambiar e ter mais ideias sobre a utilização da imagem.

- Porque muitos ainda não utilizam imagens como poderiam, seja por não conhecerem as possibilidades ou as diversas possibilidades sobretudo de fazerem essa utilização e/ou pela riqueza de explorações que podem ser feitas a nível didático e pedagógicos!

- Porque facilita e anima e desperta mais o interesse dos alunos. 
- Para o correto emprego desta ferramenta.

- Ter algumas noções básicas sobre artes plásticas ajuda a entender melhor as referências feitas na publicidade, no cinema ou na literatura. A educação do olhar é um trabalho delicado que pode complementar o ensino/aprendizagem de uma língua estrangeira na medida em que pensamos a língua como fazendo parte de uma cultura, ou melhor, como expressão de uma visão de mundo.

- Ter a competência para trabalhar bem a imagem em aula de FLE pode auxiliar imensamente na produção de material didático, na exploração eficaz dos conteúdos (linguísticos, culturais, ...) durante a aula e também tornar a aula mais interessante e leve.

- Parece-me um campo um pouco inexplorado ainda.

- Para auxiliar na elaboração de novas estratégias para trabalhar com esse recurso.

- Porque como professores de classe, temos a tendência de nos preocupar mais em passar os conteúdos gramaticais e executar as tarefas indicadas para isso, deixando de lado o aspecto convidativo, instigante, motivador e informativo da imagem, que além de tornar a abordagem dos conteúdos de aprendizado mais leve para o aluno, complementa o papel do professor que por isso pode passar a exercer mais o papel de facilitador do que o papel de "mestre".

Em conclusão e de forma bastante geral, podemos afirmar que os exemplos e argumentos trazidos pelos professores por meio da coleta de dados - tanto os pontos positivos quanto negativos - confirmam vários elementos que havíamos identificado nas análises práticas dos livros didáticos feitas neste trabalho.

Observamos também que, ao responder ao questionário, muitos professores refletiram pela primeira vez sobre esse tema de forma mais aprofundada. Eles foram levados a adotar uma posição de distanciamento em relação aos livros didáticos, aos guias pedagógicos e também em relação às suas próprias práticas de aula, o que é bastante positivo, a nosso ver. De fato, alguns professores comentaram pessoalmente e também por escrito no questionário e em algumas frases que recopiamos acima que jamais haviam pensado em certas questões.

Essa simples reflexão, a nosso ver, validou o interesse da aplicação do questionário. Acreditamos que o mesmo contribuiu para o desenvolvimento de um "professor reflexivo", termo definido da seguinte forma pela pedagoga portuguesa Isabel Alarcão: 
A noção de professor reflexivo baseia-se na consciência da capacidade de pensamento e reflexão que caracteriza o ser humano como criativo e não como mero reprodutor de ideias e práticas que Ihe são exteriores. É central, nesta conceptualização, a noção do profissional como uma pessoa que, nas situações profissionais, tantas vezes incertas e imprevistas, atua de forma inteligente e flexível, situada e reativa.

(ALARCÃO, 2010:44) 
CONSIDERAÇÕES FINAIS 


\section{CONSIDERAÇÕES FINAIS}

Vimos nesta tese que somos constantemente convidados a analisar, a compreender e a interpretar imagens sem termos sido iniciados a essa análise, a essa leitura, a essa interpretação. Como estamos imersos em um mundo de imagens, temos a impressão de que essa simples convivência nos capacita a compreendê-las e a analisá-las. No entanto, pesquisadores como Kress e van Leeuwen (2006), Dondis (2007) e Joly (2007) nos mostram que a imagem possui uma linguagem própria cuja compreensão exige um aprendizado particular. A linguagem visual deve, portanto, ser estudada, lida e analisada com ferramentas que Ihe sejam próprias, tanto quanto a linguagem verbal. O simples fato de estarmos imersos em uma civilização da imagem não nos capacita a analisá-la.

Os textos multimodais - cada vez mais presentes nas sociedades contemporâneas - invadiram também os livros didáticos e isso é extremamente positivo, mas sentimos que falta ainda um estudo e uma exploração mais aprofundada desse discurso tanto na sociedade quando na esfera educacional. De fato, o discurso visual permite construir significados por si só e também em interação com os outros suportes semióticos do texto multimodal e, por essa razão, ignorá-lo ou não analisálo implicará em perda de significados. A vasta presença da imagem e dos textos multimodais nos LDs de FLE e sua restrita exploração pedagógica foram confirmadas nesta pesquisa, cujas perguntas retomamos a seguir.

- Qual espaço físico os livros didáticos de FLE reservam para a imagem do ponto de vista estrutural, ou seja, na composição das páginas dos manuais? A evolução tecnológica acompanhou-se de um aumento na presença da imagem nos livros didáticos?

Um grande espaço, como pudemos comprovar. Dos anos 1980 até a época atual, esse espaço cresceu de forma intensa refletindo o mesmo processo ocorrido em nossa sociedade, como pudemos constatar ao analisar as capas de jornais desses mesmos períodos. É comum afirmar que vivemos em uma "sociedade da imagem", mas acreditamos que a definição mais correta seria dizer vivemos em uma sociedade 
cada vez multimodal, já que os textos por ela produzidos não são compostos exclusivamente por imagens, mas são constituídos também por elas de forma cada vez mais sistemática.

No que diz respeito aos livros didáticos de FLE analisados nesta tese, passamos de um livro com 60\% de páginas ilustradas em preto-e-branco (Archipel, 1982) para livros com cerca de 100\% de páginas ilustradas coloridas - e isso já na década seguinte (Espaces, 1990) e de forma constante até os dias atuais.

A qualidade gráfica é altíssima e a variedade das imagens, muito grande: fotos, desenhos, charges, histórias em quadrinhos, imagens de sites da Internet, de anúncios publicitários, de cartazes... Os gêneros textuais representados também são bastante variados. Documentos autênticos estão cada vez mais presentes nos LDs analisados, o que se explica também em razão das metodologias nas quais eles se inserem. Muitas vezes, e por se tratar de livros para iniciantes, os documentos não são totalmente autênticos, mas sim "realistas", ou seja, documentos fabricados mas que seguem as características do discurso verbal e visual de um documento autêntico. Trata-se de um aspecto extremamente positivo pois o LD parece mais próximo da vida real, conectado e imerso nela e não em um mundo à parte.

Além do aumento do número de páginas ilustradas e da variedade das imagens, vimos que as mesmas passaram a ocupar um espaço maior nas páginas do livro. Em livros como Écho A1, uma imagem pode ocupar dois terços de uma dupla página multimodal. E a questão da multimodalidade também é importante, houve um aumento do "diálogo" entre os diferentes suportes (sobretudo os escritos e visuais) que compõem as páginas. Notamos essa maior interação graças a elementos como a utilização de flechas que ligam imagens ao texto escrito (Espaces 1) e também de diferentes tipos de imagens sobrepostos em textos escritos ou em transcrições de diálogos.

Por outro lado, apesar desse aspecto positivo, não identificamos esse mesmo diálogo quando analisamos a exploração desses suportes. Ou seja, a multimodalidade está presente nas páginas do LD, mas não nas propostas para a sua exploração, como veremos a seguir na resposta à segunda pergunta de nossa pesquisa. 
- Que espaço pedagógico é previsto para as imagens nesses livros didáticos e em seus respectivos guias para o professor?

Ao analisarmos os enunciados das atividades propostas no livro do aluno e também as preconizações para o uso da imagem no guia do professor, constatamos que as indicações para a exploração do suporte visual são muito reduzidas. Nossa estatística mostrou uma variação progressiva de $11 \%$ para $35 \%$ nas menções no guia do professor às imagens presentes no LD. Ou seja, para $65 \%$ das imagens presentes no livro do aluno - e isso levando-se em conta o caso mais recente e com índice de menções à imagem mais elevado - não há nenhuma orientação ou mesmo menção ao suporte visual no guia do professor. Esse "esquecimento" é preocupante pois poderá levar o professor ao mesmo procedimento: negligenciar o suporte visual e se concentrar somente nos textos e nos áudios, ou seja, deixar de lado uma parte importante dos sentidos que o aluno poderia e deveria - construir em seu percurso de aprendizagem de uma língua estrangeira e de sua cultura. Quando as menções à imagem são feitas no guia pedagógico, notamos que se reserva geralmente ao suporte visual um papel de subordinação ao texto escrito. A imagem ocupa uma função "iluminura", ou seja, uma posição muitas vezes submissa e/ou decorativa em relação ao texto escrito. Esse "esquecimento" pelo LD em propor atividades para a exploração imagem pode se traduzir, em sala de aula, por um “esquecimento" (com ou sem aspas, conforme explicamos mais adiante) da parte do professor em explorar com os alunos o texto multimodal de forma plena.

Por "esquecimento", com aspas, compreendemos que a não-menção ou a pouca quantidade de menções à exploração da imagem por parte do autor do LD possa ter sido voluntária, uma opção tomada em razão de sua forma de trabalhar ou por circunstâncias independentes de sua vontade, já que, como vimos, múltiplos fatores estão envolvidos na construção de um projeto gráfico-editorial. Por "esquecimento", com aspas, da parte do professor, entendemos os casos em que ele identifica essa falta de instruções no LD mas opta, também do seu lado, por não buscar essa exploração. As razões podem ser diversas: falta de conhecimento sobre como explorar a imagem, falta de tempo causada por um programa muito vasto ou então - e o que nos parece mais preocupante - o professor pode chegar à conclusão que, se o próprio livro didático - instrumento associado à ideia de poder e revestido de legitimação - não propôs esse trabalho, é porque o mesmo não deve ser muito importante. 
Já por esquecimento, sem aspas, da parte do professor, concebemos o sentido próprio do termo. Influenciado pelo LD e pelo guia pedagógico que citam tão pouco as imagens e propõem ainda menos frequentemente atividades para as mesmas, o professor acaba por se concentrar nos diálogos, nas atividades de gramática, nos textos escritos do livro e se esquece, por sua vez, dessas questões.

A nosso ver, esse esquecimento do professor - voluntário, não-voluntário e/ou influenciado pelo LD - acarreta um empobrecimento da própria prática e aquisição de uma língua estrangeira e de sua cultura.

\section{- Em caso de aumento da presença da imagem nos livros didáticos, houve mudanças} no tratamento pedagógico reservado ao suporte visual?

Como vimos anteriormente, a intensificação da presença da imagem no LD foi confirmada nesta pesquisa. Constatamos, no entanto, que essa grande riqueza de suportes visuais não está acompanhada de uma riqueza de possibilidades de exploração dos mesmos. Não identificamos mudanças significativas no tratamento pedagógico reservado à imagem, apesar do aumento de sua presença. Sua exploração pedagógica permanece restrita em todos os livros analisados. Mesmo nos LDs mais recentes, que possuem um belo projeto gráfico-editorial, as atividades mais aprofundadas para a imagem são raras e, quando propostas, não costumam privilegiar a interação da mesma com outros suportes semióticos - como o texto escrito ou o áudio.

Na maioria dos casos, e para todos os LDs analisados, os enunciados costumam se restringir à seguinte formula: "Observe a imagem e, em seguida, escute o diálogo e responda às perguntas". Trata-se praticamente de um "clássico" no que diz respeito aos enunciados para a exploração da imagem nos LDs e vimos que ele resiste ao tempo, já que se mantém bastante presente mesmo em publicações mais atuais.

Dois aspectos nos chamam particularmente a atenção na frase-tipo "Observe a imagem e, em seguida, escute o diálogo e...". O primeiro diz respeito a uma redução do trabalho com a imagem a uma simples observação, sem atividades específicas para ela. De fato, o professor - e/ou o aluno - poderiam se perguntar: “Observar a imagem para quê? Com que objetivos? Para dizer o quê sobre ela? Se vou observá-la, gostaria de poder dizer algo sobre ela, utilizá-la de forma ativa, aprender e me expressar com ela e por meio dela..." Vimos nesta tese que Yaiche (2002) considera a imagem um meio de expressão 
importantíssimo para o aluno em sala de aula. Graças à ela, o aluno se expressa com menos reticências e toma a palavra mais facilmente. Ora, para que isso aconteça, ou seja, para "dar voz" ao aluno é necessário, antes de tudo, “dar voz" à imagem. Quando dizemos a um aluno: "Observe a imagem e ouça o diálogo..." não estamos permitindo que ele analise e se expresse sobre a mesma, estamos tirando a voz da imagem da sala de aula e, consequentemente, a voz do aluno.

O segundo aspecto em relação a essa frase-tipo diz respeito à multimodalidade do LD que, apesar de presente, é pouco explorada pela própria publicação. De fato, nos LDs que analisamos, a observação da imagem aparece geralmente separada da compreensão do áudio e sabemos que passaremos, em seguida, à leitura da transcrição do diálogo. Essa "segmentação" é contraditória com a própria opção gráfica e editorial do texto multimodal. Muitas vezes o próprio professor, ao terminar as atividades de compreensão oral e ao pedir aos alunos que leiam a transcrição do diálogo a fim de verificar suas respostas, não se dá conta da importância de que essa leitura de verificação seja feita juntamente com a escuta do áudio correspondente, em uma associação texto escrito/texto sonoro. O mesmo acontece com a imagem. Poucas vezes sua exploração se integra, se relaciona, interage diretamente com outros suportes (escritos ou sonoros) da página. E as orientações do livro didático e do guia do professor favorecem essa segmentação.

A multiplicidade de signos que caracteriza os textos produzidos pela sociedade contemporânea deve trazer, também para a sala de aula, uma multiplicidade de leituras e não uma segmentação das mesmas. Identificamos nesta pesquisa uma necessidade de exploração de caminhos multimodais em sala de aula. De fato, apesar de o LD trazer cada vez mais textos multimodais, suas páginas e duplas páginas ainda costumam ser trabalhadas - e com a legitimação do próprio material e do guia do professor, o que é mais preocupante - apenas em torno das antigas "quatro competências", ou seja, abordando ora a compreensão oral, ora a compreensão escrita, ora a produção oral, ora a produção escrita, de forma segmentada, sem interações entre as mesmas. O próprio enunciado “Observe a imagem e, em seguida, escute o diálogo" reforça essa segmentação. A nosso ver, esse tipo de exploração empobrece a compreensão do texto multimodal e, consequentemente, o processo de aprendizagem de uma língua em diferentes aspectos: comunicativo, linguístico e cultural. 
O QECR concebe essas "competências" como "atividades da linguagem" e acrescentou a elas também a mediação e uma insistência sobre a interação, o que consideramos extremamente positivo. Resta ainda que essa mesma interação se faça também entre as diferentes atividades da linguagem, às quais poderíamos acrescentar a compreensão e a produção visual. Uma mudança na leitura e na exploração do texto multimodal no ensino-aprendizagem de uma língua estrangeira se faz, portanto, necessária.

A nossa quarta pergunta de pesquisa buscava entender as funções reservadas para a imagem pelos LDs e buscar pistas de trabalho para favorecer a descoberta de outras funções e o desenvolvimento de letramentos múltiplos:

- Que funções estão previstas para a imagem nos livros didáticos de FLE? Que funções a imagem pode exercer no ensino e aprendizagem do FLE? Que tipos de atividade podem favorecer o desenvolvimento de letramentos múltiplos e promover, consequentemente, uma melhor aprendizagem e aquisição da língua?

Para compreender melhor as funções previstas para o suporte visual nos LDs de FLE, analisamos a estrutura recorrente das lições/unidades que compõem esse tipo de publicação. Apesar das variações próprias a cada publicação, encontramos com frequência páginas ou elementos de páginas dedicados a temas como introdução da lição, diálogos acompanhados de transcrições, atividades de produção ou de interação oral, gramatica, fonética, textos e atividades para a compreensão e produção escritas, elementos interculturais da língua-alvo. Analisamos também a tipologia das imagens utilizadas em cada elemento dessa estrutura, o que nos ajudou a compreender melhor as funções previstas para o suporte visual nessas publicações.

Os elementos de resposta à questão anterior nos mostraram que as funções previstas para a imagem nos LDs são frequentemente limitadas. Com o intuito de ajudar o professor de FLE a não se esquecer da importância do trabalho com a imagem no ensino-aprendizagem da língua, propusemos a definição de quatro funções básicas para a imagem em um texto multimodal no ensino-aprendizagem de FLE: situacional, conceitual, atuante e expressiva. 
Mais do que uma classificação, nosso objetivo principal é transmitir ao professor uma referência simples que o ajude a se manter atento quanto às diferentes funções que a imagem pode exercer no ensino-aprendizagem do FLE. São "lembretes" não exaustivos para atividades que ele poderá propor a cada vez que se deparar com uma imagem ou com um texto multimodal no LD. Se ele preferir não utilizar nenhuma delas, terá sido uma decisão em razão de um objetivo específico e não um esquecimento, o que para nós, já representaria um grande progresso na busca por uma exploração mais consciente da imagem no ensino-aprendizagem do FLE. É justamente pensando no professor que elaboramos a última pergunta desta pesquisa.

- Qual a opinião dos professores sobre as imagens dos livros didáticos e as respectivas preconizações para o seu uso? Quais utilizações os professores de FLE preveem para a imagem e realizam efetivamente em sala de aula?

A coleta de dados, realizada por meio de um questionário, nos permitiu ouvir a voz do professor sobre essas questões. De fato, ele é o elemento principal nesse processo, já que ocupa uma posição central entre os produtores do material didático e os alunos. Todos os professores que responderam ao questionário afirmaram que a imagem exerce um papel importante em sua vida. Todos eles disseram também considerar que a imagem pode exercer um papel importante dentro do processo de ensino-aprendizagem do FLE.

Essas respostas nos mostraram que os professores estão conscientes da importância da exploração da imagem em sala de aula. Além disso - ou talvez por isso - a maioria deles considerou "limitada" tanto a quantidade quanto a qualidade das orientações pedagógicas para o uso da imagem no guia do professor.

Esse quadro confirma, por meio da voz do professor, os dados que obtivemos a partir da análise dos LDs. Alguns professores afirmaram criar eles próprios atividades para as imagens presentes no livro, tentando explorá-las dentro do objetivo comunicativo proposto na unidade. Uma busca louvável que confirma que os professores têm consciência de que as inúmeras imagens do LD merecem mais atenção e uma exploração mais atenta em sala de aula. Outros professores afirmaram que não 
tinham ainda refletido sobre o fato de que o guia pedagógico poderia trazer mais instruções para a exploração da imagem. É como se o que consideramos uma ausência nessas publicações fosse, na verdade, um fato.

Dissemos anteriormente que o professor ocupa uma posição central entre o polo de "criação" do material didático e seu polo de "recepção", ou seja, o aluno. Colocamos essas duas expressões em parênteses, pois concebemos o LD - assim como o ensinoaprendizagem de uma língua - dentro da mesma visão bakhtiniana adotada nesta tese para a linguagem. Ou seja, acreditamos que a "criação" do livro didático pode - e deve acontecer também em sala de aula, graças à apropriação que o professor fará desse material e à leitura que ele proporá a seus alunos e com seus alunos para esse material, já que os mesmos também fazem parte da "orquestra" - para retomarmos outro termo utilizado nesta tese. Como vimos neste estudo, é por meio dessa apropriação que o professor poderá transformar o artefato livro didático em instrumento.

Essa associação que fazemos agora entre o livro didático e a noção de linguagem corrobora com a ideia defendida por vários autores citados nesta tese de que o LD não pode ser concebido como um conteúdo a ser "transmitido" ao aluno e que o professor exerce um papel bem mais atuante do que o de um simples mediador entre produtores e receptores desse material.

Acreditamos que a própria concepção do guia pedagógico deveria ser revista e também nossas expectativas em relação a esse suporte. Atualmente, esse material traz informações mais descritivas do que sugestivas ou construtivas. Como consequência, já que todas as atividades estão descritas, os esquecimentos ficam mais evidentes.

No que diz respeito à exploração da imagem, mais do que uma descrição exaustiva de atividades, deveríamos esperar que esse material trouxesse ao professor indicações de caminhos e de explorações possíveis - tanto para a imagem quanto para os outros componentes do texto multimodal. O ideal seria que o guia propusesse dois ou três caminhos possíveis de exploração para uma mesma página multimodal. Ao professor, caberia analisar as sugestões e se apropriar daquela que the parecesse corresponder melhor aos seus objetivos, aos seus alunos, ao seu contexto de trabalho. Sem esquecer que, para que haja apropriação, é preciso que haja também criação. 0 “espaço” para que o professor crie, modifique, adapte deve sempre estar presente e é essencial para o processo de ensino-aprendizagem de uma língua. O professor encontrase no meio desse processo e exerce o papel de maestro dessa orquestra. A nosso ver, 
diante de todas as questões levantadas e analisadas nesta tese, confirma-se, antes de tudo, a necessidade da formação dos professores.

\section{Formação de professores e caminhos multimodais}

Diante do silêncio que os materiais didáticos costumam reservar para a exploração da imagem, a formação dos professores confirma-se como um ponto fundamental para que o discurso visual e multimodal não seja ignorado. É necessário, portanto, que o professor de FLE esteja atento não só ao que o LD diz sobre a imagem, mas também - e sobretudo - ao que esse material não diz.

Foi justamente pensando na formação dos professores que propusemos nesta tese a definição de quatro funções básicas para a exploração pedagógica da imagem em um texto multimodal no ensino-aprendizagem de uma língua estrangeira. Acreditamos que o conhecimento dessas funções contribuirá para que o professor desenvolva um olhar mais crítico e mais consciente em relação à exploração das imagens em sala de aula.

Algumas dessas funções já são bem conhecidas de todos os docentes. As funções situacional e conceitual para a imagem - tal como a definimos neste trabalho - podem estar previstas pelo LD ou, em caso negativo, o professor costuma trabalhá-las de forma quase que intuitiva. De fato, muitos deles confirmaram no questionário que sempre trabalham a imagem que acompanha os diálogos situacionais para fazer uma antecipação do documento sonoro, trabalhar hipóteses sobre o diálogo, etc. No entanto, é preciso ir além e atribuir novas leituras, novas funções e novas possibilidades de exploração do suporte visual no ensino-aprendizagem do FLE. As funções atuante e expressiva da imagem trazem, a novo ver, elementos de resposta para essa busca pois contribuem para uma exploração mais consciente da imagem e exploram, ao mesmo tempo, a multimodalidade tanto na recepção e quanto na produção. Novas funções e novos caminhos multimodais devem ser buscados de forma constante por professores e formadores da área do FLE.

Acreditamos que esta pesquisa tenha posto em evidência que a capacidade de leitura de uma imagem aumenta conforme aumentam as funções que lhe atribuímos dentro do processo de ensino-aprendizagem de uma língua. A exploração da imagem no texto multimodal em uma aula de língua estrangeira é essencial pois favorece a 
expressão dos alunos, possibilita novas leituras e dá espaço para a compreensão e a criação de sentidos. Em outras palavras, é por meio dessas atividades que podemos "dar voz à imagem" e, pela voz do professor, romper com o silêncio que tem sido imposto ao suporte visual no meio educacional.

Dissemos anteriormente neste capítulo que quando tiramos a voz da imagem estamos, na verdade, tirando a voz do aluno. O inverso também nos parece verdadeiro. Quanto mais a imagem for trabalhada em sala de aula, quanto mais atividades forem propostas para sua leitura e interpretação, mais se escutará a voz da imagem, a voz o aluno e também a voz do professor. Consequentemente, mais ricos e completos serão o ensino, a aprendizagem e a aquisição de uma língua estrangeira e de sua cultura. 


\section{REFERÊNCIAS BIBILOGRÁFICAS}

ALARCÃO, Isabel. Professores reflexivos em uma escola reflexiva. São Paulo: Editora Cortez, 2010.

ALVES, Danielle Fernandes. Análise de imagens de alguns livros didáticos de italiano como língua estrangeira. 2011. 125f. Dissertação de Mestrado. Departamento de Letras Modernas da Faculdade de Filosofia, Letras e Ciências Humanas da Universidade de São Paulo. 2011.

ARAUJO, Rosilma Diniz. Gramática Visual: Trazendo à Visibilidade Imagens do Livro Didático de LE. SIGNUM: Estud. Ling., Londrina, n. 14/2, p. 61-84, dez. 2011.

ARAUJO-BÜHLER, Rosilma Diniz. Gramática visual - uma leitura contrastiva de imagens em material didático de línguas alemã e inglesa. 01/01/2010 1v. 98p. Mestrado. UNIVERSIDADE FEDERAL DA PARAÍBA/JOÃO PESSOA - LINGÜÍSTICA Orientador(es): Danielle Barbosa Lins de Almeida. Biblioteca depositária: Biblioteca Central da UFPB.

AUSTIN, John Langshaw. 1962. How to do things with words. London: Oxford University Press, 1962.

BAKHTIN, Mikhail. Gêneros do discurso, in Estética da criação verbal. São Paulo: Martins Fontes, 1997.

BAKHTIN, Mikhail / VOLOCHINOV. Marxismo e filosofia da linguagem. São Paulo: Hucitec, 2004, 11 $1^{a}$ edição, tradução de Michel Lahud e Yara Frateschi Vieira, pp. 112-114.

BARTHES, Roland. «Rhétorique de l'image », in Communications, 4, pp. 40-51. Paris : Seuil, 1964.

BOUTIN, Jean-François. « De la paralittérature à la littératie médiatique multimodale une évolution épistémologique et idéologique du champ de la bande dessinée " In : 
LEBRUN, Monique ; LACELLE, Nathalie : BOUTIN, Jean-François (org.). Québec : Presses Universitaires du Québec, 2012.

BUNZEN, C. \& ROJO, R. (2005). “Livro didático de língua portuguesa como gênero do discurso: autoria e estilo". In: Maria da Graça Costa Val e Beth Marcuschi (Orgs.). Livros didáticos de língua portuguesa: letramento e cidadania. Belo Horizonte: CEALE/Autêntica.

CHOPPIN, Alain (2004). História dos livros e das edições didáticas: sobre o estado da arte. Revista Educação e Pesquisa [online], 30 (3), 549-566. Disponível em: http://www.scielo.br/pdf/ep/v30n3/a12v30n3.pdf

CHOPPIN, Alain. O manual escolar: uma falsa evidência histórica. História da Educação, ASPHE/FaE/UFPel, Pelotas, v. 13, n. 27 p. 9-75, Jan/Abr 2009.

Disponível em: http//fae.ufpel.edu.br/asphe

CHOPPIN, Alain. Le manuel scolaire : un objet commun, des approches plurielles. In : Le manuel scolaire, d'ici et d'ailleurs, d'hier à demain. LEBRUN, Monique (direction). Québec: Presses de l’Université du Québec, 2007.

CONSEIL DE L'EUROPE. Cadre européen de référence pour les langues. Apprendre, enseigner, évaluer. Paris : Didier, 2001.

CORACINI, Maria José (Org.). Interpretação, autoria e legitimação do livro didático. Campinas: Pontes, 1999.

CORACINI, Maria José. O processo de legitimação do livro didático na escola de Ensino fundamental e médio: uma questão ética. In: CORACINI, Maria José (org.) Interpretação, autoria e legitimação do livro didático. Campinas: Pontes, 1999.

COSTE, Daniel. "Textes et documents authentiques au Niveau 2 ", dans Le français dans le monde ${ }^{\circ}$ 73. Paris : Hachette, Juin 1970, p. 88 à 94. 
DIONÍSIO, Angela Paiva. "Gêneros multimodais e multiletramento". In: Gêneros textuais: reflexões e ensino. KARWOSKI, Acir M. ; GAYDECZA, Beatriz ; BRITO, Karim Siebeneicher (orgs.). Rio de Janeiro: Nova Fronteira, 2008.

DOLZ, Joaquim; SCHNEUWLY, Bernand. Gêneros orais e escritos na escola. Campinas, SP: Mercado de Letras, 2004. 278 p. (Tradução e organização: Roxane Rojo; Glaís Sales Cordeiro).

DONDIS, Donis A. [1973] Sintaxe da Linguagem Visual. São Paulo: Martins Fontes, 2007.

FÁVERO, Leonor Lopes; KOCH, Ingedore Villaça. Linguística textual: introdução. São Paulo: Editora Cortez, 1983.

GERMAIN, Claude. Évolution de l'enseignement des langues : 5000 ans d'histoire. Paris : CLE International, 1993.

GRIGOLETTO, Marisa. "Leitura e funcionamento discursivo no livro didático". In: CORACINI, Maria José (org.) Interpretação, autoria e legitimação do livro didático. Campinas: Pontes, 1999.

GUICHON, Nicolas \& SOUBRIÉ, Thierry (2013). «Manuels de FLE et numérique : le mariage annoncé n'a pas (encore ?) eu lieu ". In : Le français dans le monde - Recherches et applications. Artigo disponível on-line:

https://hal.archives-ouvertes.fr/hal-00870132/document - Site acessado em 23.12.2014.

HALLYDAY, Michael. An Introduction to Functional Grammar. London: Edward Arnold, 1994.

HAMON, Philippe. Imageries : littérature et image au XIXe siècle. Paris : Éditions José Corti, 2001.

JOLY, Martine. A imagem e a sua interpretação, Lisboa, Ed.70, 2003. 
JOLY, Martine. Introdução à análise da Imagem, Lisboa, Ed.70, 2007.

KLEIMAN, Ângela. Preciso ensinar o Letramento? Não basta ensinar a ler e a escrever? Ministério da Educação. CEFIEL/IEL/UNICAMP. Ministério da Educação, 2005. http://www.letramento.iel.unicamp.br/publicacoes/artigos/preciso_ensinar_letramento -Kleiman.pdf - Site acessado em 19.05.2013.

KLEIMAN, Ângela. $O$ conceito de letramento. 2007.

Disponível em: http://www.letramento.iel.unicamp.br/publicacoes/artigos.html Site acessado em 19.05.2013.

KOMENSKY, Jan Amós (Comenius). Orbis Sensualium Pictus. Edição inglesa de 1659, reproduzida on-line integralmente, com exceção dos índices : 309 páginas. (Primeira edição latim-alemão: 1658)

http://www.uned.es/manesvirtual/Historia/Comenius/OPictus/OPictusAA.htm Site consultado em 12.10.2010.

KRESS, Gunther, VAN LEEUWEN, Theo R. Multimodal Discourse. The modes and media of contemporary communication. London: Arnold, 2001.

KRESS, Gunther, VAN LEEUWEN, Theo R. Reading images: the Grammar of visual design. Gunther Kress and Theo van Leeuwen. New York: Routledge, 2006.

LOUSADA, Eliane Gouvêa. "Elaboração de material didático para o ensino de francês". In: DIONÍSIO, Ângela Paiva: MACHADO, Anna Rachel; BEZERRA, Maria Auxiliadora (org.). Gêneros textuais \& Ensino. Rio de Janeiro: Editora Lucena, 2005.

LOUSADA, Eliane Gouvêa. "Das prescrições oficiais ao livro didático: uma reflexão sobre o processo de elaboração de material didático de português". In: BUNZEN, Clecio (Org.). Livro didático de Português: políticas, produção e ensino. São Carlos: SP. Pedro \& João (no prelo). 
MACHADO, Anna Rachel; LOUSADA, Eliane Gouvêa. Apropriação de gêneros textuais pelo professor: em direção ao desenvolvimento pessoal e à evolução do "métier". Linguagem em (Dis)curso, Palhoça, SC, v. 10, n. 3, p. 619-633, set./dez. 2010.

MANGUEL, Alberto. Lendo imagens. São Paulo: Companhia das Letras, 2009.

MARCONI, Marina de A. \& LAKATOS, Eva. M. Técnicas de pesquisa. São Paulo: Atlas, 2011.

MARCUSCHI, Luiz Antônio, 1946-. Produção textual, análise de gêneros e compreensão. São Paulo: Parábola Editorial, 2008.

MARSARO, Fabiana P. Projeto gráfico-editorial de livros didáticos de Língua Portuguesa: definição, tensões e possibilidades. In: Pesquisas em Discurso Pedagógico 2011.1 PUC-Rio de Janeiro.

MEIRIEU, Pierre. L'évolution du statut de l'image dans les pratiques pédagogiques, Deuxièmes rencontres nationales cdidoc-fr, Lyon : 13 et 14 octobre 2003.

http://www.ac-caen.fr/ia5o/circo/mor/IMG/pdf/statut_image.pdf

Site consultado em 30.07.2012.

MELOT, Michel. Une brève histoire de l'image, L'Oeil neuf, 2007.

MAYER, Richard E. Multimedia Learning. New York: Cambridge University Press, 2009.

MIRANDA, Carlos Eduardo Albuquerque. Orbis Pictus. Pro-Posições [online]. 2011, vol.22, n.3, pp. 197-208. ISSN 0103-7307 http://www.scielo.br/pdf/pp/v22n3/14.pdf

Site consultado em 23.12.2014.

NOVELLINO, Marcia Olivé. Fotografias no livro didático de inglês como língua estrangeira: Análise de suas funções e significados. 01/03/2007 1v. 203p. Mestrado. PONTIFÍCIA UNIVERSIDADE CATÓLICA DO RIO DE JANEIRO - Letras. Orientador(es): Barbara Jane Wilcox Hemais. Biblioteca depositária: Biblioteca Central. 
PÁDUA, Elisabete M. M. de. Metodologia da pesquisa - abordagem teórico-prática. São Paulo: Papirus Editora (2002).

PIETRARÓIA, Cristina Casadei. Percursos de Leitura - Léxico e Construção do Sentido em Língua Estrangeira. São Paulo: Annablume, 1997.

PIETRARÓIA, Cristina Casadei. Questões de leitura: aspectos práticos e teóricos da leitura em Francês língua estrangeira. São Paulo: Annablume, 2001.

POSTMAN, Neil. Enseigner, c'est résister. Traduction de J. Chambert et D.-J. Piveteau. Paris : Le Centurion, 1981.

RABARDEL, Pierre. From artefact to instrument. Editorial. In: Interacting with Computers 15 (2003) 641-645.

RAMOS, Flávia B; PANOZZO, Neiva S. P. O papel da ilustração na leitura infantil. In: ZINANI, Cecil J. A.; SANTOS, Salete R. P. (Orgs.) Multiplicidade dos signos: diálogos com a literatura infantil. Caxias do Sul, RS: EDUCS, 2004.

SALLES, Michely W. S. Textos multimodais e letramento: o trabalho com os textos imagéticos em livros didáticos de língua portuguesa. 2014. 118 f. Dissertação de Mestrado. Orientadora: Regina Lúcia Péret Dell'Isola. Universidade Federal de Minas Gerais, Faculdade de Letras.

SAUJAT, F. Systèmes d'apprentissage : systèmes d'évaluation. 2002. Thèse (Doctorat) Université de Provence, Provence, 2002.

SHANNON, C. AND WEAVER, W. The Mathematical Theory of Communication. Urbana: University of Illinois Press, 1949.

SOARES, Magda B. Letramento e alfabetização: as muitas facetas. 2003. Disponível em: http://www.scielo.br/pdf/rbedu/n25/n25a01.pdf/ - Site acessado em 11.02.2013. 
SOARES Magda B. Alfabetização e letramento: caminhos e descaminhos. Revista Pátio, n. 29, fevereiro de 2004. Disponível em:

http://pt.scribd.com/doc/18892732/Artigo-Alfabetizacao-e-Letramento-Magda-Soares1 Site acessado em 19.05.2013.

SOUZA, Adriana Baptista de. A multimodalidade no livro didático de inglês como língua estrangeira: padrões de representação narrativa e de interação. 01/03/2011. 1v. 120p. Mestrado. UNIVERSIDADE DO ESTADO DO RIO DE JANEIRO - LETRAS. Orientador(es): Anna Elizabeth Balocco. Biblioteca depositária: Biblioteca do Instituto de Letras.

SOUZA, Deusa Maria de. Autoridade, autoria e livro didático. In: CORACINI, Maria José (Org.) Interpretação, autoria e legitimação do livro didático. Campinas: Pontes, 1999.

SOUZA, Tânia Clemente. Discurso e imagem: perspectivas de análise do não verbal. Comunicação apresentada no $2^{\circ}$ Colóquio Latinoamericano de Analistas Del Discurso, La Plata e Buenos Aires, agosto/1997 e artigo publicado on-line em 1998:

http://www.uff.br/mestcii/tania1.htm - Site consultado em 10.05.2013.

STREET, Brian Vincent. Literacy in Theory and Practice. Cambridge (MA): CUP, 1984.

VION, Robert. La communication verbale. Analyse des interactions. Paris : Hachette, 1992.

VYGOTSKY, L.S. Pensamento e Linguagem. 2ed. São Paulo: Editora Marins Fontes, 1998.

WINKIN, Yves. La nouvelle communication. Paris : Le Seuil, 1981.

YAICHE, Francis. Photos-Expressions. Paris : Hachette, 2002.

\section{REFERÊNCIAS BIBILOGRÁFICAS DE LIVROS DIDÁTICOS}

AUGÉ, Hélène et al. Tout va bien 1. Paris : CLE INTERNATIONAL, 2004. 
BAGLIETO, David ; GIRARDEAU, Bruno ; MISTICHELLI, Marion. Agenda 1. Paris : Hachette, 2010.

BAYLON, Christian ; CAMPA, Angels ; MESTREIT, Claude ; MURILLO, Julio ; TOST, Manuel. Forum 1. Paris : Hachette, 2000.

BÉRARD, Évelyne ; CANIER, Yves ; LAVENNE, Christian et al. Tempo 1. Paris : Didier/Hatier, 1998.

BERTHET, Annie ; DALIL, Emmanuelle ; HUGOT, Catherine ; KIRIZIAN, Véronique ; WAENDENDRIES, Monique. Alter Ego+1. Paris : Hachette, 2012.

BOUDOT, Jean. Voix et images de France. Paris : Didier, 1968.

CAPELLE, Guy ; GIDON, Noëlle. Espaces 1. Paris : Hachette, 1990.

COCTON, Marie-Noëlle ; HEU, Elodie ; HOUSSA, Catherine ; Kasazian, Emilie. Saison 1. Paris : Didier, 2014.

COURTILLON, Janine ; RAILLARD, Sabine. Archipel 1. Paris : Didier, 1982.

GIBERT, Pierre ; GREFFET, Philippe. Bonne Route 1. Paris : Hachette, 1988.

GIRARDET, J. ; PÊCHEUR, J. Écho A1. Paris : CLE INTERNATIONAL, 2010.

GIRARDET, Jacky. Panorama 1. Paris : CLE International, 2000.

MAUGER, Gaston. Cours de langue et de Civilisation françaises. Paris : Hachette, 1953.

MERIEUX, Régine ; LAINÉ, Emmanuel ; LOISEAU, Yves. Latitudes. Paris : Didier, 2009.

MOGET, Marie-Thérèse ; NEVEU, Pierre. De vive voix. Paris : Cours CREDIF, Didier, 1972. 


\section{QUESTIONÁRIO}

\section{Imagem do questionário on-line:}

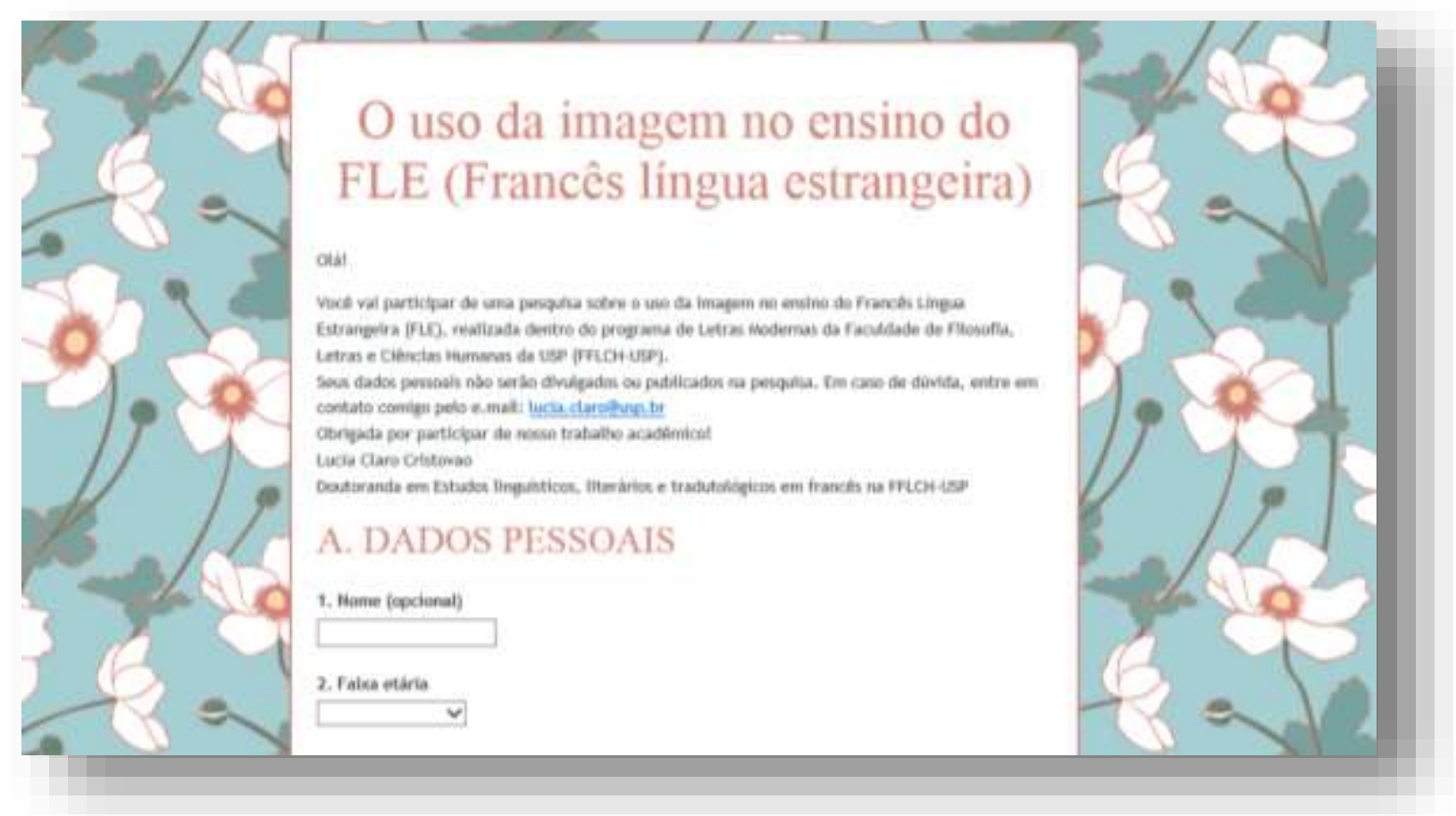

\section{Conteúdo do questionário:}

Olá!

Você vai participar de uma pesquisa sobre o uso da imagem no ensino do Francês Língua Estrangeira (FLE), realizada dentro do programa de Letras Modernas da Faculdade de Filosofia, Letras e Ciências Humanas da USP (FFLCH-USP).

Seus dados pessoais não serão divulgados ou publicados na pesquisa. Em caso de dúvida, entre em contato comigo pelo e-mail: lucia.claro@usp.br

Obrigada por participar de nosso trabalho acadêmico!

\section{A. DADOS PESSOAIS}

1. Nome (opcional):.

2. Idade:

3. Sexo: [ ] Feminino [ ] Masculino

4.Formação:

$\begin{array}{ll}\text { [ Ensino Médio } & {[\text { ] Curso superior }} \\ \text { [ } & \text { Mestrado }\end{array}$

5.Há quantos anos você é professor de FLE?

[ ] menos de 5 anos [ ] de 6 a 10 anos [ ] de 11 a 15 anos

[ ] de 16 a 20 anos [ ] mais de 20 anos 


\section{B. PRÁTICAS CULTURAIS}

1. Em sua vida cotidiana, você procura se informar e se formar sobre a imagem?

[ ] Sim [ ] Não

Em caso afirmativo, especifique como você busca essa informação/formação:

2. De que forma a imagem está mais presente em sua vida?

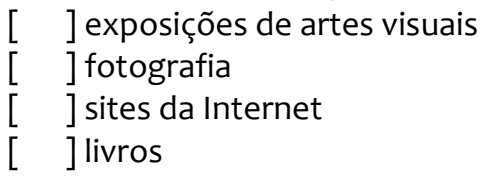

[ ] ] livros didáticos
$\left[\begin{array}{l}\text { [ revistas } \\ {[}\end{array}\right]$ jornais
$[\quad]$ publicidade

Outros:

3. Como leitor, você aprecia o fato de um texto estar acompanhado por uma imagem?
[ ] Nunca
[ ] Raramente
[ ] Às vezes
[ ] Frequentemente [ ] Sempre

4. Em quais desses gêneros textuais você prefere, como leitor, que o texto esteja acompanhado por uma imagem:
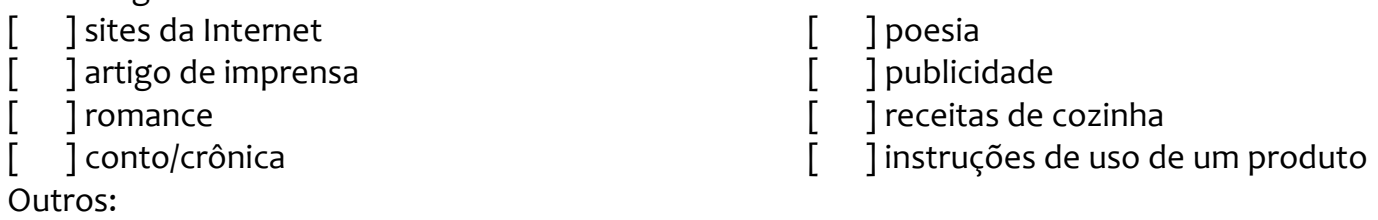

5. A imagem exerce um papel importante em sua vida cotidiana?

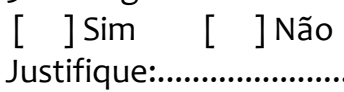

\section{POSSIBILIDADES PARA O USO DA IMAGEM EM UMA AULA DE FLE}

1. Dentro do processo de ensino/aprendizagem do Francês língua estrangeira (FLE), você considera que a imagem pode exercer um papel importante:

[ ] Sim [ ] Não

Com que frequência você utiliza A IMAGEM em sala de aula para trabalhar com seus alunos os objetivos abaixo?

2. Objetivos linguísticos: LÉXICO

[ ] Nunca [ ] Raramente [ ] Às vezes [ ] Frequentemente [ ] Sempre

3. Objetivos linguísticos: GRAMÁTICA

[ ] Nunca [ ] Raramente [ ] Às vezes [ ] Frequentemente [ ] Sempre

4. Objetivos linguísticos: FONÉTICA

[ ] Nunca [ ] Raramente [ ] Às vezes [ ] Frequentemente [ ] Sempre

5. Objetivos CULTURAIS E INTERCULTURAIS

[ ] Nunca [ ]Raramente [ ] Às vezes [ ] Frequentemente [ ] Sempre

6. Objetivos comunicativos: COMPREENSÃO (ESCRITA/ORAL)

[ ] Nunca [ ]Raramente [ ] Às vezes [ ] Frequentemente [ ] Sempre

7. Objetivos comunicativos: PRODUÇÃO (ESCRITA/ORAL)

[ ] Nunca [ ] Raramente [ ] Às vezes [ ] Frequentemente [ ] Sempre

8. Objetivos comunicativos: INTERAÇÃO EM SALA DE AULA

[ ] Nunca [ ]Raramente [ ] Às vezes [ ] Frequentemente [ ] Sempre 
9. Para auxiliar os alunos a desenvolver ESTRATÉGIAS DE APRENDIZAGEM

[ ] Nunca [ ] Raramente [ ] Às vezes [ ] Frequentemente [ ] Sempre

10. Para auxiliar os alunos na identificação e na produção de diferentes GÊNEROS TEXTUAIS (anúncios publicitários, e-mails, receitas de cozinha, blogs, etc.)
[ ] Nunca
[ ] Raramente
[ ] Às vezes [ ] Frequentemente [ ] Sempre
11. Para a realização de JOGOS E DE ATIVIDADES LÚDICAS
[ ] Nunca [ ] Raramente [ ] Às vezes [ ] Frequentemente [ ] Sempre

Outros objetivos para o uso da imagem em uma aula de FLE:

Comentários sobre as questões acima:

\section{PRECONIZAÇÕES DOS GUIAS PEDAGÓGICOS PARA O USO DA IMAGEM NOS LIVROS DIDÁTICOS DE}

FLE

1. Assinale o livro didático de FLE (público adulto) que você utiliza com mais frequência.
Echo
Mobile
Alter Ego
Outro

Analise O GUIA PEDAGÓGICO correspondente ao livro didático com o qual você trabalha e responda às perguntas abaixo:

2. No guia pedagógico que você utiliza, o uso da imagem é preconizado com que objetivo? (Várias respostas possíveis):

Para introduzir um conteúdo comunicativo, linguístico ou cultural

Para a memorização/ aquisição de um conteúdo comunicativo, linguístico ou cultural

Para o reemprego de um conteúdo comunicativo, linguístico ou cultural

Para ilustrar um contexto

Na recepção, análise e produção de um gênero textual (anúncios publicitários, e-mails, receitas de cozinha, blogs, etc.)

1. Qual sua opinião sobre a QUANTIDADE de orientações do guia pedagógico para O USO DAS IMAGENS presentes no livro do aluno?

Muito limitada

Limitada

Satisfatória

Boa

Muito boa

2. Qual sua opinião sobre a QUALIDADE das orientações do guia pedagógico para o USO DAS IMAGENS presentes no livro do aluno?

Muito limitada

Limitada

Satisfatória

Boa

Muito boa

3. Essas orientações lhe parecem claras e pertinentes?
[ ] Nunca
[ ] Raramente
[ ] Às vezes [ ] Frequentemente [ ] Sempre 
4. As orientações do guia pedagógico para o USO DAS IMAGENS contribuem para que os objetivos didáticos sejam atingidos em sala de aula?

[ ] Nunca [ ]Raramente [ ] Às vezes [ ] Frequentemente [ ] Sempre

Comentários sobre as questões acima:

5. Indique uma página do livro didático com o qual você trabalha na qual o uso da imagem lhe parece particularmente bem sucedido e explique porquê.

\section{E. UTILIZAÇÕES EFETIVAS DA IMAGEM EM UMA AULA DE FLE}

1. Você costuma incluir imagens quando cria uma sequência didática?

[ ] Sim [ ] Não

2. Em caso afirmativo, você trabalha mais frequentemente a imagem com seus alunos (várias respostas possíveis):

Para introduzir um conteúdo comunicativo, linguístico ou cultural

Para a memorização/ aquisição de um conteúdo comunicativo, linguístico ou cultural

Para o reemprego de um conteúdo comunicativo, linguístico ou cultural

Para ilustrar um contexto

Na recepção, análise e produção de um gênero textual (anúncios publicitários, e-mails, receitas de cozinha, blogs, etc.)

Outros:

3. Você sente a necessidade de adaptar as orientações do guia pedagógico para o USO DAS IMAGENS em sala de aula?
[ ] Nunca
[ ] Raramente
[ ] Às vezes
[ ] Frequentemente [ ] Sempre

4. Você sente a necessidade de criar atividades suplementares para explorar as imagens presentes no livro do aluno em sala de aula?
[ ] Nunca
[ ] Raramente
[ ] Às vezes
[ ] Frequentemente [ ] Sempre

Comentários sobre as questões anteriores:

5. Em caso de adaptações em relação às prescrições do guia pedagógico, que elementos orientam essas mudanças? (Várias respostas possíveis)

Perfil dos alunos (idade, centros de interesse, estilos de aprendizagem)

Nível de língua dos alunos

Interação possível entre a imagem e os outros elementos que compõem as páginas do livro didático (textos, gráficos, etc.)

Outros:

6. Você poderia citar um exemplo de adaptação de uma atividade para trabalhar uma imagem?

7. Dentro de seu contexto de trabalho, você identifica uma necessidade em formação de professores para trabalhar a imagem em aula de FLE?

[ ] $\operatorname{Sim}$ [ ] Não

Por quê?

\section{Merci beaucoup !}

